Manuscripts and Archives 


\section{Studies in Manuscript Cultures}

Edited by

Michael Friedrich

Harunaga Isaacson

Jörg B. Quenzer

Volume 11 


\section{Manuscripts and Archives}

Comparative Views on Record-Keeping

Edited by

Alessandro Bausi, Christian Brockmann, Michael Friedrich, Sabine Kienitz 
ISBN 978-3-11-054136-6

e-ISBN (PDF) 978-3-11-054139-7

e-ISBN (EPUB) 978-3-11-054157-1

ISSN 2365-9696

\section{(cc) BY-NC-ND}

This work is licensed under the Creative Commons Attribution-NonCommercial-NoDerivs 3.0 License. For details go to http://creativecommons.org/licenses/by-nc-nd/3.0/.

\section{Library of Congress Cataloging-in-Publication Data}

A CIP catalog record for this book has been applied for at the Library of Congress.

\section{Bibliographic information published by the Deutsche Nationalbibliothek}

The Deutsche Nationalbibliothek lists this publication in the Deutsche Nationalbibliografie; detailed bibliographic data are available on the Internet at http://dnb.dnb.de.

(C) 2018 Alessandro Bausi, Christian Brockmann, Michael Friedrich, Sabine Kienitz, published by Walter de Gruyter GmbH, Berlin/Boston.

The book is published with open access at degruyter.com.

Printing and binding: CPI books $\mathrm{GmbH}$, Leck

(2) Printed on acid-free paper

Printed in Germany

www.degruyter.com 
Gianfranco Fiaccadori (1957-2015) in memoriam 



\section{Contents}

The Editors

Preface - IX

\section{Prologue: Contemporary Practices of Archiving}

Dietmar Schenk

How to Distinguish between Manuscripts and Archival Records: A Study in Archival Theory -3

Charles Ramble

Archives from Tibet and the Himalayan Borderlands: Notes on Form and Content -19

\section{The Ancient World up to Late Antiquity}

Cécile Michel

Constitution, Contents, Filing and Use of Private Archives: The Case of the Old Assyrian Archives (nineteenth century BCE) -43

Fredrik Hagen, with a contribution by Daniel Soliman

Archives in Ancient Egypt, 2500-1000 BCE — 71

Jean-Luc Fournet

Archives and Libraries in Greco-Roman Egypt -171

Max Jakob Fölster

Libraries and Archives in the Former Han Dynasty (206 BCE-9 CE):

Arguing for a Distinction —201

Alberto Camplani

Setting a Bishopric / Arranging an Archive: Traces of Archival Activity in the Bishopric of Alexandria and Antioch — 231 
Thomas Graumann

Documents, Acts and Archival Habits in Early Christian Church Councils:

A Case Study -273

\section{The Middle Ages}

Mikael S. Adolphson

Weighing in on Evidence: Documents and Literary Manuscripts

in Early Medieval Japan — 297

Michael Grünbart

Securing and Preserving Written Documents in Byzantium —319

Jürgen Paul

Archival Practices in the Muslim World prior to $1500-339$

Christian Müller

The Power of the Pen: Cadis and their Archives

From Writings to Registering Proof of a previous Action taken — 361

Emmanuel Francis

Indian Copper-Plate Grants: Inscriptions or Documents? - 387

\section{Epilogue: Why and how to compare}

Markus Friedrich

Epilogue: Archives and Archiving across Cultures-Towards a

Matrix of Analysis - 421

List of Contributors -446

Indices - 449 


\section{Preface}

Manuscripts and Archives is not only the name of a reading room at Yale University Library, but also the title of a British Library catalogue, which spans 'Manuscripts and unpublished documents; Personal papers, correspondence and diaries; Family and estate papers; India Office Records and Private Papers; India Office Prints, Drawings and Paintings; Photographs'. ${ }^{1}$ The surprising company of manuscripts, i.e. single written artefacts, and archives, i.e. bodies of documents, is easily understood once the use of the latter term is not restricted to state institutions such as national archives, but seen as comprising all sorts of materials short of or even including printed books.

Considerations of this kind led scholars at the Centre for the Study of Manuscript Cultures at the University of Hamburg (CSMC) to organise a conference entitled Manuscripts and Archives from 19 to 22 November 2014. In their announcement, they wrote:

Archives are collections of administrative, legal, commercial and other records or the space where they are located. They have become ubiquitous in the modern world, but came into being not much later than the invention of writing. Following Foucault, who first used the word archive in a metaphorical sense as 'the general system of the formation and transformation of statements' in his Archaeology of Knowledge (1969), postmodern theorists have tried to exploit the potential of this concept and initiated the 'archival turn'. In recent years, however, archives have attracted the attention of anthropologists and historians of different denominations attempting to treat them as historical objects and 'ground' them again in real institutions.

The archive is traditionally considered the counterpart of the library, the one storing records, the other housing literary works or 'books'. There is evidence, however, that this institutional division of labour is neither natural nor necessary, but reflects certain historical and social constellations. In societies with elite literacy, for example, records, letters as well as books and even artefacts may be kept together in the same place, or books may be used for recording important events and legal acts in the margins and in the blanks. On the other hand, complex organisations such as courts, states, temples, monasteries and others as a rule develop institutional ways to deal with the documents they produce, from exclusive places of storage to employment of professionals whose only task is to guard them and to keep them for eventual use.

The conference will explore the complex topic of the archive in a historical, systematic and comparative dimension and try to contextualise it in the broader context of manuscript cultures by addressing the following questions: How, by whom and for which purpose are

$1 \mathrm{http}: / /$ searcharchives.bl.uk/primo_library/libweb/action/search.do?dscnt=1\&dstmp=151180 4535605\&vid=IAMS_VU2\&fromLogin=true (accessed on 27/11/2017)

https://doi.org/10.1515/9783110541397-001, (c))BY-NC-ND @ 2018 Alessandro Bausi, Christian Brockmann, Michael Friedrich, Sabine Kienitz published by De Gruyter. This work is licensed under the Creative Commons Attribution-NonCommercial-NoDerivs 3.0 License. 
archival records produced? Is there any observable difference between literary manuscripts concerning materials, formats or producers (scribes)? Where are they stored, how organised? Are there other objects stored together with the records? Which practices are involved inside the archive, and how and by whom are they used? Is there a term or a concept of the archive as opposed to library, museum, cabinet (of curiosities) and the like? Is there a relation to historiography? Is there an archival science (archivology)?

Eight of the seventeen original papers have been published in this volume in addition to five other contributions that have been specially commissioned for it. The saddest lacuna here is the paper by Gianfranco Fiaccadori (1957-2015) entitled 'Archives in Ethiopia and Eritrea: from Antiquity to Early Modern. A Historical Survey' as the author passed away before he could deliver it to print. As a tribute to him, we have dedicated this volume to the memory of this great scholar. ${ }^{2}$

The 'Prologue' of this work contrasts two contemporary modes of archiving: 'modern' institutional practices represented by Archival Science on the one hand and 'traditional' ways of keeping documents on the other hand, such as those used in Himalayan villages. This Gleichzeitigkeit des Ungleichzeitigen shows that, despite all differences over time and space, the desire to store written artefacts and to do so in a more or less organised manner for at least some time is deeply rooted in many cultures that use the technique of writing. Dietmar Schenk addresses archival practices from a practitioner's point of view. Drawing on classical authors from Archival Science since the late nineteenth century and on more recent developments in this field, he emphasises a broader interpretation of the famous 'principle of provenance', which requires the archiver to keep any items together that come from one and the same source. Since these items may not just include what are traditionally considered to be archival records, but literary manuscripts, non-textual artefacts and other objects as well, he suggests taking this as a starting point for comparison. In stark contrast to these 'modern' notions, archival practices in remote areas with their own distinct traditions are little known in the outside world. Charles Ramble provides insights into one of these traditions, namely the archives of Tibetan

2 See Alessandro Bausi, 'Obituary: Gianfranco Fiaccadori (1957-2015)', in Scrinium: Journal of Patrology and Critical Hagiography, 11 (2015), 2-3; Paul Marie Glaouaër, 'In memoriam: Gianfranco Fiaccadori', in Pount, 9 (2015 = Écrits de la mer Rouge), 241-242; Beatrice Daskas and Agostino Soldati, 'In memoriam Gianfranco Fiaccadori (1957-2015)', in Aethiopica, 18 (2015), 200-213, with bibliography; still in print, Alessandro Bausi, "'Bisanzio e il regno di Aksum”': il contributo di Gianfranco Fiaccadori agli studi etiopici', in Agostino Soldati and Pierluigi Valsecchi (eds), Persona, trascendenza e poteri in Africa - Person, transcendence, powers in Africa. In memoria di Gianfranco Fiaccadori. Atti del Secondo Dies Academicus della Classe di Studi Africani della Accademia Ambrosiana, Milano, Biblioteca Ambrosiana, 12-14 novembre 2015 (Africana Ambrosiana, 2), Milano: Accademia Ambrosiana. 
communities in the Himalayas. He illustrates the differences between books and documents with regard to terminology, form, script, content, material and storage. Documents were and are either kept in cloth wallets and in trunks made from leather or metal or in wicker baskets and sacks, which are often suspended from the rafters to protect them from rodents. Recently discovered archives provide important information on social stratification, taxation, jurisdiction and the relationship between people and state. These documents, which are often fragile, offer glimpses of a world otherwise not accessible any more since Chinese communists destroyed most of the archives after China's occupation of Tibet.

The second section of the present volume, 'The Ancient World up to Late Antiquity', covers three millennia and combines case studies with diachronic surveys from the ancient Near East, from ancient and Greco-Roman Egypt, early Imperial China and early Christianity. Dealing with archives and libraries of private households, temples and various levels of administration up to imperial courts, the contributions to this section provide overwhelming evidence of the necessity of taking a fresh look at the seemingly clear-cut distinction between both means of storage. In many cases, it is difficult to uphold this distinction, while in others, especially those connected to state power, there obviously existed institutions serving various functions.

The private archives of Assyrian merchants, unearthed at Kültepe (the ancient town of Kaneš) in Central Anatolia, contained contracts and business letters. Cécile Michel studies this largest group of private cuneiform archives in the history of ancient Mesopotamia, which mainly date back to the nineteenth century BCE. They were arranged on shelves or stored inside containers, with a classification system that allows archaeologists and researchers to reconstruct the use merchants made of their archives. The merchants accumulated documents as long as they considered them to be useful, after which the items were discarded. What kind of archives existed in ancient Egypt and how they were used, is discussed in the contribution by Fredrik Hagen and Daniel Soliman. The authors provide a comprehensive overview of the evidence we have, relating to surviving archives for the period c.25001000 BCE using largely unpublished material. Many administrative documents from pharaonic Egypt are essentially stray finds, primarily from tombs, and although they do not always shed light on archival practices per se, they do reveal a great deal about the types of documents drawn up by various institutions. Despite the difficulties posed by the very nature of the evidence, certain features of ancient Egyptian archives emerge: they contained 'day-books' recording the activities of administrative, military, religious and other institutions as well as accounts and letters, and were regularly discarded after some time. 
According to Jean-Luc Fournet, the traditional distinction between archives and libraries used in papyrology is misleading. This distinction would have made little sense to the ancients since one and the same Greek word, $\beta \iota \beta \lambda เ \theta \dot{\eta} \kappa \eta$, designated both a public archive and a library in Greco-Roman Egypt, and individuals would store documents and literary texts in the same place. Fournet proposes the concept of an 'archive-library' in order to study the interaction between both, which sometimes resulted in the 'literarisation' of documents and the 'documentarisation' of literature. In contrast, Max Jakob Fölster shows that the oldest collection of Chinese manuscripts for which we possess a catalogue only contains literary texts. In the first years of the Common Era, this imperial collection clearly excluded certain types of written artefacts: besides those with legal content all administrative records which were kept at other places. It should therefore be identified as a library.

Early Christian authors mentioned archives for apologetic or theological purposes even before their congregations created such depositories. Alberto Camplani argues that the main impulse to create archives came from the bishops, whose synods produced a huge number of written records, which were needed for later reference, for which archiving was essential. Increasingly complex organisation and increasingly autocratic leadership by the bishops led to a new type of archival organisation arising, which Camplani traces in the episcopal sees of Rome, Alexandria and Antioch. Thomas Graumann presents a case study of the handling and archiving of documents and acts related to Church councils. A wide range of documents were examined and utilised in a series of inter-related events both before assemblies of bishops and at meetings convened by imperial officials in the run-up to the Council of Chalcedon (451). Administrators of the Church and of the Roman Empire made their staff pay meticulous attention to the characteristic features of the written artefacts and inferred their validity, provenance and previous handling from them. Graumann reconstructs the movement of documents from church archives to government ones and outlines a range of administrative practices underlying their use.

The third section of this volume assembles contributions spanning one-and-ahalf millennia under the heading of 'The Middle Ages'. This term is notoriously unwieldy, especially if transplanted to Asian cultures with distinct social formations and historical patterns, and often betrays the approach taken more than the period under investigation. However, since the term is commonly used in quite a few disciplines and has the charm of suggesting evidence, it has been employed here for the sake of simplicity.

The twelfth century saw the decline of imperial authority and growing disorder in Japan. Parallel to warrior rule, it appears there was increased reliance on documents and literary manuscripts. Mikael Adolphson analyses the cases of Taira no 
Kiyomori (1118-1181), the first warrior-aristocrat to control the imperial court, and of Japan's first warrior government, the Kamakura shogunate (1185-1333). Despite their military background, both of these parties made extensive use of written artefacts. The more competitive the political scene became, the more important was the possession of valuable manuscripts and the handling of documents. The prestige of the written word is also emphasised by Michael Grünbart in his contribution on record-keeping and collecting knowledge in Byzantium. Due to the lack of firsthand evidence, his reconstruction is based on literary sources, which provide evidence of collections generally. Following the precedent of Late Antiquity, no sharp distinction seems to have been made between storing manuscripts and storing documents, although the written artefacts kept by an erudite would certainly have been distributed in a different way from a government agency. Private libraries became symbols of the exclusiveness of their owners, who liked to donate them to monasteries in order to keep their memory alive.

It is evident that most of the documents that have been discovered are not cases of preserved archives, but rather remains of them. What is preserved today are 'negative archives' (Fournet), which holds true for much of the pre-Ottoman Islamic world as well. In his critical evaluation of the current debate on the question of why so little remains of a large body of documents from both government and cadis' offices in the Near and Middle East, including the Persian-speaking lands, Jürgen Paul is concerned with archival practices: who stored which documents where and why? These practices included discarding and 'thrashing', which is closely linked to the reuse of paper. Paul's central question of whether archive-keeping was an institutional task or a private concern is taken up by Christian Müller, who focuses on cadis' archives and their institutional importance from a long-term perspective. The role of the cadi was long underestimated due to the lack of source material available. In a detailed analysis of a corpus of nearly 2,400 authentic Arabic legal documents from the eighth to the sixteenth century, Müller provides new insights into the evolution of judicial practices and the judge's role in guaranteeing subjective rights. His paper combines information on the cadi's archive as reported in documentary sources since the mid-eighth century with an analysis of surviving legal documents and with juridical discussion on the legal status of writing as proof in literature on law (fiqh). The refusal by ninth-century jurists to see a judge being bound by writings from their predecessor's archive to conduct a lawsuit was eventually replaced by accepting cadi's certificates as a means of providing proof. Hence, documents from the cadi's archive acquired the function of a living archive that could safeguard subjective rights for long periods of time.

The last paper in this section, which is by Emmanuel Francis, deals with copper-plate grants from Southern India. At the ends of them, these grants often have 
the formula 'As long as the moon and the sun endure'. Not only this formula but also the material of these title-deeds, which were kept by their owners, expresses the claim to durability. Usually, these copper plates issued from the third century $\mathrm{CE}$ onwards were regarded as inscriptions. However, if the main characteristic of an inscription is its being publicly displayed, then copper-plate grants are not inscriptions at all, as they were often found buried for their own safety. On the other hand, copper plates are not archival records either, which were written on palm leaves. Francis' consideration of this special type of written artefact also demonstrates how closely connected archiving occasionally was to changes in the materiality of writing: palm-leaf documents were copied onto more durable copper in order to increase the chances of an archive's survival.

The volume is concluded with an 'Epilogue' by Markus Friedrich, who read the contributions closely and suggests a 'matrix for comparison' stressing the enormous extent to which archiving was part of writing everywhere. After critically evaluating prominent ideas about archives, namely their being modern, related to state power and exerting rationalising effects, he deliberates on the promising concept of 'counter-archival practices', that is, recycling, burying and even destroying archives or parts of them. His matrix includes five perspectives which supply tertia comparationis.

Finally, the editors would like to express their gratitude to all the authors and participants in the inspiring 2014 conference, including those whose contributions have not been included in this volume; to the German Research Foundation (DFG) for its generous support of the Sonderforschungsbereich 950 Manuscript Cultures in Asia, Africa, and Europe; and last but not least to Carl Carter and Jacqueline Bornfleth for their attentive proofreading of many of the contributions and to Cosima Schwarke, who played an essential role in forming a book out of the individual pieces.

The Editors

Hamburg, December 2017 
Prologue: Contemporary Practices of Archiving 



\title{
Dietmar Schenk
}

\section{How to Distinguish between Manuscripts and Archival Records: A Study in Archival Theory}

\begin{abstract}
According to a narrow, classical definition, an archive consists of records of juridical, administrative or commercial activities. In the twentieth century, however, the emerging field of Archival Science increasingly focused on how archives were initially structured, i.e. how records were organised before being transferred to an archive. The archival principle of provenance requires archivists to pay attention to the order given to an archive by its creator. As a consequence, a sort of 'structuralism' elaborated in archival theory has changed the notion of what an archive is. Referring to archival writers from Germany, Britain and the United States and using a type of nineteenth-century German registry as an example, the article examines this concept of an archive as opposed to a manuscript collection and deals with the distinction between manuscripts and archival records, and takes this as a starting-point for comparison.
\end{abstract}

\section{Introduction}

Archival records often pertain to local or at least geographically restricted concerns. Archival holdings are generally related to matters concerning the place where they are kept, and as archives seldom move, the best opportunity of finding your grandparents' marriage records is to turn to the archives of their home town. Many archivists are experts in historical issues related to the archives they administer, so they often deal with regional history.

Archival Science surmounts these limitations insofar as it addresses technical problems and examines the nature of archives and their role in society and culture. Nowadays, the need for standardisation is handled at a global level-the German Archive Portal (Archivportal-D) is based on the XML standard for Encoding Archival Description (EAD), for instance. There is also a worldwide network for the archival community: the International Council on Archives (ICA), established in 1948, promotes the preservation and use of archives all around the

This paper is based on a lecture given in Hamburg on 20 November 2014 at the 'Manuscripts and Archives' Conference held at the Centre for the Study of Manuscript Cultures.

https://doi.org/10.1515/9783110541397-002 (c)BB-NC-ND (c) 2018 D. Schenk, published by De Gruyter. This work is licensed under the Creative Commons Attribution-NonCommercial-NoDerivs 3.0 License. 
world. ${ }^{1}$ Moreover, archivists have been attempting for some years to find a consensus on the main principles of their discipline within an international framework. A Universal Declaration on Archives initiated by the ICA was adopted by UNESCO in 2011 as a result.

However, globalisation has not reached Archival History ${ }^{2}$ yet, at least not in Germany, although the impact of colonialism has become an important issue in recent scholarly debates on archives. Archival Science applies strictly to archival practice $^{3}$ and is hesitant to focus on the bewildering variety of non-European historical phenomena in the archival sphere. Archival History no longer plays a major role on the whole, and up to the middle of the twentieth century, when the scenario was substantially different, archivists did not reflect on the possibility that they might be dealing with an area of interest which crosses continental boundaries. ${ }^{4}$ The archives of ancient Mesopotamia, Greece and Rome were the only exception; they were regarded as preceding the archival landscape of Europe that had emerged since the Middle Ages. ${ }^{5}$

Three years ago, the journal of the Society of German Archivists published an article on 'international archival relations'. ${ }^{6}$ The author, who is President of the Federal Archives, seems to be weary of diplomatic dealings in the field: a great deal of time and energy is required to regularly attend to international contacts, he says. He begins his contemplations with a rather down-to-earth question which is far from enthusiastic about looking abroad: 'Don't we all have enough to do at home?'.

It would thus appear to be a privilege of the theorist to give free rein to their thoughts and let them wander back to the past or roam to another part of the world. To be interested in the history of archives in other parts of the world is a

1 The 1988 Dictionary of Archival Terminology is one of a wide range of publications initiated by the ICA that are worth mentioning. It is still useful today.

2 In the sense of a subdiscipline of Archival Science. On the relevance of Archival History, see Reininghaus 2008.

3 In North America and other parts of the English-speaking world, the archival discourse is currently rather more open-minded about theoretical questions. A useful overview is provided by MacNeil/Eastwood 2017.

4 An interesting case is Brenneke 1953, a major German monograph on archival theory and archival history. In spite of the title of the book announcing a European archival history, the historical account includes non-European regions of the world as well to a certain extent, albeit only those with archives under strong European influence such as those in the United States and South America. Also see Brenneke 2018 and Schenk 2018b.

5 Posner 1972.

6 Hollmann 2014. 
matter of 'intellectual' or 'theoretical curiosity' (Hans Blumenberg) ${ }^{7}$; it is not relevant for professional archivists' everyday work, but it is a fascinating topic nevertheless.

Although the history of archives has not been rediscovered yet as a key area of interest within the scope of Archival Science (at least not in Germany), there is one feature which may be interesting in the present context: a sort of 'structuralism' in archival theory elaborated during the first half of the twentieth century. In what follows, I will explain and discuss this characteristic trait of the discipline step by step. I will argue that archival records are distinct from manuscripts and that there is a difference between archives and collections of manuscripts.

What follows is divided into four sections. Firstly, I will outline what is understood by the term 'archive' today (section 2). Secondly, I will introduce the famous principle of provenance as it was defined at the end of the nineteenth century (section 3). Extending the dialogue between two distinct though overlapping areas, manuscript culture and archive culture, I will discuss the term 'manuscript' from an archivist's point of view (section 4), and finally, the somewhat peculiar structuralist trait of archival theory will be outlined (section 5).

To approach the issue of manuscripts, it is necessary to shed some light on exactly what archives are in order to learn how to distinguish them from collections of manuscripts. A manuscript may be part of an archive, but obviously it does not necessarily have to be. We should take account of the parallels and differences between archival records and manuscripts on the one hand and between archives and collections of manuscripts on the other.

\section{The term 'archive': past and present}

Historians, philologists, archaeologists and scholars of other disciplines are not archival professionals and are not generally familiar with archival practice and its specialist terminology. It can be assumed that they take recourse in a colloquial understanding of the term 'archive' when dealing with archives related to their particular field of interest. They are likely to have reflected on whether the concept of the archive they have in mind is appropriate for their specific purposes, and will be forced to modify it slightly if it is not. If they are able to draw upon literary sources, they can take up what was said there. As specialists in the

7 Blumenberg 1973. 
field of manuscript cultures, some researchers will take it for granted that archival records represent a certain type of manuscript and that archives can be defined as a type of manuscript collection. Nowadays, they tend to pick up the concepts of a 'new' kind of archival thinking that has emerged over the last few decades, influenced particularly by French philosophy. ${ }^{8}$ In his 1969 treatise on the Archaeology of Knowledge, Michel Foucault speaks of the archive as the 'general system of the formation and transformation of statement', for example. ${ }^{9}$ This notion is highly metaphorical and speculative. Foucault stated that it was not his intention to refer to materials left over from a bygone era, and he did not distinguish between libraries and archives either. In my opinion, his perspectives do not help in the current context. ${ }^{10}$

Foucault's unconventional use of the term 'archive' was taken up by Jacques Derrida two-and-a-half decades later. Derrida's famous 1995 book entitled Mal d'Archive in French (Archive Fever) inspired extensive debate. ${ }^{11}$ With his interest in psychoanalysis, Derrida is in danger of playing down the differentiation between memory and archive. When individuals or communities remember the past, they transform their memories in the course of time against the backdrop of a continually changing present. Psychologists or sociologists might seek to explain these phenomena. Yet it is useful to reserve the term 'archive' for physical objects which are remains of the past and may be discovered as traces of previous events or circumstances. Archival records are in any case authentic relics.

Therefore, it seems appropriate to return to the old, narrow definition of an 'archive' as a holding of juridical, administrative and commercial records. This means that archival records are defined by the sphere of life from which they originate. Not all documents which appear in the context of administrative, juridical or commercial affairs necessarily find their way into an archive-there may be documents which are less important or not even filed at all. Nowadays, archivists have to appraise the vast amount of documents and data being produced today: not all of them have a long-lasting value, so they will select some of them and destroy the rest. Nevertheless, these materials are at the core of archival holdings.

The spheres of literacy mentioned above-administration, jurisdiction and commerce-have something in common: all of the records which originate in

8 See Ebeling/Güntzel 2009. Lepper/Raulff 2016 provide a summary of the recent debates on archives from a German perspective.

9 Foucault 1969.

10 For a broader discussion on the issue, see Schenk 2014. The ideas of Foucault and Derrida have been taken up by archivists in a multi-faceted way. An inventive contribution comes, for instance, from the South African archivist Verne Harris 2007. Also see Cook 2001.

11 Derrida 1995. 
these fields belong to 'pragmatic literacy', as the mediaevalist Hagen Keller termed it. ${ }^{12}$ Documents have a good chance of surviving the rigours of time if the conduct of affairs is organised, at least to a certain extent. This is the case with state archives. However, even a family might possess their own archive (without employing an office clerk). Some archives are very small; all the old documents in someone's possession might be contained in a box just a few inches in size. ${ }^{13}$ In contrast, modern archives used to be measured in linear metres of shelf space and comprise hundreds and thousands of files. They are usually 'an archive of archives', in the sense that holdings of different provenance come together in a larger-scale archival institution.

Furthermore, a modern archive collects documents to complete its holdings, which may be recognised as historical sources in the future. Nowadays, it is disputed that collecting is merely supplementary to archiving in the narrow sense of acquiring records from administrative contexts.

There is a further distinction which is worth mentioning here, too: a registry is different to an archive. The place where documents are kept in an office or in the office responsible for an organisation's information pool is called a registry. Documents from the registry are passed on to the archive when they are no longer in regular use. In this case, the aim of preserving the documents becomes just as important as the opportunity to access them. However, the difference between a registry and an archive need not be particularly distinct; the two are often combined, with one person responsible for both. It is therefore quite common to speak of a registry as an archive.

In Europe, many centuries of history have resulted in highly complex archives being created. The development of archives went hand in hand with the expansion of literacy. They preserve products of pragmatic literacy, which spread widely-approximately since the twelfth century in Italy and most often later in other parts of Europe. During the Early Modern Period, archives were 'armouries' of judicial documents: old rights had priority in legal disputes. Historical expertise was required long before writers of history such as Leopold von Ranke understood themselves as 'researchers'. In the nineteenth century, the archive was discovered by historiography as a main resource. Although antiquarians already used archival records in the seventeenth century, the historical use of archives increased rapidly after the epoch of the French Revolution. Today, public archives are accessible to everyone; they serve as 'institutions of memory' for civil

12 Keller 1992.

13 I recently described a private archive of this type belonging to an unknown woman who lived in Neustettin, a small town in eastern Germany, in the nineteenth century. See Schenk 2015. 
society. A characteristic feature of the archive after the transition from the Ancién Regime to modern times is that documents lost their primary administrative and legal function and became sources of history. As relics they seemed to directly reveal the past, so to speak. ${ }^{14}$

Archivists have been building up their own expertise for a long time. Archival theory, in the limited sense of being a type of instruction guiding the registrar, has existed ever since the sixteenth century. The development of archival studies in the nineteenth century led to the establishment of special schools focusing on teaching diplomatics, like the École des Chartes in Paris (founded in 1821) and the Institute of Austrian Historical Research in Vienna (founded in 1854). As it turns out, these institutions ended up training future archivists as well as diplomats.

It may widen the scope of all researchers dealing with archives to know how archivists approach archival issues. It is important to recognise that their starting point is not generally an investigation of individual records or types of records; instead of focusing on individual documents such as a manuscript, they are concerned with groups of records, some of which are referred to as 'archives'. There is a wide range of types of records that can belong to an archival holding, such as files, books, deeds, maps, pamphlets, posters and photographs. ${ }^{15}$ Yet archivists do not like to define their areas of responsibility according to particular types of archival material for practical reasons: if documents or even artefacts are part of a group of items, they should not be split up; a forged coin may belong to a juridical file as evidence of what happened, and a children's violin to an estate as a treasured keepsake and souvenir. They should not be separated.

\section{The principle of provenance and its impact}

Thus, one important feature of an archive is that all the records that belong to it are strongly interconnected. In the past, archivists liked to use organic metaphors to address this key point: an archive was not artificial, but 'natural'. They suggested that the 'organic unity' of the archive expressed the life of the organisation or the organism which created it. Other metaphors used in the same context are 'body' and 'organic growth', for instance.

These metaphors were widespread in the era of Romanticism. German archivists were as familiar with them as Dutch or English archival writers. They all

14 For a histoire problème of the societal functions of archives, see Schenk 2013.

15 The wide range of archival sources is being investigated by Beck/Henning 1994. 
spoke of 'organic growth' in order to characterise archiving processes as a whole. ${ }^{16}$ The most fundamental concept of archival thinking-the principle of provenance-is based on this understanding of the archive. In general, it demands that an archive should be preserved in the order given to it by its creator; any exemptions or modifications must be justified. It even makes sense to reconstruct the original order in some cases.

In 1898, the Dutch archivists Samuel Muller, Johan Adriaan Feith and Robert Fruin published a manual presenting a practical method of describing and arranging archives according to this principle. ${ }^{17}$ It was translated into several languages, and a resolution adopted at a conference of European archivists in Brussels in 1910 approved the principle of provenance in a single vote. Nowadays, the emergence of a type of archival thinking based on this tenet is seen as a turning point in modern archival theory. ${ }^{18}$

An episode in German intellectual history may serve to illustrate the lasting significance of the principle of provenance. Friedrich Meinecke (1862-1954), a renowned German historian, ${ }^{19}$ started his career as an archivist at the Prussian Privy State Archives in Berlin (Geheimes Preußisches Staatsarchiv) and worked there for fourteen years. He took up his position just a few years after the principle of provenance was introduced in $1881 .^{20}$ The original order had already been destroyed in this case, however-by archivists, of all people. Some records, for example, originally belonged to a registry of the Prussian king Frederick William III, organising the affairs of his Cabinet. This small registry had existed separately from other record offices of the Prussian government and its ministries, which were larger. When records of this kind were transferred to the archive, they were not regarded as an autonomous archival holding and were filed according to the classification scheme applied to all archival material. To make matters worse, this scheme had its origins in the seventeenth century and did not match current requirements any more. The procedure of 'filing' according to a category is wrong, according to advocates of the principle of provenance.

16 For example, Brenneke 1953, 20.

17 Muller/Feith/Fruin 1898. (Translation of the second Dutch edition by Leavitt 1940, ${ }^{2} 1968$. )

18 This is the reason why a recent survey of archival theories starts with the Dutch Manual. See Ridener 2009.

19 Meinecke was a teacher of no less than a dozen emigré historians, ranging from Hans Baron to Felix Gilbert. They all stayed in touch with their teacher long after having gained their university degrees and wrote letters to him from across the Atlantic until he died. See Ritter 2006. An overview of his life and work is given by Bock/Schönpflug 2004.

20 See his autobiographical records in Meinecke 1941, 142-143. 
Young Mr Meinecke was asked to reconstruct the registry of the Cabinet. This was only achievable with the help of the reference numbers and notes from the registry on each file. He had to search for the files that were distributed among the various categories of the classification schedule, and restored the original arrangement as a separate archive.

Meinecke enthusiastically embraced the shift in archival thinking, which he got to know as an archival practitioner. He saw the new way of archiving as a consequence of the historicist paradigm ${ }^{21}$ and called it a 'revolution'. He had the impression that the past had come alive, and was delighted to have been part of this experience and be witness to the changing times. He wrote: 'The idea now realised by investing all available manpower brought an incredible amount of vividness and individuality into the archive. Each registry became a living thing of its own, with its own rule of life, and individual human beings with their particular traditions and impulses came to light'. ${ }^{22}$

What did this type of registry look like? At this point, I would like to give an example to illustrate how they were constructed. It is taken from the archival holdings of which I am custodian and is a typical Sachaktenregistratur, that is, a registry arranged according to a set of subjects. At the end of the nineteenth century, the office of the Academy of Arts in Berlin was managed by a single official who was responsible for every aspect of the administration. The registry was stored in a cupboard. The official placed all incoming letters, copies of outgoing letters, notes and minutes on the shelves. Each shelf was reserved for a certain subject belonging to a 'plan of files'. Gradually, a small stack accumulated on each shelf, containing papers categorised by subject matter and arranged in chronological order within each category. Each file was inserted into a cover or 'lid' and bound as soon as a stack was large enough. The reference number and title were put on the side of the cover.

These files only make up half of the registry, however. In addition, all the papers were recorded in a handwritten book: an annual register known as a 'diary of letters' or journal in French. Each entry starts with the name and address of the sender of an incoming letter, and its subject matter is mentioned thereafter. This is followed by a summary of how the administration reacted, with a summary of the answer provided in the corresponding outgoing letter. Finally, the reference number was noted down so that the official was able to find the original letter on

21 For a modern perception of German historicism, see Beiser 2011. It was Meinecke who discussed the emergence of historicism in a 1936 monograph.

22 Meinecke 1941, 141 (translation by the author). For further details, see Schenk 2013, 117-120. 
file. In addition, the registration number was written on each sheet of paper in the file, and a draft of the answer could be found, usually on the reverse.

What I wish to emphasise by explaining this precise method of registration is just how closely the individual papers or documents are bound together, not just physically, but logically. This old-fashioned and complicated registry is in some ways similar to a modern database. The material files or books which belong to an archived registry are 'archival units', as archivists refer to them, but as logical units they are less independent than what archivists would call a manuscript. A file of this type can be compared with one volume of a multi-volume dictionary comprising only the letter ' $C$ ' or ' $D$ '. This is clearly insufficient if you also need the letter ' $E$ ' or ' $F$ '. In other words, it is impossible to remove one piece without destroying the whole thing.

\section{Manuscripts and archival records}

Having sketched some of the main characteristics of an archive, I will now turn to the subject of manuscripts. Archival Science has adopted this term, but it is still a little unfamiliar to traditionalists as it is understood to allude to the manuscript department of libraries. The word covers a specific category of documents: they are handwritten, unlike a typescript, ${ }^{23}$ and contain drafts or autographs of a work or part of a work. It need not be a masterpiece, but it must at least be possible to identify an individual creator. Manuscripts often belong to the personal papers of writers, scholars or artists. In contrast, files are generated by a process involving several people.

The rules of cataloguing literary estates and autographs as defined by librarians distinguish between four types of document: manuscripts, correspondence, records of personal life and collected materials. ${ }^{24}$ It would be wrong to dogmatise this typology, however. From the archivist's viewpoint, these terms can be useful in order to characterise certain documents, but it is not advisable to arrange an archive or the estate of a writer or scholar according to this type of pattern since

23 However, it is sometimes used as a generic term for types of documents, handwritten texts and typescripts.

24 Regeln für die Katalogisierung von Nachlässen und Autographen (RNA) (Rules for Cataloguing Personal Papers and Autographs) 2010 (http://kalliope-verbund.info/_Resources/Persistent/5bf5cd96ea4448bfec20caf2e3d3063344d76b58/rna-berlin-wien-mastercopy-0802-

2010.pdf). 
the arrangement should preserve the structure discovered within the materials; in fact, classically trained archivists try to avoid any kind of schema at all.

While the term 'manuscript' has never played a role in German archival theory, in the United States a curator of historical collections at a university is called an archivist and the documents kept are called manuscripts. ${ }^{25} \mathrm{~A}$ pioneering American archival theorist, Lester J. Cappon (1900-1981), who had the job of administering this type of archive, ${ }^{26}$ came to terms with 'manuscripts' as a type of archival record. He refers to Hilary Jenkinson (1882-1961), a major English archival writer, who was a historian and archivist at the Public Record Office in London for nearly half a century and taught palaeography and archival practice at various institutions in London. In 1922, Jenkinson published A Manual of Archive Administration. ${ }^{27}$ In search of viable definitions, Cappon reverted to Hilary Jenkinson and accepted his definition of archives as 'Documents drawn up for the purposes of, or used during, the conduct of Affairs of any kind, of which they themselves formed a part, and subsequently preserved by the persons responsible for the transactions in question, or their successors, in their own custody for their own reference'. ${ }^{28}$

It is characteristic of Jenkinson's concept of the archive that he links the principle of provenance with unbroken custody. If an office builds up an archive but subsequently loses control of it, some of the documents might get lost and those that survive might get scattered. In Jenkinson's opinion, these 'leftovers' are no longer archival. In a further explanation, Jenkinson refers to the difference between 'archives' and 'collections' and tries to point out why this distinction is so important. He stresses: 'Archives are not Documents collected artificially like objects in the Museum [...], but accumulating naturally in Offices for the purposes of Administration'.29

25 See Berner 1983 on the historical manuscript tradition in the United States. It would be interesting to compare this tradition to the archives of literature in Germany, most of which are curated by librarians and scholars, not by archivists. See Schenk 2018a.

26 Cappon started his career as an archivist at the University of Virginia where he was appointed in that specific role. Later on, he became heavily involved in field collecting and historical research; he spent his whole career editing historical documents and is the author of several leading reference works. He was also President of the Society of American Archivists. See Cox 2004. 27 Jenkinson 1922, rev. ed. 1937. Also see Jenkinson 1980.

28 Public Record Office 1949, 2. Also see Cappon 1956, 102, and Cox 2004, 36.

29 Public Record Office 1949, 2. Also see Cappon 1956, 103, and Cox 2004, 36. The Canadian archivist Luciana Duranti refers to the cited text passage in her reading of Jenkinson as well. See Duranti 1997, 335. 
Cappon chose the daring title 'Historical Manuscripts as Archives' for one of his articles. ${ }^{30}$ But how does his suggestion that a collection of historical manuscripts might be called an archive fit in with Jenkinson's definition of an archive with which Cappon, on the whole, agrees? Cappon analyses the historical collections he is so familiar with and discovers that they are partly archival. Beyond that, the collector's policy aspires to get closer to what constitutes an archive: a vast number of documents which belong together and ideally allow a precise historical account of a matter to be reconstructed.

Concerning the definition of the term 'archive', Cappon rejects just one element: the insistence on unbroken custody. He observes that, in most instances, the custody of bodies of historical papers is broken when they are transferred to manuscript repositories; he refers to this type of repository as an archive nevertheless.

Therefore, Cappon defines historical manuscripts as 'records of historical value, written by hand or typewriter or its equivalent (as distinguished from printed records), in single or multiple form'. With reference to the concept of the archive, he states that '[h]istorical manuscripts can be classified in three categories: (1) bodies or groups of papers with organic unity, in the nature of archives, personal or institutional; (2) artificial collections of manuscripts acquired by a private collector from various sources, usually gathered according to plan but without respect des fonds; ${ }^{31}$ (3) individual manuscripts acquired by the repository for their special importance to research and comprising a collection of what, for want of a better term, are sometimes called miscellaneous manuscripts. ${ }^{32}$ Cappon indicates that the arrangement of a registry of non-current records is not always lost when the chain of custody is interrupted; transferring the registry to another archive or to a historical collection might be a means of safeguarding it.

Furthermore, the curator of a historical collection or research library might have developed a plan of collecting with a sound historical basis. He knows that his richest material consists of bodies of related papers belonging to individuals, families, organisations or institutions, in their original order of arrangement, 'as the hypothetical archivist of any one of them would have preserved them'. ${ }^{33}$ Thus, he is eager to access holdings of an archival nature in this broader sense from a network of owners. Acquiring material in this way, the collection comes closer to

30 Cappon 1956. Reprinted in Cox 2004, 35-42.

31 Respect des fonds is the French term for a specific interpretation of the principle of provenance.

32 Cappon 1956, 104-105, and Cox 2004, 36.

33 Cappon 1956, 103, and Cox 2004, 37. 
being an archive. At this point, the principle of provenance intermingles with what I would call the principle of context..$^{34}$

Finally, the barrier between an 'official' and a 'private' document is not as rigid as it initially seems in Cappon's view, and it should not be a decisive criterion. The withdrawal of records that a retiring official presumes to be his personal property has occurred most often in high administrative positions of government. Cappon concludes that 'the reputable curator of manuscripts must be an archivist at heart to do his job well'. ${ }^{35}$

\section{A kind of structuralist approach}

A small introductory book on archival studies written by Eckhart G. Franz (19312015), a former director of the State Archive of Hessen in Darmstadt near Frankfurt, ${ }^{36}$ refers to the changes in the concept of an archive that have taken place over the last two centuries: 'The previous limitation of the archive to scripturae publicae, to juridical and administrative materials, was dropped long ago. Archivists preserve and take care of all written, visual and sound records which manifest the activities of offices of the state or non-governmental institutions, of associations, companies or individual persons as far as they are worthy of being permanently preserved on the basis of their juridical, administrative, historical, technical, scientific or artistic relevance as sources' ${ }^{37}$

It is obvious that Franz extends the field of archival records in a similar way to Cappon and he reflects on the history of archiving. For further clarification, he presents numerous examples underlining the broader notion of the archive and demonstrating that various types of records may belong to an archive. If the term 'archival record' tends to be ubiquitous, the question arises of how to limit its proliferation. Franz's proposal is convincing. In order to distinguish between an archive and a library or museum, he points out: 'It is not the difference between handwriting, prints and objects that distinguishes an archive from a library or museum. More important than this crude distinction is the particular structure of naturally accumulated archival materials ${ }^{38}$ Franz sticks to organic metaphors

34 It is beyond the scope of this article to touch upon the notion of provenance as it was discussed recently in North America. See Douglas 2017 for coverage.

35 Cappon 1956, 110, and Cox 2004, 42.

36 Franz 1990.

37 Franz 1990, 1-2 (translation by the author).

38 Franz 1990, 2 (translation by the author). 
and, to a certain extent, radicalises the archivist's eschewal of collecting by redefining the archive as a structure.

It is typical of structural features that they are not limited to a particular cultural environment. Archives from one period might be similar to archives from a totally different era, while archives from one region of the world might resemble those from a completely different area. One archivist who was fully aware of this comparative perspective was Ernst Posner (1892-1980). He became acquainted with archives on both sides of the Atlantic during his career.

Posner was employed as a Prussian state archivist in the era of the Weimar Republic, but after the Nazis seized power, he fled to the United States where he made an important contribution to the professional training of American archivists. ${ }^{39}$ In later years, Posner was able to travel widely in Europe and other parts of the world where he studied the history of archives intensively. The only volume of a planned history of the archives of the Western world he completed dealt with the archives of the Ancient World, comprising archives of clay tablets. ${ }^{40}$ During the post-war period in Germany, Posner was invited to teach at the Archivschule in Marburg as a visiting lecturer. A farewell ceremony was held at the end of his time there and his students surprised him by building a brick wall. This may seem like a strange idea at first, but it was supposed to allude to one of his favourite pedagogical examples: the clay tablets of five thousand years ago, which he used as a model to explain the structure of archives. ${ }^{41}$

We do not know exactly how Posner referred to the archival significance of clay tablets during his lessons, which were aimed at preparing students to understand and critically engage with archives in present-day Europe. But in any case, he drew parallels across extremely wide stretches of time. I have attempted to explain the mode of archival thinking that allows us to identify these kinds of similarities as it has proved to be a powerful tool: it serves to appraise, describe, arrange, locate and interpret archival records and even to define the nature of an archive. Many archivists share this way of thinking, and it might also be developed as a tool for comparative studies.

39 See Posner 1967. For an account of Posner's individual fate as one of the few Jews who worked as archivists in Prussia and an appreciation of his merits, see Menne-Haritz 2015.

40 Posner 1972.

41 See Posner 1967, 23. 


\section{References}

Beck, Friedrich, and Eckart Henning (eds) (1994), Die archivalischen Quellen. Eine Einführung in ihre Benutzung, Weimar: Böhlau (5th rev. ed. 2012).

Beiser, Frederick C. (2011): The German Historicist Tradition. Oxford: University Press.

Berner, Richard C. (1983), Archival Theory and Practice in the United States: A Historical Analysis. Seattle: University of Washington Press.

Blumenberg, Hans (1973), Der Prozess der theoretischen Neugierde, Frankfurt/M.: Suhrkamp. Bock, Gisela, and Daniel Schönpflug (eds) (2006), Friedrich Meinecke in seiner Zeit. Studien zu Leben und Werk. Stuttgart: Franz Steiner.

Brenneke, Adolf (1953), Archivkunde. Ein Beitrag zur Theorie und Geschichte des europäischen Archivwesens, edited by Wolfgang Leesch, Leipzig: Koehler \& Amelang. (2nd ed. 1988)

Brenneke, Adolf (2018), Die 'Archivartikel'. Schriften zur Theorie und Geschichte der Archive, edited by Dietmar Schenk, Hamburg: University Press.

Cappon, Lester J. (1956): 'Historical Manuscripts as Archives: Some Definitions and Their Application', in American Archivist, 19, 101-110.

Cook, Terry (2001), 'Fashionable Nonsense or Professional Rebirth: Postmodernism and the Practice of Archives', in Archivaria, 51, 14-35.

Cox, Richard J. (2004), Lester J. Cappon and the Relationship of History, Archives, and Scholarship in the Golden Age of Archival Theory, Chicago: Society of American Archivists.

Derrida, Jacques (1995), Mal d'archive: Une impression Freudienne. Paris: Éditions Galilée. Translation by Eric Prenowitz, published as Archive Fever, Chicago, 1996.

Dictionary of Archival Terminology / Dictionnaire de terminologie archivistique. English and French, with Equivalents in Dutch, German, Italian and Spanish (1984), Munich: Saur (2nd, rev. ed. 1988).

Douglas, Jennifer (2017), 'Origins and Beyond: The Ongoing Evolution of Archival Ideas about Provenance', in Heather MacNeil and Terry Eastwood (eds), Currents of Archival Thinking, Santa Barbara, CA: Libraries Unlimited.

Duranti, Luciana (1994), 'The Concept of Appraisal and Archival Theory', in American Archivist, 57, 328-344.

Ebeling Knut, and Stephan Güntzel (eds) (2009), Archivologie. Theorien des Archivs in Wissenschaft, Medien und Künsten, Berlin: Kulturverlag Kadmos.

Foucault, Michel (1969), L'archéologie du savoir, Paris: Éditions Gallimard. Translation by A. M Sheridan Smith, published as The Archaeology of Knowledge (London and New York, 2002).

Franz, Eckhardt G. (1990), Einführung in die Archivkunde. 3rd, rev. ed. Darmstadt: Wissenschaftliche Buchgesellschaft.

Harris, Verne (2007), Archives and Justice. A South African Perspective, Chicago: Society of American Archivists.

Hollmann, Michael (2014), 'Internationale Archivbeziehungen: Einführende Bemerkungen', in Archivar, 67, 338-340.

Jenkinson, Hilary (1922), A Manual of Archive Administration, London: P. Lund, Humphries \& Co., Ltd. (rev. ed. 1937).

Jenkinson, Hilary (1980), Selected Writings of Sir Hilary Jenkinson. Edited by Roger H. Ellis and Peter Walne. Gloucester, England: Alan Sutton Publishing Ltd. 
Keller, Hagen (1992), “Vom “heiligen Buch” zur “Buchführung”. Lebensfunktionen der Schrift im Mittelalter', in Frühmittelalterliche Studien, 26, 1-31.

Lepper, Marcel, and Ulrich Raulff (eds) (2016), Handbuch Archive. Geschichte, Aufgaben, Perspektiven. Stuttgart: Metzler.

MacNeil, Heather, and Terry Eastwood (2017), Currents of Archival Thinking, Santa Barbara, CA: Libraries Unlimited.

Meinecke, Friedrich (1936), Die Entstehung des Historismus. 2 vols, Munich, Berlin: Oldenbourg (2nd ed. 1959).

Meinecke, Friedrich (1941), Erlebtes 1862-1901, Leipzig: Koehler und Amelang.

Menne-Haritz, Angelika (2015), 'Ernst Posner. Professionalität und Emigration', in Sven Kriese (ed.), Archivarbeit im und für den Nationalsozialismus. Die preußischen Staatsarchive vor und nach dem Machtwechsel 1933, Berlin: Duncker \& Humblot, 111-141.

Muller, Samuel, Johan Adriaan Feith and Robert Fruin (1898), Handleiding voor het ordenen en beschrijven van archieven, Groningen: Erven B. van der Kamp. Translation of the second Dutch edition 1920 by Arthur H. Leavitt, published as Manual for the Arrangement and Description of Archives (New York, 1940, ${ }^{2} 1968$ ).

Posner, Ernst (1967), Archives and Public Interest. Selected Essays, Washington: Public Affairs Press (2nd ed. Chicago 2006: Society of American Archivists).

Posner, Ernst (1972), Archives in the Ancient World, Cambridge, Mass.: Harvard University Press

Public Record Office (1949), Guide to the Public Records, Part I: Introductory, London: Public Records Office, 1949.

Regeln für die Katalogisierung von Nachlässen und Autographen (RNA) (2010), http://kalliopeverbund.info/_Resources/Persistent/5bf5cd96ea4448bfec20caf2e3d3063344d76b58/ rna-berlin-wien-mastercopy-0802-2010.pdf.

Reininghaus, Wilfried (2008), 'Archivgeschichte. Umrisse einer untergründigen Subdisziplin', in Archivar, 61, 352-359.

Ridener, John (2009), From Polders to Postmodernism: A Concise History of Archival Theory, Duluth, Minnesota: Litwin Books, LLC.

Ritter, Gerhard A. (ed.) (2006), Friedrich Meinecke, Akademischer Lehrer und emigrierte Schüler. Briefe und Aufzeichnungen 1910-1977, Munich: Oldenbourg.

Schenk, Dietmar (2008), Kleine Theorie des Archivs, Stuttgart: Franz Steiner Verlag (rev. ed. 2014).

Schenk, Dietmar (2013), 'Aufheben, was nicht vergessen werden darf'. Archive vom alten Europa bis zur digitalen Welt, Stuttgart: Franz Steiner Verlag.

Schenk Dietmar (2014), 'Pouvoir de l'archive et vérité historique', in Écrire l'histoire, 13/14, 3553.

Schenk, Dietmar (2015), 'Archiving. On the Staying Power of the Art of Preservation', in Barbara Segelken (ed.), The Art of Preservation, Mettingen: Draiflessen Collection, 18-23.

Schenk, Dietmar (2018a), 'Getrennte Welten? Literaturarchive und Archivwissenschaft', in Petra-Maria Dallinger and Klaus Kasterger (eds), Archive für Literatur. Der Nachlass und seine Ordnungen, Berlin, New York: De Gruyter (forthcoming).

Schenk, Dietmar (2018b), 'Adolf Brenneke', in Luciana Duranti and Patricia Franks (eds), Encyclopedia of Archival Writers 1550-2015. Lanham, MD: Rowman \& Littlefield (forthcoming). 



\title{
Archives from Tibet and the Himalayan Borderlands: Notes on Form and Content
}

\begin{abstract}
While Tibetan literary production generally evokes images of clothbound loose-leaf longbooks filling the shelves of monasteries, the culture also has a well-developed, though less widely known, archival tradition. The documents that make up these archives differ from books with respect to terminology, form, script, content and storage. Archival literature has received relatively little scholarly attention, but it nevertheless constitutes a vitally important source for our understanding of domains such as law, taxation and social history. Archives from Central Tibet tell us about the relations between authorities-mainly the government, the church and the aristocracy-and the peasantry; but it is mainly thanks to archival collections from culturally Tibetan areas in countries adjacent to China (notably India and Nepal) that we can obtain a privileged insight into the lives of local communities in past centuries.
\end{abstract}

\section{Books and documents}

Certain cultures make no categorical difference between a library and an archive. This is not the case of Tibet, which distinguishes between the two in terms of systems of storage, the material aspects of the texts in question, the types of script used and their subject matter. As far as books are concerned, Tibetan distinguishes between two main kinds. One, known as pecha (dpe cha), ${ }^{1}$ is the traditional looseleaf longbook, sometimes referred to as the pothi format after the Indian term for the model on which it was based. The Indian prototype is made out of palm leaves, and it is this form that the Tibetan longbook reproduces in paper. The folios of Indian books were kept in order by a pair of strings that passed through their entire thickness. Tibetan books do not have these strings, but some books-especially certain larger-format categories of canonical works-have two small circles drawn on each folio as a sort of pious vestige

Part of the research on which this article is based was carried out in the framework of two FrancoGerman (ANR/DFG) projects: 'The Social History of Tibetan Societies, $17^{\text {th }}-20^{\text {th }}$ Centuries' (20122016) and 'Social Status in the Tibetan World' (2016-2019).

1 Tibetan terms will be presented in a roughly phonetic form, followed by an orthographic transliteration at their first occurrence.

https://doi.org/10.1515/9783110541397-003, (c) BY-NC-ND () 2018 Ch. Ramble, published by De Gruyter. This work is licensed under the Creative Commons Attribution-NonCommercial-NoDerivs 3.0 License. 
of the ancestral design. The other type of book is the modern Western-style book, known as dep (Tib. deb). The term dep is an abbreviation of the older depther (deb ther), 'records' or 'annals'. Deb ther corresponds to the Persian and Arabic daftar, meaning the same thing, and daftar is in turn derived from the Greek diphthera, 'skin'-a writing surface. Since the form and content of deb and the systems used for storing them are not significantly different from those that are familiar in the case of Western books, they will not concern us here. Pecha are now produced by modern methods, such as laser printing or, in India until relatively recently, offset lithography. Traditionally, however, they were of two types: blockprints and manuscripts, production methods that continue even now to be widely used.

Certain fantastic claims to the contrary notwithstanding, all forms of the Tibetan script are derived from a seventh-century Indian model known as Gupta or Late Brahmi. Over the course of centuries, more rounded and eventually a true cursive form of the script developed. Nearly all blockprints and many manuscripts feature the 'headed' Tibetan script, ucen ( $d b u$ can), though many manuscripts also use one or another of several more rounded, 'headless' ume ( $d b u$ med) varieties.

Pecha volumes are often wrapped in a cloth called pere (dpe ras, 'pecha cloth'). The volume is then sandwiched between two wooden boards, which are often quite lavishly decorated objects, and then tightly bound with a cloth or leather strap. If they are pressed between boards in this way, the cloth wrapping is sometimes dispensed with. Pecha are normally stored either in the temples and assembly hall of a monastery, or in a library, pendzökhang (dpe mdzod khang, lit. 'treasury of books'), a term that is also used for libraries of modern Western-style books. The storage shelves for pechas are adapted to their general form and the particular size of certain volumes, and are therefore relatively deep. The shelves usually consist of open wooden frames with a pigeonhole for one or more volumes, and the volumes themselves are stored so that they are perpendicular to the wall against which the shelves stand. The contents of the volume are identified by a cloth label tucked into the wrapping and displayed on the end, sometimes covered by a cloth flap that can be lifted to reveal the information beneath. Pecha are used for a vast array of subjects: religious and philosophical treatises, rituals, histories, biographies, scientific works and many other topics besides. The paper used for making pecha tends to be relatively rigid, an advantage in the case of liturgical texts in that it permits monks and priests to turn folios easily with one hand, while leaving the other free to manipulate ritual objects and musical instruments in the course of a ceremony. Thickness is sometimes obtained by gluing several layers together.

To these features of pecha we may contrast the kind of material that one is likely to find in a Tibetan archive. In short, these are all documents, known as yikcha or yiktsak (yig cha, yig tshags). They do not consist of longbook-style folios, but 


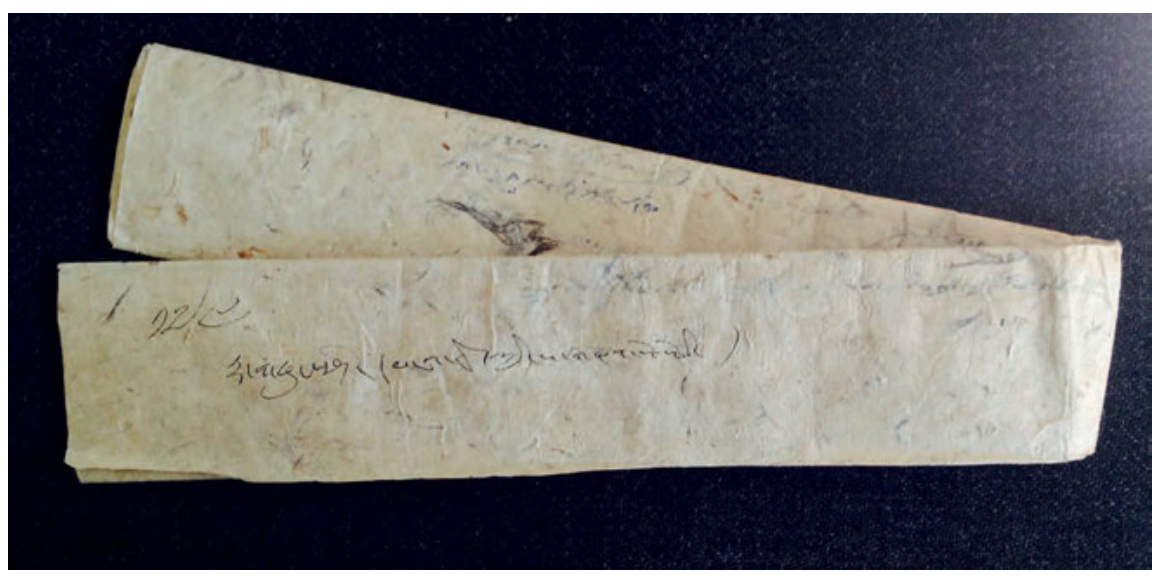

Fig. 1: Folded document from western Tibet. Photo: Charles Ramble.

are usually written on a single side of a sheet of paper. The size and shape of such sheets varies considerably. A receipt for a donation to a monastery, for example, may require just two or three lines of text. Typically, such a receipt will have a foreshortened 'landscape' format, perhaps five centimetres or so along its vertical axis, and twenty centimetres wide. Longer documents tend to be in 'portrait' format, and if more space is required, further sheets are glued to the ends of those that have been filled. Documents that have been extended in this way may measure several metres in length. The paper for documents is much thinner than that preferred for pechas. It generally consists of a single layer, and the plants that are sometimes used-such as Stellera spp.--produce a softer and more pliable material. Documents are stored by folding them horizontally, beginning roughly a centimetre from the end, and working upwards. It is common practice to begin writing a document several centimetres from the top of the sheet, so that the blank section can be wrapped around the folded document to form a protective envelope. Once the series of horizontal folds has been completed, the document, which now resembles a flattened scroll, is folded in half along a vertical axis, and a brief note about its contents may be inscribed on the outside (Fig. 1).

Documents are occasionally folded concertina-style, but this is something of a rarity. Other forms of documents include booklets made by folding a set of pages in half along a horizontal axis and stitching them together along the fold. This format, which is sometimes referred to as the depther style, may serve a wide range of genres. As the name indicates (see above), it is often used for records of one sort or another, such as tax payments and liabilities, endowments for rituals, and legal manuals. However, the generic range is not restricted to texts that one 
might typically find in archives, and may include historical and didactic works that were intended for public recitation. These volumes tend to be quite small, and may have been designed for ease of transportation and to be held while the reader was standing in a public assembly.

Less commonly, the stitching may bind the pages at the left margin to resemble a Western-style book, although the pages have the shape of longbook folios rather than a 'portrait' format. Stitched texts of this sort are also commonly used for almanacs as well as manuals for divination and astrology.

It is common practice to protect documents with cloth or leather reinforcement. In the case of single-sheet documents, the paper may be pasted onto a silk backing, and the procedure for folding the document will be the same as if it were unprotected. Stitched books, too, may have covers, consisting of cotton or silk cloth or, more rarely, leather.

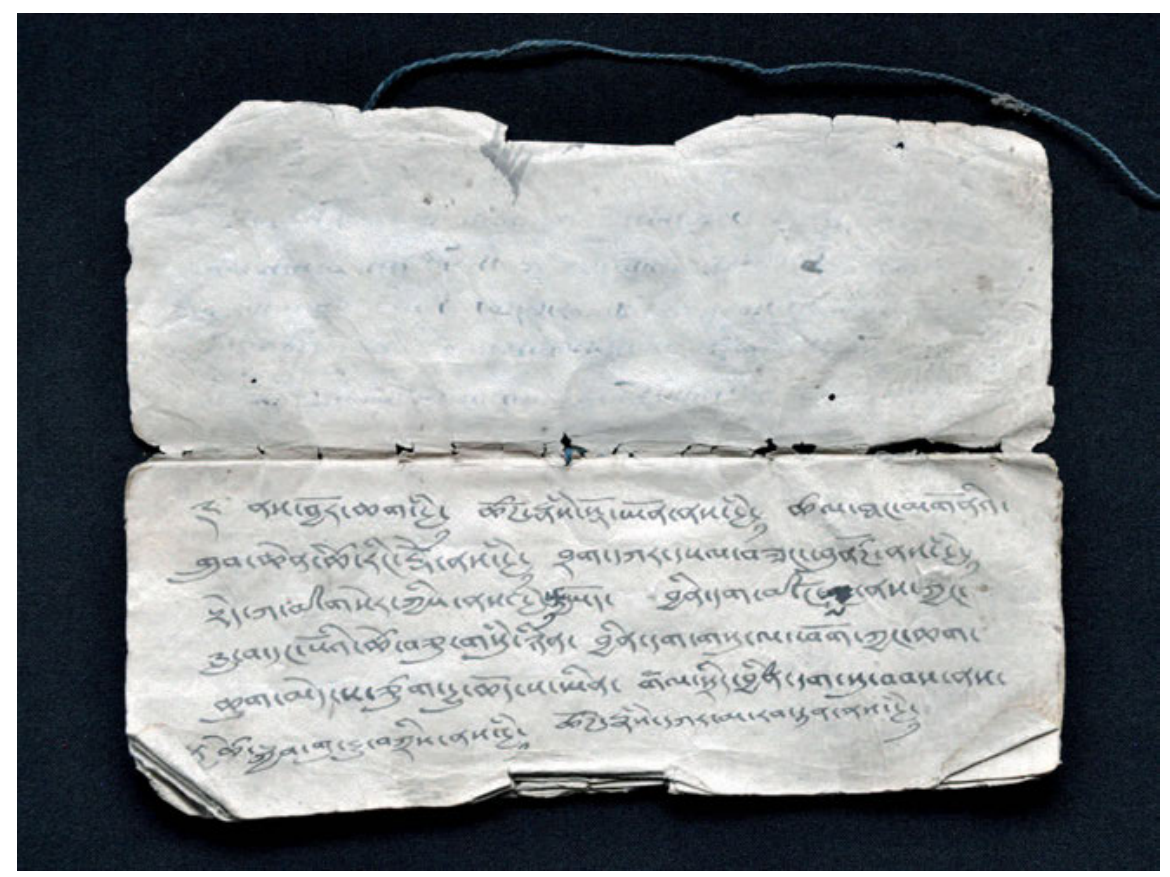

Fig. 2: Depther style register from southern Mustang, Nepal. Photo: Agnieszka Helman-Ważny. 


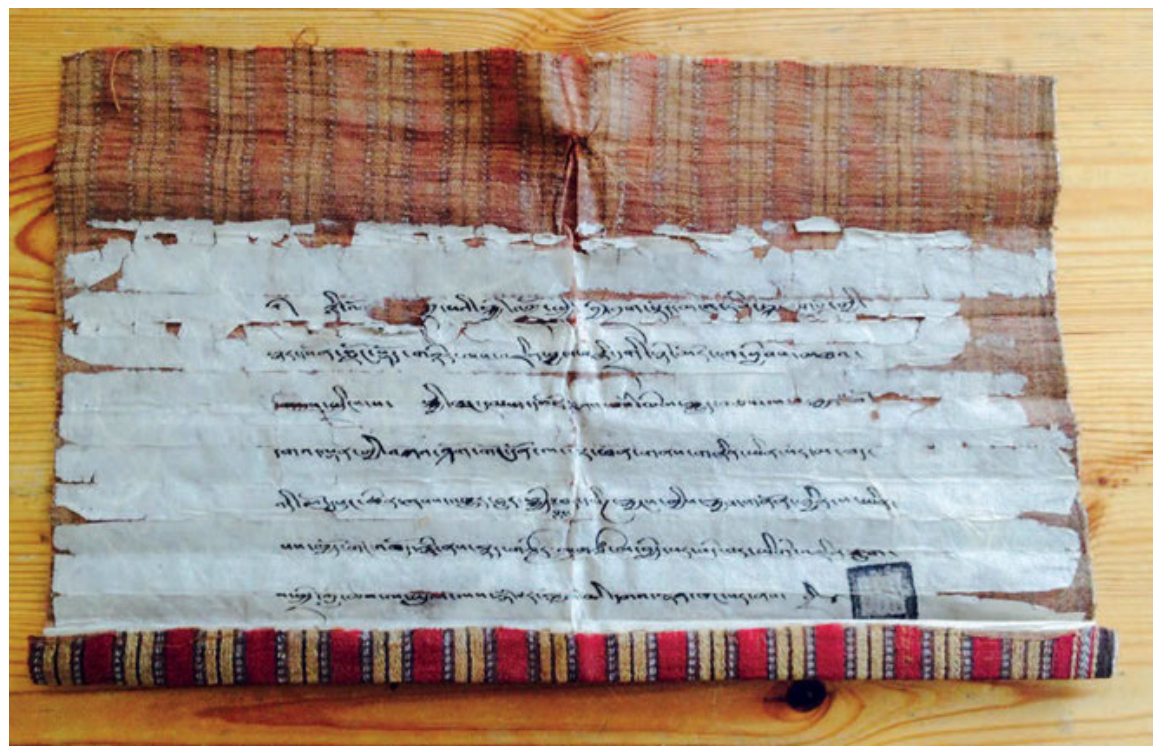

Fig. 3: Silk cloth-backed document from western Tibet. Photo: Charles Ramble.

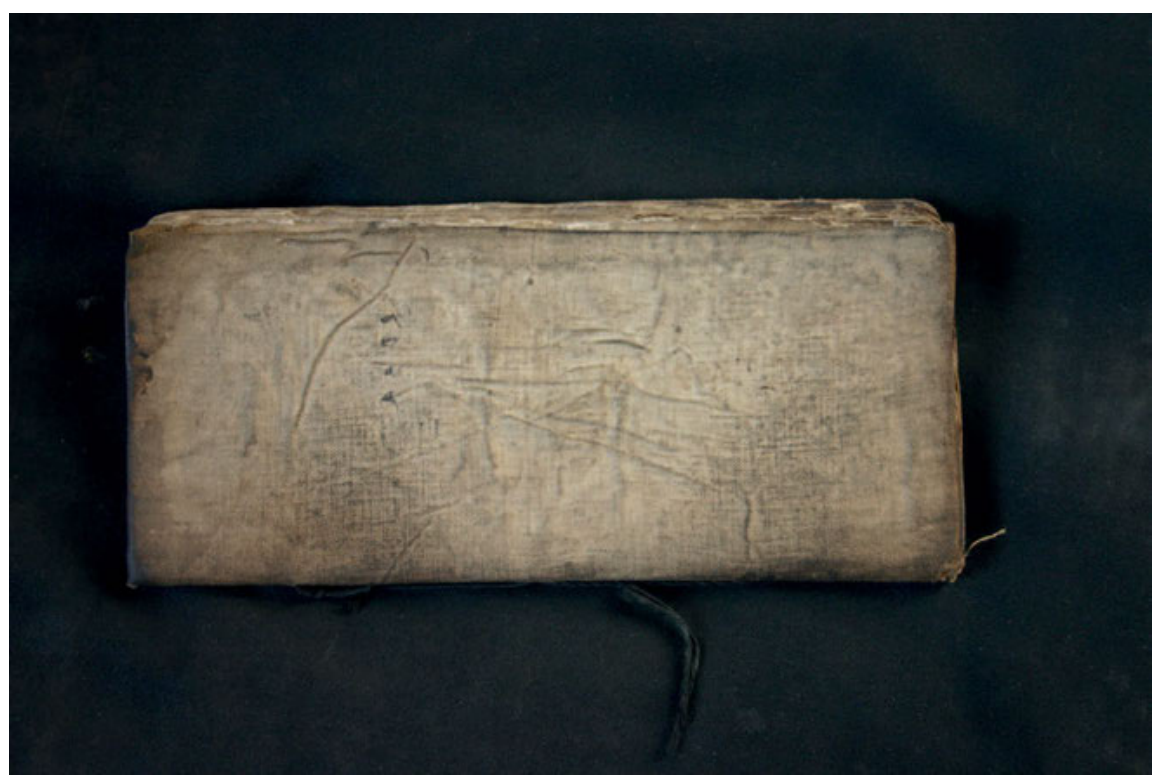

Fig. 4: Cotton cloth-backed register of endowments for temple ceremonies, Mustang, Nepal. 
The script that is used for writing documents is almost never ucen, the headed form; nor indeed do documents use the various types of large ume, the 'headless' variety, that frequently occur in pecha. The headless category subsumes a wide variety of styles, ranging from the clearly formed, unconnected letters typical of pecha to a fluid hand that can properly be described as cursive. Tibetan has names to describe numerous sub-categories of headless script, depending on features such as the length of the descenders, the form of the vowels and so forth. Most official documents were written in the cursive script, known as khyuk ('khyug). This script was a requirement for private documents in Central Tibet, though a slightly more formal version, known as sharma (gshar ma), was sometimes used until the end of the nineteenth century (Schneider 2002, 417). In the examples from the Himalayan borderlands that will be considered below, we are likely to find a wider variety of hands than is generally to be found in Central Tibetan collections. This variety is likely to be the result of the setting in which scribes were trained. Many scribes were hereditary village lamas who would have been taught to write not in a school or monastery but at home, by their fathers, or else by another lama to whom their basic education had been entrusted. This situation would favour a greater degree of scribal idiosyncrasy than an environment in which the transmission of stylistic norms was more regulated.

An obstacle facing any attempt to classify scripts in provincial archives is that the formal Tibetan scriptural categories denote ideal types, whereas in reality there are numerous intermediate forms that do not correspond precisely to one category or another. Whereas some documents are written in khyuk, and in others the script is closer to the more rounded, larger-lettered tshuk (tshugs), most fall into the category called khyukmatshuk ('khyug ma tshugs, lit. 'neither khyuk nor $t s h u k$ '): that is, a script that exhibits features of both.

\section{Archival collections}

Documents are not stored in libraries but in archives. The usual term for an archive is yiktsang (yig tshang), literally a 'nest of letters'. The documents themselves may be kept in a variety of different ways. They may, for instance, be collected together into cloth wallets or kept in leather or metal trunks, or wicker baskets, or even sacks, which are often suspended from rafters to protect them from the depredations of rodents. 


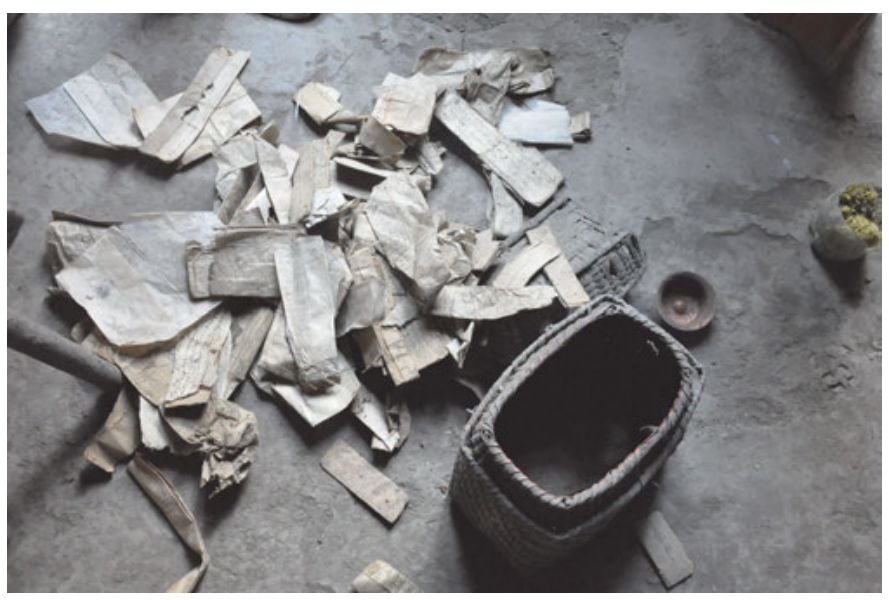

Fig. 5: Family archive from southern Mustang, Nepal. Photo: Agnieszka Helman-Ważny.

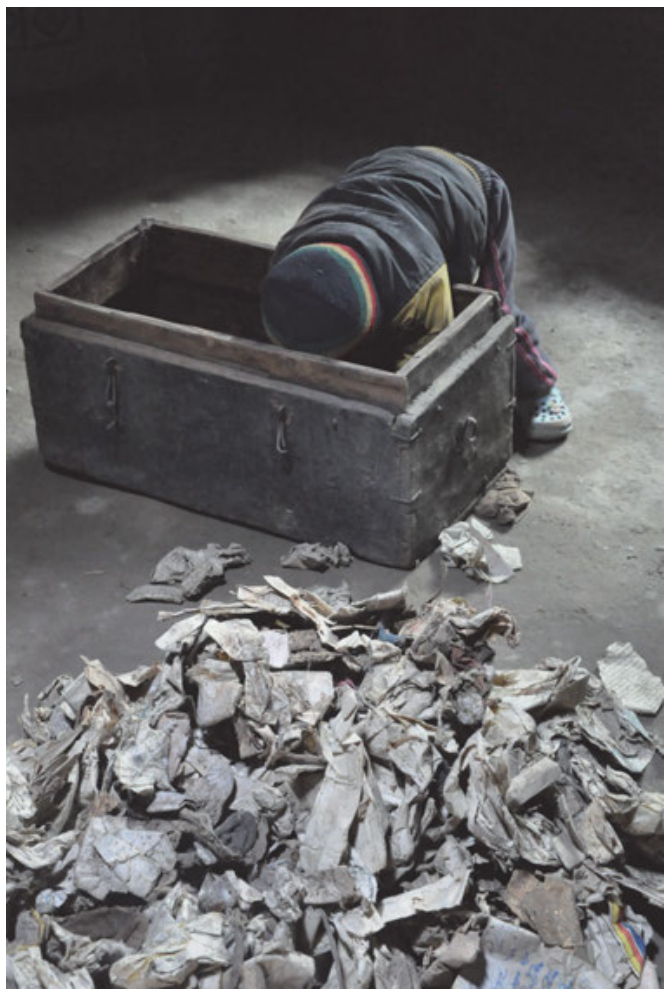

Fig. 6: Family archives from southern Mustang, Nepal. Photo: Agnieszka Helman-Ważny. 


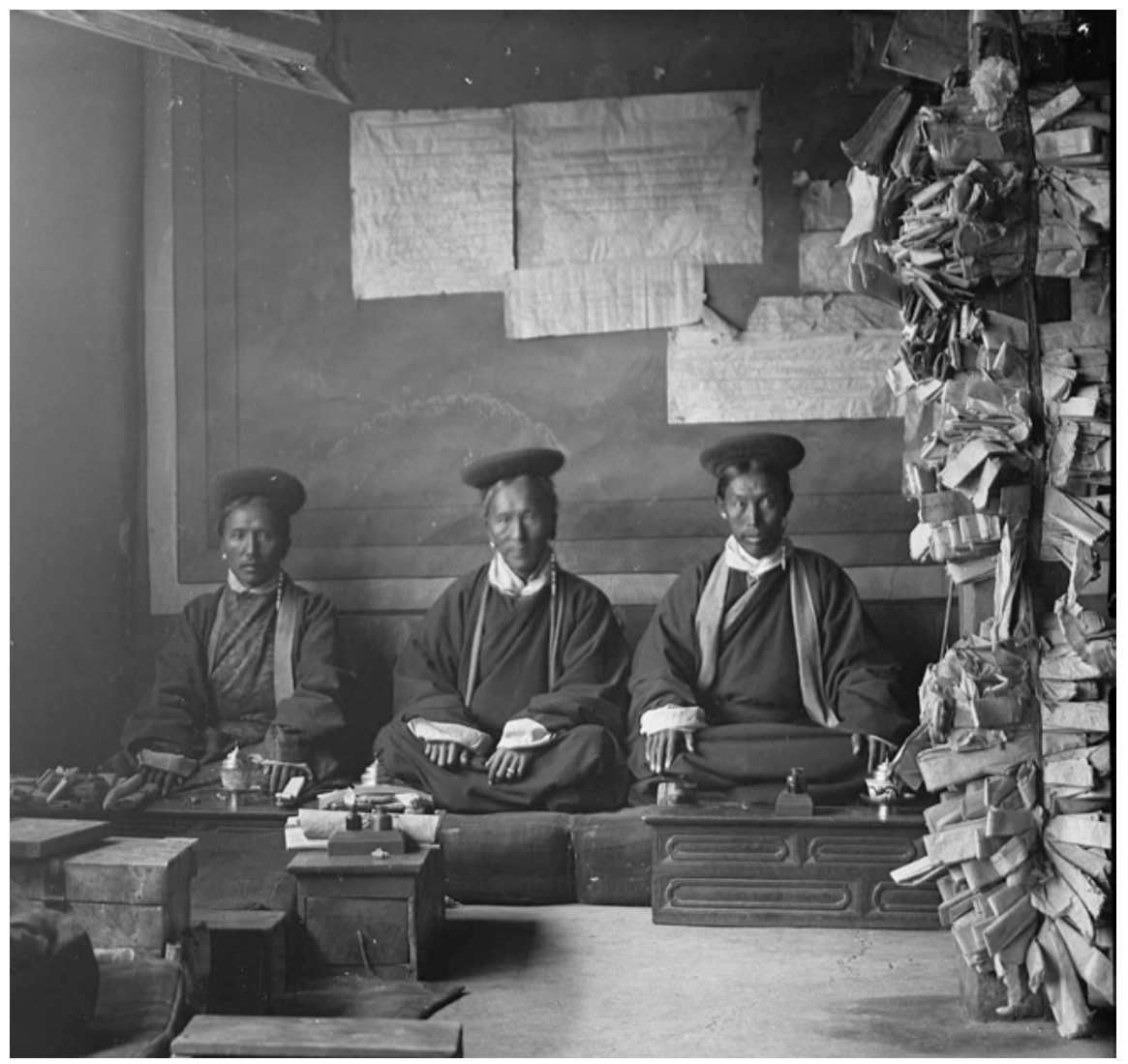

Fig. 7: Lhasa magistrates (detail). Photo: Sir Charles Bell, 1921. Courtesy of Pitt Rivers Museum, Oxford.

Fig. 7, a photograph of magistrates in Lhasa that was taken in 1924, shows what was probably a common way of archiving legal documents-by stringing them together and attaching them to a pillar.

Archives of one sort or another are known to have existed ever since Tibet developed a system of writing early in its imperial period (seventh to ninth centuries), and remnants of archives have survived from all periods and regimes since then. However, the most prolific producer of documents in Tibetan history was unquestionably the Ganden Phodrang and its related institutions. The Ganden Phodrang was the name of the government that was established by the Fifth Dalai Lama in 1642 with the patronage and military support of the Oirat Mongol leader Gushri Khan, the founder of the Qoshot Khanate. The military campaigns 
led by Gushri resulted in the defeat of the Dalai Lamas' political rivals, and the unification of the country under the rule of Lhasa for the first time since the collapse of the empire seven centuries earlier, albeit across a much more limited territory. The Ganden Phodrang government lasted until it was dismantled following the Lhasa uprising against the Communist Chinese presence in 1959, and the flight of the Fourteenth Dalai Lama to India.

Under the Ganden Phodrang, there were three entities that were entitled to receive revenue from estates, which consisted of agrarian and pastoral communities. These were the state itself, the aristocracy, and-the largest landholder-the Buddhist church. The management of these peasant estates generated a wealth of documentation, to which we must add other categories, such as correspondence related to international relations. In the four hundred years of its existence, the Ganden Phodrang and its satellites generated a vast quantity of documentary material that was archived in government and monastic repositories, as well as the private collections of noble families.

\section{Archives and social history}

The destruction of archives that took place in Tibet between 1959 and the end of the Cultural Revolution in the 1970s resulted in the obliteration of most of this material. Communist propaganda photos from the period proudly show the immolation of entire archives at public gatherings. ${ }^{2}$ The stated justification for this destruction was the argument that the documents symbolised the oppression of the population through indebtedness and bonded servitude, and the pyres were a dramatic expression of the people's liberation from their condition of abjection. Current opinions about conditions in Tibet before 1959 are starkly polarised: it was either a paradise on earth, or else it was a feudal hell. Knowledge of the reality of the situation cannot advance by simple reiteration of either position, but through the analysis of the administrative documents of that time. The millions of documents that were destroyed between the 1950s and the 1970s may well have been perceived as symbols of fiscal and legal oppression, but their destruction means that the possibility of knowing the condition of the peasantry in the areas of Tibet concerned has been lost for ever. The most and systematic scholarly studies of the social system under the Ganden Phodrang government are provided by

2 For one such public immolation of archives, see https://s-media-cache-ak0.pinimg.com/ 736x/96/b1/d1/96b1d1433483efc4a3c688b6aa8573c6.jpg 
the work of Melvyn Goldstein although, as anthropological studies based substantially on interviews, they naturally cover only the last period of the old Tibetan government (e.g. Goldstein 1968, 1971). Goldstein's well-defined characterisation of the socio-economic structure of 'old' Tibet as a form of serfdom has provoked much criticism, much of it far less well justified and documented than his own position. What most accounts lack are, on the one hand, extensive and representative philological and diplomatic analyses of archived materials, which would provide a solid basis for the examination of the whole legal, administrative and bureaucratic processes involved; and on the other hand, analyses of material that might offer insights into earlier periods of the Ganden Phodrang. Such material has been edited and analysed extensively by Dieter Schuh, who has pioneered the field of diplomatics within Tibetan Studies (see for example Schuh 1988, 2008), but the examination of such material on a larger scale as sources for a social history has only begun within the past few years. ${ }^{3}$ Studies of Tibetan history have been based almost exclusively on historiographic sources. Now that other sources are available they, too, should come to form the basis of scholarly writing. This will not only complete our picture of Tibet's past, but also modify it in many ways.

The destruction of archives in Tibet may have been very extensive, but it was not complete. It is estimated that there are some two to three million documents in the National Archives in Lhasa. This institution even publishes a Chinese-language periodical with the English title Tibetan Archives. Selections from the archive occasionally appear in its pages, and though examples of this material are always very welcome, the fact that each selection is made only after a careful vetting of its contents necessarily compromises the value of such material for research on any aspect of social history: this sort of selectiveness gives us a very partial view of what was surely a complex overall picture. In 1998, the University of Bonn initiated a DFG-funded collaborative project with the Archives of the Tibet Autonomous Region to digitise a part of the collection. The corpus that was selected for attention was the archive of the monastery of Kundeling, which is located close to Lhasa itself. 2,700 documents were digitised, and may now be consulted online on the website Digitized Tibetan Archives Material at Bonn University. ${ }^{4}$ These documents, which cover the period from the thirteenth to the twentieth centuries, as well as those contained in Schuh (1988), are a priceless resource for our understanding of the relationship between a well-known monastery of the dominant school of Tibetan Buddhism and the revenue-yielding

3 See, for instance, Ramble/Schwieger/Travers 2013.

4 http://www.dtab.uni-bonn.de/tibdoc/index1.htm 
peasant estates that were under its control. Perhaps the most important thing about the documents in this archive is precisely that-they are an archive, something that is qualitatively more than merely the sum of the parts that make it up. As interesting as an individual document may be, the availability of the context in which it was produced might make it possible for us to see the event to which it relates unfolding over the course of time, or perhaps to realise that it is an aberration, conveying a message that is at odds with the evidence of the other material available. An example of two such documents will be given at the end of this article. Access to a large number of documents that span an extended period is essential if we are ever to begin to address the vexed questions that underlie certain political, social and economic institutions-the matter of whether Tibet was a feudal society or not being just one of these.

We are very fortunate indeed that certain archival collections from Central Tibetan dependencies and semi-autonomous enclaves were brought into exile by groups of refugees who fled Tibet in 1959. A catalogue of one such collection from the south-western part of Central Tibet, notably the principality of Porong (Pong rong) and nearby areas, has recently been published by Hanna Schneider (2012). The importance of such archives is that they significantly modify the image of the Tibetan polity as a homogenous entity under a monumental centralised bureaucracy. Although principalities such as Porong were within the political orbit of the Dalai Lamas, they enjoyed considerable autonomy under hereditary rulers, and sometimes with their own system of priesthood.

\section{Tibetan archives in the Himalayan region}

The Tibetan cultural area extends beyond the territory of the PRC to include numerous enclaves in contiguous parts of the Himalayan region. Certain areas of Pakistan and India that now follow Islam have retained their use of the Tibetan language, and archives from some of these regions-such as Purig in northwest India-have been published by Dieter Schuh. The same author has also published archival collections from Ladakh and Spiti, also in northwest India (Schuh 2008, 2016).

Mention has been made above of the losses to Tibet's archival heritage suffered during the period of democratic reform and the Cultural Revolution, but there are factors other than politically motivated excesses that can lead to such destruction. The late Professor Tsering Gyalpo, a senior researcher at the Tibetan Academy of Social Science in Lhasa, was brought up in a nomad family in the far west of Tibet. On one occasion in the 1990s when he was revisiting his family while on leave, he noticed a young male relative making cheese by straining whey from curd through 
what appeared to be an unusually fine piece of cloth. On inspecting it more closely he saw that the cloth was a length of silk brocade, and he asked his relative where he had found it. The young man replied that, after the recent death of one of the clan elders the family had sorted through his belongings and found numerous such pieces of brocade. Some were quite old and worn, but it was found that if the paper that was glued to one side of each of the pieces was peeled off, the cloth itself made a fine curd strainer. Tsering Gyalpo then realised that the items to which the young man was referring were in fact old cloth-backed documents, and he was able to salvage those that were left from being converted into dairy accessories. ${ }^{5}$

A similar chance encounter was responsible for saving a particularly important Tibetan archive from oblivion. The country of Sikkim, located in the eastern Himalayas, was created in the seventeenth century. It later became a protectorate under the British Raj, and was eventually incorporated into the Republic of India as a state in 1975. The uncrowned son of the last king to rule, the Chögyal, is a devout Buddhist, and in the 1990s in a visionary moment he decided to make a bonfire of the palace archives on the grounds that they were emblems of ephemeral worldly affairs. He heaped up the documents and set light to the pile. As luck would have it, a member of the Namgyal Research Institute for Tibetology, which is situated in Gangtok, the capital of Sikkim, happened to be passing. He extinguished the fire and took the collection to the institute. The documents were later digitised, and a catalogue of them published by Saul Mullard and Hissey Wangchuk (2010).

The Sikkim Palace Archive comprises over 700 documents, ranging in topic from village-level land disputes to legal codes introduced by the government. This collection of materials illustrates the relationship between the common people of Sikkim and the state, which was defined not only by the political structures of Sikkim, but also through legal cases and law codes. Indeed, unlike other monarchic polities, the relationship between king and subjects was an intimate one, defined by the right of people, even from the lowest social strata, to correspond directly with the king over legal disputes. This collection contains examples from most regions of Sikkim, in which individuals wrote directly to the king about legal cases, ranging in scale from minor disputes over uprooting of cardamom plants, for example, to major conflicts between powerful estates. The archives also include royal decrees and tax documents, lists of government expenditure, trade licences, and government loans, all of which are vital to understanding the economic history of the region. This archive, together with smaller collections that have recently come to light in Sikkim, have effectively made it possible to rewrite important chapters of the

5 Tshering Gyalpo, personal communication 1998. 
early history of the principality (Mullard 2009), while providing important information for the analysis of stratification, taxation, legal codes and the relationship between people and state with other areas of Tibet and the Himalaya.

Insofar as most of the examples discussed above are the archives of monasteries or else political centres of one sort or another, the type of documents they contain are to a great extent concerned with 'vertical' communication between authorities and ordinary people. Even if, as in the case of Sikkim, there was a certain amount of 'upward' correspondence in the form of petitions to the ruler or higher authorities, much of the material in these collections consists of edicts and other orders to social inferiors, records of ceremonies and other official events, lists of gifts, financial matters and suchlike. These collections contain relatively few documents concerning dealings between villagers; the overwhelming majority of them consist of different categories of communication from institutions or individuals in positions of authority to lower-ranking members of the population, such as the peasantry.

An exception to this general pattern is to be found in the archives of Mustang, a district of Nepal that was an autonomous kingdom until the late eighteenth century. The southern part of the kingdom had seceded from the north earlier than this, and was ruled by a succession of dukes who belonged to a local noble family. After the Gorkhas' annexation of the entire territory during their unification of Nepal, the king and the duke became the representatives of the Kathmandubased government of the new country, and retained a high degree of autonomy. There is evidence that, prior to the arrival of the ancestors of those local rulers, many of the communities in the territory operated as something akin to miniature democratic city states, with elected rotating leaders and a strong sense of integrity (several of them were even endogamous), and this system survived both monarchic rule and modern government structures in the form of a vibrant civil society down to the present day. Consequently, with the exception of a few letters from the King of Mustang, local dignitaries and monasteries in Tibet, much the greater part of the archives concern dealings inter pares. Many private households and most communities possess archives of documents dealing with a wide range of mainly secular affairs. (Where religion does feature in these, it is usually in relation to the financial or organisational aspects of ceremonies.) Community archives are usually kept in a public building; responsibility for their care lies with the annually-rotating headmen, and they may be opened only in the presence of the village assembly. Alternatively, the box of documents may be kept in the house of one headmen, and the key with the other. In the case of private archives, the status of some households is such that the archives contain a certain 
proportion of items of a public character. Private archives typically consist of documents such as contracts for loans of grain or cash, sales of land, wills, disputes over ownership and inheritance of property. Community archives may be classified according to various criteria, but broadly fall into two categories: documents relating to internal affairs and those concerned with dealings with outsiders. The former includes records of community gatherings, rules for local natural resource management (such as forests, water and grazing), disputes between fellow-villagers that were mediated by the community, and annual grain taxes to the communal fund. Those dealing with outsiders may include pasture boundary agreements with neighbours, and directives or other correspondence from political authorities such as the King of Mustang or the Government of Nepal.

\section{What can we learn from archives?}

As mentioned earlier, local archives are the only reliable basis we have for addressing general themes such as whether Tibet had a feudal economy. They are also the only source we have for the actual operation of institutions for which there is an abundance of prescriptive literature. This is the case with Tibetan law, for example. Although there are numerous law codes from different periods of Tibetan history, we should be careful about taking them at face value, or assuming that they were actually applied in practice. James Scott has alerted us to the existence of 'hidden transcripts'-the oral or written strategies adopted by 'subaltern' groups to express collective dissent, and their refusal to subscribe in anything other than a superficial way to the ideology of the dominant powers (Scott 1990). Two examples of such 'hidden transcripts' from Mustang may be cited by way of an illustration. The documents in question, which both date from the late nineteenth century, are from two communities that are situated some six hours' walk from each other. The first contains a general formulation for the management of disputes within the community:

There should be no legal disputes within the community. But if there are, should [the disputants] go down to the government court without paying money to the community they shall be fined 8 rupees. After paying one flask of beer and 1 anna [one-sixteenth of a rupee] to the headmen, one rupee shall be taken from each of the disputants, and the headmen shall sit and pass judgment. One rupee shall be given to the community, and one rupee shall be for the headmen. If someone rejects [the judgment], he may not go [to the courthouse] before paying 1 anna [to the community]. If the dispute is settled internally, one part 
[of the deposited sum] shall be taken from the winner, and two parts from the loser, and the council...shall take it. ${ }^{6}$

The document explicitly states that members of the village could, if they wished, take their disputes to be heard in the government court. However, in order to do so they first had to pay a fee to the community, and failure to pay this fee would have been punishable by a fine. There was an obvious preference for dealing with legal issues within the community, without having recourse to government structures. The second example concerns a particular case in which a villager was fined for carelessness while irrigating his fields.

While Kāmi Sarki was irrigating his fields, the water ran into the community house, and his goats were seized [as security]. In violation of his fine and customary village law he went to the government court, where he received a [favourable] judgment. However, when he was later tried according to community law, because he did not know that he had violated village law in going [to court] the fine of 50 rupees was reduced to 25 rupees. $^{7}$

In this particular village, it seems, there was a blanket prohibition on taking any internal dispute to a government court. Is it possible that a similar reluctance to turn to official legal channels prevailed in villages in Central Tibet? We do not know; if villages ever did have archives that contained the answer, they have either been lost or destroyed.

\section{The lives of people without history}

While there is little in the archives of Mustang that might tell us about its political or economic relations with the rest of Nepal or Tibet, the documents do offer a rare insight into the day-to-day concerns of local communities: the regulation of taxes and the use of natural resources, counts of livestock, and conflicts with neighbouring settlements over territorial boundaries, among other things. But beyond what they might tell us about local institutions and social organisation, the archives shine a patchy but nevertheless precious light onto the lives of ordinary people. As in the case of Europe or America, historians of Tibet have understandably focused on the bigger picture relating to the nation of Tibet and its affairs with its neighbours, with the vicissitudes of the religious schools, and the

6 Undated Tibetan document from the village of Shang, southern Mustang, photographed by Charles Ramble and Nyima Drandul in 1993.

7 Tibetan Sources 1, document HMA/Te/Tib/23. 
fortunes of great men. The perspective of 'history from below', which owes so much to the French Annales school that flourished between the two World Wars, has not yet featured prominently in historical writing on Tibetan societies. Founded in 1929 by Marc Bloch and Lucien Febvre, the school has broadly favoured a focus on what would later come to be known, in Gramsci's phrase, as 'subaltern' groups, in combination with methods of other disciplines in the social sciences. Among the more recent authors in this lineage we might count Emmanuel Le Roy Ladurie, whose best-known work, Montaillou, catalogues three decades in the life of a mediaeval French community through the records of the Inquisition (Le Roy Ladurie 1978); and, even more pertinently, Carlo Ginzburg, whose studies of heterodoxy and witchcraft in the Friuli have so enriched our perspectives on popular religion in Early Modern Europe (1980a, 1980b).

In spite of their macabre context, and allowing for inevitable distortions, inquisition records such as these-the experiences and beliefs of subjects extracted under interrogation over a protracted period-offer rare opportunities for developing a three-dimensional profile of the individuals in question, as the historians cited above have amply demonstrated. Mercifully, there are no such records as these in Mustang, although the testimonies of defendants in court cases can illuminate a single event (an elopement, a fight, a theft) by presenting the same incident from a number of different perspectives.

Some of the documents have a touch of the absurd: the record of a quarrel between two people, one of whom had failed to honour an undertaking that he would give the other a quid of chewing tobacco; others give a picture of desperation and drama, as when, in the late seventeenth century villagers who were besieged during a war were forced to take refuge from an invading army, 'starving in the cliff caves of the birds' and surviving on nothing but buckwheat husks; and glimpses of private sadness, like that of a young woman named Ngachok Butri, abandoned by the man who left her pregnant, wandering the freezing hills of Mustang in mid-winter while her father fretted that 'she has taken her own life from the cliffs or in the river'.

Family archives are a particularly valuable source. Individually, the kinds of documents contained in such collections may not be particularly inspiring-contracts for sale of fields, inheritance disputes, arguments over fiscal payments, loan receipts and so forth-but taken together they can tell us a great deal about the life and character of a person. Biographical writing is a very abundant and popular genre in Tibet. However, since the purpose of life writing is to present an exemplary spiritual life, much of this literature is hagiographic, and tells us little about the mundane day-to-day life of the subjects. At the opposite extreme to 
such accounts of saintly lives we have the archive of a family of hereditary Buddhist lamas from southern Mustang. The last member of the line died, heirless, in 1992, but the archives remained in a wicker basket in the abandoned family house. This archive made it possible to reconstruct the history of the family over six generations, and although some of this information is rather skeletal, there are enough documents pertaining to certain individuals that we can obtain a reasonably substantial picture of their lives. 'Substantial' is not the same as 'rounded': if classical Tibetan biography focuses on the subject's piety to the exclusion of all else, documents are likely to emphasise the contrary characteristics. If a person generates a large volume of such material, that is likely to be because he (or she) was embroiled in disputes, or was litigious, or the target of lawsuits-or, in the case of one of the lamas in the family, Ösal Dorje, all the above.

The picture that emerges from the archives is not the beatific face that we would have seen from his biography, had he or anyone else thought to write one. Ösal Dorje, who probably died some time in the second decade of the twentieth century, emerges from the archives as acquisitive, ruthless, and probably violent. In 1907, for example, he was accused of brutally beating a personal enemy and of practising destructive black magic. But of course, this portrait is no more rounded a picture of the man than we would have had from that unwritten hagiography: while it may be true that Tibetan biographies tend to inflate the spiritual qualities of the protagonist, the very nature of archival documents casts the subject in an unfavourable light and underrepresents his spiritual qualities. Given the circumstances of Ösal Dorje's birth and childhood, it is obvious that he had to fight to make his way in the world. He was the illegitimate son of a feckless trader, and his mother had forfeited her inheritance rights by virtue of this brief liaison. Before her death she bequeathed to him the house she had been grudgingly allocated by her brother, but was later evicted from it on the grounds that the property was non-impartible. He inherited absolutely nothing. There is little in such a childhood to foster open-handed generosity or financial recklessness.

Here I would like to return to a point made earlier, about the immense value of an archive as opposed to an individual document, however spectacular or interesting the document may be. An archive provides documents with a context without which they might be completely misleading. Two examples will serve to illustrate this point. One is a claim by Ösal Dorje's son, Tenpa Gyaltsen, that he is the rightful heir to the house that his father had inhabited. Ösal Dorje had inherited the house from his mother, Phurba Angmo, who had two brothers. To support his claim, Tenpa Gyaltsen cites the will of his great-grandmother-Phurba Angmo's mother-to the effect that 'this house of ours, from its topmost point to its foundations, shall be the exclusive possession of our daughter Phurba Angmo, 
who gave us the filial service that ought to have been provided by all three of our children, and not in the possession of her two brothers'. Tenpa Gyaltsen won the case against the cousin who wanted to evict him. If this document was all we had to go on, we might have no reason to doubt the veracity of the argument, and would probably derive a sense of satisfaction from the thought that justice had been done, and that the disadvantaged Tenpa Gyaltsen and his father Ösal Dorje had been allowed to retain the property. In fact, the situation was more complicated than this. Phurpa Angmo had got on well with her older brother, Rigden, but not the younger, Rangdrol. The two brothers allowed her to live in a small house belonging to the main estate, but in 1866, after the death of Rigden, who had protected her, Rangdrol wanted to evict her-and he would have been legally entitled to do so because her welfare was technically not his responsibility but that of her common-law husband. Thanks to the intercession of intermediaries, however, she was allowed to remain in the house under certain conditions:

Phurba Angmo was distressed at having no house in which to live, and begged Lama Rangdrol and his son Tshewang Bumpa to lend her a house in which to live until her death. But the lama and his son refused, and the petitioners begged them respectfully [to change their minds]. This is document of agreement between the two parties. Until Phurba Angmo's death, the lama and his son may not turn her out of the house, forbidding her to live in it. ${ }^{8}$

According to this excerpt, then, Tenpa Gyaltsen's grandmother, Phurba Angmo, had been permitted to occupy the house until her death, after which it would not be inherited by her son, Ösal Dorje, but should revert to the main estate. The will that Tenpa Gyaltsen cited forty-six years later, in which Phurba Angmo's mother is reported to have bequeathed the house to her, obviously never existed. He simply made it up. In the event, the court's decision was later reversed, and Tenpa Gyaltsen had to move to another village.

The other document, which dates from 1906, concerns a community of nuns from a group of four villages. From the seventeenth century until this time, it was customary for the second of three daughters born into any family in these four villages to join a local convent named Künzang Chöling. The convent stands on the territory of one of these four villages, named Tshug. Te, which is also mentioned in the document, is another of these four villages. Upper Tshognam is the name of the area in Te to which Lama Ösal Dorje moved after his eviction from his previous house, which stood on the territory of Tshug.

8 Tibetan Sources 2, document HMA/LTshognam/Tib/08. 
Seven nuns of Te [who are then named] have been dragged outside by the nuns of Tshug's convent, who expelled them with the notification that they need never come back. Henceforth these nuns shall be affiliated with the temple of Upper Tshognam, and the lama [Ösal Dorje] has agreed to this proposal. ${ }^{9}$

The nuns of Te, then, were mistreated by their sisters in Künzang Chöling and were forced to leave their convent. Fortunately for them, Ösal Dorje, the lama of Tshognam, agreed to become their mentor. A contemporary document from the archive of the convent itself presents a rather different version of this event. On the day in question, the nuns of Te had failed to arrive for the beginning of a ceremony, and only turned up after it was over. According to the written testimony of the other nuns,

We asked them why they had come so late, but they... said, 'From this day on, we beg to take our leave!' We nuns invited them to sit down with us and to have some beer, but they refused to have any, and left amid much shouting and yelling. On a later occasion, when the preceptor Sister Pen Trashi died, we sent our steward to call the nuns of Te to take part in the prayers, they did not come; and when we sent them the 'corpse food' [the food that is distributed after the death of an individual], they refused to accept it, saying that they were no longer members of the convent. ... Now these seven nuns have made an illicit agreement with a new religious establishment, Upper Tshognam.... They should not be allowed to join the temple of Upper Tshognam, and we ask the law to apprehend them and to compel them to return them to our nunnery, which from past times has been the convent of our community. ${ }^{10}$

When the construction of the convent of Künzang Chöling was completed in 1696, Mustang was still a vassal of the powerful kingdom of Jumla, in the far west of what is now Nepal. A minister of Jumla who visited the building in the company of its founder described it as 'the jewel in the crown of the realm'. Since it stood on land belonging to Tshug, the convent was a source of considerable pride for the settlement. The rift in the community of nuns that Lama Ösal Dorje had managed to achieve was a double victory for him: he had succeeded in consolidating his position as a lama of some consequence in Upper Tshognam by gathering under his tutelage all the nuns from the village of Te; and incidentally, by purloining these nuns from Künzang Chöling, he had dealt a fatal blow to a convent that for three centuries had been the glory of the village from whose territory he had been evicted.

9 Tibetan Sources 2, document HMA/UTshognam/Tib/23.

10 Unpublished document from the archive of Tshug: HMA/Tshug/Tib/1/04. 
I had photographed the archive of this family of lamas in 1993, and in 2016 returned with my colleague Agnieszka Helman-Ważny to rexamine them for codicological features. The new owner of the abandoned building managed to find them in the basket in which they were contained in the house's chapel. When Dr Helman-Ważny returned in 2017 to complete her work, the owner of the house, who was renovating it to convert it into a lodge, informed her that he had thrown them away. Archives such as these do not tell us about famous battles, or the achievements of saints and kings, or affairs of state. They are, however, the only window we have onto the lives of local priests like Ösal Dorje and his family, forgotten nuns, and ordinary villagers; the kinds of things that were important to them and their daily triumphs and disappointments. It does not need a Cultural Revolution to obliterate their memory. As the photos of the two village archives show (Figs 3, 4), the documents are unprepossessing scraps of paper, resembling nothing so much as litter; all it takes is a morning of house-cleaning to erase all traces of a family for ever.

\section{References}

Digitized Tibetan Archives Material at Bonn University, http://www.dtab.uni-bonn.de/tibdoc/ index1.htm (last accessed 22/04/2017)

Ginzburg, Carlo (1980a), Les batailles nocturnes: sorcellerie et rituels agraires en Frioul, Lagrasse: Verdier.

Ginzburg, Carlo (1980b), The Cheese and the Worms: The Cosmos of a Sixteenth-century Miller, London: Routledge \& Kegan Paul.

Goldstein, Melvyn C. (1971), 'Serfdom and mobility: an examination of the institution of "human lease” in traditional Tibetan society', in The Journal of Asian Studies, 30, no. 3, 521534.

Goldstein, Melvyn C. (1968), An Anthropological Study of the Tibetan Political System, Ph.D. Dissertation: University of Washington.

Le Roy Ladurie, Emmanuel (1975), Montaillou, village occitan: de 1294 à 1324, Paris: Gallimard. Mullard, Saul, and Hissey Wangchuk (2010), Royal Records: A Catalogue of the Sikkimese Palace Archive, Andiast: International Institute for Tibetan and Buddhist Studies / Gangtok: Namgyal Institute of Tibetology.

Ramble, Charles, Peter Schwieger and Alice Travers (eds) (2013), Tibetans who Escaped the Historian's Net: Contributions to the Social History of Tibetan-speaking Societies, Kathmandu: Vajra Books.

Schneider, Hanna (2012), Tibetischsprachige Urkunden aus Südwesttibet (sPo-rong, Ding-ri und Shel-dkar), 2 vols, Stuttgart: Franz Steiner Verlag.

Schneider, Hanna (2002), 'Tibetan legal documents of south-western Tibet: structure and style’, in Henk Blezer (ed.), Tibet, Past and Present, Leiden: Brill, 415-428. 
Schneider, Hanna (2003), 'The formation of the Tibetan official style of administrative correspondence $\left(17^{\text {th }}-19^{\text {th }}\right.$ century)', in Alex McKay (ed.), Tibet and her Neighbours: A History, London: Hansjörg Mayer, 117-126.

Schuh, Dieter (2016), Herrschaft, örtliche Verwaltung und Demographie des äußersten Westens des tibetischen Hochlandes: Rechtsdokumente aus Purig und Spiti, Teil 1: Purig; Teil 2: Spiti, Andiast: International Institute for Tibetan and Buddhist Studies.

Schuh, Dieter, unter Mitarbeit von Wangdu Lama (2015), Rekonstruktion von Sozialgeschichte anhand von Rechtsdokumenten: Untersuchungen zur historischen Demographie von Marpha (Südmustang), Andiast: International Institute for Tibetan and Buddhist Studies.

Schuh, Dieter (2008), Herrscherurkunden und Privaturkunden aus Westtibet (Ladakh), Halle (Saale): International Institute for Tibetan and Buddhist Studies.

Schuh, Dieter (1988), Das Archiv des Klosters bKra-śis-bsam-gtan-glin von sKyid-gron், Bonn: VGH Wissenschaftsverlag.

Scott, James (1990), Domination and the Arts of Resistance: Hidden Transcripts, New Haven: Yale University Press.

\section{Tibetan Sources I}

Ramble, Charles (2007), Tibetan Sources for a Social History of Mustang, Nepal. Volume 1: The Archive of Te, Halle (Saale): International Institute for Tibetan and Buddhist Studies.

\section{Tibetan Sources 2}

Ramble, Charles (2016), Tibetan Sources for a Social History of Mustang, Nepal. Volume 2: The Archives of the Tantric Lamas of Tshognam, Andiast: International Institute for Tibetan and Buddhist Studies. 

The Ancient World up to Late Antiquity 



\title{
Cécile Michel
}

\section{Constitution, Contents, Filing and Use of Private Archives: The Case of Old Assyrian Archives (nineteenth century BCE)}

\begin{abstract}
The archives of the ancient Near East do not correspond to a collection of cuneiform tablets preserved for their historical value, but more to a set of texts all kept in the same place, concerning the same individuals or dealing with the same topics. They were accumulated as long as they were considered to be useful. Besides uncovering official archives used by large organisations (palaces and temples), archaeologists have also excavated many private archives; these belonged to individuals and were found in their houses. Assyrian merchants' archives unearthed at Kültepe (the ancient town of Kaneš) in Central Anatolia represent the first important group of private cuneiform archives and they mainly date back to the nineteenth century BCE. These archives consist of letters, legal texts and memoranda. They were arranged on shelves or inside labelled containers using a classification system that gives us hints about the use merchants made of their archives.
\end{abstract}

For more than three millennia, populations of the ancient Near East used cuneiform script to write down all types of texts, whatever the purpose, be it administrative, official, scholarly or private, for example. Cuneiform signs could be engraved on stone, metal or wax spread on wooden or (in exceptional cases) ivory tablets. However, the vast majority of texts in cuneiform script were impressed on fresh clay. Unbaked clay tablets were the standard vehicle of writing; clay was one of the most durable materials of antiquity. As a matter of fact, hundreds of thousands of clay tablets have been unearthed at sites all over the Near East, from central Anatolia to Iran, and to Egypt and Bahrain.

Found in palaces, temples and private houses and arranged in specific rooms or areas of buildings, some groups of cuneiform tablets have been referred to as 'libraries', while the great majority of them are now known as 'archives'. The archives' content varies according to the type of building in which they were found. This paper focuses on private archives that once belonged to Assyrian merchants and were unearthed in their houses in the lower town of Kaneš (modern-day Kültepe in Central Anatolia). The content of these archives gives us information about their historical context and allows us to study their constitution. As an example, the analysis of the tablets excavated in 1993 has provided us with data about their owners, the filing systems employed for tablets and what such archives were used for. 


\section{Some definitions}

The words 'archive' and 'archives' are most commonly used by Assyriologists to refer to the groups of inscribed clay tablets found at numerous archaeological sites in the Near East. Several series titles with volumes of text publications and editions include these words, such as 'Archives Royales de Mari', 'Old Assyrian Archives' and 'State Archives of Assyria'. A Rencontre Assyriologique Internationale, the annual congress of Assyriology, was dedicated to Cuneiform Archives and Libraries in 1983 (Veenhof 1986), and this was also part of the title of a study by Olof Pedersén (1998). Two recent collective thematic volumes deal more specifically with archives: Archives and Archival Traditions (Brosius 2003) and Archives and Archival Documents (Faraguna 2013). ${ }^{1}$

\subsection{Libraries and archives in the ancient Near East}

Studying the groups of tablets excavated in the city of Aššur, Olof Pedersén (1986, 20-21) proposed the following distinction:

Each group of interrelated texts is classified [here] either as a library or an archive. 'Library' describes a group of literary texts in the widest sense of the word, including for example lexical texts. 'Archive' describes a group of texts of administrative, economic, juridical and similar types, including letters. The occurrence of a few texts of the opposite type has not led to a classification change from library to archive or vice versa, but when there are any considerable number of texts of the opposite categories, the collection is described as a library with [an] archive.

Such a definition has been further developed by $\mathrm{Ph}$. Clancier in his study of first-millennium libraries in Babylonia; he distinguishes three groups of texts here $(2009,16-17)$ :

1. Les archives. Il s'agit de fonds conservant des textes de la pratique qui se composent de documents légaux (contrats par exemple), de textes administratifs, de correspondance, etc.

2. Les fonds de manuscrits et les fonds d'archives. Ce sont des collections mixtes de documents de la pratique et de tablettes littéraires et savantes [...]..$^{2}$

3. Les bibliothèques. Ce sont des fonds de tablettes littéraires et savantes.

1 The first scholar to highlight the importance of archives and archival practices in the ancient Near East was E. M. Posner (1972); see the chapter by D. Schenk in this volume.

2 Here the author refers to a study by G. Ouy ('Les Bibliothèques', in L'histoire et ses méthodes, Encyclopédie de la Plêiade XI, Paris 1973, 1061-1106, esp. 1093) in which he defines 'fonds de manuscrits' as follows: 'un fonds de manuscrits est l'ensemble des livres ou documents manuscrits intéressant l'histoire intellectuelle - ensemble entendu au sens large - de la collectivité, de la famille ou de l'individu qui les a copiés, fait copier, reçus en hommage ou réunis [...]. La différence la plus importante qui oppose fonds de manuscrits et fonds d'archives [...] est liée au caractère propre du livre manuscrit.' 
It is common among Assyriologists to use the term 'library' when referring to groups of texts dealing with divination, medicine, religion, technical matters, science, literature and words (lexical lists). Such texts were kept in the houses of priests, diviners or other scholars, but more often in palaces and temples. Palatial libraries had a special status; the best known and documented of these is the library of Aššurbanipal at Nineveh (seventh century BCE), which was truly encyclopaedic. The king sent letters to all the high officials of his empire and even to Babylonia asking for rare tablets:

Search out for me [...] any texts that might be needed in the palace, as many as there are, also rare tablets that are known to you but do not exist in Assyria, and send them to me. ${ }^{3}$

Tablets from the royal library of Nineveh form the largest known collection of scholarly cuneiform texts, amounting to more than 20,000 tablets, which are now preserved in the British Museum.

The other groups of tablets, which make up the majority of tablets discovered in the Near East, are called 'archives'. These correspond to collections of texts kept together in the same place, recording the activities of the same individuals or dealing with the same topics. A better term for them in French is possibly 'fonds d'archives' which has not equivalent in English. ${ }^{4}$ Their owners accumulated them until they were no longer useful or the owners left their homes-after a catastrophe of some kind, for example. In fact, cuneiform archives usually kept on growing-with some interruptions from time to time-until something happened that put an end to the collection-when the building in which they were kept collapsed or was abandoned, for example. ${ }^{5}$ This moment can be determined from the dates of the latest records. Such archives were used for practical purposes.

Archives sometimes contained a few samples of literary texts: an Old Assyrian version of the Legend of Sargon was preserved inside a merchant's archive, for instance (Günbatt1 1998). We occasionally find archival texts in libraries as well, as in the Royal Library of Aššurbanipal (Parpola 1986).

\subsection{Dead and living archives}

Assyriologists usually distinguish between 'dead archives', i.e. tablets that have expired, been cancelled, thrown away or recycled, and 'living archives', which are

3 CT 22, 1: 27-30, edited by Frame/George 2005, 280-281.

4 See the detailed introduction to cuneiform archives by Veenhof 1986.

5 Concerning the end of archives, see the contributions in Joannès 1995. 
tablets normally discovered in situ that belonged to the last person who lived in the building in which they were discovered (Charpin 1985, 255). Both dead and living archives were left on the spot when the buildings housing them were destroyed. Maria Brosius prefers the expressions 'active' or 'working' archive 'to express the fact that an archive was in constant use during its lifetime' (Brosius 2003, 9).

It is worth noting that in the Old Assyrian dialect, some tablets bearing loan contracts could 'die' (muātum) or be 'killed' (duākum), i.e. cancelled, when the debt was repaid because they had no more legal validity (Veenhof 1987, 47-48). There were many ways to 'kill' a tablet: by destroying it physically, putting a specific mark on it or simply by breaking the envelope in which the tablet was kept and which bore the seal impressions of the witnesses and parties involved. In such cases, the 'dead' tablet could be kept as a memorandum together with the 'living archives’, possibly stored in a different container (Michel 1995).

\subsection{Official and private archives}

Assyriologists also make a distinction between official archives from large organisations, temples, palaces, and governmental institutions on the one hand and private archives belonging to individuals on the other, the latter usually being excavated in buildings that were once their homes (Veenhof 1986, 9). Palace archives often contain a large proportion of administrative texts, which document the 'economic resources handled by the palace' (Sallaberger 2013, 220). The tablets found in the Ebla Early Dynastic Palace G (in north-western Syria, twentyfourth century BCE) often consisted of registers of incomes and deliveries, not to mention inventories of stock, but they also contained diplomatic letters and treaties as well, or descriptions of rituals and school texts (Archi 2003). ${ }^{6}$ Palace chancery archives found in Mari (Middle Euphrates, eighteenth century BCE) also included royal correspondence (Durand 1997-2000). Private archives contain details of the economic and social realities of the society that produced them, sometimes on domestic affairs and daily life.

These are naturally modern definitions, and in some cases, there is no clear distinction between official and private archives. As an example, among the archives of Šamaš-hazir discovered at Larsa (eighteenth century BCE), we find letters sent by King Hammurabi of Babylon to his high official and letters sent by

6 Texts from Ebla are accessible in the following database: http://virgo.univie.it/eblaonline/ cgi-bin/home.cgi. Photos of the Ebla tablets preserved at Idlib Museum are accessible at this source: http://cdli.ucla.edu/search/search_results.php?Collection=Idlib\&Provenience=Ebla. 
Šamaš-hazir to his own wife while he was away from home (Kraus 1968; Veenhof 2005, nos 162-164).

Archaeologists have sometimes found tablets that were issued by officials in private archives. For example, some of the letters that the king of Aššur sent to the Assyrian assembly in Kaneš were kept by merchants at Kaneš (Central Anatolia, nineteenth century BCE), apparently because these letters contained verdicts about a case in which they were involved (Michel 2015d). In another case, some administrative texts concerning the temple in the ancient city of Sippar (seventeenth century BCE) were discovered at Tell ed-Der in the remains of a house belonging to Ur-Utu, the chief lamentation priest of the goddess Annunitum; these tablets were found among a large number of other texts relating to Ur-Utu and his family (2,500 tablets were retrieved altogether).

In contrast, tablets containing private information have also been found in palaces and temples. In the palace of Nuzi (Transtigris, fourteenth century), for example, archaeologists unearthed the archive of Tulpunnaya, daughter of Šeltunnaya, in room $\mathrm{N} 120$. This was found to contain 37 tablets, most of which were contracts (Abrahami/Lion 2012). Tablets were also found in the Nuzi temple which would have been identified as belonging to private archives if the archaeological context had not been so clear (Jas 2000). In first-millennium Assyria, the governor's palace at Kalhu contained private archives belonging to the officials who used to work there (Postgate 1973).

Tablets discovered in private houses often concern several generations of a family, but look more like piles of individual archives than related family archives. They are often the result of sorting, which was done from time to time, a fact that must be taken into account when studying such archives. In the city of Sippar in the eighteenth century BCE, for example, Ur-Utu, the chief lamentation priest of the goddess Annunitum, was sorting his tablets when his house fell down; texts have been discovered in various places in his house, sorted according to their content (Tanret 1991). 


\section{Old Assyrian private archives}

The archives of the Assyrian merchants are the first large group of private cuneiform archives in the history of ancient Mesopotamia; they mainly date back to the nineteenth century BCE. ${ }^{7}$

\subsection{The archaeological and historical context}

Private archives have been unearthed at Kültepe, the ancient town of Kaneš, $21 \mathrm{~km}$ north-east of the modern town of Kayseri in Central Anatolia. Official excavations started in 1948 under the scientific direction of Tahsin Özgüç, who worked there for 57 years until his death in 2005 (Özgüç 2003). In 2006, the excavation teams adopted some new methodologies under the direction of Fikri Kulakoğlu (Kulakoğlu/Kangal 2010). Every year up to 2005, archaeologists found Old Assyrian tablets in the lower town. Since then, the excavations have mainly been carried out on the mound, but during the annual cleaning of the lower town, a few tablets still get unearthed regularly. The total number of tablets discovered at Kaneš, 22,500, makes this site one of the biggest sources of cuneiform tablets from the ancient Near East.

Kültepe is a huge site measuring about 200 hectares with an estimated population of around 30,000 inhabitants (Barjamovic 2014). It is divided into two main sectors: the mound and the lower town. Much of the top of the mound has been destroyed by illicit digging (Özgüç 1999). The remains of a huge palace with about sixty rooms dating back to the eighteenth century BCE have been uncovered. It seems that this building was emptied before being destroyed by a fire, which means that almost no tablets were found in it. Two nineteenth-century palaces have also been partly unearthed, but did not contain any tablets (Michel 2015a). Since 2009, archaeologists have been uncovering a very large official building dating back to the early Bronze Age (end of the third millennium BCE), a period during which there was no writing in Anatolia (Kulakoğlu 2015, Kulakoğlu/Öztürk 2015). All in all, only 40 cuneiform tablets were found in the mound. We do not have any official archives kept by the local rulers-in fact, these may never have even existed.

7 For a catalogue raisonné of the Old Assyrian tablets and a bibliography, see Michel 2003, with supplements in Michel 2006; 2011a and 2015c. There have been several publications dedicated to the Old Assyrian archives, such as Michel 1998, Veenhof 2003a, 2013a; on filing specific archives, see Larsen 2008, Michel 2016; on women's archives, see Michel 2009, and on Anatolian archives, see Michel 2011b. 


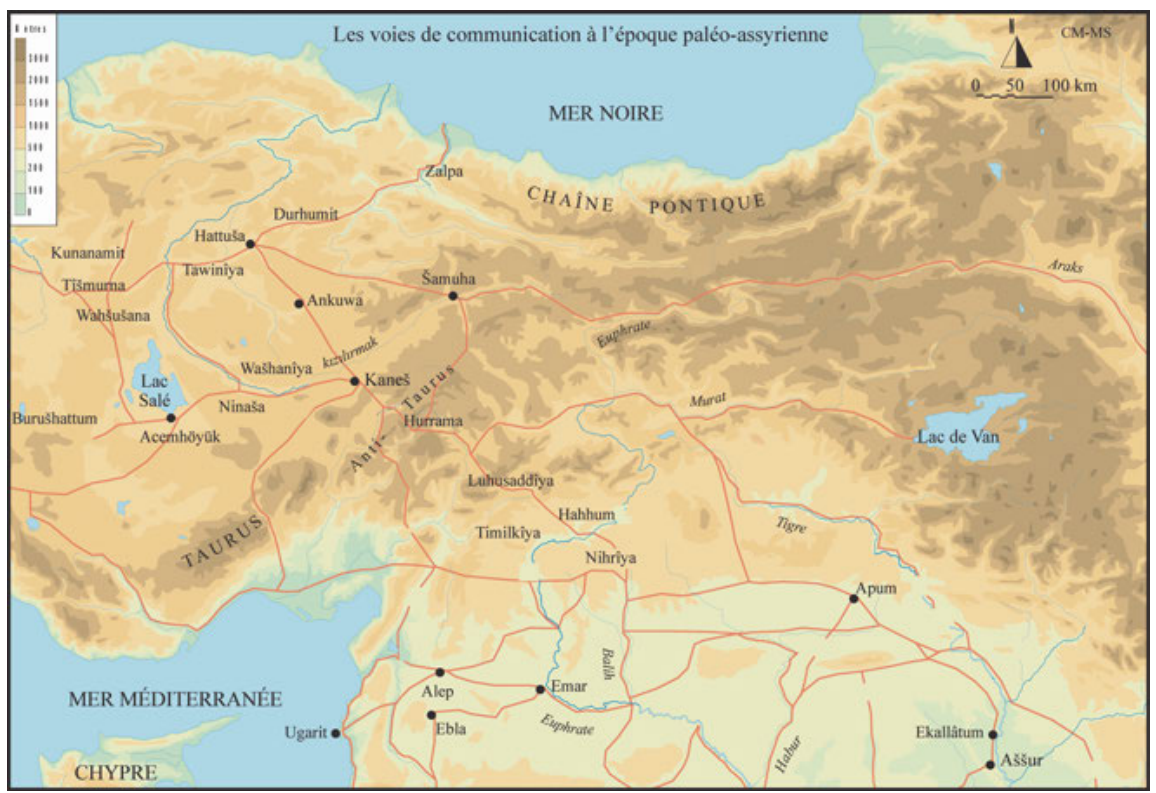

Fig. 1: Roads in Anatolia and Upper Mesopotamia during the Old Assyrian period.

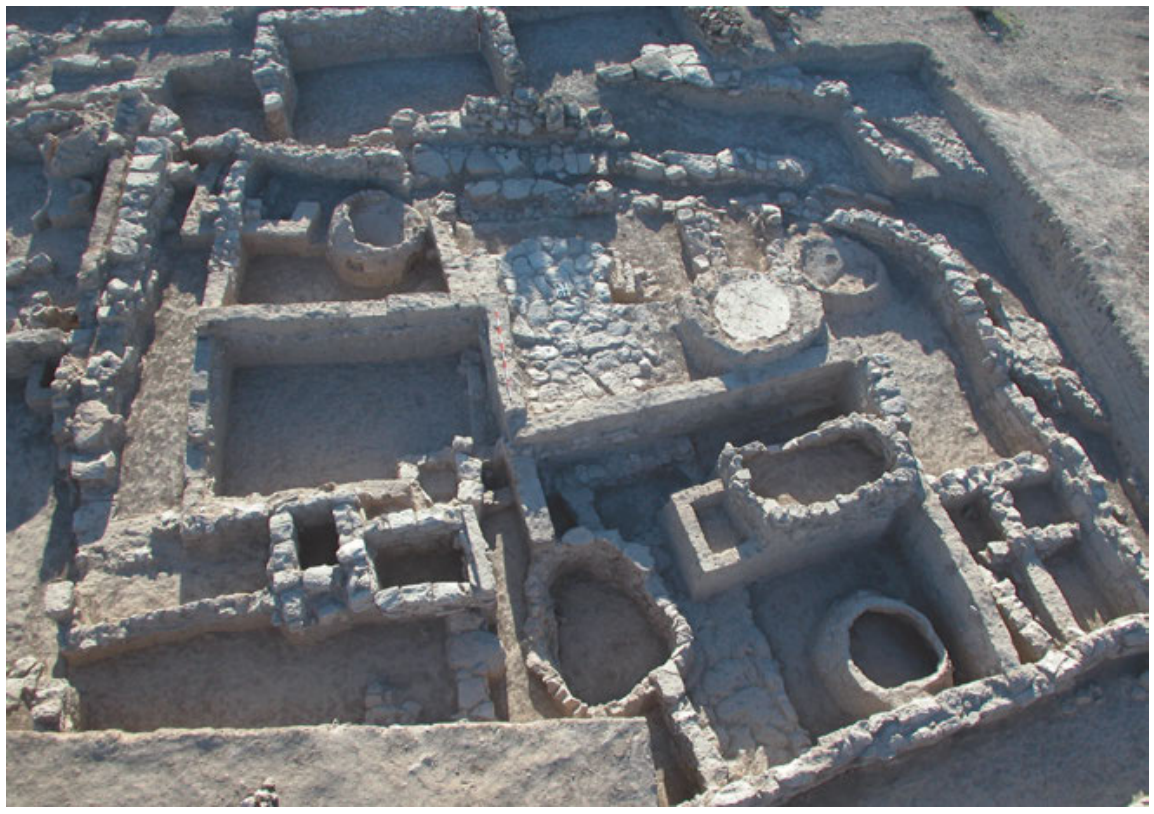

Fig. 2: Houses in the lower town. (C) Kültepe Archaeological Mission. 
In the lower town, only part of the merchant district about nine hectares in size has been excavated up to now, which is located north-east of the mound. Roughly 3,000 to 3,500 inhabitants may have lived there during its main period of habitation (level II of the excavations), the majority of them Assyrians (Hertel 2014); this period largely corresponds to the nineteenth century BCE. This commercial district is divided into quarters separated by large streets and open spaces. A host of artefacts have been excavated in the houses, including some 22,000 clay tablets. At the end of this period, many houses burnt down, which actually baked the tablets, helping to preserve them for posterity. The next level, level Ib (eighteenth century BCE), has only provided 460 tablets up to now, even though the site was more densely inhabited in this period than it was in 'level II'.

The Assyrian merchants who owned houses in Kaneš originally came from Aššur, located on the River Tigris south of Mosul in modern-day Iraq. Aššur has been excavated on and off for a century, but because of various wars the excavations have not been conducted for more than a total of 30 years (Marzahn/Salje 2003). The archaeological discoveries from the beginning of the second millennium BCE are rare and lie scattered about-the main constructions to have been unearthed to date are official or religious buildings-and the Old Assyrian district has not been identified yet, apart from some graves belonging to rich merchants (Hockmann 2010). Thus, for the Old Assyrian period, Aššur has only supplied us with 24 tablets scattered among later archives, including school texts and some 30 royal inscriptions from temples (Grayson 1987). So all we can say about Assyrian society is based on the private archives of the Assyrian merchants who settled in Anatolia, mostly in Kaneš; these archives are currently being deciphered by a dozen specialists from Europe and Turkey.

At the beginning of the second millennium BCE, Aššur was an independent city-state dominated by an oligarchy of merchants. The city played an important role in large-scale trade from the third millennium onwards. Encouraged by political and economic measures taken by Aššur kings and commercial treaties concluded with the local authorities (Günbatt1 2004, Veenhof 2003b; 2013b), the merchants developed long-distance trade links to Central Anatolia, settling down there and building up some forty trade settlements whose centre was located in Kaneš. 


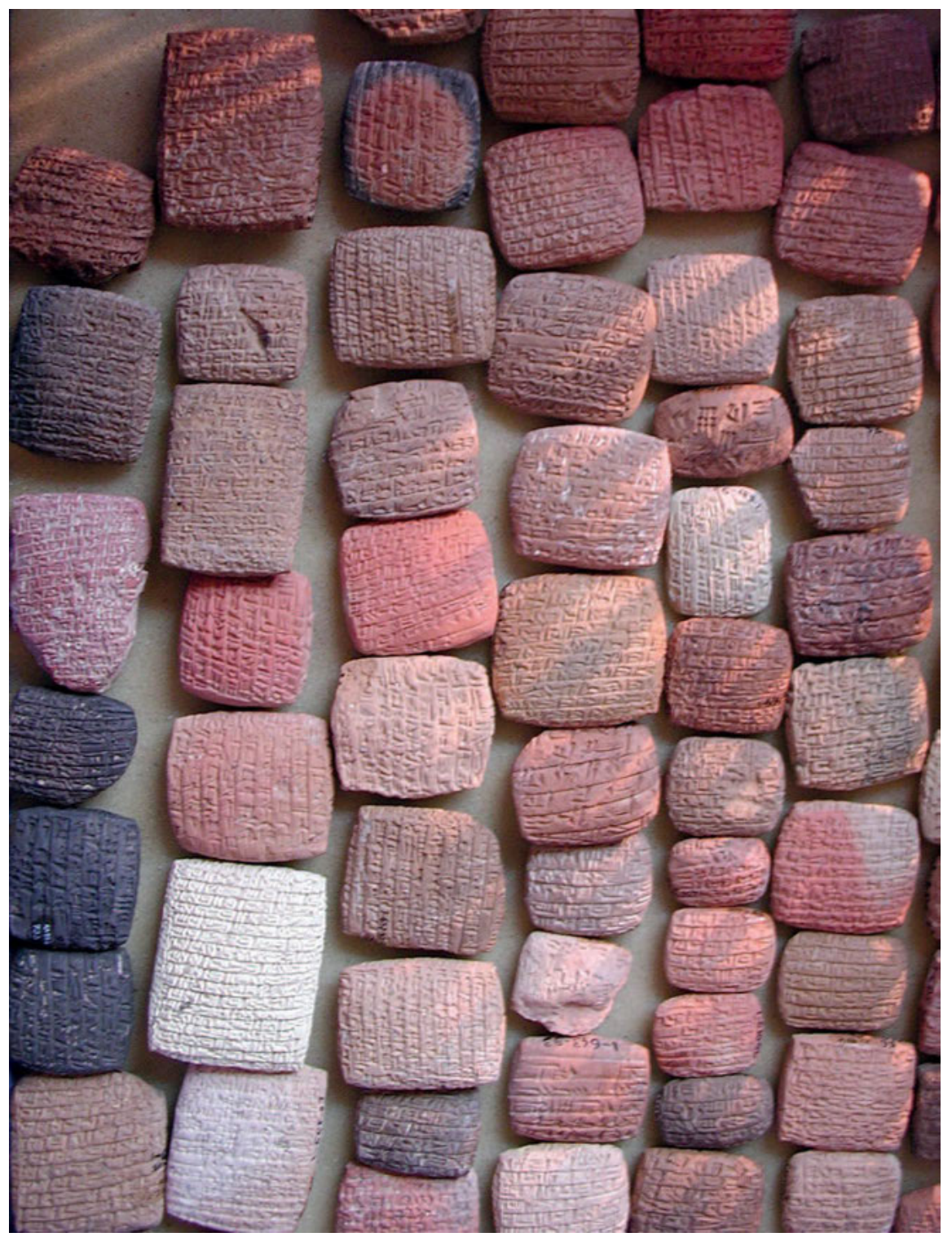

Fig. 3: Tablets belonging to the archives of Ali-ahum and Aššur-taklāku. Photo: Cécile Michel. (c) Kültepe Archaeological Mission. 


\subsection{The contents and purpose of Old Assyrian archives}

The Old Assyrian tablets excavated in the lower town of Kültepe mainly belonged to Assyrian merchants who had originally settled there during the first half of the nineteenth century BCE. In their letters, when they mention their archives, the Assyrians usually referred to them as 'my tablets' (tuppūa), as in the expression 'open my tablets (container)' (țuppēa peteā) or 'my tablets' containers' (șiliānū/ tamalākū ša tuppēa). The word 'tablet' (țuppum, from the Sumerian DUB) is a generic term which corresponds to the object itself on which a text is written, a 'letter' or a 'legal text', and in the plural 'the group of tablets forming (part of) an archive'.

The tablets found in an archive may be classified into several text genres according to modern categories: letters, legal texts, personal memoranda and noncommercial texts.

\subsubsection{Letters}

A letter is referred to by the words țuppum ('tablet') or našpertum ('message', 'shipment'). Letters often make up a large part of an archive-from 40 to $45 \%$ of it. They provide a considerable amount of data about the way trade was organised, but also cover domestic matters and aspects of daily life. They are never dated, however (Michel 2001; 2008a). The displacement of family members and colleagues to Central Anatolia explains the existence of so many Old Assyrian letters; these were a unique means of communication between the inhabitants of Kaneš and their families and colleagues in Aššur, and the only way to exchange news. In one case, a woman wrote to a relative of hers, saying: 'I'm fine. Don't worry! Please send me some news about yourself and the household as soon as you hear my letter' (Michel 2001, no. 373). And in another case, a merchant explained that he had been writing a lot of correspondence: 'I have exhausted the clay of this town by constantly sending you letters."

There was no standard size for letters: the size simply depended on the length of the message to be written. Some were extremely short, written on very small tablets, as suggested by a woman who wished to receive some news from her relatives: 'Why haven't you even sent me a tablet two fingers long with some good

$8 \mathrm{Kt}$ 89/k 232: 6-8, ți-țá-am, ša a-lim ${ }^{\mathrm{ki}}$ : a-nim i-na, tí-ša-pu-ri-im: ag-da-am-ra-ku-ni-ma (cited by Veenhof 2008, 201, n. 8). See also AKT 4, 30: 28-29 and Kt n/k 161: 37-38. 
news?', she wrote. ${ }^{9}$ Other tablets could be very long, spanning more than a hundred lines. The size originally planned sometimes turned out to be too small, so a second flat, oval tablet written on one side was added to the first tablet. The Assyrians called this second 'page' șibat tuppim, i.e. 'additional tablet' (Veenhof 2003a, 91). It is not easy for researchers to match up the first and second pages if these got separated.

Letters were covered by clay envelopes which reveal the identity of the correspondents as well as the sender's seal impression, which was usually made with a cylinder seal that produced a long, rectangular miniature scene sometimes including the name of its owner. The envelope protected the confidentiality of the letter and the tablet during transportation. Letters enclosed in envelopes were wrapped in textiles and leather to protect them when they were sent off to Kaneš using caravans of donkeys; it took about six weeks to reach the town.

When a merchant received a letter, he first had to break the envelope to read the text. Envelopes should thus have been open in Antiquity. However, many envelopes and fragments of envelopes have been discovered in Old Assyrian archives, which suggests that they did not get opened. Some of them will have got broken when the house they were kept in was destroyed (most of the pieces are generally found by archaeologists). Indeed, some letters were never even sent off. In other cases, their intended recipients were out when they were delivered or had even died by the time they arrived, so the envelopes did not get opened. Preserved envelopes allow the identification of the seal users. These envelopes also kept the two pages of long letters together, which often got separated once an envelope was opened.

The recipient kept the letters he received in his archives for personal reasons or because of the information they contained-as a reminder of his commercial activities, because of the answers received from colleagues or representatives to whom he had given instructions, etc. One could also keep copies of the letters one sent, as we learn from a letter written by a merchant whose archives have been unearthed in Kaneš: 'I have kept a copy of all the tablets I have sent you over time.'10

9 ICK 1, 17: 4-7: mì-nu-um : a-ni-tum, ša țup-pá-am 2 ú-ba-an, šu-lu-um-ku-nu, lá tù-šé-ba-lá-ni-ni. 10 CCT 2, 6: 14-15, mì-ma țup-pì ša uš'-té-né-ba-lá-ku-n[i], me-eh-ri-šu-nu : ú-kà-al. 


\subsubsection{Contracts and other legal texts}

Tablets containing legal texts usually form a second category: contracts and judicial records (Michel 2000a, Hertel 2013, 133-183). Numerous contracts have been discovered; they concern family law (marriage, divorce and wills), loans and receipts for repayments, caravan services and transport, investments, deposits, business partnerships, deeds of purchase and so on. The judicial records contain witnessed depositions, records of private arbitration cases, binding orders, verdicts, etc. The legal validity of such tablets is certified (tuppum harmum) by an envelope sealed by the parties involved and their witnesses (Larsen 1977, Tessier 1994). Seals were often rolled along every single side of the envelope, then the text was written. It always started with the names of the individuals who had sealed the envelope, but the order of the seals on the envelope is not usually respected. Since the seals are generally uninscribed, it is not very easy to identify their owners nowadays, whereas in the past, family members and colleagues will have recognized the seals their relatives and acquaintances used.

The text written on the envelope usually duplicates the one on the tablet, meaning that it was possible to read it without actually opening the envelope. Indeed, when the envelope was opened, the tablet lost its legal validity. In fact, since clay tablets were never baked, it was always possible to moisten the surface of them and erase particular signs or even whole lines on them. In one case we know of, a merchant specifically asked a colleague to search for a tablet in his archives and erase some lines on it:

Concerning the tablet referring to the house of Wašhuba, which you wrote to me about, take Ilabrat-bāni with you and open the tablets (archive) [...]. There is a tablet concerning a loan of 21 minas 10 shekels of silver that the merchant made to Šalim-Aššur, Ikūnum and Sanasiya, and concerning that silver we share responsibility for. Take that tablet out, examine it and moisten it with water where it says 'the silver was taken in the name of Iliš-tikal', (erase it) and show the son of Šalim-Aššur what is important to you (KTS 2, 9; see Michel 1995, 25, n. 47).

Loan contracts are the most numerous in the category of legal texts and concern loans in silver, grain and copper. These are simple loans or, more often, loans issued from the credit sale of merchandise. Documents of this type are often dated and were kept in the creditor's archives until the debt was repaid. In exchange for the payment, he had to give the tablet back to the debtor, who would logically 
'kill it', i.e. destroy it: 'Hand the tablets recording my debts over to me so that I can destroy (them)', says one. ${ }^{11}$

Sometimes the tablet was lost or got broken:

\begin{abstract}
We went through Durhumit and saw the fragments of a tablet on which Țāb-ṣilli-Aššur, son of Hinnaya, (is named). He got angry with me about the 10 shekels of silver from Aššur-bāni and didn't get the tablet out. He submitted a claim against you, saying: 'We'll take a tablet (order) from the trade office in Kaneš (i.e. the central Assyrian office there) and they will shape our tablets again. Then the trade office at Durhumit will seal them for us' (TPAK 1, 7; see Michel 1995, 23-24).
\end{abstract}

Loan tablets were not cancelled systematically, it seems-lots of them remained in the archives. Those of them preserved in their envelopes were either never repaid or some of the debts were paid elsewhere and the creditor gave a receipt to the debtor. Those preserved without their envelopes had no more legal validity, as we have said, but the debtor still kept them in the archives for his personal accounts (Michel 1998). Many loans were also copied in long memoranda (tahsistum), which were useful to the traders, helping them to remember all their outstanding claims.

The other contracts dealing with long-distance trade concern the hiring of caravan people, the transport or storage of merchandise, investments in business partnerships or joint-stock companies, and closure of accounts. Purchase agreements relate to houses and slaves. The deed of a house purchase was kept by the buyer and used as a title of ownership; it was transferred during every transaction concerning the same building, as we have learnt from some of the contracts that have been found:

They sold the house of Ištar-lamassī and Aššur-țāb to Šalimma for $21 \frac{1}{2}$ minas of silver. And Aššur-țāb and Ištar-lamassī are satisfied with the silver, the price of their house [...]. Aššurțāb gave to Šalimma the contract recording the sale of this house bearing the seal of the Anatolian, its previous owner (Michel forthcoming, no. 148). ${ }^{12}$

There is also a great variety of judicial texts among the tablets that have been discovered: minutes and proceedings of testimonies and arbitrations, and verdicts passed by the Assyrian authorities of Aššur or Kaneš. All these tablets were kept by the individuals who were primarily concerned.

Family-law texts concerned marriage, divorce, inheritance and adoption; the majority of these relate to marriage contracts. Thanks to the seal impressions found on the envelopes, it is possible to know which archive a particular contract

11 TC 3, 264a:7-9, țup-pé-e ša hu-bu-li-a, dì-na-ma, la-du-uk.

12 This kind of practice is well known during the Old Babylonian period; see Charpin 1986. 
was kept in. If the envelope bears the seals of the groom and witnesses, then the contract was kept in the girl's family archives or together with her own tablets, but if the envelope has an impression of the seals on it that were used by the bride's father and/or mother and by the witnesses, the contract was kept in the husband's archives, in some cases as proof that the bride price had been paid (Kienast 2015, Michel forthcoming, chapter 1).

All the legal tablets were kept by the parties involved. The witnesses sometimes also received a copy of the contract to put in their own archives: 'A copy of this tablet is with Ennam-Aššur', says one such find. ${ }^{13}$ Some lists of loans bear a subscript to indicate that the text is a copy of several loans, e.g.: 'this tablet is a copy of the certified tablets. ${ }^{14}$

\subsubsection{Miscellaneous texts}

The other tablets found in archives are all those which have no legal value, and are not letters: lists, private account notices, memoranda and various miscellaneous texts. These are anonymous, so it is often impossible to link them to their owner. It seems they were used as an aid to memory. There are also a few noncommercial texts among them, such as school texts, incantations, lists of eponyms, and rare historical or literary texts.

\subsubsection{Other inscribed objects}

Besides tablets, archives contained bullæ, or pieces of clay which were used both as labels and to close bags and containers. These bullæ had seal impressions and could bear a text linked to the content of the sealed containers or to their owner. Some of the cylinder seals were inscribed with the name of their owners and patronyms. In exceptional cases, other objects could have a very short text: the name of Amurru-bāni was written on a fragment of a jar excavated in 1992, for instance (Kulakoğlu/Kangal 2010, no. 448).

13 TC 3, 211:57-58, me-[he-e]r țup-pí-im a-nim, ki En-na-A-šur.

14 ICK 1, 187:63-64, [țup]-pu-um a-ni-um me-he-e[r], țup-pè ha-ru-m[u-tim]. 

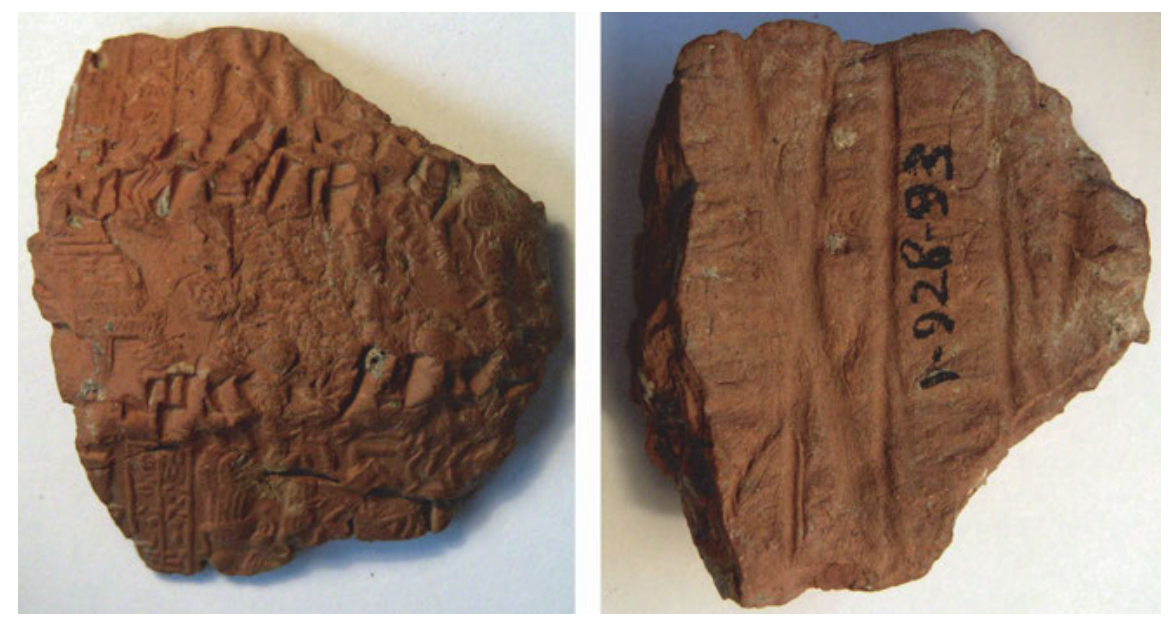

Fig. 4: Bulla Kt 93/k 804. On the recto, the text mentions a shipment to a merchant whose name is broken. There are three seal imprints, two of them bearing the name of their owners, Puzur-Ana, son of Elālī, and Aššur-țāb, son of Ali-ahum. On the verso, there are traces of textiles and strings, suggesting that this bulla was attached to objects (tablets or merchandise) wrapped in a textile. Photos: Cécile Michel. @ Kültepe Archaeological Mission.

\section{The archives and their owners}

Every year since 1948, several houses in Kültepe have been emptied, some of which have contained archives of tablets. Each of these archival groups contains all the tablets accumulated during the lifetime of one or more members of a family. These vary a great deal in terms of their size and content (Michel 2003; 2006; 2011a; 2015c).

To identify the owner of an archive and, by extension, of a house, one has to look for the recipients of letters, providers of loans and persons involved in the other legal texts. The result is not always obvious because some Assyrian merchants did not have a house of their own in Kaneš and left tablets in colleagues' houses instead. A house excavated in 1990 yielded 230 tablets highlighting the activities of two merchants, for example (Michel/Garelli 1997). The first one, Šumi-abiya, son of Puzur-Ištar, was the recipient of several letters and the owner of several loan contracts. His father and brothers also appear as creditors. The second one, Aššur-mūtappil, son of Iddin-abum, was the recipient of several letters, and the only other texts mentioning him also mention Šumi-abiya. So he probably stored his tablets in his colleague's house (Michel 1998). 
This was a common practice, as many texts reveal. In one of these, for example, a trial was taking place that concerned two boxes of tablets that two merchants each claimed to be their own property: 'When I was in Kaneš with my wife, you went to Durhumit, and although I didn't owe you anything, you entered my second home on your own authority and took 2 boxes of tablets with you, which contained ...' [then a detailed description of the tablets follows ] '... and tablets from other people who had left them with me as a safe deposit ...' [then another detailed description of the tablets follows] '... and apart tablets belonging to my witnesses, concerning you and me, which they had certified at the Gate of the God' (CTMMA 1, 84, Michel 2000a, no. 93).

\subsection{The owner of the archive excavated at Kültepe in 1993}

In 1993, archaeologists working on the Kültepe site unearthed a large building or two adjoining houses (named hereafter 'house 1' and 'house 2') in grid LVII/127 and LVIII/127-128 in the lower town, which were badly damaged. These contained almost a thousand tablets, envelopes and fragments. In terms of our modern categories, these tablets may be classified as follows:

\begin{tabular}{ll}
\hline Type of text & \% of total \\
\hline Letters & 40 \\
Loan contracts & 10 \\
Other contracts & 10 \\
Legal proceedings & 7 \\
Personal accounts & 15 \\
Not identified & 18 \\
\hline
\end{tabular}

In terms of proportions, there were more letters in 'house 1' than in 'house 2', while the latter contained more loans and other contracts than the former. Three merchants are often mentioned in this archive, which was spread over several rooms: Aššur-taklāku, Ali-ahum and Iddin-Suen, along with a woman called Tariša (Michel 2008b). ${ }^{15}$ Iddin-Suen was the recipient of 40 letters and the sender of only 4, although these belong to a homonym. The vast majority of the letters sent to Iddin-Suen were discovered in 'house 1'. None of his loan contracts have been found, and only two lawsuits pertain to him.

15 Due to the very poor state of the buildings, there is no exact indication of the tablets' locations. 
Ali-ahum, his son, was the recipient of 31 letters and the author of 18 others, mainly sent to members of his family while he was away. He had a house in Burušhattum and may have had a house in Aššur as well. He was also the owner of 11 loan contracts and was involved in a dozen lawsuits and other judicial matters. The total number of texts related to Ali-ahum in the houses excavated in 1993 is not as substantial, which may be explained by the distribution of his archives in different houses located in Burušhattum and Aššur.

The most frequent correspondent in the 1993 letters is Aššur-taklāku, son of Ali-ahum: he was the author of 72 letters and the recipient of 72 others. He sent a lot of letters to members of his family living in 'house 2'. Since Aššur-taklāku sent as many letters as he received, he presumably travelled a great deal and was away from home for long periods. The numerous loan contracts in which Aššur-taklāku is mentioned as a creditor are the best proof that the archive belonged to him. In fact, he was the creditor behind 48 loan contracts in all, most of which were found in 'house 2'. Finally, about 30 judicial texts exist that reflect his lawsuits and disputes with other merchants.

Some of the women in the family are also mentioned in this archive. A ššrurtaklāku's wife, Lušitiya, was the recipient of 7 letters, some of them written by her husband. His sister, Tariša, was the recipient of 26 letters and the sender of 7 . Almost all of the letters she received were written by her brother and were found in 'house 2' where she lived with other members of her family. She had previously spent some time in Aššur (Michel 2015b). Other individuals mentioned in this corpus also belonged to the family. Moreover, Elamma, a brother of Ali-ahum whose archives are being studied by Klaas R. Veenhof, practically lived next door (Veenhof 2015); it has thus been possible to reconstruct the whole family tree in this case.

\subsection{The content of the 1993 archive}

This archive concerns three generations of a merchant's family who inhabited two neighbouring houses that were largely destroyed at some point. Obviously, we do not have the entire archive of this family over three generations (see Michel $2008 \mathrm{~b}$ as well). What kind of texts were preserved and what kind of texts are absent?

Let us start with the grandfather, Iddin-Suen. The archive in question contains some letters he received and a few legal texts mentioning action taken in the court of law. More than a third of the letters addressed to Iddin-Suen are only known to us from fragments of their envelopes, which have been preserved together. These letters possibly arrived at Kaneš when their recipient was away or 
already dead; they were kept together in the same container, presumably by Iddin-Suen's son. The absence of any loan contracts relating to Iddin-Suen means that either they were all repaid and the tablets were then discarded or that new tablets concerning the unpaid debts were written in his sons'name.

Ali-ahum, who lived there after his father, at least for a while, left even fewer letters. He owned another house in Burušhattum (south-west of the Tuz Gölü Lake) where he left some tablets as well. It is even possible that he died there. Thus we have only part of his archive in Kaneš.

Aššur-taklāku was the main owner of the archives discovered at Kültepe in 1993 as most of the letters, loan contracts and other legal texts belonged to him. At the time the houses were destroyed, he was the one who had spent the most time there and was one of the last people to be in them. His archive could be called a 'living archive' as his certified loan contracts were still valid.

\subsection{Dating the 1993 archive}

Practically the only tablets to have a date on them are the loan contracts. Most of those excavated in 1993 belong to a period covering 34 years (c.1893-1859 BCE) and concern Ali-ahum and his son Aššur-taklāku almost exclusively. Only four dates fall outside this period: the oldest one (c.1901 BCE) is on a tablet associated with an anonymous creditor, while the three others bear much later dates lying between $c .1840$ and 1838. If we take these extreme dates into account, the dated texts from 1993 span a period of 64 years altogether.

Almost all the loans dated between c.1893 and 1878 BCE, a 15-year period, concern Ali-ahum, while all the loans in which his son, Aššur-taklāku, appears as the creditor are dated between c.1877 and 1859 BCE, an 18-year period. This very clear distribution of the loans between the father and the son is only disturbed by a single loan belonging to Ali-ahum dated to the end of $c .1874$ BCE. This suggests that father and son where not active at the same time in Kaneš.

\section{Uses and filing of archives}

The archives were regularly consulted, which explains why so many letters and various texts were kept: the merchants kept every tablet concerning their activities as well as letters from their relatives. Since the archives grew in size over the years, it was obviously necessary to file them. 


\subsection{Use of the archives}

As noted some years ago by Klaas R. Veenhof (2008b, 200):

There probably is no Mesopotamian text corpus in which written documents are mentioned so often and that offers so much information on their writing, consultation, storage, transfer, exchange and cancellation. This explains why many archives contain hundreds of letters, lists and notes and why we frequently read about the making and use of copies of documents (mehrum).

Many tablets were regularly extracted from the archive, consulted and sometimes transferred. As custodians of the tablets, wives could be directed to provide the men in the family with certain ones that they needed. In the following case, a merchant asks his wife and a colleague to retrieve a specific tablet from his archives (AKT 3, 84; Michel forthcoming, no. 214):

I have sealed a tablet with the (names of) my witnesses at the Gate of the God: Aššur-țāb, son of Kīki, and Enna-Suen, son of Ilānum. So look where the tablets have been deposited inside a container at the Gate of the God, take out the tablet with the seal of Aššur-țāb and Enna-Suen, wrap it securely in leather and seal it, then entrust it to Hašta'ili or to Šamašrē'î so he can bring (it) over to me; make sure (to do it properly)!

\subsection{Filing archives}

Every year until 2005, archaeologists unearthed up to three houses in the lower town in Kültepe, some of which contained one or more archives. The houses unearthed in the first half of the 1990s in squares LV-LXV/126-131 mainly belonged to Assyrian merchants. All in all, 4,190 tablets were excavated in eleven or twelve different houses over a five-year period, as the following table shows (the number of houses is indicated in brackets):

- 1990 (1): 242 tablets in the house of Šūmì-abiya, son of Puzur-Ištar, with tablets belonging to Aššur-mūtappil, son of Iddin-abum (published by Michel/Garelli 1997)

- 1990 (2): 123 tablets belonging to PN? (studied by S. Çeçen)

- 1991 (1): 282 tablets + 90 tablets from 1992 in the house of Elamma, son of Iddin-Suen (published by Veenhof, in press)

- 1991 (2): 154 tablets belonging to various other archives

- 1992 (1): 73 tablets + 3 tablets from 1989 in the house of Kuliya (published by Veenhof 2010)

- 1992 (2): 774 tablets in the house of Šū-Ištar, son of Aššur-bāni (Erol 2015) 
- 1993 (1 or 2): 915 tablets + 61 tablets from $1994+2$ tablets from 1998 in the house(s) of Ali-ahum, son of Iddin-Suen and his son Aššur-taklāku (Michel 2008d)

- 1994 (1): 370 tablets presumably in the house of Irma-Aššur (studied by G. Barjamovic)

- 1994 (2): 1,101 tablets in the house of Šalim-Aššur, son of Issu-arik, and his sons (published in Larsen 2010; 2013; 2014).

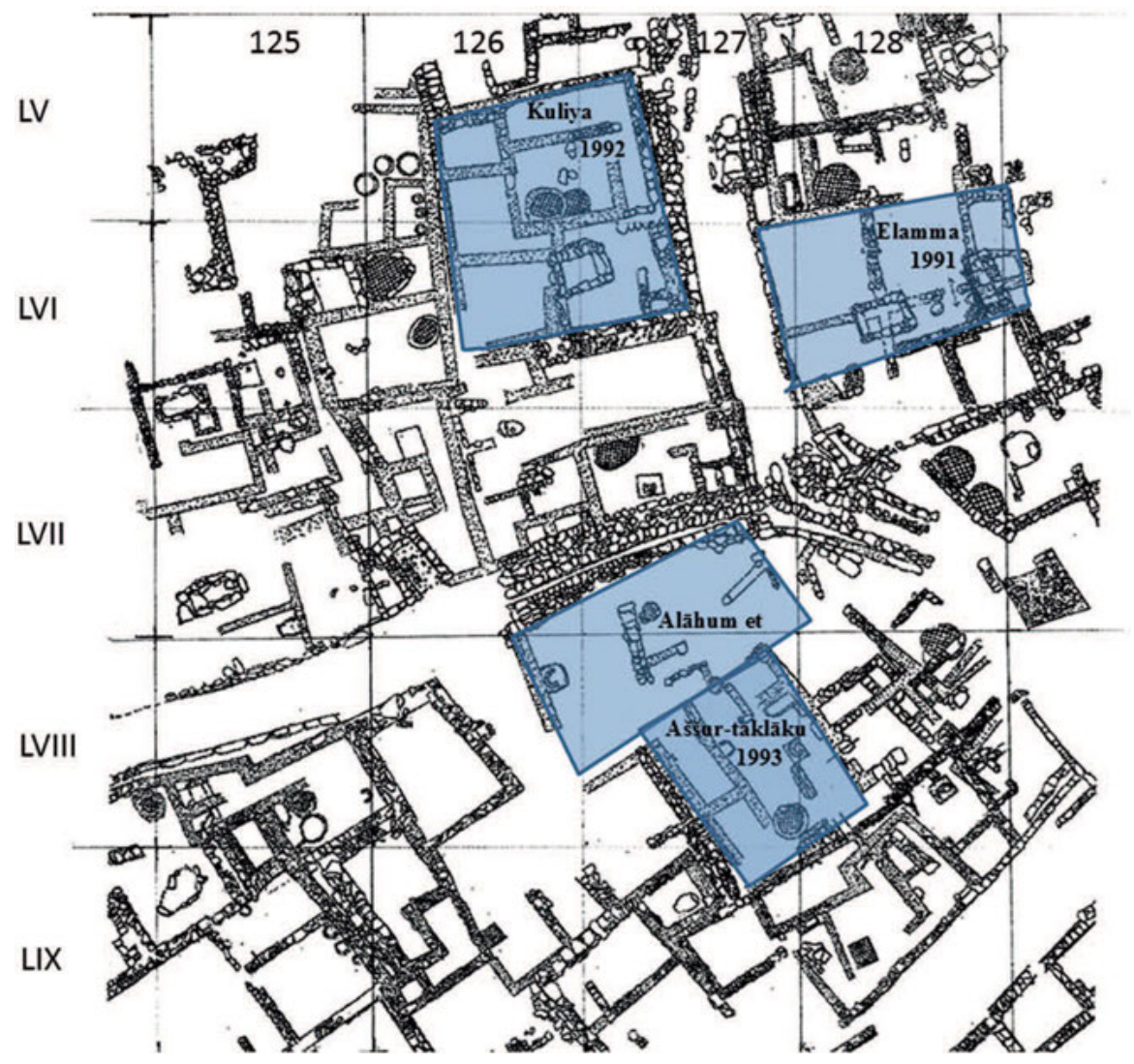

Fig. 5: Plan of a district of the lower town excavated at the beginning of the 1990s. (c) Kültepe Archaeological Mission.

Large archives such as those excavated in 1993 and 1994 contained a thousand or more tablets, which will certainly have required filing. According to excavation reports, tablets were found in piles on the ground in the corners of rooms or along 
the walls of the buildings. They were stored in bags, baskets and chests made of perishable materials or in clay containers. Thus, Elamma's archives excavated in 1991 were 'found along the base of the east wall of room 3 and in rooms 4-5, in groups once packed in boxes, bags, sacks and straw mats. On top of each group lay one or two bullæ' (Özgüç 1994, 369). ${ }^{16}$ Indeed, tablet containers were usually identified by a clay docket or bulla. Unfortunately, the links between the bullæ and the tablets have been lost.

Within a period of sixty years, archaeologists only unearthed 240 bullæ in the commercial district, 144 of which bear a text (bullæ were used to seal all kinds of containers). The texts refer either to merchandise or to tablets. ${ }^{17}$ Some of these bullæ only have a seal on them indicating who the owner of the archive was or what goods had been sealed, but others also bear a short text, which sometimes gives us an idea about the way tablets were filed. In 1963, for example, 207 tablets and 10 bullæ were found in one house (in square B-D/11-12); one of the bullæ bearing the text 'Tablets concerning Agūa's will' (Kt o/k 203) could be linked to the will itself (Kt o/k 196), which was kept in its envelope. Presumably, other tablets linked to Agūa's inheritance were kept in the same container (Michel 2000b).

In the two houses excavated in 1993, the archaeologists unearthed 37 bullæ. The imprints left on the inside of these show traces of strings and ropes and sometimes the type of material on which they were applied: wood, textile, clay, etc. Twenty of these bullæ do not bear any text at all. Two of those applied on tablets' containers are the following (Michel 2016):

- Kt 93/k 273, bearing the seal of Ali-ahum, has a text which indicates that it was used to seal a container with certified tablets, verdicts from the trade office concerning Suen-pilah. According to the traces on the inside of the bulla, the container was protected by a textile attached to it with reeds.

- Kt 93/k 813 was fixed to a reed basket with tablets sealed by the trade office and containing verdicts of the Aššur assembly according to its text.

16 Note, however, that some tablets excavated in 1950 have a pair of holes in one of the vertical edges; according to Dercksen 2015, 50, these were stored by suspending them from a rope. Unbaked clay is quite fragile, however, so this is unlikely; these holes may have been useful during the process of manufacturing the tablets or better for filing. Moreover, holes of this kind are unusual.

17 Bullæ were also attached to merchandise or tablets sent from Aššur to Anatolia or between two different towns in Anatolia; only some of the bullæ found in the houses had archival functions and were used to file archives, for example; see Özgüç/Tunca 2001, 132-133, 307; Veenhof 2003a, 102. 
In fact, most of the bullæ texts deal with certified tablets which are verdicts from the Assyrian trade office in Kaneš or the Aššur assembly, or loan contracts concerning identified merchants. Thus, legal texts were kept separately, classified by topics.

Letters could be arranged according to who their sender was. Some bullæ only bear the name of a merchant (Kt 93/k 807; tablets belonging to Aššurdamiq), referring presumably to tablets belonging to him or letters sent by him. ${ }^{18}$ From the study of the archives excavated in 1993, we also observe that the archives of the successive owners of the houses were arranged in different containers. The letters received by the grandfather, Iddin-Suen, and kept after his death were found in 'house 1', presumably separated from the other tablets.

The tablets belonging to the older generations were also sorted: the vast majority of 1993 archives belonged to Aššur-taklāku, whereas only a few letters and other tablets belonged to his grandfather, Iddin-Suen.

\section{Conclusions}

In summary, the archives found in the houses of Assyrian merchants in the lower town of Kaneš belonged to members of families over several generations. Archives of this kind look more like piles of individual archives than family archives, however. Most of them are the result of sorting, which was necessary from time to time. The archives of the ancestors were kept apart from one another. What's more, the merchants travelled a great deal, and several of them stayed in Anatolia for a while because of their commercial activities before retiring in Aššur; Aššur-taklāku, the main owner of the 1993 archive, stayed in Kaneš for almost twenty years. His father, Ali-ahum, lived in three different towns, Kaneš, Burušhattum and Aššur, and presumably left tablets in each of his three houses there. Consequently, whenever a find is made, it is usually an incomplete archive or an accumulation of 'dossiers'.

Letters were the unique means of communication between the inhabitants of Kaneš and their families and colleagues in Aššur, which explains why there are so many of them in the archives, where they are the oldest texts preserved; they were kept as a reminder of specific acts. This does not necessarily mean that they took precedence over the other types of texts, though; on the contrary, they had

18 Larsen 2008 also suggests that the bulla that bears the words 'For Ali-ahum, son of ŠalimAššur; sealed by Zukua, son of Aššur-idī' (Kt 94/k 1059) could be linked to the 14 letters from Zukua to Ali-ahum found in the archive. This author also noted that the 1994 archive contained very old texts, written a century before the destruction of the house in which they were kept. 
less value and were left behind as part of a 'dead' archive, while other texts could be cancelled because they had expired, or they were carefully arranged in dossiers and moved elsewhere when their owner moved house, for example.

Private archives were arranged in logical groups: texts dealing with a specific matter or referring to a certain person, whatever their literary genre, were stored together in a container identified thanks to its bulla. A distinction was usually made between certified tablets preserved in their sealed envelope and tablets with no legal validity. However, the modern classification of cuneiform tablets in terms of text genres (letters, legal texts, memoranda, literary, official inscriptions, etc.) should not hide the ancient logic of archive storage in antiquity.

\section{Abbreviations}

AKT 3 E. Bilgiç, C. Günbattı, Ankaraner Kültepe-Texte, III (Freiburger Altorientalische Studien Beihefte 3), Stuttgart 1995.

AKT 4 i. Albayrak, (Ankara) Kültepe Tabletleri (Kto/k), IV (Türk Tarih Kurumu Yayınları $\mathrm{VI} / 33 \mathrm{~b})$, Ankara 2006.

CCT 2 S. Smith, Cuneiform Texts from Cappadocian Tablets in the British Museum, II, London 1924.

CT 22 R. Campbell Thompson / L. W. King, Cuneiform Texts from Babylonian Tablets, \&c., in the British Museum, XXII, London 1906.

CTMMA 1 M. T. Larsen, in I. Spar (ed.), Tablets, Cones and Bricks of the Third and Second Millennia B.C., Cuneiform Texts in the Metropolitan Museum of Art New York, I, New York 1988.

ICK 1 B. Hrozný, Inscriptions cunéiformes du Kultépé, I (Monografie Archivu Orientálního 14), Prague 1952.

Kt ?/k Tablet found during the Turkish excavations at Kültepe since 1948 and onwards, preserved in the Anadolu Medeniyetleri Müzesi (Museum of Anatolian Civilisations, Ankara).

$\mathrm{Kt} \mathrm{n} / \mathrm{k} \quad$ Tablets found during the 1962 excavations.

Kt o/k Tablets found during the 1963 excavations.

Kt 89/k Tablets found during the 1989 excavations.

Kt 93/k Tablets found during the 1993 excavations.

Kt 94/k Tablets found during the 1994 excavations.

KTS 2 Veysel Donbaz, Keilschrifttexte in den Antiken-Museen zu Stambul, II (Freiburger Altorientalische Studien Beihefte 2), Stuttgart 1989.

TC 3 J. Lewy, Tablettes cappadociennes du Louvre (Textes cunéiformes du Louvre XIX, XX, XXI), Paris 1935-1937.

TPAK 1 C. Michel, P. Garelli, Tablettes paléo-assyriennes de Kültepe, I (Kt 90/k), Istanbul 1997. 


\section{References}

Abrahami, Philippe, and Brigitte Lion (2012), L'archive de Tulpun-naya (Studies on the Civilization and Culture of Nuzi and the Hurrians, 19), Cornell, 3-86.

Archi, Alfonso (2003), 'Archival Record-Keeping at Ebla 2400-2340 BC', in Maria Brosius (ed.) 2003, 17-36.

Barjamovic, Gojko (2014), 'The Size of Kanesh and the Demography of Early Middle Bronze Age Anatolia', in Levent Atici, Fikri Kulakoğlu, Gojko Barjamovic and Andrew Fairbairn (eds), Current Research at Kültepe/Kanesh: An Interdisciplinary and Integrative Approach to Trade Networks, Internationalism, and Identity (Journal of Cuneiform Studies Sup. 4), Atlanta, GA, USA: Lockwood Press, 55-68.

Brosius, Maria (ed.) (2003), Archives and Archival Tradition. Concepts of Record-Keeping in the Ancient World (Oxford Studies in Ancient Documents), Oxford: Oxford University Press.

Charpin, Dominique (1985), Les archives d'époque assyrienne (Mari Annales de Recherches Interdisciplinaires, 4), Paris.

Charpin, Dominique (1986), 'Transmission des titres de propriété et constitution des archives privées en Babylonie ancienne', in Klaas R. Veenhof (ed.), Cuneiform Archives and Libraries, Papers read at the 30e Rencontre Assyriologique Internationale Leiden, 4-8 July 1983 (Publications de l'Institut historique-archéologique néerlandais de Stamboul, 57), Leiden: Nederlands Instituut voor het Nabije Oosten, 121-140.

Clancier, Philippe (2009), Les bibliothèques en Babylonie dans la deuxième moitié du ler millénaire av. J.-C. (Alter Orient und Altes Testament, 363), Münster: Ugarit-Verlag.

Dercksen, Jan G. (2015), 'The Archives of Ali-ahum (I). The documents excavated in N-P-O/20 in 1950 ', in Fikri Kulakoğlu and Cécile Michel (eds), Proceedings of the $1^{\text {st }}$ Kültepe International Meeting. Kültepe, 19-23 September, 2013. Studies dedicated to Kutlu Emre (Kültepe International Meeting 1, Subartu XXXV), Turnhout: Brepols, 47-58.

Erol, Hakan (2015), 'The Archives of Šu-Ištar son of Aššur-bāni (Kt 92/k 264-1008)', in Fikri Kulakoğlu and Cécile Michel (eds), Proceedings of the $1^{\text {st }}$ Kültepe International Meeting. Kültepe, 19-23 September, 2013. Studies dedicated to Kutlu Emre (Kültepe International Meeting 1, Subartu XXXV), Turnhout: Brepols, 59-73.

Faraguna, Michele (ed.) (2013), Archives and archival documents in ancient societies: Legal documents in ancient societies IV, Trieste 30 September-1 October 2011, Trieste (http://www.openstarts.units.it/dspace/handle/10077/8649)

Frame, Grant, and Andrew R. George (2005), 'The Royal Libraries of Nineveh: New Evidence for King Ashurbanipal's Tablet Collecting', in Iraq, 67, 265-284.

Grayson, Kirk A. (1987), Assyrian Rulers of the Third and Second Millennium BC (to 1115 BC) (The Royal Inscriptions of Mesopotamia, Assyrian Periods, 1), Toronto: University of Toronto Press.

Günbattı, Cahit (1998), 'Kültepe'den Akadlı Sargon'a Ait Bir Tablet', in Archivum Anatolicum, 3, 131-155.

Günbattı, Cahit (2004), 'Two treaty texts found at Kültepe', in Jan Gerrit Dercksen (ed.), Assyria and Beyond. Studies Presented to Mogens Trolle Larsen (Publications de l'Institut historique-archéologique néerlandais de Stamboul 100), Leiden: Nederlands Instituut voor het Nabije Oosten, 249-268. 
Hertel, Thomas Klitgaard (2013), Old Assyrian Legal Practices. Law and Dispute in the Ancient Near East (Old Assyrian Archives Studies, 6, Publications de l'Institut historique-archéologique néerlandais de Stamboul, 123), Leiden: Nederlands Instituut voor het Nabije Oosten.

Hertel, Thomas Klitgaard (2014), ‘The Lower Town of Kültepe: Urban Layout and Population', in Levent Atici, Fikri Kulakoğlu, Gojko Barjamovic and Andrew Fairbairn (eds), Current Research at Kültepe/Kanesh: An Interdisciplinary and Integrative Approach to Trade Networks, Internationalism, and Identity (Journal of Cuneiform Studies Sup. 4), Atlanta, GA, USA: Lockwood Press, 25-54.

Hockmann, Daniel (2010), Gräber und Grüfte in Assur, I: Von der zweiten Hälfte des 3. bis zur Mitte des 2. Jahrtausends v. Chr. (Wissenschaftliche Veröffentlichungen der Deutschen Orient-Gesellschaft, 129), Wiesbaden: Harrassowitz.

Jacquet, Antoine (2013), 'Family Archives in Mesopotamia during the Old Babylonian Period', in Michele Faraguna (ed.) 2013, 63-85.

Jas, Remko M. (2000), 'Old and New archives from Nuzi', in A.C.V.M. Bongenaar (ed.), Interdependency of Institutions and Private Entrepreneurs (MOS Studies, 2), Istanbul, 213-228.

Joannès, Francis (ed.) (1995), 'Les phénomènes de fin d'archives en Mésopotamie : Présentation', in Revue d'Assyriologie et d'Archéologie Orientale, 89, Paris.

Kienast, Burkart (2015), Das altassyrische Eherecht. Eine Urkundenlehre (SANTAG 10), Wiesbaden: Harrossowitz.

Kraus, Fritz Rudolf (1968), Briefe aus dem Archive des Šamaš-Hazir: in Paris und Oxford (TCL 7 und OECT 3) (Altbabylonische Briefe, 4), Leiden: Brill.

Kulakoğlu, Fikri (2015), 'Current Research at Kültepe', in Fikri Kulakoğlu and Cécile Michel (eds), Proceedings of the 1st Kültepe International Meeting. Kültepe, 19-23 September, 2013. Studies Dedicated to Kutlu Emre (Kültepe International Meetings 1, Subartu XXXV), Turnhout: Brepols, 9-21.

Kulakoğlu, Fikri, and Selmin Kangal (2010), Anadolu'nun Önsözü Kültepe Kaniş-Karumu. Asurlular Istanbul'da/Anatolia's Prologue Kültepe Kanesh Karum. Assyrians in Istanbul (Kayseri Metropolitan Municipality Cultural Publication, 78), Istanbul.

Kulakoğlu, Fikri, and Güzel Öztürk (2015), 'New Evidence for International Trade in Bronze Age Central Anatolia: Recently Discovered Bullae at Kültepe-Kanesh', in Antiquity, 89/34 (http://journal.antiquity.ac.uk/projgall/kulakoglu343).

Larsen, Mogens Trolle (1977), 'Seal Use in the Old Assyrian Period', in McGuire Gibson and Robert D. Biggs (eds), Seals and Sealing in the Ancient Near East (Bibliotheca Mesopotamica, 6), Malibu: Undena Publications, 89-105.

Larsen, Mogens Trolle (2008), 'Archives and filing systems at Kültepe', in Cécile Michel (ed.), Old Assyrian Studies in Memory of Paul Garelli (Old Assyrian Archives Studies, 4, Publications de l'Institut historique-archéologique néerlandais de Stamboul, 112), Leiden: Nederlands Instituut voor het Nabije Oosten, 77-88.

Larsen, Mogens Trolle (2010), (Ankara) Kültepe Tabletleri VI-a. The Archive of Šalim-Aššur, Family volume 1: The First Two Generations (Türk Tarih Kurumu Yayınları, VI/33c), Ankara: Türk Tarih Kurumu.

Larsen, Mogens Trolle (2013), (Ankara) Kültepe Tabletleri VI-b. The Archive of Šalim-Aššur, Family volume 2: Ennam-Aššur (Türk Tarih Kurumu Yayınları, VI/33d-b), Ankara: Türk Tarih Kurumu. 
Larsen, Mogens Trolle (2014), (Ankara) Kültepe Tabletleri VI-c. The Archive of Šalim-Aššur, Family volume 3: Ali-ahum (Türk Tarih Kurumu Yayınları, VI/33d-c), Ankara: Türk Tarih Kurumu.

Marzahn, Joachim, and Beate Salje (eds) (2003), Wiedererstehendes Assur: 100 Jahre deutsche Ausgrabungen in Assyrien, Mainz: Philipp von Zabern.

Michel, Cécile (1995), 'Validité et durée de vie des contrats et reconnaissances de dette paléoassyriens', in Francis Joannès (ed.) 1995, 15-27 (http://halshs.archives-ouvertes.fr/ halshs-00821255).

Michel, Cécile (1998), 'Quelques réflexions sur les archives récentes de Kültepe', in Sedat Alp and Aygül Süel (eds), 3. Uluslararası Hititoloji Kongresi Bildirileri, Ankara, 419-433 (http://halshs.archives-ouvertes.fr/halshs-00708857).

Michel, Cécile (2000a), 'Les litiges commerciaux paléo-assyriens', in Francis Joannès (ed.), Rendre la justice en Mésopotamie. Archives judiciaires du Proche-Orient ancien (IIle-ler millénaire avant J.-C.), Saint-Denis, 113-139 (http://halshs.archives-ouvertes.fr/halshs00821273).

Michel, Cécile (2000b), ‘À propos d'un testament paléo-assyrien: une femme 'père et mère' des capitaux', in Revue d'Assyriologie et d'Archéologie orientale, 94, 1-10 (http://halshs.archives-ouvertes.fr/halshs-00642823).

Michel, Cécile (2001), Correspondance des marchands de Kaniš au début du Ile millénaire av. J.-C. (Littératures du Proche-Orient ancien, 19), Paris: Cerf.

Michel, Cécile (2003), Old Assyrian Bibliography of Cuneiform Texts, Bullæ, Seals and the Results of the Excavations at Assur, Kültepe/Kanis, Acemhöyük, Alishar and Bogazköy (Old Assyrian Archives Studies 1, Publications de l'Institut historique-archéologique néerlandais de Stamboul, 97), Leiden.

Michel, Cécile (2006), 'Old Assyrian Bibliography 1 (February 2003-July 2006)', in Archiv für Orientforschung, 51, 436-449.

Michel, Cécile (2008a), 'La correspondance des marchands assyriens du XIXe s. av. J.-C.: de l'archivage des lettres commerciales et privées', in Laure Pantalacci (ed.), La lettre d'archive. Communication administrative et personnelle dans l'Antiquité proche-orientale et égyptienne (Topoi Suppl. 9), Le Caire, 117-140 (http://halshs.archives-ouvertes.fr/halshs00644198).

Michel, Cécile (2008b), 'The Alāhum and Aššur-taklāku archives found in 1993 at Kültepe Kaniš', in Altorientalische Forschungen, 35, 53-67 (abstract p. 359) (http://halshs.archivesouvertes.fr/halshs-01186428).

Michel, Cécile (2009), 'Les femmes et l'écrit dans les archives paléo-assyriennes (XIXe s. av. J.-C.)', in Françoise Briquel-Chatonnet, Saba Fares, Brigitte Lion and Cécile Michel (eds), Femmes, cultures et sociétés dans les civilisations méditerranéennes et proches-orientales de l'Antiquité (Topoi Supplément 10), Lyon, 253-272 (http://halshs.archives-ouvertes.fr/halshs00644211).

Michel, Cécile (2011a), 'Old Assyrian Bibliography 2 (August 2006-April 2009)', in Archiv für Orientforschung, 52, 416-437.

Michel, Cécile (2011b), 'The Private Archives from Kaneš Belonging to Anatolians', in Maria Elena Balza (ed.), Archival, Scribal, and Administrative Spaces among the Hittites, Altorientalische Forschungen, 38, 94-115 (http://halshs.archives-ouvertes.fr/halshs-01186438).

Michel, Cécile (2015a), 'L'organisation du palais de Kaneš d'après la documentation textuelle', in Cécile Michel (ed.), Bâtiments publics et lieux de pouvoir dans l'Orient ancien, Thème 
VIII (Cahiers des thèmes transversaux d'ArScAn 12, 2013-2014), Nanterre, 161-174

(https://halshs.archives-ouvertes.fr/halshs-01186393).

Michel, Cécile (2015b), 'Women in the Family of Ali-ahum son of Iddin-Suen (1993 Kültepe archive)', in Fikri Kulakoğlu and Cécile Michel (eds), Proceedings of the 1st Kültepe International Meeting, Kültepe, 19-23 September, 2013. Studies Dedicated to Kutlu Emre (Kültepe International Meetings 1, Subartu XXXV), Turnhout: Brepols, 85-93.

Michel, Cécile (2015c), 'Old Assyrian Bibliography 3 (May 2009-June 2015)', in Archiv für Orientforschung, 53, 525-559.

Michel, Cécile (2015d), 'Les lettres des rois d’Aššur découvertes à Kaniš (XIX siècle av. J.-C.)', in Stefan Procházka, Lucian Reinfandt and Sven Tost (eds), Official Epistolography and the Language(s) of Power. Proceedings of the First International Conference of the Research Network Imperium \& Officium. Comparative Studies in Ancient Bureaucracy and Officialdom. University of Vienna, 10-12 November 2010 (Papyrologica Vindobonensia 8), Vienna: Verlag der österreichischen Akademie der Wissenschaften, 43-60 (https://halshs.archives-ouvertes.fr/halshs-01426483).

Michel, Cécile (2016), 'Quelques remarques sur les bullæ inscrites de la ville basse de Kültepe', in Bérengère Perello and Aline Tenu (eds), Parcours d'Orient. Recueil de textes offerts à Christine Kepinski, Oxford: Archaeopress, 175-184.

Michel, Cécile (forthcoming), Women from Aššur and Kaniš according to the private archives of the Assyrian merchants at beginning of the $I^{\text {nd }}$ millennium B.C. (Writings from the Ancient World, SBL), Baltimore.

Michel, Cécile, and Paul Garelli (1997), Tablettes paléo-assyriennes de Kültepe, I: (Kt 90/k), Istanbul: Institut Francais d'Etudes Anatoliennes / De Boccard.

Özgüç, Nimet, and Önhan Tunca (2001), Kültepe-Kanis. Sealed and Inscribed Clay Bullæ (Türk Tarih Kurumu Yayınları V. Dizi - Sayi, 48), Ankara: Türk Tarih Kurumu Basimevi.

Özgüç, Tahsin (1994), 'A Boat-Shaped Cult-Vessel from the Karum of Kanish', in Hermann Gasche et al. (eds), Cinquante-deux réflexions sur le Proche-Orient Ancien offertes en hommage à Léon de Meyer (Mesopotamian History and Environment, Occ. Publ. II), Leuven: Peeters, 369-375.

Özgüç, Tahsin (1999), The Palaces and Temples of Kültepe-Kaniš/Neša (Türk Tarih Kurumu Yayınları V/46), Ankara: Türk Tarih Kurumu Basımevi.

Özgüç, Tahsin (2003), Kültepe Kaniš/Neša. The earliest international trade center and the oldest capital city of the Hittites (The Middle Eastern Culture Center in Japan), Istanbul: Yap। Kredi Yayınları.

Parpola, Simo (1986), ‘The Royal Archives of Niniveh', in Klaas R. Veenhof (ed.) 1986, 223-236.

Pedersén, Olof (1986), Archives and Libraries in the City of Assur. A Survey of the Material from the German Excavations, part I: 1985, part II: 1986 (Acta Universitatis Upsaliensis, 6), Uppsala: Uppsala University.

Pedersén, Olof (1998), Archives and Libraries in the Ancient Near East 1500-300 BC, Bethesda: CDL Press.

Posner, Ernst M. (1972), Archives in the Ancient World, Cambridge: Harvard University Press.

Postgate, John Nicholas (1973), The Governor's Palace Archive (Cuneiform Texts from Nimrud 2, British School of Archaeology in Iraq), Hertford: Stephen Austin and Sons, Ltd.

Sallaberger, Walther (2013), 'The Management of Royal Treasure. Palace Archives and Palatial Economy in the Ancient Near East', in Jane A. Hill, Philip Jones and Antonio J. Morales (eds), Experiencing Power, Generating Authority. Cosmos, Politics, and the Ideology of Kingship in Ancient Egypt and Mesopotamia, Philadelphia: University of Pennsylvania Press, 219-255. 
Tanret, Michel (1991), The Ur-utu Archive (Mesopotamian History and Environment, Series 3, Texts), Ghent: University of Ghent.

Tessier, Béatrice (1994), Sealing and Seals on Texts from Kültepe kārum Level 2 (Publications de l'Institut historique-archéologique néerlandais de Stamboul 70), Istanbul: Nederlands Historisch-Archaeologisch Instituut te Istanbul.

Van Lerberghe, Karel (2003), 'Private and public: The Ur-Utu archive at Sippar-Ammanum (Tell ed-Der)', in Maria Brosius (ed.) 2003, 59-77.

Veenhof, Klaas R. (ed.) (1986), 'Cuneiform Archives. An Introduction', in Klaas R. Veenhof (ed.), Cuneiform Archives and Libraries, Papers read at the 30e Rencontre Assyriologique Internationale Leiden, 4-8 July 1983 (Publications se l'Institut historique-archéologique néerlandais de Stamboul, 57), Leiden: Nederlands Instituut voor het Nabije Oosten, 1-36.

Veenhof, Klaas R. (1987), “'Dying Tablets” and "Hungry Siver”... Elements of Figurative Language in Akkadian Commercial Terminology', in Murray Mindlin, Markham J. Geller and John E. Wansbrough (eds), Figurative Language in the Ancient Near East, London: University of London, School of Oriental and African Studies, 41-75.

Veenhof, Klaas R. (2003a), 'Archives of Old Assyrian Traders', in Maria Brosius (ed.) 2003, 78123.

Veenhof, Klaas R. (2003b), 'Trade and Politics in Ancient Assur. Balancing of Public, Colonial and Entrepreneurial Interests', in Carlo Zaccagnini (ed.), Mercanti et Politica nel Mondo Antico (Saggi di Storia Antica 21), Rome: L’Erma di Bretschneider, 69-118.

Veenhof, Klaas R. (2005), Letters in the Louvre (Altbabylonische Briefe, 14), Leiden, Boston: Brill.

Veenhof, Klaas R. (2008), 'Communication in the Old Assyrian Trading Society by Caravans, Travelers and Messengers', in Cécile Michel (ed.), Old Assyrian Studies in Memory of Paul Garelli (Old Assyrian Archives Studies, 4, Publications de l'Institut historique-archéologique néerlandais de Stamboul, 112), Leiden: Nederlands Instituut voor het Nabije Oosten, 199-246.

Veenhof, Klaas R. (2010), (Ankara) Kültepe Tabletleri V. The Archive of Kuliya, son of Ali-abum (Kt 92/k 188-263) (Türk Tarih Kurumu Yayınları VI/33c), Ankara: Türk Tarih Kurumu Basimevi.

Veenhof, Klaas R. (2013a), 'The Archives of Old Assyrian Traders: their Nature, Functions and Use', in Michele Faraguna (ed.) 2013, 27-71.

Veenhof, Klaas R. (2013b), 'New Mesopotamian Treaties from the Early Second Millennium BC from kārum Kanesh and Tell Leilan (Šehna)', in Zeitschrift für Altorientalische und Biblische Rechtsgeschichte, 19, 23-57.

Veenhof, Klaas R. (2015), 'The Archive of Elamma son of Iddin-Suen and his Family', in Fikri Kulakoğlu and Cécile Michel (eds), Proceedings of the $1^{\text {st }}$ Kültepe International Meeting, Kültepe, 19-23 September 2013. Studies dedicated to Kutlu Emre (Kültepe International Meeting 1, Subartu XXXV), Turnhout: Brepols, 73-83.

Veenhof, Klaas R. (in press), (Ankara) Kültepe Tabletleri V. The Archive of Elamma, son of IddinSuen (Kt 91/k) (Türk Tarih Kurumu Yayınları, VI), Ankara: Türk Tarih Kurumu Basimevi. 


\title{
Fredrik Hagen, with a contribution by Daniel Soliman (3.8) Archives in Ancient Egypt, 2500-1000 BCE
}

\begin{abstract}
The article gathers and describes the evidence relating to archives in ancient Egypt in the period c.2500-1000 BCE, and discusses its importance for our understanding of archival practices and functions. The material, which consists primarily of papyri, ostraca and, in some extraordinary cases, of clay tablets, is invariably fragmentary, widely distributed both chronologically and geographically, and in many cases largely unpublished. The article provides a convenient overview of the contents of the surviving archives with a notable focus on types of documents and their uses, as well as archaeological context and the materiality of manuscripts. Contextual material is only occasionally cited, and the emphasis throughout is on the physical documents as remains of archival holdings.
\end{abstract}

\section{List of contents:}

1. Egyptological histories of archives

2. The nature of the evidence

3. Overview of the main corpora

3.1. Early archives: Wadi el-Jarf, Gebelein, Balat and Saqqara

3.2. Temple archives: Abusir, Lahun and Thebes

3.2.1. Old Kingdom temple archives from Abusir

3.2.2. A Middle Kingdom temple archive from Lahun

3.2.3. A New Kingdom temple archive from Thebes

3.3. Archives from royal palaces: Thebes, Gurob and Memphis

3.3.1. A Late Middle Kingdom palace archive from Thebes

3.3.2. A New Kingdom palace archive from Gurob

3.3.3. A New Kingdom palace archive from Memphis

3.4. Military archives

3.5. Archives relating to shipping, taxation and trade

3.6. A state diplomatic archive: the Amarna tablets

3.7. Conscription and census documents

3.8. The archives of the tomb-builders of Deir el-Medina

4. Patterns of use

5. Conclusions

https://doi.org/10.1515/9783110541397-005, (c) BY-NC-ND (C) 2018 F. Hagen, D. Soliman (3.8), published by De Gruyter. This work is licensed under the Creative Commons Attribution-NonCommercial-NoDerivs 3.0 License. 


\section{Egyptological histories of archives}

My aim in this article is to present the main groups of material relating to archives in ancient Egypt c.2500-1000 BCE, and-to a lesser extent-to look at the interpretation of this evidence, and its implications for our understanding of Egyptian culture and history. The lengthy descriptive introduction to the material is necessary because many of the largest and most important groups remain unpublished, and there is no good overview readily accessible, neither to scholars in general nor to specialists. The final part deals briefly with the vexed question of the extent to which the archives can be said to have been used.

As a philologist working with papyri and ostraca, many of them from archives, my focus is materially bound in a literal way: I am more concerned with case studies than generalisations. Definitions and terminology are not dealt with at length, in favour of a presentation of material and the processes it represents. That is not a value-judgment on the importance of such lexicographic aspects, but rather an admission that the ancient evidence for these aspects is severely limited, and its potential rather modest. ${ }^{1}$

This article is largely a work of synthesis, and thus owes much to the previous work of others; this will be clear from the references supplied in the text. For economy of space I have had to be selective in providing bibliographical information for individual sources, and not all relevant discussions are cited. I have drawn on a substantial amount of unpublished material, both my own $(3.2 .3,3.3 .2)$ and that of others, and I am grateful to the following colleagues for material, assistance and advice: Hratch Papazian and Paolo del Vesco on the Gebelein archive (3.1), Kim Ryholt on the Djoser archive (3.1), and Jürgen Osing and Matthias Müller on the Lahun archive (3.2.2). In presentations of ancient texts I follow Egyptological conventions (e.g. in the use of small capitals to indicate red ink in the original document). Translations are loose and aim to convey the sense of the Egyptian, and I have avoided overburdening the text with transliterated words and passages on the grounds that specialists will be able to check the originals with no difficulty, while the non-specialist would only be distracted by this level of detail.

Postscript: Brian Muhs' monograph on the economy of ancient Egypt (Muhs 2016) appeared too late to take into account here, but readers should be aware of a degree of overlap in the material we discuss, albeit from rather different perspectives.

1 Studies of Egyptian words that might be translated as 'archive' or 'library' have not made much progress in understanding the ancient institutions they denote; see e.g. Trapani 2008. There is also a fundamental methodological problem in trying to map essentially modern categories and concepts onto the ancient evidence in the way suggested by Zinn 2007. 
As the papers at the conference from which this book stems made clear, there are many definitions of archive, not all of which can be pursued within the limits of a single article. The focus on administrative archives in this contribution excludes many aspects that are inextricably linked to the notion of archive and archival thinking. For example, in his lecture Dietmar Schenk, an archivist and archival scholar, emphasised the archive as 'an institution, in which the authentic evidence of the past is preserved in the long term'. This function, represented perhaps most paradigmatically in Egypt by the preservation of king-lists over several millennia, ${ }^{2}$ is less relevant to administrative archives which tend not to be long-lived and do not seem to have been conceived of-or at least not consciously so-as repositories of cultural knowledge.

Archives from the earlier periods of Egyptian history are rarely discussed outside Egyptology, ${ }^{3}$ perhaps mainly because of the various informal constellations of scholars (and their impact on conference line-ups), rather than any implicit disciplinary bias. The topic is not a new one, however, and different scholars have had different views on both the definition and nature of archives in the Egyptian context. ${ }^{4}$ Christopher Eyre's Use of Documents in Pharaonic Egypt (2013) represents the most recent in-depth analysis of the functioning of documents and recording as a social process-inextricably linked to the notion of archive-and my interpretative framework for the material outlined below is influenced in part by that work, even if some of my underlying assumptions about the nature and function of archives may be more traditionalist.

It is worth noting at the outset that the importance of archives for the writing of Egyptian history is itself a thorny issue. On the one hand, an inestimable amount of information has been lost because so few archives survive, but on the other Egypt was at all times and in all places primarily an oral culture: 'The use of writing... remained the tool of small and inefficient government, in a society where personal, face-to-face interaction and oral witness held primacy. ${ }^{5}$ This was true even for a village like Deir el-Medina, which arguably had the highest literacy rate of any community in the country; here too writing was the exception

2 The literature on this topic is vast, but see Baines 2008; Ryholt 2006; Redford 1986.

3 See e.g. the conference proceedings volumes edited by Brosius 2003 and Faraguna 2013.

4 There is no recent synthesis but various aspects are discussed by Donker van Heel/Haring 2003; Haring 2007; Allam 2009, with references to earlier work. Other key contributions include Quirke 1996, who focused on groups of literary manuscripts rather than administrative documents, and Helck 1975 who was mainly concerned with lexicographic and organisational aspects.

5 Eyre 2013, 349. 
and not the rule. ${ }^{6}$ However, this view of the role of writing, and implicitly also of archives, should not be interpreted as making them peripheral to the reconstruction of Egyptian history. For example, if not for the survival of temple archives (3.2) our knowledge about how temples operated as economic institutions would be greatly diminished, or-an even more extreme example-if not for the survival of parts of the private archive of the mortuary priest Hekanakhte we would know much less about how agricultural estates were managed. ${ }^{7}$ Simplifying somewhat one could say that archives are particularly useful in the case of Egypt because modern history writing has relied to a large extent on material that is heavily influenced by ideology-temple and tomb walls, for instance-whereas archives offer the historian an opportunity to observe social practices rather than just social ideals.

\section{The nature of the evidence}

The archaeological history of papyri in Egypt is essentially a history of loss. The physical properties of papyrus ensure that it can survive for thousands of years under appropriate conditions; however, these conditions are very rarely met in Egypt itself. The vast majority of the population in Egypt in all periods lived on or near arable land, and the great Nile Delta for example is traditionally assumed to have been home to two thirds of the population. There are almost no papyri from such sites due to the presence of moisture: the papyrus rolls have simply rotted away. Survival, then, is the exception, and there are few settlement sites that have yielded substantial papyrus finds, and those are in practice restricted to exceptional cases where the state established towns and temples on the desert edge.

Most of the well-preserved papyri from the pharaonic period were found in tombs-placed in the desert they provide conditions conducive to survival-including, perhaps surprisingly, significant numbers of administrative papyri.

6 Haring 2003.

7 Allen 2002. 


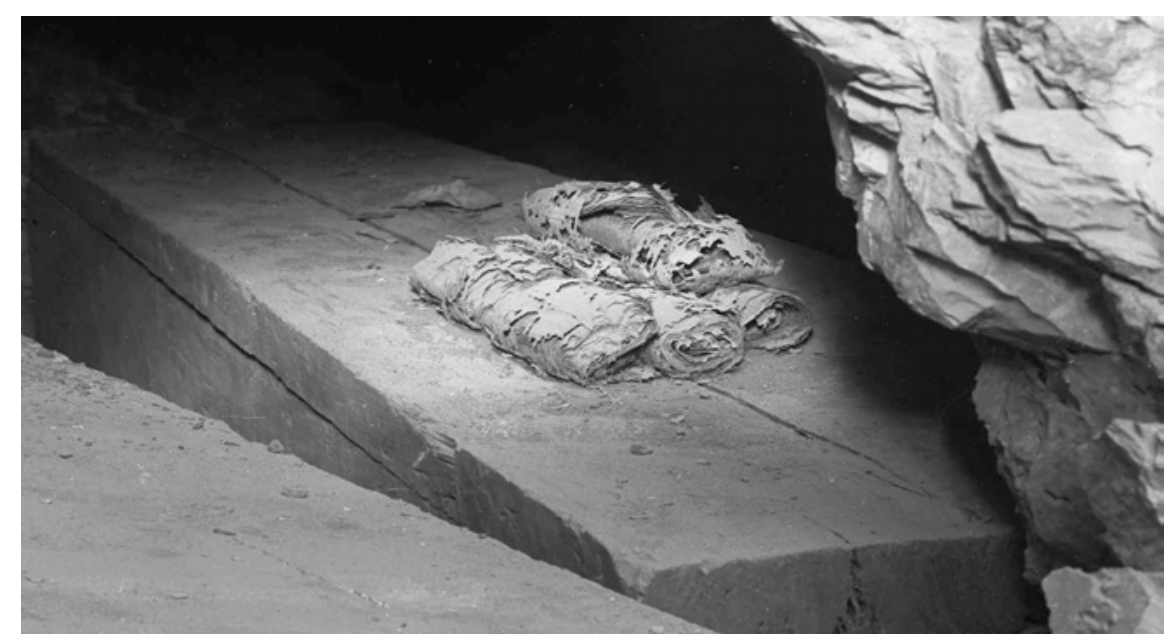

Fig. 1: The Reisner papyri, now in the Museum of Fine Arts in Boston, as found in tomb no. N 408/406 at Naga ed-Deir in Egypt around 1903. The papyri consist of two rolls with records relating to the construction of a building (nos I and III), one roll dealing with the management of resources at the royal dockyards at This (no. II), and one roll with name-lists and rations (no. IV). Image (C) The Museum of Fine Arts, Boston.

The presence of administrative papyri in tombs is partly explained as an identity marker for the deceased, but in any case the nature of such deposits means that only a small number of rolls are normally found, not entire archives, so that even in the case of large, well-preserved manuscripts, these represent just one document from what will have been much more comprehensive archives. How much of the papyrus material from these early periods of Egyptian history is lost is impossible to say, but if the surviving fragments discussed below are indicative of the general level of scribal activity then they represent only a tiny fraction.

\section{Overview of the main corpora}

I present a number of case studies below that shed light, in different ways, on Egyptian archives as institutions and on archiving as a social process, but the list is not exhaustive and I have refrained, for reasons of space, from including many indirect sources that would have been of relevance, such as letters, inscriptions, literary texts, etc. Similarly, I do not explore the titles relating to archival activities in detail, 
although this offers one alternative way to assess the evidence: for example, individuals such as the "chief guardian of the writings of the department of the granary of Pharaoh in Memphis' would have been responsible for recording and presumably-to the degree that it occurred-for facilitating consultation of the archives of the state administration of agricultural taxation. ${ }^{8}$ I do not believe that the documents presented below would have been exceptional or unrepresentative in their original context, but today they are certainly both in the sense that they survive at all.

\subsection{Early archives: Wadi el-Jarf, Gebelein, Balat and Saqqara}

There are relatively few papyri from the early periods of Egyptian history. The earliest archive of administrative papyri consists of the papers of an official called Merer who was involved in the building of the Great Pyramid of Khufu at Giza $\left(4^{\text {th }}\right.$ Dynasty, $c .2580$ BCE). ${ }^{9}$ These papyri were recently discovered at Wadi el-Jarf on the Red Sea coast, a harbour site complete with a quay and several hundred anchors, as well as man-made underground galleries for the storage of boats and supplies. The papyri had been deposited, presumably deliberately, in-between some large boulders which had been placed in front of the underground galleries. The full publication of the material is still pending but the preliminary reports indicate that in terms of contents tabular accounts are numerous, including deliveries-daily or monthly-of food, and that many of the other fragments-perhaps from three rolls covering about two months each-come from a journal where the daily activities of Merer and his team of workers are recorded. Much of the work described in the daybook consists of bringing limestone blocks by boat from the quarries at Tura to the building site, and it regularly notes the location of the boat when spending the night or day somewhere. The journey between quarry and work-site, a distance of some $20 \mathrm{~km}$ downstream, normally took about two days with a fully loaded boat, and one day less when returning upstream with an empty boat. The documents provide welcome evidence of the administrative structures surrounding the building project, and demonstrate among other things that the king's half-brother and vizier Ankhaef, known from other sources to have carried the title 'chief of all works of the king', was the official in charge of the work, at least towards the end of Khufu's reign. ${ }^{10}$

8 For the title, see Caminos 1954, 454.

9 All dates cited are from Shaw 2000 and are approximate only.

10 Tallet 2014a, 2014b. 
Another Old Kingdom archive is a group of papyri from Gebelein which probably belonged to a scribe and administrator of a rural estate; here, as in so many cases, the line between a private professional archive and an institutional archive becomes blurred. ${ }^{11}$ There were about twelve separate rolls originally, but only five survive in a substantial form. They were found together with a number of reed pens, ink cakes and pieces of a small vessel (for mixing the ink?), all lying in a rectangular wooden box (Fig. 2a); this had been deposited in a tomb as part of the burial equipment of the tomb owner. ${ }^{12}$ The identity of this individual is not known with certainty, nor is that of any of the copyists involved in the archive, but it has been suggested that the scribe Sobekaa, who appears in the name-lists and who seems to have 'signed' roll IV, might have been the tomb owner and responsible for at least some of the documents. ${ }^{13}$

Several types of documents are attested in the archive, most of which are in the full roll format of the time (c.20-22 cm in height): these include lists of personnel organised by village, perhaps in connection with various work projects (one has a heading mentioning a temple of King Snefru); accounts listing individuals and the grain they received on different dates, as well as outstanding amounts; the delivery of grain from Aswan, some $200 \mathrm{~km}$ further down the Nile; linen and cloth accounts, etc. There are also two extraordinary documents relating to the sale of houses, one of which explicitly mentions the village of Inertyinpu which figures prominently in the accounts and name-lists too. Both these texts were copied on the back of rolls containing accounts. ${ }^{14}$ The house sales may have been relevant to the management of the estate in some way, or were of personal interest to the scribe writing the accounts-it is not uncommon to find private notes inserted in uninscribed areas of documents related to institutions. ${ }^{15}$ The wooden box itself had also been written on, effectively turning the lid into a writing board (Fig. 2b); this contained name-lists and a grain account similar to those of the papyri. ${ }^{16}$ This practice of using the lids of boxes as writing boards is attested in at least one other instance from the same site and in the same period, where it was also used for copying textile accounts. ${ }^{17}$

11 Posener-Kriéger 2004, edited posthumously by Sara Demichelis.

12 Posener-Kriéger 1986.

13 Papazian forthcoming.

14 Posener-Kriéger 1979, 321.

15 Menu 1985.

16 Posener-Kriéger 1994.

17 Roccati 1970. 

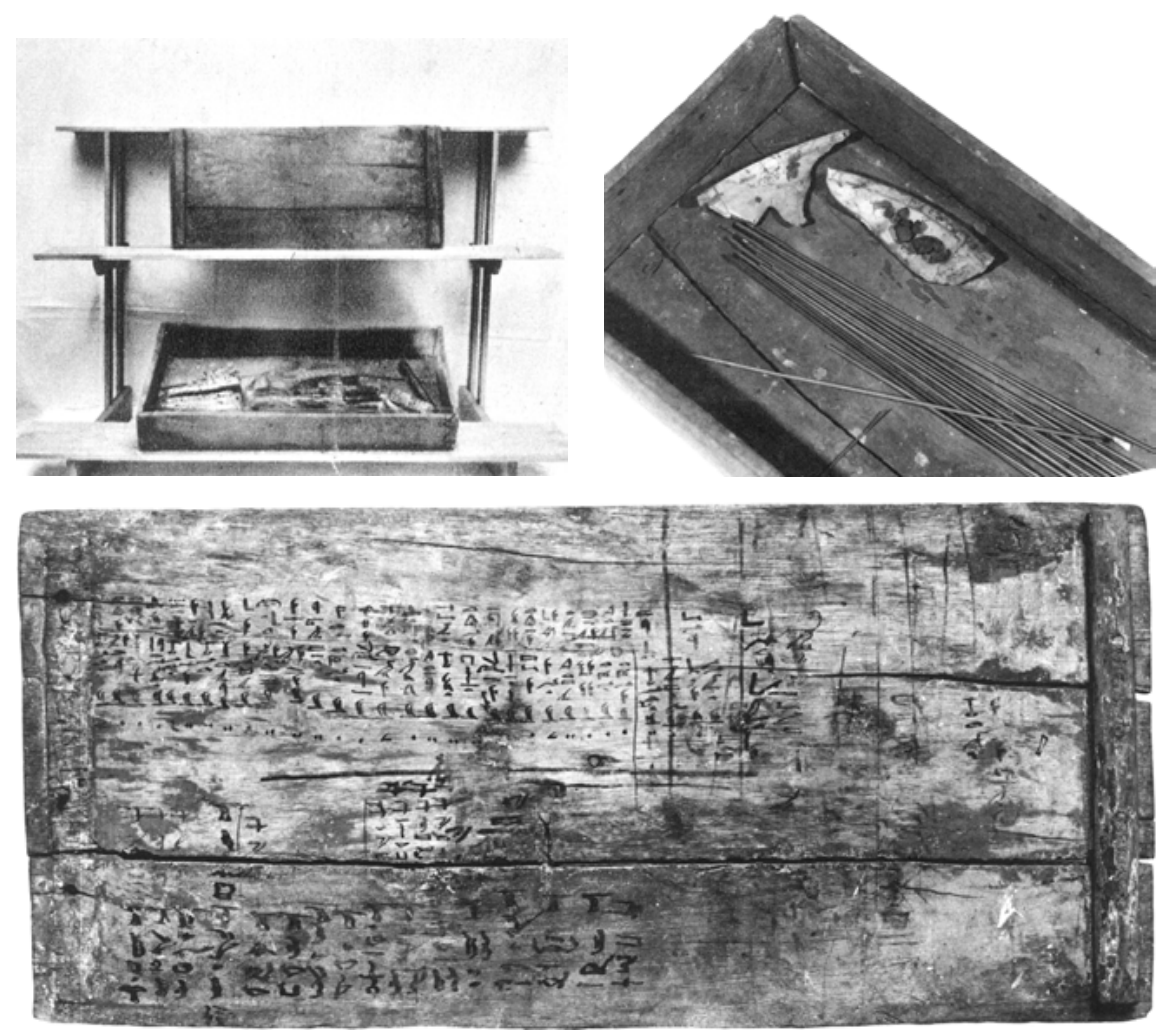

Figs 2a-c: A wooden box found in an anonymous tomb at Gebelein (Cairo JE 66844, c. $55 \times 26 \times$ $8 \mathrm{~cm}$ ) which contained a papyrus archive of twelve fragmentary rolls and some writing equipment, perhaps from around 2500 BCE. Top left: This is the only known photograph of the box while the papyri were still inside (Farina 1937, 345). Top right: a close-up photo of the inside after the removal of the papyri but with the reed pens and ink cakes still visible (Posener-Kriéger 1994, Fig. 2). Bottom: the lid of the box which had been used as a notebook by the scribe for the same kind of texts that he copied on the papyrus rolls (Posener-Kriéger 1994, Fig. 5).

It is impossible to date the archive precisely, and although suggestions based on the palaeography have placed it in the $4^{\text {th }}$ Dynasty, there is little comparative material to confirm this; in any case it has to be later than King Snefru as a temple of his is mentioned in one of the papyri. There are several different years in dated entries-cattle counts nos 2, 3, and 11 of an unnamed king-suggesting that the archive was in use for at least 22 years. 
In the Dakhla oasis, some $350 \mathrm{~km}$ to the west of Thebes, French excavations over the last thirty years have resulted in the discovery of over 500 clay tablets. ${ }^{18}$ Here the distance from the oasis to the Nile valley meant that it was not easy to ensure a regular supply of papyrus, which in turn led to the use of clay tablets for writing administrative accounts and letters: hieratic writing on such tablets is a material practice otherwise unattested for Egypt in any period. In this oasis, towards the end of the Old Kingdom and the beginning of the First Intermediate Period (c.2200-2000 BCE), small rectangular tablets of wet clay were inscribed using a bone stylus, and some of the tablets have holes punched through them, potentially allowing them to be strung together into dossiers. ${ }^{19}$

Most of the clay tablets found to date came from the Ayn Asil area where the residence of the local governors was situated. ${ }^{20}$ The editor has identified two main groups of active archives (archives vivantes) in the archaeological deposits, one in the northern part of the site and one in the palace area, as well as an inactive archive (une archive morte) of discarded material found outside the northern enclosure wall of the palace. ${ }^{21}$

The active northern archive (sondage nord) consisted of some 40 tablets, mostly administrative documents but with relatively few letters, and is rather fragmentary in nature. The other active archive was found in the palace area, in three lots, and had been fired when the palace burned down: one near the western gate of the compound, one at the north-western entrance to the palace building, and one in the columned courtyard of the apartment of the governor. The lot from the gatehouse area had a concentration of letters relating to matters internal to the administration of the oasis, perhaps suggesting that messages on such matters were received and handled separately, in what has been described as a type of porters' lodge (une sorte de conciergerie). ${ }^{22}$ The lot from the apartment of the governor is particularly interesting from an archaeological point of view in that the tablets were found in or on a wooden cupboard or podium between two columns, where copper nails were found along with stucco-covered bits of wood, perhaps the remains of boxes for the storage of the tablets. Far from all tablets would have been stored separately like this, however, and many were kept in storerooms, presumably near the goods they mentioned, rather than in dedicated archival

18 Pantalacci 2013; 2008.

19 Pantalacci 2013, 207.

20 Pantalacci 2008, 142.

21 Pantalacci 2013, 198; 2008, 142.

22 Pantalacci 2008, 147. 
rooms ${ }^{23}$ This palace archive was in other words found in situ, unlike so many others. How long the tablets were archived for, and what the criteria for eventual disposal may have been remains largely unknown: the editor has suggested a relatively short period of archiving, ranging from a few months to perhaps a year. The basis for this estimate is partly due to the discovery of an inactive archive with several hundred discarded clay tablets in an area north-east of the palace (sondage o). The discarded tablets from this area, all of which relate to the official business of the governors of the palace as representatives of the Egyptian government at Memphis, demonstrate a periodic process of disposal of tablets because the stratigraphy clearly shows layers of tablets interspersed with natural layers of sand and dirt. It has been suggested that the discarding of the tablets is linked to the transfer of the information they contained to papyrus, thus rendering them superfluous, although there are few surviving traces of the use of papyrus at the site. ${ }^{24}$

Not all the tablets have been published but a series of preliminary reports show that the range of texts attested is comparable to that of papyrus archives: letters, lists of people, accounts for grain and rations, inventories, and distribution lists. ${ }^{25}$ Letters were occasionally copied in duplicate, allowing the sender to keep an archival copy of the correspondence, and one extant letter explicitly asks the addressee to make a copy. ${ }^{26}$ This is a practice well attested in institutional archives of all periods (see below). A single event, such as the issuing of goods from a palace storeroom, may have involved several types of written records: a letter ordering the issuing, two clay seals (one broken when the room or container was opened, another produced when it was re-sealed), and a writing or updating of the relevant inventory. ${ }^{27}$

The provincial nature of the find, as well as its unique material form, its quantity and its secure archaeological context, make it one of the most important groups of material for reconstructing the socio-economic history of the period, such as record-keeping and organisation of work, the relationship between the state and local government, writing and literacy, and communication networks. ${ }^{28}$ The importance of the tablet archives notwithstanding, they are only part of the puzzle, and even within the restricted group of literates there is much variation in the ability to read

23 Pantalacci 2013, 206-207.

24 Pantalacci 2013, 197, 206.

25 See in general Pantalacci 2013, with references to earlier publications.

26 Pantalacci 2008, 147.

27 Pantalacci 2013, 198, 208, n. 3.

28 Pantalacci 2010, 2001, 1998, 1996. 
and write; many of the tablets were found alongside inscribed clay seals, a reminder that archives of written texts were only a part of the wider organisational and accounting practices at the site. ${ }^{29}$

In the late Old Kingdom the necropolis of Saqqara, adjacent to the capital at Memphis, was an active hub of state administration in relation to the building of a number of royal pyramids there, and not surprisingly there have been finds of papyrus archives at the site. Several groups of papyrus from the area are known, and a volume dedicated to the material, based on a recent conference, is in preparation by Pierre Tallet and Philippe Collombert, but what all the groups have in common is that the circumstances of their discovery and their archaeological context are obscure. One exception to this is the archive of an administrative unit situated within the step pyramid complex of Djoser. ${ }^{30}$ There were two separate finds of papyrus fragments within the area known as 'Temple T', but only one of these can be related to a specific location within the structure itself. The first group, which has no specific find-spot, includes a dozen or so fragments, of which about half have been published: these include a letter about a crew of quarry workers and the issuing of textiles, as well as some accounts mentioning work on the pyramids of King Neferirkare and King Merenre. ${ }^{31}$ The second group is entirely unpublished to date, and although the archaeological report referred to them as being extremely fragmentary, it also stated that they, like the previously mentioned fragments from the same structure, were related to the construction of the royal pyramids of the $5^{\text {th }}$ and $6^{\text {th }}$ Dynasties. ${ }^{32}$ It seems clear that the old temple building was being re-used, some 250 years after its construction, as an administrative centre for the scribes involved in the construction work, although an exact date for its conversion and its period of operation cannot be established with certainty. The value of the find lies partly in the fact that it has a recorded archaeological context. The second group of fragments were found in a corridor at the back of the temple that had been converted into a storage facility by the division of the space into a series of niches, presumably originally with shelves and chests, by the addition of various mudbrick architectural elements. ${ }^{33}$ These architectural changes were not restricted to the storage space itself, and other storerooms as well as several guard huts or porter's lodges

29 Pinarello 2015, 101-115; cf. Hayes 1951 for the evidence of papyrus sealings from Malqata in relation to archival practices at a royal palace of the New Kingdom.

30 Ryholt forthcoming a.

31 For the letter, see Wente 1990, 42; for the accounts see Posener-Kriéger 1980.

32 Firth/Quibell 1935, I, 13.

33 Ryholt forthcoming a. 
were erected inside the old temple. It is noteworthy that the construction of the latter emphasised security, resulting in a layout where all points of entry were controlled by line of sight: the archive would have been almost impossible to access by unauthorised personnel. The archival space itself was not preserved beyond a height of four or five courses of mudbricks, so precisely what the storage would have looked like is not known, but the extremely limited width of the 'walkway' down the middle of the corridor after the construction of the mudbrick niches on either side $(c .30 \mathrm{~cm})$ would have complicated any use of material stored there after it had been archived. Moving around and searching for papyrus rolls in the dark and cramped space would have been extremely difficult, and it is obvious that it was not constructed with such concerns in mind.

\subsection{Temple archives: Abusir, Lahun and Thebes}

Archaeologically speaking, temples survive relatively well in Egypt, but as with most categories of material they are, as a general rule, fewer and less well preserved the further back in time one goes. Paradoxically the opposite is true of temple archives: those of the late Old Kingdom from Abusir (c.2470-2440 BCE) are more numerous than the single Middle Kingdom one from Lahun (c.1850-1825 BCE), and the one New Kingdom temple archive from Thebes (c. 1350 BCE) is smaller and more fragmentary than any of these earlier groups. This is simply an accident of survival. In addition to the main groups of material outlined in this section, there are several extant documents that must have originated in temple archives but which lack a recorded archaeological context and/or consist of an isolated papyrus roll, and some of these are discussed briefly below (3.4-3.7).

\subsubsection{Old Kingdom temple archives from Abusir}

The oldest extensive institutional archives from pharaonic Egypt are those of the memorial temples of the $5^{\text {th }}$ and $6^{\text {th }}$ Dynasty kings at Abusir (c.2470-2440 BCE). Here, the temples dedicated to the royal cult of the deceased kings and queens, erected next to their pyramids, yielded significant numbers of papyri, most of which were administrative in nature. Three separate archives have survived: that of the temple of King Raneferef, that of King Neferirkare Kakai, and that of Queen 
Khentkawes. ${ }^{34}$ Of these the former two are the most extensive, and the first is particularly interesting in that it has a well-documented archaeological context, having been excavated relatively recently. ${ }^{35}$ The main groups of fragments were found in the western row of storerooms north of the inner temple, with some other groups from the storerooms to the south of the hypostyle hall (Fig. 3):

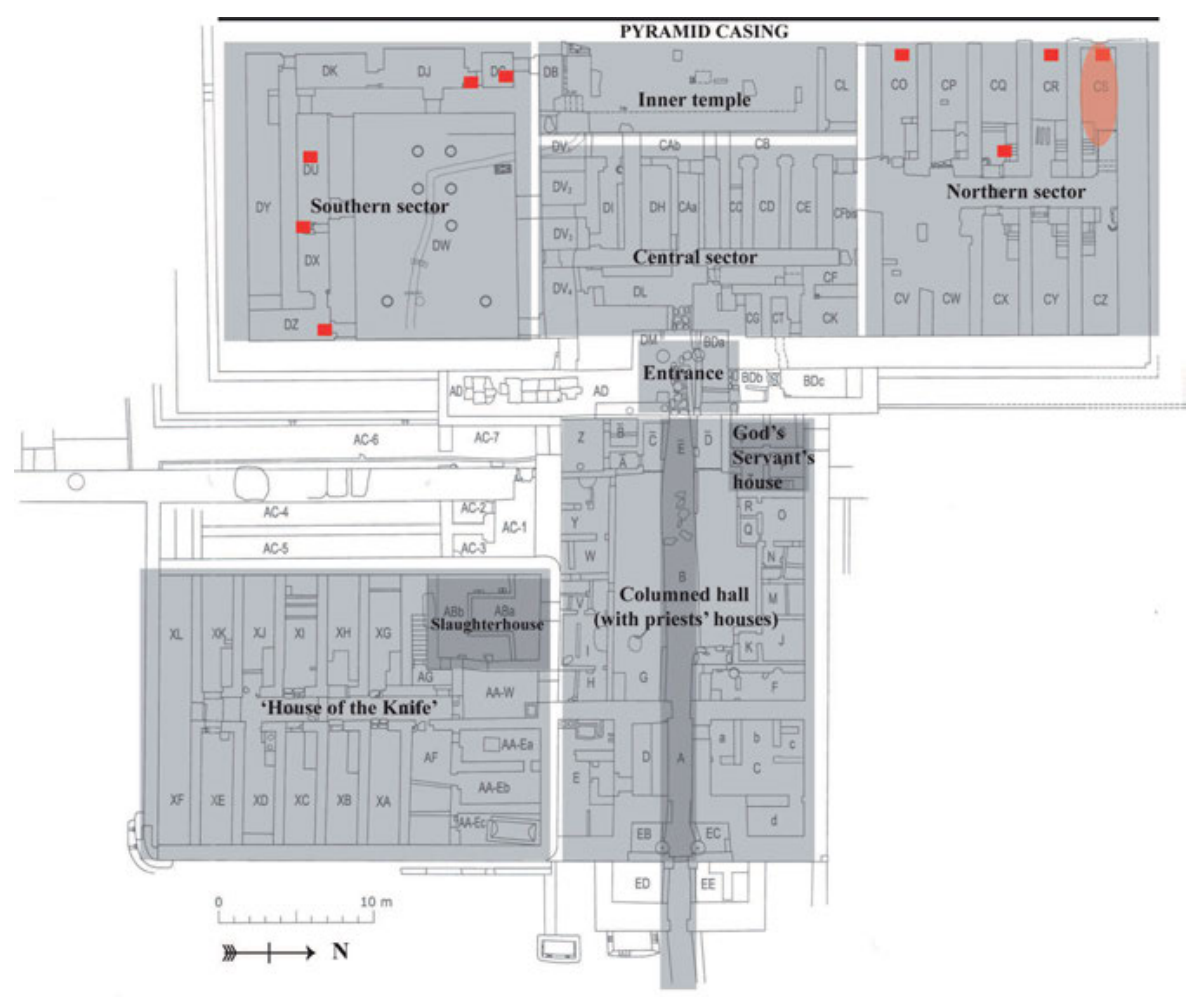

Fig. 3: A schematic map showing where the papyrus fragments from the mortuary temple of Raneferef were found, adapted from Posener-Kriéger/Verner/Vymazalová $(2006,24)$ with the addition of captions and location markers for papyrus finds (red squares). The fragments were discovered in storerooms to the north and south of the inner temple area, and in the case of the northern sector the excavators suggested that they were originally stored in room CS (upper right hand corner, red ellipse).

34 For the Raneferef archive see Posener-Kriéger/Verner/Vymazalová 2006; for the Neferirkare archive see Posener-Kriéger/De Cenival 1968, and Posener-Kriéger 1976, and for the Khentkawes archive, by far the smallest of the three, see Verner 2001.

35 Verner et al. 2006. 
The Raneferef papyri were in other words found in several locations in and around the temple, although in the case of the storerooms to the north the greater concentration of fragments in room CS suggested to the excavators that this was the location of one original archive, perhaps stored in wooden chests. ${ }^{36}$ As with the material from Balat, numerous clay seals were found next to the papyri, as were various types of cult equipment and other objects (model instruments, vessels, faience inlays and beads, flint knives, sandals, etc.), so it seems reasonably clear that there was not a single room dedicated exclusively to the storage of the papyrus archive.

Documents from these archives can be divided into several types. ${ }^{37}$ Duty tables or duty rosters note the presence of individual priests, and their duties, and although they vary a little in form they describe the basic template for temple service that survived for most of Egyptian history: groups (called phyles in the Egyptological literature) who were in service for one month at a time. One example has a monthly duty table that lists temple staff according to area of service and responsibility: those involved in the morning and evening rituals, those who should receive the cultic papyrus roll after the rituals had been carried out (here for the royal mother Khentkawes), those on duty at the gates, or on the roof, or guarding the entrance to the magazines, as well as those responsible for dressing, purifying and adorning the royal cult statues, those who provide incense in the presence of the ritual priest, and so on. ${ }^{38}$ The main physical focus for the royal mortuary cults were statues of the deceased, of which the temples had many: the Khentkawes temple, which was the smallest of the three, had at least fourteen, ${ }^{39}$ and in the Raneferef temple the excavators found fragments of numerous royal statues of wood, basalt, diorite, granite, travertine, quartzite and limestone..$^{40}$ These statues were also mentioned in the papyrus documents, sometimes with accompanying drawings (Fig. 4).

36 Posener-Kriéger/Verner/Vymazalová 2006, 21-23.

37 Posener-Kriéger 1968, xiii-xv.

38 Posener-Kriéger 1968, plates 3-4; 1976, 14-57, table II.

39 Verner 2001, 134, 172.

40 Verner 2006, 430-437. 

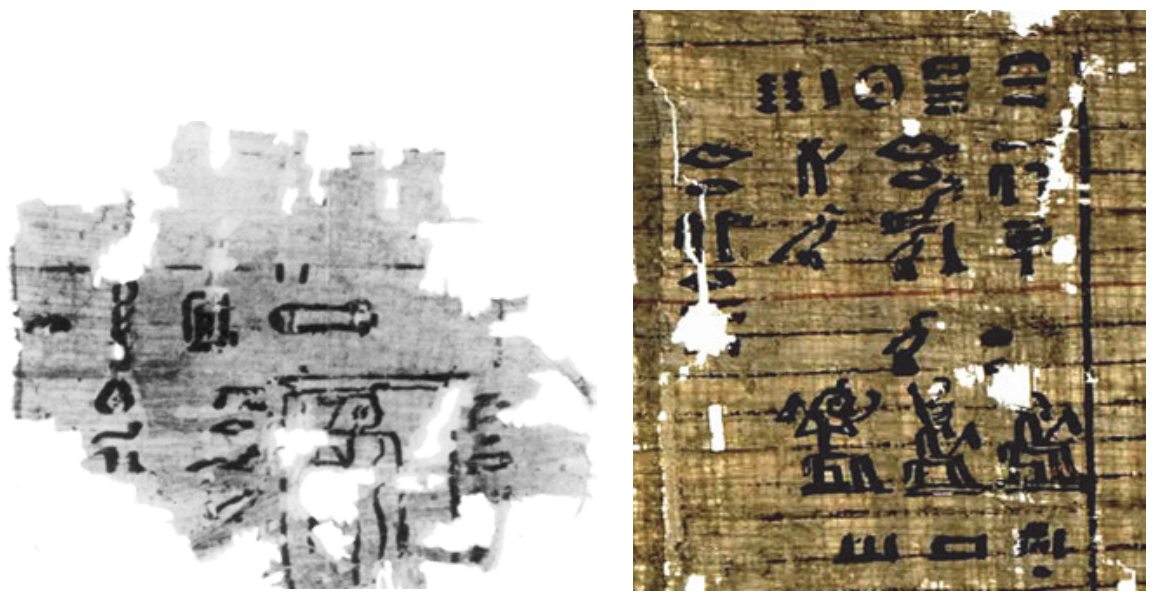

Fig. 4a (left): A papyrus fragment with a drawing of a cult statue of Queen Khentkawes from her mortuary temple at Abusir (Verner 2001, plate 27 no. A; image courtesy of the Czech Institute of Egyptology, Faculty of Arts of Charles University). The statue is depicted standing within a protective shrine or chapel under a heading reading 'chapel' ( $t p h t$ ), with vertical bands of text mentioning the walls of the shrine and indicating that it had door rings $(\underline{d} b)$ made of copper. The fragment would have formed part of an inventory of such statues and shrines, and there are several similar fragments in the same archive.

Fig. 4b (right): Detail from a duty list showing three seated statues of King Neferirkare Kakai, from his mortuary temple at Abusir (P.BM EA 10735, image courtesy of the Trustees of the British Museum). The king is shown in the form of Osiris (left), and with the Red Crown of Lower Egypt (middle) and the White Crown of Upper Egypt (right). The heading reads 'Second month of the Shomu season, day 18. Clothing, purifying, dressing and providing incense for the statues', followed by the three drawings and-not included here-a list of the personnel assigned to these tasks (Posener-Kriéger 1968, plate IV; 1976, 52-57, table II).

The Abusir archives also include rare examples of royal decrees or edicts on papyrus, a genre of text that otherwise survives primarily as monumental inscriptions. ${ }^{41}$ There are numerous copies in the Raneferef archive, as well as some in the Neferirkare archive, which deal, as far as can be established, with rights to temple income, often relating to individuals of rather low rank..$^{42}$ The sheer number of such documents, explicitly said to have been 'signed in the presence of the king himself', suggests relatively frequent communication between the king and the temples, and-notablythat this communication was not limited to letters announcing royal bequests and

41 Vernus 2013, 294-300; Eyre 2013, 89-94.

42 Posener-Kriéger/Verner/Vymazalová 2006, 234-240; Posener-Kriéger 1976, 472-478. 
privileges to the temple and its priesthood as a whole which is what many of the monumentally inscribed examples are concerned with. The layout of the papyrus decrees is identical to those of monumental copies, but despite their origin in a high-status context, some were written on re-used papyrus. ${ }^{43}$ They appear to be the original letters sent from the king rather than secondary copies made locally for the archive. That such documents should be preserved in the archive is no surprise, and the practice is echoed in later periods: an original (?) royal decree on papyrus, sent from King Ramesses IX (c.1125 BCE) to the High Priest of Amun-Re, was pasted into an archival roll from the temple of Karnak along with other letters and an account. ${ }^{44}$

Another type of document that occurs frequently in the Abusir archives are inventories of objects belonging to the temple. These are often organised based on material, with tables listing individual objects of silver, hematite, silex, quartz, or different types of wood. In one example the silver section includes many different types of cups, saucers and plates, as well as offering tables (big and small), and each object is described in terms of integrity and damage: a cup may be 'dented', its rim noted as 'cracked', or a libation vessel might be 'repaired in its pouring area, twice'. ${ }^{45}$ Many of these objects would have been used in the daily cult rituals, and the documents record the presence and condition of more or less valuable cult equipment.

It was not only movable objects that were inventoried and checked. For example, a fragment from the Raneferef archive lists eight rooms of the temple being 'inspected' and the relevant seals 'checked', including the treasury, the storeroom for fat and oil, the store room for textiles, and the house of the statues, amongst others. ${ }^{46}$ Architectural elements could also be inspected, such as divine barques, and lintels and columns of wood or stone: in one case an inventory records of a lintel that ' $[\mathrm{t}]$ here are no more stones on it: the wall fell. It happened during the service of the group of priests called Menunefer ${ }^{97}$ In theory such detailed inventories might be used to establish responsibility and to assign blame in case of problems, but there is no evidence for the actual use of the archival records for this purpose.

The economic life of the institution was the primary focus for scribal activity, with all deliveries to and from the temples noted down on a daily basis, and these daily accounts could then be assembled into monthly accounts. A typical example of the latter has a tabular structure with one line for each day and a set of columns with commodities delivered (Fig. 5):

43 Posener-Kriéger 1985.

44 Kitchen 1975-89, VI, 517.1-522.15; Wente 1990, 37-39.

45 Posener-Kriéger 1968, plates 20-21; 1976, 134-136, fig. III.

46 Posener-Kriéger/Verner/Vymazalová 2006, 262-264, plate 45.

47 Posener-Kriéger 1968, plate 31; 1976, 430. 
Divine offerings delivered to (the mortuary temple) Bakakai

That which was brought

(1) from the royal residence

Hetjat-bread

Day Due Delivered Outstand-

144

244

344

$4 \quad[4] \quad 4$

5 [4] [lost]

6 [4] [lost]

7 [4] [lost]

8 [4] [lost]

9 [4] [lost]

10 [4] [lost]

114 [lost]

$\begin{array}{lll}12 & 4 & 4\end{array}$
Pes-bread

020

0

0

0

[lost]

[lost]

[lost]

[lost]

[lost]

[lost]

[lost]

0

[2] [0]

[2] 0

[2] 0

20
(2) from the sun-temple

Setibre

Pat-bread

Due Delivered Outstanding ing

$2 \quad 14 \quad 14$

$\begin{array}{lll}2 & 14 & 14\end{array}$

$\begin{array}{lll}2 & 14 & 14\end{array}$

$\begin{array}{lll}2 & 14 & 14\end{array}$

[lost] [14] $70 \quad$ [lost]

2 [14] 14

214

[14]

[2] $0 \quad 2$

[2]

14

14

14

14

14

2

2

$\begin{array}{lll}{[14]} & & 14 \\ 14 & & 14 \\ 14 & & 14 \\ 14 & 14 & 0\end{array}$

Fig. 5: Stylised representation of the beginning of a tabular account showing deliveries of bread to the mortuary temple of King Neferirkare Kakai from the royal residence and from the sun-temple Setibre, over 12 days. The table has been adapted from Posener-Kriéger (1968, plates 33-34), with minor modifications and omissions (the complete table covers an entire 30-day month period, with several more institutions and types of commodities). The careful recording of actual deliveries against the amount due is striking, with separate columns noting the outstanding amount for each type of bread, allowing for the quick compilation of summary accounts of deficits. Patterns in delivery can be traced, such as the arrival in bulk of pat-bread (70 pieces) from the sun-temple Setibre on day five, which on day 12 onwards was mainly delivered daily in the correct amount (14 pieces), and the special delivery of 'good things, bread and beer' which was restricted to the weekend, i.e. days nine and ten of the Egyptian week (not shown in the above table).

The tabular accounts are amongst the most common type of document and record information about the revenues of the temple, such as the institutions from which deliveries were made, the name and title of the person delivering, and the actual amounts delivered compared to what was expected (and consequently what was outstanding). These rather dry tables are of the first importance for reconstructing the frequently complex economic relationship between different institutions: 
the royal residence supplied a large proportion of the daily income-and was good at delivering on time-whereas deliveries from other neighbouring temples (meat was normally brought from the sun-temple Setibre, for example) or palaces were often less reliable. The accounts show that the actual exchange of goods was not always in line with the agreed or expected quotas, but to what extent the arrears noted in the documents were ever used as grounds for complaint or redress is less clear. One document from the Raneferef archive shows a summary of monthly deliveries of over 3,000 loaves of bread (?), with arrears, but this may be related to the division of the revenues amongst the priesthood. ${ }^{48}$ This division was recorded in writing, with the number of shares dependent on the office held: examples from both the Neferirkare and the Raneferef archive show that the number of rations allocated to higher-ranking priests were considerably higher than those of regular priests. ${ }^{49}$

The temple archives also contain letters, perhaps both locally produced copies of letters received at, or sent from, the temple, as well as original letters. Certainly both types are found in the archive of the royal memorial temple of Senwosret II at Lahun, some 600 years later (3.2.2). Letters in the Abusir archives are remarkably few, however, in comparison with the later Middle Kingdom archive, with only two certain examples from the Neferirkare group..$^{50}$

The period of use of these archives is frequently difficult to pin down based on internal evidence, but combined with the archaeology of the sites where they were found it seems that they were in use over several generations. In the case of Raneferef the excavators concluded that the mortuary cult of the king gradually declined until it was discontinued early in the reign of King Pepi I (c. 2320 BCE), so approximately one hundred years after the building of the temple, ${ }^{51}$ but many of the dated documents have been ascribed to the reign of King Djedkare some fifty years before this final stage. ${ }^{52}$ The Khentkawes archive was perhaps in use over a similar period but the fragmentary nature of the papyri make this impossible to establish with any certainty. ${ }^{53}$

The archives of the memorial temples of the late Old Kingdom paint a detailed picture of administrative processes in a medium-sized temple of the period, and are a useful tool when modelling the operations of such institutions. They

48 Posener-Kriéger/Verner/Vymazalová 2006, 393-394.

49 Vymazalová 2013, 186, 192.

50 Posener-Kriéger 1976, II, 451-472.

51 Verner 2006, 109-110.

52 Posener-Kriéger/Verner/Vymazalová 2006, 335.

53 Verner 2001, 172. 
form a base-line against which the later and more fragmentary temple archives from the Middle and New Kingdom can be measured (see below), both in terms of the range of different document types available and the mechanics of operation (e.g. in the hand-over of responsibility between the monthly service staff when entering or leaving the temple). They are also important for the study of institutional economics, allowing scholars to reconstruct the complex relationship between different temples in the area as well as between the temples and the royal administration. ${ }^{54}$

\subsubsection{A Middle Kingdom temple archive from Lahun}

The Lahun archive, most of which dates to the late Middle Kingdom (c.1850-1750 $\mathrm{BCE}$ ), was not found as a result of archaeological excavations, unlike the Abusir archives of Raneferef and Khentkawes. The papyri were looted and then dispersed on the antiquities market in the late nineteenth and early twentieth centuries, and the German Egyptologist Ludwig Borchardt acquired most of the material for the Berlin museum. ${ }^{55}$ He surmised based on their content and date that they probably came from Lahun, and subsequent exploration of the site allowed him to pin-point the most likely find-spot as a rubbish dump to the north of the Valley temple of Senwosret II, a location where he managed to find some more fragments of the archive (Fig. 6). ${ }^{56}$ The papyri were, in other words, found discarded outside the temple proper, like those from the archive of the memorial temple of Thutmose III (3.2.3), rather than in the location where they were originally copied and stored.

54 Vymazalová 2013; Posener-Kriéger 1990.

55 Borchardt 1899.

56 On the context see Quirke 2005, 31-32, and for examples of papyri found by Borchardt, see Luft 1992b, 101-105. 


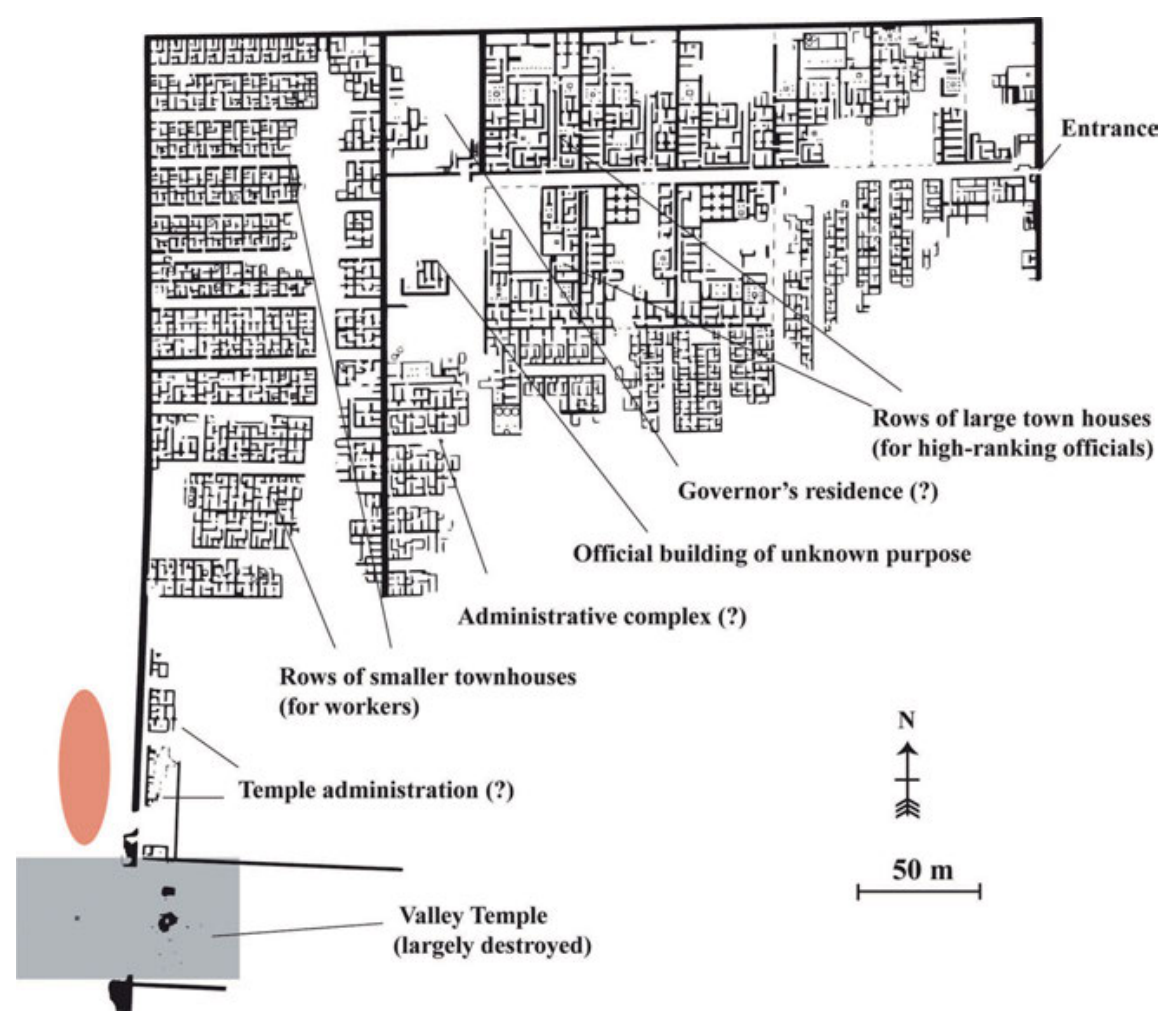

Fig. 6: Map of the town of Lahun, at the entrance of the Fayum oasis, showing the find-spot of the temple archive (adapted from Kemp 2006, 212; Petrie/Brunton/Murray 1923, plate 33; Borchardt 1899,89 ). There was almost nothing left of the temple itself but its location is indicated on the map by the grey square at the south-west corner of the site. Borchardt's excavations, carried out over two weeks in June 1899, aimed at discovering the origin of the papyri that had appeared on the antiquities market. He eventually found a number of additional fragments, clearly belonging to the same group, in an area suggested by local inhabitants as the most likely location: a rubbish heap to the north of the temple and outside the enclosure wall of the town (red ellipse).

Like the Abusir temples, the temple of Senwosret II at Lahun was an institution dedicated to the maintenance of the royal mortuary cult, and the administration of the temple and its archival practice is broadly similar to those earlier examples. The priesthood consisted of two types of positions, permanent and temporary. The permanent members of staff were the administrative manager ('overseer of the temple') who was also the local mayor, as well as the temple scribe and the 
chief ritualist ('chief lector priest'), and various lower-ranking servants and labourers. The temporary priesthood consisted of a variety of other types of priests who served for one month at a time, on a rotational basis, and who were divided up into four groups or phyles.

Unlike the situation at Abusir, however, the royal memorial temple at Lahun was almost entirely destroyed, ${ }^{57}$ so that it is not possible to link, say, the topographical terminology of the documents (names of rooms etc.) with the archaeological monument itself. ${ }^{58}$ Despite the close similarity with earlier and later archives the nature of the Lahun find as an institutional archive has been debated, with some scholars preferring to see part of it mainly as a collection of personal 'business files' belonging to the temple scribe who figures so prominently in the correspondence, Horemsaf, ${ }^{59}$ but in the absence of more detailed information about the archaeological context it is difficult to evaluate to what extent the material might represent one or more groups of fragments as originally found. Due to the present state of publication a detailed overview is impossible, but the following is an attempt to synthesise the available material. ${ }^{60}$

In terms of quantity there are just over 200 frames of glass, most c. $25 \times 40 \mathrm{~cm}$ in size, plus some other fragments still not conserved, most of which are in Berlin. Borchardt's preliminary assignment of the fragments to different categories of documents may have to be revised when publication is completed, but they arein order of frequency-temple accounts, letters to temple staff, daybook fragments, lists of festivals, and lists of priests, although admittedly there is a substantial set of frames (26, plus 6 'pappartige Konglomerate') still unassigned. ${ }^{61}$

The journal of the temple, known as the 'day-roll' ( $h r y t)$ in Egyptian, appears to have been written continuously, as a series of papyrus rolls, and perhaps filed at the end of each year: one letter refers explicitly to 'the day-roll of year 2', ${ }^{62}$ In these daybook fragments there is a strong sense of a journal in the restricted sense

57 Petrie/Brunton/Murray 1923, 39-40.

58 Luft 2006, 109-112.

59 Quirke 1996, 379, followed by Kóthay 2015, 763.

60 The modern history of the material has hindered evaluation of the internal coherence (or otherwise), not least because a large part of the fragments demonstrably belonging to the institutional daybook have remained unpublished for several generations; these are now being prepared for publication by Jürgen Osing in Berlin and should appear in the foreseeable future. The letters of the archive have fared better, with many of the more substantial pieces available in transcription and translation. See in general Kaplony-Heckel 1971, x-xi (overview); Borchardt 1903; Luft 1992a; 1992b; 2006; Scharff 1924.

61 Borchardt 1899, 90.

62 Scharff 1924, 43. 
of a day-to-day jotting down of events, accounts and communications. The extract reproduced in Fig. 7 is a representative example of the manner in which information is structured. It starts off with a copy of a presumably written message that had been delivered to the temple about providing leather for a sandal maker-and the need to record the transaction in writing-and then continues with another entry for the following day. It moves on to the assignment of consumables and incense in relation to festivals, one of which mentions a mortuary priest of a queen, before documenting the hand-over of administrative responsibility for the temple from one group of priests to the next.

This monthly transfer of responsibility is a recurring topic in the daybook, ${ }^{63}$ and involved an inspection of the temple and its stores in the presence of both groups. The duty-period of the priests entering their service on the first day of the first month of the Shomu season starts with a list of their names being entered into the journal. The range of topics covered on a single page is typical of such institutional journals, and other fragments expand the range considerably. The monthly inspection of the temple when a new group of priests took over is noted in distinctly formulaic terms ('all your affairs are safe and sound') that do not reveal much of the associated activities, but other texts in the archive show that such occasions could be accompanied by written reports detailing the inspection, room by room, with objects of gold, silver, bronze, and wood dutifully listed, along with textiles, myrrh, etc. Inventories of cult statues, as in the Abusir archives, are also attested, albeit without illustrations: in addition to the material being recorded-various types of wood, stone, and ivory-the Lahun inventories also list the vestments of the statues. ${ }^{64}$

In addition to the daily entries there are also a number of accounts, some dealing with extended periods of time. These may note offerings on successive days over several weeks or more: one papyrus has an 'Account of the provisions brought from the temple of Hathor from month 2 of Akhet day 9 up to month 3 of Akhet day 7', i.e. a period of about a month. ${ }^{65}$ Other examples cover longer periods of time: one has a '[c]alculation of earth almonds and honey for one year', followed by a tabulated list of various leading priests with relevant quantities of these commodities next to their names, while another document records the allocation of offerings for the temple of Anubis at Lahun for almost an entire year; ${ }^{66}$ the latter may be compared with P.Berlin 10055 which has a summary account of fowl deliveries over a similar period. ${ }^{67}$

63 For a list of this in the material, see Kaplony-Heckel 1971, 274.

64 Luft 1992, 31; Kaplony-Heckel 1971, plate 1.

65 Luft 1992b, 43.

66 Luft 1992b, 74-77, 44.

67 Kaplony-Heckel 1971, 25. 
Copy of the letter brought from Hetep-SenwosretMaakheru,

which the sandal-maker Werenptah son of Sankhptah, brought:

Let a cow-skin or, alternatively, a goat-skin be brought.

It is to the sandal-maker Werenptah that you should give it, putting it in writing.

A cow-skin has been given to this sandal-maker.

Year 6, month 4 of Peret, day 27. The libationer Dedusobek son of Senwosret.

Year 6, month 4 of Peret, day 28. The royal wab-priest Mentuhotep son of Senwosret.

Bringing of the khenty-esh of year 5, month 3 of Shomu, day 22.

Sobekhotep son of Ky.

$\begin{array}{ll}\text { Beer, des-jars: } & 3 \\ \text { Various bread: } & \text { [lost] } \\ \text { Mereret-loaves: } & 3 \\ \text { White bread: } & 3\end{array}$

[Year 6,] month 4 of Peret, day 29. The royal wabpriest Senwosret son of Nofret.

[Year 6,] month 4 of Peret, last day. The embalmer Ameny son of Ipi.

[...] festivals conducted accordingly by the chief of the phyle, and fixed for him monthly:

$\begin{array}{ll}\text { [Various bread?] } & 350 \\ \text { [Beer, des-jars?] } & 3 \\ \text { [Mereret-loaves?] } & 3 \\ \text { [White bread:] } & 3\end{array}$

[...] embalmer who is on duty monthly.

[...] incense, padj-pellets: 15

[...] mortuary priest of the Queen and King's Mother Khenemetneferhedjet the elder.

[...] incense, crushed: [...]
Report of the phyle of month 4 of Peret which is on duty this month (to) the phyle of month 1 [of Shomu], To wit: all your affairs are safe and sound. We have made an inspection of [all the] things

of the phyle which is entering its monthly service, and they are safe and sound.

Report of the phyle which is entering its monthly service.

To wit: all your affairs are safe and sound. We have made an inspection for [this ?] phyle

of the temple and of that which is under their authority and it is safe and sound.

Year 6, month 1 of Shomu, day 1. [...] son of Hetepet. Name-list of the phyle which is entering its monthly service:

The chief of the phyle Senwosret son of Senwosret. The scribe of the temple <? > son of Inpy.

The regular lector priest Senwosret son of Sasopdu. The embalmer <?> son of Hetep.

The imiseta-priest Senwosret son of Sahathor. The libationer Senwosret son of Senet.

[...] Ameny, son of Sat [...]

[...] Khenty-Senwosret, son of Khety

The royal wab-priest Ameny, son of Sobekemsaes. Senwosret, son of Senet.

The overseer of the district and the temple Ahahotep, son of Netjeru (?).

The doorkeeper of the temple Ameny, son of Senet.

Ameny, son of [...]wy

[...], son of Hetepu.

Ankhkhety, son of Satrenenutet.

Senwosret [...] 
Fig. 7: Translation of a page from the daybook of the mortuary temple of Senwosret II at Lahun (P.Berlin 10050), dated to a year 6 of an unknown king, but probably Senwosret III (Luft 1992a, 65-66). The layout mirrors that of the original document. Much of the text is previously unpublished, with the exception of the transfer protocol in the second column, and the first entry relating to the sandal maker. The latter passage was included in a modern reading book (Sethe 1928) and has been widely read by undergraduate students of Egyptology for generations. I am grateful to Jürgen Osing for permission to use his unpublished material on the Lahun archive as a basis for the translation, and for the possibility to contextualise this well-known extract here. The back of the fragment contains a table, as well as a copy of a report dealing with what seems to be a break-in at the temple (Kaplony-Heckel 1971, 24; Scharff 1924, 48-49, plates 11-12).

One of the entries in the daybook of a year 11 of an unnamed king is a list of cattle supplied as offerings by various leading priests ('chiefs of phyles') in years 8 and 11 presumably of the same king, so going back about three years in time, i.e. medium- to long-term record-keeping. ${ }^{68}$ Although the heading to that list makes it clear that it has been compiled in order to have it 'brought... in writing', and as such may represent an extraordinary accounting procedure, it still demonstrates access to relevant information in the archive over a three-year period.

Historical events of relevance to the running of the temple are mentioned in the documents, but only in passing: in addition to regular festivals this included isolated events like burials of members of the royal family, as in year 6 of an unnamed king when the temple took delivery of quantities of grain in connection with the burial of the king's sister. ${ }^{69}$

Provisions for festivals are mentioned repeatedly, and accounts provide convenient lists of festivals celebrated at the temple, as well as the offerings associated with them. ${ }^{70}$ Lists of priests seem mainly to document the presence of personnel on certain days and during certain festivals, rather than distribution patterns of consumables, for example. ${ }^{71}$ One of the most substantial published documents of this kind of attendance record is a yearly overview from year 35 of Amenemhat III, with a table of dates and festivals with the dancers and singers hired on the relevant occasions, although this was seemingly found in the adjacent town rather than among the other fragments of the temple archive. ${ }^{72}$ The famous list of temple staff with their corresponding share in temple offerings is also relevant here, ${ }^{73}$ although

68 Luft 1992b, 70-73.

69 Luft 1992b, 128.

70 Luft 1992b, 215-223.

71 Luft 1992b, 19: 'Anwesenheitslisten'.

72 Collier and Quirke 2006, 92-95.

73 Borchardt 1903. 
it deals with offices and not with individuals. ${ }^{74}$ That document contains a tabulated list of both the permanent staff of the temple (the overseer of the temple, the chief lector priest, and various guards and manual labourers) and the group of priests on monthly duty (the chief of the phyle, the scribe of the temple, the regular lector priest, the embalmer, the imiseta-priest, the 3 libationers, the 2 royal wabpriests), along with their shares in the daily temple income of bread and beer. The value of the papyrus for the reconstruction of the administrative structure of the temple is considerable, ${ }^{75}$ but it is noteworthy that a relatively small proportion of the income is divided between these people: they received only 70 out of a total of 410 loaves of bread, for example, with the vast majority of the daily income being handed over directly to the mortuary priests, a category of priest which is often conspicuously absent in lists of priests in the temple. ${ }^{76}$ Another conspicuous absence is the lack of any direct state involvement in the funding of the cult, and the overall impression is that of a local institution interacting with state level administration only rarely, leading Stephen Quirke to suggest that its organisation should be compared to the great estate of an official, with the deified deceased king in place of a lord: 'Like any other landowner, the deity is served by men who cultivate and manage his estates, supervise supplies and expenditure, prepare his meals, and guard and maintain his properties'. ${ }^{77}$

Name-lists of priests were important for the distribution of offerings, but for other categories of personnel they could also have a different use: one extraordinary papyrus refers to the 'law of registering singers', and makes clear that singers who were absent from their duties were liable to be whipped, with the number of lashes being dependent on the number of days they failed to turn up (10 lashes for 1-10 days, 30 for 11 days, 50 for 12, etc.). ${ }^{78}$ Name-lists were also compiled of manual labourers in connection with the organisation of extra-mural construction work, ${ }^{79}$ and letters make frequent reference to temple officials recruiting, assigning or releasing workers. ${ }^{80}$

The detailed records of temple income in the form of offerings were used to keep track of missing deliveries, and one message, copied into the daybook of the temple for future reference, complained that 45 days had passed in months 2 and

74 Luft 1982, 146-149.

75 Kóthay 2015.

76 Luft 1986, 135, 147-148.

77 Quirke 1990, 162.

78 P.Berlin 10001A, unpublished but see Kaplony-Heckel 1971, 1. I am grateful to Jürgen Osing for sharing information about this and other unpublished documents with me.

79 Quirke 1990, 162-163.

80 Kóthay 2015; Luft 2006, 97-99. 
3 of Akhet without certain commodities having been supplied from a temple of Sobek, despite the matter having been raised 'a multitude of times' in previous letters. The troubles with deliveries from the Sobek temple did not end there, and the scribe goes on to state that there had been no sign of the deliveries for the entire period 'from month 1 of Peret day 14 and up to this day'. ${ }^{81}$

Correspondence arriving at the temple, like the message about the sandal maker (Fig. 7), might be entered into the journal on the relevant day it was received and could include various types of letters: the most famous example is probably a letter from the overseer of the temple of Amenemhat II informing the chief lector priest at Lahun about the predicted occurrence of a celestial phenomenon (the heliacal rising of the star Sothis). The information in the letter, which arrived some 22 days before the event was to take place, has been important for modern reconstructions of ancient Egyptian chronology. ${ }^{82}$ There are other, similar letters regarding the date of various festivals in the material, ${ }^{83}$ or reporting that a festival list has been drawn up, ${ }^{84}$ as well as entries recording the arrival of other types of written messages, suggesting a considerable network of communication through which temples could, inter alia, coordinate their cult calendars. It is not surprising to find documents related to the liturgical year in a temple archive, and there are also a number of lists of festivals among the fragments, some of which are provided with dates. ${ }^{85}$

In addition to the copies of letters in the daybook, there is a substantial number of original letters in the material from Lahun, ${ }^{86}$ easily identified by the presence of the titles and names of the addressee on the back, sometimes accompanied by the name and title of the messenger bringing the letter. Many of these letters make reference to other (now lost) letters having been sent or received, indicating that written communication was not unusual or rare in this context. The original letters could be written in either columns or lines, or both, whereas letters copied into the daybook were normally transcribed into a linear format. Not all letters were recorded in the daybook, perhaps partly because it was not

81 P.Berlin 10056A recto; this is unpublished but see Luft 1992b, 70-78 and Kaplony-Heckel 1971, 26; the entry itself is dated to month 2 of Peret day 21.

82 Krauss 2006; Luft 1992b, 54-57.

83 Luft 1992b, 50, 63, 89.

84 P.Berlin 10066: Luft 1992a.

85 Luft 1992b, 78-81, 85-86, 93-95, 98-103.

86 Luft 1992a; 2006. 


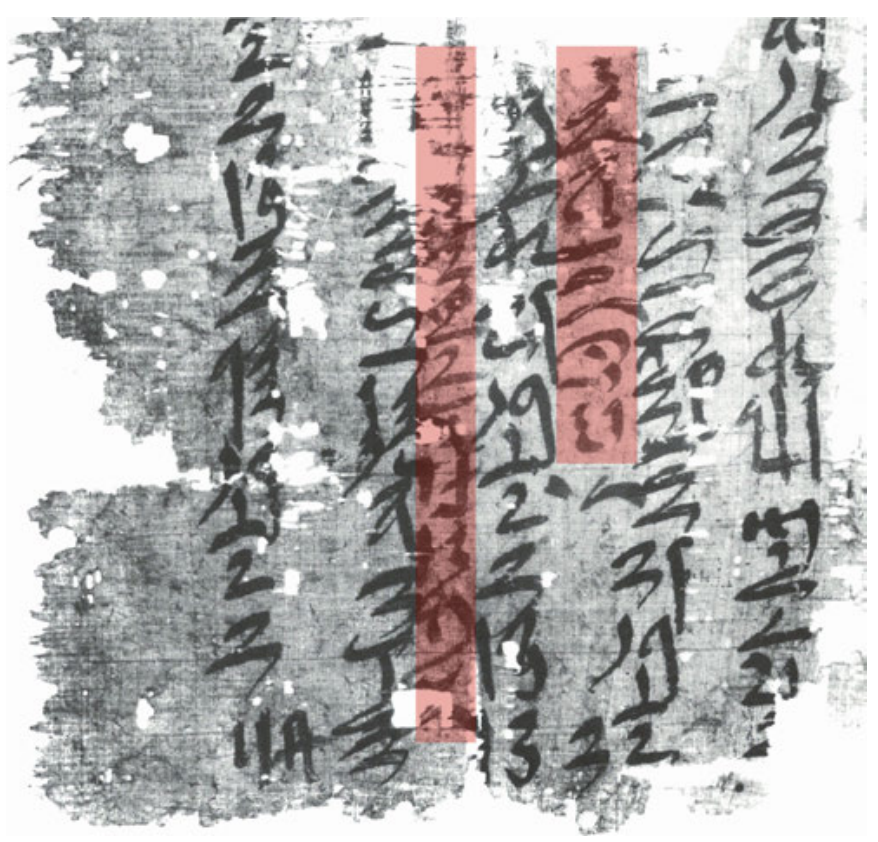

Fig. 8: Detail from a photograph of P.Berlin 10023B, a letter where the temple scribe of Lahun, Horemsaf, wrote to ask a superior for wine, grain, earth almonds and fowl for the offering rituals. The answer was inserted, in red ink (highlighted on the photograph), between the columns of the original letter, and confirmed that the goods he asked for had been sent. @ Ägyptisches Museum und Papyrussammlung, Staatliche Museen zu Berlin.

always necessary: a good number of letters were returned to the temple after they had been received by the addressee, with the answer simply written on the original letter itself, inserted in red ink between the columns of the first text (Fig. 8).

The letters were presumably archived with the daybook rolls and accounts. The physical delivery of written documents was not restricted to letters, and one entry in the Lahun temple daybook refers to 'the papyrus roll with the daybook of the temple of Sobek, Lord of Rasehui' being 'given' by a scribe whose name is lost. ${ }^{87}$ The context is unfortunately obscure, but it does suggest that even an essentially archival type of document like a daybook would sometimes be circulated and consulted.

87 Luft 1992b, 81-82. 
The topics covered by the letters are diverse, from concerns about individuals being taken for labour duties and unspecified grievances between superiors and their subordinates, to the celebration of private cult ceremonies, the recruitment of musicians, and the arrangement of deliveries to the temple. Information from the letters frequently complement that of other archival documents like accounts. To what extent the accounts of the temple were checked or inspected is apparent only rarely in the daybook or in the documents themselves, but the letters shed some light on the procedures involved. One mentions the addressee having 'given him the accounts' in connection with some wrongdoing, ${ }^{88}$ while another records a subordinate informing his superior that the 'surplus' of a given day has been recorded (?) and that he should send him the final account, because 'today is the day that my lord views the documents, one after the other', with a further mention of four account documents that had been sent. ${ }^{89}$ The practice of keeping yearly records reappears in a letter where the local governor seems to be asking the administrative chief of the temple to assemble the accounts relating to both offerings and different categories of personnel, but the relevant passage contains technical terminology and grammatical oddities which hinders a detailed analysis. ${ }^{90}$ Another letter talks of an inspection, implicitly of accounts, relating to a period of time described as 'from year 30 to the present day' (the letter is itself undated), when the writer was obstructed in his work by a refusal to hand over the relevant material, ${ }^{91}$ and there is a reference in a fragmentary message at the end of another letter where an 'inspection' had been carried out, but where the record of this could not subsequently be 'found'.$^{22}$ The purpose of the accounting was partly to keep a record of obligations fulfilled (or otherwise), and it is clear from both the accounts themselves and the letters that certain individuals-presumably ex officio-had a responsibility to provide deliveries for the divine offerings as 'dues', and that failure to deliver was duly noted by the temple scribes. One particularly revealing letter complains that a number of offerings, including cattle, had not been delivered for a given festival, and the scribe of the temple informed the addressee that 'accounts had been made of the shortcomings (? $s n b^{3}$ ) of the royal $w a b$-priest Senwosret son of Senwosret' ${ }^{93}$ It seems that due to

88 P.Berlin 10038A; Luft 1992a.

89 P.Berlin 10038C; Luft 1992a.

90 Luft 2006, 119-128; Brose 2014, 316 no. 511, 381 no. 101, 402 no. 234.

91 P.Berlin 10074; Luft 1992a.

92 Luft 2006, 59-62.

93 Luft 2006, 35-41. 
some confusion in the record-keeping, the checking of the accounts was becoming difficult, although the reply to the letter indicates that the matter was eventually resolved.

Many of the letters are not easy to translate accurately, not least because of the technical vocabulary, ${ }^{94}$ but what emerges is a clear sense of both auditing and the circulation of written accounts. The frequency of such use of the archival material, or even the circumstances under which it was likely to take place, remain elusive.

\subsubsection{A New Kingdom temple archive from Thebes}

With the exception of the few fragments of papyrus from the memorial temple of Ramesses II at Thebes, ${ }^{95}$ the only surviving temple archive from the New Kingdom is that of Thutmose III of the $18^{\text {th }}$ Dynasty (c.1350 BCE) which-like the archive of the royal memorial temple of Senwosret II at Lahun-was found in the rubbish dumps of the temple, outside the enclosure wall (Fig. 9).

The papyri were recently discovered by the Spanish-Egyptian mission working at the site, directed by Myriam Alvarez-Seco, and the following preliminary description is based on my initial examination of the material in November 2016. The archaeological context of the find is a secondary deposit, but there is no doubt that the majority of the papyri stem from the official archive of the temple. There are perhaps around a thousand fragments of varying size, many no bigger than a stamp, and they are currently mounted in 14 frames of glass. The vast majority of the fragments are administrative in nature, and these stem, for the most part, from a daybook roll. It is organised chronologically with headings in red ink for each day, often simply followed by a list of offerings. The extremely fragmentary state of the papyri means complete headings are only rarely preserved, but extant examples include a date in year 10 of Amenhotep III, that is to say some two or three generations after the founding of the temple by Thutmose III. Some of the lists have a heading reading ' $[t]$ hat which was brought from the temple of Amun', indicating that at least a portion of the offerings were delivered from the large Karnak temple complex across the river. The formula used here is identical to that in the Abusir temple accounts a thousand years earlier. Occasionally offerings are said to come from elsewhere, with one example listing 'offerings of the great royal wife' (perhaps Queen Tiye if the fragment is also from the reign of Amenhotep III, but the name is unfortunately lost). There are many mentions of

94 Quirke 1998.

95 Spiegelberg 1898; cf. Hagen forthcoming. 


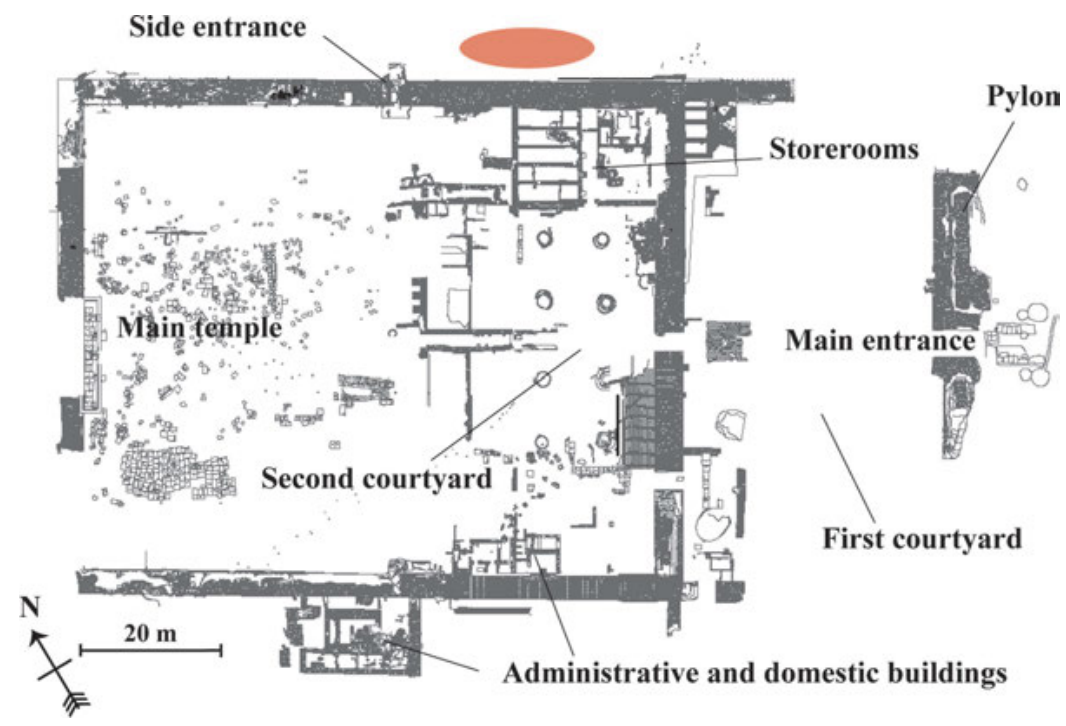

Fig. 9: A map of the mortuary temple of Thutmose III at Thebes (courtesy of Myriam AlvarezSeco) indicating the find-spot of the papyrus archive (red ellipse) in the rubbish dumps outside the northern enclosure wall. The material was deposited here by temple staff using the small side-entrance in this wall; most of the papyri were found mixed in with general debris a short distance to the right of the gate. The only location inside the temple proper where papyrus fragments have been found is in a production area (bakery?) to the north-east of the main temple where a handful of tiny fragments of an account were discovered in November 2016 (not indicated on the map).

different festivals, including a coronation festival ('festival of the appearance of the king'), the well-known Nehebkau-festival, and an otherwise unattested 'festival of Amun during Khoiak', among others. Once the material has been processed a comparison with existing festival calendars on contemporary temple walls, with their accompanying donation records for offerings, may shed light on the ritual activities of the memorial temple.

The offerings themselves are listed, with amounts, either line-by-line or as continuous text (different scribes may have had different preferences for the format). A range of bread and cakes is attested every day, as is beer and wine, incense, honey, fruit, dates and milk, whereas other commodities appear more irregularly: textiles, fowl, cattle, etc. ${ }^{96}$

96 The daily amounts are generally modest; a few jars of beer, wine, or milk, and rarely more than a handful of bread and cakes. The commodities being offered in the temple are remarkably 
The detailed records of the offerings were presumably kept to document the deliveries made, and to keep track of temple income in relation to the redistribution of offerings to the priests and officials associated with the temple, but there are surprisingly few mentions of outstanding amounts, a feature which is otherwise common in the accounts from the Abusir temple archives. One isolated fragment has the phrase 'remainder (i.e. outstanding) up to year [X]', but such references are rare.

The daybook dominates the archive as it survives, but there are other types of documents. One fragment is from an inventory list of different types of silver vessels, similar to those known from Abusir and Lahun, and there are several fragments of letters. Whether the latter are original letters or copies made for the archive (as is common in daybook type documents) is not clear. There are also isolated notes that deal with the organisation of labour but which seem not to belong to the daybook: one has a list of rations provided to various stone masons (literally 'necropolis-men').

Most of the fragments from the rubbish dump came from the temple archive, but perhaps not all of them. In addition to the administrative documents there are also a few literary fragments, notably from a hymn, from one or more papyrus rolls in cursive hieroglyphs, and from an illustrated magical or mythological roll with illustrations of the serpent Apophis. These need not have been stored with the administrative archival material originally, and may have come from a temple library instead.

\subsection{Archives from royal palaces: Thebes, Gurob and Memphis}

Royal palaces, like temples, were organisationally complex institutions that required detailed record-keeping and accounting procedures, but few such archives have survived. Individual documents that would have originated in these contexts exist, and they are suggestive, but the lack of a recorded archaeological context frequently impedes a full understanding.

homogenous over the course of days and months, suggesting that the aforementioned donation records known from contemporary temple walls and stelae are, to an extent, real historical records that were used as a basis for the cult operations of the temples themselves. The temple archive of Thutmose III is the only extant source that allows for an evaluation of the extensive monumental records in this way. 


\subsubsection{A late Middle Kingdom palace archive from Thebes}

The earliest examples of administrative documents from a palace archive are known collectively as Papyrus Boulaq 18, and consist of two rolls that were found in a tomb belonging to a scribe in a state department called Neferhotep; ${ }^{97}$ one of the Amherst fragments (no. X) has also been thought to come from the same document. ${ }^{98}$ The tomb owner may have been the writer responsible for the larger of the two rolls (they are in different hands), and their presence in a funerary context is presumably to be explained as a symbol of the social identity of the deceased.

The document is still not fully published, despite having been available in facsimile for almost 150 years, ${ }^{99}$ and there is to date no full published translation of the text, although the incomplete transcription and commentary of Scharff provides a starting point for analysis; ${ }^{100}$ the following summary is based on this work as well as on that of Quirke. ${ }^{101}$ The larger roll is a daybook recording the visit of the court of a late $13^{\text {th }}$-Dynasty king, perhaps Sobekhotep II (c.1760 BCE), to a palace at Thebes, and covers a period of twelve days. It was inscribed on both sides with the daybook, and although the precise relationship between the two sides is debated-a period of eleven days is missing between the last entry on the front and the first on the back-it would seem that at least part of the back was used also for drawing up preliminary versions of some of the entries on the front. ${ }^{102}$

Papyrus Boulaq 18 is the longest and most complete example of a daybook to survive. Like all daybooks it is organised chronologically with a dated heading for each day, and it records a wide range of activities which Quirke has classified as belonging to four basic types of entries: (1) statements of accounts, (2) orders for provision, (3) expenditure of valuable commodities, and (4) official reports and documents.

Entries of type (1) reflect the main concern of the document which is the regular palace income and expenditure, ${ }^{103}$ and these note daily deliveries etc., along with the origin of the goods. The issuing of consumables took the form of tabular lists of individuals (title and name) with columns for e.g. beer, meat, vegetables, dates and various types of bread. There were different types of income, from the

97 Miniaci/Quirke 2009; 2008.

98 Newberry 1899, 48.

99 Mariette 1872.

100 Scharff 1922.

101 Quirke 1990.

102 Spalinger 1986a, 227, 239; Quirke 1990, 17-21.

103 Spalinger 1985; 1986a. 
regular deliveries of 'ordinary provisions' ( $k w$ ) to 'extraordinary deliveries' (inw) that would cover 'extraordinary provisions' $(f k 3 w)$.

Entries of type (2) include supplies for crews of workers not normally provided with regular provisions, ${ }^{104}$ and orders to provide officials with goods in connection with journeys away from the palace, or visits to the palace, with copies of the written orders as well as the oral commands being duly entered into the archive, along with short notes asserting that the orders had been fulfilled ('One has acted according to this order'), followed by the relevant information on goods provided ('Various bread: 30 loaves. Beer jars: 3. Jar of meat: 1').

The entry for month 2 of Akhet, day 28 is fairly typical: after the date this starts with a heading explaining that an official had issued an order to prepare 'extraordinary provisions' for another palace official who was travelling to the temple of Montu at Medamud, some $8 \mathrm{~km}$ to the north: it includes the details of the food issued, and a statement that the order had been completed. Then another order was dealt with, this one about providing bread, beer and meat to a group of craftsmen, again with details of the 'extraordinary provisions' issued and an assertion that the order had been carried out. A section recording the issuing of incense for the same temple of Montu from the 'strongroom' (htm) follows. Finally, the scribe entered a detailed account of the income and expenditure for the day: for the category 'various types of bread' this was listed as 1680 loaves 'of the king', plus 200 as a remainder carried over from the previous day, plus 100 loaves delivered from the nearby temple of Amun, for a total of 1,980 loaves. A list of expenditure was then drawn up, with various departments and groups of personnel getting their share, to a total of 1,780; the remainder of 200 loaves were carried over to the next day. ${ }^{105}$ Whether these numbers represent actual loaves of bread (and jars of beer, bundles of vegetables, etc.) or simply standardised numbers for book-keeping that note the shares of income and expenditure that the different institutions and departments were entitled to receive, or obliged to supply, is debated. ${ }^{106}$ As with the palace archives from Gurob (3.3.2) and Memphis (3.3.3), the income at the Theban palace appears to be coming from the local administrative area ('The District Head-of-the-South'), ${ }^{107}$ and the absence of institutions like the state treasury is noteworthy. ${ }^{108}$ The different parts of the palace that received provisions were (1) the palace proper, that is to say the

\footnotetext{
104 Quirke 1990, 106-107.

105 Scharff 1922, plates 7-8.

106 Quirke 1990, 112.

107 Spalinger 1985, 190.

108 Spalinger 1986a, 209-210; Quirke 1990, 51.
} 
administrative staff of the court; (2) the 'household of the nurses', effectively the royal family and their dependents (when present), and (3) the 'regular clients' or support staff of the palace (servants, guards, etc.). It has been noted that the king is not generally mentioned in the papyrus, unlike the king's wife, the king's children (one son, three daughters), the king's brothers and his nine sisters, ${ }^{109}$ but whether this is a matter of decorum or an indication of his absence is unclear. The groups of individuals that belonged to the different parts of the palace can be subdivided into ranking blocks, with rank inferred based on the amount of provisions allocated. ${ }^{110}$

The provision lists show fluctuations in the amounts consumed, and these changes can sometimes be linked to specific events at the palace: ${ }^{111}$ one of the clearest examples is a feast in honour of the god Montu where a long list of consumables issued is accompanied by a 'Name-list of the officials admitted to eat in the audience hall on this day', including high-ranking individuals like the vizier Ankhu and the general and royal seal-bearer Iaib. ${ }^{112}$ Another illustrative example is the arrival of a group of five or six medjay-bedouins at the palace on day 2 of Akhet, for whom provisions then had to be issued following a written order to that effect. The order, which included information about the amount of bread and beer to be issued, as well as the institutions or departments which were going to be responsible for the 'extraordinary provisions', was copied into the daybook. This entry was followed by a formulaic statement about the order having been received and carried out. The first time these visitors are mentioned they are described as 'medjay who came in obeisance', and although there is no further information about the purpose of the visit in the document, ${ }^{113}$ the delegation included two 'chiefs' who were treated well: they were, for example, provided with dates, a commodity which at the aforementioned feast was only given to the two highest-ranking Egyptian officials present.

Entries of type (3) often deal with more valuable commodities like incense, wood, galena, different types of wine, sesame oil, honey, etc., and this is issued or withdrawn from the 'strongroom', mainly for individuals but also for the temple of Montu as divine offerings on an occasion when the divine statue returned to the temple. ${ }^{114}$ Such luxury items were not part of the regular provisions, and

109 Quirke 1990, 120-121; Spalinger 1985, 235.

110 Quirke 1990, 74-76.

111 Spalinger 1985, 193; Quirke 1990, 108.

112 Scharff 1922, plate 18.

113 Spalinger 1985, 220-222.

114 Spalinger 1985, 230-234. 
were issued ad hoc: the queen herself was on one occasion supplied with eyepaint, wine, and an ebony box. ${ }^{115}$

In terms of the use of this particular archival document it is noteworthy that despite the short period of time covered by the daybook, there are several mentions of written messages being circulated and copied, ${ }^{116}$ so that it represents only a small part of the original textual material produced at the palace. Notwithstanding the fact that the document is an exceptionally rich source for the reconstruction of the administrative structure of the court in the late Middle Kingdom, as well as for various aspects of socio-economic history, it was a functional accounting document with a relatively narrow focus: it dealt with income and expenditure of the palace. The arrival or departure of officials or delegations, as noted above, is only mentioned in those cases where provisions are affected. In this sense the document is much more restricted than the daybook of the temple of Lahun, for example: it is not a daybook of the entire royal palace but rather a daybook for the administrative section of the palace dealing with the provision of food and drink (and occasionally other commodities from the 'strongroom'). The purpose of the papyrus seems obvious, and the attention to deficits of goods delivered, ${ }^{117}$ so common in these types of documents, hints at its potential as a reference point in case of trouble with deliveries, as so clearly illustrated by the letters from the slightly earlier Lahun temple archive.

\subsubsection{A New Kingdom palace archive from Gurob}

During the late nineteenth century excavation of a royal palace at Kom Medinet Gurob, Sir Flinders Petrie-who at the same time was excavating the settlement of Lahun where a temple archive of an earlier period was found (3.2.2)-discovered a set of papyrus fragments. ${ }^{118}$ Many of them were from the palace archive, but the excavation was poorly documented, even according to the standards of the time, and how many separate find-spots were involved is unknown: the presence of a number of literary fragments in the material need not suggest that material from the palace library was mixed with the administrative documents from the palace archive in its original context. ${ }^{119}$

\footnotetext{
115 Spalinger 1986a, 223-225.

116 Quirke 1990, 105-106.

117 Quirke 1990, 112.

118 Petrie 1890, 36; Griffith 1898.

119 Hagen forthcoming; cf. Fischer-Elfert 1998.
} 
The majority of the papyri from the site are Ramesside in date (c.1250-1200 $\mathrm{BCE}$ ), as shown by a number of dates and regnal years in the headings, including in some cases a notation of where the king is - a feature common to many administrative documents relating to the royal court. ${ }^{120}$ Although there is a group of private legal documents of the $18^{\text {th }}$ Dynasty sometimes said to be from here, the actual provenance of these could equally well have been Lahun. ${ }^{121}$ As is the case with several other archives, the Gurob palace papyri were never fully published, and although there are transcriptions of some of the fragments available, ${ }^{122}$ only a few select pieces have been translated. ${ }^{123}$

The fragmentary nature of the material means that it is challenging to evaluate archival practices at the site in any detail, but many of the papyri can be assigned to the daybook-genre. The best-preserved page from this daily palace journal, dated to year 2 of Seti II and written on the usual large-scale format roll with a height of $c .42 \mathrm{~cm}$, displays a range of topics and types of entries:

1. Copy of a letter sent from the palace to the king, where a woman thanks him for having sent foreign workers in connection with an unnamed project. It ends with a date which is presumably the date the actual letter was sent.

2. Dated entry with the heading for a list of personnel of the palace (the list itself was never included).

3. Dated entry recording the delivery of fish from the local governor.

4. A tabular account recording the daily payment of wages, in oil, to workers and their overseers for half a month.

5. Dated entry recording the delivery of fish, mats and loaves of bread.

6. Dated entry recording the delivery of fish from the governor through various fishermen.

7. Dated entry recording the delivery of fish from the governor, as well as provisions of bread and beer from the overseer of the king's household.

8. Dated entry (incomplete) of the extraction of goods from the storehouse of the palace for a doorkeeper.

The broad range of entries echoes that of daybooks from temple archives (see Fig. 7 above); accounts of deliveries received, goods distributed, letters sent, etc.

Other fragments from the palace daybook are diverse to say the least, but the management of resources is a recurring theme. A copy of a letter from a Theban

120 Hagen 2016a.

121 Compare the accounts of Griffith 1898, 19, 91-92, Petrie 1890, 50 and Gardiner 1906, 27; 1957, 23.

122 Gardiner 1948, 14-35.

123 Griffith 1898; Gardiner 1953; Helck 1961-1969. 
official deals with the branding of various cattle with the mark of the Gurob palace, followed by a list of 38-40 cows grouped according to age and colour. ${ }^{124}$ The palace received income through the collection of the harvest tax, and this was also noted in the daybook: one passage deals with the tax in the very last year of the reign of Ramesses II and the first year of his successor Merenptah, and despite its fragmentary state it shows that in this case the grain is received from the local governor rather than collected directly. ${ }^{125}$ The dependence on local governors for supplies is well documented in the archive and is directly comparable to the provisions supplied to the palace of Seti I at Memphis by the local governor there (see 3.3.3 below). The palace presumably also collected harvest tax directly from its own fields, as seems to be the case in another daybook fragment that mentions the harvest tax of specific individuals, including 'cultivators'. ${ }^{126}$

Precious materials issued from storerooms were also recorded in the daybook, such as one case where deliveries (of lapis lazuli and malachite, as well as linen) were sent to 'the place where the king is' ${ }^{127}$ Other high-value commodities like textiles were issued perhaps primarily in connection with specific events such as festivals, ${ }^{128}$ but only rarely are names or titles of recipients preserved. The most famous example records a foreign princess and wife of Ramesses II who was issued two large rolls of high-quality cloth $(c .14 \times 1 \mathrm{~m}$ and $7 \times 1 \mathrm{~m}$ in size, respectively), presumably for the preparation of suitable garments, but there is another fragment that has garments being supplied to a member of the royal family too, perhaps to the king's son. ${ }^{129}$

Other events at the palace were also recorded in the daybook, but there are few examples in the surviving material. The departure and arrival of officials was registered in a manner similar to that known from the contemporary archives of the royal tomb construction projects from Deir el-Medina (3.8): one entry reads 'Day 27: Arrival of the royal scribe Mahu at the palace [...]'. ${ }^{130}$

The organisation of labour is not as prominent in the surviving archival material from Gurob as it is in the Lahun temple archive, but this may partly be explained by its fragmentary nature and partly by the fact that there were few largescale building programmes in the area of Gurob that would be comparable to the

124 Gardiner 1948, 18-19.

125 Gardiner 1948, 30.

126 Gardiner 1948, 33.

127 Gardiner 1948, 21.

128 See Gardiner 1948, 20-21 for a substantial range of garments issued on the occasion of a New Year festival.

129 Gardiner 1948, 22-23.

130 Gardiner 1948, 24. 
construction of the royal pyramids at the time the Lahun archive was in use. However, a single fragment from the daybook with a list of builders, coppersmiths and sandalmakers delivering some 39000 bricks (as their work quota?) shows that large-scale construction work certainly took place intermittently. ${ }^{131}$ One unpublished fragment has as a list of personnel belonging to the palace that are being sent out to work 'in the northern region', including 'servants' and 'washermen'; the work is presumably related to cultivation as they are collectively referred to as 'cultivators' despite their titles in the list. ${ }^{132}$ The workers are divided up into two groups, each under the supervision of an official (one is an 'agent', $r w d w)$, and it seems to be forced labour because one man is said to have 'run away', two were excused on the grounds that they were dead, and three had already been drafted as soldiers and so could not be sent out with the others. The list includes a significant proportion of foreign names.

There are other name-lists of people associated with the palace, with many different titles attested: priests, 'citizenesses', shepherds, guards, and so on, but due to their fragmentary nature there is little contextual information to go on. ${ }^{133}$

As with the Lahun material there is at least one original letter, this one sent to a chief of guards called Raia from one of his colleagues whose name is lost, and dealing with various deliveries and problems of communication. The presence of an address on the back shows that it is an original letter, rather than an archival copy from the daybook. ${ }^{134}$

Archival usage, beyond the production of the documents themselves, is rarely attested in this material. There is a single reference to a 'report of year 61' that had been 'put onto a papyrus roll', ${ }^{135}$ but the context is broken. The fragmentary nature and only limited publication of the material notwithstanding, the content and form of the Gurob archive echo that of other institutional archives, including the daybook format with the copying of correspondence sent out from the palace as a record of official communication. The mix of letters, tabular accounts, and dated entries recording income and expenditure, is very similar to that found in the other archives discussed above, and demonstrates a remarkable longevity of format and administrative practice over well over a thousand years.

131 Gardiner 1948, 34.

132 P.BM EA 10776; this is perhaps a loose sheet rather than a fragment of the daybook although it is from a similar full-size roll.

133 E.g. the unpublished P.BM EA 10777.

134 P.BM EA 10779; also unpublished.

135 Gardiner 1948, 27. 


\subsubsection{A New Kingdom palace archive from Memphis}

A roughly contemporary group of papyri from Memphis, the precise archaeological context of which is not known, stems from a palace archive from the second and third regnal years of King Seti I. Having been acquired on the antiquities market in the first half of the 1800s-Champollion had seen some with a dealer in Cairo as early as 1828 - they eventually made their way to Paris, where the Bibliothèque nationale de France $(\mathrm{BnF})$ bought them from the dealer Rollin in 1846. Although some pieces were gradually made accessible for study it was not until 1896 that Wilhelm Spiegelberg collected and published a full edition of the material. The state of preservation of the papyri suggests a find-spot in a tomb, probably somewhere in the Saqqara necropolis. The date of the archive is fixed by a number of full dating formulas in the headings, many of which also note the whereabouts of the king, and these can be used to build up an overview of the travels of the royal court. ${ }^{136}$ To the manuscripts in Paris should probably be added the following three groups (1) three papyri acquired in Egypt in the early 1890s by Lord Warkworth, ${ }^{137}$ (2) two fragments in the Amherst collection, ${ }^{138}$ and (3) perhaps-although less probable-some fragments in the Egyptian Museum in Turin. ${ }^{139}$

Group (1) consists of exceptionally well preserved papyri that must also have come from a tomb; one of them is a baking account very similar to the BnF documents and is dated to precisely the same regnal year of the same king, Seti I. ${ }^{140}$ Another includes an intriguing literary text with a eulogy in honour of Seti I on the front, and then on the back a curious text relating to the weighing of the heart ceremony, ${ }^{141}$ while the last one is a letter written by a scribe working at Memphis. ${ }^{142}$ This could be a coincidence but it is more plausible to interpret it as coming from the same find as the Paris papyri.

Group (2) could well belong to the material, and although their fragmentary state makes this difficult to confirm it is noteworthy that both collections also included fragments of a single literary manuscript from the same period (The Story of Astarte and the Insatiable Sea), and that the dealer who sold both this literary manuscript and the administrative material to the BnF, Camille Rollin, had assigned the former the shop catalogue number 1886 and the first of the latter

\footnotetext{
136 Hagen 2016a.

137 Barns 1948.

138 Newberry 1899, 48 no. XI, plate 21 nos IV and V.

139 Kitchen 1993a, 185.

140 P.BM EA 73668.

141 P.BM EA 73667.

142 P.BM EA 73666.
} 
(P.BnF 203) the number 1887. There is relatively little evidence about the provenance of either group but on balance I am inclined to believe they may have come from the same original find..$^{143}$

Group (3) consists of two fragments of accounts dealing with grain, one of which mentions King Seti I, but there is little else to tie the fragments to the Memphis archive and they could equally well belong to a Theban find. ${ }^{144}$

Over all the material can be divided into two types of papyri where one is characterised by a quickly-written and rather cursive hieratic and the other by a more careful and formal register of hieratic that has been described as 'calligraphic' ${ }^{145}$ The latter papyri are invariably written only on the front of the roll (i.e. where the papyrus fibres run horizontally) and are laid out in a more considered manner. The impression is that one is seeing two distinct stages of archival practice, one initial stage where preliminary accounts are drawn up, perhaps on the spot as deliveries are made, and one secondary stage where preliminary accounts are written 'clean' onto a final roll that is destined for the archive; this may be compared with the daily accounts compiled into monthly accounts in the temple archives from Abusir and Lahun (3.2.1 and 3.2.2).

The Memphis archive has not been fully published in modern photographs, and some of the inscribed areas have been cut up and pasted onto cardboard in modern times, and this obstructs an assessment of the materiality of the group as a whole. However, a particularly striking physical feature of the documents left intact is the extravagant use of papyrus. Papyrus BnF 204 (Fig. 10) is a case in point: in this papyrus, which is one of the finely written archival copies, the hieratic text has been distributed on the page with no concern about the efficient use of space, but this is not always obvious from the published photographs and facsimile drawings. Combined with the format of the document-the regular full format height of $42 \mathrm{~cm}$-and the uncial handwriting, the visual aspects alone signal the exceptional status of its original institutional context.

143 Cf. Collombert/Coulon 2000, 195-199.

144 See Kitchen 1993a, 185.

145 Spiegelberg 1896, 5. BnF 203-208 are hastily written, while BnF 209-213 are 'calligraphic' in style. 


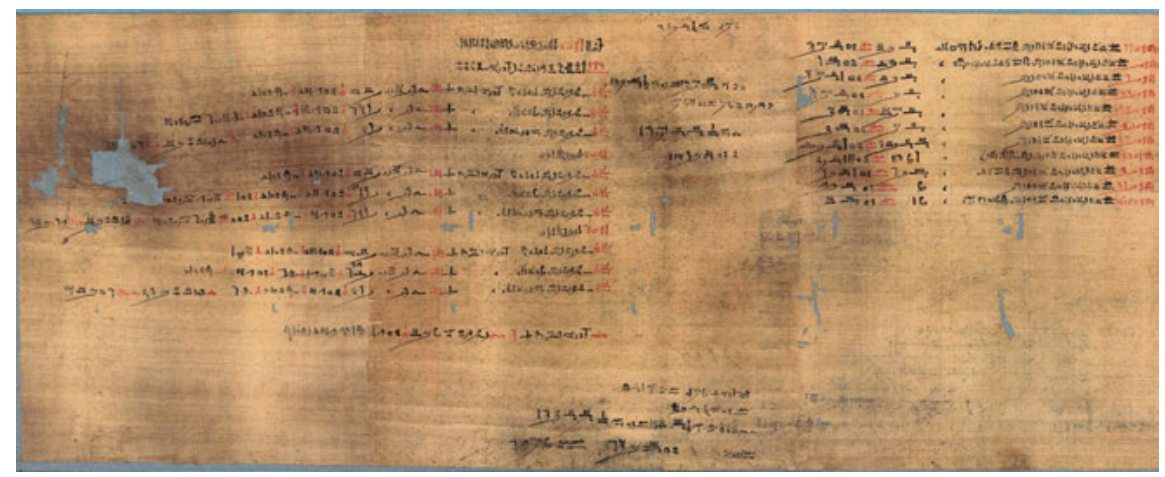

Fig. 10: Photograph of P.BnF 204, an administrative document recording the receipt of bread at the storehouse of the royal residence at Memphis. The bread had been delivered from the bakery of the local mayor, who in turn had been issued the grain from the royal granary, and the amounts were considerable: the summary at the bottom mentions 112090 small loaves. The extravagant use of space is unusual and shows that economic factors like the cost of papyrus were irrelevant to the scribe drawing up the accounts. Courtesy of the Bibliothèque nationale de France.

The papyri are occasionally referred to as 'the baking accounts of Seti I' in Egyptological literature, but the contents are more diverse than this label suggests: only about a third of the papyri deals with the organisation of bread production and delivery. The largest group of papyri is in fact a set of accounts dealing with the 'requisitioning' $(n h m)$ of timber in various city districts of Memphis by house or institution. ${ }^{146}$ Despite the general lack of contextual information in the headings of the timber accounts it seems plausible that the main purpose was to survey material for use in shipbuilding. In one account 'carpentry timber' is mentioned, and many of the officials supplying this specific type of timber held nautical titles; in general a high proportion of the timber can be identified as ship's parts. ${ }^{147}$ Precisely why or how the state could lay claim to the timber possessed by all these individuals and institutions is a matter of debate, ${ }^{148}$ but it illustrates the problems involved when historians try to distinguish between Egyptian private property and resources to which an individual had access through the holding of an office. The officials listed include a variety of high- and mid-

146 Kitchen 1993b.

147 Kitchen 1993a, 178-179.

148 Kitchen 1993a, 176-177. 
ranking titles, and the institutions mentioned range from the estates of the king and of the queen to various other religious institutions and estates.

The second largest group of papyri is the baking accounts, a term that encompasses several different types of documents. The first type relates to the delivery of grain, explicitly said to be for baking, from the royal granary in Memphis to the bakeries run by the local governor, typically around 180 sacks (c.13,500 litres) at a time. The second type are accounts detailing the deliveries to the palace of the bread itself every few days, where the number of bread loaves is entered against the names of various individuals, along with the type and weight of the bread. A third type, also an account of bread baked, lists the bakers responsible each day, normally four, and the amount of flour they had been issued, and how many loaves of bread they had baked from it.

The number of bread baked fluctuates, but the accounts do not generally give any reason for the changes. It seems obvious that the differences are due to the presence or absence of certain groups of people, or perhaps the celebration of festivals - the whereabouts of the king is mentioned in many dating lines, for example, although it is not possible to correlate this with production levels. One document includes a comment to the effect that the Chief of the Granary changed the volume of grain issued, but the reason is not given. ${ }^{149}$

The average size of a loaf was about $300 \mathrm{~g}$, and the number of loaves per entry ranged mostly from around 1,000 to 6,000, but how many people were fed from this is impossible to say-somewhere in the region of 500 individuals has been suggested but there are too many unknown factors for reliable estimates. ${ }^{150}$ The baking accounts note the amount of flour issued to individual bakers, and the bread they baked from it each day (often around 350 loaves each), by number and by weight, and the calculations include a set rate of $10 \%$ loss of weight as a result of the baking process. The detailed records facilitate control over production levels (at least one calculation on the back of a document is a preliminary estimate of needs), ${ }^{151}$ but were presumably also intended as a measure to avoid or discourage theft. Some bakers delivered less bread by weight than the accepted rates for the flour they had received, and this was duly noted by the scribes as a deficit: one example involved the baker Khuru who had delivered about five loaves too little one day, and this was duly recorded in the account. The latter is important because it shows that the deliveries were actually weighed-it was not just a standard formula that was filled in automatically. There are no indications in the

149 Kitchen 1975, 218.

150 See in general the comments by Kitchen 1993a, 165.

151 Spalinger 1986b, 316. 
archive of sanctions based on the deficits, but these particular accounting documents may not have been the obvious place to record it. Certainly patterns in deficits relating to specific individuals are apparent even to modern eyes, and the baker Khuru often delivers less than he should, leading one scholar to label him 'light-fingered'. ${ }^{152}$

One account (BnF 203) deals with the delivery of fowl under the heading 'Account of the handing over of fowl to the fowl-yard of Seti I', that is to say a record of the delivery of living fowl either bred or captured elsewhere and brought to suitable structures at the residence, but the numbers of birds involved are unfortunately lost. Contemporary texts and reliefs show that both palaces and temples could have fowl-yards of considerable size, and although the figures quoted sometimes seem unrealistic-one ostracon mentions 22530 people overseeing some 34230 birds each-the sector certainly played an important part in providing food for these institutions. ${ }^{153}$ The document lists the deliveries made each day, as well as who is bringing the birds, but there is no mention of which office or department is involved.

The commodities are dealt with mainly in separate accounts, and the overall range of goods is in practice relatively narrow: grain, bread, fowl, reeds, timber, leather and textiles. There are many categories of resources not mentioned in the archive as it survives, although undoubtedly they too would have been administered at the palace, including precious metals like gold, silver and copper, minerals, eye-paint and perfume. The implication of the absence of such records in the surviving material is not clear: they could have been issued by a separate department, perhaps responsible for a 'strongroom' as in the Theban palace of the late Middle Kingdom (3.3.1), or they could simply be lost.

The above-mentioned letter (P.BM EA 73666) which may be associated with the archive includes a glimpse of the informal economy of institutional provisions that only rarely appears in the accounts themselves. In an aside about treating the bearer of the letter with respect, the writer accuses the addressee of having kept half of the rations allocated to the writer (presumably by the hosting institution) during a previous visit, explicitly in order to sell the ill-gotten grain for silver. ${ }^{154}$ Such misuse of institutional resources must have been widespread.

In terms of archival processes the material provides parallels but also differences when compared to other archives. As with the Abusir and Lahun archives there are both daily accounts and summary accounts in the Memphis papyri. The

152 Kitchen 1993a, 167.

153 Kitchen 1993a, 160-161.

154 Barns 1948, 38. 
longest period covered by a single account are the 8 months summarised in $\mathrm{BnF}$ 205, where three deliveries per month (every ten days) are listed from month 4 of Akhet to month 3 of Shomu, and another document covers just over four months (BnF 206). ${ }^{155}$

One of the striking characteristics of the Memphis material is the fact that the subject matter is often restricted on a single 'page', so that one does not get the mixture of event, deliveries, letters, etc. that characterises daybooks. The Memphis accounts are more specialised in nature, but even here there are some examples of a single roll used for multiple types of entries, albeit not in a daybook format. The most informative example is BnF 209 which on the front has one column dealing with grain delivery from various women and the issuing of the same to bakers, followed by four columns listing the 'remainder' of wood in the southern quarter of Memphis. ${ }^{156}$ The back of the roll was used for an even wider range of notes and jottings: the issuing of grain (including to 'those who were sick'), a list of work done by various bakers on certain days and the bread received from the bakeries, notes regarding the delivery of textiles by women (written upside-down in relation to the other texts on this side), and a name-list of Nubians 'brought from the settlement'. The impression is that the back of the roll was used effectively as a notebook by the scribe, perhaps for a limited time because all the recorded dates (relating to three of the independent sections listed above) fall within a period of nine days in month 2 of Peret.

The exceptional state of preservation of many of the Memphis accounts allow for an analysis of the stages of use of individual documents. In several papyri there are marginal signs and check marks (dots and thin oblique strokes), as well as corrections or crossing out of numbers, mainly in red ink. ${ }^{157}$ This is not a practice unique to the Memphis archive, ${ }^{158}$ but it seems to be more widely used in this material than in any of the other archives of the same period, although the poor state of preservation of the latter may in part explain this. As in both literary and administrative texts a missing or left-out part of the text can be added, for example above the line: one of the timber accounts has the phrase 'for work on the door' added in this way, specifying the eventual destination of the timber. There are also marked 'ticking off' entries, in red and black ink, for example in a name

155 Note that the 'sheet' as published by Spiegelberg (1896, plate IV) consists of three separate fragments whose original position relative to each other is unknown; consequently we do not here have evidence of a daily account next to a summary account.

156 Spiegelberg 1896, plate IX.

157 Kitchen 1975.

158 Helck 1974, 61-62. 
list, as well as numbers that are crossed out. ${ }^{159}$ It is readily apparent that most of these signs of use are found in the documents with a less formal register of hieratic, but significantly they are also found in the stylised formal accounts, ${ }^{160}$ so the distinction is not absolute.

The question naturally arises as to which government or palace department the material originally belonged. Assuming that the find-spot was a single tombwhich although plausible cannot be proven-the archive was in any case deposited away from its original location. What the papyri have in common is that they deal with royal, that is to say state property, including the daily provisioning of food. The central department in the baking accounts is the storehouse of the royal residence, which acts as a nexus that oversees the grain sent from the royal granary (under the authority of the king) to the bakeries (under the authority of the mayor of Memphis) which eventually supplies bread back to the palace. Perhaps all the papyri would have been produced and kept at this storehouse, which would then have overseen and organised resource collection and expenditure along similar lines as the office responsible for provisioning in Papyrus Boulaq 18 (3.3.1). Whatever the case may be, the department operated in a slightly different way, with a more stringent division of account types on separate rolls, and an extravagant use of papyrus.

\subsection{Military archives}

There are few fragments from military archives from pharaonic Egypt, although it is clear that they existed. The army had its own hierarchy of scribes, and they would have kept records in connection with their duties: conscription, keeping track of rations, equipment, and the spoils of war, etc. ${ }^{161}$ Expeditionary troops had army scribes with them, so for instance in the case of five thousand men sent out to quarry stone in the Wadi Hammamat under Ramesses IV the list of personnel includes 'twenty army scribes'. ${ }^{162}$ Such scribes would have been responsible for both logistics and the keeping of records of various activities, and the extensive lists of loot from the military victories in the Levant under Thutmose III will have been derived from their field-notes. ${ }^{163}$ Some of the original journals recording these campaigns were written by the army scribe Tjanuni (owner of Theban Tomb no. 74),

159 Spiegelberg 1896, plates XI-XV; Goelet 2015, 353-354; Kitchen 1975, 207.

160 Kitchen 1975, 212, 215.

161 Schulman 1964, 62-66.

162 Kitchen 1975-89, VI, 14.4.

163 Redford 2003, 4-5, 58-59; 1985, 151. 
who in his tomb claims that '[i]t was I who wrote down the victories he (i.e. king Thutmose III) won in every foreign land, they being made in writing according to what he had done', ${ }^{164}$ suggesting involvement with other types of records than simply army accounts. A model letter from c.1280 BCE (The Satirical Letter of Hori) lists areas of knowledge expected of a New Kingdom scribe-within a semi-literary framework-including that of an army scribe. One part of the text concerns the problem of provisioning for a group of five thousand soldiers: 'The number of men is too large for you (to calculate), and the provisions are insufficient for them... The troops are ready and all set, so you must divide the provision up into portions, one for each man' ${ }^{165}$ Such logistical challenges would have been met by extensive use of accounts papyri, and although these rarely survive there are some fragments that preserve relevant material. One document is a sort of daybook from the Karnak temple, dated to the reign of Ramesses IX (c.1125 BCE), that includes an archival copy of a letter to some Nubian soldiers sent out to guard the temple's gold-washers somewhere on the Red Sea coast. The Nubian troops had defeated local Bedouins who were attacking the mining operation, and the letter instructs the troops to stay put and be on guard for further trouble. Along with the letter the daybook also has a copy (mitt) of a list of provisions that is being shipped to the soldiers, ${ }^{166}$ but despite dealing with military personnel the document itself stems, strictly speaking, from a temple archive.

The only extensive remains of a military archive are the fragments known in the Egyptological literature as the Semna Dispatches. ${ }^{167}$ These texts were written on the front of a full-format papyrus roll with an estimated original height of perhaps 21-27 cm. The back of the roll was then subsequently used to copy a magical text, perhaps an execration ritual-and it has been suggested that this text on the back may also have been copied on-site at the Nubian fortress of Semna-before it made its way over $500 \mathrm{~km}$ northwards. The Semna Dispatches were in fact found, along with a number of other papyri, in a box in a late Middle Kingdom tomb (c.1820 BCE) at Thebes, together with various objects like reed pens, fertility figures, model faience vessels, ritual objects of ivory (including wands and 'clappers'), a bronze serpent wand, and a small wooden figurine of a female holding two bronze serpent wands. There was a definite focus on medico-magical compositions in the collection of papyrus material in the box (along with literary narratives, wisdom poetry

164 Sethe 1906-1909, 1004.9-10.

165 Fischer-Elfert 1986, 121; Wente 1990, 106.

166 P.BM EA 10752 = P.Ramesseum C; Kitchen 1975-89, VI, 519.12-521.11; Wente 1990, 38-39. The provisions include textiles, metal cups, knives and axes, bread, livestock, and spices.

167 Smither 1945. 
and hymns) and this, along with the other objects found, have led scholars to believe that the owner was a priest or ritual practitioner. ${ }^{168}$ Whoever the owner was there is no information available as to how this document, originally from a military archive, made its way to Thebes and into the box where it was found. ${ }^{169}$ The box also contained another document related to the administration of the Nubian forts, but this appears to have been written in Thebes, perhaps at the local office of the vizier who was formally in charge of the forts, rather than at Semna. ${ }^{170}$ This second papyrus, which consists of two fragments that do not join directly, contains copies of letters dealing with the external administration (here sip, 'inspection') of the forts, and so differs also in content from the Semna Dispatches, even if they deal with the same institutions.

A sense of the original archival context of the Semna Dispatches can be gained by a comparison with papyrus fragments found at other contemporary forts guarding the Nubian border. The forts at Buhen, Uronarti, and Shalfak have all yielded hieratic documents, albeit very fragmentary ones; the finds appear to include letters, accounts, and perhaps a daybook type document, although their poor state of preservation means the identification of text types is often uncertain. ${ }^{171}$ The exact find-spots were recorded, so in most cases the material can be plotted onto maps of the site, an example of which is given in Fig. 11.

The data show a wide dispersal of fragments that do not readily lend themselves to an identification of an archive in the physical sense of a single location for the storage of administrative documents: at Uronarti the fragments came from 'block II', an area which 'may well have housed administrative offices', but alsoand in greater numbers and higher concentrations-from 'block III' and 'block VIII', areas which were identified as barrack rooms by the excavators. ${ }^{172}$ At Buhen, the papyrus fragments were found in the residence and headquarters of the commander of the fortress ('block A'), in what was believed to be a secondary context: effectively 'a closet under the stairs'. ${ }^{173}$ The excavator thought they might have been deliberately swept in from the adjoining 'Painted Hall' (room 4), an audience chamber with 15 pillars and a brick pavement, when that room was being refurbished in the early New Kingdom. ${ }^{174}$ There is no further information about the original storage conditions available.

168 Parkinson 2009, 138-172; Quirke 2016.

169 Kraemer/Liszka 2016, 56.

170 P.BM EA 10771 = P.Ramesseum 18; Liszka/Kraemer 2016, 185.

171 Smith 1976, 31-38, plates 61-68; Dunham 1967, 89-108.

172 Dunham 1967, 37-56.

173 Room 12: Emery et al. 1979, 9, 47.

174 Emery et al. 1979, 47-51, plate 16; Smith 1976, 31. 


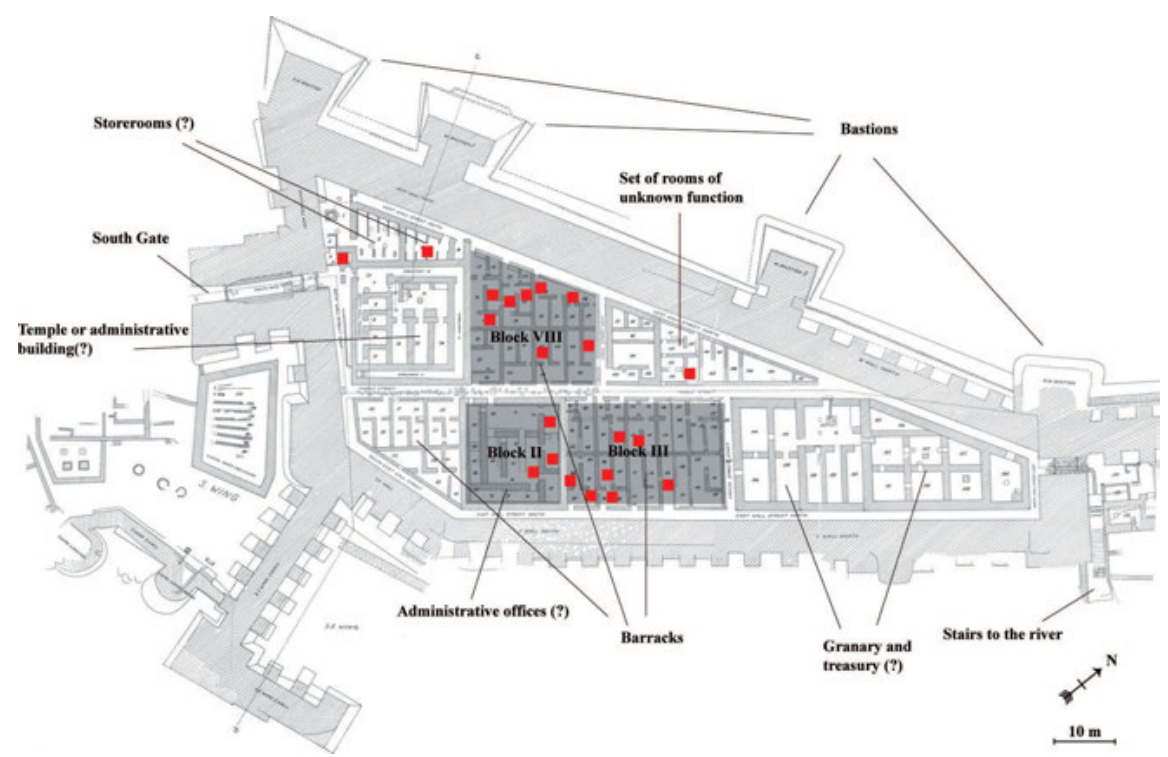

Fig. 11: A map of the central area of the fortress at Uronarti, indicating the find-spots of papyrus fragments (red squares). The identification of function and purpose of some areas are debated, but block II was thought by the excavators to contain the administrative offices of the fort, partly due to the papyri found here, while blocks III and VIII were thought to be living quarters for the soldiers. Adapted from Dunham (1967, map no. III).

The Semna Dispatches consist of a daybook roll recording events that took place over a period of three weeks (but with the actual entries perhaps copied over the course of a single day), written by a single scribe, in the third year of king Amenemhat III (c.1828 BCE). In contrast with many other daybooks of both the Middle and the New Kingdom, this particular daybook is exclusively concerned with outgoing and incoming letters: there are no accounts, lists of personnel or deliveries. ${ }^{175}$ The roll was simply a record of communication between a series of forts along a stretch of the Nile that marked the border between Egypt and Nubia. ${ }^{176}$ The Egyptian term for the letters is literally 'that which fortress sends to fortress', and the reports focus on the movement of desert-dwelling medjay-people and other Nubians (called Nehesy) in the border area, and only secondarily their trading activities which are known to have been policed by the Egyptian state. The

175 Kraemer/Liszka 2016, 30.

176 Kemp 2006, 231-244. 
main concern is the number and identity of people travelling, where they come from, and where they are going:

\begin{abstract}
ANOTHER LETTER WHICH WAS BROUGHT TO HIM, ONE WHICH WAS BROUGHT BY THE OVERSEER OF THE STOREHOUSE SOBEKWER, WHO IS IN MIRGISSA FORT, AS THAT WHICH FORTRESS SENDS TO FORTRESS: It is a letter to your scribe, may he live, be prosperous, and be healthy, about the fact that those two guards and seventy medjay-people who went following that track in month 4 of Peret day 4, came to report to me on this day in evening, while bringing three medjay-men and [...], saying: 'We found them on the southern edge of the desert, below the inscription of Shomu, along with three women', so they said. Then I questioned these medjay-people, saying 'Where have you come from?', and then they said, 'It is from the well of Ibhyt that we have come'...

...

COPY OF A DOCUMENT WHICH WAS BROUGHT TO HIM, BEING ONE BROUGHT FROM THE FORTRESS OF ELEPHANTINE, AS THAT WHICH FORTRESS SENDS TO FORTRESS:

Take note, while being healthy and alive, of the fact that two medjay-men, three medjaywomen, and two youths (?) came down from the desert in year 3, month 3 of Peret day 27. They said: 'It is to serve Pharaoh, may he live, be prosperous and healthy, that we have come!'. A question was then asked regarding the situation in the desert. Then they said: 'We have not heard anything, but the desert is dying of hunger', so they said. Then this servant of yours had them dismissed to their desert on this day... ${ }^{177}$
\end{abstract}

This is not the place to explore the wider historical importance of the document, but in terms of the archival activities taking place-most of which have left no trace outside this papyrus roll-one of the key implications is the transmission of information, in written form, as missives being circulated not just between individual forts but (in several copies?) between a whole chain of forts. The recording is limited to letters, and the administrative documents from Buhen show that this was only a small part of the records that were produced in the forts; it seems likely that the Semna Dispatches papyrus formed part of the archive of the official responsible for monitoring the movement of people in the border region of this one fort, perhaps in an 'Office of reporting' as attested in the fort at Uronarti. ${ }^{178}$

This level of recording may or may not have been representative for border control during periods of strong central government. The slightly later text known as The Duties of the Vizier, which lays out the duties associated with the highest civil office in the state administration, indicates that the vizier's office would receive reports-presumably in writing ('to him is reported the state of fortresses of the south

177 Smither 1945, 7-9.

178 Kraemer/Liszka 2016, 28, 36, 40. 
and the north' $)^{179}$-but this need not have been detailed reports of the kind represented by the Semna Dispatches.

The extensive fortifications along the Egyptian border in the Nile Delta region have not yielded material of a similar nature, primarily because local conditions here at Egypt's northern border do not favour the survival of papyrus. The impressive New Kingdom fortifications are comparable to the Nubian forts in the south, of the Middle Kingdom, in terms of infrastructure, ${ }^{180}$ and it is reasonable to assume that similar archives would have existed there. A Ramesside letter explicitly states that written records detailing the movement of Bedouins in the border area in the north were being circulated, and a copy of a couple of pages from such a border journal exists. ${ }^{181}$ The surviving extract was copied into a papyrus roll alongside various literary compositions and so is not an archival copy stricto sensu:

Regnal year 3, MONTH 1 OF SHOMU, DAY 15. Going up by the retainer Barry son of Djapur, of Gaza. That which was with him for Syria: 2 dispatches (wh3). Specifically: One dispatch for the Overseer of the Garrison, Khay; one dispatch for the Chief of Tyre, Barremgu.

Regnal year 3, MONTH 1 of SHOMU, DAY 17. Arriving by the Troop Commanders of the Wells of Merenptah-Hetephermaat, may he live, prosper, and be healthy, which are in the hills, in order to investigate matters in the fortress (htm) of Tjaru.

Regnal year 3, MONTH 1 OF SHOMU, DAY 22. Coming by the retainer Djehuti son of Tjakaruma, of Gaza (?), Matjaduti son of Shamabar, ditto (of Gaza), Sethmose son of Aperdegar, ditto (of Gaza). That which was with him for the place in which One (= the king) is: Tribute and one dispatch for the Overseer of the Garrison, Khay... ${ }^{182}$

The copy of the daybook covers two sheets of the papyrus roll, and it retains the layout of actual daybooks with new dates and new consecutive entries noted in red ink on separate lines. Judging by the contents it would have originated at a border outpost on the Eastern edge of the Delta, perhaps the fortress of Tjaru (Tell el-Hebua I) along the main route between Egypt and the Levant known in Egyptian as the Ways of Horus, ${ }^{183}$ and its entries record the movements, over a period of ten days, of various officials. Many carry letters while 'going up' to different locations in the Syria-Palestine area, or bring letters back from the foreign territories when 'returning' to Egypt (Fig. 12):

179 Quirke 2004, 19.

180 Overview by Morris 2005; recent work in the area is published by Snape and Wilson 2007 and Hoffmeier 2014.

181 Caminos 1954, 293.

182 Gardiner 1937, 31; Caminos 1954, 108-113.

183 Morris 2005, 478-486. 


\begin{tabular}{|c|c|c|c|}
\hline $\begin{array}{l}\text { Date of Arrival } \\
\text { (verb used) }\end{array}$ & Origin & Destination & Purpose \\
\hline $\begin{array}{l}\text { I Shomu } 15 \\
\text { (ts, 'going up') }\end{array}$ & Egypt & $\begin{array}{l}\text { Syria-Palestine } \\
\text { (Kharu) }\end{array}$ & $\begin{array}{l}\text { Delivery of letters to (1) the } \\
\text { garrison commander Khay, } \\
\text { and } \\
\text { (2) the Chief of Tyre Bar- } \\
\text { termegu }\end{array}$ \\
\hline $\begin{array}{l}\text { I Shomu } 17 \\
\text { (spr, 'arriving') }\end{array}$ & $\begin{array}{l}\text { Syria-Palestine } \\
\text { (Wells of King Meren- } \\
\text { ptah) }\end{array}$ & Egyptian border & $\begin{array}{l}\text { To 'investigate' (smtr) matters } \\
\text { at the fortress of Tjaru }\end{array}$ \\
\hline $\begin{array}{l}\text { I Shomu } 22 \\
\text { (ii 'returning') }\end{array}$ & $\begin{array}{l}\text { Syria } \\
\text { (Kharu) }\end{array}$ & Egypt & $\begin{array}{l}\text { Delivery of tribute (?) and a } \\
\text { letter (for the king) from the } \\
\text { garrison commander Khay }\end{array}$ \\
\hline (ts, 'going up') & Egypt & $\begin{array}{l}\text { Syria-Palestine } \\
\text { (Kharu) }\end{array}$ & $\begin{array}{l}\text { Delivery of letters to (1) the } \\
\text { garrison commander Pena- } \\
\text { mun, and } \\
\text { (2) the steward 'of this town' } \\
\text { Ramessenakhte }\end{array}$ \\
\hline (ii, 'returning') & Syria-Palestine & Egypt & $\begin{array}{l}\text { Delivery of letters to (1) the } \\
\text { garrison commander } \\
\text { Preemheb, and } \\
\text { (2) the deputy Preemheb }\end{array}$ \\
\hline $\begin{array}{l}\text { I Shomu } 25 \\
\text { (ts, 'going up') }\end{array}$ & Egypt & Syria-Palestine & Not stated \\
\hline
\end{tabular}

Fig. 12: An overview of the movement of travellers recorded in a daybook from a border official during the reign of Merenptah (P.BM EA 10246 = P.Anastasi III, C.1210 BCE) over a period of ten days. The Egyptian terms for the different places mentioned are given in brackets; for a discussion of the geography see Morris 2005, 480-489. The site where the journal was originally written cannot be identified with certainty but it may well have been kept in the fortress-town of Tjaru (Tell el-Hebua I) itself, despite the reservations of Morris (p. 480), and such complexes could be denoted by both 'town' (dmit) and 'fortress' ( $h t m)$ in Egyptian. On this interpretation the htm in the entry for day 17 and the dmit in the entry for day 22 would refer to, respectively, the fortress and town at Tjaru.

The focus is, as with the Semna Dispatches, on registering the movement of people, and the fact that many of the entries deal with messengers carrying letters is due to the high frequency of that type of traffic. ${ }^{184}$ The material form and language of the letters is not known, but at least some may have been clay tablets with

184 It is not a 'postal register' as posited by Smithers 1939, 103. 
cuneiform inscriptions-in Akkadian, the 'lingua franca' of the time-such as the letter to the 'Chief of Tyre', rather than papyrus letters written in Egyptian. For the slightly earlier comparative material from the state archive of diplomatic correspondence from Amarna, see below (3.6).

\subsection{Archives relating to shipping, taxation and trade}

The complex infrastructure of the Egyptian state and its various departments is rarely visible in the papyrus record, and we do not have a full archive from any single government department-nor of any government official-dealing with key areas of activity for a national bureaucracy like state organisation or taxation. There are individual documents that would presumably have formed part of such archives, but they are from secondary archaeological contexts. In this section I outline some of the most important groups of documents, but the list is not exhaustive and is simply meant to give an impression of the types of documents that would have been produced for, and stored in, archives relating to state departments dealing with infrastructure and resource management.

A papyrus produced by the administration of the royal shipyard at This from the early $12^{\text {th }}$ Dynasty (c.1920 BCE), known as Papyrus Reisner II, was found deposited in a tomb at Naga ed-Deir along with three other administrative papyri (see Fig. 1 above). ${ }^{185}$ The roll itself is almost $1.7 \mathrm{~m}$ long and with the Middle Kingdom full-format height of $c .33 \mathrm{~cm}$, and contains entries relating to the management of the institution, with considerable diversity in terms of types of entries:

Section A: account of deliveries of copper tools and leather (five columns).

Section B: account of deliveries of equipment for boats, including oars. Copy of a message to the shipyard about sending personnel and a boat to Thebes after a refit. Deliveries of copper tools and wood (continuation of Section A).

Section C: a table with a name-list of shipyard personnel that is concerned with types of copper tools that were to be sent southwards for re-casting. The names are

185 Published by Simpson 1963, 1965, 1969, 1986. The dates in the material as a whole relate to a period of nine or ten years (regnal years 16 to 25 of an unnamed king of the early $12^{\text {th }}$ Dynasty, either Amenemhat I or Senwosret I), but the specific shipyard account covers three years and five months. Despite the fact that the reading of several of the dates is problematic it seems clear that not all entries follow each other chronologically as one would expect (the table in Section C, for example, contains the latest date in the entire document despite its physical location in the middle of the roll): Simpson 1965, 16-17. 
grouped according to geographical locations, probably indicating where the operation was to take place. ${ }^{186}$

Section D: a letter to the stewards of the palace from the vizier, with orders to provide some wooden implements and crewmen, to be sent by boat. The letter was delivered by a messenger called Intef from the boat Saagerteb. Copied in vertical columns (probably mimicking the layout of the original letter), under a horizontally written date line.

Section E: another letter to the stewards from the vizier, dated to a day later than the previous letter (and delivered by different messengers arriving by the same boat), with orders to supply grain, bread, and perhaps a serving girl to the capital. Copied in vertical columns under a horizontally written date line, as above.

Section F: account of deliveries of copper tools to the shipyard.

Section G: another letter to the stewards from the vizier. The message is in two parts, one dealing with some previous complaint about the recruitment of workers for the shipyard, the other dealing with the provisioning of wood for some work on boats in connection with a festival. Copied in vertical columns under a horizontally written date line, like the other letters, but this one was explicitly labelled a 'copy'.

Section H: an unfinished name-list, followed by an account of copper tools handed over to a coppersmith.

(Section I is a blank area, perhaps originally meant for the name-list of Section $\mathrm{H}$ above.)

Section J: an account of deliveries of copper tools to the shipyard from various locations.

Section K: a summary account covering five pages, unfortunately with many of the column headings missing. The account covers a period of nine months, with one day per line and monthly tallies, and appears to list labour resources (in man-days) relating to the shipyard. At the end there are calculations of bread and beer based on the labour listed in the main body of the account.

Section L: an account of copper tools.

Section M: a similar account of copper tools.

Fragments: various accounts of grain, mats, timber, leather and pottery vessels.

\section{The three other rolls found with the shipyard account were:}

(1) Papyrus Reisner I: an accounting roll relating to the administration of manpower in connection with one or more building projects (including a temple), with tables detailing both man-days and attendance. Most entries are divided up into groups of workmen under a supervisor, and these groups are sometimes linked in the headings to certain localities. The work includes moving rubble, stone and sand, and the making of bricks in relation to different elements of the temple, the installation of architectural elements like doorways, but also other parts of the building operations like the delivery of wood and plant fibre. ${ }^{187}$ There are numerous checkmarks, showing that it is a working document.

186 Simpson 1965, 31.

187 Simpson 1963, 52-63. 
(2) Papyrus Reisner III: a roll with an account of manpower, occasionally listed by institution, with summaries for each individual month as well as longer periods of time, and occasional notes on mustering and the absence of workers. The headings, where preserved, do not explain what type of work the personnel is involved in, but as the second half of the roll deals with construction work on various parts of a temple (including work with bricks, stone and wood, the transport of straw, etc.), perhaps the entire roll relates to building works. Some numbers are struck out in red, again indicating a working document, and there are calculation aids in the form of multiplication tables inserted in the tables (both for the number eight, which is frequently used as a multiplier, and both written upside-down in relation to the rest of the text). There are several mistakes in various sums, so that 'a meticulous accounting is severely compromised by [the] errors'; ${ }^{188}$ this is worth bearing in mind when modelling the potential use of the documents in antiquity. ${ }^{189}$

(3) Papyrus Reisner IV: a roll relating to the administration of manpower, with workers organised in crews under various officials; the lack of preserved headings means that the project(s) that they worked on cannot be identified. This roll was a palimpsest papyrus that had originally been used in an earlier period for various accounts relating to the delivery and distribution of textiles.

One of the most prominent administrators in the papyri is Sefkhy son of Intef, and it has been suggested that he was the copyist responsible for most of the accounts, and that the coffin on which they were found belonged to him. ${ }^{190}$ The fact that the shipyard accounting roll was found in a private tomb along with three other papyri dealing with other institutions and projects raises questions about the nature of archival practices at the shipyard, and about the demarcation of private versus institutional ownership of administrative documents. In particular, the lack of a thematic cohesion among papyrus rolls that were demonstrably found together suggest that the common denominator is the scribe responsible for the documents, who like any administrator would have had a wide range of responsibilities and would have been associated with many different institutions over the course of his career. The documents show evidence of being working accounts with calculations including numbers that were crossed out, as well as a number of marginal notes related to their use. ${ }^{191}$

A somewhat later document from the $18^{\text {th }}$ Dynasty sheds some light on another shipyard at a location called Perunefer, perhaps near Memphis. The papyrus was written in the reign of Thutmose III and is a half-format roll of about $3 \mathrm{~m}$ in length. ${ }^{192}$ The text deals with the building of, and repair work on, a number of

188 Simpson 1969, 18, 26.

189 On the (in)accuracies in later New Kingdom documents, see Janssen 2005.

190 Simpson 1980, 728.

191 Helck 1974, 61-62.

192 P.BM EA 10056; Glanville 1931, 1933; for the date see also Pasquali 2007. 
ships in the Egyptian navy, including the royal barge. The document is chronological in nature, with entries for each day: the typical format consists of a dateline, followed by information on the type and amount of wood and timber issued from a place or institution, under whose authority the transaction occurred, and to whom the material was delivered. The destination of the materials is normally noted as being a captain in charge of re-fitting his ship, simply the name of the ship in question, or, in some cases, the name of the shipwright in charge of the project. The concern is, again, that of tracking the movement of goods.

The roll is inscribed on both sides, but how it has been used is not entirely clear. The text on the front, distributed over eighteen columns, contains dates that cover only five days in a single month, in other words it records quite a lot of activity for each day. The text on the back, in contrast, covers a much longer period (roughly four months) in a total of twelve columns, with a similar level of detail as the entries on the front. However, there are three major gaps in the entries: one gap of 72 days between the last entry on the front to the first on the back (which could in part be explained by the missing beginning and end of the papyrus), and two gaps of 45 and 47 days between some of the dates on the back. Unless the entire shipyard was inactive for these periods, which is unlikely, then the document would appear to be an incomplete record for the period it covers, and would, implicitly, be an attempt to summarise information from daily or monthly accounts that have not survived. Further, this papyrus represents only one type of record-the issue of materials-but in view of the range of documents preserved in other institutional archives there would presumably have been many others. A shipyard, which is focused on production through manual labour, might also have wished to keep track of work and levels of production, for example. A later literary text contains a passage where an individual with the same title as the shipwrights in the dockyard account ('craftsman') is involved in a conflict over work quotas-he has effectively tried to present the work done the day before as current work. ${ }^{193}$ Presumably the administration of the Perunefer dockyard was also concerned with keeping track of work done beyond simply recording what materials were used.

Two papyri in St. Petersburg have frequently been thought to have been found with the dockyard papyrus described above (nos 1116A and B). These two rolls were perhaps originally a single administrative roll, cut in two in order to receive the two literary texts now written on the back, ${ }^{194}$ but in terms of contents they are rather different from the dockyard account. The first (1116A) has a set of

193 Caminos 1954, 384.

194 Helck 1961-1969, 424-437; Griffith 1931, 108; cf. Gardiner 1914, $20-21$. 
accounts, arranged chronologically with date-lines in red ink as in other daybooks, that primarily deal with the weekly issuing of grain to a number of storehouses (one line mentions 60 of them) that supply the royal administration with bread and beer. In addition to regular deliveries there are a number of instances where the purpose of the grain is explained in more detail: this includes (1) additional resources issued for visits by the king and the royal children; (2) provisions for offerings of food and beer for various festivals-amongst others a temple of Seth at Perunefer, and one of a royal statue in a private chapel, as well as a king who reigned some four or five generations previously; (3) daily and monthly rations for certain personnel; and (4) beer and grain for visiting messengers, some from foreign lands. There are also mentions of providing fodder for cattle in several instances, and here, notably, deliveries are made on a monthly rather than weekly basis. The amounts are added up in a running account which occasionally notes the 'excess' both in relation to offerings and storehouse delivery, and the amounts circulated are considerable: one total speaks of over 8,000 sacks of grain (1 sack = 76 litres), with emmer generally accounting for 2-4 times as much-by volume-as barley.

The institutional context of the document seems to be that of a state department: the two most prominent departments in the account are the 'household of the overseer of the treasury' and the 'household of the Adoratrice' (i.e. the Queen). The connection to the dockyard account is thus not obvious, beyond the fact that both relate to state departments, and that the site Perunefer is mentioned in both, if only tangentially in the present document.

The second papyrus (1116B) would appear to have more in common with the dockyard account in that it deals mainly with the issue of wood-most frequently ebony, but also other exotic commodities like ivory and feathers-to carpenters, sculptors, and even some Syrians (with Egyptian names) 'working in the household of his majesty' for different purposes. Arranged chronologically with dated entries like a daybook, the document also includes a letter copied into one of the daily entries, after a list of wood issued, where some scribes write to 'the scribe of the treasury in the royal palace, Hututu' about ebony required for the decoration of a room (lintels, doorposts, columns, and other architectural elements). A link with the dockyard of Perunefer has been suggested based on the mention of ebony and ivory issued for work on the royal barge in one of the entries (lines 5659), but looking at the document as a whole it seems to belong to a palace storehouse for exotic materials that supplied craftsmen working for the king, rather than a dockyard: there is only one entry dealing with a ship, and the work seems to be exclusively decorative unlike the structural work at the dockyard. 
This is not to say that the three papyri were not found together-if anything the Reisner papyri would provide a good parallel for a similar range of texts deposited as a single group-but strictly speaking only one of them relates to the operation of the dockyard itself. What survives of the archive of that institution is then, again, reduced to a single roll of papyrus whose existence is a result of it being removed from this primary context and deposited in a tomb in antiquity.

The logistical challenges of shipping, especially in the case of large transportation vessels, also gave rise to detailed record-keeping. The earliest examples seem to be a pair of ship logs in Brooklyn, perhaps from the reign of Seti I (c.1290 BCE). Like other documents of this genre they have the form of a list of dates, under which is listed each harbour visited by the ship, and the transactions that took place there. On one side of the largest roll the ancient scribe noted deliveries of goods due to the institution (perhaps a temple) it represented-textiles, silver and honey-and the names and identities of the people delivering, most of which were women. On the other side of the roll the scribe recorded transactions, in the same locations and on the same dates as on the front of the roll, involving other and less valuable commodities, including consumables like grapes, vegetables and bread. The criteria for the division of entries on the front and the back seem to relate to the nature of the transactions with the high-value ones being linked to temple dues and the others to the upkeep of the crew and boat as it sailed on the Nile. A separate account was kept of outstanding amounts of honey and textiles from the previous year, implying that there would have been an annual quota of work involved, and that information about previous deliveries would have been accessible to the scribes drawing up the accounts for the present year, perhaps having been retrieved from the institutional archive before departure.

A slightly later ship log, this one in Leiden and dated to year 52 of Ramesses II, represents a rare case of a literary manuscript-with a hymn to the god Amunhaving been reused for an administrative text. ${ }^{195}$ The papyrus in question is a largeformat roll $(89 \times 38 \mathrm{~cm})$, and was bought by the Leiden Museum of Antiquities in 1828 along with a number of other papyri, some of which may have originally been found together. ${ }^{196}$ In addition to the ship log, this group would appear to consist of:

(1) A group of nine letters written by officials in the capital Piramesse and dispatched to recipients at Memphis. ${ }^{197}$ The impetus for the communication seems to be an official letter about tracking down some personnel (no. 368) in relation to the estate of the prince and High Priest of Ptah, Khaemwaset, whereas the other eight

195 P.Leiden I 350 verso; Janssen 1961, 2-52.

196 Enmarch 2005, 2-5.

197 Janssen 1960; Wente 1990, 31-34. 
messages are essentially social in nature. The most obvious explanation is that the occasion of sending a business letter prompted a group of individuals to write between one and three letters each to other recipients, to be sent as a group to the same location: of the latter, five were found still sealed (by the writer) and with an address written on the outside.

(2) Two short papyri of administrative character, one with a list of stolen property (no. 352), the other a journal recording the distribution or delivery of various commodities to or by individuals (no. 351). ${ }^{198}$

A second group of papyri in Leiden that arrived from the same sale could originally also have been found with the administrative material: this is a group of literary manuscripts with a wisdom poem (Ipuwer, with a hymn to Amun on the back), some model letters, and no less than five magico-medical rolls. ${ }^{199}$ If all of the above papyri do stem from a single original find-and this can be no more than a hypothesis-then this assemblage is perhaps also best explained, in view of their state of preservation, as a group of papyri deposited in the tomb of one of the scribes responsible for the documents, perhaps in the necropolis of Memphis.

The Leiden ship log belonged to a ship of the High Priest of Ptah at Memphis, more specifically the well-known Khaemwaset, son of Ramesses II, and contains the records of a journey over some nine days as it sailed in the area around the capital Piramesse and Heliopolis. Arranged chronologically, the entries generally start with a date-line and a note giving the location of the ship ('Year 52, month 2 of Peret, day 6: In Piramesse'), followed by information on the issuing of consumables to the crew, the receipt of deliveries from various individuals, and other events. A notable feature of the latter is the semi-regular departure of a messenger carrying a letter, sent to the High Priest at Memphis, every two or three days, presumably with updates on the mission of the ship. Although the text provides a good example of a type of working document that may have been ubiquitous on board grain barges and trading vessels, details on archival practices in the text itself are few.

Another similar papyrus in Turin contains the log of a ship under the authority of the High Priest of Amun-Re, this one too sailing in Lower Egypt, in the area around Memphis, and covers a period of about sixteen days. ${ }^{200}$ The format is the same as that of other ship logs, with the exception that the scribe has added, after the regular dating formula, a note of how long it has been since the ship left Thebes in the south (about two months earlier). In addition to information on the move-

198 Černý 1937; the latter is unpublished but cf. Hagen forthcoming.

199 Enmarch 2005, 5.

200 P.Turin 2008+2016; Janssen 1961, 53-95. 
ments of the ship, the log was used for keeping accounts relating to various transactions of commodities and the occasional extraordinary issue of grain for officials departing on specific missions. There are preliminary accounts inserted between the regular columns, and several of the main accounts have headings preserved: one on the back reads 'List of the freight which is in the boat of the High Priest of Amun Ramessesnakhte, under the authority of', followed by the names and titles of three officials (a scribe of the treasury, a regular scribe, and a guard), and then a list of various goods in three columns. The headings suggest that one of the most important types of transactions was the exchange of textiles belonging to the High Priest and presumably originally brought from Thebes, for consumables like sesame oil, grain and vegetables. The impression is that of a ship bringing capital in the form of storable products from the temple and exchanging this for consumables which are then returned to the temple-one passage even notes textiles having been left behind, presumably against future deliveries. From an archival perspective it seems reasonable to infer that, for example, the latter information from the ship log would have been stored by the temple in some form, perhaps in a 'clean' summary account based on the working document represented by the Turin log.

The date of the Turin ship log, as far as can be established, falls in the reign of Ramesses VIII and mentions the highest administrative official of the temple of Amun at the time, the High Steward Ramessesnakhte, by name. ${ }^{201}$ Coincidentally, this individual also seems to be mentioned in another papyrus relating to a fleet of ships which records the journey of 21 grain barges from the great temple of AmunRe at Thebes. ${ }^{202}$ The full-format roll $(c .250 \times 42 \mathrm{~cm})$ seems to have been found at Assiut, probably in a tomb, and it was divided in two by the modern looters before it was sold on. ${ }^{203}$ The front of the roll has accounts of grain collected, listed by ship and location, with a short note about the institution and the individual responsible. It ends with a summary account for all the grain collected by the different ships, but listed by the institutions supplying the grain, apparently listed in order of foundation. The overlaps in locations between the separate ship accounts suggest that this side of the papyrus is a compilation or 'clean' copy, not a working document filled out sequentially during the journey. The back of the papyrus, on the other hand, appears to have been used slightly differently, and at least in part as a notepad: a similar grain collection account to those on the front, but dealing with much smaller quantities; an account of textiles brought from seven different villages; a working account of grain delivery, organised first by ship and then as a summary

201 Janssen 1961, 55-56.

202 P.Baldwin + Amiens; Janssen 2004.

203 On this practice see Hagen and Ryholt 2016, 131, n. 348. 
account by institution; a separate calculation of the rations of the same ships; a record of grain inspected at various locations (granary, magazine, storerooms, roof of the temple, etc.) within a single settlement. The range of topics is broader, the types of accounts more diverse, and although some of the texts on the back may in turn have been copied from other draft accounts it conforms to the common practice of using the reverse side of 'clean-copy' documents for less tightly structured texts. ${ }^{204}$

Although the two documents may be roughly contemporary and relate to the same institution, the Turin log certainly did not belong to one of the 21 ships in the grain fleet of the temple whose activities are detailed in the grain account of P.Baldwin + Amiens. However, they clearly represent the different types of accounts that might be produced during such missions: an overall account of the grain collected by the expedition as a whole, or a detailed log-book for an individual ship where the daily business of that particular ship was recorded.

Finally, a recently discovered ship log written by the famous scribe Djehutymose, one of the best-known scribes from the community of the royal tomb builders at Thebes, was presented by Robert Demarée at a conference in Liège in October 2014. This appears similar in format to the other examples, but seems to have been kept by Djehutymes himself, perhaps among his other letters and business papers (3.8).

The detailed log-books described above are generally short on contextualising detail, and we know little about where they would have been kept or deposited, or to what extent they would have been consulted after the ships returned home. It seems reasonable to assume that in the case of ships representing institutions like temples or palaces there would have been a need to keep track of the collection of grain as rent or taxes from individuals, in addition to the many transactions of other commodities outlined in the papyri, but how or in what form they were archived in the respective institutions, and what processes of checking and accounting might take place at that stage, remains largely unknowable. ${ }^{205}$

Part of the taxation process involved the surveying of (inundated) land to establish tax liability, a task inextricably linked to land ownership and land use, and this part of the state administration would have relied in part on the production and storage of documents recording agricultural data. Some of these documents survive, but again there is no single archive that would allow for an in-depth analysis of the archival process. An indication of what has been lost is the fragment of a

204 Janssen 2004, 69.

205 Janssen 1961, 4-5. 
daybook belonging to a team of field surveyors, from the late Middle Kingdom, consisting of two scribes and a messenger, as well as two assistants who did the physical surveying of fields with a rope (Fig. 13). ${ }^{206}$ The fragmentary part of the journal that survives deals not with the actual surveying, however, but with the recording of their findings in registers and accounts back in the office of the 'department of fields' in the presence of their superior, the 'royal sealbearer and overseer of fields of the northern district'; in practice the archiving process resulting from their fieldwork.

What such registers might look like is most clearly seen in the later document known as Papyrus Wilbour, a large roll $(1030 \times 42 \mathrm{~cm})$ that surveys some 2,800 fields in a stretch of land in Middle Egypt, together with their holders and cultivators, noting the institutions they owe tax to. ${ }^{207}$ The calculations of tax follow standard rates based on the size of the plots, and although not all aspects are fully understood, it seems that the document was the result of a survey, and that it would have functioned as the basis for the actual collection and transport of the tax: the very same activities documented in the papyrus discussed above (P.Baldwin + Amiens) for the grain fleet of Karnak temple. Fragments of similar documents exist, both relating to surveying and the actual collection of tax, albeit less well preserved. ${ }^{208}$

Such documents would have been used and updated as the need arose, and would presumably have been kept accessible in an institutional archive for future consultation, either for further revenue assessment or to settle disputes about liability. That is not to say that we are looking at a vast and all-encompassing bureaucratic system capable of surveying and assessing all land-holdings in Egypt in a systematic manner, but neither are there grounds for doubting that the few fragmentary texts we have are representative of the general approach of temple and state departments in their work to assess and collect revenue on their lands. ${ }^{209}$ The taxation of grain production necessitated a considerable administrative apparatus with correspondingly extensive archival holdings, but none of these archives have survived.

206 Smither 1941.

207 Katary 1989; Gardiner 1941-1952.

208 Convenient overview by Katary 1989, 169-224; cf. Haring 1997, 283-345; Gardiner 1941.

209 Haring 2005; 2010, 229-231. 


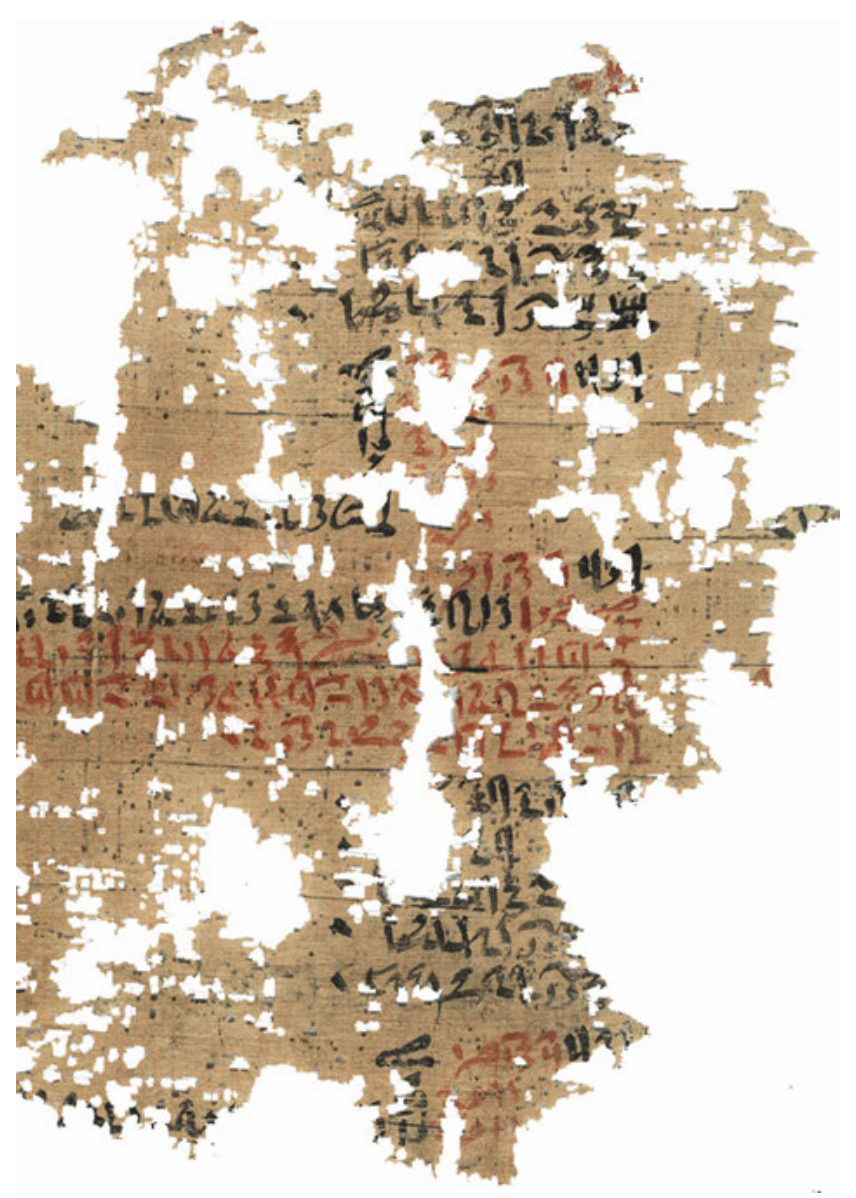

Fig. 13: A page from the journal of a team of field surveyors working to assess taxable land, from the late Middle Kingdom (P.Harageh $3=$ UC 32775). The entry in red ink in the middle explains how the team was in the office of a royal official to 'register' their tax assessments based on their fieldwork, presumably to be stored in the archive belonging to the 'Office of Land of the Northern District' mentioned in the heading. Courtesy of the Petrie Museum of Egyptian Archaeology, London.

The management of other types of resources by temples and state departments, either by trade or by the collecting of goods due, would also have involved an extensive use of administrative documents, but here the surviving record is even more patchy, and it reveals relatively little of the archival process as opposed to the accounting procedures. One example of this is a well-preserved papyrus from the royal granary under Thutmose III which has two sets of accounts (for grain 
and date deliveries) that were copied for two separate groups of workers by two different scribes from the same institution. ${ }^{210}$ It was initially suggested that the papyrus was a copy of an original account, ${ }^{211}$ but a more detailed analysis argued that it represents a working document, drawn up as and when the transactions took place. ${ }^{212}$ This conclusion was partly based on infrared photography which revealed that the scribes had jotted down preliminary calculations in the margins during the process of putting together the account as it survives today. ${ }^{213}$ Whatever stage of the accounting procedure the papyrus represents-and it is clearly a compilation of information that has been and/or is processed-it remains unclear if it should be seen as a fair copy destined for the archives of the royal granary, and if so, where it might have been stored or how (or if) it might have been retrieved from the hundreds or thousands of identical-looking rolls in the same archive.

Another example which deals with other types of commodities that are being collected as taxes is a papyrus in the British Museum from the Ramesside Period which has a 'list of objects brought by the Chief Taxing-Master' from six temples in Upper Egypt, including gold, copper, textiles, fruits, millstones, cattle, and bread. ${ }^{214}$ Despite its obvious historical interest the document does not shed much light on archives and their functions beyond illustrating another activity that was recorded in writing in great detail. The hieratic hand is exceptionally clear and deliberate for an administrative papyrus, and one can only assume that it was drawn up on the basis of various preliminary accounts, but where it might have been kept, or whether it was envisaged that it would have been consulted after archiving, cannot be established. Further examples could be adduced, but the paucity of recorded archaeological contexts, the probable secondary contexts of most well-preserved documents even when known, as well as the acute lack of substantial and coherent groups of documents relating to these spheres of activity, means that they would not necessarily add much to our understanding of Egyptian archives.

210 P.Louvre E. 3226; Megally 1971.

211 Helck 1961-1969, 774-775.

212 Megally 1977a, 57, 68-69; 1977b, 22.

213 Megally 1977a, 156, 193-194; 1977b, 49-50.

214 P.BM EA 10401; Janssen 1991. 


\subsection{A state diplomatic archive: the Amarna tablets (c.1300- 1400 BCE)}

Arguably the most famous example of an archive from ancient Egypt is the state archive of diplomatic correspondence between King Akhenaten and various powerful rulers in the Levant that was found at the site of Tell el-Amarna in the late nineteenth century. ${ }^{215}$ Since its discovery it has been extensively discussed and so it is treated only briefly here: the reader is referred to the literature cited for more details.

Although a large proportion of the material was found through illicit looting, subsequent archaeological excavation established where the archive had been found: a set of mudbrick buildings labelled 'The Office of Pharaoh's Correspondence' in Egyptian. ${ }^{216}$ This was an administrative structure where just under 400 cuneiform tablets, written in the 'lingua franca' of the Ancient Near East, Akkadian, had been stored. Whether this was in boxes, on shelves, or a combination of the two, is not entirely clear due to the looting of the area, and the precise methods employed in the processing and cataloguing of the correspondence (chronologically, by sender?) are not now recoverable. ${ }^{217} \mathrm{~A}$ small number of the cuneiform tablets received processing notes in black ink, in the Egyptian hieratic script, on arrival, noting the date of reception and in some cases the location of the king, as well as the names of the messengers who brought the message, or simply a single hieratic sign reading 'copied' ${ }^{218}$ Such annotations do not represent a standardised archival practice: rather, they are the exception and were only used in situations where it was important to preserve this information, in practice perhaps restricted to occasions when the king was absent from the capital.

Despite the lack of detailed information about the storage of the archive, its location (Fig. 14) does reveal something about the environment in which it was compiled and kept. The building in which it was housed was part of an administrative quarter in the central city that also included a 'House of Life', an institution closely linked to the transmission of religious texts and knowledge. The administrative quarter was effectively boxed in by various monumental buildings: the King's House and the Main Palace to the West, the great Aten temple to the North, the small Aten temple to the South, and to the East a set of buildings that may have housed military personnel, including chariots.

215 The standard reference work on this material, with translation of, and commentary on, the entire corpus, is now Rainey 2015, and cf. the widely available English translations by Moran 1992. There is also an Italian translation by Liverani 1998-1999.

216 Pendlebury 1951, I, 114-115; II, plates XIX-XX, LXXXIII no. v.

217 Abrahami and Coulon 2008, 1-26, Mynářová 2007, 33-39; 2014, 15-19; 2015, 38-39.

218 Hagen 2011; forthcoming. 


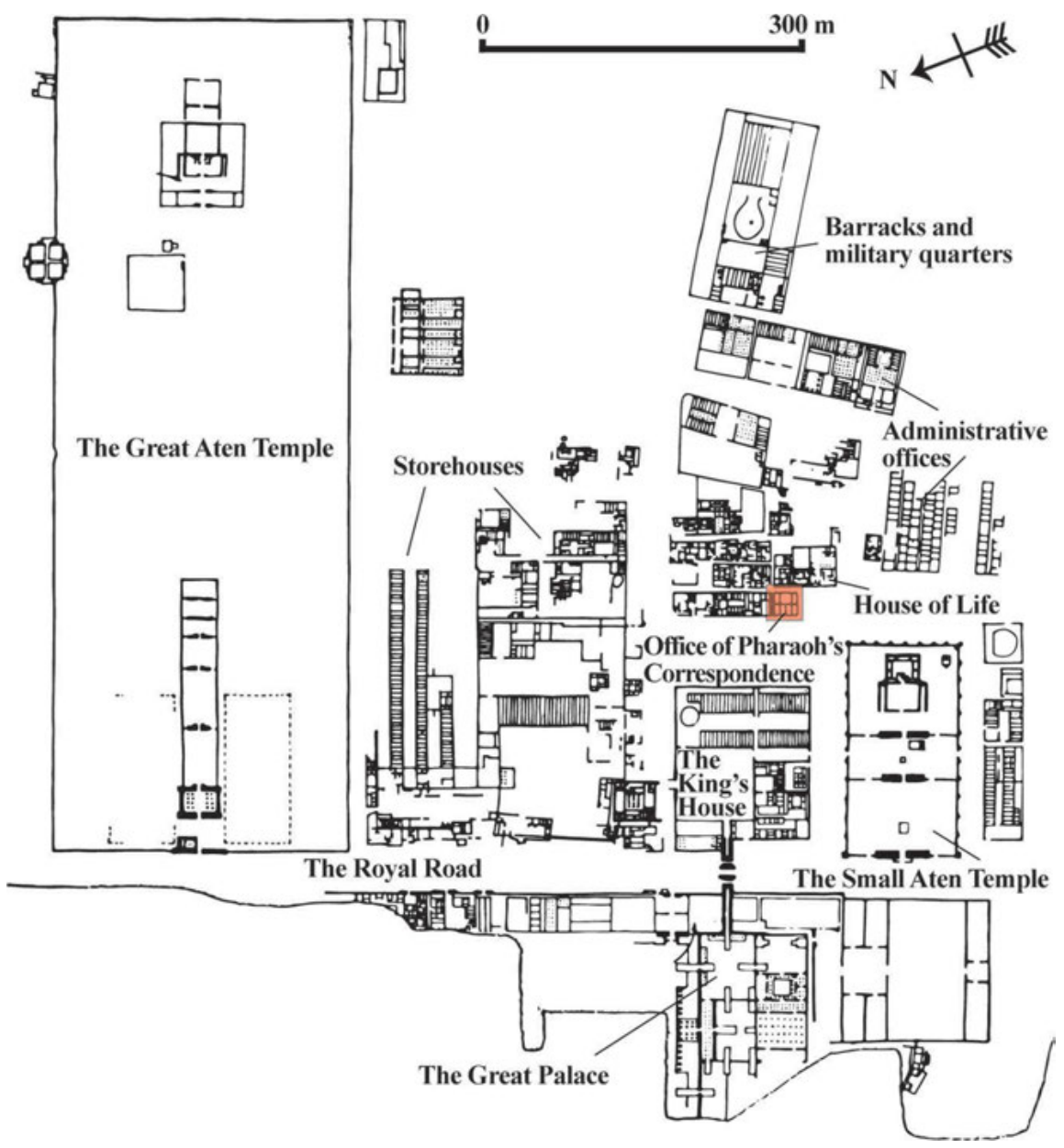

Fig. 14: A map showing the location of 'The Office of Pharaoh's Correspondence' (red square) at the heart of the administrative district of the capital city of Amarna, where an archive with state correspondence between Egypt and various rulers in the Levant was found. Based on a drawing by H. W. Fairman, published by W. Stevenson Smith (1958), The Art and Architecture of Ancient Egypt, Harmondsworth: Penguin Books, p. 195 fig. 65.

As such the archive was stored at the heart of the capital city, near to the premises where the king and the court conducted state business: the King's House in particular has been thought to be the administrative palace of Akhenaten, ${ }^{219}$ and may

219 Kemp 2012, 125-135. 
have been the venue where he received the messengers delivering the cuneiform tablets.

The correspondence appears to date to a period of about twenty years, mainly during the reign of Akhenaten. However, parts of the archive had been moved to the new capital at Amarna when this was established in the reign of King Akhenaten, perhaps from Malqata near Thebes, as shown by some letters dated to the reign of his father, Amenhotep III, who was not alive when the new city was founded. How much was moved is impossible to say because although only a few tablets are demonstrably from the earlier reign, some may also have been brought away again when the city was abandoned. In any case it demonstrates mediumterm storage of state correspondence across different reigns of kings, and similar archives presumably existed for much of the New Kingdom, even if they rarely survive. Stray finds of fragments of clay tablets from the capitals of both earlier and later periods (at Tell el-Daba and Piramesse, respectively) prove that the Amarna archive was not unique, and that comparable archives would have been kept from around 1550 BCE until at least 1150 BCE. ${ }^{220}$

The Amarna archive has been important not just for our understanding of the political landscape of the Ancient Near East, but also for mapping the transfer of linguistic knowledge, and the communication networks that existed at the time: analysis of the physical properties of the clay tablets, for example, have enabled scholars to identify those which were produced locally (with two types of clay, one for low status texts and one for official state correspondence) and those which had been sent from outside Egypt. ${ }^{221}$

\subsection{Conscription and census documents}

One of the key areas of institutional organisation, from the perspective of large-scale infrastructure, was the management of people. This management often manifested itself in the written record, and name-lists and other documents relating to the recruitment and assignment of people are numerous in corpora of administrative material. ${ }^{222}$ However, there is a danger in over-stating the importance of this sector-a sensitive area where the personal political views of scholars sometimes shine through-and I should state that I am not advocating a model of Egyptian society where the state effectively (or efficiently) controlled the population at large. There

220 Pusch/Jacob 2003, Breyer 2011; Bietak/Forstner-Müller 2009, Bietak 2011.

221 Mynářová 2014, 26; Goren, Finkelstein/Na’aman 2004.

222 Eyre 2013, 208-212. 
is no evidence for nationwide census operations in the period under discussion, only local and relatively small-scale management of specific groups of people, but even in this context the role played by written documents and archival holdings was significant. ${ }^{223}$ It seems clear that in both Lahun and at Deir el-Medina the state kept records of inhabitants by household, and in the latter village in particular there was clearly an archive of such documents that were updated as circumstances demanded: the surviving fragments come from five or six documents produced over a period of 30-40 years. ${ }^{224}$ These two settlements are unusual, however, in that they were founded by the state, and cannot be interpreted as representative of state control over the population as a whole.

Individual institutions like temples, as well as officials operating on royal authority, recruited labourers for both regular and ad hoc work, and it is symptomatic that the control and management of people is a prominent concern in several of the documents and archives already discussed (e.g. at Lahun, 3.2.2). As with so many government departments we do not have an archive of the 'office for assigning people', for example, although again individual documents that may have formed part of such archives survive. One late Middle Kingdom papyrus, originally used to keep track of individuals who had run away from forced labour service, relates to an institution known as the 'Great Enclosure' (perhaps a work-camp rather than a prison), and preserves some 80 entries with detailed information on the people who had run away. ${ }^{225}$ A selection of some typical entries can be seen in Fig. 15 below.

Interpretation of the Brooklyn work-camp register is not straightforward, and although it provides one example of how the challenge of keeping track of personnel was met by the Egyptian bureaucracy, it does not suggest that Middle Kingdom Egypt was a 'police state', as has been argued. ${ }^{226}$ The document was presumably originally archived by the institution to which the original table of fugitives pertains, but it had a relatively long period of use. Some 65 years after the last entries of the table were composed it was re-used, first to copy a letter and two royal decrees addressed to the vizier, and then finally for another set of accounts on the back relating to the personnel of a private estate of a high-ranking woman. In other words, here too is a document extracted from its original archival context and reused for a private purpose.

223 Overview by Kraus 2004; see also Demarée/Valbelle 2011, 85-103, and the review of the latter by Hagen 2016b.

224 Demarée/Valbelle 2011, 78.

225 Hayes 1955; Quirke 1990, 127-154; Menu 2010, 177-181.

226 Assmann 2002, 139. 


\begin{tabular}{|c|c|c|c|c|c|c|}
\hline Status & Name & $\begin{array}{l}\text { Title / } \\
\text { origin }\end{array}$ & Gender & Legal order & Location & Statement \\
\hline $\begin{array}{l}\text { Case } \\
\text { closed }\end{array}$ & $\begin{array}{l}\text { Sobekhotep, } \\
\text { son of Senib }\end{array}$ & Cultivator & Male & $\begin{array}{l}\text { Issued to the Great Enclo- } \\
\text { sure... [in order to activate } \\
\text { against him the law of those } \\
\text { who run away from the Great } \\
\text { Enclosure] }\end{array}$ & Here & $\begin{array}{l}\text { Statement by } \\
\text { the scribe of } \\
\text { the vizier Ded- } \\
\text { amun: } \\
\text { 'It is closed' }\end{array}$ \\
\hline $\begin{array}{l}\text { Case } \\
\text { closed }\end{array}$ & $\begin{array}{l}\text { Nakhti, son } \\
\text { of Inher }\end{array}$ & of This & Male & $\begin{array}{l}\text { [Issued to the Great Enclo- } \\
\text { sure... in order to activate } \\
\text { against him the law of those } \\
\text { who run away from the Great } \\
\text { Enclosure] }\end{array}$ & Here & $\begin{array}{l}\text { Statement by } \\
\text { the scribe of } \\
\text { the vizier, } \\
\text { Nakht: } \\
\text { 'It is closed' }\end{array}$ \\
\hline $\begin{array}{l}\text { Case } \\
\text { closed }\end{array}$ & $\begin{array}{l}\text { Minhotep, } \\
\text { son of Mer- } \\
\text { min }\end{array}$ & $\begin{array}{l}\text { Man of } \\
{[\ldots]}\end{array}$ & Male & $\begin{array}{l}\text { Issued to the Great Enclo- } \\
\text { sure... (an order) to release his } \\
\text { people in the law-court, in or- } \\
\text { der to activate against him the } \\
\text { law of one who is absent for } \\
\text { six months. }\end{array}$ & Here & $\begin{array}{l}\text { Statement by } \\
\text { the scribe of } \\
\text { the vizier Ded- } \\
\text { amun: } \\
\text { 'It is closed' }\end{array}$ \\
\hline $\begin{array}{l}\text { Case } \\
\text { closed }\end{array}$ & $\begin{array}{l}\text { Mentuhotep, } \\
\text { son of Sabes }\end{array}$ & $\begin{array}{l}\text { of the } \\
\text { Wab- } \\
\text { khet[...] }\end{array}$ & Male & $\begin{array}{l}\text { Issued to the Great Enclo- } \\
\text { sure... (an order to) assign } \\
\text { (him) to the ploughlands to- } \\
\text { gether with his people forever, } \\
\text { [according] to the court's or- } \\
\text { der. }\end{array}$ & Here & $\begin{array}{l}\text { Statement by } \\
\text { the scribe of } \\
\text { the vizier De- } \\
\text { damun: } \\
\text { 'It is closed' }\end{array}$ \\
\hline $\begin{array}{l}\text { Case } \\
\text { closed }\end{array}$ & $\begin{array}{l}\text { Teti, daugh- } \\
\text { ter of Sain- } \\
\text { her }\end{array}$ & $\begin{array}{l}\text { of the } \\
\text { scribe of } \\
\text { fields of } \\
\text { This }\end{array}$ & Female & $\begin{array}{l}\text { Issued to the Great Enclo- } \\
\text { sure... (an order) to release } \\
\text { (her people) in the law-court, } \\
\text { in order to execute against her } \\
\text { the law pertaining to one who } \\
\text { runs away without performing } \\
\text { his service. }\end{array}$ & Here & $\begin{array}{l}\text { Statement by } \\
\text { the scribe of } \\
\text { the vizier De- } \\
\text { damun: } \\
\text { 'It is closed' }\end{array}$ \\
\hline
\end{tabular}

Fig. 15: A selection of entries (lines 6, 32, 55, 57, and 63) from a register of fugitives (P.Brooklyn 35.1446) that once belonged to the 'Great Enclosure', a work-camp at Thebes in the late Middle Kingdom. Each line of the document contains the name and filiation of the fugitive, his or her title and/or place of origin, and a determinative showing whether it was a man or a woman. It goes on to mention the order from the court relating to their case, followed by a checkmark or note on the present whereabouts of the individual. In front of each line is a single sign showing the status of the case, which in almost all examples is 'case closed'.

The most obvious common denominator of the entries is the fact that all cases relate to either not turning up for labour duty or running away from it, ${ }^{227}$ but it seems unlikely that the document preserves the complete records of such cases over the 21 years that the table covers. Instead it probably contains a review of specific cases, although the criteria for inclusion are not obvious beyond the fact

227 Quirke 1990, 130-135. 
that all preserved entries are said to be 'closed' cases. In any case the notations of the final columns of each entry demonstrate (by way of the variety of hands), that different scribes were responsible for the final updating as cases were processed and closed, so that we have here another working document and not a 'fair copy' that was simply drawn up and then left in the archives. ${ }^{228}$ This process implies access to and use of archival material beyond the initial drawing-up of the table, even if the precise dates for the later updating of the document cannot be known.

\subsection{The archives of the tomb-builders of Deir el-Medina (by Daniel Soliman)}

The work on the tombs in the Valley of the Kings and the Valley of the Queens, and the lives of the necropolis workmen who constructed them, are particularly well documented thanks to the many texts that were written on papyri and ostraca in this area and in the village of Deir el-Medina. This settlement was founded behind the hill of Qurnet Murai in the early $18^{\text {th }}$ Dynasty, presumably during the reign of Thutmose I (c.1504-1492 BCE), to house the crew of royal necropolis workmen and their families. At Deir el-Medina, the workmen's living quarters, cult chapels, and tombs have been preserved relatively well, and the community provides a unique insight into various aspects of life in New Kingdom Egypt. Although much of the archaeological material from Deir el-Medina was discovered through excavations, texts from the site have also been found during uncontrolled or illicit digs. Via the antiquities trade, such finds made their way to modern collections around the world, obscuring some of our understanding of their original context.

Scholars have studied the texts from Deir el-Medina for over a century, but the majority of the documentary texts from the village still remain unpublished. Research has focused mostly on the socio-historical aspects of the texts, and besides a few studies, the materiality of the documents has not been examined in great detail. ${ }^{229}$ Complete ostraca, written on ceramic shards or flakes of limestone, vary in size from not more than a few square centimetres to exceptionally large pieces with a height of over $40 \mathrm{~cm}$. The papyri from Deir el-Medina are mostly

228 Hayes 1955, 43-44, 63, 66.

229 The recent contribution by Pelegrin/Andreu-Lanoë/Pariselle 2016 is a notable exception which stresses the material process of production of limestone ostraca. 
incompletely preserved, and are reconstructed from several fragments. They generally had an original height of around 20 or $40 \mathrm{~cm}$. The practice of reusing ostraca and papyri to add a different inscription, sometimes of a completely different genre, was common, and several of the documentary texts are palimpsests.

Most of the evidence for the administration of the tomb builders stems from the Ramesside Period (c.1295-1069 BCE) ${ }^{230}$ In contrast, very little is known about the organisation and administration of work on the royal tombs during the $18^{\text {th }}$ Dynasty (c.1550-1069 BCE), but it is generally assumed that these matters were rather different from Ramesside times. It has been suggested that the work on the royal tombs was entirely reorganised during the reign of Horemheb. From the reign of this king onwards we possess increasingly more documentary texts from Deir el-Medina. Hieratic records that may be related to work on $18^{\text {th }}$ Dynasty royal tombs, on the other hand, are very rare. ${ }^{231}$ It seems unlikely that the $18^{\text {th }}$ Dynasty texts have not survived at the Theban necropolis, because we do find non-textual ostraca of an administrative nature from that period. These ostraca are composed with identity marks, and their exact meaning is very difficult to grasp. ${ }^{232}$ Still, it is reasonable to assume that, during the $18^{\text {th }}$ Dynasty, scribes attached to the crew of workmen occasionally documented the construction process, because scribal titles are attested on objects from Deir el-Medina dating to the $18^{\text {th }}$ Dynasty. Apparently, their documents, or copies of those documents, were not kept at Deir elMedina, as opposed to the Ramesside records.

The published documentary texts from Ramesside times, all written in hieratic script, are unevenly spread throughout the period. From the reign of Seti I onwards, an increase in the amount of written administrative documents can be detected, leading to a peak under the reign of Ramesses III, and Ramesses IV (c.1153-1147 BCE). We possess fewer documents from the subsequent period, but towards the end of the $20^{\text {th }}$ Dynasty the amount of documentary texts, particularly those written on papyrus, grows again. At the end of the $20^{\text {th }}$ Dynasty, a number, if not all, of the necropolis workmen moved to the temple of Medinet Habu, and during the $21^{\text {st }}$ Dynasty (c.1069-945 BCE) the Theban necropolis was abandoned as a royal necropolis. ${ }^{233}$

The Ramesside documentation informs us of the structure of the organisation of the crew of necropolis workmen. In these records, the crew is often called the 'Gang of the Tomb'. The workforce was divided into two halves, referred to as the

230 Lesko 1994.

231 Haring 2006, 107-108; Koenig 1988, 122-123, 128-129.

232 Soliman 2013.

233 Haring 2006, 111-112. 
right 'side' and the left 'side'. Each 'side' was led by a foreman and his deputy, and the collective administration of the work was the responsibility of a single senior scribe, referred to as the 'Scribe of the Tomb'. This senior scribe was assisted by several other workmen who doubled as scribes, some of whom appear to have been tasked with specific administrative duties. For example, each 'side' of the crew had a scribe who monitored and recorded the daily deliveries of commodities to the crew. ${ }^{234}$

The administrative documents drawn up by the Ramesside necropolis scribes are relatively varied, and it is difficult to classify the texts. The scribes themselves employed a limited number of denominatives to differentiate between texts. Some terms, such as 'writing' $\left(r^{-}{ }^{-}-s{ }^{-}\right)$, are very general, while the word 'copy' (mi.t.y) refers to the function of the text. Other denominatives were used for very specific types of texts, and include 'memorandum' (sh3.w), 'name-list' (im.y-rn=f), 'property-deed' (im.y.t-pr), and 'dated record'/ 'dated document' (hry.t). To the same category belong 'account' ( $h s b)$ and 'list' / 'account' (snn), and, although the words have similar meanings, the latter seems to refer exclusively to records from the collective necropolis administration. ${ }^{235}$

Most of the document types can be recognised in the administration, and as opposed to the texts in most other pharaonic archives, denominatives of document types are occasionally preserved at the head of Deir el-Medina records. An example is found on the reverse of a papyrus that was inscribed at the beginning of the reign of Ramesses X (c.1108-1099 BCE). After the name and titles of the king we read:

[...] name-list of the people of the great and noble Tomb of millions of years of Pharaoh (may he live, prosper, and be healthy) on the West of Thebes, <who are with $>$ the High Priest of Amun-Re, king of the gods, [...] the Overseer of the Royal Treasury, the Royal Butler, and (the foreman) Amenhotep [... $]^{236}$

Based on their content, the documentary texts from the Ramesside necropolis fall into three general categories: collective necropolis administration, private administration and letters, and judicial documents. ${ }^{237}$ The records of the collective administration include lists of workmen who were absent or present at the worksite. Less frequent are progress reports that document how far the workmen had advanced in the tomb under construction. Beside work related records, there

234 Davies 1999, 90-91; 101; 123-142.

235 Donker van Heel/Haring 2003, 85-123.

236 P.Turin Cat. 1932 + P.Turin Cat. 1939, verso, 2-3; Kitchen 1975-89, VI, 686.2-5.

237 Donker van Heel/Haring 2003, 124-188. 
are numerous accounts that deal with deficits, delivery, division, and distribution of rations and supplies. Private accounts document personal transactions, and the payments and outstanding debts involved. There are also records of the division of personal property. One particular type of text records necropolis workmen hiring out a donkey in their possession, to a member of the external service personnel that was responsible for the delivery of commodities to the village. Judicial documents record events that took place in the local court, such as depositions and the taking of oaths, but there also are brief texts with questions that were submitted to an oracle deity.

Particularly in the domain of the collective tomb administration we find evidence for systematic production of records, and quite possibly of purposeful storage of such texts. This is well illustrated by a specific type of account, which was kept during the first half of the $20^{\text {th }}$ Dynasty (c.1186-1143 BCE). These texts are journal notes written on ostraca, which are primarily concerned with listing workmen who had the daily task of receiving deliveries of various commodities to the village, the specifics of these deliveries, and occasionally the deficits of commodities. Such details were usually noted down very summarily, but the scribe sometimes supplemented the day entries with notes of events he believed to be important. I say 'the scribe', because the subject matter and the layout of the texts, and the palaeographic peculiarities of the handwriting, indicate that it was indeed a single scribe who created these journal notes. The fact that almost all of the ostraca were discovered together at a dumpsite just south of the living quarters of Deir el-Medina, is a strong indication that the records were kept together before they were collectively discarded. ${ }^{238}$ It is unclear where the scribe originally kept these journal notes, but evidently he was regularly occupied with this administration.

This follows from the great amount of journal notes that have been discovered. The scribe of the accounts made a point of composing his documents in such a way that all 30 days of one month fitted on a single ostracon. A great number of such monthly reports date to the last years of the reign of Ramesses III and the first two years of the reign of Ramesses IV, and we can follow the scribe's notes throughout the years. An instructive example is a document which records the first month of Shomu in the first year of the reign of Ramesses IV. The text first lists the entries for days 1 through 27 , and then continues with the final three days of the month:

238 Donker van Heel/Haring 2003, 72-76. 


\section{$[\ldots]$}

(Month 1 of Shomu,) day 28: (on duty:) Anuynakht; (delivered) by (the woodcutter) Ptahmose: 300 units of wood; (delivered) by Usimarenakht for the deficit of 130: 153 units of wood; $2 d s$ jars of beer; 1 unit of dates for the left side (of the crew); 8 units of vegetables. On this day: the officials came to hand over the silver of the crew to them at the Enclosure (htm).

Month 1 of Shomu, day 29: (on duty:) Neferher; (delivered:) 24 units of $p s n$ bread; 8 units of bi.t cake; (delivered) by the woodcutter Ptahmose: 300 units of wood.

Month 1 of Shomu, last day of the month: (on duty:) Amenemone; (delivered) by (the woodcutter) Ptahmose: 150 units of wood; (delivered) by the woodcutter Amenhotep: 150 units of wood; the deficit: 350; deficit of the plaster: [... $]^{239}$

The text ends with the last day of the month. The records for the subsequent month were recorded by the same scribe on a different ostracon, the first three entries of which read as follows:

\footnotetext{
Year 1, month 2 of Shomu, day 1: (on duty:) Nesamun; (delivered:) 1 unit of dates for the left side (of the crew); (delivered) by (the woodcutter) Amenhotep: 150 units of wood; they were of the last day of month 1 of Shomu, to complete the 300 units; the deficit: 200 units.

Month 2 of Shomu, day 2: (on duty:) Khaemnun.

Month 2 of Shomu, day 3: (on duty:) Hori; he was in the stead of Khaemnun; (delivered:) 7 $d s$ jars of beer for the right side (of the crew); 3 units of dates for the left side of the crew; 8 units of vegetables... ${ }^{240}$
}

Essentially, the record of month 2 takes off at the point where the record of month 1 ends. What is more, the first day entry of month 2 refers to a deficit of wood, noted for the last day of the previous month. It has previously been suggested that this detail shows that Deir el-Medina scribes consulted older texts when they were working on the text at hand, ${ }^{241}$ and, by extension, that there existed an archive where these texts were stored and could be accessed.

The situation may in fact be more complicated, because there is another group of ostraca that record the same deliveries as noted in the monthly journal notes, but are composed with identity marks rather than in hieratic script. These non-textual documents have been deciphered, and, like the contemporaneous hieratic journal notes, they seem to have been created by a single individual. His inexperienced handwriting, his disorganised layout, and his spelling mistakes made in the few hieratic sign groups he used in combination with the marks, indicate that he was not a trained scribe. In a few instances, the documents created with marks display

239 O.DeM 40 + O.Strasbourg H. 42, reverse 1-10; Kitchen 1975-89, VI, 107.4-10.

240 O.DeM 41 + O.Berlin 12626, obverse 1-6; Kitchen 1975-89, VI, 107.12-15.

241 Donker van Heel/Haring 2003, 76. 
additions in a different, very neat handwriting, seemingly made by a professional scribe. It is assumed that these additions were made by the scribe of the hieratic journal notes, who checked the marks ostraca, subsequently copied them into hieratic, and amplified the hieratic records by adding notes on important events. It therefore seems more likely that the hieratic scribe consulted the marks ostracon of month 2, rather than the hieratic document of month 1, to write his own record of month 2. ${ }^{242}$ Some support for this reconstruction is found in the fact that the hieratic records for month 1 and month 2 were written on two pottery shards that belong to the same vessel, ${ }^{243}$ and are thus likely to have been written on the same day.

Despite the abundance of documentary texts from the Theban royal necropolis, many questions about administrative practices at this location remain unanswered. To begin, the purpose of the records is not fully understood. Černý assumed that the scribes first wrote down notes on ostraca of limestone chips or ceramic shards, which they then copied onto a neat daybook written on papyrus, after which the ostraca were discarded. ${ }^{244}$ A copy of the papyrus document is thought to have been subsequently sent to the office of the vizier. This interpretation of the documents has been criticised, inter alia by Allam, ${ }^{245}$ because there are numerous examples of hieratic ostraca that were not meant to be drafts, but are documents in their own right. Nevertheless, it is fair to assume that at least some of the documentation written by the scribes of Deir el-Medina was intended for the administrators of Thebes. It is evident that, to some extent, these dignitaries monitored the work on the royal tombs, and several Ramesside texts from Deir el-Medina record a visit to the necropolis by officials such as the Royal Butler, the Overseer of Treasury, the High Priest of Amun, and the Vizier. ${ }^{246}$ Officials from Thebes came to the necropolis at crucial moments in the construction process. An ostracon from the reign of Merneptah (c. 1213-1203 BCE) demonstrates that dignitaries were present to supervise the transportation of statues and coffins for the royal burial:

Year 7, month 3 of Shomu, day 23. On this day, the statues (ntr.w) of the King of Upper and Lower Egypt [Baenre-]meryamen (Merneptah) were dragged to their places under the supervision of the governor of the city, vizier Panehsy. [...] Year 7, month 4 of Shomu, day 14. On this day, the (Royal) Butler Ramessesemperre and the scribe Penpaiu came together with the

242 Soliman in press.

243 Černý 1935, 10.

244 Černý 2001, 226-227.

245 Allam 1968.

246 Janssen 1997, 147-173. 
vizier Panehsy to the Field, to let the coffins of Pharaoh (may he live, prosper, and be healthy) descend to their places. ${ }^{247}$

The vizier occasionally came to 'receive the work' (šsp b3k.w), which probably meant that he inspected the advancement of the tomb under construction. The vizier Hori, for example, came to inspect the recently commenced tomb of Merneptah:

Year 1, month 2 of Shomu, day 12. Day of receiving the work by the governor of the city, the vizier Hori. The progression was 13 cubits. What was done in progression in it after the vizier had received the work: [...] cubits. ${ }^{248}$

Additionally, there is circumstantial written evidence of the correspondence between the administrators of the necropolis and Theban dignitaries. According to a letter from the $20^{\text {th }}$ Dynasty, the vizier Neferronpet had received 'memoranda' (sh3.w) from the foreman of the crew, and brought them to the attention of Pharaoh. ${ }^{249}$ Similarly, P.Abbott VI informs us that members of the crew of necropolis workmen travelled to the vizier with their memoranda, and notes on P.Chester Beatty I mention the handing over of a box, perhaps containing administrative accounts, on two separate occasions. ${ }^{250}$ The records of Deir el-Medina also sporadically mention the arrival of letters from the vizier to the necropolis administrators, ${ }^{251}$ and actual (copies of) letters sent to the vizier, ${ }^{252}$ and sent by the vizier have survived as well. ${ }^{253}$

Similar to the debatable purposes of the necropolis administration, the storage of the documentation remains a problematic topic. This is partly due to the fact that the archaeological context of many documents, and of the papyri in particular, was never accurately recorded. Generally speaking, there is a clear difference between the documents from the work sites near the royal tombs in the Theban valleys, and the documents from the village and its vicinity. Unsurprisingly, the former relate mostly to the on-going work on the tombs, while the latter deal

247 O.Cairo CG 25504, obverse 6; 9-10; Kitchen 1975-89, IV, 155.13-15; 156.4-6.

248 O.Cairo CG 25536, obverse 1-3; Kitchen 1975-89, IV, 402.11-14.

249 P.DeM 28; Eyre 1987, 18.

250 Donker van Heel/Haring 2003, 9-10.

251 E.g. O.Cairo CG 25308, obverse 4; Kitchen 1975-89, VII, 313.14-15; and O.Cairo CG 25515, reverse IV.4; Kitchen 1975-89, IV, 382.9-10.

252 E.g. P.BM EA 10683 verso IV and V; Kitchen 1975-89, IV, 85-88.

253 E.g. P.Louvre N 3169; Kitchen 1975-89, VI, 523. 
primarily with private matters and the delivery and distribution of commodities. ${ }^{254} \mathrm{An}$ approximate provenance is often known for the ostraca that were discovered at the village of Deir el-Medina, but unfortunately it is usually not very telling, because the find spots tend to be dump sites on the outskirts of the living quarters. These ostraca were discarded at an undefined point in time, and therefore they are hardly informative of usage and storage of administrative documents. Still, there is evidence that related ostraca were thrown away as a group, as has already been noted for the journal notes recording the deliveries that took place during a single month. Similar groups of ostraca demonstrate that the case of the delivery accounts is not exceptional. One group of documents dealing with the distribution of grain rations, from the first half of the $20^{\text {th }}$ Dynasty, was found together in a large dump site called the Great Pit. ${ }^{255}$ Likewise, a group of accounts from the reign of Seti I (c.1294-1279 BCE), which record the delivery of pottery, firewood and dung, can be attributed to a single scribe. The provenance of most of the ostraca in this group is known, and these were all found in or near the village dump site called Kom 2.256 Finds outside of the village too demonstrate that assemblages of administrative ostraca covering an extended period of time were written and kept by individual scribes. Between the tomb of Ramesses II and Ramesses V/VI in the Valley of the Kings, a group of administrative texts attributable to the scribe Qenhirkhopshef were found, some of which record the amounts of lamps used during work on the royal tomb. ${ }^{257}$ Likewise, various accounts of work, and of the delivery and distribution of goods from years 22-26 of Ramesses III, all argued to have been composed by the scribe Wennefer, were found in the Valley of the Queens. ${ }^{258} \mathrm{~A}$ final group of ostraca may in fact have been found in their original context. The ostraca in question are six journal notes recording labour activities and the absence of workmen during years 3 and 4 of the reign of Amenmesse (c.1203-1200 BCE), all written by a single scribe. It can be surmised from the brief notes of the excavator of these ostraca that the documents were wrapped in a mat placed on a shelf that was cut in the rock near the tomb of Siptah. Against the rock face, a number of workmen's huts were built. Apart from the ostraca, two limestone 'desks' were found in the vicinity of the hut, so the spot may have been an abandoned office of a scribe. ${ }^{259}$

254 Eyre 2013, 235.

255 Donker van Heel/Haring 2003, 23-25.

256 Donker van Heel/Haring 2003, 13-14.

257 Donker van Heel/Haring 2003, 41-44.

258 Van den Berg/Donker van Heel 2000.

259 Donker van Heel/Haring 2003, 49-51. 


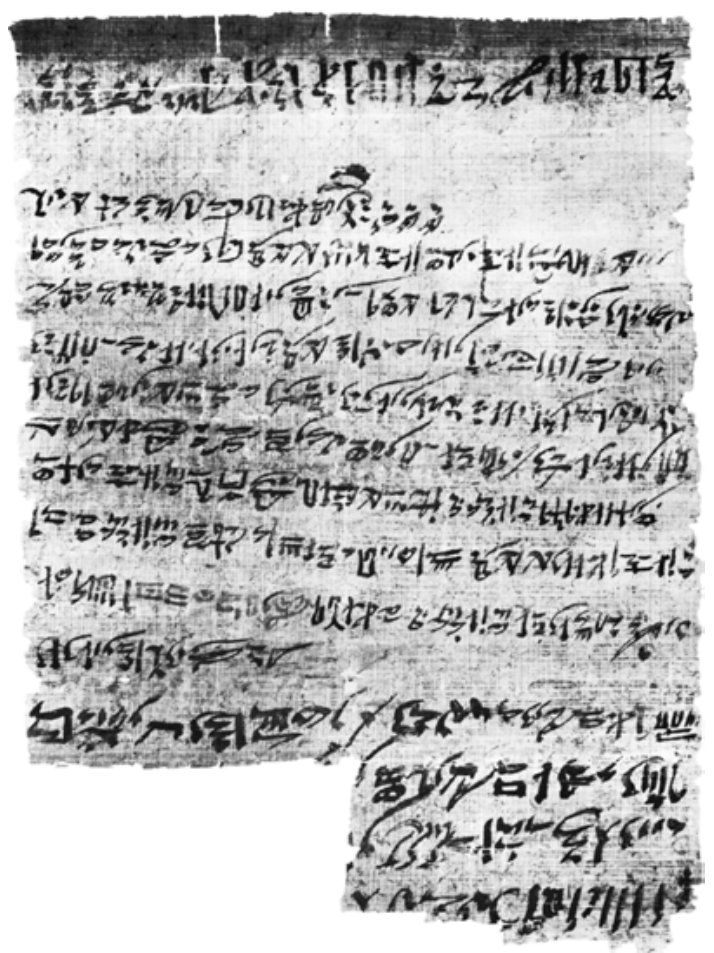

Fig. 16: Papyrus Berlin P.10496 (reproduced from Allam 1973, plate 82). The text describes two different disputes that concern the tomb of the necropolis workman Amenemope, dated three years apart. A docket is written in large handwriting along the lower edge of the verso of the papyrus. The docket is written at 180 degrees in respect to the main text, and would have been visible when the papyrus was rolled up. It reads: 'The dated record of the tomb about which the guardian Penmennefer made a statement'. A handful of similar dockets are known from the papyri from Deir el-Medina, and they have been interpreted as evidence for the storage and the need for retrieval of documents in an archive.

These small groups of ostraca were probably kept by the scribes who wrote them, but it is unclear how the many other administrative ostraca and papyri from Deir elMedina were kept. The corpus is oftentimes referred to as a singular 'archive', but there is no consensus about its existence or its nature. The debate revolves around 
the interpretation of the data, and scholars have taken a minimalist ${ }^{260}$ or a maximalist $^{261}$ stance on the matter. Those in favour of the latter approach argue that the sheer amount of records at the royal necropolis confirms the existence of a central archive, and they have found supporting data for it in various ways. It has been pointed out that there are yearly accounts and administrative documents with entries that were written at different points in time, both of which could have only been composed using earlier documentation, corroborating their view that records were kept to be accessible at a later stage in the administration process. Further evidence was found in a small number of Deir el-Medina documents that make mention of older records kept somewhere at the site, as well as of boxes in which papyri were stored. Additionally, they interpreted the handful of recorded instances of dockets on documents as proof that the records were stored to be consulted at a later moment (Fig. 16).

There certainly is evidence of the duplication of information in the necropolis administration. ${ }^{262}$ The yearly accounts brought forward by Koenraad Donker van Heel are indeed an indication that scribes compiled overviews that must have been based on previously recorded data. This is exemplified by an account that was probably written in year 30 of the reign of Ramesses III. ${ }^{263}$ The text lists the rations that were brought to the crew through year 28 (month 4 of Shomu - month 4 of Peret), year 29, and the first three months of year 30 . The reason for this summation clearly was to calculate the outstanding deficits in the supplies, and it may be presumed that the six known ostraca recording occasions on which rations were delivered in year 29, were consulted by the scribe of this account.

In addition, there are several examples of scribes who copied data from an earlier document onto a new record. The documents in question never date far apart in time, and the overlap between two documents typically is a few days, or a single month. To the latter group belong weekly or monthly reports of a specific subject matter, which were copied into more detailed monthly reports. As mentioned above, administrative documents created with identity marks sometimes played a role in the transmission of administrative details as well. There is one remarkable case from the very end of the reign of Ramesses III, which demonstrates that a monthly duty and delivery record composed with identity marks was copied onto a hieratic ostracon by a professional scribe, augmenting the text with notes of particular events. The hieratic ostracon, in turn, was most likely

260 Eyre 2013, 238-239, 242.

261 Allam 2009; Donker van Heel/Haring 2003.

262 Most of the evidence has been compiled by Donker van Heel/Haring 2003.

263 O.Turin 57072; Kitchen 1975-89, V, 535-536. 
consulted to compose parts of a large daybook written on papyrus (Fig. 17) ${ }^{264}$ As revealing as such instances of duplication might be, the documents contain several discrepancies in the recorded amounts, which remain difficult to explain. The differences may be the result of additional deliveries that were made between two stages in the copying process. On the other hand, they may be copying mistakes, illustrating Eyre's interpretation of the Deir el-Medina documentation as limited in its functionality. ${ }^{265}$
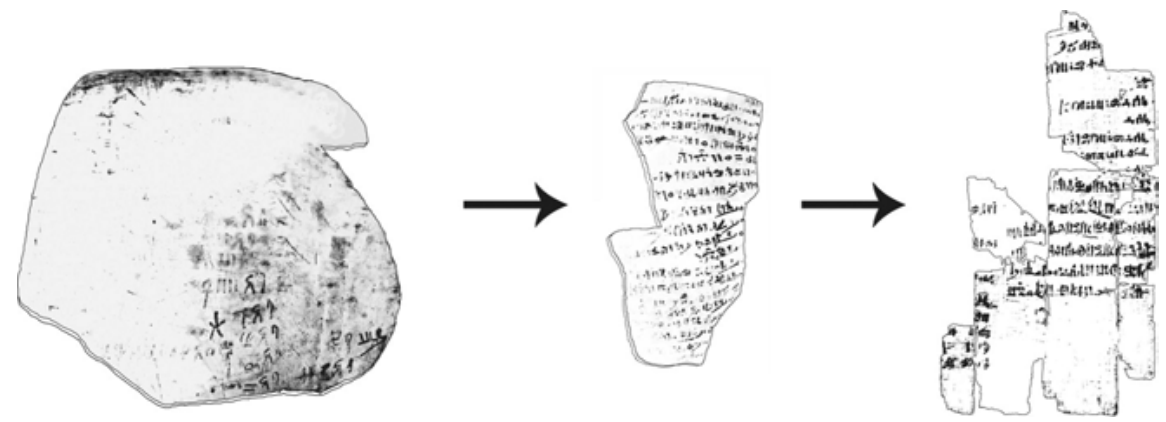

Fig. 17: The deliveries brought to the village of Deir el-Medina in month 3 of Shomu of year 30 in the reign of Ramesses III were recorded with non-textual workmen's marks on ostracon IFAO ONL $318+325$ (left). The record was copied into hieratic on ostracon DeM $39+174$ (centre) by a fully literate scribe, who inserted additional information in the text. The hieratic ostracon was subsequently used to compose the hieratic daybook written on papyrus Turin Cat. $1946+1949$ (right).

With these instances of duplication in mind, advocates of a central archive in the community of necropolis workmen presuppose that there once stood a building in which the archive was housed, while arguing against the storage of administrative documents in private houses, where they would not have been accessible at all times for consultation. ${ }^{266}$ Such a building is often thought to have been the structure that is referred to in the documentation of Deir el-Medina as the "Enclosure' ( $\mathrm{htm}$ ). Although this building has not been securely identified in the archaeological record, it undoubtedly existed somewhere in the vicinity of the village of Deir el-Medina, most probably to the east of Deir el-Medina's temple site. Textual sources relate that the 'Enclosure' was used for sessions of the local judicial court,

264 Donker van Heel/Haring 2003, 35-37; Soliman in press.

265 Eyre 2009.

266 Allam 2009, 66. 
and to receive visiting officials. On a daily basis, the 'Enclosure' was the place where a workman stood guard to collect the deliveries of commodities and tools, transferred to the community by members of an external service personnel. All such events were recorded with some regularity in the administration of the necropolis, and therefore it has been suggested that these texts themselves were both composed and stored at the 'Enclosure'.

In opposition to this, Eyre has rightly remarked that the Deir el-Medina documentation never mentions the storage of any records at the 'Enclosure', nor are there any references to an 'office' $\left(h{ }^{3}\right)$ at this location. ${ }^{267}$ Eyre also contested the view that the necropolis records were created in order to be accessible for reviewing or auditing. He stressed the impracticality of retrieving data from ostraca and papyri heaped up at a single location. Instead, he interpreted the texts as the output of administrative processes, maintaining that the motivation for the creation of documents was much more the assertion of the authority of the scribes, than the functionality of the bureaucratic process. Therefore, the documents could well have been kept in the possession of the scribe who wrote them. ${ }^{268}$

This brings us to the private library of the family members of a necropolis scribe called Qenhirkhopshef. The precise provenance of a large portion of this group of papyri is known, as it was found during controlled excavations. The other papyri were stolen from the site of Deir el-Medina, but must have belonged to the same find. The group was discovered in 1928 in a tomb chapel in the middle of the Western Cemetery, and contains a variety of genres that include a dream book, literary texts, hymns, medical texts, letters, records of depositions made in court, and private accounts. ${ }^{269}$ The content of the documents indicates that the oldest documents belonged to the scribe Qenhirkhopshef himself, who had passed on his library to family members of his, who in turn added texts to the archive. The recovered corpus of papyri had been in use for over a century. Qenhirkhopshef's family library does not contain any texts that deal with the collective administration of the necropolis and it is therefore not an archive, but still something can be said in favour of Eyre's suggestion that this group of texts is exemplary of the way the Deir el-Medina scribes kept their documents: in their own possession, with the possibility to pass them on to family members. ${ }^{270}$

In support of that theory is the interpretation of another, much larger group of papyri. The majority of these papyri are now in the Egyptian Museum of Turin,

267 Eyre 2009, 18.

268 Eyre 2013, 234-235.

269 Convenient overview by Hagen forthcoming; cf. Pestman 1982.

270 Eyre 2009, 21. 
brought there in 1823 as part of the first batch of antiquities offered to the museum by the diplomat and antiquities collector Bernardino Drovetti. Unfortunately there is no record of where exactly Drovetti's agents discovered the papyri, but they appear to have been found together. Further papyri from Deir el-Medina in other collections, such as those in the Bibliothèque nationale de France in Paris or those in the British Museum in London, were acquired around the same time as the Turin papyri, and could have been part of the same Drovetti collection. ${ }^{271}$ Like the Qenhirkhopshef library, the Deir el-Medina papyri that reached Europe around 1823 contain court proceedings, private accounts, so-called love songs, hymns and ritual texts, and several letters. Most of the texts, however, concern the collective tomb administration, which are almost exclusively datable between the reign of Ramesses III and the beginning of the $21^{\text {st }}$ Dynasty.

As it happens, this period coincides with a local dynasty of Scribes of the Tomb, which originates with Amennakht, son of Ipuy, who was appointed by the vizier Ta in the reign of Ramesses III. After his death, the office of senior scribe was passed on from father to son, and his descendants would hold the position until the beginning of the $21^{\text {st }}$ Dynasty. It is therefore theoretically possible that the aforementioned corpus of papyri was entirely written by members of the family of Amennakht, who passed on the archive through the generations, as the descendants of Qenhirkhopshef and his wife had done. Indeed, several papyri have been ascribed to the hand of one of the members of Amennakht's family. He himself has been proposed as the author of famous texts such as the Strike Papyrus, the Mining Papyrus, and perhaps the papyrus with the tomb plan of Ramesses IV. At least two papyrus documents have been attributed to the scribe Djehutymose, a descendant of Amennakht. Additionally, there is a dossier of about 60 letters commonly known as the Late Ramesside Letters. These papyri, written by and to the aforementioned Djehutymose, and his son, the scribe Butehamun, provide a unique insight in historical events of the end of the $20^{\text {th }}$ Dynasty and the beginning of the $21^{\text {st }}$ Dynasty. They demonstrate that, as the Theban valleys ceased to be used as a royal necropolis, the scribes were sent beyond the Theban region, to supervise the administration of tax collection and of an expedition in Nubia. ${ }^{272}$

An indication that this body of papyri from Deir el-Medina was indeed kept in the possession of the family of Amennakht is found in one of these letters. The letter is Djehutymose's reply to a letter written by his son Butehamun, in which the former refers to documents, which they end up storing in the tomb of their ancestor, Amennakht, son of Ipuy:

271 Rocatti 1984.

272 Demarée 2008, 51-52. 
Now as for the documents onto which the sky rained in the hut $\left({ }^{c} . t\right)$ of the scribe Harshire, my (grand)father, you brought them out, and we found that (they) had not become erased. I said to you: 'I will unbind them again'. You brought/will bring them down below, and we deposited/will deposit (them) in the tomb of Amennakht, my (great-grand)father. ${ }^{273}$

We learn from this communication that the documents had previously been stored in a structure referred to as an '. $t$ (hut). Demaree has pointed out that such as place does not designate a house, but rather a workplace or an office. ${ }^{274}$ It can, however, be argued that at the time the letter was written, Djehutymose and his son had already moved to the temple of Medinet Habu, possibly together with other necropolis workmen. ${ }^{275}$ The old house of Harshire, son of Amennakht and grandfather of Djehutymose, could thus have been abandoned quite a while ago, and was therefore used as a storage room. The fact that Butehamun had to rescue the documents from the ${ }^{c} . t$ fits this reconstruction of events. Since the old house was no longer in use, Djehutymose may have chosen to describe it as an '.t. At any rate, the documents of which Djehutymose speaks, eventually seem to have been deposited in the tomb of Amennakht. This way of storing a family archive is not only similar to what happened to Qenhirkhopshef's library, but there are also reasons to take Djehutymose's statement at face value, and even though the nature of the documents is not specified in Djehutymose's correspondence, they may have been the papyri that were found by the agents of Drovetti.

This is suggested by the find of snippets of papyri in and near Deir el-Medina tomb 1340, which has been attributed to Amennakht son of Ipuy on the basis of vessel fragments inscribed with his name, as well as graffiti left by his descendants. ${ }^{276}$ One of the papyrus fragments reportedly is a part, or a copy, of Amennakht's plan of the tomb of Ramesses IV in Turin, suggesting a connection between the Drovetti papyri and Amennakht's tomb. It could therefore be this very tomb where Drovetti's agents stumbled upon the papyrus archive. Although this cannot be proven, it is clear that his agents had been active near the tomb, because several funerary figures of Amennakht were part of the Drovetti collection. ${ }^{277}$ Additionally, one of the door jambs from the tomb's chapel ended up in the Turin Museum, ${ }^{278}$ and it could well belong to the same collection, since several stelae from the vicinity were found by Drovetti's agents.

273 P.BM EA 10326; cf. Demarée 2006, 62.

274 Demarée 2006, 65-66.

275 Haring 2006, 111-112.

276 Bruyère 1937, 75-82; Černý 2001, 349-350.

277 Černý 2001, 76.

278 Tosi/Roccatti 1972, 192. 
It would thus seem that in the community of Deir el-Medina, the distinction between private administration, collective administration, and judicial administration can only be made on the basis of the content of the accounts themselves. There is no unambiguous evidence that these categories of documents were stored separately from each other. This does not mean that the documentary texts from Deir el-Medina served no meaningful purpose. Some administrative accounts were certainly written to inform Theban authorities about events related to the community of tomb builders and their work, and the scribes of Deir el-Medina were to some extent concerned with duplicating and summarising data in overviews. Still, there are no clear indications that there existed a single archive where the collective administration of the necropolis was stored and could be accessed for revision. On the contrary, there are several series of administrative ostraca, which were systematically written, kept, and finally discarded or abandoned by a single scribe, and even parts of the large group of late $20^{\text {th }}$ Dynasty daybooks may have belonged to the private collection of papyri of the Amennakht family.

\section{Patterns of use}

As the outline of the main groups of archival material above makes clear, very few archives have been found in their original context, so that aspects such as the physical storage of the papyrus rolls, for example, is difficult to reconstruct. ${ }^{279}$ It is similarly difficult to address the use of archives beyond the initial copying and storing of documents, partly because the very act of accessing and retrieving information has left few traces in the archival material itself. This has led to some scholars suggesting that this would in practice have been a rare occurrence, ${ }^{280}$ while others suggest that such consulting would have been a key function of archives. ${ }^{281}$

The evidence, such as it is, comes mainly from legal contexts where archival information is accessed in order to provide evidence in court cases, but such examples are rare and may represent unusual cases. The most famous example, illustrative of the ways in which archives could be consulted, as well as of situations where it might be necessary, is the tomb inscription of Mose, an official

279 Eyre 2013, 298-303; Ryholt forthcoming b.

280 Eyre 2013, passim.

281 Allam 2009. 
under Ramesses II. In the inscriptions on his tomb walls at Saqqara he relates, in a series of episodes, how ownership of some ancestral family land was contested in court on several occasions over the course of almost 300 years. ${ }^{282}$

As part of the legal proceedings in the time of Mose's grandmother, the part of the family that disputed her ownership of the land presented documents from their personal archive that sought to demonstrate their claims, but this was dismissed by the court as being unreliable and potentially biased because it belonged to one of the parties in the case. Mose's grandmother then asked, in the High Court, for the land-register of the state treasury to be brought, as well as that of the granary department (which dealt with taxation) to support her claims. This clearly involved an elaborate process: first a journey to the capital where the archives were held, then a search in both the treasury and the granary office, and finally the retrieval of the relevant papyrus rolls from the right period. The two land-registers were then presented in court, but they are said to have been 'wrong' or 'false' (the Egyptian is ambiguous), and she lost the case. Mose himself later challenged the decision, claiming again that the archival documents cited previously were wrong or false, and suggesting that the dispute be settled by recourse to witnesses from the village where the land was held. The outcome is not recorded but must have been in Mose's favour as he had the texts, including copies of some of the actual legal documents, inscribed in his tomb for posterity.

The case is noteworthy for its implications of procedure. Firstly, it demonstrates that the archives of state departments-in this case no less than two archives covering the same physical plot of land at some distance from the capitalexisted and were accessible for consultation, and that this was in fact done, if only in exceptional cases. It does not follow that such central archives contained records relating to all land in Egypt: the land in Mose's family may have been a royal reward and so could belong to a special category of land. Secondly, it suggests that the oral testimony of witnesses (who could identify who had farmed the land and paid tax on it) weighed more heavily as evidence than a written document that could be wrong or false, and it hints at a basically sceptical attitude towards documents produced by one of the parties in a case-a powerful reminder of the limitations of written evidence in a predominantly oral culture.

Court cases would themselves produce documents which would have been kept-in practice archived-primarily by the litigants themselves, as in the case of Mose, but perhaps also in some cases by the court. A possible example of this is the Turin Indictment Papyrus from the reign of Ramesses V (c. $1145 \mathrm{BCE}$ ) which records a long list of accusations against various individuals associated with the

282 Cf. the recent discussion by Eyre 2013, 155-162, with references. 
temple of Khnum at Elephantine. ${ }^{283}$ One section of the document deals with a certain Khnumnakht, who worked as a ship's captain and transported grain to the temple from properties along the Nile. Khnumnakht had allied himself with temple scribes, inspectors and cultivators in order to embezzle more than 6,000 sacks of grain (almost half a million litres) over a period of ten years, and he and his accomplices simply divided the grain between their families instead of entering it into the temple granaries. Important for the question of the use of archives is that in the charges, the delivery record of Khnumnakht is listed year by year, as if the scribe had access to records of grain deliveries going back through the reigns of two if not three kings. The document may be more than a simple record of historical reality-for one thing some of the figures cited look standardisedbut there seems to be an implicit suggestion that such information could realistically have been retrieved from the temple archives.

Underlying any such use of archives is the practicalities of storage, and the methods of identifying relevant papyrus rolls. The former is rarely recoverable for Egyptian material, and the latter is only exceptionally detectable in the form of labels or dockets that might have allowed for a reasonably efficient retrieval of documents. A notable example of legal documents kept together (at one point in a couple of jars), with a single sheet containing an inventory of the other documents, are the famous tomb robbery papyri, to which Papyrus Ambras may have served as a list of contents. ${ }^{284}$ The latter is a papyrus sheet that contains a statement about the legal documents, largely records of the interrogation of people accused of stealing from the royal tombs, which had somehow been removed from the archival holdings of the temple of Medinet Habu, and which were subsequently bought back by the 'chief taxing master' from 'the people of the land'. The precise circumstances of the original removal of the documents from the archive are not known (who, when or why they were removed), nor are the circumstances of recovery (how they were offered for sale, and by whom) beyond the simple statement that they were 'bought' back, but there was obviously a desire to preserve these archival records as part of the temple holdings. The extraordinary contents-a high-profile criminal investigation of the theft of state property-may account for this interest; in any case the documents in the jars were presumably deposited again in the archive upon their return. Papyrus Ambras contains a list of these legal documents, although it is perhaps better classified as a report on their recovery rather than an inventory per se. ${ }^{285}$ This method of

283 Vittmann 2011.

284 Peet 1930, 177-182.

285 Eyre 2013, 306-307. 
cataloguing is rarely attested, especially for administrative documents, but one might perhaps compare a Ramesside list of some literary rolls that were evidently kept together in a chest. ${ }^{286}$ Despite the evidence for extensive archives in pharaonic Egypt, it is clear that modern scholars' reconstructions of the degree and frequency of use remain to a large extent a matter of conjecture.

\section{Conclusions}

The methodological challenges facing scholars studying Egyptian archives of the Pharaonic period are essentially the same as those studying the archives of the Greek or Roman periods. ${ }^{287}$ The lack of an archaeological context, the problems involved in reconstructing archives rather than dossiers, and the blurred line between private and institutional, make analysis difficult. The problem in distinguishing private from institutional arises primarily because documents relating to institutional administration were sometimes kept by the individual scribes responsible for the paperwork. Apart from the examples of the official Merer (3.1), the scribe Neferhotep (3.3.1), or the anonymous owner of the Reisner papyri (3.5), there are several other private archives from Egypt of a more obvious personal nature, ${ }^{288}$ and other collections that are less easy to classify, ${ }^{289}$ which it has not been possible to discuss here for reasons of space. Of the examples included, a significant proportion consists of individual papyrus rolls that would-or so I assume-originally have been part of an archive but which were, for various reasons, extracted from this primary context in antiquity and then deposited in tombs. ${ }^{290}$ Although such isolated documents are important when attempting to outline the types of archives that may have existed, they are by their nature less useful when analysing archival practice because they cannot be related to the rest of the material with which they would originally have been stored.

286 Fischer-Elfert 2016.

287 Vandorpe 2011; Depauw 2013.

288 See for example the famous Hekanakhte letters and accounts: Allen 2002.

289 The most important being the 'El-Hibeh' archive, see Müller 2009; Lefèvre 2008, and the daybook and letters of a scribe responsible for building a tomb at Saqqara, see Kitchen 1975-89, VII, 263.4-273.7.

290 This assumption about the original social context of administrative rolls found in tombs cannot be proven, and it would be possible to argue that many of them originally belonged in a private context instead (i.e. that we are dealing with papers related to institutional operations but privately held). I think this is a less likely interpretation in view of the archaeological contexts of temple archives in particular, but it remains an assumption on my part. 
The amount of material listed above may seem impressive for such a distant past, but the period dealt with covers more than fifteen hundred years and so the density of evidence is limited. Actual examples of substantial archives are relatively rare in the archaeological record, but they survive across considerable spans of time, and from different locations within Egypt, so that the archival practices of royal memorial temples, for example, can be compared over a period of well over a thousand years. Here, striking similarities in archival procedures are observable, for example relating to the handing over of responsibility from one group of priests to another, when entering or leaving their monthly duty period, or the detailed inventories of temple equipment (and its condition). The redistribution of offerings to temple personnel, and the clear hierarchies implicit in the shares allocated, is evident across time, even if some of the individual titles as well as the organisational structure may differ (e.g. the use of five monthly phyles in the Old Kingdom, as compared to four in the Middle Kingdom). Lists of divine cult statues are also found several hundred years apart, both at Abusir and at Lahun, even if there are minor differences in how they are listed. The daybooks from royal palaces also show similarities over hundreds of years in the way they organise information, and in the management of resources where separate departments are responsible for daily consumables (like bread and beer) and for more exotic or valuable commodities (like eye-paint, precious metals, and textiles).

There are also differences in archival practices, for example in the types of accounts drawn up, and for which commodities, and here the evidence from Deir el-Medina is particularly important because it suggests (3.8) that this may be more due to the personal preferences of individual scribes than to institutional tradition. The temple archive at Lahun includes many letters to and from the temple, which interestingly is not paralleled to the same extent in the Old and New Kingdom examples. Whether this is due to a different practice (less use of written documents for communication), a different archival procedure (letters stored separately, for example), or simply an accident of survival, is not easy to establish. In any case the Lahun letters provide welcome evidence of the use of archives, in particular the preservation, consultation and even circulation of accounts.

The archetypical format of an archival document from ancient Egypt was the daybook, a set of records, organised chronologically, that detailed the activities of any given institution: the arrival of goods and people, the issuing of resources, letters sent out or received, etc. They were used in a wide range of institutions, including royal palaces, military installations, temples, and on ships, but not all 
were all-encompassing and certain daybooks appear to restrict themselves thematically, as with the border journals which are mainly concerned with tracking the movement of people. Alongside daybooks, and sometimes incorporated within them, were accounts: daily, monthly and in rare cases also yearly summaries of income and expenditure, and the discrepancies between them. As a genre of document they make up, along with daybooks and letters, one of the main components of institutional archives, and they are particularly useful for observing the scribe at work. Careful reading of the archival material reveal that some of it-notably monthly and yearly accounts-rely on information already stored, implying access to, and use of, earlier documents with pertinent data. Most archives demonstrate short- to medium-term use, and only rarely anything beyond a couple of years. Periodic clean-ups of material are sometimes observable, as at Balat (3.1), and the archaeological context of at least two major temple archives (3.2.2, 3.2.3), both found in rubbish dumps outside the enclosure wall, also implies a disposal process whereby accumulated material was removed once its reference value diminished. Exceptionally some cases show or at least suggest access to archival records over a longer period of time. A list of fugitives from a work-camp archive (3.7) includes cases spanning 21 years, and a judicial document (4) seems to draw on records of grain delivery to a temple that covers ten years. The life span of any given archive would have been dependent on a number of factors (nature, scope, purpose, storage space, personal preferences of archive personnel, etc.), but it is clear that most archival documents had limited relevance in the long term.

The wider use of archives, as in the Mose case where state archives were consulted in the course of a legal battle, is not often documented, but then this type of activity would not normally have been recorded in a durable form, if at all. There is a real dearth of evidence, but a minimalist-and to my mind plausibleinterpretation would be that this happened relatively rarely in practice. The creation of archives may simply be a predictable consequence of the social process of writing and recording, rather than an expression of a desire to store massive amounts of data for later retrieval as a means in and of itself. On this interpretation the establishment of archives is comparable to the adoption of writing as a symbol of authority and status, where scribal activity can be as much about performance as about practical organisation and resource management. ${ }^{291}$

Egyptian sources do not shed much light on this aspect of archives, but the central role of the notion of archive in terms of Egyptian (elite) cultural identity, for example, can occasionally be seen in literary references. A good example of

291 On this topic see the analysis by Eyre 2013. 
this is a poem from c.2000 BCE, called The Dialogue of Ipuwer and the Lord of All, which contains a description of a world turned upside-down, where the rich have become poor, women cannot conceive, and 'the land is spinning as does a potter's wheel'. ${ }^{292}$ As part of the evocative imagery used in the description, writing in its many forms is thematised, and closely linked to social control: ${ }^{293}$

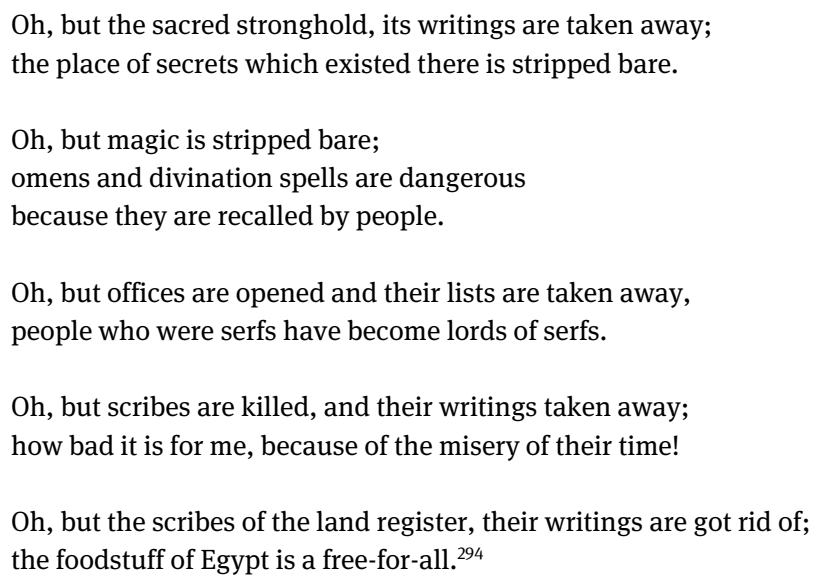

The fate of writing, both in terms of ritual texts and administrative documents (lists of people, land registers), becomes another symptom of this topsy-turvy state of affairs. There is naturally a self-serving dimension to the poem in that the composer and copyists were themselves scribes who may well have felt that social stability and cohesion was in a sense predicated on their own offices, but it is nonetheless a powerful indication of the role that the storage of writing, including in archives, played in the construction of the self-image of Egyptian elite society: a world without archives would be a world without order.

292 Parkinson 1997, 172; Enmarch 2008, 222-223.

293 Eyre 2013, 73.

294 Parkinson 1997, 177. 


\section{References}

Abrahami, Philippe, and Laurent Coulon (2008), 'De l'usage et de l'archivage des tablettes cunéiformes de'Amarna', in Laure Pantalacci (ed.), La lettre d'archive: Communication administrative et personnelle dans l'antiquité proche-orientale et égyptienne (Bibliothèque générale 32), Cairo: Institut français d'archéologie orientale, 1-26.

Allam, Schafik (2009), 'Using administrative archives in pharaonic times', in Patrizia Piacentini and Christian Orsenigo (eds), Egyptian archives: proceedings of the first session of the International Congress Egyptian Archives / Egyptological Archives, Milano, September 9-10, 2008, Milano: Cisalpino, 61-70.

Allam, Schafik (1973), Hieratische Ostraka und Papyri aus der Ramessidenzeit, vol. 2. Tafelteil. Transkriptionen aus dem Nachlass von J. Černý (Urkunden zum Rechtsleben im alten Ägypten, 1), Tübingen.

Allam, Schafik (1968), 'Sind die nichtliterarischen Schriftostraka Brouillons?', in Journal of Egyptian Archaeology, 54, 121-128.

Allen, James P. (2002), The Heqanakht Papyri (Publications of The Metropolitan Museum of Art Egyptian Expedition, 27), New York: Metropolitan Museum of Art.

Assmann, Jan (2002), The Mind of Egypt. New York: Henry Holt.

Baines, John (2008), 'On the evolution, purpose and forms of Egyptian annals', in Eva-Maria Engel, Vera Müller and Ulrich Hartung (eds), Zeichen aus dem Sand: Streiflichter aus Ägyptens Geschichte zu Ehren von Günter Dreyer, Wiesbaden: Harrassowitz, 19-40.

Barns, John W. B. (1948), 'Three Hieratic Papyri in the Duke of Northumberland's Collection', in Journal of Egyptian Archaeology, 34, 35-46.

Bietak, Manfred (2011), 'A Hyksos palace at Avaris', in Egyptian Archaeology, 38, 38-41.

Bietak, Manfred, and Irene Forstner-Müller (2009), 'Der Hyksos-Palast bei Tell el-Dab'a. Zweite und Dritte Grabungskampagne (Frühling 2008 und Frühling 2009)', in Ägypten und Levante, 19, 91-119.

Bogoslovsky, Evgeni S. (1982), Review of Alain-Pierre Zivie, La tombe de Pached à Deir elMédineh [No. 3] in Chronique d'Égypte, 57, 274-281.

Borchardt, Ludwig (1899), 'Der zweite Papyrusfund von Kahun und die zeitliche Festlegung des mittleren Reiches der ägyptischen Geschichte', in Zeitschrift für Ägyptische Sprache und Altertumskunde, 37, 91-105.

Borchardt, Ludwig (1903), 'Besoldungsverhältnisse von Priestern im mittleren Reich', in Zeitschrift für Ägyptische Sprache und Altertumskunde, 40, 113-117.

Breyer, Francis A. K. (2011), 'Hethitologische Bemerkungen zum Keilschrift “Zipfel” aus Qantir/ Pi-Ramesse', in Ägypten und Levante, 20, 43-48.

Brose, Marc (2014), Grammatik der dokumentarischen Texte des Mittleren Reiches (Lingua Aegyptia Studia Monographia, 13), Hamburg: Widmaier Verlag.

Brosius, Maria (ed.) (2003), Ancient Archives and Archival Traditions. Concepts of Record-Keeping in the Ancient World, Oxford: Oxford University Press.

Bruyère, Bernard (1937), Rapport sur les fouilles de Deir el Médineh (1933-1934) (Fouilles de l'Institut français d'archéologie orientale du Caire, 14), Cairo: Institut français d'archéologie orientale.

Caminos, Ricardo Augusto (1954), Late-Egyptian Miscellanies (Brown Egyptological Studies, I), Oxford: Oxford University Press. 
Černý, Jaroslav (1935), Catalogue des ostraca hiératiques non littéraires de Deir el Médineh. Vol. I. Nos. 1 à 113 (Documents de fouilles de l'Institut français d'archéologie orientale du Caire, 3), Cairo: Institut français d'archéologie orientale.

Černý, Jaroslav (1937), 'Restitution of, and penalty attaching to, stolen property in Ramesside times', in Journal of Egyptian Archaeology, 23, 186-189.

Černý, Jaroslav (2001), A Community of Workmen at Thebes in the Ramesside Period, 2nd ed. (Bibliothèque d'Étude, 50), Cairo: Institut français d'archéologie orientale.

Collier, Mark, and Stephen Quirke (2006), The UCL Lahun Papyri: Accounts (British Archaeological Reports International Series, 1471), Oxford: Archaeopress.

Collombert, Philippe, and Laurent Coulon (2000), 'Les dieux contre la mer: le début du "papyrus d'Astarté” (P. BnF 202)', in Bulletin d'Institut français d'archéologie orientale, 100, 193-242.

Davies, Benedict G. (1999), Who's who at Deir el-Medina. A prosopographic Study of the Royal Workmen's Community (Egyptologische Uitgaven, 13), Leiden: Nederlands Instituut voor het Nabije Oosten.

Demarée, Robert J. (2006), 'A House is not a Home - What exactly is a Hut?', in Andreas Dorn and Tobias Hofmann (eds), Living and Writing in Deir el-Medine. Socio-historical Embodiment of Deir el-Medine Texts (Aegyptiaca Helvetica, 19), Basel: Schwabe, 57-66.

Demarée, Robert J. (2008), 'Letters and Archives from the New Kingdom Necropolis at Thebes', in Laure Pantalacci (ed.), La lettre d'archive: Communication administrative et personnelle dans l'antiquité proche-orientale et égyptienne (Bibliothèque générale, 32), Cairo: Institut français d'archéologie orientale, 43-52.

Demarée, Robert J., and Dominique Valbelle (2011), Les registres de recensement du village de Deir el-Medineh (Le "Stato Civile"), Leuven: Peeters.

Depauw, Mark (2013), 'Reflections on Reconstructing Private and Official Archives', in Michele Faraguna (ed.), Archives and Archival Documents in Ancient Societies, Trieste: Edizioni Università di Trieste, 259-266.

Donker van Heel, Koenraad, and Ben J. J. Haring (2003), Writing in a workmen's village: scribal practice in Ramesside Deir el-Medina (Egyptologische Uitgaven, 16), Leiden: Nederlands Instituut voor het Nabije Oosten.

Dorn, Andreas (2011), Arbeiterhütten im Tal der Könige. Ein Beitrag zur altägyptischen Sozialgeschichte aufgrund von neuem Quellenmaterial aus der Mitte der 20. Dynastie (ca. 1150 v. Chr.), 3 vols (Aegyptiaca Helvetica, 23), Basel: Schwabe.

Dunham, Dows (1967), Uronarti, Shalfak, Mirgissa (Second Cataract Forts vol II), Boston: Museum of Fine Arts.

Emery, Walter Bryan, Harry Sidney Smith, and Alan Millard (1979), The Fortress of Buhen: The Archaeological Report (Excavation Memoirs, 49), London: Egypt Exploration Society.

Enmarch, Roland (2005), The Dialogue of Ipuwer and the Lord of All. Oxford: Griffith Institute.

Enmarch, Roland (2008), A World Upturned: Commentary on, and Analysis of, The Dialogue of Ipuwer and the Lord of All. Oxford: Oxford University Press for the British Academy.

Eyre, Christopher (1987), 'Papyrus Deir el-Medîna XXIV: an appeal for wages?', in Göttinger Miszellen, 98, 11-21.

Eyre, Christopher (2009), 'On the Inefficiency of Bureaucracy', in Patrizia Piacentini and Christian Orsenigo (eds), Egyptian archives: proceedings of the first session of the International Congress Egyptian Archives / Egyptological Archives, Milano, September 9-10, 2008. Milano: Cisalpino, 15-30. 
Eyre, Christopher (2013), The Use of Documents in Pharaonic Egypt, Oxford: Oxford University Press.

Faraguna, Michele (ed.) (2013), Archives and Archival Documents in Ancient Societies: Trieste, 30 September - 1 October 2011 (Legal documents in ancient societies, 4; Graeca tergestina, storia e civilitá, 1), Trieste: Edizioni Università di Trieste.

Farina, Giulio (1937), 'Come si restaura un papiro', in Sapere (Italian magazine), Milan, 344346.

Firth, Cecil Mallaby, and James Edward Quibell (1935), The Step Pyramid, 2 vols, Cairo: Institut français d'archéologie orientale.

Fischer-Elfert, Hans-Werner (1986), Die Satirische Streitschrift des Papyrus Anastasi I: Übersetzung und Kommentar (Ägyptologische Abhandlungen, 44), Wiesbaden: Otto Harrassowitz.

Fischer-Elfert, Hans-Werner (1992), Die Satirische Streitschrift des Papyrus Anastasi I (2nd revised edition), Wiesbaden: Otto Harrassowitz.

Fischer-Elfert, Hans-Werner (1998), 'Neue Fragmente zur Lehre eines Mannes für seinen Sohn (P. BM EA 10775 und P. BM EA 10778)', in Journal of Egyptian Archaeology, 84, 85-92.

Fischer-Elfert, Hans-Werner (2016), 'Aus dem Inhalt einer 'fd.. -Bücherkiste (Pap. Berlin P. hier. 15779)', in Sandra L. Lippert, Maren Schentuleit and Martin A. Stadler (eds), Sapienta Felicitas: Festschrift für Günter Vittmann (Cahiers ‘Égypte Nilotique et Méditerranéenne’, 14), Montpellier: Université Paul-Valéry, 149-170.

Gardiner, Alan H. (1906), 'Four papyri of the $18^{\text {th }}$ Dynasty from Kahun', in Zeitschrift für Ägyptische Sprache und Altertumskunde, 43, 27-47.

Gardiner, Alan H. (1914), 'New Literary Works from Ancient Egypt', in Journal of Egyptian Archaeology, 1, 20-36.

Gardiner, Alan H. (1937), Late-Egyptian Miscellanies (Bibliotheca Aegyptiaca, 7), Brussels: La fondation égyptologique Reine Élisabeth.

Gardiner, Alan H. (1941), 'Ramesside Texts Relating to the Taxation and Transport of Corn', in Journal of Egyptian Archaeology, 27, 19-73.

Gardiner, Alan H. (1941-1952), The Wilbour Papyrus, 4 vols, Oxford: Oxford University Press. Gardiner, Alan H. (1948), Ramesside Administrative Documents, Oxford: Griffith Institute.

Gardiner, Alan H. (1953), 'The Harem at Miwer', in Journal of Near Eastern Studies, 12, 145-149.

Gardiner, Alan H. (1957), Egyptian Grammar (3rd revised edition), Oxford: Griffith Institute.

Glanville, Stephen Ranulph Kingdon (1931), 'Records of a Dockyard of the Time of Tuthmosis III: Papyrus British Museum 10056', in Zeitschrift für ägyptische Sprache und Altertumskunde, 66, 105-121.

Glanville, Stephen Ranulph Kingdon (1933), 'Records of a Dockyard of the Time of Tuthmosis III: Papyrus British Museum 10056 (part II)', in Zeitschrift für ägyptische Sprache und Altertumskunde, 68, 7-40.

Goelet, Ogden (2015), 'Verse Points, Division Markers, and Copying', in Ogden Goelet (ed.), The Art and Culture of Ancient Egypt: Studies in Honor of Dorothea Arnold (Bulletin of the Egyptological Seminar, 19), New York: Egyptological Seminar, 347-358.

Goren, Yuval, Israel Finkelstein and Nadav Na'aman (2004), Inscribed in Clay: Provenance Study of the Amarna Tablets and other Ancient Near Eastern Texts, Tel-Aviv: Emery and Claire Yass Publications in Archaeology.

Griffith, Francis Llewellyn (1898), Hieratic Papyri from Kahun and Gurob, London: Bernard Quaritch.

Hagen, Fredrik (2011), 'The hieratic dockets on the cuneiform tablets from Amarna', in Journal of Egyptian Archaeology, 97, 214-216. 
Hagen, Fredrik (2016a), 'On Some Movements of the Royal Court in New Kingdom Egypt', in Jacobus van Dijk (ed.), Another Mouthful of Dust: Egyptological Studies in Honour of Geoffrey Thorndike Martin (Orientalia Lovaniensia Analecta, 246), Leuven: Peeters, 155-181.

Hagen, Fredrik (2016b), Review of Robert Demarée and Dominique Valbelle, Les registres de recensement du village de Deir el-Medineh, in Journal of Egyptian Archaeology, 102, 205212.

Hagen, Fredrik (forthcoming), 'Libraries in Ancient Egypt, c. 1600-800 BC', in Kim Ryholt and Gojko Barjamovic (eds), Libraries Before Alexandria, Oxford: Oxford University Press.

Hagen, Fredrik, and Kim Ryholt (2016), The Antiquities Trade in Egypt 1880-1930: The H. O. Lange Papers (Scientia Danica. Series H, Humanistica, 4, vol. 8), Copenhagen: The Royal Danish Academy of Sciences and Letters.

Haring, Ben (1997), Divine households: administrative and economic aspects of the New Kingdom royal memorial temples in western Thebes (Egyptologische Uitgaven, 12), Leiden: Nederlands Instituut voor het Nabije Oosten.

Haring, Ben (2003), 'From oral practice to written record in Ramesside Deir el-Medina', in Journal of the Economic and Social History of the Orient, 46, 249-272.

Haring, Ben (2005), 'Institutional Agriculture and the Temples in Ramesside Egypt', in Cahier de recherches de l'Institut de papyrologie et égyptologie de Lille, 46, 249-272.

Haring, Ben (2006), 'Scribes and Scribal activity at Deir el-Medina', in Andreas Dorn and Tobias Hofmann (eds), Living and Writing in Deir el-Medine. Socio-historical Embodiment of Deir el-Medine Texts (Aegyptiaca Helvetica ,19), Basel: Schwabe, 107-112.

Haring, Ben (2007), 'Inventories and Administration in the Egyptian New Kingdom', in Katelijn Vandorpe and Willy Clarysse (eds), Archives and Inventories in the Eastern Mediterranean, Brussels: Koninklijke Vlaamse Academie van Belgïe voor Wetenschappen en Kunsten, 4757.

Haring, Ben (2010), 'Administration and Law: Pharaonic', in Alan B. Lloyd (ed.), A Companion to Ancient Egypt, 2 vols, Oxford: Blackwell, 218-236.

Hayes, William Christopher (1951), 'Inscriptions from the Palace of Amenhotep III', in Journal of Near Eastern Studies, 10, 156-183.

Hayes, William Christopher (1955), A Papyrus of the Late Middle Kingdom in the Brooklyn Museum, New York: Brooklyn Museum.

Helck, Wolfgang (1961-1969), Materialien zur Wirtschaftsgeschichte des Neuen Reiches (Akademie der Wissenschaften und der Literatur, Abhandlungen der Geistes- und Sozialwissenschaftlichen Klasse, Jahrgang 1960, Nr. 10), Wiesbaden: Franz Steiner Verlag.

Helck, Wolfgang (1974), Altägyptische Aktenkunde des 3. und 2. Jahrtausends v. Chr. (Münchner Ägyptologische Studien, 31), Munich: Deutscher Kunstverlag.

Helck, Wolfgang (1975), 'Archive', in Wolfgang Helck and Eberhard Otto (eds), Lexikon der Ägyptologie, vol. I, Wiesbaden: Otto Harrassowitz, 422-424.

Hoffmeier, James K. (2014), Tell el-Borg I: The "Dwelling of the Lion" on the Ways of Horus. (Excavations in North Sinai), Winona Lake: Eisenbrauns.

Janssen, Jac. J. (1960), 'Nine letters from the time of Ramesses II', in Oudheidkundige Mededelingen uit het Rijksmuseum van Oudheden te Leiden, 61, 31-47.

Janssen, Jac. J. (1961), Two Ancient Egyptian Ship's Logs, Leiden: Brill.

Janssen, Jac. J. (1991), 'Requisitions from Upper Egyptian Temples (P. BM 10401)', in Journal of Egyptian Archaeology, 77, 79-94. 
Janssen, Jac. J. (1997), Village Varia. Ten studies on the history and administration of Deir elMedina (Egyptologische Uitgaven, 11), Leiden: Nederlands Instituut voor het Nabije Oosten.

Janssen, Jac. J. (2004), Grain Transport in the Ramesside Period: Papyrus Baldwin (BM EA 10061) and Papyrus Amiens (Hieratic Papyri in the British Museum, 8), London: British Museum Press.

Janssen, Jac. J. (2005), 'Accountancy at Deir el-Medina: How Accurate are the Administrative Ostraca?', in Studien zur Altägyptischen Kultur, 33, 147-157.

Kaplony-Heckel, Ursula (1971), Ägyptische Handschriften, vol. I (Verzeichnis der Orientalischen Handschriften in Deutschland, 19.1), Wiesbaden: Franz Steiner Verlag.

Katary, Sally (1989), Land Tenure in the Ramesside Period, London: Kegan Paul.

Kemp, Barry J. (2006), Ancient Egypt: Anatomy of a Civilization, London: Routledge.

Kemp, Barry J. (2012), The City of Akhenaten and Nefertiti: Amarna and its People, London: Thames \& Hudson.

Kitchen, Kenneth A. (1975), Ramesside Inscriptions: Translated and Annotated, vol. I, Oxford: Blackwell.

Kitchen, Kenneth A. (1975-89), Ramesside Inscriptions, 8 vols, Oxford: Blackwell.

Kitchen, Kenneth A. (1993a), Ramesside Inscriptions: Translated and Annotated, Notes and Comments, vol. I, Oxford: Blackwell.

Kitchen, Kenneth A. (1993b), 'Towards a reconstruction of Ramesside Memphis', in Edward Bleiberg and Rita Freed (eds), Fragments of a Shattered Visage: Proceedings of the International Symposium of Ramesses the Great, Memphis, Tennessee: Memphis State University, 87-104.

Koenig, Yvan (1988), 'Nouveaux textes hiératiques de la Vallée des Reines [I]', in Bulletin de l'Institut français d'archéologie orientale, 88, 113-129.

Kóthay, Katalin Anna (2015), 'Duties and Composition of the Personnel of the Cults as Lahun', in Panagiotis Kousoulis and Nikolaos Lazaridis (eds), Proceedings of the Tenth International Congress of Egyptologists (Orientalia Lovaniensia Analecta, 241), vol. 1, Leuven: Peeters, 763-775.

Kraemer, Bryan, and Kate Liszka (2016), 'Evidence for Administration of the Nubian Fortresses in the Late Middle Kingdom: The Semna Dispatches', in Journal of Egyptian History, 9, 165.

Kraus, Jürgen (2004), Die Demographie des alten Ägypten: Eine Phänomenologie anhand altägyptischer Quellen, Göttingen: PhD Dissertation.

Krauss, Rolf (2006), 'Egyptian Sirius/Sothic Dates and the Question of the Sirius based Lunar Calender', in Erik Hornung, Rolf Krauss and David A. Warburton (eds), Ancient Egyptian Chronology (Handbook of Oriental Studies. Section 1, The Near and Middle East, vol. 83), Leiden: Brill, 439-457.

Lefèvre, Dominique (2008), 'Les papyrus d'El-Hibeh: Archives de temple ou archives familiales ?' in Laure Pantalacci (ed.), La lettre d'archive: communication administrative et personelle dans l'antiquité proche-orientale et égyptienne (Topoi Supplement 9, Bibliothèque générale d'Institut français d'archéologie orientale, 32), Cairo: Institut français d'archéologie orientale, 109-116.

Lesko, Leonard H. (ed.) (1994), Pharaoh's Workers. The villagers of Deir el Medina, Ithaca and London: Cornell University Press.

Liverani, Mario (1998-1999), Le lettere di el-Amarna, 2 vols (Testi del Vicino Oriente antico, 2.3), Brescia: Paideia. 
Liszka, Kate, and Bryan Kraemer (2016), 'Evidence for Administration of the Nubian Fortresses in the Late Middle Kingdom: P. Ramessesum 18', in Journal of Egyptian History, 9, 151208.

Luft, Ulrich (1982), 'Illahunstudien, I: Zu der Chronologie und den Beamten in den Briefen aus Illahun', in Oikumene, 3, 101-156.

Luft, Ulrich (1986), 'Illahunstudien, III: Zur sozialen Stellung des Totenpriesters im Mittleren Reich', Oikumene, 5, 117-153.

Luft, Ulrich (1992a), Das Archiv von Illahun: Briefe 1, Berlin: Akademie Verlag.

Luft, Ulrich (1992b), Die chronologische Fixierung des ägyptischen Mittleren Reiches nach dem Tempelarchiv von Illahun (Österreichische Akademie der Wissenschaften PhilosophischHistorische Klasse Sitzungsberichte 598, Veröffentlichungen der ägyptischen Kommission Nr. 2), Vienna: Verlag der Österreichischen Akademie der Wissenschaften.

Luft, Ulrich (2006), Urkunden zur Chronologie der Späten 12. Dynastie: Briefe aus Illahun (Österreichische Akademie der Wissenschaften Denkschriften der Gesamtakademie, 34 / Contributions to the Chronology of the Eastern Mediterranean, 7), Vienna: Österreichische Akademie der Wissenschaften.

Mariette, Auguste (1872), Les papyrus égyptiens du musée de Boulaq, vol. II, Paris: A. Franck.

McDowell, Andrea G. (1994), 'Contact with the Outside World', in Leonard H. Lesko (ed.), Pharaoh's Workers. The Villagers of Deir el Medina, Ithaca and London: Cornell University Press, 41-59.

McDowell, Andrea G. (1999), Village Life in Ancient Egypt. Laundry Lists and Love Songs, Oxford: Oxford University Press.

Megally, Mounir (1971), Le papyrus hiératique comptable E. 3226 du Louvre (Bibliothèque d'Étude, 53), Cairo: Institut français d'archéologie orientale.

Megally, Mounir (1977a), Recherches sur l'économie, l'administration et la comptabilité égyptiennes à la XVIIIe dynastie d'après le papyrus E. 3226 du Louvre (Bibliothèque d'Étude, 71), Cairo: Institut français d'archéologie orientale.

Megally, Mounir (1977b), Notions de comptabilité à propos du papyrus E. 3226 du Musée du Louvre (Bibliothèque d'Étude, 72), Cairo: Institut français d'archéologie orientale.

Menu, Bernadette (1985), 'Ventes de maisons sous l'ancien empire égyptien', in Francis Geus and Florence Thill (eds), Mélanges offerts à Jean Vercoutter, Paris: Ed. Recherche sur les civilisations, 249-262.

Menu, Bernadette (2010), 'Quelques aspects du recrutement des travailleurs dans l'Égypte du deuxième millénaire av. J.-C.', in Bernadette Menu (ed.), L'organisation du travail en Égypte ancienne et en Mésopotamie, Cairo: Institut français d'archéologie orientale, 171183.

Meyrat, Pierre (2012), Les papyrus magiques du Ramesseum. Recherches sur une bibliothèque privée de la fin du Moyen Empire. PhD dissertation. Université de Genève.

Miniaci, Gianluca, and Stephen Quirke (2008), 'Mariette at Dra Abu el-Naga and the Tomb of Neferhotep: a mid-13 ${ }^{\text {th }}$ Dynasty Rishi Coffin (?)', in Egitto e vicino oriente, 31, 5-25.

Miniaci, Gianluca, and Stephen Quirke (2009), 'Reconceiving the Tomb in the Late Middle Kingdom. The Burial of the Accountant of the Main Enclosure Neferhotep at Dra Abu al-Naga', in Bulletin d'Institut français d'archéologie orientale, 109, 339-383.

Moran, William (1992), The Amarna Letters, London and Baltimore: Johns Hopkins University Press.

Morris, Ellen Fowles (2005), The Architecture of Imperialism: Military Bases and the Evolution of Foreign Policy in Egypt's New Kingdom (Probleme der Ägyptologie, 22), Leiden: Brill. 
Müller, Matthias (2009), 'The “El-Hibeh”-Archive: Introduction \& Preliminary Information', in Gerald P. F. Broekman, Robert J. Demarée and Olaf E. Kaper (eds), The Libyan Period in Egypt: Historical and cultural studies into the $21^{\text {st }}-24^{\text {th }}$ dynasties (Egyptologische Uitgaven, 23), Leiden: Nederlands Instituut voor het Nabije Oosten, 251-264.

Mynářová, Jana (2007), Language of Amarna - Language of Diplomacy: Perspectives on the Amarna Letters, Prague: Czech Institute of Egyptology.

Mynářová, Jana (2014), 'Egyptian State Correspondence of the New Kingdom: The Letters of the Levantine Client Kings in the Amarna Correspondence and Contemporary Evidence', in Karen Radner (ed.), State Correspondence in the Ancient World, Oxford: Oxford University Press, 10-31.

Mynářová, Jana (2015), 'Discovery, Research, and Excavation of the Amarna Tablets - the Formative Stage', in Anson F. Rainey, The El-Amarna Correspondence (Handbook of Oriental Studies / Section 1 / Ancient Near East / 110), 2 vols, Leiden: Brill, 37-46.

Newberry, Percy (1899), The Amherst Papyri, London: Bernard Quaritch.

Pantalacci, Laure (1998), 'La documentation épistolaire du palais des gouverneurs à Balat-Ayin Asil', in Bulletin d'Institut français d'archéologie orientale, 98, 303-315.

Pantalacci, Laure (2001), 'L'administration royale et l'administration locale au gouvernorat de Balat d'après les empreintes de sceaux', in Cahiers de Recherches de l'Institut de Papyrologie et d'Égyptologie de Lille, 22, 153-160.

Pantalacci, Laure (2008), La lettre d'archive, communication administrative et personelle dans l'Antiquité proche-orientale et égyptienne, actes et colloque de l'université de Lyon 2, 910 juillet 2004 (Topoi Supplement, 9), Cairo: Institut français d'archéologie orientale.

Pantalacci, Laure (2010), 'Organisation et contrôle du travail dans la province oasite à la fin de l'Ancien Empire. Le cas des grands chantiers de construction à Balat', in Bernadette Menu (ed.), L'organisation du travail en Égypte ancienne et en Mésopotamie (Bibliothèque d’Étude, 151), Cairo: Institut français d'archéologie orientale, 139-154.

Pantalacci, Laure (2013), 'Balat, a frontier town and its archive', in Juan Carlos Moreno García (ed.), Ancient Egyptian Administration (Handbook of Oriental studies / Section 1 / Ancient Near East / 104), Leiden: Brill, 197-214.

Papazian, Hratch (forthcoming), 'Life and Labour in the Twin Towns: The View from Old Kingdom Gebelein', in Philippe Collombert and Pierre Tallet (eds), 'Les archives administratives de l'Ancien Empire. État de la question': actes de la table ronde tenue à Paris, 12 et 13 février 2015, Bern: Peter Lang.

Parkinson, Richard B. (1997), The Tale of Sinuhe and Other Egyptian Poems 1940-1640 BC, Oxford: Oxford University Press.

Parkinson, Richard B. (2009), Reading Ancient Egyptian Poetry: Among Other Histories, Oxford: Blackwell.

Pasquali, Stéphane (2007), 'La date du papyrus BM 10056: Thoutmosis III ou Amenhotep II?', in Revue d'Égyptologie, 58, 71-86.

Peet, Thomas Eric (1930), The Great Tomb Robberies of the Twentieth Egyptian Dynasty, 2 vols, Oxford: Oxford University Press.

Pelegrin, Jacques, Guillemette Andreu-Lanoë, and Christine Pariselle (2016), 'La production des ostraca en calcaire dans la nécropole thébaine: étude préliminaire', in Bulletin de l'Institut français d'archéologie orientale, 115, 325-352.

Pendlebury, John Devitt Stringfellow (1951), The City of Akhenaten, Part III (vol. I, Text, vol II, Plates), London: Egypt Exploration Society. 
Pestman, Pieter W. (1982), 'Who were the Owners, in the "Community of Workmen", of the Chester Beatty Papyri', in Robert J. Demarée and Jac. J. Janssen (eds), Gleanings from Deir el-Medîna (Egyptologische Uitgaven, 1), Leiden: Nederlands Instituut voor het Nabije Oosten, 155-172.

Petrie, William M. Flinders (1890), Kahun, Gurob and Hawara, London: David Nutt.

Petrie, William M. Flinders (1891), Illahun, Kahun and Gurob, London: David Nutt.

Petrie, William M. Flinders, Guy Brunton, and M. A. Murray (1923), Lahun II, London: Bernard Quaritch.

Pinarello, Massimiliano (2015), An archaeological discussion of writing practice: Deconstruction of the Ancient Egyptian scribe, London: Golden House Publications.

Posener-Kriéger, Paule (1976), Les archives du temple funéraire de Néferirkarê-Kakaï, 2 vols (Bibliothèque d’Étude, 65), Cairo: Institut français d'archéologie orientale.

Posener-Kriéger, Paule (1979), 'Le Prix des Etoffes', in Manfred Görg and Edgar Pusch (eds), Festschrift Elmar Edel (Ägypten und Altes Testament, 1), Bamberg: Manfred Görg, 318-331.

Posener-Kriéger, Paule (1980), 'Fragments de papyrus provenant de Saqqarah', in Revue d’Égyptologie, 32, 83-93.

Posener-Kriéger, Paule (1985), 'Décrets envoyés au temple funéraire de Rêneferef', in Paule Posener-Kriéger (ed.), Mélanges Gamal Eddin Mokhtar, vol. II (Bibliothèque d’Étude, 97/2), Cairo: Institut français d'archéologie orientale, 195-210.

Posener-Kriéger, Paule (1986), 'Old Kingdom Papyri: External Features', in Morris Leonard Bierbrier (ed.), Papyrus: Structure and Usage (British Museum Occasional Paper, 60), London: British Museum, 25-42.

Posener-Kriéger, Paule (1990), 'Aspects économiques des nouveaux papyrus d’Abousir', in Sylvia Schoske (ed.), Akten des vierten internationalen Ägyptologen Kongresses München 1985, vol. 4 (Studien zur altägyptischen Kultur Beihefte, 4), Hamburg: Helmut Buske Verlag, 167-176.

Posener-Kriéger, Paule (1994), 'Le coffret de Gebelein', in Catherine Berger, Gisèle Clerc and Nicolas Grimal (eds), Hommages à Jean Leclant, vol. I (Bibliothèque d’Étude, 106/1), Cairo: Institut français d'archéologie orientale, 315-326.

Posener-Kriéger, Paule (2004), I Papiri di Gebelein (ed. Sara Demichelis), Turin: Ministero per i beni e le attività culturali - Soprintendenza al Museo delle Antichità Egizie.

Posener-Kriéger, Paule, and Jean-Louis de Cenival (1968), The Abu Sir Papyri (Hieratic Papyri in the British Museum Fifth Series), London: British Museum.

Posener-Kriéger, Paule, Miroslav Verner and Hana Vymazalová (2006), Abusir X: The Pyramid Complex of Raneferef - The Papyrus Archive, Prague: Czech Institute of Egyptology.

Pusch, Edgar B., and Stephan Jacob (2003), 'Der Zipfel des diplomatischen Archivs Ramses' II.’, in Ägypten und Levante, 13, 143-153.

Quirke, Stephen (1990), The Administration of Egypt in the Late Middle Kingdom. The Hieratic Documents. New Malden: Sia Publishing.

Quirke, Stephen (1996), 'Archive', in Antonio Loprieno (ed.), Ancient Egyptian Literature: History and Forms (Probleme der Ägyptologie, 10), Leiden: Brill, 379-401.

Quirke, Stephen (1998), 'A preliminary study of technical terms in accounts of the Illahun temple archive', in Ägypten und Levante, 7, 9-16.

Quirke, Stephen (2004), Titles and Bureaux of Egypt 1850-1700 BC (Egyptology, 1), London: Golden House Publications.

Quirke, Stephen (2005), Lahun: A town in Egypt 1800 BC, and the history of its landscape, London: Golden House Publications. 
Quirke, Stephen (2016), 'Writings for good health in a social context: Middle and New Kingdom comparisons', in Campbell Price et al. (eds), Mummies, magic and medicine in ancient Egypt: Multidisciplinary essays for Rosalie David, Manchester: Manchester University Press, 183-196.

Rainey, Anson F. (2015), The El-Amarna Correspondence, 2 vols (Handbook of Oriental Studies / Section 1 / Ancient Near East / 110), Leiden: Brill.

Redford, Donald B. (1985), 'Tagebuch' in Wolfgang Helck and Eberhard Otto (eds), Lexikon der Ägyptologie, vol. VI, Wiesbaden: Otto Harrassowitz, 151-153.

Redford, Donald B. (1986), Pharaonic king-lists, annals and daybooks: A contribution to the study of the Egyptian sense of history (Society for the Study of Egyptian Antiquities Publications, 4), Mississauga: Benben.

Redford, Donald B. (2003), The Wars in Syria and Palestine of Thutmose III (Culture \& History of the Ancient Near East, 16), Leiden: Brill

Reeves, C. Nicholas (1990), Valley of the Kings: The decline of a royal necropolis. Studies in Egyptology, London, New York: Kegan Paul.

Roccati, Alessandro (1970), 'Una tabella lignea inscritta da Gebelein', in Rivista degli studi orientali, 45, 1-10.

Roccati, Alessandro (1984), 'Les papyrus de Turin', in Bulletin de la Société française d'Égyptologie, 99 (March), 9-27.

Ryholt, Kim (2006), 'The Turin king-list or so-called Turin Canon (TC) as a source for chronology', in Erik Hornung, Rolf Krauss and David A. Warburton (eds), Ancient Egyptian Chronology, Leiden: Brill, 26-32.

Ryholt, Kim (forthcoming a), 'The Late Old Kingdom Archive at the Pyramid Complex of Netjerikhet (with an appendix on the Old Kingdom papyri from South Saqqara)', in Philippe Collombert and Pierre Tallet (eds), 'Les archives administratives de l'Ancien Empire. État de la question': actes de la table ronde tenue à Paris, 12 et 13 février 2015, Bern: Peter Lang.

Ryholt, Kim (forthcoming b), 'The Storage of Papyri in Ancient Egypt', in Eva CancikKirschbaum, Jochem Kahl, Eun-Jeung Lee and Michela Engert (eds), Scholarship between Clay and Light, Wiesbaden: Harrassowitz.

Scharff, Alexander (1922), 'Ein Rechnungsbuch des königlichen Hofes aus der 13. Dynastie', in Zeitschrift für Ägyptische Sprache und Altertumskunde, 57, 51-68.

Scharff, Alexander (1924); 'Briefe aus Illahun', in Zeitschrift für Ägyptische Sprache und Altertumskunde, 59, 20-51.

Schulman, Alan Richard (1964), Military Rank, Title and Organization in the Egyptian New Kingdom (Münchner Ägyptologische Studien, 6), Berlin: Verlag Bruno Hessling.

Sethe, Kurt (1906-1909), Urkunden der 18. Dynastie, 4 vols, Leipzig: J. C. Hinrich'sche Buchhandlung.

Sethe, Kurt (1923), Ägyptische Lesestücke zum Gebrauch im akademischen Unterricht, Leipzig: J. C. Hinrichs'sche Buchhandlung.

Shaw, Ian (ed.) (2000), The Oxford History of Ancient Egypt, Oxford: Oxford University Press.

Simpson, William Kelly (1963), Papyrus Reisner I: Transcription and Commentary, Boston: Boston Museum of Fine Arts.

Simpson, William Kelly (1965), Papyrus Reisner II: Accounts of the dockyard workshop at This in the reign of Sesostris I, Boston: Boston Museum of Fine Arts.

Simpson, William Kelly (1969), Papyrus Reisner III: The records of a building project in the early Twelfth Dynasty, Boston: Boston Museum of Fine Arts. 
Simpson, William Kelly (1986), Papyrus Reisner IV: Personnel accounts of the early Twelfth Dynasty, Boston: Boston Museum of Fine Arts.

Smith, Harry Sidney (1976), The Fortress of Buhen: The Inscriptions (Excavation Memoirs, 48), London: Egypt Exploration Society.

Smither, P. C. (1939), 'A Postal Register of the Ramesside Age', in Journal of Egyptian Archaeology, 25, 103.

Smither, P. C. (1941), 'A Tax-Assessor's Journal of the Middle Kingdom', in Journal of Egyptian Archaeology, 27, 74-76.

Smither, P. C. (1945), 'The Semnah Despatches', in Journal of Egyptian Archaeology, 31, 3-10.

Snape, Steven, and Penelope Wilson (2007), Zawiyet Umm el-Rakham I: The temple and the chapels, Bolton: Rutherford Press.

Spalinger, Anthony (1985), 'Notes on the day-summary accounts of P. Bulaq 18 and the intradepartmental transfers', in Studien zur Altägyptischen Kultur, 12, 179-241.

Spalinger, Anthony (1986a), 'Foods in P. Bulaq 18', in Studien zur Altägyptischen Kultur, 12, 179-241.

Spalinger, Anthony (1986b), 'Baking during the Reign of Seti l', in Bulletin d'Institut français d'archéologie orientale, 86, 307-352.

Spiegelberg, Wilhelm (1896), Rechnungen aus der Zeit Setis I. (circa 1350 v.Chr.), mit anderen Rechnungen des Neuen Reiches, 2 vols, Strassburg: Karl J. Trübner.

Spiegelberg, Wilhelm (1898), Hieratic Ostraka \& Papyri found by J. E. Quibell, in the Ramesseum, 1895-6, London: Bernard Quaritch.

Soliman, Daniel (2013), 'The Functional Context of the 18th Dynasty Marks Ostraca from the Theban Necropolis', in Carl Graves, Gabrielle Heffernan, Luke McGarrity, Emily Millward and Marsia Sfakianou Bealby (eds), Current Research in Egyptology 2012. Proceedings of the Thirteenth Annual Symposium. University of Birmingham 2012, Oxford: Oxbow Books, 157-170.

Soliman, Daniel (in press), 'Duty rosters and delivery records composed with marks and their relation to the written administration of Deir el-Medina', in Ben J. J. Haring, Kyra van der Moezel and Daniel Soliman (eds), Proceeding of the symposium 'Decoding of Identity' (Egyptologische Uitgaven), Leiden: Nederlands Instituut voor het Nabije Oosten.

Tallet, Pierre (2014a), 'Des papyrus du temps de Chéops au ouadi el-Jarf (golfe du Suez)', in Bulletin de la Société Française d'Égyptologie, 188, 25-49.

Tallet, Pierre (2014b), 'The Harbor of Khufu on the Red Sea Coast at Wadi al-Jarf, Egypt', in Near Eastern Archaeology, 77,1, 4-14.

Tosi, Mario, and Alessandro Roccati (1972), Stele e altre epigrafi di Deir el Medina. N. 50001 N. 50262 (Catalogo del Museo Egizio di Torino. 2nd. Series, 1), Turin.

Trapani, Marcella (2008), 'La terminologie concernant les archives dans les textes du Nouvel Empire', in Patrizia Piacentini and Christian Orsenigo (eds), Egyptian archives: proceedings of the first session of the International Congress Egyptian Archives / Egyptological Archives, Milano, September 9-10, 2008, Milano: Cisalpino, 103-114.

Valbelle, Dominique (1985), 'Les ouvriers de la tombe'. Deir el-Médineh à l'époque Ramesside (Bibliothèque d’Étude, 96), Cairo: Institut français d'archéologie orientale.

Van den Berg, Hans, and Koenraad Donker van Heel (2000), 'A scribe's cache from the Valley of Queens? The palaeography of documents from Deir el-Medina: Some remarks', in Robert J. Demarée and Arno Egberts (eds), Deir el-Medina in the Third Millenium AD: a tribute to Jac. J. Janssen (Egyptologische Uitgaven, 14), Leiden: Nederlands Instituut voor het Nabije Oosten, 9-49. 
Vandorpe, Katelijn (2011), 'Archives and Dossiers', in Roger Bagnall (ed.), The Oxford Handbook of Papyrology, Oxford: Oxford University Press, 216-255.

Verner, Miroslav (2001), Abusir III: The Pyramid Complex of Khentkaus, Prague: Czech Institute of Egyptology.

Verner, Miroslav et al. (2006), Abusir IX: The Pyramid Complex of Raneferef-The Archaeology. Prague: Czech Institute of Egyptology.

Vernus, Pascal (2013), 'L’acte fondamentale du poivoir dans l'Égypte pharaonique: l'ordre royal (oudj-nesou)', in Silvia Bussi (ed.), Egitto dai Faraoni agli Arabi: atti del convegno Egitto: amministrazione, economia, societá, cultura dai Faraoni agli Arabi. Milano, Università degli Studi, 7-9 gennaio 2013, Pisa: Fabrizio Serra, 21-35.

Vittmann, Günther (2011), 'Charges against several officials (P. Turin 1887)', in Bezalel Porten et al. (eds), The Elephantine Papyri in English (2nd revised edition), Leiden: Brill, 46-57.

Vymazalová, Hana (2013), 'The Administration of the Royal Funerary Complexes', in Juan Carlos Moreno García (ed.), Ancient Egyptian Administration (Handbook of Oriental studies / Section 1 / Ancient Near East / 104), Leiden: Brill, 177-195.

Wente, Edward Frank (1990), Letters from Ancient Egypt, Atlanta, Georgia: Scholars Press.

Zinn, Katharina (2007), 'Libraries and Archives: The Organization of Collective Wisdom in Ancient Egypt', in Maria Cannata (ed.), Current Research in Egyptology VII, Oxford: Oxbow, 169-176. 


\title{
Archives and Libraries in Greco-Roman Egypt
}

\begin{abstract}
Owing to the mass of its documentation, Egypt gives many examples of discoveries of documentary and literary papyri. The papyrologists traditionally speak of 'archives' for documentary texts and 'libraries' for literary texts, a polarity which reflects the two fundamental branches of papyrology, namely documentary papyrology and literary papyrology. But is it epistemologically correct? Does this reflect reality? The situation is actually less clear: many ancient sets combined both documents and books. After presenting the archives and the libraries as evidenced by papyri, I will try to show examples of these combinations and expose the reasons that make them so difficult to detect, to the detriment of papyrology and of our understanding of ancient culture in general.
\end{abstract}

\section{Introduction}

'Archives' and 'libraries' are two terms used by papyrologists to designate collections of either documentary or literary texts (henceforth 'documents' and 'books' respectively). As far as classical Antiquity is concerned, archives and libraries are best known from allusions made to them in literary sources. And, with a few exceptions (including the famous case of Herculaneum), Greco-Roman Egypt is the only place where climatic conditions allowed for the massive preservation of documents and books which constituted ancient archives and libraries. But the conditions in which they were discovered in the nineteenth and twentieth century unfortunately did not permit these ancient collections to come down to us in their entirety.

The interest in these ancient collections, which has developed particularly in recent decades, is doubly justified:

(a) Apart from the content of the texts they are composed of (which are the delight of historians and philologists), these collections are archaeological objects that form a whole and that we need to reconstruct and study as such. They tell us about the ways of keeping and filing written texts practiced by the ancients. In other

I thank Adam Bülow Jacobsen and Korshi Dosoo for revising my English and Antonio Ricciardetto for proof-reading my paper.

https://doi.org/10.1515/9783110541397-006, (c) BY-NC-ND (c) 2018 J.-L. Fournet, published by De Gruyter. This work is licensed under the Creative Commons Attribution-NonCommercial-NoDerivs 3.0 License. 
words, the information they give us is a matter of library studies, archival studies and the history of knowledge;

(b) We must analyse documents or books, not only in themselves, but in relation to the way they were organized. The relationship between the components of a collection is meaningful and provides new data in addition to those provided by each of the components; more precisely, it strengthens, enlivens and puts into perspective such information. As Orsolina Montevecchi wrote about archives,

l'archivio, e specialmente un archivio privato che si estenda per un certo lasso di tempo, è un insieme più vivo e istruttivo, per certi aspetti, di una serie di documenti omogenei, i quali ci possono dare in modo impersonale l'evoluzione di un determinato istituto giuridico nella sua prassi. L'archivio ci permette una specie di sondaggio in un settore del mondo antico, a scala reale: lo studio di un campione, che può essere una famiglia per due generazioni, con tutte le sue vicende di nascite, morti, matrimoni, relazioni di lavoro e di affari, rapporti con le autorità, ecc. Oppure l'estensione cronologica può essere minore ma più ampia la cerchia in senso orizzontale: relazioni d'interessi, questioni giudiziarie, affinità sprirituali o religiose, ecc. ${ }^{1}$

This applies even to books which constitute libraries. When put back in the context of the collections to which they once belonged, documents or books are put back in the context of their drafters or readers; they illuminate and complement one another so as to uncover historical, institutional, cultural facts, which are not the result of the 'cobbling-together' which we are often obliged to practise, bringing together data originating from various communities, places and periods. Thus, reconstructing archives and libraries is not merely an enjoyable jigsaw puzzle, it is a real tool for analysing ancient texts.

It is only fairly recently that we have begun to realize the importance of archives. The first generations of papyrologists paid more attention to unique and exceptional documents, without taking into account the groups to which they belonged; they also organized their discipline by dividing these texts into meaningful categories (such as the various documentary genres). As outstanding texts became scarcer, and as discoveries of important archives (for instance, that of the katochoi of the Serapeum or that of Dioscorus of Aphrodite, masterfully edited respectively by Ulrich Wilcken ${ }^{2}$ and Jean Maspero ${ }^{3}$ ) began to show how interesting the archival method could be, they began to pay more attention to the ancient groups of texts, and the reconstruction of these groups little by little took precedence over the study of individual texts.

1 Montevecchi 1988, 247.

2 UPZ I 2-105.

3 P.Cair.Masp. I-III. 
The so-called 'museum archeology' method ${ }^{4}$ was developed and theorized these last decades: it aims at reconstructing antique archives dismembered when they were illegally discovered, by trying to trace the history of purchases by European or American collections through a police-like investigation conducted in the inventory registers.

For instance, if one and the same archive has been split up or if one and the same papyrus has been torn to pieces and if those papyri or fragments have turned up in different collections, there must be a link between the acquisitions of the collections in question. ${ }^{5}$

In the case of discoveries made during authorized excavations, one began to take better account of the archaeological data: in a seminal article, Peter van Minnen demonstrated how fruitful the method of the 'house-to-house enquiry' is for the village of Karanis excavated by the Americans, using the old excavations reports and taking into account all the material found in these houses, so that he could individuate the house and the archive of the tax-collector Socrates. ${ }^{6}$ In 1989 the papyrologists Jean Bingen and Willy Clarysse decided-for the first time to my knowledgeto publish the ostraca found in the Belgian excavations in Elkab (Upper Egypt) not by documentary types (as it was usual), but by finding areas, i.e. by houses they were discovered in: thus they were able to reconstruct archives owned by the inhabitants of these houses. ${ }^{7}$ Finally, I must not forget a book that gave, so to speak, its pedigree to the archival method: A Guide to the Zenon Archive by P.W. Pestman in $1981 .^{8}$ So today we publish new papyri only after trying to reconstruct the archives they come from. The development of this interest in archives can be read in the following figures:

- in 1973, Montevecchi in the first edition of her handbook La papirologia made a census of 96 archives;

- $\quad$ in her second edition (1988), she added 39 more, bringing the total to 135;

- in 2014, the online database devoted to Archives on the Trismegistos website registers 482 archives. $^{9}$

4 See Vandorpe 1994.

5 Vandorpe 2009, 228-229.

6 Van Minnen 1994.

7 O.Elkab.

8 Pestman/Clarysse/Korver/Muszynski/Schutgens/Tait/Winnicki 1981.

9 Papyrus Archives in Graeco-Roman Egypt (http://www.trismegistos.org/arch/index.php). References to the archives as registered in this database will be made with \# followed by a number. The figure I have just given includes groups of texts that are not actual archives, but libraries 
It is true that it includes archives that are not only in Greek but also in Demotic or Coptic (since papyrology in recent years has become interdisciplinary). But as a matter of fact, this exponential growth is the result of a deep trend.

If, in this introduction, I have mostly considered archives, that is because there has been much less interest in libraries. The archival method has more rarely been applied to libraries, for reasons related not only to the difficulty of tracing the books that made up antique libraries now scattered into several collections, but above all because of the state of mind of literary papyrologists who were more interested in the content of the texts than in their context. It is symptomatic that Orsolina Montevecchi, in her handbook, did not devote a single line to libraries while she dedicated a chapter to archives. Fortunately, this has been changing in recent years, especially through the study of some famous ensembles such as the so-called 'Bodmer Library'. ${ }^{10}$

After this long introduction setting out the methodological framework, I will review the two types of sets (archives and libraries), such as documented by the Egyptian papyri and the epistemological reflections which papyrologists have been led to by studying them. But I would also question the distinction we draw between archives and libraries by analysing, in the last part, cases where archives and libraries are mixed and the lessons we can draw from this combination.

\section{Archives}

\subsection{Problems of definition}

The term 'archive' encompasses many realities and there has not always been a general agreement on the meaning and use of this word. ${ }^{11}$

\subsubsection{Public and private archives}

The first distinction that was made between public archives-containing official documents produced by the administration and/or private documents registered

(17), not to mention the mixed ensembles of the recluses of the Serapeum (\# 72) and of Dioscorus of Aphrodite (\# 119). See below.

10 See recently the conference I papiri Bodmer: Biblioteche, comunità di asceti e cultura letteraria in greco e copto nell'Egitto tardoantico, Rome, Università La Sapienza, 3 February 2014 (the proceedings are now published in Adamantius 21 [2015]). See below.

11 See Pestman 1989; Martin 1994; Jördens 2001; Van Beek 2007; Vandorpe 2009. 
and kept by the administration-and private archives, i.e. documents accumulated by an individual, a family or a community of individuals. In papyri, only the first of these receive a designation, i.e. a generic one as $\alpha \rho \chi \varepsilon \tilde{o v}$, or a more specific one

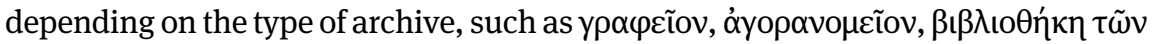

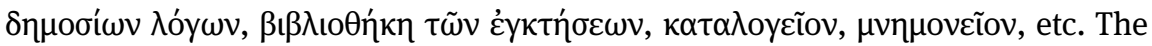
latter ones are never identified by name. People speak of their papers ( $\chi \alpha \rho \tau \alpha i)$, their

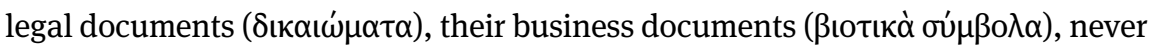
of their 'archives' as a whole. ${ }^{12}$

\section{See for example P.Cair.Masp. II 67167, 33-38 (566-573 CE):}

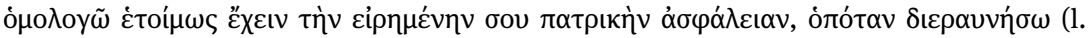

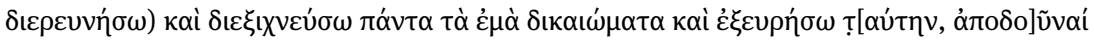

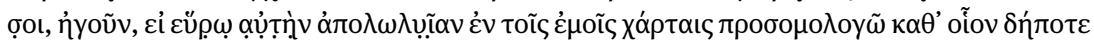

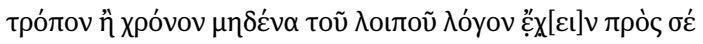

I declare that I am ready to give you back the document (= acknowledgement of debt) signed by my father when I have searched, identified and found it in all my business documents and, if I see that it is lost in my papers, then I also declare that in any way and at any time I will not be holding you any more to account for anything. ${ }^{13}$

Some historians and papyrologists have argued that only public records should be called 'archives' ${ }^{14}$ and denied that denomination to private archives. ${ }^{15}$ But this position is now very much a minority.

The German papyrologist Andrea Jördens, following the terminology developed by Eckhart G. Franz in his Einführung in die Archivkunde, proposed to use, for private archives, the term Nachlass 'succession, inheritance', which is actually more accurate in that it insists on the fact that private archives are collections of documents left by people after their death. ${ }^{16}$

12 P.Tebt. I 52 (114 BCE).

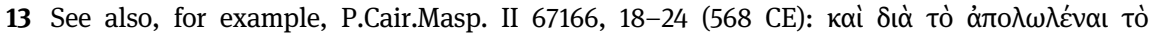

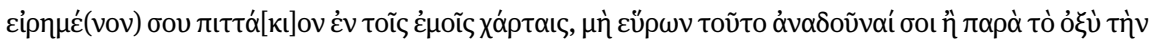

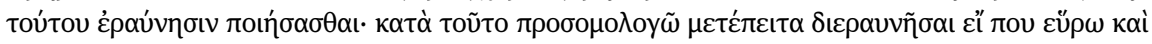

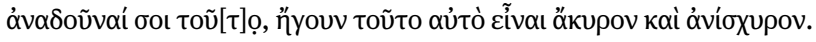

14 See Mélèze-Modrzejewski 1979, 120: ‘[...] les vraies [archives], c’est-à-dire les dépôts publics de documents, et non pas ce qu'on appelle archives dans le jargon papyrologique'.

15 See Moses I. Finley, quoted by Mélèze-Modrzejewski 1989, 559-560 in a new critique of the usage of the word 'archives' by papyrologists. One might note his constant use of inverted commas ('guillemets' in the French print, « archives ») around the word.

16 Jördens 2001, 261. Franz 1993 defines 'Nachlass' as 'die nachgelassene private Registratur einer Persönlichkeit.' He distinguishes between 'echter Nachlaß’ ('der tatsächlich aus der Tätig- 


\subsection{2 'Archive'}

The use of the word 'archive' for collections of a private nature is nonetheless legitimate. However, we need first to agree on what it means. Not every group of papyri is necessarily an archive. The criteria that justify the term 'archive' has been the subject of much debate in recent years.

The first criterion, the most objective, is the fact that the papyri were found together. But it is far from enough. For example, Achille Vogliano discovered, in 1934, in the village of Tebtynis a collection of 750 texts (including Callimachus' Diegeseis) in the cellar of a house, now known as the 'cantina dei Papiri'. But they are actually discarded papyri from various origins and various archives (at least three: Patron's descendants [\# 66], Kronion son of Cheos [\# 125] and Pakebkis' descendants [\# 64]). ${ }^{17}$

Pieter W. Pestman added another decisive criterion: archives are documents 'which in Antiquity had been brought together, for some precise purpose'. ${ }^{18}$ Alain Martin in turn refined this definition: 'elles doivent, dès l'Antiquité, avoir fait l'objet d'une accumulation et d'un classement délibéré'. ${ }^{19}$ Otherwise, we are dealing with a dossier, not an archive. If the criterion of accumulation is objective, that of classification is more subjective and difficult to distinguish a posteriori, especially after the disturbances suffered by the sets before reaching the collections or even before being discovered by archaeologists. However, we may cite some examples of discoveries of archives, classified or arranged as such when they were abandoned or hidden. For instance, the archive of the Narmouthis temple discovered in 1937 by Achille Vogliano:

Un nucleo di questi ostraca era disposto in due grossi recipienti d'argilla e si aveva l'impressione che la loro collocazione-adagiati com'erano l'uno sull'altro-rispondesse ad un vero e proprio ordinamento. ${ }^{20}$

\footnotetext{
keit einer bestimmten Person erwachsen ist und als provenienzmäßig geschlossener Fonds erhalten bleibt'), 'angereicherter Nachlaß' ('der durch eigene Briefe des Nachlassers, einzelne Autographen und Materialien über ihn vervollständigt ist') and 'unechter Nachlaß’ ('der ohne echten Kern nachträglich als Sammlung von Briefen, Manuskripten und Sekundärmaterial über eine Person zusammengetragen worden ist').

17 See Gallazzi 1989, 1990.

18 Pestman 1990, 51.

19 Martin 1994, 570: 'They must be the result of a deliberate accumulation and classification since ancient times'.
}

20 Vogliano 1938, 543. 
Moreover, the ostraca have numbers that correspond to a filing order. ${ }^{21}$

Claude Orrieux added a third criterion: an archive must have been the result of a process of selection:

'Real' archives are identified by two objective criteria: first, they have a natural growth in that they are the spontaneous result of individual or collective activity which gives birth to them and is reflected in them; secondly, they are subject to a partial discrimination, namely between pieces to keep or to destroy, depending on their future use. ${ }^{22}$

But, as noted by Alain Martin, the criterion of partial discrimination is difficult to prove. ${ }^{23}$ In addition, the archives that have survived are themselves discarded material, that is to say sets of pieces that at some point someone decided not to keep, but to discard. In other words, they are 'negative' or 'hollow' archives.

Alain Martin finally distinguishes a special type of archive: the documentary cache ('cachette documentaire'). ${ }^{24}$ It is a group of documents intentionally buried by their owners and being the result of a more drastic selection due to exceptional circumstances (war, rebellion, persecution). They differ from the archives found in situ or those discarded.

\subsubsection{Location of archives}

We can see that the places of discovery of archival collections are crucial to define their profile.

(a) A few have been found in their original location after being suddenly abandoned or destroyed. This is the case of the Thmuis or Bubastos public archives, found carbonized (but legible) after a fire. They are archives that were still being used when they were burned.

(b) Others consist of documents that were still useful but that were hidden at some point. These are archives temporarily out of use but intended to be used again. This is probably the case of the still unpublished archive of Karanis (\# 251)

21 See O.Narm.Dem. II, l-li.

22 Orrieux 1985, 41, my translation (see the original French, 'De "vraies” archives se reconnaissent à deux critères objectifs: d'une part elles ont une croissance naturelle, en ce sens qu'elles résultent spontanément de l'activité individuelle ou collective qui leur donne naissance et s'y reflète; d'autre part, elles font l'objet d'une discrimination partielle, à savoir entre les pièces à conserver ou à détruire, en fonction de leur utilisation future').

23 Martin 1994, 572.

24 Martin 1994, 575. 
'found in a hollow threshold of a door in the 1920,' and certainly of the two archives found in the 'cave of letters' in the Nahal Hever in the Judean Desert where refugees of the Bar Kokhba revolt (132 CE) took shelter. Among them there was a certain Babatha who buried 35 documents having previously taken care to classify them into bundles wrapped in linen and tied with a string, put into a leather pouch, itself put into a water skin (\# 41). ${ }^{25}$ The care taken by Babatha to pack these texts shows that she wanted to recover them, once peace would be restored, to assert her rights to certain properties.

(c) Most archives were discarded in secondary areas of the house: in the basement or cellars (see the Milon archive [\# 141] ${ }^{26}$ ), behind a staircase, or in a tomb (see the archive of the embalmers or choachytai $[\# 50]^{27}$ ). They are collections that people wanted to keep even if they had become obsolete. Most of the time one or more ceramic containers were used: among these is the Totoes archive, from the second century BCE (\# 248), placed in two jars and that of Papas, from the seventh century CE (\# 170) (Fig. 1). Care was taken to protect documents, even if they were out of use, so that they would not shatter, by wrapping them in bundles with a piece of cloth (see archive of Teos, fourth century BCE [\# 228] $]^{28}$ ) or by protecting them with reeds to prevent the rolls from being broken (see the Melitian archive from Labla, 511-513 [\# 83]). ${ }^{29}$ Bundles often demonstrate a clear arrangement, and this arrangement explains the fact that batches of papyri which are held in different collections, but which originally came from larger illegally discovered archives (such as Zeno's [\# 256]) often show an internal coherence corresponding to the original bundles.

25 Yadin 1962, 231-232: 'In one of [a water-skin], a large collection of balls of flax thread and a well packed parcel were found. The outer wrapping of the parcel consisted of a sack, carefully fastened with a twisted rope; inside there was a leather case with many papyri packed tightly together. When the parcel was opened, it was found to contain the archive of Babata daughter of Simeon. [...] Under the skins was found an elegant leather purse, with a rosette design on each of its sides. The purse was torn and the batch of documents it had contained had apparently slipped out of it onto the sloping bottom of the crevice. This batch included a leather scroll fastened with thread; a papyrus deed placed in a reed container; and five rolled papyri.'

26 P.Eleph., 34.

27 See P.Choach.Survey, 10-13.

28 See the picture in Vandorpe 2009, 220-221.

29 Flinders Petrie, quoted by McGing 1990, 67: 'Each [deed] was rolled up separately; the rolls were then bound round, along with slips of reed, to prevent their being bent or broken; then tied up in a linen cloth; next in a large lump of old tattered woollen embroidery; and the bundle placed in a big jar sunk in the ground'. 


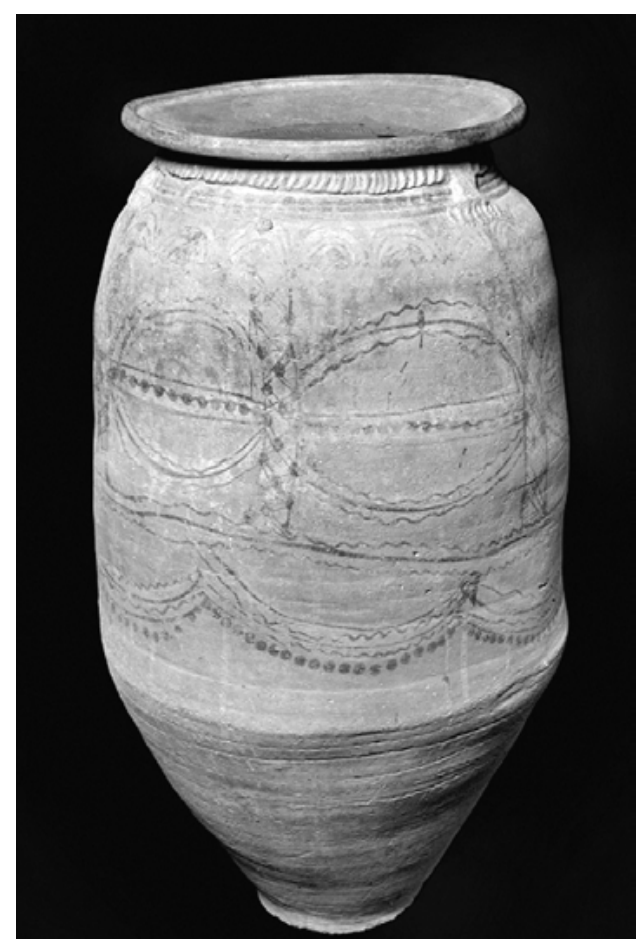

Fig. 1: The jar in which the Archive of Papas was discovered. (C IFAO.

(d) Obsolete archives might also be simply discarded: they ended up in garbage dumps (public or private), more or less scattered or mixed. The way they were excavated did not help matters: in the past, dumps were often excavated without respecting their stratigraphy: 'one attacked the mound laterally, caused slices of it to fall one by one, and sorted out the papyri after each "landslide"” instead of 'removing the layers separately, which demands a high degree of concentration when they cross over or under each other'. ${ }^{30}$ When excavating dumps in the Eastern Desert fortresses, we were able to distinguish mini-archives of ostraca corresponding to the contents of the basket with which the soldier discarded documents which had accumulated in his room when he wanted to clean it. $^{31}$

30 Cuvigny 2009, 53.

31 See J.-P. Brun in Cuvigny (ed.) 2006, 63-67. 
(e) Obsolete archives could be also recycled. The scrolls they were composed of, normally only written on the front side, could serve as second-hand paper: their back could be used for copying other documents. This was the case with two rolls from the archive of the strategos of the Panopolite nome (written in 298 and $300 \mathrm{CE}$ ), which were reused by an individual, Besas Alopex Antoninus, after being stuck together (one written face against the other), and then cut into sheets to make a codex (P.Panop.Beatty). Papyrus could also be reused for other purposes: for mummy cartonnage (masks, foot cases, pectorals, or leg guards made with papyrus and covered with stucco before being painted), or for wrapping and stuffing mummified crocodiles such as those discovered by Grenfell and Hunt in 1900 at Tebtynis, or in 1901 at Talit. ${ }^{32}$ After dismantling cartonnage and opening mummies, papyri sometimes forming archives were discovered, especially administrative archives since the bureaucratic process obliged offices to discard their papers regularly. Some archives (such as that of Adamas, head of the public granary, 199-196 BCE [\# 2]) were scattered among several crocodiles. Unfortunately, information about the provenance of the papyri extracted from crocodile mummies was not recorded by the excavators.

\subsubsection{Common characteristics of archives}

All this shows that the term 'archive' encompasses a variety of archaeological realities corresponding to collections of a different nature. Most papyrological archives, however, have several common characteristics that must be carefully considered by the historians who exploit them:

(a) They are out-of-date, dead. With the rare exception of those which were found in situ, fossilized by an incident like a fire, archives are actually sets of documents that were deemed unnecessary at some point and that were discarded, while relevant documents continued to be used and therefore retained. ${ }^{33}$ As I have already noted, they are 'negative' or 'hollow' archives, and the principles of selection and organization they underwent, which are inherent in the concept of archive, are almost always disturbed by losses and subtractions.

(b) They are partial: either, as we have seen, because of the choices made by heirs or successors, or because of the choices made by the owner who, under the

32 See http://www.papyrology.ox.ac.uk/POxy/VExhibition/images/c7.jpg. (last accessed on 27/02/2017).

33 Nevertheless, the fact that they were often discarded in a part of the house (such as the cellar) shows that they could continue to have some historical or sentimental value. 
constraints of particular circumstances, may have wanted to keep the part of his archive he considered most useful (thus Babatha hid the documents which were strictly necessary); or because of accidents which occurred during their discarding, recycling and conservation. Whatever their size (the smallest contains two papyrus found bound together, ${ }^{34}$ and the largest, the Zenon archive [\# 256], has nearly 2,000 papyri), these archives are fundamentally incomplete. Still worse, with the exception of archives discovered in a scientific excavation, one is never sure, when working on an archive, that it has been discovered in its entirety, given that it could have been scattered all over the world. When trying to reconstruct it, we may deal only with a subset, a dossier. That is why the list of papyrological archives is full of dossiers, and not actual archives.

Problems of definition and methods are more serious than they seem to be due to the fact that archives rarely came down to us in full; these problems affect the way we reconstruct and analyse these sets. It is time to try to sketch a typology of the archives from Greco-Roman Egypt-I shall be brief because this typology is in no way specific to Egypt.

\subsection{Typology}

Three types of archives can be distinguished:

\subsubsection{Official or state archives ${ }^{35}$}

These represent less than a quarter of the known archives. ${ }^{36}$ But this figure is misleading. We have in fact only very few examples of real official record offices: for example, the Bibliotheke of Thmouis (\# 43) or the central archive of the Boubastite nome (\# 22), both destroyed by fire that has virtually 'fossilized' them. Most of the time we are dealing either with discarded texts (mummy-cartonnages) or texts taken by officials when they left their offices, and found in their houses, often mingled with their personal papers. In other words, we do not know much about official archives, except their organization, which may be reconstructed from documentary

34 P.Mich. VIII 490-491 (\# abest).

35 See in general Cockle 1984 and Burkhalter 1990.

36127 entries in the Papyrus Archives in Graeco-Roman Egypt database, among which 117 are exclusively 'official'. 


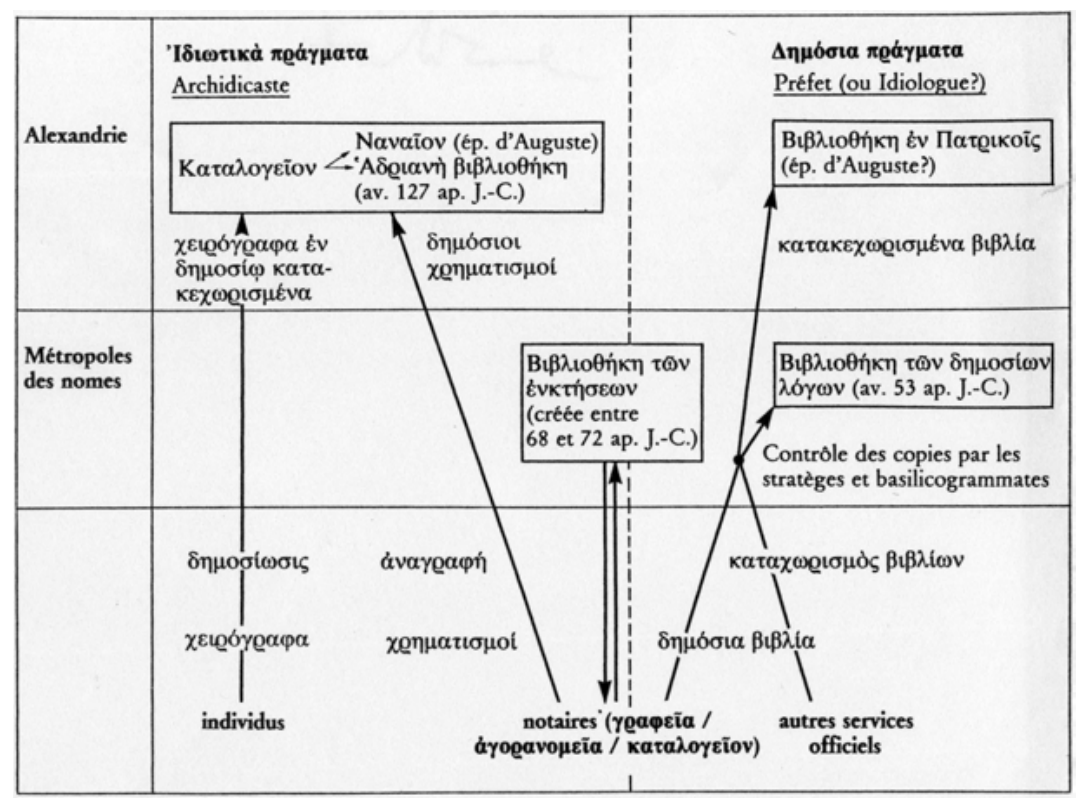

Fig. 2: Local and central archives in Roman Egypt after Burkhalter 1990, 216.

sources (Fig. 2). In fact we know them mainly through 'privatized' samples, documenting the various levels of local administrations-one must keep in mind that weather conditions did not allow the preservation of papyri in Alexandria, the capital of Egypt. ${ }^{37}$

\subsubsection{Private archives}

In theory, we should differentiate between:

(a) personal archives, consisting of papers of an individual;

(b) family archives, consisting of contemporary documents belonging to various members of the same family and collected by the head of the family, but also created diachronically by the accumulation of papers over several generations.

The best example is perhaps the archive of the Apions, an important aristocratic family (\# 15) we can follow from Strategios I in 436 down to Apion III in $619 / 620 .^{38}$

37 On the special case of the tomoi synkollêsimoi, see Clarysse 2003.

38 See Gascou 2008, 183-195 for the Apion family; Mazza 2001; Hickey 2012. 
(c) professional archive (business or book-keeping archive) made up of documents related to the owner's profession.

Generally, these three types of archives are mixed. The best example is the Zenon archive (\# 256) that contains business papers collected by Zenon while he was a representative of the dioikêtês (= minister of finance) Apollonios in Palestine (Phase I, 261-258), a secretary of Apollonios in the Delta (Phase II, 258-256) and a manager of Apollonios' estate in the Fayyum (Phase III, 256-247), as well as all of the private papers written during these three phases and when he retired in Philadelphia as a private citizen (Phase IV, 248/247-229). ${ }^{39}$

\subsubsection{Community archives}

Community archives include archives of professional and cult associations, temples, church, monasteries. They are half-way between official and private archives.

\section{Libraries}

Libraries, public or private collections of literary texts, raise other problems. The most important of these are of a heuristic nature. ${ }^{40}$

\subsection{Tracing libraries}

In comparison to archives, the number of libraries discovered in Egypt is difficult to assess. The Papyrus Archives database of Trismegistos lists 17 libraries plus 2 libraries combined with archives (4\%), against 463 purely documentary archives (96\%). Even if this database does not intend to be exhaustive for libraries, the numerical disproportion between libraries and archives is striking. This is a wellknown phenomenon as far as papyrology in general is concerned: among the nearly 70,000 edited papyri, only 9,000 are literary texts ${ }^{41}$ against 60,000 documents, that is to say, literary papyri account only for $12.8 \%$ of papyrological sources. This is due not only to an extensive bureaucracy that generated many

39 On these phases, see Clarysse/Vandorpe 1995, 24-31.

40 See now in general Houston 2014, which I was, unfortunately, unable to use for this paper.

41 I limit myself to the papyri of Egyptian origin. 
documents, but also to the fact that books, because they were expensive, not as immediately useful as documents, and required owners to have a good level of literacy, could concern only a narrow segment of the population. But the disproportion between libraries and archives is even greater than that between literary and documentary texts ( $4 \%$ versus $12.8 \%$ ). This is due to the insurmountable difficulty of contextualizing literary papyri, that is to say, to put them in connection with other literary texts and with readers or owners. And yet, a library is by definition a group of books stored together at the disposal of one or more individuals. The majority of literary papyri were indeed found illegally, in other words they have no provenance and were scattered (through the networks of antique dealers), while documentary texts that might have accompanied them and thus could have delivered information on their context were separated from them or, conversely, documents of other contexts or provenances were unduly mixed with them. An example is the library (combined with an archive) from Lycopolis and now in the Bibliothèque de l'Institut de France (Paris)..$^{42}$ Among the literary texts of this homogeneous set, there is a fragment of a copy of Aristophanes' comedies which can be joined to three fragments belonging to the Bodleian Library (Oxford $)^{43}$ (Fig. 3). But these were published in 1905 by Grenfell and Hunt who had bought them 'in December 1904 in Cairo, chosen out of a box full of Byzantine papyri from Ashmunen' (ancient Hermopolis). ${ }^{44}$ In fact, the Paris papyri were acquired at about the same time as the Oxford ones (December 1904 and early 1905). It is likely that they were purchased from the same antique dealer, who mixed papyri from various provenance. ${ }^{45}$ This is an example of the difficulties literary papyrologists have to cope with when trying to find the provenance of ancient books.

No internal data make it possible to determine the provenance of a papyrus or its connection with a library: with very few exceptions, books in this periods had no colophon (unlike the Coptic ${ }^{46}$ or Greek medieval books) that could provide

42 See Fournet/Gascou 2008. An edition of these texts (as well as many documentary texts) is being prepared by myself and Jean Gascou.

43 Bodl. Ms. Gr. class. f. 72 (P), edited by Grenfell/Hunt 1905, 212-217.

44 Grenfell/Hunt 1905, 212. For this reason, they were included in the list of literary texts from Hermopolis provided by van Minnen and Worp 1993, 151-186.

45 Fournet/Gascou 2008, 1045-1046.

46 See van Lantschoot 1929. 


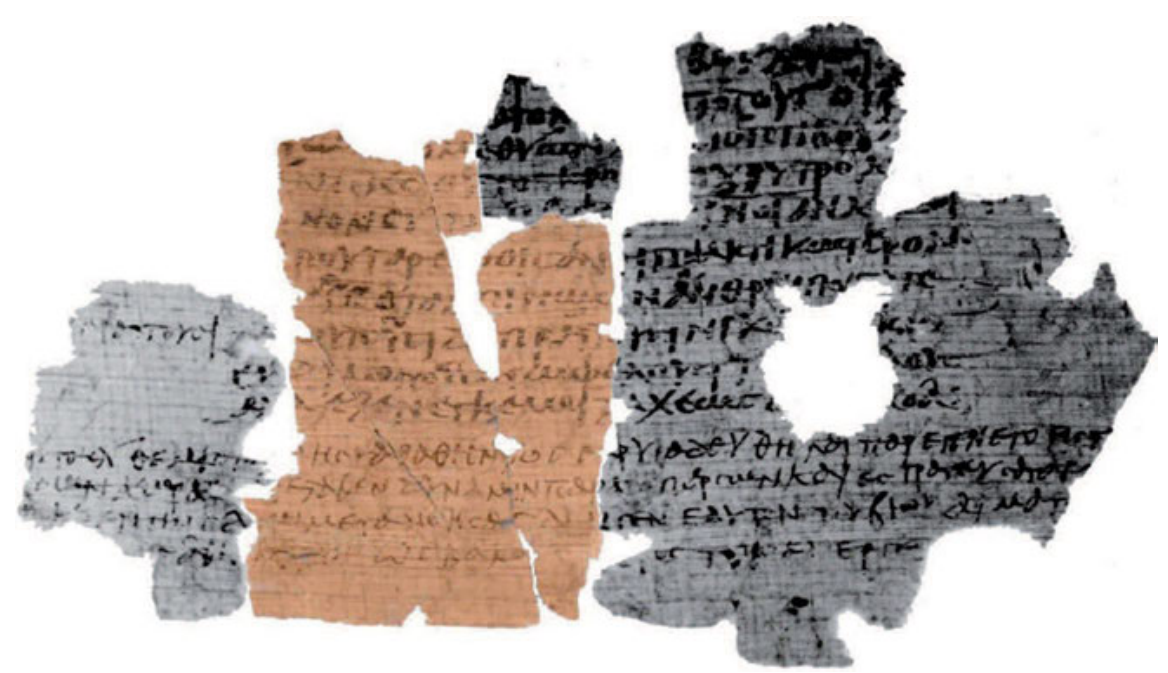

Fig. 3: A sheet from a copy of Aristophanes' Knights: the black-and-white fragments are in Oxford, the colour one in Paris (From CLGP Pars I, vol. 1, fasc. 4, tab. II).

information about the copyist, date and context of the copy; ${ }^{47}$ they had no exlibris or bookplates that would have allowed us to know the owner.

Under these conditions, reconstructing ancient libraries is an almost impossible task. And it is true that it has not aroused the same interest from scholars as the reconstruction of archives. In the past, attention has too often been focused on the famous Library of Alexandria, of which we know little, and only through literary sources, at the expense of the other more real and less fantastic libraries. Moreover, the mass of literary texts found in Egypt has led papyrologists to devote themselves to editing and studying them for their contents and what they can bring to our knowledge of literate practices, neglecting their documentary dimension, their Sitz im Leben. Finally, Egypt has not delivered as spectacular archaeological remains as the great libraries of Asia Minor, Greece and Italy, on which most of the books about libraries of antiquity are based. Elsewhere, we have the

47 There are a few counter-examples: among them are P.Lond.Lit. 11 (first century CE, $\mathrm{MP}^{3}$ 0697, TM 60829), a copy of Iliad to which a kollêma was added with the title and a colophon giving the name of the copyist (Kallinos)-although there is some doubt about the connection of this kollema with the rest of the roll (see edition); P.Lond.Lit. 97 (second century CE, MP ${ }^{3}$ 2434, TM 63519), a mime with, on the verso, the name of the copyist and of the library where the manuscript used for copying the papyrus was; P.Mil.Vogl. I 19 (MP ${ }^{3}$ 1197; TM 59147), where there may be an allusion to the Roman copyist Sosius (see Turner 1980, 51). 
buildings, but not the texts they contained; in Egypt, we have the texts but rarely the buildings, and yet the texts originating from them are scattered. Therefore, paradoxically, Egypt is the country where the least is known about libraries, despite the fame of the Library of Alexandria.

Libraries in Egypt can be reconstructed from several types of data:

\section{(a) Archaeological data}

Very rare are the libraries that have been found in situ: the most famous is Lucius Calpurnius Piso's library found in his villa at Herculaneum. ${ }^{48}$ But this case is unrelated to Egypt. The other examples are late and from religious contexts:

- The White Monastery library (\# 500) was partially discovered in a small room of the monastery in 1883 by Gaston Maspero. 'Ils y étaient entassés, pêle-mêle sur le sol, “couverts de taches d'eau, de dépôts de terre, de fiente de pigeons ou même d'ordures humaines." ${ }^{49}$ But in fact, the narrowness of the room, for a library that had probably contained more than 2,000 books shows that it was a secondary deposit.

- Smaller are the personal 'libraries' of some monks from the Monastery of Saint Epiphanius, found in their owner's cells. For instance, in Cell A, archaeologists discovered on a mattress fifteen ostraca (sixth-seventh century CE; \# 436) containing biblical and liturgical texts and other texts elsewhere in the same cell. ${ }^{50}$

- Books from ancient libraries have more often been found in dumps, or in contexts which cannot be reconstructed because of excavations which were poorly documented or which ignored stratigraphy. This is the case of most of the papyri from Oxyrhynchus, a city which has delivered the greatest quantity of literary papyri ever found (more than 3,000, or $1 / 3$ of all the literary papyri from Egypt), particularly during the three great 'Literary Finds' (in the winters of 1905-1906), but in excavations carried out according to outdated standards, ignoring the stratigraphic method. By studying the concentration of finds, some collections can be restored. This method was recently applied by George W. Houston, especially for the 'Second Great Find', ${ }^{51}$ which allowed him to reconstitute the profile of the owner of the library and the history of its formation:

\footnotetext{
48 See the introduction to this library recently published by Delattre 2006.

49 See Lefebvre 1920, 500. On this library, see Orlandi 2002; Emmel 2008.

50 Bucking 2007.

51 Houston 2009, esp. table 10.2 and 10.3.
} 
The history of our collection, then, would look something like this: toward the middle of the second century, our collector began to assemble a collection strong in poetry. He may have inherited a preexisting collection, or perhaps he bought a number of rolls (hence the volumes copied in the first century and earlier); he certainly purchased or commissioned a number of new rolls (thus the large number of texts copied in the middle and second half of the second century). The collection so formed reflected its originator's interest in poetry and maintained its shape over time, being added to even when it passed to other owners. At some point toward the middle of the third century, the collection seems to have stopped growing and fallen out of use, and within two or three generations after that the fragments we now have were discarded.52

- Most of the great literary discoveries have been made illegally. This is the case of the 'Bodmer Library' (third-fifth century CE, \# 519), the Gnostic Library of Nag Hammadi (fourth-sixth century CE, \# 496), the Origenian Library of Tura (sixth-seventh CE, \# abest), the Theban Magical Library (third-fourth century CE, \# 363), the Manichean Library of Medinet Madi (third-fourth century CE, \# 497), to name only the most famous. And almost all of them (\# 519, \# 496, \# abest, \# 363) were hidden in caches. We have no archaeological data for them and must resort to other methods.

\section{(b) Data from 'Museum archaeology'}

I have already mentioned this method, but its most spectacular application has been in the case of the 'Bodmer Library', also known as the 'Dishna Papers' (thirdfifth century CE, \# 519), discovered clandestinely in the 1950s. By conducting an inquiry into museums or collections that had acquired papyri at this time and interviewing the persons involved in this discovery, James G. Robinson proposed a reconstruction of the events which led to the papyri being scattered around the world, and, more importantly, established a list of the texts that were part of this library. ${ }^{53}$ Even if some of his conclusions are questionable, I was recently able to confirm the find-site which he had proposed, using a documentary papyrus from the binding of one of the books of this library; this discovery has demonstrated that it came from the region of Dishna, and not Panopolis, as some had thought. ${ }^{54}$

52 Houston 2009, 260-261.

53 Robinson 2011.

54 See Fournet 2015a. 


\section{(c) Codicological and palaeographical data}

The form of literary texts, the type of writing, and the use of diacritics and decorations in their copying can inform us about the milieu of a particular book and, consequently, when scriptoria and libraries are connected, about its possible provenance. ${ }^{55}$ This is how many books have been connected with the library of the White Monastery, or those of the Wadi Natrun monasteries. But much work remains to be done in this area.

\section{(d) Textual data}

Libraries can be known through texts that talk about them. Papyrological sources have transmitted lists of books. Rosa Otranto has identified, in Greek papyri, 19 lists of non-Christian books and six of Christian books. ${ }^{56}$ We must add to them lists in Coptic. ${ }^{57}$ These lists are of various kinds:

- Some tell us about how books circulated and were copied: these are letters in which one asks to borrow books or calls for the return of lent books, or talks about books that have been commissioned. For example, P.Mil.Vogl. I 11 (= Corpus dei Papiri filosofici I.1 * 6), letter from the second century CE:

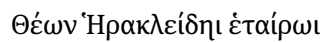

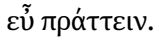

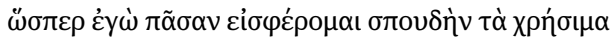

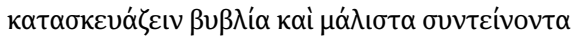

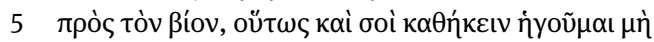

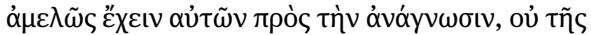

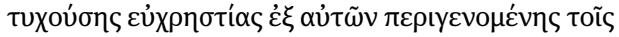

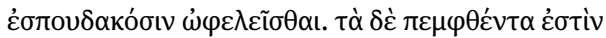

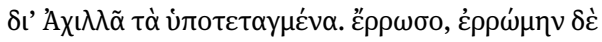

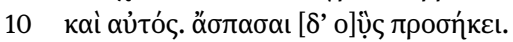

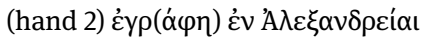

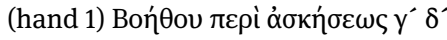

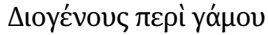

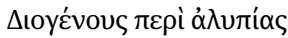

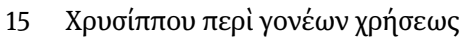

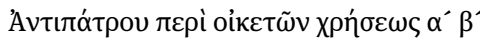

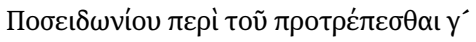

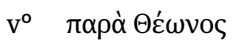

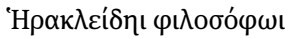

55 See one example with Gascou 2008, 361-363 about the 'Panopolite format.'

56 Otranto 2000.

57 These lists were reviewed by Schmelz 2002, 93-102. Add SB IV 1831, 6-11. 
Theon wishes success to his companion Heracleides.

As I put my zeal in the task to provide you with useful books, and especially those that give meaning to life, I do not think you can overlook their reading given the advantage taken from them by those seeking this benefit. Below is the list of books I am sending via Achillas. Farewell. As for me, I am well. Give my greetings to those to whom it is appropriate.

Written in Alexandria.

Boethus, Exercise, Book III and IV.

Diogenes, Marriage.

Diogenes, Freedom from pain.

Chrysippus, Relationship with parents.

Antipater, Relationship with the house staff, Book I and II.

Posidonius, Exhortation, Book III.

verso

From Theon to Heracleides philosopher.

- Some lists are, however, real inventories (partial or complete) of book collections from a library or institutions (as monasteries or churches) including a library.$^{58}$ One of the finest specimens of inventory is preserved on an ostracon from the library of the Monastery of Saint Elias (SBKopt. I 12, seventh-beginning of the eighth century CE).$^{59}$ For each entry in this 111 line text, it is specified if the book is on papyrus (ХАPTHC) or parchment (ME $<M>$ BPANON), even-

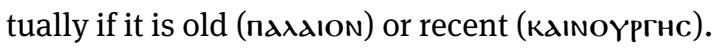

These inventories compensate somewhat for the disappearance of ancient libraries that the sands of Egypt have not preserved, and the scattering of those that were discovered illegally.

\subsection{Typology}

Unlike archives, libraries are never mentioned as such in papyri. The most common term to designate a library, $\beta \iota \beta \lambda_{\llcorner} \theta \eta \dot{\kappa} \kappa$, is used in the documentary sources only for official archives, as we have seen. Yet, it is also the word that designated libraries in Greco-Roman Egypt as evidenced by a note added in red ink on the back of a copy of prose mimes, P.Lond.Lit. 97 (second century CE),${ }^{60}$ which provides not only the name of the copyist, but also that of the library where he got the manuscript he copied:

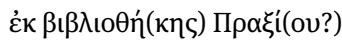

58 Houston 2009, table 10.1.

59 Coquin 1975.

$60 \mathrm{MP}^{3}$ 2434, TM 63519. Last edition: Gammacurta 2006, no. 9. 


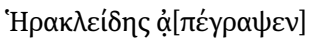

From Praxias’ library. Copied by Heracleides

The typology of libraries is quite similar to that of archives:

\section{(a) Public or institutional libraries}

In this category, we know, strictly speaking, only the famous Great Library attached to the Museum and the Library of the Serapeum, both founded and subsidized by the king. If the first seems to have been reserved for scholars of the Museum, the second might have been open to the public, according to a passage from Aphthonius' Progymnasmata, telling us that it was intended 'to give the whole city an opportunity to philosophize' ${ }^{61}$ These two libraries, widely mentioned in literary sources,${ }^{62}$ have left no trace in documents, ${ }^{63}$ and so I will not dwell on them.

Among institutional libraries, there were those of gymnasia, where young Greeks received sport, military and secondarily cultural training. But we have, for Egypt, no proof of their existence, although it may be inferred from what is known to the rest of the Greek-speaking world. ${ }^{64}$

\section{(b) Private libraries}

These have left more traces in the documentation, and some have even come down to us, as seen before, although not without accidents. While some libraries are general and correspond to the literary tastes of their owner (we saw above that of a lover of poetry in Oxyrhynchus), many others are related to the owner's profession or explained by it. We are fortunate to have some of these specialized libraries: those of two magicians (one from Thebes, third-fourth century CE, \# 363, one from Heracleopolis, fifth-sixth century CE, \# 380); that of an alchemist or magician (Arsinoite, seventh-eighth century CE, \# 435 $5^{65}$ ); perhaps that of a doctor (Lycopolis, fifth century CE, \# 434); that of a rhetorician, Ammon the scholasticus (Panopolite, fourth century CE, \# 31).

61 Prog. 12. According to Canfora 1988, 75-76, Diodorus visited this library during his stay in Egypt. 62 See Calderini 1935, s.v. A` $\lambda \varepsilon \xi \alpha_{\alpha} v \delta \rho \varepsilon เ \alpha, 102$ and 140-141.

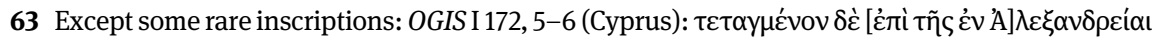

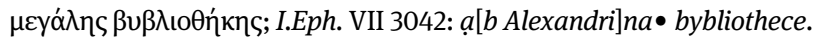

64 See Delorme 1960, 137-140; Maehler 1983, 197.

65 See Dosoo forthcoming. 


\section{(c) Libraries belonging to communities}

These are perhaps best known through spectacular and often clandestine discoveries. Most of them are the libraries of religious communities. With the exception of the library of the Tebtynis temple (fourth century BCE-third century CE), containing books in hieratic and demotic, found in dumps around the temple and scattered among at least eight collections, they are related to Christian monastic establishments: ${ }^{66}$ besides the White Monastery library, mentioned above, we know the Origenian library of the Monastery of Saint Arsene found in Tura (sixth-seventh century CE, \# abest), ${ }^{67}$ the library of the Monastery of Apa Jeremias in Saqqara (fifthsixth century CE, \# 443), and the library composed of the Chester Beatty biblical papyri I-XII, the location of which is still debated (third-fourth century CE, \# abest). Some books may have also belonged to school libraries: it has been suggested that the 'Bodmer library'68 (third-fifth century CE, \# 519), which, alongside Christian books, contained works of secular literature, was a school library; other scholars are inclined to think it was rather the library of a church, a monastery or a sectarian community. It is not, ultimately, impossible that it was a school library in a monastic environment. ${ }^{69}$

The example of the 'Bodmer library' is symptomatic of the difficulties we may encounter when we have to reconstruct the profile of the users of a library of which we no longer know the environment. Attempts have been made to extrapolate from the books it contained, but 'a text, or even a whole library of texts, does not make a sect or a community'. ${ }^{70}$ Is not the very term 'community' improper, in that it implies a homogeneous profile for all the users? Moreover, the 'Bodmer library' developed over three centuries; it is therefore likely to be the aggregate of several collections from various origins that do not necessarily reflect the state of mind of the users at the end of its life. In short, what we lack, in this case, are documents that would tell us more about the context and environment of this library.

But sometimes literary and documentary texts are found in the same collection.

66 The location of the monasteries, installed in the desert, allowed better conservation of texts than churches in urban areas.

67 See Koenen/Müller-Wiener 1968, 41-63 and van Haelst 643 (with bibliography).

68 See van Haelst 7.

69 See Fournet 2015a.

70 Bagnall 1993, 304, on the Nag Hammadi Library. 


\section{Archives and libraries: two sides of the same coin}

So far I have spoken of archives and libraries separately. This separation corresponds to an epistemological cleavage that divides papyrology: on one side, documentary papyrology, on the other literary papyrology. And papyrologists often specialize in one or the other. But this cleavage between documentary collections (archives) and literary collections (libraries) is reductive and unhelpful.

\subsection{Subliterary papyri}

This black and white perception of papyrology does not take into account an intermediate category of texts which makes the link between archives and libraries, between documentary and literary papyrology: subliterary papyri (school texts, magical or medical recipes, etc.). What to do with them? Should we put them on the side of archives (since these are texts that reflect an action in the everyday life) or of libraries (as they result from the study of literature)?

\subsection{An artificial difference}

The difference between archives and libraries that we make today did not have much meaning for the ancients:

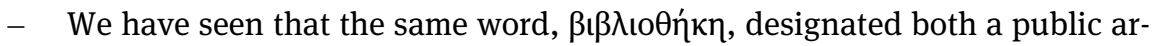
chive and a library.

- As far as individuals are concerned, books and documents were stored in the same place.

- Literary and documentary texts could be written on the same sheet of papyrus, which shows a permeability between these two types of texts. One could reuse a document in order to copy texts of a literary nature in the areas left blank. That is the case of a scroll containing a Coptic settlement that has been transformed into a codex for a handbook of verb conjugation, found in the archive or library of Dioscorus of Aphrodite. ${ }^{71}$ Conversely, literary rolls could

71 P.Aphrod.Lit. III 1, sixth century CE; MP 0355 \& 2161.01, TM 59707. A revised edition of this handbook (taking into account new fragments) is in press (Fournet forthcoming). 
be reused as support for documents, such as a copy of Homer from the archive or library of Epagathos (first century CE; \# 134), the back of which was reused for writing or copying a lease contract, in addition to writing exercises using the text of Homer, in Epagathos' hand. ${ }^{72}$ These secondary uses are not always accidental and can provide interesting information on the profile of those who made them: in the archive of Heroninos, a manager of Appianus' estates (third century CE; \# 103), there was found a letter from Timaios to Heroninos (SB XVIII 13609), written on a sheet cut from a used roll containing the Iliad. ${ }^{73}$ The same Timaios sent another letter to Heroninos, P.Flor. II 259 (249-268), to claim corn he had delayed in shipping to him. He added in the

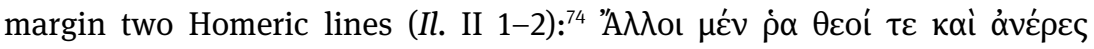

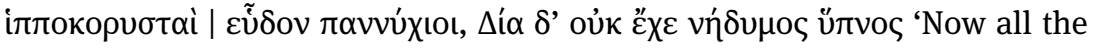
other gods and men, lords of chariots, slumbered the whole night through, but Zeus was not holden of sweet sleep'. These lines are a kind of postscript and are 'ironicamente allusive all'inerzia di Heronino o della gente del suo ufficio'. ${ }^{75}$ 'Possibly the central secretariat [sc. of the administration of Appianus' estate] included one or two scribes who were partly employed as literary copyists, and, when they recopied damaged rolls from Appianus' library, the rolls were then reused for estate correspondence. ${ }^{76}$ Timaios was one of them, which would explain not only his knowledge of Homer, but also the fact that he used old copies of this author to write his letters.

- Finally, books and documents, after mixing on the same shelves, were often stored in the same jar or in the same cache and ended their lives together. The result is a set that combines an archive and a library, what we could call an 'archive-library'. The two most notable examples are the archive-library of the katochoi (recluses) of the Serapeion (Memphis, second century BCE, \# 119) and that of Dioscorus of Aphrodite (Aphrodite, sixth century CE, \# 72).

I have to add a caveat to what I have just said. There is a difference between literary and documentary collections that historians and specialists of literature must take into account: if archives could become quickly outdated and therefore put aside in a jar, or discarded, books could be of interest to future generations, and thus had a longer period of use. Therefore, successors might decide to put away

72 MP $^{3}$ 0643; TM 60260.

73 The recto contains Il. VIII 30-54 (MP³ 819.1). See Rathbone 1991, 12-13.

$74 \mathrm{MP}^{3}$ 623; TM 60203.

75 Comparetti in the edition.

76 Rathbone 1991, 12. 
documents and keep books for themselves. As a result, libraries found along with the archives only partially reflect the owner's literary interests; they are rather evidence of the disinterest of the person who discarded them. For instance, the jar into which Dioscorus' library was put away contained classical literature (Homer, Menander, Old comedies), but no Christian text, which may seem strange for someone whose father founded the monastery where Dioscorus probably ended his life. This means that these classical texts were not of interest to Dioscorus' heirs (as shown by the fact they employed the codex of Menander as a stopper for the jar!) while they continued to use the Christian texts which they kept.

\subsection{The necessity of establishing links between archives and libraries}

Reconstructing archives or libraries, as we saw in the first two parts, is not enough: we have to combine them as much as possible and cross-check the information given by each of them. Only then will we be able to put books back into the context of their readers and therefore to offer a sociological approach to literature, but also, conversely, to put documents back into the context of their drafters' and readers' literary training. This would lead to the abolition of the cleavage which I have discussed between literature and documents, by trying to identify potential interactions between these two spheres-interactions which became stronger and stronger from the third century onwards. One archive-library demonstrates this particularly well, namely that of Dioscorus of Aphrodite (sixth century CE). ${ }^{77}$

This collection contains not only documents written by Dioscorus and by others, but also poems that he composed ${ }^{78}$ and a part of his own library, including two codices containing Greek comedies (notably of Menander, one of the most important comic poets), ${ }^{79}$ a codex of Homer's Iliad ${ }^{80}$ and another one containing scholia on the Iliad (that is to say a glossary of difficult words or expressions in Homer) ${ }^{81}$ It is the sole papyrological set containing at the same time an original work (Homer), a scholastic book allowing to learn and understand it (the scholia) and literary compositions bearing evidence of its influence on them (the poems). Thus, it sheds light on the three main stages of the Greek learning: schooling,

77 See Fournet 1999 and 2015b.

78 P.Aphrod.Lit. IV (edited in Fournet 1999).

$79 \mathrm{MP}^{3} 1301$ et MP $375=$ TM 61596 (the TM and Cedopal bases do not make the difference between the two codices).

80 P.Aphrod.Lit. I; MP ${ }^{3}$ 658; TM 61072.

81 P.Aphrod.Lit. II; MP ${ }^{3}$ 1171; TM 61011. 
reading books during one's life and composing literature. The archive-library of Dioscorus shows how those three stages could link to one another.

The archive thus affirms the interaction between literature and documents. The first phenomenon arising from this interaction is one that I have proposed to call the 'literarisation of the document': ${ }^{22}$ quotations from literary works, paraphrases of famous authors, refined expressions, sophisticated terms often derived from poetry began to invade documents. ${ }^{83}$ Even in daily life, one tried to assert one's culture and to use it to one's advantage. The archive-library of Dioscorus exemplifies this phenomenon. Even when he drafts a document, Dioscorus continues to be a poet. This is especially obvious in his petitions. ${ }^{84}$

A reverse, but actually complementary, development also took place: a 'documentarisation' of literature. Literature is also influenced and invaded by documents. The literary corpus opens to documentary genres. Letters and those characteristic artefacts of Late Antiquity, petitions, become, as we have already seen, literary products and sometimes claim a literary status. This phenomenon goes so far that Dioscorus does not hesitate to use poetry for merely documentary purposes. The 'documentarisation' of literature also lies in the fact that the most famous authors, such as Homer or Menander, were given a new function, and obtained a practical role. If Dioscorus had in his library the works of Homer and Menander, it is perhaps because he regarded them as practical handbooks useful to aid in the composition of all sorts of written deeds. This hypothesis is favoured by the number of quotations from these two poets in the documentary production of Dioscorus.

All of these phenomena would not be visible if his library and his archive were not placed in relationship to one another. But this is often hard to do: the first obstacle lies in the nature of literary papyri, which are, as we have seen, difficult to contextualize. But the biggest obstacle could be the epistemological blockage that still separates the world of documents, domain of historians, and the world of books, domain of philologists and specialists of literature. Dialogue between these groups is still too rare, at the expense of a richer and more comprehensive vision of reality. I hope I have made my contribution to this dialogue by promoting the concept of the 'archive-library.'

82 Fournet 2003, 112.

83 On this phenomenon, see recently Fournet 2013.

84 See Fournet 2004, 61-74. 


\section{List of sigla, abbreviations and online resources}

Papyrological publications are abbreviated according to the:

Checklist of Greek, Latin, Demotic and Coptic Papyri, Ostraca and Tablets (http://pa-

pyri.info/docs/checklist).

Otherwise:

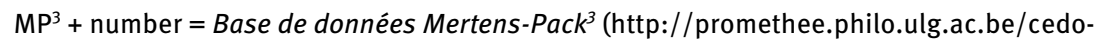
palMP3/indexanglaisMP3.aspx);

Van Haelst + number $=$ van Haelst 1976;

$\mathrm{TM}+$ number = Trismegistos texts database (http://www.trismegistos.org/index2.php);

\# + number = Papyrus Archives in Graeco-Roman Egypt (http://www.trismegistos.org/arch/index.php).

\section{References}

Bagnall, Roger S. (1993), Egypt in Late Antiquity, Princeton: Princeton University Press.

Bagnall, Roger S. (ed.) (2009), The Oxford Handbook of Papyrology, Oxford: Oxford University Press.

Bucking, Scott (2007), 'Scribes and Schoolmasters? On Contextualizing Coptic and Greek Ostraca Excavated at the Monastery of Epiphanius', in Journal of Coptic Studies, 9, 21-47.

Burkhalter, Fabienne (1990), 'Archives locales et archives centrales en Égypte romaine', in Chiron, 20, 191-216.

Calderini, Aristide (1935), Dizionario dei nomi geografici e topografici dell'Egitto grecoromano, I/1, Il Cairo: Società reale di geografia D'Egitto.

Canfora, Luciano (1988), La véritable histoire de la Bibliothèque d'Alexandrie, Paris : Éditions Desjonquères.

Clarysse, Willy (2003), 'Tomoi synkollesimoi', in Maria Brosius (ed.), Ancient Archives and Archival Traditions. Concepts of Record-Keeping in the Ancient World, Oxford: Oxford University Press, 344-359.

Clarysse, Willy, and Katelijn Vandorpe (1995), Zénon, un homme d'affaires grec à l'ombre des Pyramides (Ancorae 14), Louvain: Leuven University Press.

Cockle, Walter E.H. (1984), 'State Archives in Graeco-Roman Egypt from 30 BC to the Reign of Septimius Severus', in Journal of Egyptian Archaeology, 70, 106-122.

Coquin, René-Georges (1975), 'Le catalogue de la bibliothèque du couvent de Saint-Élie “du rocher"', in Bulletin de l'Institut Français d'Archéologie Orientale, 75, 207-239.

Cuvigny, Hélène (ed.) (2006), La route de Myos Hormos. L'armée romaine dans le désert Oriental d'Égypte (Fouilles de l'IFAO, 48), 2nd ed., Le Caire : Institut français d'archéologie orientale.

Cuvigny, Hélène (2009), 'The Finds of the Papyri: The Archaeology of Papyrology', in Roger S. Bagnall (ed.), The Oxford Handbook of Papyrology, Oxford: Oxford University Press, 30-58.

Delattre, Daniel (2006), La Villa des Papyrus et les rouleaux d'Herculanum. La Bibliothèque de Philodème (Cahiers du CEDOPAL 4), Liège : CEDOPAL et Les Editions de l'Université de Liège. 
Delorme, Jean (1960), Gymnasion. Études sur les monuments consacrés à l'éducation en Grèce (des origines à l'Empire romain), Paris : Éd. E. de Boccard.

Dosoo, Korshi (forthcoming), 'Horus, Sabaoth, Satanas: La "Bibliothèque de Berlin" et autres fonds d'archives magiques dans l'Égypte romaine et les premiers siècles de la période islamique', in Jean-Charles Coulon (ed.), La magie et les sciences occultes dans le monde islamique, Paris.

Emmel, Stephen (2008), 'The Library of the White Monastery in Upper Egypt', in Harald Froschauer and Cornelia Römer (eds), Spätantike Bibliotheken. Leben und Lesen in den frühen Klöstern Ägyptens (Nilus 14), Vienna: Phoibos-Verlag, 5-14.

Fournet, Jean-Luc (1999), Hellénisme dans l'Égypte du VI siècle. La bibliothèque et l'œuvre de Dioscore d'Aphrodité, 2 vols (Mémoires de l'Institut français d'archéologie orientale 115/1-2), Cairo: Institut français d'archéologie orientale.

Fournet, Jean-Luc (2003), 'Between Literary Tradition and Cultural Change. The Poetic and Documentary Production of Dioscorus of Aphrodite', in Alasdair A. MacDonald, Michael W. Twomey and Gerrit J. Reinink (eds), Learned Antiquity. Scholarship and Society in the NearEast, the Greco-Roman World, and the Early Medieval West, Leuven: Peeters, 101-114.

Fournet, Jean-Luc (2004), 'Entre document et littérature : la pétition dans l'Antiquité tardive', in Denis Feissel and Jean Gascou (eds), La pétition à Byzance (Centre de recherche d'Histoire et Civilisation de Byzance, Monographie, 14), Paris: Association des amis du Centre d'histoire et civilisation de Byzance, 61-74.

Fournet, Jean-Luc (2013), 'Culture grecque et document dans l'Égypte de l'Antiquité tardive', in Journal of Juristic Papyrology, 43, 135-162.

Fournet, Jean-Luc (2015a), 'Anatomie d'une bibliothèque de l'Antiquité tardive', in Adamantius, $21,8-40$.

Fournet, Jean-Luc (2015b), 'At the Desk of a Man of Letters: Literate Practices in Byzantine Egypt according to the Dossier of Dioscorus of Aphrodite', in Scott F. Johnson (ed.), Languages and Cultures of Eastern Christianity: Greek (The Worlds of Eastern Christianity, 300-1500, 6), Farnham: Ashgate, 221-248.

Fournet, Jean-Luc (forthcoming), Apprendre à conjuguer dans l'Égypte byzantine : un manuel de conjugaison grecque de la bibliothèque de Dioscore d'Aphrodité (Papyrologica Bruxellensia), Bruxelles.

Fournet, Jean-Luc, and Jean Gascou (2008), 'Un lot d'archives inédit de Lycopolis (Égypte) à l'Académie des Inscriptions et Belles-Lettres', in Comptes rendus des séances. Académie des Inscriptions \& Belles-Lettres, 1041-1074.

Franz, Eckhart G. (1993), Einführung in die Archivkunde, 4th ed., Darmstadt: Wissenschaftliche Buchgesellschaft.

Gallazzi, Claudio (1989), 'Fouilles anciennes et nouvelles sur le site di Tebtynis', in Bulletin de l'Institut Français d'Archéologie Orientale, 89, 180-202.

Gallazzi, Claudio (1990), 'La “Cantina dei Papiri” di Tebtynis e ciò che essa conteneva', in Zeitschrift für Papyrologie und Epigraphik, 80, 283-288.

Gammacurta, Tatiana (2006), Papyrologica scaenica, Alessandria: Edizioni dell'Orso.

Gascou, Jean (2008), Fiscalité et société en Égypte byzantine (Bilans de Recherche, 4), Paris: Association des amis du Centre d'histoire et civilisation de Byzance.

Grenfell, Bernard P., and Arthur S. Hunt (1905), 'Some Classical Fragments from Hermopolis', in Mélanges Nicole, I, Genève: W. Kündig, 212-217.

Hickey, Todd M. (2012), Wine, Wealth, and the State in Late Antique Egypt: The House of Apion at Oxyrhynchus, Ann Arbor: University of Michigan Press. 
Houston, George W. (2009), 'Papyrological Evidence for Book Collections and Libraries in the Roman Empire', in William A. Johnson and Holt N. Parker (eds), Ancient Literacies: The Culture of Reading in Greece and Rome, Oxford: Oxford University Press, 233-267.

Houston, George W. (2014), Inside Roman Libraries: Book Collections and Their Management in Antiquity, Chapel Hill: University of North Carolina Press.

Jördens, Andrea (2001), 'Papyri und private Archive. Ein Diskussionsbeitrag zur papyrologischen Terminologie', in Eva Cantarella and Gerhard Tür (eds), Symposion 1997: Vorträge zur griechischen und hellenistischen Rechtsgeschichte (Altafiumara, 8.-14. Sept. 1997) (Akten der Gesellschaft für griechische und hellenistische Rechtgeschichte, 13), Cologne: Böhlau, 253-267.

Koenen, Ludwig, and Wolfgang Müller-Wiener (1968), 'Zu den Papyri aus dem Arsenioskloster bei Tura', in Zeitschrift für Papyrologie und Epigraphik, 2, 41-63.

Lefebvre, Gustave (1920), 'Deir-el-Abiad', in Fernand Cabrol and Henri Leclercq (eds), Dictionnaire d'archéologie chrétienne et de liturgie, IV: D-Domestici, Paris: Letouzey et Ané, 459-502.

Maehler, Herwig (1983), 'Die griechische Schule im ptolemäischen Ägypten', in Edmond van’t Dack, Peter van Dessel and Wilfried van Gucht (eds), Egypt and the Hellenistic World (Studia Hellenistica 27), Leuven : Peeters, 191-203; repr. in Csaba Láda and Cornelia Römer (eds), Schrift, Text und Bild. Kleine Schriften von Herwig Maehler (Archiv für Papyrusforschung und verwandte Gebiete. Beiheft 21), Munich, Leipzig: K.G. Saur 2006, 187-196.

Martin, Alain (1994), 'Archives privées et cachettes documentaires', in Adam Bülow-Jacobsen (ed.), Proceedings of the 20th International Congress of Papyrologists. Copenhagen, 2329 August 1992), Copenhagen: Museum Tusculanum Press, 569-577.

Mazza, Roberta (2001), L'archivio degli Apioni. Terra, lavoro e proprietà senatoria nell'Egitto tardoantico, Bari: Edipuglia.

McGing, Brian C. (1990), 'Melitian Monks at Labla', in Tyche, 5, 67-94.

Mélèze-Modrzejewski, Joseph (1979), 'Chronique. Droits de l’Antiquité. Égypte gréco-romaine et monde hellénistique', in Revue historique de droit français et étranger, 57, 120-147.

Mélèze-Modrzejewski, Joseph (1989), 'Chronique. Droits de l’Antiquité. Égypte gréco-romaine et monde hellénistique', in Revue historique de droit français et étranger, 67, 505-568.

Montevecchi, Orsolina (1988), La papirologia, 2nd ed., Milano: Vita e pensiero.

Orlandi, Tito (2002), 'The Library of the Monastery of Saint Shenute at Atripe', in Arnold Egberts, Brian P. Muhs and Jacques Van der Vliet (eds), Perspectives on Panopolis: An Egyptian Town from Alexander the Great to the Arab Conquest (Papyrologica Lugduno-Batava, 31), Leiden: Brill, 211-231.

Orrieux, Claude (1985), Zénon de Caunos, parépidèmos, et le destin grec, Besançon, Paris: Les Belles Lettres.

Otranto, Rosa (2000), Antiche liste di libri su papiro (Sussidi eruditi 49), Rome: Ed. di Storia e Letteratura.

Pestman, Pieter W. (ed.) (1989), Familiearchieven uit het land van Pharao, Zutphen: Uitgeverij Terra (non vidi).

Pestman, Pieter W., with contributions by Willy Clarysse, Monika Korver, Michel Muszynski, Annette L. Schutgens, William John Tait and Jan Krzystof Winnicki (1981), A Guide to the Zenon Archive. Lists and Surveys; Indexes and Maps (Papyrologica Lugduno-Batava 21AB), Leiden: Brill.

Pestman, Pieter W. (1990), New Papyrological Primer, Leiden: Brill. 
Rathbone, Dominic (1991), Economic Rationalism and Rural Society in Third-Century A.D. Egypt. The Heroninos Archive and the Appianus Estate, Cambridge: Cambridge University Press.

Robinson, James M. (2011), The Story of the Bodmer Papyri. From the First Monastery's Library in Upper Egypt to Geneva and Dublin, Eugene, OR: Cascade Books.

Schmelz, Georg (2002), Kirchliche Amtsträger im spätantiken Ägypten nach den Aussagen der griechischen und koptischen Papyri und Ostraka (Archiv für Papyrusforschung und verwandte Gebiete. Beiheft 13), Munich: K.G. Saur, 93-102.

Turner, Eric G. (1980), Greek Papyri. An Introduction, 2nd ed., Oxford: Clarendon.

Van Beek, Bart (2007), 'Ancient Archives and Modern Collections: The Leuven Homepage of Papyrus Archives and Collections', in Jaakko Frösén, Tiina Purola and Erja Salmenkivi (eds), Proceedings of the XXIVth International Congress of Papyrology. Helsinki, 1-7 August 2004 (Commentationes humanarum litterarum 122), Helsinki: Societas scientiarum Fennica, 1033-1044.

van Haelst, Joseph (1976), Catalogue des papyrus littéraires juifs et chrétiens (Série ‘Papyrologie' 1), Paris: Publications de la Sorbonne.

van Lantschoot, Arnold (1929), Recueil des colophons des manuscrits chrétiens d'Égypte, I: Les colophons coptes des manuscrits sahidiques (Bibliothèque du Muséon, 1), Louvain: J.-B. Istas.

van Minnen, Peter, and Klaas A. Worp (1993), 'The Greek and Latin Literary Texts from Hermopolis', in Greek, Roman and Byzantine Studies, 34, 151-186.

van Minnen, Peter (1994), 'House-to-House Enquiries: An Interdisciplinary Approach to Roman Karanis', in Zeitschrift für Papyrologie und Epigraphik, 100, 227-251.

Vandorpe, Katelijn (1994), 'Museum Archaeology or How to Reconstruct Pathyris Archives', in Egitto e Vicino Oriente, 17 (= Acta Demotica. Acts of the Fifth International Conference for Demotists. Pisa, 4th-8th September 1993), 289-300.

Vandorpe, Katelijn (2009), 'Archives and Dossiers', in Roger S. Bagnall (ed.), The Oxford Handbook of Papyrology, Oxford: Oxford University Press, 216-255.

Vogliano, Achille (1938), 'Un rapporto preliminare della IVa campagna di scavo a Medinet Madi', in Annales du Service des Antiquités de l'Égypte, 38, 533-549.

Yadin, Yigael (1962), 'The Cave of the Letters', in Israel Exploration Journal, 12, 227-257. 



\title{
Libraries and Archives in the Former Han Dynasty (206 BCE-9 CE): Arguing for a Distinction
}

\begin{abstract}
The imperial collection of the Former Han dynasty, the oldest Chinese manuscript collection of which we possess a catalogue, has both been called an archive and a library. This paper discusses the fundamental difference between an archive and a library in the manuscript age. On the basis of this distinction, it argues for the imperial collection to be identified as a library and provides evidence of a clear distinction between 'archive' and 'library' in this period of Chinese history.
\end{abstract}

\section{Introduction}

The imperial collection of the Former Han dynasty (206 BCE-9 CE) is the oldest Chinese manuscript collection about which we have detailed information in the form of a catalogue. This catalogue, in turn, has come down to us in the form of a chapter in the History of the Han (Hanshu 漢書) entitled Treatise on Classics and other Texts (Yiwenzhi 藝文志). ${ }^{1}$ As is well known, the compiler of the History, Ban Gu 班固 (3292), shortened an earlier catalogue for the Treatise composed by Liu Xin 劉歆 (c.50 BCE-23 CE), but this earlier version has now been lost. The former catalogue known as Seven Epitomes (Qilüe 七略) was based on elaborate editorial reports, most of which have also been lost. These were written down as part of the grand collation project initially headed by Liu Xin's father, Liu Xiang 劉向 (79-8 BCE) and continued by the son after the latter's death. This project, which began in $26 \mathrm{BCE}$, aimed at assessing the holdings at the imperial court, but also included major editorial work. It signifies a crucial point in the history of most if not all early Chinese literature, because it involved the fixation of editions and documentation of these.

Researchers variously refer to this manuscript collection as a 'library' or 'archive'. Scholars working in the field of library history generally label the collection a library or even the first library in Chinese history. ${ }^{2}$ Those working on the history

1 HS 30:1701-1781.

2 This is true of Western scholarship (e.g. Koh Thong-ngee 1964, 40; Drège 1991, 19-24; Lewis 1999, 325-331; Dudbridge 2000, 5-6), but also of Chinese scholarship, where we have a few arti- 
of archives, on the other hand, tend to identify it as an archive. ${ }^{3}$ One reason for this is the often repeated argument that there was no clear distinction between the two in early China; the same places are said to have been used to store documents and literary or historical works. ${ }^{4}$ It is typically argued that the archive came first and the library gradually developed out of this. ${ }^{5}$ There seems to be no general consensus regarding what point in time a clear distinction is possible. To some, this division can only be made fully with the introduction of printed books in the tenth century CE. ${ }^{6}$ This obviously is based on modern notions, according to which libraries keep published and thus printed books, while archives store what is unpublished and thus not printed. This is a concept that is clearly unsuitable for the pre-printing age, though.

Essentially, this is a problem of definition. Most of the above-mentioned scholars do not define their use of the terminology; they use the modern terms without giving much thought about either their origins or the concepts behind them. To begin with, there was no genuine term for 'library' in the Han era. The modern word for 'library', tushuguan 圖書館, was adopted as a loanword from Japanese in the late nineteenth century to denote modern public libraries. ${ }^{7}$ Older terms, such as cangshulou 藏書樓 (lit. 'book collecting building'), cangshushi 藏書室 (lit. 'book collecting chamber'), shuku 書庫 (lit. 'book repository') and wenku 文庫 ('literature repository') did not exist in Han times, but were introduced later. ${ }^{8}$ Some scholars,

cles specifically devoted to libraries under the Han (Chiang 1963; Lu Hesheng 1983; Wang Qiming 2003) and, of course, standard library histories such as Xie Zhuohua 2005, 45-64 and Ren Jiyu 2001, 382-390.

3 Again, there are a number of specialized articles on Han archives (Li Deyun 1980; Huang Caigeng 1988; Zhang Wei 1992) as well as standard works on the history of the archive in China (e.g. Zou Jiawei/Dong Jian 1985, 33-34; Zhou Xueheng 1994, 124-127).

4 Zhang Wei 1992, 49-50; Zhang 2004, 25. Based on this assumption, Nylan 2014 puts forward the argument that Liu Xiang's collation project, which eventually led to the compilation of the catalogue of the imperial collection, was a 'conversion of part of the administrative archives into a real library' (160).

5 Di Chongde/Chen Bolan 1981. The same argument is also made about the emergence of the library in the West: see Harris/Johnson 1999, 14. To me, it is questionable whether using the term 'archive' is appropriate. It would seem advisable to use a third term such as 'repository' or 'storage room' from which a distinction between 'library' and 'archive' evolved.

6 Drège 1991, 84.

7 Wu Xi 1996, 9-10. Wu purports that the term was first used by Liang Qichao 梁啟超 in 1896. Many new terms for Western ideas and concepts were imported into China from Japan in this period; see Amelung/Kurtz/Lackner 2001.

8 According to Wu Xi 1996, 9-10, cangshulou first appeared in Tang times (seventh-tenth century $\mathrm{CE}$ ) and was initially only used to refer to private collections. For a preliminary list of terms used for libraries throughout Chinese history, which I put together myself, see Delhey/Lorusso 2015, 4-8. 
like $\mathrm{Wu} \mathrm{Xi}$ and P. A. Herbert, make a sharp distinction between the modern library (tushuguan) as opposed to the traditional library (cangshulou), and $\mathrm{Wu} \mathrm{Xi}$ even comes to the conclusion that China did not have any libraries at all prior to the introduction of the modern public library. According to them, the main difference is that the modern public library aims to make books available to everyone, while the traditional Chinese library aims to store and preserve books. ${ }^{9}$ The traditional library is thus very close to a mere repository. The dichotomy of traditional versus modern also denies any kind of development prior to the introduction of the modern concept, which surely is oversimplifying things.

The picture is somewhat different in the archive's case. As will be shown later, a genuine term for 'archive' did indeed exist in Han times. However, it is not the same as the modern word for 'archive', dang'an 檔案 (dang'anguan 檔案館 or dang'anku 檔案庫 for the place). It is a fact that dang'an was first employed during the Qing dynasty (1644-1911), as it does not appear in any sources prior to 1638. Whether the term also has its origin in the Manchu language is contested, though. ${ }^{10}$ Archival practices in the Qing period nonetheless differ from the modern European archival concepts. Like the case of the library in China, what is found to be characteristic of the traditional Chinese archive is its mere storage function and a lack of systematic organization for the purpose of retrieval. At the same time, it is argued that the state, which was the dominating force in archival preservation, was more interested in controlling historical records than preserving them; there was no special interest in keeping original documents. According to Western scholarship, premodern Chinese archives completely served the needs of official historiography. As soon as official historical compilations were put together, the original documents were of no interest anymore and were simply destroyed. ${ }^{11}$

As already mentioned above, the modern notion of the difference between 'library' and 'archive', which is based on the physical appearance of the objects found in a collection, is not suitable for understanding the situation for the age prior to

9 Wu Xi 1996, 1-2; Herbert 1980, 120-121.

10 Fitzgerald 2015 argues that it stems from the Manchu dangse with the meaning 'wood on which a document is written' (77). Because of the shortage of paper, the Manchu had used wooden slips for their administrative documents. Later, the term supposedly fused with the Chinese an. Zhao Zhiqiang 2016 summarizes the various explanations of the origin of the word. Basing his thinking largely on linguist grounds, Zhao comes to the conclusion that the term rather stems from older Chinese words. Also see Wagner 2006, 28 (Wagner 2004 is basically identical to the introduction in Wagner 2006).

11 Wagner 2006, 27-29; Ye/Esherick 1996, 4-5. It should be noted that the main focus of the two studies is on archives in the People's Republic of China. They only deal with traditional archives as precursors to the modern archive. 
the invention of printing technology. In our case, it is worth looking at how disciplines dealing with ancient manuscript cultures other than that of China have discussed this issue. Due to the rather imperishable nature of clay tablets, the field of Assyriology is in the fortunate position of being able to work with numerous extant collections. Although scholars have lamented about a similar confusion concerning the use of the two terms in question, they have made a considerable effort to distinguish between 'library' and 'archive'. In the 1950s, Mogens Weitemeyer differentiated them according to the function and content of a particular collection, for instance:

[...], a distinction between library (bibliothèque) and archive must be considered practical, seeing that they differ essentially in their functions. An archive consists of a collection of documents drawn up and used in some administrative, legal or economic process and forming part of the same; [...]. [...]. While the archive contains documents recording phenomena of material life, the library holds products of the mental activity of man: a library is a collection of works (religious, literary, mathematical, legal, philological, etc.) gathered with a view to immediate or later use by the group of persons served by the library. ${ }^{12}$

In a more recent study, Olaf Pedersén has drawn a similar distinction between the two, adding that even in the age prior to the invention of mechanical reproduction, the number of copies of a text in a collection may be regarded as a further point of distinction:

The term 'archive' [...] refers to a collection of texts, each text documenting a message or statement, for example, letters, legal, economic, and administrative documents. In an archive there is usually just one copy of each text, although occasionally a few copies may exist. 'Library', on the other hand, denotes a collection of texts normally with multiple copies for use in different places at different times, and includes, e.g. literary, historical, religious, and scientific texts. In other words, libraries may be said to consist of the texts of tradition. With rather broad definitions of the terms 'document' and 'literary text', it may be simplest to say that archives are collections of documents and libraries are collections of literary texts. ${ }^{13}$

At the same time, Pedersén is aware of the possibility that both types may be found in one and the same collection. However, in his analysis of 253 collections, he found that only 27 (11\%) were of the mixed kind. In all the other cases, a clear distinction was possible based on the content. ${ }^{14}$

Further research on the topic of the archive in ancient times stresses that '[a]rchives were not merely a storage place for "all kinds of records". Rather, it

12 Weitemeyer 1956, 218.

13 Pedersén 1998, 3.

14 Pedersén 1998, 278-280. 
is evident that documents placed in an archive were specifically selected for retention. Documents must have been classified by different types, and a selection of these made to identify those for storage'. ${ }^{15}$ The same argument is also made about the library: 'Libraries are not simply storehouses of books. They are the means of organizing knowledge ... of controlling that knowledge and restricting access to it'. ${ }^{16} \mathrm{~A}$ certain degree of organization is what essentially differentiates both libraries and archives from incidental assemblages of manuscripts. What obviously differentiates the two from each other is their function, which is reflected in the different types of texts found within them.

\section{The imperial collection of the Former Han}

Turning to the Han dynasty's imperial collection, one of the first things that are apparent about it is that unlike the collections Assyriologists deal with, it is a collection that has completely vanished. Very few manuscripts were discovered during the archaeological excavation of Weiyang Palace in Chang'an 長安, the capital of the Former Han, which took place in the 1980s. Only 115 wooden slips were unearthed, most of which were severely damaged and all of which had been burnt. According to Xing Yitian's research, they largely contain records of various benevolent omens. He links the scorch marks to the pillaging of Chang'an by Red Eyebrows rebels in $25 \mathrm{CE}$. This rebellion is also believed to have inflicted major damage on the imperial collection. ${ }^{17}$ Although the Treatise on Classics and other Texts (hereafter: Treatise) does include titles with reference to omens and both Liu Xiang and Liu Xin are known to have written about and used omenology, it is unlikely that these slips once were part of the imperial collection, because they were not found at the site identified as the place mentioned in historical sources where the collection is said to have been kept. ${ }^{18}$ In recent decades, numerous

15 Brosius 2003, 6.

16 Harris/Johnson 1999, 6 quoting Mary Beard (London Review of Books, Feb. 1990, 11). Jacob 1998, 94 equally stresses that it is not just the accumulation of books, but the classification of them that defines a library.

17 Xing Yitian 2011a. For details of the Red Eyebrows, see HS 99B:4193 and Bielenstein 1959, 91-102.

18 The Treatise includes Divine Communication (Shenshu 神輸, see HS 30:1703), which according to a text fragment of Liu Xiang's editorial report talks about the link between the emperors' conduct and the emergence of calamities and propitious omens (cited in commentary by Yan Shigu, HS 30:1704). There are five other titles with reference to baleful omens (zaiyi 災異); see HS 30:1703, 1768. On Liu Xiang's use of omenology, see Yang 2015. The place most directly linked to the collation project is the Celestial Deer Pavilion (Tianluge 天祿閣/天鹿閣). This is probably 
manuscripts have been brought to light dating to the pre- and early imperial period (roughly the fifth century BCE to third century $\mathrm{CE}$ ). However, none of these were found in the core regions of the Han Empire, but in its outer periphery to the north and south. Hence, it can be ruled out that they once belonged to the imperial collection. ${ }^{19}$

Although none of the manuscripts in the imperial collection have survived the ravages of time, and even though well over 80 per cent of the catalogue's 631 entries are only known by their title, ${ }^{20}$ the Treatise nonetheless tells us exactly what kind of texts the collection once contained. More importantly, we can also tell what was not in the collection from the little information we do possess.

Apart from an introductory section at the beginning of the Treatise, it is basically a classified catalogue divided into six main categories and 38 sub-categories. The six main categories are as follows:

1. Six Arts (liuyi 六藝), which include the classics and manifold commentaries on them.

2. Various Masters (zhuzi 諸子), which include the writings of various thinkers for the most part from the pre-imperial period, including the well-known Mengzi, Laozi and Zhuangzi.

3. Poems and Rhapsodies (shifu 詩賦), in which we find various poetic works listed.

4. Military Writings (bingshu 兵書) with manuals on strategy and tactics in warfare.

5. Calculations and Methods (shushu 數術), which collects texts concerning occult or cosmological matters, such as almanacs, works on astrocalendrical science and divination.

6. Recipes and Techniques (fangji 方技), which is devoted to medical matters, including general medical writings, works on pharmacy, on techniques for the prolongation of life and on sexual practices.

\footnotetext{
also where the collection was kept. Archaeologists have identified the remains of the Pavilion, and this is not where the wooden slips were found. See the excavation report: Zhongguo shekeyuan kaogusuo 1996, 17-18, 238-248.

19 There is, of course, the possibility of copied manuscripts from the imperial collection being given to local dignitaries. In one case, a sealing clay (fengni) relating to the imperial collection was found in a tomb dated to the Western Han. It has been argued that the tomb's owner must have received manuscripts from the imperial collection. However, the excavation did not bring any manuscripts to light. All the manuscripts are thought to have rotted away. See Liu Zunyan/Liang Yong 2003.
}

20 For more exact numbers, see my dissertation: Fölster 2016, 72. 
The first three categories in particular may be readily identified as bringing together 'texts of tradition'. The latter three categories group texts of a more technical nature, which were certainly not administrative documents. The only entries seemingly related to the administrative realm are the Memorials with Opinions (Yizou 議 奏) found at the very end of each listing for four of the six classics. ${ }^{21}$ However, all of these are clearly linked to the famous scholarly debate about the meaning of the classics, which took place in 51 BCE at the Stone Ditch Pavilion (Shiquge 石渠閣). ${ }^{22}$ These are probably summaries of the different scholarly positions regarding the classics and not documents of the administrative machinery. There is yet another entry with the title Memorializing Matters (Zoushi 奏事). However, from an additional remark to this entry, it becomes clear that these are not administrative documents either, but rather acclaimed memorials and epigraphic texts from the Qin dynasty (221-207 BCE), the predecessor to that of the Han. ${ }^{23}$

What is not found in the Treatise is, in fact, more illuminating. Beginning with Wang Yinglin 王應麟 (1223-1296), Chinese scholars have noted that the collection was not all-encompassing. However, a thorough examination of the many titles identified as missing reveals that most of them are either variant titles, mere chapter titles of works found in the Treatise or later works attributed to men of the Former Han period..$^{24}$ Legal texts, or more precisely what is listed in later catalogues as Statues and Ordinances of the Han (Han lü 漢律, Han ling 漢令), are conspicuously missing. ${ }^{25}$ It is only through the manifold manuscripts excavated in recent decades that we have learnt more about the content and modus operandi of these statues and ordinances since they include many texts of this kind. ${ }^{26}$

Judging from the following statement in the History of the Han, the reason such texts were not included in the Treatise is simply that they were the responsibility of a special government agency and were thus kept in a separate place:

21 HS 30:1705, 1710, 1714, 1716.

22 The debate is mentioned in HS 73:3113, 88:3598. Also see Tjan 1949, 6.

23 HS 30:1714. Also see Fu Rongxian 2007, who equally argues that Liu Xiang did not work with administrative documents during the grand collating project.

24 Fölster 2016, 73-83, 197.

25 Jinshu 30:922.

26 The most authoritative publications in Western languages in this field are Lau/Lüdke 2012, and Barbieri-Low/Yates 2015. On legal manuscripts dated to the Qin dynasty, see Hulsewé 1985 and Staack/Lau 2016. 
今叔孫通所撰禮儀, 與律令同錄, 藏於理官, 法家又復不傳。27

Now the rites and ceremonies compiled by Shusun Tong (d. in 188 BCE) were recorded together with statutes and ordinances and stored at the regulatory office, and the legal experts ${ }^{28}$ did not transmit them again.

Unfortunately, we do not know much about the regulatory office. The seventhcentury commentary by Yan Shigu 顏師古 defines it as the 'legal office' (faguan 法官). ${ }^{29}$ In the Han period the term 'regulatory office' is said to be an unofficial name for the office administering lawsuits. ${ }^{30}$ Furthermore, it has been suggested that a sub-unit-the Bureau for the Direction of Legal Principles (dianfa cao 典法曹)-'probably organized and archived the voluminous written statutes and ordinances' ${ }^{31}$ Despite the details we have being rather scant, they suggest that there was a specific office responsible for storing statutes and ordinances. ${ }^{32}$

The fact that other administrative documents were also archived is mentioned in the Embellishments on the Heart of Writing (Wenxin diaolong 文心雕龍), a literary critique composed many centuries later by Liu Xie 劉照思 (c.465-c.521):

按七略、藝文, 謠詠必錄; 章表奏議, 經國之樞機, 然闒而不纂者, 乃各有故事, 布在 職司也。

We find included in the Seven Epitomes and the [Treatise on] Classics and other Texts records of all poetic writings; and yet the petitions, presentations, memorials, and opinions, all crucial in the conduct of government, are omitted, because they each were concerned with precedents and were kept in the files of government offices. ${ }^{33}$

This explanation follows the above distinction between literary texts on the one hand and administrative documents on the other quite closely.

27 HS 22:1035.

28 Judging from the context, these legal experts (fajia) are not the Legist Experts (fajia) under the Various Masters category of the Treatise (HS 30:1735-1736), but probably regulatory office staff. For the Later Han period, such legal experts are mentioned among the staff of the Director of the Imperial Clan (zongzheng); see Bielenstein 1980, 42.

29 HS 22:1035. In another commentary, Yan Shigu identifies the term to denote the staff of the Minister of Justice (sikou 司寇); see HS 23:1088.

30 Hucker 1985, 3618. For details about the offices, see Bielenstein 1980, 38.

31 Barbieri-Low/Yates 2015, 131.

32 In Mogens Weitemeyer's opinion, legal texts were kept in libraries (see above). This obviously was not the case in Han time China.

33 Wenxin diaolong, Zhangbiao 22, 5:243 (modified transl. of Shih 1959, 127). The term 'precedent' is discussed below. 
We may conclude that in terms of its content, the collection documented in the Treatise complies with the above definition of a library. The same may be said about the other criteria that are mentioned. The Treatise itself is evidence of a clear organization, even though we lack definite proof that it was also the basis for the physical organization of the manuscripts in the collection. As for the function of the collection, from the little we know about the collation project, which basically created the collection as we know it from the Treatise, the editorial reports address the emperor and were probably presented to him together with the respective work. Despite the reports' assessment of the texts' usefulness to the emperor-one could say they recommend what the emperor should read-the set phrase '[so that] this writing can be neatly copied (書可縍寫)' found at the end of the reports seems to imply that it should also serve to make further fair copies. ${ }^{34}$ However, there only is one reference attesting that the emperor did actually give away copies of manuscripts from his collection. ${ }^{35}$ Apart from producing further copies, the collection contained various duplicate texts to begin with. The identification and comparison of these duplicates was one of the main tasks in Liu Xiang's collation project. The few editorial reports we know of include the exact number of duplicates employed. This underpins Olaf Pedersén's argument about the library being a collection of works containing multiple copies of each text. Although the ostensible purpose was to create a collection of items for immediate and later use by the emperor, this 'library' evidently also served the scholarly community. The entire collation project was a scholarly endeavour involving not only Liu Xiang and his son, but many other men, about a dozen of whom we know by name. Certain people are conspicuously missing here, however: the Erudites (boshi 博士), i.e. the official court scholars appointed to academic chairs for the imperially acknowledged classics. ${ }^{36}$ This reinforces an accurate remark by Marcel Lepper, according to which libraries are places for the production and reproduction of texts and not predominantly places of safekeeping and registration. ${ }^{37}$

34 Fölster 2016, 84-87, 139.

35 HS 100A:4203. It is telling that the beneficiary of the emperor's gift was an ancestor of Ban $\mathrm{Gu}$, who was involved in the collation project. The manuscripts were kept within the family and the collection attracted scholars who came to view them; see HS 100A:4205.

36 See Fölster 2016, 133-139.

37 Lepper 2012, 66. 


\section{Archives of the Former Han}

As for the archives in the 'various organs of government', we unfortunately lack information that is as detailed as that in the Treatise; no substantial catalogue or inventory of the central archives has come down to us. However, it is clear that administrative documents were produced, circulated and probably stored in large quantities. This is simply due to the fact that the Han maintained an elaborate bureaucracy with more than 120,000 officials employed throughout the entire realm, which in turn was divided into 13 provinces, 103 commanderies and more than 1,500 county-level government units. ${ }^{38}$ That the task of storing such large amounts of documents created its own problems is evident from the following two statements about statutes and ordinances:

方今律令百有餘篇, 文章繁, 罪名重, 郡國用之疑惑, 或淺或深。自吏明習者, 不知所 處, 而況愚民！律令塵冨於棧閣, 吏不能遍睹, 而況於愚民乎！ ${ }^{39}$

Nowadays, the statues and ordinances amount to more than a hundred chapters. Their paragraphs are numerous and the offences [therein] repetitive, so the implementation in the commanderies and kingdoms has become uncertain and confused. Some [officials] have superficial [knowledge of the statues and ordinances], while others are very [knowledgeable about them]. If even well-versed officials do not know how to assess [statutes and ordinances], how much less would untaught people know! The statutes and ordinances lie in stacks gathering dust and get eaten by worms, [so many that] officials are unable to look at them all. How much less able would untaught people be!

及至孝武郎位, $[\cdots]$ 。律令凡三百五十九章, 大辟四百九條, 千八百八十二事, 死罪決 事比萬三千四百七十二事。文書盈於几閣, 典者不能徧睹。

Coming down to the time when [Emperor] Xiaowu (r. 141-87 BCE) ascended the throne, [...]. The Statutes and Ordinances [contained] in all 359 sections: for the death penalty 409 articles [covering] 1,882 cases, and 13,472 cases of judicial precedents for crimes [deserving] death. Writings and documents filled tables and cupboards and the officials in charge were unable to look at them all. ${ }^{40}$

38 The most authoritative study on the Han bureaucracy in a Western language is Bielenstein 1980. See Loewe 2006 for a less technical account. For briefer accounts, see Loewe 1986 and more recently Ding 2015.

39 Yantielun 55: Xingde, 10:566.

40 HS 23:1101 (modified transl. of Hulsewé 1955, 338). 
Statutes and ordinances were only one type of document. We can safely assume that the elaborate communication system used by the central administration created even larger numbers of documents, which probably involved frequent copying of documents for archival purposes. Imperial decisions handed down to the regions and provinces and certificates of appointment were probably copied, ${ }^{41}$ but there also is evidence that the imperial secretariat forwarded memorials to the emperor 'not in the original, but only in transcription, which was checked against its copy text'. ${ }^{42}$ Indirect evidence of archived documents existing is found in the ' $[r]$ eference to a precedence in the form of [...] (the rest shall be) like the ... precedent (它)如故事', a formula frequently found in various sources..$^{43}$ The imperial secretariat and other agencies probably routinely filed documents 'as precedents', ${ }^{44}$ which complies with Liu Xie's statement about 'petitions, presentations, memorials and opinions' being precedents 'kept in the files of government offices'. Further evidence of the practice of submitting multiple copies is also found in the History of the Han:

又故事諸上書者皆為二封, 署其一曰副, 領尚書者先發副封, 所言不善, 屏去不奏。

Another precedent was that all letters submitted to the throne had to be [presented] in duplicate. One of them was inscribed with the term 'duplicate copy'. The supervisor [of the affairs] of the imperial secretariat opened this copy first. If the wording was improper, it was rejected and not memorialized..$^{45}$

In fact, Wang Guihai argues that the final draft of an imperial instruction (zhao$s h u$ 詔書) was kept and filed away while copies of it were being sent out. ${ }^{46} \mathrm{He}$ also takes the term 'precedent' (gushi 故事) to mean archived documents in general. ${ }^{47}$ The actual meaning of the term gushi is somewhat more complicated, as Xing Yitian has discussed extensively: precedents 'were decisions, policies, or actions of the past that had been either incorporated into the legal code or otherwise constituted a usually esteemed and growing body of reference that could be used in order to argue for the re-enactment of a former political decision' ${ }^{48}$ Xing Yitian

41 Giele 2006, 208.

42 Giele 2006, 166.

43 Giele 2006, 239-245, quote 239.

44 Giele 2006, 242.

45 HS 74:3135 (modified transl. of Giele 2006, 67).

46 Loewe 2004, 530 mentions the possibility that two copies were made, a practice we know of from Tang times.

47 Wang Guihai 1999, 121-124.

48 Giele 2006, 239. Giele’s discussion is based on Xing Yitian 1987. 
further notes that gushi could also refer to conventions or practices that were not written down..$^{49}$ Nonetheless, there is abundant evidence of the recourse to 'precedents' noted in writing: ${ }^{50}$ although evidence from the Later Han (25-220) far exceeds that from the Former Han, this 'may just be a simple reflection of the proportional increase of precedents', as Enno Giele says. ${ }^{51}$ Moreover, the continuous use of Former Han precedents during the Later Han period shows these documents must have been archived. The following example indicates that such documents were stored:

Wei Xiang 魏相, who served as chancellor from 67 to $59 \mathrm{BCE},{ }^{52}$ not only emphasizes the great importance of 'precedents', but also clearly makes use of them to support his argument in a memorial to the emperor.

好觀漢故事及便宜章奏, 以為古今異制, 方今務在奉行故事而已。數條漢興已來國家便 宜行事, 及賢臣賈誼、塦錯、董仲舒等所言, 奏請施行之, 曰: 《 $[\ldots]$ 臣相不能悉 陳, 昧死奏故事詔書凡二十三事。臣謹案王法必本於農[....]》

[Wei Xiang] delighted in looking up precedents of the Han and [former] memorials that had argued for expediencies. He was of the opinion that although the institutions of the past and present were different, one's duty today was merely to follow the precedents [of the past]. He frequently drew up accounts of the measures adopted by the government since the founding of the Han to meet expediencies as well as accounts of what eminent statesmen like Jia Yi, Chao Cuo, and Dong Zhongshu had stated, and submitted them to the throne with the request that they should be put into practice: '[...]. I cannot go into detail [here, but instead], risking capital punishment, I submit a total of twenty-three [former] edicts containing [or constituting] precedents [that may serve to illustrate my point]. [In sum,] I would like to state that the policies of the ruler must be rooted in [a desire to promote] agriculture $[\ldots] ., 53$

This clearly shows that officials resorted to documents constituting precedents. Hence, these documents must have been stored in some place. Xing Yitian even

49 He also points out various alternative terms used for the same phenomena; see Xing Yitian 1987, 336-338.

50 Xing Yitian 1987, 385-409 puts together all the cases of gushi he found in the relevant historical sources, presenting them in 12 categories. Tang Yongping 1990 includes a less extensive collection, differentiating between just three categories.

51 Giele 2006, 241.

52 For Wei Xiang's biography, see Loewe 2000, 578-579.

53 HS 74:3137-3138 (I have made use of previous translations by Giele 2006, 240 and Watson 1974, 180-181). Loewe 2004, 530 takes this as evidence that 'a complete file of decrees was included in the records and documents that were kept under the control of the Imperial Counsellor'. 
goes as far as to speak of a state archive (guojia dang'an 國家檔案) in this context. ${ }^{54}$ According to a commentary by Yan Shigu, the Recorders of Precedents (zhanggu 掌故) were the officials whose task it was to manage these precedents. ${ }^{55}$ However, it has been noted that at least from the reign of Emperor $\mathrm{Wu}$ onwards (141-87 BCE) there are no more examples mentioning the Recorders in connection with the precedents. In fact, all the textual evidence suggests that the officials at the Secretariat (shangshu 尚書) were in charge now. ${ }^{56}$ Members of the Secretariat are often described as being 'well versed in the precedents (明習故事)' ${ }^{57}$ The same holds true for the chancellors, like Wei Xiang, who was mentioned above. Another chancellor, when asked who should succeed him in office, recommended a man on the grounds that he 'had a clear understanding of the laws and knowledge of the state's precedents (明於法度, 曉國家故事)'. ${ }^{58}$

This may also be seen as an indication that not only the Secretariat kept copies of documents containing precedents. For the Later Han, at least, there is one case of a letter submitted to the throne, 'copies [of which] were forwarded to the Three Offices (移副三府). ${ }^{59}$ The term 'Three Offices' refers to the Three Excellencies (sangong 三公), denoting 'the three (or at times two) officials who stood at the most senior level of the [...] imperial administration'. During the Former Han, these were the Chancellor (chengxiang 丞相), Imperial Counsellor (yushi dafu 御 史大夫) and Supreme Commander (taiwei 太尉). In Later Han times, the Grand Minister of Works (da sikong 大司空) replaced the Imperial Counsellor and the Grand Minister over the Masses (da situ 大司徒) replaced the Chancellor. ${ }^{60}$ An epigraphic source dated to 169 CE corroborates this practice and mentions that the Senior Tutor (dafu 大傅) and the office of the Grand Minister of Agriculture ( $d a$ sinong 大司農) also received copies of a submitted letter. ${ }^{61}$

54 Xing Yitian 1987, 382.

55 HS 57B:2605. Also see Xing Yitian 1987, 349-350. I have followed the translation provided by Loewe 2000, 764. Bielenstein 1980, 207 translates it as ‘Authority on Ancient Matters', which I find rather misleading.

56 Xing Yitian 1987, 150, Tang Yongping 1990, 43. Yan Shigu tells us that the Recorders of Precedents were subordinate to the Grand Master of Ceremonies (taichang 太長) and therefore did not belong to the Secretariat. It is stated that there were a total of thirty Recorders of Precedents, but there is no reference on them for the Later Han; see Bielenstein 1980, $22,98$.

57 HHS 27:902. For further references, see Xing Yitian 1987, 354-356 and Tang Yongping 1990, 43.

58 HS 74:3148.

59 HHS 57:1851.

60 Loewe 2006, 19-20.

61 Lu xiang Shi Chen zou si Kongzi miao bei 魯相史晨奏祀孔子廟碑, in Quan Hou Hanwen 101:1019-1. 
During Emperor Cheng’s reign (33-7 BCE), Xue Xuan 薛宣 was recommended to the emperor as Imperial Counsellor. According to the History of the Han, 'the assessments of Xuan's achievements [were] recorded on bamboo slips in the two offices (宣考績功課, 簡在兩府)'. ${ }^{62}$ This seems to imply that the Chancellor's office and the Imperial Counsellor's office both kept records on the performance of officials. This is corroborated by an anecdote about Bing Ji 邴吉, who succeeded Wei Xiang as Chancellor and served in this position from 59 to $55 \mathrm{BCE} .{ }^{63} \mathrm{Bing} \mathrm{Ji}$ was known for treating his subordinates leniently. When one of his carriage drivers vomited on the cushions of a carriage, others immediately called for the driver to be dismissed. Bing Ji refused to do so, however. Not much later, the same carriage driver informed his master about an invasion at the frontier, which he had learnt about by pure chance. Since he was originally from the border provinces, he shared his knowledge with Bing Ji, making the following suggestion in the process:

《恐虜所入邊郡, 二千石長吏有老病不任兵馬者, 宜可豫視。》吉善其言, 召東曹案邊 長吏, 瑣科條其人。未已, 詔召丞相、御史, 問以虜所入郡吏, 吉具對。御史大夫卒遽 不能詳知, 以得譴讓。而吉見謂憂邊思職, 馭吏力也。

\begin{abstract}
'I'm afraid that in the border provinces where the barbarian invasions have taken place, the senior officials are in some cases too old and sickly to take up arms and ride a horse. It might be wise to make a preliminary check about the matter.' [Bing] Ji, approving this suggestion, ordered the clerk in charge of such matters to examine the files on the senior officials in the border provinces and make a detailed report on each man. Before the reports were completed, a command came from the emperor, summoning the Chancellor and the Imperial Counsellor into his presence, where he informed them of the barbarian invasion and asked about the officials in the provinces that were affected. Bing Ji gave him some very thorough answers, but the Imperial Counsellor, having been caught off guard, was unable to supply any detailed information himself and was reprimanded as a consequence. Bing Ji, on the other hand, was looked upon as a man who was truly concerned about the safety of the border and who paid close attention to the duties of this office - all because of the help his carriage driver had given him. ${ }^{64}$
\end{abstract}

The following account from the History of the Later Han (Hou Hanshu 後漢書) confirms the practice of keeping records about the performance of officials and shows that these also served as the basis for making decisions about personnel:

62 HS 83:3391. For details on Xue Xuan, see Loewe 2000, 628-629.

63 For more details on the biography of Bing Ji, see Loewe 2000, 12-13.

64 HS 74:3146 (modified transl. of Watson 1974, 191-192). 
舊制, 州牧奏二千石長吏不任位者, 事皆先下三公, 三公遣像史案驗, 然後黜退。65

According to the old rules [of the Former Han?], if a regional commissioner proposed that a superior officer ranked 2000 bushels was not to serve in his post, the matter was sent to the Three Excellencies first, who would dispatch a Senior Clerk to check the records and investigate the case. [A superior officer] could only be discharged after that.

As for the places used for archives in the capital, precedents seem to have been stored in the Southern Palace (Nangong 南宮):

\section{弘前後所陳有補益王政者, 皆著之南宮, 以為故事。}

Every [suggestion] that [Zheng] Hong made at some point [during his career] to improve upon his ruler's policies was written down in [the files kept at] the Southern Palace [to serve as] precedents. $^{66}$

There is no mention of the Southern Palace during the Former Han period, though. Rather, the place most often identified as an archive by modern scholars is the Orchid Terrace (Lantai 蘭臺). ${ }^{67}$ The History of the Han mentions it simply as the office of one of the Secretary Assistants to the Imperial Counsellor, which was situated within the palace. This assistant 'was in charge of charts, registers and the secret writings (掌圖籍祕書) ${ }^{\prime}{ }^{68}$ It is not at all clear from this information whether it was also a place to archive documents permanently. Basing his knowledge on later sources, Hans Bielenstein remarks that this assistant 'passed on to the throne memorials from the Three Excellencies, the Nine Ministers, and the local administration, and transmitted imperial edicts addressed to commanderies and kingdoms' ${ }^{6}{ }^{6}$ Enno Giele argues that the men at this office 'were the central government's watchdogs who routinely screened memorials for offensive language. Or they were legal experts who were consulted to supply the policy makers with applicable legal arguments to decide either for or against a matter brought up from among the officials; or both' ${ }^{70}$ This rather suggests that the Orchid Terrace was an office to supervise the transmission of documents within the central bureaucracy.

65 HHS 33:1143.

66 HHS 33:1155 (modified transl. of Giele 2006, 240-241).

67 E.g. Zhou Xueheng 1994, 127. In the Later Han period, the other another prominent archive was the Eastern Tower (Dongguan 東觀).

68 HS 19A:725 (modified transl. of Dubs 2009, 23).

69 Bielenstein 1980, 9.

70 Giele 2006, 62. 
Moreover, the term 'secret writings' (mishu 祕書) is also used to denote those writings subject to Liu Xiang's collation project. ${ }^{71}$ Although the collation project dealt with anything but administrative documents, as we have seen above, the term 'secret writings' seems to refer to any writings found in the inner palace and thus directly related to the emperor. In his discussion of the history of the imperial collection, Liu Xin's Seven Epitomes (Qilüe) mentions that in 'the inner [palace] there are the repositories of the Pavilion of Perpetuation, the Spacious Interior and the Secret Chamber (內則有延閣、廣內、祕室之府) ${ }^{72}$ But since none of these place names occur elsewhere in the relevant sources, we cannot tell what kind of manuscripts were actually stored there.

Other important documents, such as those recording the enfeoffement of regional kings and other nobilities, are said to have been stored in what is called 'Stone Chamber and Metal Casket' (shishi jinkui 石室金貴):

\section{又與功臣剖符作誓, 丹書鐵契, 金貣石室, 藏之宗廟。}

With his meritorious followers [Liu Bang, the Han's founding emperor,] split tallies and made oaths, [recorded] in red writing on an iron certificate, [which were put in] a metal casket and a stone chamber, and kept in the ancestral temple. ${ }^{73}$

Keeping records of this kind in the ancestral temple seems to follow an earlier tradition. ${ }^{74}$ In any case, '[m]aintenance of an up-to-date list of the kings and nobles of the empire, and of the holders of other orders of honour (jue 爵), would seem to have been an essential duty of government, in the interests of controlling the administration of their estates and their exercise of their privileges' ${ }^{75}$ The fact that Liu Bang also consulted such a register is suggested in the following passage: 'When Gaozu (i.e. Liu Bang) reached Luoyang, he summoned all those who had attained [the rank of] marquis according to the register [...] (高祖至雒陽, 舉通侯籍召之 [...])' ${ }^{76}$ That this register was also maintained after Liu Bang's death can be seen in

71 HS 10:310: '[...] Liu Xiang collated the secret writings of the inner [palace] ([...] 劉向校中祕書)'. Also see HS 36:1950, 1967.

72 Quoted in HS 30:1702.

73 HS 1B:81 (modified transl. of Dubs 1938-1955, I:146).

74 See SJ 130:3319, which mentions these places when talking about the state of stored documents prior to the Han dynasty.

75 Loewe 2004, 253.

76 SJ 8:381 (modified transl. of Nienhauser 1994-, II:69). Loewe 2004, 319 suggests that this refers to a register going back to the Qin period, since Liu Bang had not conferred any ranks of honour yet at that time. 
the following imperial instruction from 187 BCE, which was promulgated by his widow, Empress Lü:

高皇帝匡飭天下, 諸有功者皆受分地為列侯, 萬民大安, 莫不受休德。朕思念至於久遠而 功名不著, 亡以尊大誼, 施後世。今欲差次列侯功以定朝位, 蔵于高廟, 世世勿絕, 嗣子 各襲其功位。其與列侯議定奏之。

The Emperor Gao[zu] reformed and ordered the world. All those who distinguished themselves received a share of its territory and were made marquises. All the people [now enjoy] great peace; not one who has not received of his bountiful virtue. We have been thinking and reflecting [on this matter]. If, in the distant future, their merits and names have not been made manifest, there will be nothing to honour their great conceptions and exhibit them [for the benefit of] later generations. Now [We] wish to classify and rank the merits of the marquises, so as to determine upon their positions in the court and preserve them in the Temple of Gao[zu] from generation to generation without end, so that their heirs may each inherit their merits and positions. Let [this matter] be discussed with the marquises, settled and memorialized [to Us $].^{77}$

Empress Lü's suggestion was met with approval by the marquises, so a register was stored in the temple of Gaozu accordingly. It is reported that Emperor Xuan (reigned 74-49 BCE) 'opened the treasuries attached to the shrines and had the old registers inspected (開廟蔵, 覽舊籍)' ${ }^{78}$ This shows that the register continued to be consulted. It was probably the Director of the Imperial Clan (zongzheng 宗正), who was responsible for keeping an up-to-date list of the kings and nobles of the empire belonging to the imperial clan. ${ }^{79}$ Records of other nobilities were presumably the responsibility of the Chief Commandant over the Nobility (zhujue zhongwei 主爵中尉).$^{80}$ At the same time, it has to be noted that the Treatise includes titles that may be identified as genealogies, probably containing similar information to what would be noted in the nobility register. How far this is related to the fact that Liu Xiang served as Director of the Imperial Clan earlier in his career is unclear, though. ${ }^{81}$

77 HS 3:96 (modified transl. of Dubs 1938-1955, I:194-195). Also see Loewe 2004, 320.

78 HS 16:528 (transl. by Loewe 2004, 253).

79 At least this is suggested by SJ 60:2118: 'The Director of the Imperial Clan is in charge of the register for the clan and all lesser members of the Liu [family] (宗正者, 主宗室諸劉屬籍)'. Also see Loewe 2004, 319.

80 Loewe 2004, 319. He also discusses the different changes in name and the institutional reforms related to this office. Also see Bielenstein 1980, 87. See Loewe 1997, 185 for an actual example of a certificate of bestowal of a rank of honour.

81 Judging from the titles, these seem to be rather historical or mythological genealogies predating Han times: Generational Chronologies of Emperors, Kings, and Feudal Lords (Diwang zhuhou shipu 帝王諸侯世譜), A Yearly Chronology of Emperors and Kings since Antiquity (Gulai 
Sima Qian 司馬遷 (145/135-86 BCE), compiler of the Records of the Grand Scribe (Shiji 史記), also names 'the writings of the Stone Chamber and Metal Casket' as some of his sources. ${ }^{82}$ Michael Loewe argues that the table of nobilities found in both the Records of the Grand Scribe and Ban Gu's History of the Han 'drew immediately from documents compiled in the course of imperial administration'. ${ }^{83}$ Although we cannot be absolutely sure whether Sima Qian was referring to the nobility registers when he mentioned the writings of the 'Stone Chamber and Metal Casket', there is no doubt that he and Ban $\mathrm{Gu}$ both made extensive use of administrative documents. This not only includes the registers, but imperial instructions or memorials to the emperor as well. ${ }^{84}$ Of course, we should not forget that all these are only 'abbreviated versions of original documents' and 'the results of a skilful selection', as Michael Loewe has put it. ${ }^{85}$ However, it would be wrong to assume that the main purpose of the archives was to preserve documents for writing history. ${ }^{86}$ None of the two histories were initiated by the central government. In fact, when the imperial court found out that Ban $\mathrm{Gu}$ was compiling a history, he was first imprisoned on the accusation that he 'privately altered and produced a state history (私改作國史)'; it was only after Ban Gu's work had been shown to the emperor that his compilation received imperial sanction. ${ }^{87}$

Finally, the 115 wooden slips mentioned above that were found in the remains of the Former Han capital, Chang'an, have been interpreted as part of an archive for documents on omens. ${ }^{88}$ They may have belonged to the Grand Scribe's collection (taishi 太史), who among other things was in charge of keeping record of portents and auspicious omens. ${ }^{89}$ For lack of any further information, this assumption remains speculative, though.

What are known as 'bone tags' (guqian 骨簽) are yet another case: around 60,000 of these items have been found among the remains of Chang'an, 57,000 with records inscribed on them. These seem to be inventories of tributes and goods (mostly weapons) produced by workshops outside the capital and presented to the

diwang nianpu 古來帝王年譜) and Origins of the Hereditary Houses (Shiben 世本); see HS 30:1714, 1766. Regarding Liu Xiang as Director of the Imperial Clan, see HS 19B:813, 36:1929. Also see Loewe 2004, 209-210.

82 SJ 130:3296.

83 Loewe 2004, 288.

84 For a detailed discussion of imperial decrees found in the two histories, see Loewe 2004, 524-546.

85 Loewe 2004, 528, 546.

86 See Wang Guihai 1999, 218.

87 HHS 40:1334. Also see Clark 2008, 20-25.

88 Xing Yitian 2011a, 140. Xing does not expressly use the term 'archive', but speaks of a 'storage place'.

89 Bielenstein 1980, 19. 
imperial court. 'The bone objects were found in piles close to the walls of the rooms, suggesting that they were once stacked on shelves or hung on racks. The objects seem to be of two complementary shapes, inscribed in two different formats. Some paired examples were bound loosely together at the time of excavation', says Anthony Barbieri-Low. ${ }^{90}$ It is thought that bone was used instead of wood or bamboo because it was more durable. Together with the fact that many of the records have serial numbers on them and that the dates recorded span much of the Former Han period, this appears to be an example of systematic storage. It therefore seems appropriate to speak of an archive here, which probably stored these tags to keep track of shipments and ensure the quality of the items that were to be delivered. ${ }^{91}$

\subsection{Local archives}

So far, we have only dealt with archives in the capital, but as already mentioned above, the administration permeated the realm all the way down to the local level. It was the county-level government units that provided the information necessary to govern an empire as extensive as that of the Former Han. The officials on the county level would send biannual reports to the next-highest level in the administration, the commandery. These reports provided basic information on the area, including 'figures for the registered population, the acreage of land newly put under the plough, the figures of both cash and grain received and disbursed and figures for the extent of crime'..$^{92}$ Information from every county was gathered and processed by the commandery government before being sent to the capital once a year. This annual submission of accounts (shangii 上計) also included reports on the performance of officials, which would be used for decisions about their promotion or demotion. The processing of the reports on the central level was the responsibility of the Chancellor and his ministry. ${ }^{93}$ This was essential for the government since ' $[\mathrm{t}]$ he registers of population and land were necessary for the collection of tax and the conscription of men for service'. ${ }^{4}$ The population figures for the year 2 CE recorded in the History of the Han, the earliest such data available for China, certainly must go back to the central register of the Chancellor,

90 Barbieri-Low 2001, 4. For more details see the excavation report: Zhongguo shekeyuan kaogusuo 1996, 91-122.

91 Zhongguo shekeyuan kaogusuo 1996, 122, Liu Guoneng 2007. For further interpretations on the function of the bone tags, see Barbieri-Low 2001, 4-5.

92 Loewe 2004, 44.

93 Bielenstein 1980, 8.

94 Loewe 1986, 483-484. 
which assembled all the information submitted from across the realm. ${ }^{95}$ It also seems likely that on returning to their commanderies, those officials who submitted the accounts in the capital 'would have taken with them copies of the latest decisions and orders of the government, in the form of decrees, statutes and ordinances, or the calendar that had been drawn for the ensuing year, ${ }^{96}$

It is clear that the many documents sent either way would have been archived at the various administrative levels. The manuscript finds of recent decades have brought examples of such documents to light. Take the manuscripts found in a tomb at Yinwan 尹灣 (Jiangsu), for instance, which include documents dated to the late Former Han period. Many of these have been identified as belonging to the annual procedure of submitting accounts to the central government. ${ }^{97}$ Another example is the slips and boards found in a well at Liye 里耶 (Hunan), which are believed to stem from a Qin dynasty county archive. ${ }^{98}$ It is well known-and not only from the Liye manuscripts-that the elaborate bureaucracy was not invented by the Han; they basically took over the system from their predecessors, the Qin dynasty. Furthermore, among the manuscripts found in a tomb in Shuihudi 睡虎地 (Hubei) dated to 217 BCE, there are statutes of the Qin in which we find the term shufu 書府 (lit. 'repository for writings'). Anthony F. P. Hulsewé has aptly translated this term as 'archive':

冊敢以火入藏 (藏) 府、書府中。吏已收藏（藏）, 官巫夫及吏夜更行官。册火, 乃閉 門戶。令令史循其廷府。節（即）新為吏舍, 冊依藏（藏）、書府。

One must not venture to enter storehouses or archives with fire. When the officials have finished collecting the stores, the Bailiff of the office and the officials take turns inspecting the office at night. If there is no fire, they close the doors. The Scribe Directors must be ordered to patrol the [Prefect's] office and the storehouses. In case of new construction of official hostels, these must not adjoin any storehouses or archives. ${ }^{99}$

More details on local archives can be found among the manuscripts containing Han statutes found in a tomb in Zhangjiashan 張家山 (Hubei) dated to 187 BCE. The 'Statutes on Households' (Hulü 户律) stipulate how local officials were to

95 HS 28A:1543-1603. Also see Bielenstein 1947, 135-139.

96 Loewe 2004, 44.

97 For a study on these documents in English, see Loewe 2004, 38-88.

98 Yates 2012/2013 offers a brief introduction to these manuscripts, which are still awaiting full publication. Also see Hsing 2014, 155-165. For details of further administrative documents found among manuscripts at other sites, see Hsing 2014, 165-184.

99 Shuihudi Qinmu zhujian zhengli xiaozu 1990, 64 (modified transl. of Hulsewé 1985, A105 (slips 97-98), 89). Xing Yitian 2011b, 19 points out some further sources mentioning special measures of fire protection, which were probably related to archives as well. 
handle the various registers containing the information that would eventually be submitted to the next-higher level in the administrative hierarchy:

民宅園戶籍、年細籍、田比地籍、田合籍、田租籍, 謹副上縣廷, 皆以筴若匣實盛, 緘 閉, 以令若丞、官嫱夫印封。獨別為府, 封府戶。節 (即) 有當治為者, 令史、吏主者 完封奏（湊）令若丞印。嗇夫發, 即雜治為。其【事】已, 輙復緘閉封藏（藏）。[...]

As for the ordinary people's household registers of their homesteads and grounds, the detailed age registers, the land registers indicating neighboring fields, the unified registers of agricultural fields, and the registers of their agricultural field taxes, carefully make copies and forward these up to the County Court, and, in every case, contain them in a bamboo chest or a wooden coffer, bound shut with cords, and seal [the chest or coffer] using the seal of the Magistrate, the Assistant Magistrate, or the Bailiff of the Office. Place them by themselves as a document archive and seal the door of the archive. When it is necessary to put some of the registers in order or create [new ones], the Scribe Director and the official in charge are to ensure that the seals are intact and to match [the impression] with the seal of the Magistrate or the Assistant Magistrate. Once the Bailiff [of the Office] has opened [the archive], they can then manage or create [registers] together. When the affair is complete, immediately bind shut [the archive] with cords, seal [it], and store [it] away once more. $[\ldots]{ }^{100}$

Although the term shufu is not employed in the statute, it is clear from the context that $f u$ 府 must refer to the county archive. ${ }^{101}$

\subsection{Physical organization of archives}

The Statutes on Households also show that the management of the documents implied some kind of organization. Evidence of the physical organization of documents in archives has also been noted among other manuscript findings. Among the documents found at Wuwei 武威 (Gansu) there is one bamboo manuscript that refers to ‘Orchid Terrace Ordinance no. 33 (蘭臺令第卅三)' and 'Secretariat of the Imperial Counsellor Ordinance no. 43 (御史令第冊三)'. ${ }^{102}$ In further bamboo slips found at the same site at a later time, there are more examples, such as 'the ordinance is at Orchid Terrace no. 43 (令在蘭臺第冊三)'. ${ }^{103}$ These numbers are considered to be serial numbers, which were probably used to file and retrieve archived documents.

100 Barbieri-Low/Yates 2015, Hulü 17, 798-799.

101 In an earlier translation of the same statute, Robin Yates actually translated it as 'document repository', not 'archive'; see Yates 2012/2013, 327.

102 Wang Guihai 1999, 218, 223; Gansu sheng bowuguan/Zhongguo kexueyuan kaogu yanjiusuo 2005, 140-141.

103 Wuwei xian bowuguan 1984, 35. 
Judging from the institutions mentioned, this obviously refers to documents archived in the capital. ${ }^{104}$ Evidence of the numbering of imperial ordinances can also be seen in the History of the Han. The term 'first ordinance (令甲)' is generally understood to refer to an enumeration system. ${ }^{105}$

Wang Guihai also takes some of the Juyan 居延 manuscripts, which were found at garrisons along the military defence lines in the north-west, to represent archives of the lowest unit, called 'company' (houguan 候官). ${ }^{106}$ 'Here officials maintained registers of the items that they dispatched or received, recording the name of the originator as seen in the seal, the contents or subject of the item, its date, the time taken for delivery and the names of the servicemen who had handled the process', says Michael Loewe. ${ }^{107}$ Among these manuscripts there are also numerous examples of labels referring to the time and content of documents, such as the following two:

\section{建始三年正月以來刺史書 ${ }^{108}$}

Letters of the Regional Inspector since the $1^{\text {st }}$ month of the $3^{\text {rd }}$ year of the Jianshi era (30 BCE) onwards

永始四年李敏自言書 109

Letters reported by Lin Min in person during the $4^{\text {th }}$ year of the Yongshi era (13 BCE)

The labels often come with a small hole in them, which was probably used to attach them to manuscripts for the purpose of creating files of documents on a certain subject and to facilitate their retrieval. ${ }^{110}$ Among the Juyan manuscripts there are also some examples of catalogues or file registers, which list the contents of imperial instructions (zhaoshu) together with a serial number:

104 Wang Guihai 1999, 218, 223. For a detailed discussion, see Wuwei xian bowuguan 1984, 51-53. 105 HS 8:252 (Dubs 1938-1955, II:227). According to later commentators, this refers to the numbering of the ordinances. Also see Wang Guihai 1999, 218.

106 Wang Guihai 1999, 223-227. Loewe 1997, 191 equally refers to the Juyan manuscripts as 'parts of official archives, drawn up in the course of administrating the empire'.

107 Loewe 2006, 110. For a brief discussion of the different kinds of documents among the Juyan manuscripts, see Loewe 1997, 177-191.

108 EPT50:182AB; see Gansu sheng bowuguan/Zhongguo kexueyuan lishi yanjiusuo 1990, 164.

109 EPT50:199; see Gansu sheng bowuguan/Zhongguo kexueyuan lishi yanjiusuo 1990, 164165. Also see Wang Guihai 1999, 204-206, who presents a list with a total of twelve labels of this kind. On the meaning of the legal term ziyan 自言, see Staack/Lau 2016, 154, n. 755.

110 Wang Guihai 1999, 211-213. 


\title{
縣置三老二 行水兼興船十二 置孝弟力田廿二 徵吏二千石以符卅二 郡國調列侯兵冊 二 年八十及孕朱需頌旉五十二
}

\begin{abstract}
'Prefectures establish Three Elders, no. 2; requisitioning of boats for traveling on water, no. 12; establishing the filial, brotherly, and strong farmers, no. 22; conscripting officials with [a nominal salary] of two thousand piculs with tallies, no. 32; commanderies and states transfer soldiers of the Marquis, no. 42; commoners eighty years old, pregnant women, and babies free from chaining, no. $52^{111}$
\end{abstract}

In other cases, there are further details on the time documents arrived. ${ }^{112}$ There are also examples of 'communication registers' recording the compilation and delivery of documents. The information in these includes 'summaries of the subject matter', 'names and titles of the originators and addresses' and records 'of the servicemen responsible for delivery and of the time that was taken'. ${ }^{113}$

It is evident that most of the documents that have been discovered are not cases of preserved archives, but rather remains of such-documents which were discarded at some point. The documents found among manuscripts in tombs, such as those from Zhangjiashan or Yinwan, are yet another problem, since there is no consensus among scholars about the question of why manuscripts were entombed in the first place. ${ }^{114}$ However, it seems very likely that they were not original documents, but rather copies made specifically for the purpose of burial. ${ }^{115}$

Based on the analysis of different layers in which around 3,000 discarded documents were found at Pochengzi 破城子 (Gansu), Wang Guihai surmises that archivists must have discarded documents that were no longer needed roughly once every thirteen years. It seems that these documents were burned or dumped in the immediate vicinity of the archive. At the same time, there are also plenty of examples of such documents being recycled for various purposes, including use as 'toilet paper' ${ }^{116} \mathrm{It}$ seems very likely that archivists at the central level of the administration also got rid of 'expired' documents regularly, but we lack explicit physical evidence of this.

111 Xie Guihua/Li Junming/Zhu Guozhao 1987, (5•3, 10•1, 13•8, 126•12), 7 (transl. by Li 2014, 81, n. 132). For a detailed study, see Chen Mengjia 1980, 275-285.

112 Xie Guihua/Li Junming/Zhu Guozhao 1987, (33•8), 51. Wang Guihai 1999, 213-215.

113 Loewe 1997, 178.

114 See Giele 2003, 428-431 for a general discussion of possible motives.

115 Hsing 2014, 177-178; Loewe 1997, 190-191.

116 Wang Guihai 1999, 227-232. Wang also mentions the administrative direction on the disposal of documents every three years stated in the Tang code, which might have antecedents in Han law. Also see Xing Yitian 2011b, 20-21. On recycling expired documents as 'toilet paper', see Hu Pingsheng 1996, 296-297. 
Not all manuscript finds outside tombs are necessarily discarded archive documents, though, as one might assume. ${ }^{117}$ The Liye manuscripts mentioned above were found in a well, which may seem like a clear case of them being discarded. Robin Yates, however, remarks that the layers in which the documents were found within the well do not show any clear temporal sequence; rather, he thinks that when the Qin dynasty started to collapse, the local archive was looted by the local population in an effort to cover up their massive debts recorded in administrative documents in the archive. ${ }^{118}$

\section{Conclusion}

My point of departure for this article on the distinction between 'library' and 'archive' in the Former Han dynasty was the imperial collection as it is presented in the Treatise on Classics and other Texts (Yiwenzhi). It is very clear that this collection constitutes a library and not an archive. The major points in distinguishing whether a collection is a library or archive are its content and function. As the Treatise shows us, the imperial collection only contains literary texts (in a broad sense); there are no administrative documents in it whatsoever. There is abundant evidence that the Han bureaucracy had archives for various government agencies on all levels of the administrative machinery, which were intended to store documents containing information that was needed. The archives played an important part in the smooth functioning of the bureaucracy and helped to ensure the empire could be governed properly. The imperial collection or library was apparently intended to serve the emperor. Nonetheless, it is evident from the grand collation project that the collection as we know it from the Treatise was the product of a scholarly endeavour involving the production and reproduction of a host of texts. It may be said that while the library was a place for scholarly and literary activities using its holdings, the many archives, on the other hand, stored documents produced, dispatched and employed by a bureaucratic apparatus, of which they were an essential part. Both institutions show a certain degree of organization so as to allow manuscripts to be located within the collections, otherwise we would have to speak of incidental assemblages of manuscripts. The Treatise, basically a classified catalogue, shows an obvious form of organization. In contrast, the evidence of archival organization is

117 Xing Yitian 2011a, 21, for instance, argues that the Liye manuscripts are discarded archive documents.

118 Xing Yitian 2011b, 21; Yates 2012/2013, 302-303, 327-328. 
very fragmentary. There is no fully preserved catalogue or inventory of an archive transmitted in the historical sources and the excavated documents are usually discarded files, which thus only yield a very fragmented picture of the organizational system.

Obviously, many archives existed in the Han period and they had already existed in the Qin period. This article has only dealt with one library, however: the imperial collection. One might ask whether the imperial collection was, in fact, the very first library in Chinese history (as some have already argued). We certainly know of numerous other collections: Emperor Wu's brother, Liu De 劉德 (d. in 130/129 BCE), who was enfeoffed as King Xian of Hejian 河間獻王 in 155 BCE, is said to have collected manuscripts on a large scale. ${ }^{119}$ From Liu Xiang's editorial reports we can tell that he made use of other manuscripts than those in the imperial collection, including manuscripts from the Grand Scribe (taishi) as well as some from his own (private?) collection. Finally, the Erudites (boshi 博士)-the official court scholars-certainly had manuscript collections of their own. In fact, the infamous burning of books ordered by the Qin's founding emperor explicitly excluded the manuscripts of the Erudites. ${ }^{120}$ However, there is no detailed information on the content of all these collections, let alone on their organization. It is because of this lack of information that the imperial collection of the Han is currently referred to as China's first library.

119 HS 53:2410-2411.

120 SJ 6:255. Also see Petersen 1995, 5-12. 


\section{References}

Amelung, Iwo, Joachim Kurtz, and Michael Lackner (eds) (2001), New Terms for New Ideas, Western Knowledge and Lexical Change in Late Imperial China (Sinica Leidensia, 52), Leiden: Brill.

Barbieri-Low, Anthony J., and Robin D. S. Yates (2015), Law, State, and Society in Early Imperial China. A study with critical edition and translation of the legal texts from Zhangjiashan tomb no. 247 (Sinica Leidensia, 126), 2 vols, Leiden, Boston: Brill.

Barbieri-Low, Anthony J. (2001), The Organization of Imperial Workshops during the Han Dynasty. $\mathrm{PhD}$ dissertation. Princeton University, Princeton.

Bielenstein, Hans (1947), 'The Census of China during the period 2-742 A.D.', in Bulletin of the Museum of Far Eastern Antiquities, 19, 125-163.

Bielenstein, Hans (1959), The Restoration of the Han Dynasty, Volume II. The Civil War. Reprint from the Museum of Far Eastern Antiquities Bulletin No. 31, Göteborg: Elanders.

Bielenstein, Hans (1980), The Bureaucracy of Han Times (Cambridge studies in Chinese history, literature, and institutions), Cambridge, New York: Cambridge University Press.

Brosius, Maria (2003), 'Ancient Archives and Concepts of Record-Keeping. An Introduction', in Maria Brosius (ed.), Ancient Archives and Archival Traditions, Oxford: Oxford University Press, 1-16.

Chen Mengjia 陳夢家 (1980), Hanjian zhuishu 漢簡緅述, Beijing: Zhonghua shuju 中華書局.

Chiang, Fu-tsung 蔣復璁 (1963), 'Handai de tushuguan 漢代的圖書館', in Dalu zazhi 大陸雜誌, 27/8:33-36, 9:31-34, 10:30-35.

Clark, Anthony E. (2008), Ban Gu's History of Early China, Amherst NY: Cambria Press.

Delhey, Martin, Vito Lorusso et al. (2015), Wordlists for Libraries and Closely Related Phenomena in Different Manuscript Cultures from Asia, Africa and Europe (CSMC - Occasional Paper, 2). https://www.manuscript-cultures.uni-hamburg.de/papers/CSMC_Occasional_Paper_2_Delhey_Lorusso_et_al.pdf (viewed on 26/09/16).

Di Chongde 狄蘢德, and Chen Bolan 陳伯蘭 (1981), 'Lunshu dang’an shiye he tushuguan shiye zai lishi shang de qubie 論述檔案事業和圖書館事業在歷史上的區別', in Dang'an gongzuo 檔案工作, 3, 56-57, 61 .

Ding, Xinzhao (2015), 'The Han Bureaucracy, Its Origin, Nature, and Development', in Walter Scheidel (ed.), State Power in Ancient China and Rome, Oxford: Oxford University Press, 56-89.

Drège, Jean-Pierre (1991), Les bibliothèques en Chine au temps des manuscrits, Jusqu'au Xe siècle (Publications de l'Ecole française d'Extrême-Orient, 161), Paris: École française d'Extrême-Orient

Dubs, Homer H. (1938-1955), The History of the Former Han Dynasty, 3 vols, Baltimore: Waverly.

Dubs, Homer H. (2009), The History of the Former Han Dynasty, Introduction to the 'Tables of the Hundred Officials' In the Ch'ien Han-shu 19A. https://library.uoregon.edu/ec/easia/read/Dubs_Vol_IV.pdf (viewed on 1/11/16).

Dudbridge, Glen (2000), Lost Books of Medieval China, London: British Library (The Panizzi lectures).

Fitzgerald, Devin (2015), 'Between Paper and Wood, or the Manchu Invention of the Dang'an', in Saksaha: A Journal of Manchu Studies, 13, 75-80.

Fölster, Max Jakob (2016), The Imperial Collection of the Former Han and the Origins of Philology in China. A Study of the Bielu, Qilüe and Hanshu Yiwenzhi. PhD dissertation. Universität Hamburg, Hamburg. 
Fu Rongxian 傅榮賢 (2007), 'Lun Liu Xiang wenxian zhengli de duixiang shi tushu er bu shi dang'an 論劉向文獻整理的對象是圖書而不是檔案’, in Dang'an guanli 檔案管理, 6, 35-37.

Gansu sheng bowuguan 甘肅省博物館, and Zhongguo kexueyuan lishi yanjiusuo 中國科學院历史\# 研究所 (eds) (1990), Juyan xin jian 居延新簡, Jiaqu houguan yu di si sui 甲渠候官與第四燧, Beijing: Wenwu chubanshe 文物出版社.

Gansu sheng bowuguan 甘肅省博物館, and Zhongguo kexueyuan kaogu yanjiusuo 中國科學\# 院考古研究所 (eds) (2005), Wuwei Han jian 武威漢簡, Beijing: Zhonghua shuju 中華書局 (Kaoguxue zhuankan 考古學專刊, Yi zhong di shier hao 乙種第十二號).

Giele, Enno (2003), 'Using Early Chinese Manuscripts as Historical Source Materials', in Monumenta Serica, 51, 409-438.

Giele, Enno (2006), Imperial Decision-Making and Communication in Early China. A Study of Cai Yong's Duduan, Wiesbaden: Harrassowitz.

Harris, Michael H., and Elmer D. Johnson (1999), History of Libraries in the Western World. 4th ed., Lanham, Maryland and London: Scarecrow Press.

Herbert, P. A. (1980), 'From Shuku to Tushuguan. An Historical Overview of the Organisation and Function of Libraries in China', in Papers on Far Eastern History, 22, 93-121.

HHS = Hou Hanshu 後漢書, Beijing: Zhonghua shuju 中華書局, 1973.

HS = Hanshu 漢書, Beijing: Zhonghua shuju 中華書局, 1962.

Hsing, I-tien (= Xing Yitian 邢義田) (2014), 'Qin-Han Census and Tax and Corvée Administration. Notes on newly discovered materials'. Transl. by Hsieh Mei-yu and William G. Crowell, in Yuri Pines, Gideon Shelach, Lothar von Falkenhausen and Robin D. S. Yates (eds), Birth of an Empire. The State of Qin Revisited (New perspectives on Chinese culture and society, 5), Berkeley, Los Angeles, London: Global Area and International Archive University of California Press, 155-186.

Hu Pingsheng 胡平生 (1996), 'Dunhuang Maquanwan jian zhong guanyu xiyu shiliao de bianzheng 敦煌馬圈灣簡中關於西域史料的辯證, in Wu Rongzeng 吳榮曾 (ed.), Jinxin ji: Zhang Zhenglang xiansheng bashi qingshou wenji 盡心集: 張政烺先生十八慶壽文集, Beijing: Zhongguo shehui kexue chubanshe 中國社會科學出版社, 273-297.

Huang Caigeng 黄才庚 (1988), 'Liang Han shiqi de dang'an yu dang’an gongzuo 兩漢時期的檔 案與檔案工作', in Zhejiang dang'an 浙江檔案, 8, 19-21.

Hucker, Charles O. (1985), A Dictionary of Official Titles in Imperial China, Stanford, California: Stanford University Press.

Hulsewé, Anthony F. P. (1955), Remnants of Han Law, Vol. 1: Introductory studies and an annotated translation of chapters 22 and 23 of the History of the Former Han Dynasty (Sinica Leidensia, 9), Leiden: Brill.

Hulsewé, Anthony F. P. (1985), Remnants of Ch'in Law. An annotated translation of the Ch'in legal and administrative rules of the $3^{\text {rd }}$ century B.C., discovered in Yün-meng Prefecture, Hu-pei Province, in 1975 (Sinica Leidensia, 17), Leiden: Brill.

Jacob, Christian (1998), 'Vers une histoire comparée des bibliothèques: Questions préliminaires, entre Grèce et Chine anciennes', in Quaderni di Storia, 48, 87-122.

Jinshu 晉書, Beijing: Zhonghua shuju 中華書局, 1974.

Koh Thong-ngee (1964), 'The Beginning of Chinese Bibliography, A Study of the Record of Literature in the History of the Former Han Dynasty', in Ts'e-fu, The Repository, 7/8, 26-41.

Lau, Ulrich, and Michael Lüdke (2012), Exemplarische Rechtsfälle vom Beginn der Han Dynastie. Eine kommentierte Übersetzung des Zouyanshu aus Zhangjiashan/Provinz Hubei 
(Study of languages and cultures of Asia and Africa monograph series, 50), Tokyo: Research Institute for the Languages and Cultures of Asia and Africa (ILCAA), Tokyo University of Foreign Studies.

Lepper, Marcel (2012), Philologie zur Einführung, Hamburg: Junius Hamburg.

Lewis, Mark Edward (1999), Writing and Authority in Early China, Albany N.Y.: State University of New York Press (SUNY series in Chinese philosophy and culture).

Li Deyun 李德運 (1980), ‘Xihan wangchao de dang’an ku 西漢王朝的檔案庫, Tianluge he shiquge 天祿閣和石渠閣', in Dang'an gongzuo 檔案工作 1, n. pag.

Li, Jingrong (2014), The Ernian lü ling Manuscript. PhD dissertation. Universität Hamburg, Hamburg.

Liu Guoneng 劉國能 (2007), 'Wo guo zui zao de zhuanmen dang'an guanku-Handai guqian dang'an guanku 我國昨早的專門檔案庫一漢代骨簽檔案館庫', in Zhongguo dang'an 中國 檔案, 7, 50-52.

Liu Zunyan 劉尊志, and Liang Yong 梁勇 (2003), “Xuzhou chutu “mifu” fengni de fengzhen fangfa qianxi 徐州出土「祕府」封泥的封緘方法淺析’, in Huaxia kaogu 華夏考古, 3, 96.

Loewe, Michael (1986), 'The Structure and Practice Government', in Denis C. Twitchett and John King Fairbank (eds), The Cambridge History of China, Vol. 1: The Ch'in and Han Empires, 221 B.C.-A.D. 220, Cambridge: Cambridge University Press, 463-490.

Loewe, Michael (1997), 'Wood and Bamboo Administrative Documents of the Han Period', in Edward L. Shaughnessy (ed.), New Sources of Early Chinese History. An Introduction to the Reading of Inscriptions and Manuscripts, Berkeley: The Society of the Study of Early China, The Institute of East Asian Studies, University of California, Berkeley, 159-192.

Loewe, Michael (2000), A Biographical Dictionary of the Qin, Former Han and Xin Periods (221 $B C-A D$ 24) (Handbook of Oriental Studies. Section 4 China, 16), Leiden: Brill.

Loewe, Michael (2004), The Men Who Governed Han China. Companion to A Biographical Dictionary of the Qin, Former Han and Xin Periods (Handbook of Oriental Studies. Section 4 China, 17), Leiden, Boston: Brill.

Loewe, Michael (2006), The Government of the Qin and Han Empires, 221 BCE-220 CE, Indianapolis, Ind.: Hackett.

Lu Hesheng 盧荷生 (1983), 'Handai de tushuguan shiye 漢代的圖書館事業’, in Furen xuezhi 輔仁學志 12, 417-439.

Nienhauser, William H. (ed.) (1994-), The Grand Scribe's Records, 9 vols, Bloomington: Indiana University Press.

Nylan, Michael (2014), 'Manuscript culture in late Western Han, and the implications for authors and authority', in Journal of Chinese Literature and Culture 1/1-2, 155-185.

Pedersén, Olof (1998), Archives and Libraries in the Ancient Near East, 1500-300 B.C, Bethesda, Md.: CDL Press.

Petersen, Jens Østergard (1995), 'Which books did the first emperor of Ch'in burn? On the meaning of pai chia in early Chinese sources', in Monumenta Serica, 43, 1-52.

Quan Hou Hanwen 全後漢文, in Quan Shanggu Sandai Qin Han Sanguo Liuchao wen 全上古三代秦漢三國六朝文, Yan Kejun 嚴可均 (ed.), Shanghai: Zhonghua shuju 中華書局, 1965.

Ren Jiyu 任繼愈 (ed.) (2001), Zhongguo cangshulou 中國藏書樓, 3 vols, Shenyang: Liaoning renmin chubanshe 遼寧人民出版社.

Shih, Vincent Yu-chung (1959), The Literary Mind and the Carving of Dragons. A Study of Thought and Pattern in Chinese Literature, New York: Columbia University Press.

Shuihudi Qinmu zhujian zhengli xiaozu 睡虎地秦墓竹簡整理小組 (1990), Shuihudi Qinmu zhujian 睡虎地秦墓竹簡, 北京: Wenwu chubanshe 文物出版社. 
SJ = Shiji 史記, Beijing: Zhonghua shuju 中華書局, 1982.

Staack, Thies, and Ulrich Lau (2016), Legal Practice in the Formative Stages of the Chinese Empire. An annotated translation of the exemplary Qin criminal cases from the Yuelu Academy collection (Sinica Leidensia, volume 130), Leiden, Boston: Brill.

Tang Yongping 唐永平 (1990), ‘Liang Han gushi dang'an kao 兩漢故事檔案考', in Dang'an guanli 檔案管理, 3, 41-44.

Tjan, Tjoe Som (1949), Po Hu T'ung, The Comprehensive Discussions in the White Tiger Hall, Vol. 1 (Sinica Leidensia, 6), Leiden: Brill.

Wagner, Vivian (2004), 'Archive am chinesischen Kaiserhof: Geheime Arsenale im Dienste dynastischer Erinnerungspolitik', in Archivalische Zeitschrift, 86/1, 9-90.

Wagner, Vivian (2006), Erinnerungsverwaltung in China. Staatsarchive und Politik in der Volksrepublik (Beiträge zur Geschichtskultur, 31), Cologne: Böhlau.

Wang Guihai 王桂海 (1999), Handai guan wenshu zhidu 漢代官文書制度, Nanning: Guangxi jiaoyu chubanshe 廣西教育出版社.

Wang Qiming 汪啟明 (2003), ‘Handai de tushu he tushuguan 漢代的圖書和圖書館’, in Wang Qiming 汪啟明 (ed.), Han xiaoxue wenxian yuyan yanjiu conggao 漢小學文獻語言研究\# 叢稿, Chengdu: Bashu shushe 巴蜀書社, 304-309.

Watson, Burton (1974), Courtier and Commoner in Ancient China: Selections from the History of the Former Han, New York: Columbia University Press.

Weitemeyer, Mogens (1956), 'Archive and Library Technique in Ancient Mesopotamia', in Libri, 6/3, 217-238.

Wenxin diaolong $=$ Wenxin diaolong zhushi 文心雕龍注释, Beijing: Renmin wenxue chubanshe 人民文學出版社, 1981.

Wu Xi 吳睎 (1996), Cong cangshu lou dao tushuguan 從藏書樓到圖書館, Beijing: Beijing tushuguan chubanshe 北京圖書館出版社.

Wuwei xian bowuguan 武威縣博物館 (1984), “Wuwei xin chutu Wang Zhang zhaoling ce 武威新 出土王杖詔令冊', in Gansu sheng wenwu gongzuodui 甘肅省文物工作隊 and Gansu sheng bowuguan 甘肅省博物館 (eds), Han jian yanjiu wenji 漢簡研究文集, Lanzhou: Gansu renmin chubanshe 甘肅人民出版社, 34-61.

Xie Guihua 謝桂華, Li Junming 李均明, and Zhu Guozhao 朱國炤 (eds) (1987), Juyan Han jian shiwen hejiao 居延漢簡釋文合校, 2 vols, Beijing: Wenwu chubanshe 文物出版社 (Qing Han Wei Jin chutu wenxian 秦漢魏晉出土文獻).

Xie Zhuohua 謝灼華 (2005), Zhongguo tushu he tushuguan shi 中國圖書和圖書館史, Wuhan: Wuhan daxue chubanshe 武漢大學出版社.

Xing Yitian 邢義田 (1987), “Cong “ru gushi” he “bianyi congshi” kan Handai xingzheng zhong de jingchang yu quanbian 從「如故事」和「便宜從事」看漢代行政中的經常與權變”, in Xing Yitian 邢義田 (ed.), Qin Han shi lungao 秦漢史論稿, Taibei: Dongda tushu gongsi 東 大圖書公司, 333-409.

Xing Yitian 邢義田 (2011a), 'Han Chang'an Weiyanggong qiandian yizhi chutu mujian de xingzhi 漢長安末央宮前殿遺址出土木簡的性質', in Xing Yitian 邢義田 (ed.), Di bu ai bao 地不愛寶. Handai de jiandu 漢代的簡牘, Beijing: Zhonghua shuju 中華書局, 138-143.

Xing Yitian 邢義田 (2011b), ‘Handai jiandu de tiji, zhongliang he shiyong 漢代簡牘的體積、重 量和使用, Yi zhongyanyuan shiyusuo cang Juyan Han jian wei li 以中研院史語所藏居延漢 簡為例', in Xing Yitian 邢義田 (ed.), Di bu ai bao 地不愛寶. Handai de jiandu 漢代的簡牘, Beijing: Zhonghua shuju 中華書局, 1-50. 
Yang, Shao-yun (2015), 'The Politics of Omenology in Chengdi's Reign', in Michael Nylan and Griet Vankeerberghen (eds), Chang'an 26 BCE. An Augustan Age in China, Seattle: University of Washington Press, 323-346.

Yantielun = Yantielun jiaozhu 鹽鐵論校注, Beijing: Zhonghua shuju 中華書局, 1992 (Xinbian zhuzi jicheng 新編諸子集成).

Yates, Robin D. S. (2012/2013), 'The Qin Slips and Boards from Well No. 1, Liye, Hunan. A Brief Introduction to the Qin Qianling County Archives', in Early China, 35-36, 291-329.

Ye, Wa, and Joseph W. Esherick (1996), Chinese Archives. An Introductory Guide (China research monograph, 45), Berkeley, California: Inst. of East Asian Studies University of California Berkeley Center for Chinese Studies

Zhang Wei 張偉 (1992), 'Shidai jishi 時代紀實, Liang Han de guojia dang’an jigou 兩漢的國家檔 案機構', in Shanghai dang'an gongzuo 上海檔案工作 4, 48-50.

Zhang, Wenxia (2004), 'A Brief History of the Chinese Imperial Archives and Its Administration', in Journal of Archival Organization, 2, 17-38.

Zhao Zhiqiang 趙志強 (2016), “'Dang'an” ciyuan kaobian「檔案」詞源考辨’, in Dang'an xue tongxun 檔案學通訊, 4, 27-30.

Zhongguo shekeyuan kaogusuo 中國社科院考古所 (ed.) (1996), Han Chang'an Weiyanggong 漢長安城未央宮, 1980-1989 nian kaogu fajue baogao 1980-1989 年考古發掘報告, 2 vols, Beijing: Zhongguo shekeyuan 中國社科院.

Zhou Xueheng 周雪恒 (1994), Zhongguo dang'an shiye shi 中國檔案事業史, Beijing: Zhongguo renmin daxue chubanshe 中國人民大學出版社.

Zou Jiawei 鄒家煒, and Dong Jian 董儉 (1985), Zhongguo dang'an shiye jianshi 中國檔案事業簡史, Beijing: Zhongguo renmin daxue chubanshe 中國人民大學出版社. 


\title{
Alberto Camplani
}

\section{Setting a Bishopric / Arranging an Archive: Traces of Archival Activity in the Bishopric of Alexandria and Antioch}

\begin{abstract}
Early Christianity was heir to the archival practice and discourse of Greek and Roman societies, in which public and private archives enjoyed a great deal of consideration. Even before creating their own archives, Christian congregations, when becoming a structured society, adhered to the archival discourse of their times, and the mention of archives in their writings served apologetic and theological aims. The article argues that the main impulse to undertake archival activity came from the new form of leadership, the bishop: alone, or in connections with other colleagues, in particular within the meetings (synods), the bishop produced a huge number of written records, which was to be arranged in archival form. After a brief presentation of the papyrological evidence, the article discusse the traces of ancient episcopal archives detectable in the historiographical and apologetic writings compiled in the main episcopal sees, such as Rome, Alexandria, and Antioch.
\end{abstract}

\section{Historical introduction and methodological issues}

Early Christianity was heir to the archival practice and discourse of Greek and Roman societies. The high amount of consideration achieved by public and private archives, ${ }^{1}$ regarded as authoritative repositories of memoirs and legal docu-

1 I will begin with a working definition of 'archive' offered by Vandorpe 2009, 217-218 in a recent handbook of papyrology, notoriously a discipline which pays great attention to the study of dossiers and archives: '[an] archive is a deliberate collection of papers in antiquity by a single person, family, community, or around an office'. Obviously, in the course of the work, I will also make use of Schenk's and Friedrich's papers and take into account the sophisticated conceptual framework they proposed at our conference: I am thinking in particular of Schenk's distinction between archival records, archives and archival thinking, and Friedrich's reconstruction of the dialectics between archival practices and archival discourse, both of which are very useful for approaching the scant clues we have about Late Antique archives. See also their books: Friedrich

https://doi.org/10.1515/9783110541397-008, (cc) BY-NC-ND (c) 2018 A. Camplani, published by De Gruyter. This work is licensed under the Creative Commons Attribution-NonCommercial-NoDerivs 3.0 License. 
ments owned by a family, a city or a state, affected Jesus' followers from the beginning of the second century CE. This was particularly true when Christianity began to conceive of itself as a structured system of congregations and as a complex society even before the birth of the monarchical episcopate. ${ }^{2}$ However, the main impulse to undertake archival activity came from the bishops themselves: from their actions within their dioceses, their relationship with the congregations and the colleagues of other cities and countries, and their official meetings (the synods), all of which produced a huge number of written records. Bishoprics and synods were an original product of the expansion and growth of the new religion, but also received and reworked models and attitudes coming from the bureaucratic offices of the Greco-Roman society, including the latter's attention to written records of collective decisions. ${ }^{3}$

For that reason, I will surmise that the evolution of the monarchical episcopate is responsible for the growth of the first Christian archives. ${ }^{4}$ My argument will be illustrated by studying some cases in which the documentation allows us to follow the development of archival activity. Despite the enormous loss of ancient Christian archives (with few exceptions, unfortunately), we know about the multiplicity of activities which could be committed to written records through other clues, such as a list of members of the clergy, a list of widows, a list of the succession of bishops, and-in dioceses owning the right to intervene in the congregations of cities and villages in the same province-a list of the subordinate bishops, which also had the ideological function of marking the communion. Another activity which could be recorded in writing was the recruitment of deacons and presbyters: the system used since the end of the third century consisted in writing a contract according to a model drawn from civil society. ${ }^{5}$ Finally, there was the transmission of letters and short messages both inside and outside the diocese, which were

2013; Schenk 2014. Interesting insights have been provided by Francia 2015 within a contribution devoted to the archives/libraries of Ninive.

2 On this process, see Gaudemet 1958, 1994.

3 Adler 2012, 919-925; Camplani 2006b.

4 I am aware of the fact that the label 'monarchical episcopate' is debated nowadays. See the documentation presented, in the framework of a new hypothesis, by Stewart 2014, who, against the general consensus on the emergence of bishops from the presbyterium responsible of a city congregation, outlines a complex evolution from original episcopoi/householders, which constituted the presbyterium of the city, and later monoepiscopoi emerging from the presbyterium. While the writing of letters between congregations is both the result of a necessity for congregations living at a certain distance and the sign of commitment to the written word per se, the archival practice takes place more easily when religious power is concentrated in one person.

5 Wipszycka 1996. 
addressed to other congregations and bishops, as well as the activity of the synods, whose development is strictly tied to the growing power of the monarchical bishop: the meetings organised in major cities to discuss important issues involved the tachygraphic transcription of debates, recording what the participants said, redacting synodical letters and providing a synthesis of the decisions made; in some cases, this even took the form of canons. ${ }^{6}$

All this documentation can only be classified as archival records if we are certain of the existence of archives. Since these are mentioned in the sources, but are lost for the most part, our first task is that of collecting evidence about the concrete situations in which it was felt necessary to record something in writing, while our second task is that of comparing the data with the information given by the sources about either archives or the persons working in them. ${ }^{7}$ This is not exactly the same as studying literacy in relation to the history of the book in Christian congregations, as proposed by Gamble. ${ }^{8}$ The kind of documentation preserved in episcopal archives is normally more practical and more linked to the necessities of communal life, although it is impossible to draw a clear line between a literary document and a document with a more practical function-a letter of recommendation can be classified as both a literary text and an archival record, for example. Much depends on the function it plays in the context in which it is preserved and used.

Of course, we should prioritise the issue of literacy in Christian congregations, which have been at the centre of current research and led to some interesting but questionable results. Gamble, Norelli and Bagnall are only a few of the members of a large group of scholars who have been devoting their time and energy to studying ancient information about books, libraries and archives. ${ }^{9}$ I am aware of the fact

6 Hess 2002, 5-88; Bernardini 2009, 34-58.

7 It often happens that literary, epigraphic or papyrological sources, witnesses to diverse historical situations, give us information about the personnel working in an archive without clearly referring to the existence of the latter. This kind of information is also to be taken into account for the history of Christian archives.

8 See Gamble 1995, whose first chapter (pp. 1-41) has the title 'Literacy and literary culture in early Christianity'. Of course, things are very complicated, since early Christian documents all had a more or less pronounced practical function. 'Early Christian letters, however, have often been described as nonliterary, either by denying that letters were a form of literature proper (Overbeck) or by locating the analogues of Christian letters in the ordinary private letters of the papyri (Deissmann)' (36). The conclusion by Gamble is that 'the letters found in the New Testament and among the Apostolic Fathers do not, as a group, closely resemble either the private letters among the papyri or the literary letters of the elite but fall between these extremes of epistolary practice' (37).

9 Gamble 1995, 28-40 (orality and literary culture), 144-161 (early Christian libraries); Norelli 2006, 8-13 ('Comunicazione scritta e comunicazione orale’); Bagnall 2009. 
that, on the one hand, the relationship between Jesus and books, or rather scrolls, and more generally between Jesus and the written word-what we would call 'literacy'-is a problematic one, which cannot be answered positively or negatively, but it deserves a complex approach in which his attitude to the written heritage of Judaism and the Bible should be taken into account and put in relation to his strong tendency to transmit his message orally. On the other hand, this tension-this problematic attitude to the written word-should be considered in terms of its influence on the future development of the diverse congregations which were formed after his death: just a few years later, we find Paul of Tarsus elaborating on a different mentality regarding the written word, but the very diverse streams of Jesus' followers were not all ready to agree with him. How relevant is this question to the history of Christian archives?

The purpose of my paper is both to define some of the methodological problems involved in the reconstruction of the episcopal archives of Late Antiquity and to explore the possible correlation between the birth and subsequent evolution of the bishoprics in the traditional sense of the term and the constitution of archives. I think that an indirect correlation may be established in the sense that an archive could be arranged more easily in a unitary congregation led by a monarchical bishop at the end of the second century or beginning of the third than in a presbyteral federation of diverse congregations typical of the first two centuries. The documentation at our disposal supports the former hypothesis. ${ }^{10}$ My perspective is obviously that of a historian of Christianity, as may be inferred from the following questions: How did the evolution of Christianity in the eastern Mediterranean involve the formation of a particular type of archive that connected with the practical, cultural and liturgical activities carried out by congregations of believers? When did the transition take place from one form of religion in which orality played a relevant role and on which communal life was based, only to a lesser extent on the writing, reading and editing of texts and documents, to a set of congregations that not only gave significant weight to the written word and the book, but also relied on writing for a good part of their practical activities? In sum, on the one hand there is a problem of methodology and analysis of the sources concerning the recovery of archives, and on the other there is an issue of a historical type. ${ }^{11}$

Marginally we have to note that our quest for archives and archival culture in the past is largely dependent on the fact that we are heirs to the archival discourse and archival practices of the Mediterranean world of Late Antiquity, medieval and modern times as well as of other regions which eventually came into contact with

10 See Bagnall 2009, chapter I.

11 On this transformation, see Norelli 2012. 
it. Is there a clear case of continuity of archival activity in bishoprics from Late Antiquity up to the present day? Given what I have said about the loss of archives, the answer should be negative. An exception has been indicated by Gianfranco Fiaccadori on many occasions, however: the archiepiscopal archives of Ravenna, ${ }^{12}$ which should be studied from this perspective.

Since this paper will not only touch on early dioceses of a small size, but also on the ones situated in the largest cities in the eastern Mediterranean world in Late Antiquity, it seems appropriate to me to offer a further methodological observation here: from the theoretical point of view, we can distinguish in the activities of a large diocese, such as that of Rome or Alexandria or Antioch, three entities having a strict relationship with written records of all kinds: the chancery of the bishopric, the archive and the library. In fact, none of the information we have at our disposal corresponds to this distinction or corroborates it in a clear fashion. Perhaps there was only one place, or a system of private places, in which the written materials were prepared, and then the staff employed the single items for the different functions corresponding to our distinction of chancery, archive and library. This applies to Alexandria and Antioch as well as to Rome. ${ }^{13}$

\subsection{The myth: the archives of Rome and Edessa between bureaucratic reality and religious idealisation}

Before facing the question of the extant papyrological archives and the issue of the recovery of lost ones, I would like to highlight how the image of efficient archives affected Christian intellectuals of the first centuries on the basis of a recent and intelligent recognition by Adler:

But whether figurative or real, the terminology of Josephus and early Christian authors shows in any case how the ancient idealization of the archive has seeped into Jewish and Christian discourse about the authority of their sacred texts. ${ }^{14}$

Here we are facing the question of the archival discourse, which feeds on archival practice: the role of archives was so important in the society in which Christianity

12 Fiaccadori 2014, 244; Montanari 1992, 274-275, 281. Gianfranco Fiaccadori, who has passed away in the meantime, stressed this fact during the debates at our conference.

13 Also from a papyrological point of view, 'the term archive is clearly reserved for documentary groups of texts, whereas a public or personal library is a collection of literary texts. Works of literature may, however, be included among documentary papers': Vandorpe 2009, 218.

14 Adler 2012, 928; see also Adler 2013, 48-52. 
was spreading that some intellectuals used the reference to them as an argument in their apologetic or theological discourse. Tertullian, for instance, claims that Rome's public archives (instrumenta) confirmed the Gospel account about the tremendous events that accompanied the crucifixion of Christ; and against Marcion, he maintains that Jesus' enrolment in the Roman census was certified in these same archives. ${ }^{15}$ One of the most famous and metaphorical occurrences of the term is preserved in Ignatius' Letter to the Philadelphians: ${ }^{16}$

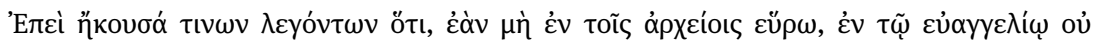

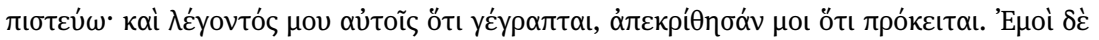

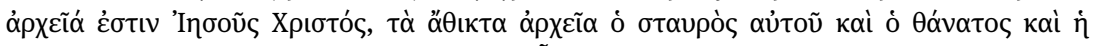

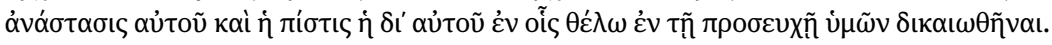

I heard someone saying: 'If I can't find it in the archives, then I won't believe [it if it's] in the Gospel'. Since I said to them: 'It is written', they replied 'This is the question'. For me, the archives are Jesus Christ, undefiled archives are his cross, and death, and resurrection, and the faith which is by him; through this I want to be justified in your prayers.

To Ignatius' adversaries, archives were the certification of theological and Christological truth. By 'archives' they meant the Old Testament, without which, according to them, nothing could be said about Christ. In his response, Ignatius seems to stress the sufficiency of Christian archives, which are not the written Gospel here, but the person of Jesus Christ. ${ }^{17}$ So, we have a double metaphoric process in this case: archives are a metaphor for the Jewish Scriptures, and, at a higher level, for the incarnate humanity of Christ, which in turn is both in continuity with the Jewish Scriptures and their fulfilment / overcoming. ${ }^{18}$

When exploring the impact of the archival ideology in the Mediterranean world and the metaphoric use of the word 'archives', Edessa comes to our attention mainly thanks to the centrality that the city achieves in Eusebius's account of the evangelisation of Osrhoene. A brief review of this account, which is shared by all its basic witnesses (Eusebius's account, a later Syriac reworking and other texts), is in order now. Abgar V, king of Edessa, is said to have sent some envoys to Palestine with a letter addressed to Jesus at the very moment of the Passion, asking him to come to Edessa in order to heal him from a serious illness. Jesus responded with a message in which he declared that it was impossible for him to make a personal visit to the king, while promising to send a disciple to Edessa

\footnotetext{
15 Apologeticum 21,19; Contra Marcionem 4,7,7.

16 Ign. Ad Philadelphos, 8,2, ed. Simonetti 2010, 402-403.

17 See Norelli 2001, 237-243.

18 Simonetti 2010, 603-605 (commentary).
} 
after his ascent into heaven, who would heal Abgar and preach the Gospel in his city. This promise was subsequently kept. The story relates the presence of a disciple of Jesus at Edessa, his working miracles and his dealings with Abgar. Such is the sequence of events related by both the Syriac source, whose Greek translation Eusebius inserted in Historia ecclesiatica (h.e.) and a later reworking of it entitled Teaching of Addai (which claims to have been written by the scribe Labubna), ${ }^{19}$ as well as implied by the Itinerarium Egeriae (17,2 and 19,2-19) and other later texts. In Eusebius h.e. I 13 we find the following statement:

\begin{abstract}
There is also documentary evidence of these things taken from the archives at Edessa which was at that time a capital city. At least, in the public documents there, which contain the things done in antiquity and at the time of Abgar, these things too are found preserved from that time to this; but there is nothing equal to hearing the letters themselves, which we have extracted from the archives, and when translated from the Syriac they are verbally as follows. ${ }^{20}$
\end{abstract}

As the reader can understand, the case of Edessa is extremely important for our enquiry, because it shows at once the historical reality of an archival culture since the establishment of an independent kingdom and above all during the Roman domination, and its mythical reworking by a Christian congregation which feels the need to connect itself to an idealised past of the kingdom with its glorious bureaucracy. The reference to the archives has been reworked in the later Teaching of Addai:

As is the custom in the kingdom of King Abgar and in all kingdoms, everything which is said before him is written and placed among the records (bēt 'ühdānā). Labubna the son of Senaq the son of Abshadar, the scribe of the king, therefore, wrote the things concerning the Apostle Addai from the beginning to the end, while Hanan, the faithful archivist (țabūlārā) of the king, set the hand of witness and placed it among the records (bèt 'ūhdānā) of the royal books, where the statutes and ordinances are placed. The matters belonging to those who buy and sell are also kept there with care and concern. ${ }^{21}$

Here we have a realistic description of Edessa's civil archives, written by a person who was familiar with them. We meet this same phenomenon in the Acts of Sharbil: in this fictional account, it is said that the archives were in front of the great altar of the city and that the exceptors wrote these acts (hypomnemata) on parch-

19 The text was first published by Phillips in 1876 and is now available with a new English translation in Howard 1981. See Desreumeaux 1993, Brock 1992-1999.

20 Eus., h.e. I 13. Edition in Schwartz and Mommsen 1999 (1903), translation in Lake 1926, 87.

21 Howard 1981, 104-107. 
ment (qartisiē) and put them in the archives (bèt arkē), where the royal parchments (qarțisē d-malkē) were preserved. According to Debié, 'le texte littéraire des Actes se présente un peu comme un document double, le texte étant le document (la scriptura interior scellée) tandis que la signature et l'attestation par le scribe et les témoins constituent la "couverture" (la partie supérieure avec la scriptura exterior, que l'on trouvait normalement sur le dessus des parchemins ou papyri) qui assure l'authentification'.22 There are important witnesses to these archives and to the presence of personnel taking care of them: according to Debié, the staff were trained in different writing systems of Aramaic / Syriac, which were adapted to the diverse contexts and functions the documents were intended for. ${ }^{23}$

A document has been published that was explicitly meant for depositing in the archive ('arkîwn, transcription of '́pxcĩov) of the 'renowned city of Edessa', viz. a contract for the sale of a slave girl (P.Dura 28), dating to 243 CE. At the head of the text there is a memorandum describing the delivery of the document to the master of taxes 'by courier'. ${ }^{24}$

In Chronicon edessenum we find another allusion to Edessene archives, from which an account was drawn about the famous flood of 201:25 'In the year 513 in the reign of [Septimius] Severus and the reign of King Abgar, son of King Ma'nu, in the month of the latter Teshrin, the spring of water that comes forth from the great palace of King Abgar the Great became abundant'. This incipit is followed by the description of the flood and the reaction of the public authorities and population. At the end we read:

Maryahb son of Shemesh and Qayoma son of Magratat - these scribes (sāprē) of Edessa wrote down this event at the order of King Abgar, and Bardin and Bulid who were in charge of the archives ('arkîwn = $\dot{\alpha} \rho \chi \varepsilon \tilde{o}$ ) ) of Edessa received it and placed it inside them as šarrīre of the city.

From the narrative, it becomes evident that one of the motives for including the whole story in the archives is exemption from taxes for a period of time that the king granted to those whose property had been damaged by flooding. This was one of the main functions of a civil archive: to preserve official decisions concerning taxes, military movements and the reorganisation of civil administration. ${ }^{26}$

22 Debié 2015, 171.

23 Debié 2015, 167.

24 Adler 2012, 930-931; Debié 2015, 168-169.

25 Ross 2001, 104-107, with a translation by Segal 1970, 24-25. Edition in Guidi 1903, 1-3.

26 Debié 2015, 359-360. 
Debié has ably demonstrated how much the use of archives and ephemerides influenced historical writing in the Syriac language. ${ }^{27}$

It must be observed that while there is a real reference to public archives in the examples presented here, in Eusebius's translation of the old Syriac text and in the Teaching of Addai the reference should be considered fictional. As I wrote some years ago, there is no serious witness to the obsessively repeated claim that the Doctrina Addai derives from the archives of Edessa rather than from those of the church there. The legend's absence from both the city's first documentary histories written by Christian authors as of the sixth century, with the exception of Joshua the Stylite, and from the works by Jacob of Edessa is worthy of note. ${ }^{28}$ This sheds light upon the ideological character of both the Eusebian narrative and the Teaching, calling into question the historical reality of a connection between the legend and the Edessene archives. We are dealing here with a propagandistic leitmotiv: already present within the Syriac text known to Eusebius, this would then have been further emphasised by the Teaching in order to confer greater authority upon the story. This leitmotiv was reproduced by Eusebius for reasons that are patently apologetic in nature. ${ }^{29}$

According to Adler, the English translation of Eusebius's passage like the one proposed above has done great harm to the historian's credibility: 'accepting it would mean that Eusebius expects us to believe that he: (1) travelled to Edessa; (2) retrieved the relevant Syriac documents from the archives; and (3) either translated them into Greek himself or had them translated into Greek for him'.$^{30}$ The

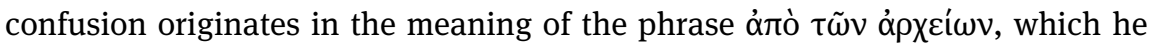
proposes to translate as 'ancient records' instead of 'archives': in this particular expression, Eusebius is not referring to Edessa's archives as in the above sentence, but rather to a longer text, the old Syriac version from which he has extracted Jesus' and Abgar's correspondence. ${ }^{31}$ This could be written on the model

27 Debié 2015, 358-367: 'Les chroniques d'Édesse ont conservé l'enregistrement des constructions et des dons aux églises de la ville' (364); 'Les chancelleries des métropoles et des patriarches produisaient ou recevaient aussi des documents qui étaient classés et enregistrés: correspondances, actes des synodes, listes des ordinations, entrée en fonction et décès au moins des patriarches et des évêques. Les chroniques ont conservés les listes de succession des évêques des villes dont elles écrivaient l'histoire' (365). On Moses of Khorene's mention of the archives of Nisibis and Edessa, see Traina 1996.

28 Van Rompay 1999.

29 Camplani 2009b.

30 Adler 2012, 936.

31 Adler 2012, 937. Adler proposes to tie the mention of the act of extracting the account from

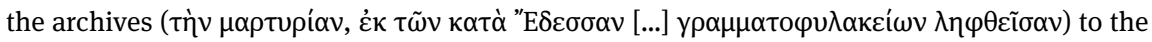


of the day book or register, in use since the time of Alexander the Great (who in turn inherited a Persian custom), composed of royal decrees, correspondence and acts; in Edessa it was called the ktābā d-bēt arke..$^{32}$

In conclusion, Edessa's elite was proud of the state archival practices, thanks to a well-trained bureaucracy, and was able to build an archival discourse to the point that the reference to public archives was used to build fictional pieces of literature outlining the origins of the Christian congregation. We have no way of knowing if the documents produced in the everyday life of the Edessene congregation were preserved in public archives or in those of the bishopric, which seems more likely, and if the two, after the 'peace' of the Church, were merged into a single archive or remained independent of each other. What we do know is that the Edessene elite was legitimising its Christian history with the mention of state archives that past generations had helped to create.

\subsection{Early archival activity and the bishops}

We have no archive arranged by the leading figures of early Christianity, such as prophets, apostles, preachers or didaskaloi, nor are we informed about their archival activity. ${ }^{33}$ This is not to say that written communications were lacking in Christian congregations, however-Clement of Rome's first epistle to the Corinthians is a clear indication of the contrary. ${ }^{34}$ Both here and in other early Christian writings, we find clues about gatherings of leaders for the purpose of sending and receiving texts and letters. These communications are not evidence of an archival practice, though.

On the other hand, we may follow the slow affirmation during the second century of more structured congregations led by groups of presbyters, among which one individual emerges, the bishop, according to a very controversial process

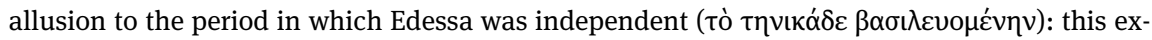
pression would be a reference not to the time of Abgar V, but to a later period, and consequently the act of extracting was done by someone in the third century, before Edessa's transformation

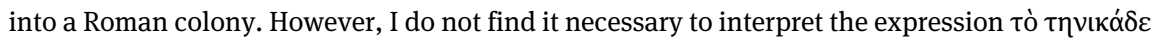
$\beta \alpha \sigma \iota \lambda \varepsilon v o \mu \varepsilon \dot{v} \eta v$ in connection with the act of extracting the story; it is preferable to refer it directly to Abgar V, who is the protagonist of the account; this same expression is used by Eusebius when, after narrating the vicissitude of Paul of Samosata, he alludes to Aurelian's attitude to-

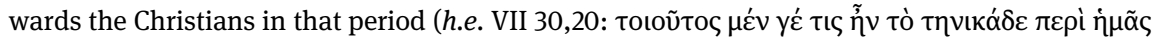

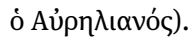

32 Adler 2012, 936; Debié 2015, 171-172.

33 This also applies to Montanism; see Eus. h.e. V 16-19.

34 See the detailed discussion in Prinzivalli 2010. 
which has been discussed in a recent book by Alastair Stewart. ${ }^{35}$ It is in relation to this process that some clues begin to appear in our sources pointing to an archival practice.

However, it is only with (1) Eusebius's repeated allusion to the preservation of documentation stemming from gatherings of presbyters and bishops since the second half of the second century (synods), ${ }^{36}(2)$ the clues about the chancery's activity in Carthage that are detectable in Tertullian's works and Cyprian's correspondence, ${ }^{37}$ and (3) the tachygraphic transcription of sentences uttered by the bishops at the synod in $256,{ }^{38}$ that we have the possibility to assume the existence of archives, although we do not possess a clear statement to that effect. In particular, the huge amounts of documentation produced by the synods, the diverse typology of their written statements (the tachygraphic transcription of the sententiae of the participants, which were edited by the process of emendatio so as to achieve the form of gesta ecclesiastica), synodical letters expressing the synthesis of such debates, libelli recording all the decisions taken (which would eventually lead to the canons), and the cross-references detectable among them are all clear signs of the fact that the correlation between the new leadership of the monarchical bishop and the spreading of synodical activity is the historical factor that gave impetus to the growth of Christian archives.

We get indirect confirmation about the importance of bishops for the growth of the archival practice in Christian congregations from Bagnall's suggestion that most of the early literary papyri from Egypt, which is normally dated to the second century, is connected to the existence of bishops along the Nile, who are not, in fact, attested before the end of the second century or the beginning of the third. ${ }^{39}$ Documentary papyri relating to the Christian congregations are even later. ${ }^{40}$ That means that libraries and archives, which were not clearly distinguished, especially in small or medium-size dioceses, were established when the leadership of the local congregation was put in the hands of a bishop. In a sense, the new archives were a reflection of a structure that was becoming more and more complex, but at the same time dominated by increasingly autocratic leaders.

35 Stewart 2014.

36 Camplani 2006b and Hess 2002. See in particular Eusebius, h.e. V 16,23-28 (synods against the Montanists and the Quartodecimans) and VII 27,1-30,17 (synods against Berillus and Paul of Samosata).

37 Duval 2000.

38 See in particular Bernardini 2009, 191-201, one of the finest studies on early Christian synods and their documentation, and Munier 1974, V-VI.

39 Bagnall 2009, 1-24, discussed in Wipszycka 2015, 64-66.

40 Luijendijk 2008. 


\subsection{The papyrological evidence}

Some ecclesiastical archives have been preserved in papyri, recovered through systematic excavation or through chance discovery. In the latter case, archives were often divided into lots by the finders and then acquired by different institutions, so one of the tasks of the papyrologists is to ascertain whether the documents belonged to a specific archive or not. However, apart from the question of recovering the archives, it is important to observe that documentary papyri are of the highest importance if we want to understand the Church's attitude to written records of any kind. On the basis of the papyrological discoveries it is becoming evident, as has been stressed by Ewa Wipszycka, that in the process of forming its institutions,

the church imitated both the Roman state administration and that of the large estates. It took over from them the habit of putting all sorts of matters into writing. The chancellery of the bishop produced Greek and Coptic documents accompanying and documenting the various activities of the church. When the bishop ordained presbyters or deacons, they gave him written declarations by which they pledged themselves not to leave their diocese, to take care of the church which had been entrusted to them, to fast on the prescribed days, to learn by heart some biblical texts (the Gospels, Paul's Epistles, the Psalms), and so on. In some cases the newly ordained presbyters or deacons handed to the bishop written declarations signed by local notables who vouched for their future good behaviour. When charging one of his subordinates with visiting a church, the bishop gave him a warrant. Examples could be easily multiplied. The earliest piece of evidence we have concerning the ecclesiastical habit of committing all sorts of things to writing is the papyrus $C P R \mathrm{~V} 11^{41}$ of the beginning of the fourth century: here a newly ordained deacon binds himself not to leave the bishop. Functioning in this way, church institutions both implied and favoured literacy among the clergy, ${ }^{42}$

and, we could add, supported the formation of archives.

Two books, by Luijendijk and Blummel, will help us in our approach to the first letters preserved on papyrus. ${ }^{43}$ Some of them are connected to Sotas, a person whom Luijendijk has proposed to identify with the bishop of Oxyrhynchus in the second half of the third century. This hypothesis has been confirmed by the historiographical text preserved in an Ethiopic manuscript which is being edited by Alessandro Bausi and commented by myself. ${ }^{44} \mathrm{I}$ do not know if it is possible to

41 Edition, Italian translation and commentary in Wipszycka 1996.

42 Wipszycka 2015, 121-122, reproducing Wipszycka 2007, 343.

43 Luijendijk 2008, 81-151; Blumell/Wayment 2015, 463-487.

44 See Bausi/Camplani 2013, 247 and the editio minor in 2016, 249-302. In Blumell/Wayment 2015, 479, the statement that the new Ethiopic text is contained in an 'Ethiopic ms that dates to 
surmise that the letters connected with Sotas of Oxyrhynchus were part of an archive-Luijendijk maintains a degree of caution about this question. ${ }^{45}$ What is particularly interesting is the exceptional fact that two of them are preserved on parchment, which was normally reserved for literary manuscripts and rarely used for documents: 'Behind a material detail-these two seemingly insignificant parchment scraps-I behold the contours of a Christian scriptorium at Oxyrhynchus', she says. ${ }^{46}$ This high level of literacy is the first condition for the formation of an episcopal archive.

The largest group of archives comes from monastic groups, the oldest of which are dated to the fourth century. ${ }^{47}$ The study of ecclesiastical archives is mainly linked with two names: Abraham, bishop of Hermonthis, and Pisenthius, bishop of Keft, who lived between the sixth and the seventh centuries. ${ }^{48}$ They are currently at the centre of scholarly attention, because their rich archives need to be edited or partially re-edited. ${ }^{49}$

Abraham's archive was discovered in the monastery of Phoibammon built into the temple of Hatshepsut at Dayr al-Bahari, where he resided for a time around 600, acting as both bishop of Hermonthis and abbot of this monastery. From the archive, a provisional edition of which has been provided in Martin Krause's dissertation, we infer that he exchanged extensive correspondence with the believers in his diocese, both clerical and secular. According to Crum: ${ }^{50}$

We see the bishop ordaining readers, deacons and priests to particular cures and formally entrusting them with their duties; arranging for the performance of service[s] in various churches, sometimes at the application of the local authorities; issuing charges on liturgical

the Aksumite age (IV-VII)' needs to be corrected to 'Ethiopic ms that dates to at least the thirteenth century, if not earlier'. In fact, the Aksumite age is the period in which the historiographical text was translated from Greek to Ge'ez and not the date of the manuscript itself. As for the Alexandrian bishop who appointed Sotas, this was not 'Theonas', as indicated, but 'Maximos'. 45 Luijendijk 2008, 89-90: 'If these papyri indeed refer to one and the same man, how do they fit together? Did they form part of an archive or is it sheer serendipity that several letters from the same person have been preserved? [...] Did Sotas store these letters in such an archive? [...] Based on the archaeology alone, we cannot determine whether these texts constitute the remains of Sota's deliberately organised documents in the strict sense of the word "archive".

46 Luijendijk 2008, 150-151; a discussion of the problem is on pp. 144-151.

47 For a list, see Giorda 2007, and Schmelz 2002, 6-14.

48 For a first approach, see the updated introduction by Wipszycka 2015, 34-41, which presents the significant advantage of looking at the two archives with the eyes of a historian.

49 For more on Abraham, it is necessary to consult Crum 1902 and Krause 1956, 1991a, 1991b; for Pisenthius, apart from the old edition by Revillout 1900-1914, see Van der Vliet 2002, 2013, 2015, and Dekker 2011.

50 Crum 1902, xvii. 
questions and edicts of interdict and excommunication against individuals and villages; dealing with vagrant priests; hearing depositions and giving judgment in local suits and communicating with the magistracy; dispensing or recommending charity. In certain functions the bishop could be replaced by the archpriest who had, for instance, powers of excommunication or interdict. The bishop's decisions might be promulgated through him; he transmits the patriarchal Festal Epistle to the clergy. The archpriest sometimes appears as attached to a particular church.

Both in Abraham's and in Pisenthius' archives we find a rich typology of documents, as can be inferred from the following select list:

- documents concerning the ordination of deacons and priests;

- documents relating to appointments to offices, including a form through which deacons were named as titular heads of churches;

- exclusion from communion of secular and clerical believers until they came to the bishop;

- requests for pardons addressed to the bishop;

- circular letters about public worship and the celebration of communion (for instance, the mention of the wafers necessary for the celebration inspected and blessed by the bishop, or of the mixing of water and wine for the chalice in the correct proportions, according to the canons; the order to other members of the clergy to administer communion temporarily in the absence of the usual clergymen, etc.); provisions for baptism and marriage;

- circular letters about sexual morality and philanthropy towards the poor;

- documents in which the bishop appears as a mediator between two parties;

- (especially in Pisenthius' archive) letters addressed to other bishops in the country;

- contracts (leases, purchase contracts, employment contracts, etc.);

- receipts;

- lists of objects;

- guarantees;

- donations;

- wills.

In these archives, we rarely find documents concerning international Church affairs and ecclesiological and theological issues or allusions to them. ${ }^{51}$ These are matters reserved for large archives located in major cities, to which we will now turn our attention.

51 One exception is the document concerning the Eucharist published in Camplani 2012, whose provenance from an archive is doubtful. 


\section{The lost archives of Alexandria and Antioch}

We have to face the problem of recovering lost church archives kept in important cities, preserving information about the clergy, buildings, the economy and, above all, major inter-diocesan affairs and the Church's relationship with the political sphere.

How can we establish whether documents in Christian writings or narratives may be attributed to church archives? It is not very easy to infer this, and a high degree of subjectivity is involved in this kind of research. First of all, we should mention the claims made by authors, redactors and scribes that a certain document or narrative is from an archivium. Not all of these claims are to be trusted, because they are often formulated to lend authority to a certain vision of things, as we have seen in the case of Edessa. However, we are often in a position to assess their credibility by way of analysis of style and comparison of documents: there are chronicles exhibiting clear signs of having been drawn from commentaria, or lists of various sorts, which could be preserved in private or congregational archives; if a sequence of documents, or the reference to a sequence of documents, occurs in a similar way in more than one historiographical writing or canonical collection, then there is a high degree of probability it is connected to official or private Christian archives. ${ }^{52}$

Although the eastern Mediterranean world is the focus of my attention here, a brief mention of Rome's church chancery and archives is unavoidable for the simple reason that I do not rule out the fact that they could have influenced Alexandrian and Antiochene church archives. These archives have raised long debates among scholars concerning their antiquity and their concrete way of functioning. In sum, looking at the issues concerning Roman archives means achieving greater awareness of the methodological problems involved in the reconstruction of the archives of other cities. ${ }^{53}$

The sources concerning Rome are not rich in information about archives and the personnel working in them for the fourth century. We know of the existence of a chartarium (also called a scrinium), ${ }^{54}$ but it is unclear whether this was an archive

52 On the relationship between archives and historiographical production, see Van Nuffelen 2004 and Burgess 2013.

53 The bibliography on the subject is very extensive: a good discussion is in Moreau 2012a, 177242; Martello 2012, 33-104; and Dalmon 2015, 109-168. The latter criticises reconstructions of church archives excessively influenced by the image we have of the imperial chancery and archives.

54 See Jerome, Adv. Rufin. 20; Leo, Epist. 69,1 (scrinia); Simplicius, Epist. 58 (scriniis). See the discussion of these passages in Dalmon 2015, 145-146. 
or a private collection. For the period of Pope Damasus, scholars are generally confident that forms of archival storage were practised, although there is no consensus about the modalities and the places involved, as has been illustrated by Dominic Moreau. ${ }^{55}$ In a first phase, there may not have been an official archive of the bishopric as such, but private places and libraries were used whose items could be connected by individuals who were familiar with their contents. What is important from our point of view is that this network of minor repositories was thought to serve an archival purpose in the fourth century.

A source like the famous Liber pontificalis (beginning of the sixth century) gives us a number of details about the personnel involved, but this information needs to be evaluated critically: organised as a series of biographies of Roman bishops from the apostle Peter onwards, the Liber is interested in documenting the history of the bureaucratic traditions of its milieu, giving them great antiquity. ${ }^{56}$

We know from the Liber and other earlier writings (of the late fourth century) of the existence of notarii, ${ }^{57}$ a term which originally denoted both the scribes devoted to the reproduction of documents and experts on juridical matters; in a second moment, the first charge is often but not always expressed by the word exceptor. In the course of time, the organisation of notarii became a complex hierarchy, so that through the sources we see other leading figures emerging in the bureaucratic organisation: exceptor, primicerius, secundicerius and notarius regionarius. ${ }^{58}$ In later redactions of the Liber pontificalis, we observe the tendency to stress the antiquity of the notarii, as in the famous passage in which their juridical role is anachronistically attributed to the era of Pope Julius II:

Fuit autem temporibus Constantini filii Constantini heretici a consulatu Feliciani et Maximini. [...] Hic constitutum fecit ut nullus clericus causam quamlibet in publico ageret, nisi in ecclesia, et notitia quae omnibus pro fide ecclesiastica est per notarios colligeretur, et omnia monumenta in ecclesia per primicerium notariorum confectio celebraretur, sive cautiones vel extrumenta aut donationes vel conmutationes vel traditiones aut testamenta vel allegationes aut manumissiones, clerici in ecclesia per scrinium sanctum celebrarentur (I 36). ${ }^{59}$

55 Moreau 2010 and 2012b. On the relationship between historiography and epistolography, see Moreau 2015.

56 See Verardi 2016, 31-80 for a full discussion of the redactional problems of the work.

57 One of the first occurrences of the term is connected to the Council of Ephesus held in 431:

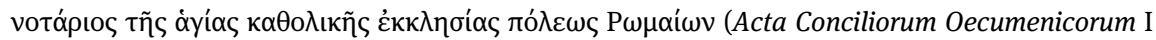
1,3.54.19).

58 Martello 2012, 33-103.

59 Duchesne 1886-1892, 205 ll. 1-2, 5-9. 
Having checked not only the sources of this passage (the so-called Liberian Catalogue) but also the parallel epitomes, which are based on more ancient editions of Liber Pontificalis, we can conclude that the development on notarii is an interpolation. ${ }^{60}$ Who was responsible for this addition? Actually, it is likely it was the notarii themselves, who, probably acting after 530, wanted their presence and activity to be reported to ancient times, up to the the era of Julius II, in order to promote the idea that they had not only been important in the development of the Papal See recently, but also in its glorious past, during the Constantinian era. It is a way to connect oneself to the memory of the past.

To conclude, archives, whatever their form and modality of operation, were in use in the fourth century and received a strong impulse from Damasus from 366 onwards: 'la notion de scrinium-chartarium ecclesiasticum, ainsi que celle de notarius, présentaient à l'époque tardo-antique des contours bien indécis. Nous savons qu'un certain nombre de tâches documentaires devaient être effectuées: réception, tri, rédaction, compilation, classement; mais les rares indices ne permettent aucune affirmation catégorique ni quant aux effectifs et à la qualité des exécutants', as Dalmon says. ${ }^{61}$

Historiographical writings such as the Chronographer of $354,{ }^{62}$ with the Liberian Catalogue, or the author(s) of Liber pontificalis drew their information from these archives, although we have no idea how they actually worked.

Some very interesting annotations about archival practices also occur in the synodical reports of the Church of Africa. The function of episcopal archives in preserving synodical records is reported more than once, and the merging of different ecclesiastical regional archives is recommended in order to standardise the canonical legislation of the centre (Carthage) with that of the periphery. ${ }^{63}$

60 Martello 2012, 86-88.

61 Dalmon 2015, 150.

62 See Burgess 2013.

63 See the documentation of the Synod of Carthage in the year 525, for example: ed. Munier 1975, 259, 11. 173-179, specifically mention of the matricula (list of contents of the acts) and the archives by the chief bishop of Numidia. See also Munier 1975, 275, 11. 120-123: Bonifatius episcopus dixit: Fiat quod haec congregatio sacerdotum iustissime flagitat. Proferantur ex archiuo huius ecclesiae scripta quae direximus et rescripta quae sumpsimus uel quaecumque ad praesentis negotii pertinent firmitatem. Redemptiolus notarius ex uolumine chartarum recitauit. And concerning a synod held in 402, see Munier 1975, 207, 1l. 845-848: De archiuo et matricula Numidiae. Deinde placuit omnibus episcopis, qui in hoc concilio subscripserunt ut matricula et archiuus Numidiae et apud primam sedem sit et in metropoli, idest Constantina. 


\subsection{Alexandria}

Some ancient information about the staff of the bishopric of Alexandria has been collected by Ewa Wipszycka. ${ }^{64}$ It was concerned in particular with economic matters, but a group of ecclesiastics was tied to the chancery, both as scribes (kankellarios) and as specialists in legal matters (nomikos, a sort of notary, the specialist authorised to write legally binding deeds). In the Life of Severus (sixth century), Bishop Peter Mongus, whose aim was to support the philoponoi's legal action against pagan students, gives them his archidiakonos and primicerius (who is clearly the chief of the notarii). ${ }^{65}$

It is obvious that this activity on the part of the bishop's chancery was reflected in the growth of Alexandrian church archives. Members of the bishop's staff looked after the documents, and it is likely that the bibliophylax attested by Anastasius the Sinaite for the end of the seventh century was in charge of them. ${ }^{66}$ Beyond the documents in the literal sense, the archives preserved texts of a theological nature as well as the acts of synods and canonical literature. We may add to this any documentation of an ecclesiological and political nature, i.e. the correspondence of the bishops with the other colleagues of the Church, with various emperors and state bureaucrats. ${ }^{67}$ In the Coptic History of the Church, notarii are engaged to transcribe Cyril's orations. ${ }^{68}$ Festal letters sent to all the bishoprics of Egypt by clerics were considered important, not only for their religious content and the information they provided on the bishop of Alexandria and the controversies in which he was involved, but also because an appendix to the annual letter contained a list of the new bishops with whom each diocese had to establish communion of faith. ${ }^{69}$ What's more, the documentation connected to the election of each bishop, including the patriarchal letter with which the new bishop came back to his diocese after the consecration in Alexandria, was preserved both in Alexandrian archives and in those of the diocese concerned. ${ }^{70}$ It is from these

\footnotetext{
64 Wipszycka 2015, 237-270, reproducing Wipszycka 2008 with additions.

65 Camplani 2013b, 134.

66 Uthemann (ed.) 1981, 189.

67 See also Cyril of Alexandria's rescript to the Church of Carthago, in Munier 1975, 162, 1l. $16-$ 20: ut de scrinio nostrae ecclesiae uerissima exemplaria ex authentico synodo apud Nicaeam ciuitatem metropolim Bythiniae a sanctis patris constituta atque firmata sub nostrae fidei professione uestrae dilectioni porrigamus. See also the contents of the Codex veronensis LX.

68 Camplani 2013b, 139.

69 The presence of festal letters among the preserved texts in the archives is mentioned in the Life of Aphou, mentioned in Wipszycka 2015, 251 n. 34. See also Camplani 2003, 95-111. 70 Camplani 2003, 53-60; Wipszycka 1996b, 145-50.
} 
kinds of documents that lists of bishops in communion with Alexandria were compiled ${ }^{71}$ giving the information to be used in chronicles and other historiographical writings.

From the style of the Alexandrian chronicles and the documents they mention, we can infer the existence of very rich archives. For example, there are passages in two chronicles composed in Alexandria, the Index to the Festal Letters of Athanasius and the Historia acephala, where it is clear that the compiler or a later scribe had a number of documents at his disposal which he decided to quote or to neglect, whose existence is pointed out to the reader, and is otherwise demonstrated not only by their preservation in manuscripts attesting the works of Athanasius, but also by their being referred to in the Church History of Sozomen and in Coptic fragments of lost works. ${ }^{72}$

Among the documents preserved by the Codex veronensis LX, we find letters that Constantine sent to the Council of Nicaea, his letter against Arius, and documentation concerning the Councils of Nicaea and Serdica: a set of texts which served to promote the Alexandrian see in the Mediterranean world, exalting Alexandria's close relationship with the imperial power and supporting its struggle for primacy vis-à-vis Constantinople. ${ }^{73}$

In other passages we find a detailed account of the movements of presbyters and bishops hour by hour as well as information about new consuls and prefects, which reminds us of the way in which provincial officials reported their own daily activity (commentaria). The attention to buildings, the dedication of churches and natural events, such as the catastrophe of 362/363 mentioned by Ammianus Marcellinus, and other local information which is not found in the standard historiographical works is easily explained by the dependence on ephemerides, ${ }^{74}$ as demonstrated by the following examples extracted from both chronicles:

\footnotetext{
Historia acephala 18. Now in the aforesaid consulship of Lupicinus and Jovinus, Lucius, being specially desirous to claim for himself the episcopate of the Arians a long time after he had left Alexandria, arrived in the aforesaid consulship and entered the town secretly by night on the xxvi day of the month Thoth (24 Sept 367): and as it is said, abode in a certain small house, keeping in hiding for that day. But next day he went to a house where his mother was staying; and his arrival being known at once all over the town, the whole people
}

71 See the lists of bishops preserved in the new Ethiopic historiographical text discussed in Bausi/Camplani 2013 and 2016. For more on Edessa and other dioceses connected to the Syriac Christianity, see Muriel 2015, 365.

72 The existence of the archives of Alexandria is discussed in Martin 1985, 20-21 and 69-73; Camplani 2003, 97-111.

73 Bausi/Camplani 2013, 239-240.

74 Camplani 2003, 87-108. 
assembled and blamed his entry. And Duke Trajanus and the Prefect were extremely displeased at his irrational and bold arrival, and sent officials to cast him out of the town. ${ }^{75}$

Index 39. In this year, when Lucius had attempted an entrance on the twenty-sixth of Thoth and lay concealed by night in a house beside the church where there is the memory of Pieirios; and when Tatianus the Præfect and Trajanus Dux brought him out, he left the city and was rescued in a wonderful manner, while the multitude sought to kill him. ${ }^{76}$

Here we have a detailed narrative, independently drawn by two redactors from the archives of the episcopate, about Lucius and his attempt to conquer the episcopal see of Alexandria. The Alexandrian control devices are so sophisticated that his movements are followed from hour to hour and registered in the ephemerides in the same way in which provincial officers were accustomed in their daily activities.

It is likely that the ephemerides and archival documents were also used by Liberatus of Carthage later, but in an updated form, which probably contained narratives concerning the period after Theophilus as well (d. 412). ${ }^{77}$

\subsection{Antioch}

While the information about the staff of the bishopric of Antioch for the fourth/fifth centuries is less detailed in comparison with that of Alexandria, Annick Martin's analysis of Theodoret's Historia ecclesiastica has suggested the existence of a rich documentation preserved in the archives of the congregations established in Antioch:

La sélection des documents opérée par l'évêque de Cyr pour fonder son point de vue montre qu'il les puise en grande partie dans les archives de l'Église d'Antioche. C'est là en effet qu'il trouve les collections de lettres très tôt regroupées qui ont alimenté la polémique théologique au commencement de la crise ariene, les recueils synodaux constitués à partir d'Euzoios (361-376) et continués sous Mélèce (360-381), contenant Actes et lettres impériales et épiscopales, parfois liés par des parties narratives, à la manière de la Synagôgê de Sabinos utilisée par Philostorge, Socrate et Sozomène - mais non par Théodoret - ou encore de la Collection du diacre Théodose. ${ }^{78}$

75 Martin/Albert 1985, 166-167.

76 Martin/Albert 1985, 200.

77 Ed. Schwartz 1936b. See Blaudeau 2010 on Liberatus. On the relationship between historiography and documents, see Camplani 2015.

78 Martin/Canivet/Bouffartigue/Pietri/Thelamon 2006, 68-69. 
The reconstruction of the contents of the archive has led to some interesting results, which include the following items:

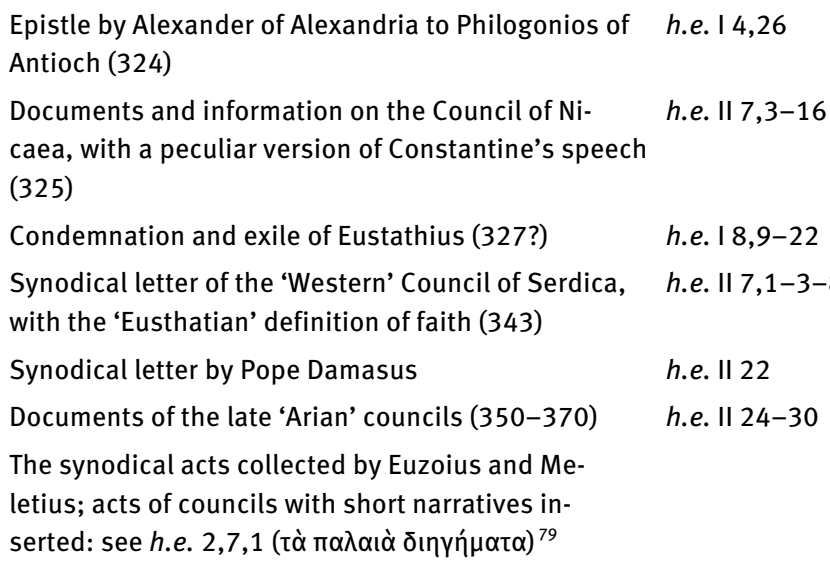

The synodical acts collected by Euzoius and Meletius; acts of councils with short narratives in-

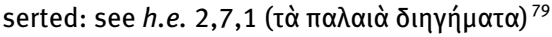

These were some of the archival documents and information used to write an apologetic history of Antioch, such as the one written by Theodoret. The epistolary by Severus of Antioch (512-518), which was penned a hundred years later and has been analysed in a recent book by Frédéric Alpi, ${ }^{80}$ is a good source for reconstructing the situation of both the contents of the Antiochene archives and the activity of their staff. The archeia (bèt-arkē) are explicitly mentioned as well as their personnel:

- the scrinarii (sqrn') for the archives;

- the group of notarii presided over by the scholastikoi; Severus refers to them in his letter to Theotecnus: 'We have [...] sent an ison or copy of the form of satisfaction (plerophoria) which our notaries have drawn up, or having compiled it from other forms (plerophorias) that were previously composed by me in the cases of various persons';

- the few copyists who had the task of producing the copies ('̈oov / isūn) of documents, or checking the style of signatures in the synodical documents to avoid falsified signatures. For instance, in the Letter 1,19 to Solon, bishop of Seleucia in Isauria, Severus discusses the crimes of one Callistus, who was charged with

79 Martin/Canivet/Bouffartigue/Pietri/Thelamon 2006, 57-70.

80 Alpi 2009, I, 83-85. For an edition of Severus' letters, see Brooks 1903-1904 and Brooks 19161920. 
forging a letter that Bishop Hilarian supposedly wrote to Severus. The deception was exposed when 'on comparing the signature of the letter that was produced with the other signatures of the aforesaid God-loving bishop Hilarian that are preserved here in synodal documents, we found them to be as far removed and as different from one another as sheep differ in their appearance from elephants'. Severus continued: '[...] it is clear to everyone that the laws of the Romans, which contain many excellent enactments upon these matters, also fix beheading as the punishment; and this is an offence against public law'.

According to Alpi, Severus' letters attest the richness and varied typology of the texts preserved in the Antiochene archives: synodical epistles (coming from both general and local synods), individual or collective acts of repentance, judgements, books of the Fathers and canon law. Following a suggestion by Honigmann, he assumes that Severus and his staff compiled an anthology of canon law or a Canonicon to support their activity on the basis of the collectio antiochena, which was preserved in the archives and the writings of the Church Fathers. ${ }^{81}$

\section{A case study: Codex veronensis $L X$ as a witness to Alexandrian and Antiochene episcopal archives}

As announced above, in the third part of my contribution to this volume, I intend to offer a number of examples of the method used for recovering lost church archives from two important cities. Such a method consists in (1) looking for claims made by authors, redactors and scribes about their archivia, (2) exploring records of church activities, such as chronicles and histories, which exhibit clear signs of having been drawn from commentaria or collections of documents, and (3) analysing collections presenting similar series of documents (or referring to similar series) and lists of clergy.

The Latin Codex veronensis LX (= Verona Codex) is both an interesting artefact and a collection of documents and narratives preserving traces of a plurality of archives of Late Antique patriarchates. There are clues in the manuscript that allow us to recognise a variety of collections from which it drew its materials,

81 Alpi 2009, 84. 
which in turn come from three different archives: Carthage, Alexandria and Antioch. I have shown elsewhere that in its final appearance it looked like a kind of history of canonical law of the Mediterranean Christian communities, composed with the aim of demonstrating the universality of certain ecclesiastical norms. ${ }^{82}$

Attributed to the seventh to eighth century, the Verona Codex appears to be a composite manuscript. The first 35 leaves are different to the other 90 leaves in terms of their format and page-numbering system. Using Gumbert's terminology, ${ }^{83}$ we can define it as a composite manuscript containing two independent codicological units, which, being written by the same hand, are to be considered 'monogenetic'.

The general content is the canonical legislation of the fourth-century Mediterranean Church, but there are a considerable number of documents concerning events in the fourth and fifth centuries which must be briefly clarified in order to understand the prehistory of some sets of texts: the Arian crisis; the activities of Athanasius of Alexandria, head of the Egyptian Church from 328 to 373; the Council of Serdica (343 CE); the conflicting views of the episcopal sees of Carthage and Rome about the question of the African priest Apiarius, which resulted in a canonical confrontation between the two sees in the years 418-425; the Vandal invasion of Africa in 430 and Vandalic rule until Justinian's reconquest.

- The Arian controversy, which originated in Alexandria around 318/320, soon became a general crisis of the eastern Christian world, also affecting the western part of the empire as well later, in which a long confrontation took place between different episcopal parties, with their own theological traditions and their political ambitions within a Christian state. The Council of Nicaea in 325 failed to result in any solution to the various issues, and the debate went on for decades until the end of the fourth century. ${ }^{84}$

- The figure of Athanasius dominates the fourth-century Church in the Mediterranean world: his anti-Arian positions, his fight against a local schism (originated by Melitius of Lycopolis) and his problematic attitude to the political power, which led him to be exiled five times by Christian emperors, all put him in the centre of eastern Mediterranean Christianity and ecclesiastical documentation from 328 onwards, the year of his election. ${ }^{85}$

82 Camplani 2006a, with a bibliography.

83 Gumbert 2004.

84 See Simonetti 1975, Barnes 1993 and Ayres 2004.

85 See Martin 1996 and Camplani 2003. 
- With the name of the Council of Serdica ${ }^{86}$ we mean an attempt by two emperors, Constant and Constantius, to convene a synod of bishops from the western and eastern part of the empire in 343. The differences in theological and ecclesiastical positions coupled with personal enmity between the attendants caused the failure of this huge meeting of bishops, with the effect that two councils met (the Western and the Eastern), one opposing the other. The synodical acts resulted in two definitions of faith, two sets of conciliar decrees and two sets of reciprocal excommunications. It must be added that while the Eastern Council adopted Greek as the language for its synodical activity, a number of documents issued by the Western bishops were written in Latin and later translated into Greek, so we actually have a double manuscript tradition here as far as Western documentation is concerned.

- As the first part of the codex is connected with the African Church at the beginning of the fifth century, we must refer to a question which is central in the documentation, viz. the 'affair' of Apiarius, a priest of the North African Church, who, condemned by the bishop of his diocese, had appealed to Rome for help. He was consequently reinstated in his post by Pope Zosimus. This intervention was not appreciated in Carthage, but Rome justified it by reference to the canons, which, according to the papal legates, were promulgated by the Council of Nicaea. At this point, Carthage asked other churches to provide the documentation on the Council of Nicaea in order to verify the existence of canons on which Rome based its right to intervene. On the basis of the documentation sent by Alexandria and Constantinople, and perhaps Antioch as well, the African bishops were able to establish and declare that the two canons on which Rome founded its right to intervene in other countries did not actually exist. ${ }^{87}$ Now, we know that although these canons were absent from the Nicene acts, they were not a pure forgery as they are found among the canons of the Western Council of Serdica, a fact of which neither the see of Carthage nor the Eastern patriarchates were aware - or would be aware of after the affair had been concluded either. Were the Roman popes only poor liars? What we know for sure now is that the earliest Roman collection of canons was apparently a document containing the canons of Nicaea and the canons of Serdica as a single combined series under the name of 'Nicaea'. The circumstances of the arrival of these two sets of canons in Rome, as well as of their combination, while generally thought to have been in the mid-fourth century, are unknown. ${ }^{88}$

86 On the synod of Serdica, see Barnard 1983.

87 Pietri 1976, II, 1288-1338.

88 Hess 2002, 56. 
- The Vandalic rule in Africa, which lasted for a century, is only mentioned here to stress the fact that circulation of writings during this period was more difficult than in the preceding and following ones, yet not impossible.

Now we have all the elements we need to come back to the contents of our codex. The first codicological unit contains the proceedings of the Council of Carthage, which, in 419, collected the legislation of the African Church against the claim of Popes Zosimus and Boniface to intervene in cases of ecclesiastical discipline initiated in Africa. The collection also contains the synodical letters sent to Boniface and Celestine later in the name of the African Church. The text of the second letter comes to an abrupt end at the top of the last page, which is blank. It is likely that a page of the exemplar is missing.

In the second codicological unit, in addition to the synodical canons, we find the symbol and canons of the Council of Nicaea, Egyptian and Oriental documents related to the double Council of Serdica of 343, narratives about Athanasius and the Melitian schism, preceding the former's episcopate, accompanied by epistles and other documents.

The hypothesis which can at least partly explain the contents of the two codicological units is that the codex contains documentation on Alexandria and Antioch's responses to the request of the Church of Carthage in 418-419: the two sees sent not only the authentic canons of the Council of Nicaea, but also documents belonging to their archives and proving their authority and importance in the context of Mediterranean Christianity.

Here is a list of the texts according to the traditional numbering:

1 The creed and canons of Nicaea (the so-called Caecilian's version), with a narrative introduction (fols $37 \mathrm{r}-42 \mathrm{v}$ ).

2 The canons of Neocaesarea, in a form of the Isidorian Vulgate (fols $42 v-43 v$ ).

3 A letter addressed by a Roman synod under Damasus in 372 CE to the Eastern bishops, followed by three dogmatic passages by Damasus, followed in turn by a notice of adhesion by Meletius and his synod at Antioch in 379 . The original is stated as being in the Roman archives (fols 43v-47r).

4 The canons of Gangra, in a form of the Isidorian Vulgate (fols $47 \mathrm{r}-50 \mathrm{v}$ ).

5 The canons of Laodicea in the Isidorian version (fols $50 \mathrm{v}-54 \mathrm{v}$ ).

6 The canons of Constantinople in the Isidorian version (fols $54 \mathrm{v}-55 \mathrm{v}$ ).

7 The canons of Ancyra in a form of the Isidorian Vulgate (fols 55v-59r).

8 Part of the Chalcedonian Definitio fidei, with the final allocution of Marcian at the close of the Sixth Session, and the canons (fols 59r-64v).

$8 \mathrm{a}$ The epitome of the canons of Hippo, held in 393 CE (fols 64v-68v).

8 b Ten canons passed by a council of Hippo in 427 CE (fols 68v-70r). 
9 A unique Latin version of the synodical letter of the Council of Nicaea to the churches of Egypt, without the paschal section (fols 70r-71v).

10 Short information about the convocation of the Council of Serdica.

11 The Apostolic canons in the second version of Dionysius Exiguus.

12 The canons of Antioch in the second version of Dionysius Exiguus (fol. 71v + additional leaves).

13 The creed and anathemas of the Eastern bishops at Serdica in a Latin version (fols $78 \mathrm{v}-$ 79v).

14 Another part of the same encyclical, otherwise unknown, proposing a paschal cycle or Easter calendar (fols 79v-80v).

15 The letter from Hosius and Protogenes to Pope Julius retranslated from a Greek version, under the heading Definitiones aput Sardicam (fols 80v-81r).

16 The synodical letter of Western Serdica retranslated from a Greek version, containing the definition of faith known only to Theodoret, h.e. II 8 (fols $81 \mathrm{r}-88 \mathrm{r}$ ).

17 The canons of Western Serdica, retranslated from a Greek version (fols 88r-94v).

18 The canons of Western Serdica in the version of Dionysius Exiguus (in a later hand, written on palimpsest leaves and on two new leaves, fols 97, 98, sewn into the codex for this purpose: fols $94 \mathrm{v}-98 \mathrm{v}$ ).

19 The unique text of an epistle written by Athanasius written from Serdica to the Church of Alexandria (fols 99v-102r).

20 The unique text of an epistle from some bishops at Western Serdica to the Church of the Mareotis (fols 102r-103r).

21 The unique text of a letter written by Athanasius after the synod of Serdica, addressed to the churches of the Mareotis (fols 103r-105r).

22 Vita Athanasii from 345 CE (fols 105r-112r).

23 Under the heading Symbolus sanctae synodi Sardici, a form of baptismal renunciation followed by a Latin confession of faith similar to that of the Council of Constantinople (fol. 112v).

24 A unique Latin version of Constantine's epistle from Nicaea to the Church of Alexandria (fols $112 v-113 v$ ).

25 A unique Latin version of Constantine's 'Porphyrian decree' about Arianism (fol. 113v). ${ }^{89}$

26 Documents connected with the Melitian schism: letter from the four martyrs to Melitius; letter from Peter to the community of Alexandria; short intermediate narrative (fols 113v-116r).

While some portions of the codex appear to retain traces of an archive serving the needs of the episcopate of Alexandria, other sections are connected to Antioch, and in particular to two different and conflicting Christian communities within

89 Note that nos 24-25 have an exclusive parallel in Ethiopic; see Bausi 2006, 62-63 (nos 14-15). 
the city (fourth-fifth centuries). A consideration of the Church History by Theodoret of Cyrrhus and of the documents quoted therein can help us understand the arrangement and precise meaning of some of the sections in the codex.

\subsection{The Alexandrian section}

Some of the historical fragments concerning Alexandria may be identified as belonging to a lost Greek History of the Alexandrian Episcopate (=HEpA, not to be confused with the later Copto-Arabic History of the Patriarchs of Alexandria or the Coptic History of the Church). This work was most likely to have been composed in the last quarter of the fourth century, during the episcopate of Theophilus, but certainly before the activity of Sozomenus the historian, who quoted some passages from it. A section / book of this work is known as Historia Athanasii, which, as we have seen, is a detailed narrative of Athanasius' episcopate; ${ }^{90}$ other sections of the codex which we may attribute to this history are related to the birth and initial development of the Melitian schism under the episcopate of Peter I, to the Nicaean acts and to the Council of Serdica. ${ }^{91}$

Other paraphrases are to be added to the witness of the Verona Codex which have been recognised by scholars in later historiographical and hagiographical sources; the most important witness is now the historical text that Alessandro Bausi has identified in an Ethiopic collection. ${ }^{92}$

On the one hand, the Verona Codex is one of the hundreds of late antique codices preserving canonical writings, such as conciliar decrees and canons, liturgical writings, official letters, from the East and the West: the codex and the compilations upon which it is based responded, as many other codices did, to the 'constantly evolving need of the Church to collect and transmit authoritative precedents by which it could govern its own affairs'.$^{93}$ On the other hand, the Verona Codex is marked by some codicological peculiarities and characterised by rare texts-features that require a correct methodology of investigation.

The fact that it contains rare texts also preserved in the Ethiopic manuscript described by Alessandro Bausi gives us reason to insist on the notion and historical reality of episcopal archives. We have to take a fact into consideration which could be useful for our investigation, whose aim is to reconstruct lost archives

90 Martin/Albert 1985, 138-213.

91 For editions of the texts, see inter alia Turner 1939, Brennecke/Heil/von Stockhausen/ Wintjes 2007; Field 2004; Martin 1985.

92 See Bausi 2002; Bausi 2006; Bausi/Camplani 2013.

93 Field 2004, 115. 
through the traces they have left in canonical and historical compilations: an archive is something that evolves over the course of time, so documents could have been added to it as soon as they were written or as soon as they were received from other sees; in other words, an archive can assume different states according to the chronology and the historical context. It is important for us to understand which state of an archive a single codex or a single set of texts is a selection of.

The authors of the HEpA selected all the items in the bishopric's archives which could support the ecclesiological and political primacy of the See of Alexandria in the eastern Mediterranean and its jurisdiction over Egypt and Libya: letters from the emperors, synodical acts, documents from the bishop-martyrs attempting to prevent ecclesiastical schisms, list of bishops appointed by the patriarchs, and suchlike. ${ }^{94}$

\subsection{The Antiochene section}

While some portions of the Verona Codex, as we have seen, retain items of an archive serving the needs of the episcopate of Alexandria, other sections should be connected not only to Antioch, but also to a specific phase of the Antiochene episcopate, from the last quarter of the fourth century to the first quarter of the fifth. ${ }^{95}$ This sub-collection of texts, ${ }^{96}$ partially attested by a group of Syriac codices as well-Paris Bibliothèque nationale de France syr. $62^{97}$ and others ${ }^{98}$-and, above all, alluded to by Theodoret of Cyrrhus, h.e. II, preserves documents with different ideological orientations side by side, which were produced on the occasion of the synod of Serdica (343) by two different groups of bishops who, in all likelihood, put them in two different archives immediately after the dramatic end of the Council's meeting. However, the fact that these contradictory documents are witnessed together by such different witnesses (a Latin collection, some Syriac canonical codices and a historian) can only be explained by arguing that they were put together in a single Greek archive at some point in history, from which

94 See Camplani 2004, 2006a, 2009a, 2011, 2013b, 2015.

95 On the Antiochene canonical collections, see Mardirossian 2010; regarding their origin, see Schwartz 1936c.

96 See Schwartz 1936a, Telfer 1943, Field 2004. A complete edition of the texts discussed in the present paper is in Turner 1939.

97 The documents which are discussed here were published on the basis of Paris syr. 62 by Schulthess 1908.

98 These are Mardin, Library of the Residence of the Archbishopric 309, 310, 320 (modern copy), Vat. Borg. syr. 148 (1576 CE). See Camplani 2013a. 
they were then drawn and subsequently translated into different languages. What are the historical circumstances that produced this strange juxtaposition of documents?

As anticipated, we should pay attention to the following items:

10 Short notice about the convocation of the Council of Serdica.

13 The creed and anathemas of the Eastern bishops at Serdica.

14 A paschal cycle or Easter calendar.

15 The letter from Hosius and Protogenes to Pope Julius retranslated from a Greek version.

16 The synodical letter of Western Serdica retranslated from a Greek version, containing the definition of faith known only to Theodoret (h.e. II 7,1-3-8,1-53).

17 The canons of Western Serdica, retranslated from a Greek version.

19 The unique text of an epistle written by Athanasius from Serdica to the Church of Alexandria.

20 The unique text of an epistle from some bishops at Western Serdica to the Churches of the Mareotis.

21 The unique text of a letter written by Athanasius after the synod of Serdica, addressed to the Churches of the Mareotis.

What needs a more critical appreciation is the fact that the symbol of the Eastern Council, accompanied by the paschal cycle (nos 13-14), whose provenance from Antioch should not be doubted, as demonstrated by Telfer, ${ }^{99}$ presents some interpolations transforming its theological language in agreement with that of the Council of Nicaea. It is as if someone, noticing some oddities in the Trinitarian orientation of the document, adapted it as closely as possible to the terminology which he regarded as 'orthodox'. This could only happen with the decline of the Arian community of Antioch around 378. This phenomenon is not unique in Codex Veronensis LX (58). The Syriac translation of the same document preserved in the codex Paris. syr. 62, fols 182-183, also shows the same interpolations. ${ }^{100}$ It is possible to argue that the text of the council of the Eastern section of the Council of Serdica has been intentionally interpolated by those who were organising the archives of Antioch when the acute phase of the Arian controversy was drawing to an end (and therefore under the bishopric of Meletius, 360-381 CE), and when the need was felt to adapt the language to that of the pro-Nicene bishops of the Western part of the empire.

99 Telfer 1943.

100 Schulthess 1908, 167-168; Camplani 2013a. 
Moreover, while the texts concerning Egypt and Athanasius may have been drawn from Alexandrian archives (nos 19-21), as evidenced by their local character, the three most important documents of the council, namely Julius' letter to Protogenes, the synodical letter of the Western section of the Synod and the famous conservative definition of faith (nos 15-17), all translated into Latin from an unknown Greek version, are unlikely to have come from this city. The synodical letter is apparently a Latin version of a Greek model that is different from the one recorded in the works of Athanasius of Alexandria (Apologia secunda contra arianos, 37-41). The definition of faith that follows is exactly the same one that Athanasius, from 362 onwards (Tomus ad Antiochenos), tried to obliterate, because its radical pro-Nicene tendency was an obstacle to his attempts to approach the party of Meletius of Antioch. More caution is required regarding the two other documents in this small series (15 and 17), but the very fact that the set constitutes a series in itself makes their Alexandrian origin unlikely.

We are therefore in search of another place of production and preservation for this little collection. Several scenarios have already been proposed. According to the first reconstruction, these documents were transmitted to Alexandria directly from Serdica and then from there to Carthage (this also happened before the beginning of the Apiarian affair). However, as I have noted, it seems unlikely that they passed through Alexandria. According to a second scenario, they were taken to Africa and Rome at the end of the Vandal domination and in connection with the circulation of the eastern canonical collections, that is to say, in the second half of the sixth century. Thessalonica and other cities have been proposed in addition as places from which these documents moved to Carthage. ${ }^{101}$

Since there are serious objections to each of these reconstructions, a new hypothesis is called for. In my view, following Annick Martin's analysis of Theodoret's history, there is only one community in which the definition of faith (no. 16) could be preserved together with the West Serdican documentation: the community of the Eustathians of Antioch, i.e. the congregation directed by Pauline, leader of the conservative Nicene group. ${ }^{102}$

Theodoret, as we know, drew his documentation from the archives in Antioch. From an ideological and ecclesiological point of view, he belonged to the group that was heir to Meletius, Diodorus of Tarsus and John Chrysostom, i.e. the rival group to the Eustathian Paulinus. However, in his historiographical activity, he oddly put two figures side by side that he considered the foundations of Antiochene orthodoxy, viz. Eustathius, exiled by the Arians, and Meletius, himself

101 See Telfer 1943.

102 Martin/Canivet/Bouffartigue/Pietri/Thelamon 2006-2009, 68-92. 
persecuted by the emperors for his moderately anti-Arian position, but originally appointed by groups of bishops close to the Arian movement, at least according to his opponents. ${ }^{103}$ We know that the historical reality is different from Theodoret's harmonising representation: gathered around the two figures there were two different and opposing communities, viz. the group heir to Eustathius, led by Paulinus, a bishop of Antioch irregulary ordained by Lucifer of Calaris around 360, and recognised as bishop by the West (Damasus, Ambrose), and Meletius, on the other side, who was not only followed by a group of believers who were moderately anti-Arian and pro-Nicene (neo-Nicene), but also attracted most of the bishops of Syria to his side. For a long time, despite the ideological proximity, there were many obstacles to the dialogue between the two communities living in the same city.

What is most striking in Theodoret's history is his quotation of the documentation related to the Eustathians led by Paulinus, who were distant from his line of thought. In fact, this group was in possession of documents issued by the Western bishops who had met in Serdica, including the definition of faith that Athanasius dismissed because its strict Nicene language was too radical.

If Theodoret speaks about Meletians and Eustathians as orthodox groups, and if he quotes documents coming from the Western section of the Council of Serdica, notoriously far from his party, it is not surprising to find the Eastern (interpolated) and Western definitions of faith next to each other in the Verona Codex. Both Theodoret and the editors of the collections copied in the Verona Codex thus drew their material from a new archive created by merging two older archives owned by two rival groups. In what historical circumstances did this happen? In the early fifth century, some attempts were made to bring about peace between the two opposing congregations. Under Bishop Alexander they came into communion, as attested by Theodoret, h.e. V 37:

By his [i.e. Bishop Alexander's] advice and exhortation, the following of the great Eustathius which Paulinus, and after him Evagrius, had not permitted to be restored, was united to the rest of the body, and a festival was celebrated, the like of which none had ever seen before. The bishop gathered all the faithful together, both clergy and laity, and marched to the assembly with them. The procession was accompanied by musicians; one hymn was sung by all in harmony, and thus he and his company went in procession from the western postern to the great church, filling the whole forum with people and constituting a stream of thinking living beings like the Orontes in its course.

103 Martin 2009, 281-287. 
In other words, Theodoret and the Verona Codex attest to the same historical climate, which, in the early fifth century, bringing peace between the communities of Antioch, resulted in the merging of their archives.

At this point, we can say we have solved the mystery of the origin of texts 1314 and 15-17 of the Verona Codex: these texts are ultimately attributable to the Antiochene archive gathering the textual heritage of both Eustathius and Meletius after the beginning of the fifth century. That means giving an answer to the question about the fate of the material required by Carthage from the Antiochene church in the context of the question of Apiarius, which some scholars considered definitively lost.

\subsection{Between Antioch's and Rome's episcopal archives: the Exemplum synodi}

Another peculiar document in the Verona Codex (text no. 3: fols 43v-47r) comes from the same context. ${ }^{104}$ It is worth mentioning because of its complicated prehistory, which left textual traces in the codex. It is introduced by the rubric 'Exemplar of the Synod of 93 Bishops Held in Rome: From the Imperial Rescript', ${ }^{105}$ which connects the contents of the composite document issued by a synod to an imperial decree. The document consists of a letter addressed by a Roman synod under Damasus (in 371?) to the Catholic bishops of the Orient (also known to Theodoret, h.e. II 22), authenticated by a deacon from Milan called Sabinus, who was renowned for his diplomatic activity in the East around 372 ('I, Sabinus, deacon of Milan, have authenticated (this) (de authentico dedi) as legate'106), followed by three dogmatic passages culled from letters written on the Roman side of the controversy with the Orientals presented as a decree (the formula item ex parte decreti, 'also from part of the decree', occurs three times before each quotation), followed again by a note which declares that Meletius and his synod, convened at Antioch in 379, adhered to these excerpts:

104 See the edition and rich commentary in Field 2004.

105 Exemplum synodi habitae Romae episcoporum XCIII ex rescripto imperiali.

106 Ego Sabinus diaconus mediolanensis legatus de authentico dedi. 
This exposition or letter from the Roman synod held under Pope Damasus was also transmitted to the East, in which a synod was made at Antioch with every Eastern church in harmony with the faith. That all believe, and thus consent to, the same faith expounded above, each individual confirmed by his own signature. ${ }^{107}$

After a certain number of signatures, we read the following information:

\begin{abstract}
Similarly, the other 146 Eastern bishops all signed their names under it. Their signatures are [still visible] on the original document, which is kept in the archives of the Roman Church. ${ }^{108}$
\end{abstract}

Thus, we have a composite document at our disposal which is connected to more than one archive, has been subject to authentication in an ecclesiastical chancery and became part of an imperial decree enforcing it-a very rare kind of document indeed. The form in which it appears in the codex is the result of a series of interventions and transformations which the paratextual elements already mentioned above help us detect:

- the letter Confidimus quidem, which is the synodical letter of a Roman synod (under Damasus);

- the authentication of it by Sabinus the legate, which occurred in a chancery or archive that probably differed from the Roman one (see below);

- the word decretum, which refers to each of the three following Roman pieces, as if the whole thing should be considered the act of another (Roman?) synod, convened later than that of Confidimus quidem;

- the notice of adhesion by Meletius and his synod;

- the fact that the whole document is taken ex rescripto imperiali;

- finally, the location of the authentic copy of the whole document.

This text has been studied by Schwartz, but it is the recent penetrating analysis by Field which allows us to understand the whole document and its elements now, including the paratextual sentences it contains.

From Thedoret (h.e. II 22) and from other historians, ${ }^{109}$ we know that around 371 a Roman synod sent a letter to the Illyrian bishops, whose Greek text is parallel to Confidimus quidem. In Codex veronensis LX, the latter is said to have been

107 Haec expositio uel epistola synodi romanae habitae sub Damaso Papa et transmissa ad Orientem in qua omnis Orientalis ecclesia facta synodo aput Antiochiam consona fide credentes et omnes ita consentientes eidem super expositae fidei singuli sua subscriptione confirmant.

108 Similiter et alii CXLVI Orientales episcopi subscripserunt, quorum subscriptio in authenticum hodie in archiuis romanae ecclesiae tenetur.

109 Field 2004, 117. 
addressed to Eastern bishops-two pieces of information that are not necessarily contradictory, since the same synod could write the same letter, or two similar letters, to different groups of bishops. As for the exact date of this first historical event, we have to consider the mention of the condemnation of Auxentius, the bishop of Milan, who is presented as still alive: his death must have been before 374, so the synod could be dated between 368 and 374. In the second of the three subsequent excerpts, a presbyter called Dorotheus is mentioned, one of Meletius of Antioch's assistants in his difficult relationship with Western Christianity and with Athanasius; he became a presbyter between 372 and 376. ${ }^{110}$ From other sources, we know that Meletius called a synod in 372 stressing the orthodoxy shared with the Nicene West; then, a persecution of the Nicene bishops in the East lasted from 373 to 378, limiting the opportunities to convene synods. After that date, things got easier and Meletius was able to convene a synod to assent to the Roman synodical letters.

Given this historical context, we need to take the following facts into consideration:

1) the authentication made by Sabinus in relation to the first part of the text, the synodical letter of the council under Damasus (Confidimus quidem, 372?), makes no sense if referred to the Roman archives, explicitly mentioned in the final note: this authentication was probably a way of identifying Confidimus quidem in the Antiochene archives after it was received from Rome, at a time when Antioch was being visited by Sabinus the deacon; ${ }^{111}$

2) the last part of the document was the result of an Antiochene synod held in 379 by Meletius and other Eastern bishops;

3) the other items of Roman provenance could have been added to Confidimus quidem or in Rome, or in Antioch, or by the author of the imperial decree;

4) the imperial rescript carrying the synodical letter, which could only be sent out after Auxentius' death in 374 (an 'Arian' bishop who was recognised by the emperor) and before 381, marks the imperial involvement in the pacification of the Eastern churches and in the Antiochene controversy; this imperial decree was probably composed on the base of pieces coming from the Antiochene archives, rather than the Roman ones;

5) the mention of the Roman archives is interesting, but difficult to date. Is it the work of a first Antiochene redactor collecting the Antiochene and Roman material before it was sent to Carthage, together with other pieces of Antiochene history,

110 Field 2004, 119, n. 7.

111 Field 2004, 133. 
as a contribution to the Apiarian case (419)? Is it a note by a later redactor who assembled Alexandrian and Antiochene materials in Carthage or other places, precisely the one who is responsible for eliminating things he considered superfluous here and there (fifth-sixth century)? Or is it a declaration made by the scribe who wrote down the codex (in the seventh-eighth century)?

If the first hypothesis could be argued in some way, this mention would be one of the very first attestations to the existence of a papal archive and its way of working around 370-380 CE.

\section{Provisional conclusions}

The partial preservation of a limited number of Christian episcopal archives from Late Antiquity has directed our research towards other kinds of sources, which give us the opportunity to reveal archival activity and archival discourse in Christian congregations. These were ecclesiastical histories, in particular those by Eusebius, Theodoret and Sozomenus, as well as the episcopal histories which we can recover from miscellaneous manuscripts preserving canonical literature. The results of our enquiry may be summarised with the following statements:

a) Christianity was born and grew in a society in which archives not only were a reality of everyday life, but had very high recognition in the public eye. Before creating their own archives, Christian congregations adhered to the archival discourse of their times, and the mention of archives in the writings of their intellectuals served apologetic and theological aims;

b) it was with the birth of the bishop as a leading figure in Christian congregations that the necessity of archives was felt. Not only did the diverse activities of a leader on whom religious, educational, cultic and practical functions converged need archival activities, but the meetings of bishops (synods) also produced a very large amount of documentation and were based on just as much documentation of the past, for the consultation of which archives were essential. The new archives were a reflection of a congregational structure that was becoming more and more articulated and complex and, at the same time, dominated by an increasingly autocratic leadership. The arrangement of these archives imitated the functioning of public or private archives while adapting their features to the specific purposes of social and religious character typical of Christian congregations. 


\section{References}

Adler, William (2012), 'Christians and the Public Archive', in Eric F. Mason (ed.), Teacher for All Generations. Essays in Honor of James C. VanderKam (Supplements to the Journal for the Study of Judaism 153), Leiden, New York, Cologne: Brill, 917-937.

Adler, William (2013), 'The Kingdom of Edessa and the Creation of a Christian Aristocracy', in Natalie B. Dohrmann and Annette Yoshiko Reed (eds), Jews, Christians, and the Roman Empire: The Poetics of Power in Late Antiquity, Philadelphia: University of Pennsylvania Press, 43-62, 277-282.

Alpi, Frédéric (2009), La route royale. Sévère d'Antioche et les églises d'Orient (512-518), 2 vols (Bibliothèque archéologique et historique, 188), Beyrouth : Presses de l'Ifpo.

Ayres, Lewis (2004), Nicaea and its Legacy: An Approach to Fourth-Century Trinitarian Theology, Oxford: Oxford University Press.

Bagnall, Roger (2009), Early Christian Books in Egypt, Princeton, NJ: Princeton University Press. Barnard, Leslie W. (1983), The Council of Serdica 343 A.D., Sofia: Synodal Pub. House.

Barnes, Timothy D. (1993), Athanasius and Constantius. Theology and Politics in the Constantinian Empire, Cambridge, MA, London: Harvard University Press.

Bausi, Alessandro (2002), 'New Egyptian Texts in Ethiopia', in Adamantius, 8, 146-151.

Bausi, Alessandro (2006), 'La Collezione aksumita canonico-liturgica', in Adamantius, 12, 43-70.

Bausi, Alessandro, and Alberto Camplani (2013), 'New Ethiopic Documents for the History of Christian Egypt', in Zeitschrift für Antikes Christentum - Journal of Ancient Christianity, 17, 215-247.

Bausi, Alessandro, and Alberto Camplani (2016), 'The History of the Episcopate of Alexandria (HEpA): Editio minor of the fragments preserved in the Aksumite Collection and in the Codex Veronensis LX (58)', in Adamantius, 22, 249-302.

Bernardini, Paolo (2009), Un solo battesimo, una sola chiesa. Il concilio di Cartagine del settembre 256 (Testi e ricerche di scienze religiose. Nuova serie 43), Bologna: Il Mulino.

Blaudeau, Philippe (2010), 'Liberatus de Carthage ou l'historiographie comme service diaconal', in Augustinianum, 50, 543-566.

Blumell, Lincoln H., and Thomas A. Wayment (2015), Christian Oxyrhynchus. Texts, Documents, and Sources, Waco, Texas: Baylor University Press.

Brennecke, Hanns C., Uta Heil, Annette von Stockhausen, and Angelika Wintjes (eds) (2007), Athanasius Werke. III/1: Dokumente zur Geschichte des arianischen Streites, 3: Bis zur Ekthesis makrostichos, Berlin, New York: De Gruyter.

Brock, Sebastian P. (1992-1999), 'Eusebius and Syriac Christianity’, in Harold W. Attridge and Gōhei Hata (eds), Eusebius, Christianity, and Judaism, Leiden, New York, Cologne: Brill 1992, 212-234; republished in Sebastian P. Brock, From Ephrem to Romanos. Interactions between Syriac and Greek in Late Antiquity (Variorum Collected Studies Series CS644), Aldershot, Brookfield, Singapore, Sydney: Routledge 1999 (no. 2).

Brooks, Ernest W. (1903-1904), The Sixth Book of the Select Letters of Severus, Patriarch of Antioch, in the Syriac Version of Athanasius of Nisibis, II: Pt. I, Pt II, London: Williams \& Norgate.

Brooks, Ernest W. (1916-1920), A Collection of Letters of Severus of Antioch from numerous Syriac manuscripts (Patrologia orientalis, 12,14), Paris: Firmin-Didot.

Burgess, Richard W. (2013), 'The Chronograph of 354: Its Manuscripts, Contents, and History', in Journal of Late Antiquity, 5, 345-396. 
Burgess, Richard W., and Michael Kulikowski (2013), Mosaics of Time. The Latin Chronicle Traditions from the First Century $B C$ to the Sixth Century $A D$, Volume I: A Historical Introduction to the Chronicle Genre from its Origins to the High Middle Ages (Studies in the Early Middle Ages, 33), Turnhout: Brepols.

Camplani, Alberto (2003), Atanasio di Alessandria: Lettere festali. Anonimo: Indice delle lettere festali (Letture cristiane per il primo millennnio, 34), Milano: Paoline.

Camplani, Alberto (2004), 'L'autorappresentazione dell'episcopato di Alessandria tra IV e V secolo: questioni di metodo', in Annali di storia dell'esegesi, 21, 147-185.

Camplani, Alberto (2006a), 'Lettere episcopali, storiografia patriarcale e letteratura canonica: a proposito del Codex veronensis LX (58)', in Rivista di storia del cristianesimo, 3, 117164.

Camplani, Alberto (2006b), 'Le trasformazioni del cristianesimo orientale: monoepiscopato e sinodi (II-IV secolo)', in Annali di storia dell'esegesi, 23, 67-114.

Camplani, Alberto (2009a), 'Pietro di Alessandria tra documentazione d'archivio e agiografia popolare', in Heike Grieser and Andreas Merkt (eds), Volksglaube im antiken Christentum. Prof. Dr. Theofried Baumeister OFM zur Emeritierung, Darmstadt: Wissenschaftliche Buchgesellschaft, 138-156.

Camplani, Alberto (2009b), 'Traditions of Christian Foundation in Edessa. Between Myth and History', in Studi e Materiali di Storia delle Religioni 75 (= Alberto Camplani, Giulia Piccaluga and Alessandro Saggioro (eds), Città pagana - città cristiana. Tradizioni di fondazione. Atti del convegno di Roma, 2-3 luglio 2007), 251-278.

Camplani, Alberto (2011), 'A Syriac fragment from the Liber historiarum by Timothy Aelurus (CPG 5486), the Coptic Church History, and the archives of the bishopric of Alexandria', in Paola Buzi and Alberto Camplani (eds), Christianity in Egypt: Literary Production and Intellectual Trends. Studies in Honor of Tito Orlandi (Studia Ephemeridis Augustinianum, 125), Rome: Istituto Patristico Augustinianum, 205-226.

Camplani, Alberto (2012), 'A Pastoral Epistle of the Seventh Century Concerning the Eucharist (Pap. Berlin P. 11346)', in Verena M. Lepper (ed.), Forschung in der Papyrussammlung. Eine Festgabe für das Neue Museum (Für das Ägyptische Museum und Papyrussammlung Staatliche Museen zu Berlin, Ägyptische und Orientalische Papyri und Handschriften des Ägyptischen Museums und Papyrussammlung Berlin Band 1), Berlin: Akademie Verlag, 377-386.

Camplani, Alberto (2013a), 'Fourth-Century Synods in Latin and Syriac Canonical Collections and their Preservation in the Antiochene Archives (Serdica 343 CE - Antioch 325 CE)', in Sofia Torallas Tovar and Juan Pedro Monferrer-Sala (eds), Cultures in Contact. Transfer of Knowledge in the Mediterranean Context (Series Syro-Arabica, 1), Cordoba, Beyrouth: Oriens Academic, 61-72.

Camplani, Alberto (2013b), 'The Transmission of Early Christian Memories in Late Antiquity: The Editorial Activity of Laymen and Philoponoi', in Brouria Bitton-Ashkelony and Lorenzo Perrone (eds), Between Personal and Institutional Religion. Self, Doctrine, and Practice in Late Antique Eastern Christianity, Turnhout: Brepols,129-154.

Camplani, Alberto (2015), 'The religious identity of Alexandria in some ecclesiastical histories of Late Antique Egypt', in Philippe Blaudeau and Peter van Nuffelen (eds), L'historiographie tardo-antique et la transmission des savoirs (Millennium-Studien zu Kultur und Geschichte des ersten Jahrtausends n. Chr. 55), Berlin, Munich, Boston: De Gruyter, 85119.

Crum, Walter E. (1902), Coptic Ostraca from the Collections of the Egypt Exploration Fund, the Cairo Museum and others, London: The Egypt Exploration Fund. 
Dalmon, Laurence (2015), Un dossier de l'Épistolaire augustinien: la correspondance entre l'Afrique et Rome à propos de l'affaire pélagienne (416-418): traduction, commentaire et annotations (Studia patristica Supplement, 3), Leuven: Peeters.

Dekker, Renate (2011), 'Reconstructing and re-editing the archive of bishop Pesynthios', in Maarten Horn et al. (eds), Current Research in Egyptology 2010, Oxford: Oxbow Books, 33-41.

Debié, Muriel (2015), L'écriture de l'histoire en syriaque. Transmissions interculturelles et constructions identitaires entre hellénisme et islam. Avec des répertoires des textes historiographiques en annexe (Late Antique History and Religion, 12), Louvain: Peeters

Desreumaux, Alain (1993), Histoire du roi Abgar et de Jésus, Présentation et traduction du texte syriaque intégral de la Doctrine d'Addaï (Apocryphes: Collection de poche de l'AELAC), Paris, Turnhout: Brepols.

Duchesne, Louis (ed.) (1886-1892), Le Liber Pontificalis. Texte, introduction et commentaire, Paris: Ernest Thorin (see Le Liber pontificalis, I, Anastatic reimpression of the first edition with a preface by Jean Bayet, Bibliothèque des Écoles françaises d'Athènes et de Rome, 2e série, Registres et lettres des papes du XIIIe siècle, III, 1-3, Paris 1955).

Duval, Yvette (2000), Chrétiens d'Afrique à l'aube de la paix constantinienne. Les premiers échos de la grande persécution (Collection des Études Augustiniennes, 164), Paris: Institut d'Études Augustiniennes.

Fiaccadori, Gianfranco (2014), 'Archives and libraries', in Encyclopaedia Aethiopica, V: Y-Z. Supplementa, Addenda et Corrigenda, Maps, Index, Wiesbaden: Harrassowitz, 244-248.

Field, Lester L. (2004), On the Communion of Damasus and Meletius: Fourth-Century Synodal Formulae in the Codex Veronensis LX (Studies and Texts, 145), Toronto: Pontifical Institute of Medieval Studies.

Francia, Rita (2015), 'Archivi e biblioteche a Hattuša: alcune riflessioni', in Elena Asero (ed.), Strade di uomini e di idee. La circolazione materiale e interculturale tra mediterraneo orientale e vicino Oriente antico. Atti del convegno (Milano, 8-9 luglio 2013), Rome: Aracne, 33-44.

Friedrich, Markus (2013), Die Geburt des Archivs. Eine Wissensgeschichte, Munich: Oldenbourg.

Gamble, Harry Y. (1995), Books and Readers in the Early Church. A History of Early Christian Texts, New Haven, London: Yale University Press.

Gaudemet, Jean (1958), L'Église dans l'Empire romain (IVe-Ve siècles), Paris: Sirey.

Gaudemet, Jean (1994), Église et cité: histoire du droit canonique, Paris: Cerf.

Giorda, Maria Chiara (2007), 'Una rassegna di fonti documentarie per lo studio del monachesimo egiziano', in Adamantius, 13, 379-393.

Guidi, Ignazio (1903), Chronica minora. Pars prior (Corpus Scriptorum Christianorum Orientalium, Scriptores Syri, Series III, Tomus IV), Paris: E Typ. Reipublicae.

Gumbert, Johan P. (2004), 'Codicological units: Towards a Terminology for the Stratigraphy of the Non-Homogeneous Codex', in Segno e Testo, 2, 17-42.

Hess, Hamilton (2002), The Early Development of Canon Law and the Council of Serdica, 0xford: Oxford University Press.

Howard, George (transl.) (1981), The Teaching of Addai (Society of Biblical Literature Texts and Translations, 16, Early Christian Literature Series, 4), Chico, CA: Scholars Press.

Krause, Martin (1956), Apa Abraham von Hermonthis. Ein oberägyptischer Bischof um 600, 2 vols, Dissertation, Berlin. 
Krause, Martin (1991a), Abraham of Hermonthis, in Aziz S. Atiya (ed.), The Coptic Encyclopedia, New York: Macmillan, 13a-b.

Krause, Martin (1991b), Archives, in Aziz S. Atiya (ed.), The Coptic Encyclopedia, New York: Macmillan, 226a-228a.

Lake, Kirsopp (transl.) (1926), Eusebius. Ecclesiastical History, I (Loeb Classical Library), London, New York: Harvard University Press.

Luijendijk, AnneMarie (2008), Greetings in the Lord: Early Christians in the Oxyrhynchus Papyri (Harvard Theological Studies, 60), Cambridge: Harvard University Press.

Mardirossian, Aram (2010), La Collection canonique d'Antioche. Droit et hérésie à travers le premier recueil de législation ecclésiastique (IVe siècle) (Centre de recherche d'histoire et civilisation de Byzance. Monographie, 34), Paris: Collège de France.

Martello, Fabrizio (2012), All'ombra di Gregorio Magno. Il notaio Paterio e il Liber testimoniorum, Rome: Città Nuova.

Martin, Annick, and Micheline Albert (eds) (1985), Histoire «acéphale» et index syriaque des lettres festales d'Athanase d'Alexandrie (Sources chrétiennes, 317), Paris: Cerf.

Martin, Annick (1985), 'Introduction', in Martin/Albert 1985, 11-67.

Martin, Annick (1996), Athanase d'Alexandrie et l'Église d'Égypte au IVe siècle (328-373) (Collection de l'École française de Rome, 216), Rome: École française de Rome.

Martin, Annick, Pierre Canivet, Jean Bouffartigue, Luce Pietri and François Thelamon (eds) (2006-2009), Théodoret de Cyr, Histoire ecclésiastique (Sources chrétiennes, 501, 530), Paris: Les Éditions du Cerf.

Martin, Annick (2009), 'Antioche aux IVe et Ve siècles. Un exemple de réécriture orthodoxe de l'histoire chrétienne', in Studi e materiali di storia delle religioni 75 (= Alberto Camplani, Giulia Piccaluga and Alessandro Saggioro (eds), Città pagana - città cristiana. Tradizioni di fondazione. Atti del convegno di Roma, 2-3 luglio 2007), 279-294.

Mathisen, Ralph W. (1998), 'Et manu papae: Papal Subscriptions Written sua manu in Late Antiquity', in Gareth Schmeling and Jon D. Mikalson (eds), Qui miscuit utile dulci. Festschrift Essays for Paul Lachlan MacKendrick, Wauconda: Bolchazy-Carducci Publishers, 243-251.

Montanari, Giovanni (1992), 'Culto e liturgia a Ravenna dal IV al IX secolo', in Antonio Carile (ed.), Storia di Ravenna, II/2: Dall'età bizantina all'età ottoniana. Ecclesiologia, cultura e arte, Venice: Comune di Ravenna and Marsilio.

Moreau, Dominic (2010), 'Non impar conciliorum extat auctoritas. L'origine de l'introduction des lettres pontificales dans le droit canonique', in Janine Desmulliez, Christine Hoët-van Cauwenberghe and Jean-Christophe Jolivet (eds), L'étude des correspondances dans le monde romain de l'Antiquité classique à l'Antiquité tardive: permanences et mutations. Actes du XXX Colloque international de Lille (Lille, 20-22 novembre 2008) (UL3: Travaux \& recherches), Lille: Presses de l'Université Charles-de-Gaulle - Lille, 487-506.

Moreau, Dominic (2012a), De rebus exterioribus. Recherches sur l'action temporelle des évêques romains, de Léon le Grand à Grégoire le Grand (440-604 ap. J.-C.). Sources et approches; Les actes pontificaux comme sources des historiens, Thèse pour obtenir le grade de Docteur de l'Université Paris-Sorbonne, Paris.

Moreau, Dominic (2012b), 'Deux notes sur l'utilisation du terme rege(/i)st(r)um pour désigner les recueils d'actes pontificaux antiques', in Stéphane Gioanni and Paolo Cammarosano (eds), La corrispondenza in Italia - Les correspondances en Italie, II: Forme, stili e funzioni della scrittura epistolare nelle cancellerie italiane (secoli $V-X V$ ) - Formes, styles et fonctions de l'écriture épistolaire dans les chancelleries italiennes (Ve-XVe siècle) (Atti 6 / Collection de l’École française de Rome, 475), Trieste, Rome: École française de Rome, 73-91. 
Moreau, Dominic (2015), 'Les actes pontificaux comme sources des historiens et des chroniqueurs de l'Antiquité tardive', in Philippe Blaudeau and Peter van Nuffelen (eds), L'historiographie tardo-antique et la transmission des savoirs (Millennium-Studien zu Kultur und Geschichte des ersten Jahrtausends n. Chr. 55), Berlin, Munich, Boston: De Gruyter, 23-53.

Munier, Charles (ed.) (1974), Concilia Africae A. 345 - A. 525 (Corpus Christianorum, Series Latina, 149), Turnhout: Brepols.

Norelli, Enrico (2001), 'Ignazio di Antiochia combatte veramente dei cristiani giudaizzanti?', in Giovanni Filoramo and Claudio Gianotto (eds), Verus Israel. Nuove prospettive sul giudeocristianesimo. Atti del Colloquio di Torino (4-5 novembre 1999), Brescia: Paideia, 220264.

Norelli, Enrico (2006), 'Scrivere per governare. Modi della comunicazione e rapporti di potere nel cristianesimo antico. Introduzione al convegno', in Rivista di storia del cristianesimo, 3, 5-30.

Norelli, Enrico (2012), 'Una pluralità limitata. Il rovesciamento di paradigma nel II secolo come base della formazione del canone neotestamentaria', in Antonio Autiero and Marinella Perroni (eds), La Bibbia nella storia d'Europa: dalle divisioni all'incontro, Bologna: Edizioni Dehoniane Bologna, 47-92.

Opitz, Hans-Georg, Hanns Christof Brennecke, Uta Heil and Annette von Stockhausen (eds) (1935-2006), Athanasius Werke, II/1: Die Apologien, Berlin, Leipzig, New York: De Gruyter.

Phillips, George (1876), The Doctrine of Addai, the Apostle, Now First Edited in a Complete Form in the Original Syriac, London: Trübner.

Pietri, Charles (1976), Roma christiana. Recherches sur l'Église de Rome, son organisation, sa politique, son idéologie de Miltiade à Sixte III (311-440) (Bibliothèque des Écoles françaises d'Athènes et de Rome, 224), Rome: École française de Rome.

Prinzivalli, Emanuela (2010), 'La lettera di Clemente ai Corinzi', in Emanuela Prinzivalli and Manlio Simonetti (eds), Seguendo Gesù. Testi cristiani delle origini, I (Lorenzo Valla), Milano: Arnoldo Mondadori, 77-275, 425, 449-541.

Revillout, Eugène (1900-1914), 'Textes coptes. Extraits de la correspondance de St. Pésunthios évêque de Koptos et de plusieurs documents analogues (juridiques ou économiques)', in : Révue égyptologique, 9 (1900), 133-177; 10 (1902), 34-47; 14 (1914), 22-32.

Ross, Steven K. (2001), Roman Edessa. Politics and culture on the eastern fringes of the Roman Empire, 114-242 CE, London, New York: Routledge.

Schenk, Dietmar (2014), Kleine Theorie des Archivs, 2. überarbeitete Auflage. Stuttgart: Franz Steiner Verlag (1st ed. Stuttgart 2008).

Schmelz, Georg (2002), Kirchliche Amtsträger im spätantiken Ägypten nach den Aussagen der griechischen und koptischen Papyri und Ostraka (Archiv für Papyrusforschung, 13), Leipzig: De Gruyter.

Schulthess, Friedrich (ed.) (1908), Die syrischen Kanones der Synoden von Nicaea bis Chalcedon, nebst einigen zugehörigen Dokumenten (Abhandlungen der königlichen Gesellschaft der Wissenschaften zu Göttingen, Philologisch-historische Klasse, Neue Folge X/2), Berlin: Weidmannsche Buchhandlung.

Schwartz, Eduard (1936a), 'Über die Sammlung des Cod. Veronensis LX', in Zeitschrift für die neutestamentliche Wissenschaft, 35, 1-23.

Schwartz, Eduard (ed.) (1936b), Liberati Breviarium causae nestorianorum et eytychianorum, in Concilium universale chalcedonense, Volumen quintum: Collectio sangermanensis (Acta Conciliorum Oecumenicorum II/5), Berolini, Lipsiae: De Gruyter, 98-141. 
Schwartz, Eduard (1936c), 'Die Kanonessammlungen der alten Reichskirche', in Zeitschrift der Savigny-Stiftung für Rechtsgeschichte, 56 (69) - Kanonistische Abteilung 25, 1-144 (= Id. (1960), Gesammelte Schriften, IV: Zur Geschichte der alten Kirche und ihres Rechts, Berlin: De Gruyter, 159-275).

Schwartz, Eduard, and Theodor Mommsen (eds) (1999 [1903]) Eusebius Werke, II/1: Die Kirchengeschichte, Anastatic reimpression of the first edition with preface by Friedhelm Winkelmann (Die Griechischen christlichen Schriftsteller der ersten Jahrhunderte. Neue Folge 6), Berlin: Akademie Verlag.

Segal, Jakob B. (1970), Edessa: The 'Blessed City', Oxford: Clarendon.

Simonetti, Manlio (1975), La crisi ariana nel IV secolo (Studia Ephemeridis Augustinianum 10), Roma: Institutum Patristicum Augustinianum

Simonetti, Manlio (2010), 'Le lettere di Ignazio', in Emanuela Prinzivalli and Manlio Simonetti (eds), Seguendo Gesù. Testi cristiani delle origini, I (Lorenzo Valla), Milano: Arnoldo Mondadori 279-425, 542-628.

Stewart, Alastair C. (2014), The Original Bishops. Office and Order in the First Christian Communities, Grand Rapids, MI: Baker Academic.

Telfer, Walter (1943), 'The Codex Verona LX (58)', in Harvard Theological Review, 36, 169-246.

Traina, Giusto (1996), 'Archivi armeni e mesopotamici: la testimonianza di Movsēs Xorenac'i', in Marie-Françoise Boussac and Antonio Invernizzi (eds), Archives et sceaux du monde hellénistique - Archivi e sigilli nel mondo ellenistico, Torino, Villa Gualino, 13-16 Gennaio 1993 (Bulletin de correspondence hellénique, Supplément, 29), Paris: De Boccard, 49-63.

Turner, Cuthbert H. (1939), Ecclesiae Occidentalis Monumenta Iuris Antiquissima. Canonum et conciliorum graecorum interpretationes latinae, Tomi prioris fasciculi alterius pars quarta: Supplementum Nicaeno-alexandrinum sive Conciliorum Nicaeni et Serdicensis Sylloge a Theodosio Diacono [Carthaginensi] adservata secundum codicem unicum veronensem bibliothecae capitularis LX (58) saec. VII-VIII, Opus postumum, Oxonii: Clarendoniano.

Uthemann, Karl-Heinz (ed.) (1981), Anastasius the Sinaite, Viae dux (Corpus Christianorum Series Graeca, 8), Turnhout: Brepols.

Van der Vliet, Jacques (2002), Pisenthios de Coptos (569-632), moine, évêque et saint, in Marie-Françoise Boussac (ed.), Autour de Coptos - Actes du colloque organisé au Musée des Beaux-Arts de Lyon (17-18 mars 2000) (TOPOI, Orient-Occident, Supplément 3), Lyon, Paris: De Boccard, 61-72.

Van der Vliet, Jacques (2013), Les archives de Pesynthios: nouvelles découvertes, nouvelles questions, in Anne Boud'hors and Catherine Louis (eds), Études coptes XII. Quatorzième journée d'études (Rome 11-13 juin 2009) (Cahiers de la bibliothèque copte, 18), Paris: De Boccard, 263-269.

Van der Vliet, Jacques (2015), Le prêtre Marc, Psan et Pesynthios: un roseau miaphysite autour du monastère d'Épiphane, in Anne Boud'hors and Catherine Louis (eds), Études coptes XIII. Quinzième journée d'études (Louvain-la-Neuve, 12-13 mai 2011) (Cahiers de la bibliothèque copte, 20), Paris: De Boccard, 127-136.

Vandorpe, Katelijn (2009), 'Archives and Dossiers' in Roger S. Bagnall (ed.), The Oxford Handbook of Papyrology, Oxford: Oxford University Press, 216-255.

Van Nuffelen, Peter (2004), Un héritage de paix et de piété. Étude sur les histoires ecclésiastiques de Socrate et de Sozomène (Orientalia Lovaniensia analecta, 142), Leuven, Paris, Dudley, MA: Uitgeverij Peeters/Departement Oosterse Studies. 
Van Rompay, Lucas (1999), 'Jacob of Edessa and the Early History of Edessa', in Gerrit J. Reinink and Alex Klugkist (eds), After Bardaisan: Studies for H.J.W. Drijvers, Leuven: Peeters, 269285.

Verardi, Andrea A. (2016), La memoria legittimante: il Liber pontificalis e la Chiesa di Roma del secolo VI (Istituto storico italiano per il Medio Evo. Nuovi studi storici, 99), Rome: Istituto storico italiano per il Medio Evo.

Wipszycka, Ewa (1996), 'Il vescovo e il suo clero. A proposito di CPR V 11', in Ewa Wipszycka, Études sur le christianisme dans l'Égypte de l'antiquité tardive (Studia Ephemeridis Augustinianum, 52), Rome: Institutum Patristicum Augustinianum, 177-194.

Wipszycka, Ewa (2007), 'The Institutional Church', in Roger S. Bagnall (ed.), Egypt in the Byzantine World, 300-700. Cambridge, New York, Melbourne, Madrid: Cambridge University Press, 331-349.

Wipszycka, Ewa (2008), 'Les gens du patriarche alexandrin', in Christian Décobert, Jean-Yves Empereur (eds), Alexandrie médiévale 3 (Études alexandrines, 16), Cairo: Institut français d'archéologie orientale, 89-114.

Wipszycka, Ewa (2015), The Alexandrian Church. People and Institutions (Supplements to Journal of Juristic Papyrology, 25), Warsaw: University of Warsaw. 


\title{
Thomas Graumann
}

\section{Documents, Acts and Archival Habits in Early Christian Church Councils: A Case Study}

\begin{abstract}
The paper presents a case study for the handling and archiving of documents and acts related to church councils during Late Antiquity. At a sequence of interrelated events-both before assemblies of bishops and in meetings convened by imperial officials-in the run-up to the Council of Chalcedon (451 CE) a wide range of documents was examined and utilised. Administrators of church and empire and their staff paid meticulous attention to the characteristic features of textual objects before them and inferred their validity, provenance and previous handling. The terminologies for such documents and acts employed by these ancient practitioners also reflect careful consideration of their status. The paper shows how observation of divergent textual formality and retrieval from different sources combined to reveal different 'loci' and modes of authority, and detects a range of administrative practices underlying their use.
\end{abstract}

At the beginning of the fourth century, the Christian churches emerged from persecution and instead found themselves, beginning with the reign of Constantine, increasingly in receipt of the favour-materially and ideologically-of emperors and government officials. Among its many effects this change sparked a rapid and intense development of the institutional features of the churches; matters of church organisation across regions and provinces, of office holding, the control of finances and of the employ of resources became more urgent. Central to these developments, a major new institution for the regulation of disputes emerged in the form of church councils or synods. ${ }^{1}$ Church councils also became a focal point and prism for the production and handling of significant amounts of texts, both theological and administrative in nature. The manifold efforts at disciplinary regulation internal to the churches, often, but not exclusively conducted at councils,

\footnotetext{
1 The meetings are in the Greek speaking parts of the empire commonly referred to as a synodos, while Latin authors either use the loanword synodus (fem.) or more commonly employ the term concilium. Importantly both terms are used interchangeably in the ancient world and do not denote a difference in authority and reach.
}

https://doi.org/10.1515/9783110541397-009, (c)BY-NC-ND (c) 2018 Th. Graumann, published by De Gruyter. This work is licensed under the Creative Commons Attribution-NonCommercial-NoDerivs 3.0 License. 
found expression in decisions that were recorded, extracted and collected as canons and eventually lead to the emergence of canon law as a specialist branch of legal learning and activity. Bishops also found themselves involved in the imperial legal system where they were tasked to hear and adjudicate disputes-the socalled episcopalis audientia. ${ }^{2}$ To these (quasi-) juridical responsibilities an emerging ecclesiastical bureaucracy is of central importance. Inevitably such activities of churchmen resulted in paperwork, which required 'professional' skills in producing and handling the documents. Specialist personnel for taking and keeping records-usually called 'notaries'-soon make their appearance in Christian sources; theirs is a new, distinct clerical function. By the turn of the fifth century, major episcopal sees like Alexandria, Antioch or Rome boast 'chief notaries' who, we may infer, oversee a larger bureau with a number of subordinate office staff, all of whom were engaged principally in textual production and record-keeping. ${ }^{3}$

In the doctrinal disputes that motivate the convening of major empire-wide church councils a similar, and increasing, focus on records and documents can be observed. There is no good reason to separate artificially the working practices in councils between matters of a doctrinal nature on the one hand and those of a disciplinary nature on the other. On the contrary, very frequently the negotiation of doctrinal differences takes the form of a hearing to uncover and condemn the alleged heterodoxy of an incriminated individual in the style of a trial. Legal scholars, thus, have amply demonstrated the similarities of conciliar transactions to the conduct of court cases. ${ }^{4}$ The proceedings of these councils have also been likened to those of the imperial senate or regional assemblies. ${ }^{5}$ Even if they fall short of explaining sufficiently the character of church councils in other respects, both analogies capture some of the mechanics at work and alert us to the fact that in order to function effectively these important events almost inevitably required a developed bureaucratic machinery. The deliberations and decisions of councils

2 For the much discussed question of the precise legal scope of this institution, see Steinwenter 1950, 915-917; Selb 1967, 162-217, and the recent brief survey by Sirks 2013, 79-88, see also Humfress 2013, 1817-18.

3 See, for the relevant functions in the late antique and early byzantine church Leontaritou 1996, s.vv. See also Graumann 2017a.

4 The classic example is Steinwenter 1934, 1-116. For a wider discussion about the judicial character of synods, see Girardet 1975.

5 Beginning with Gelzer 1907, 142-155 (first printed in 1900). Though Gelzer acknowledged the serious lack of sources for senatorial procedural conventions, he felt confident to point out numerous parallels. The complete consonance between the institutions that Gelzer, and other scholars since, wanted to detect significantly overstates the case and neglects many particular features of councils. 
produced, and dealt with, large amounts of documents and texts. They are not just of a church-historical interest. The historian Fergus Millar has recently pointed out that the surviving records of the four major church councils held between 431 and $451 \mathrm{CE}$ in the reigns of the Emperors Theodosius II (408 to 450) and Marcian (450 to 457) provide the most detailed and dense documentation for the workings of Roman imperial government of any period of roman history, showing the constant intersection between imperial and ecclesiastical (textual) communication in the context of these events. ${ }^{6}$ Archival practices and document keeping, thus, become a main interest for the understanding of the background operations of conciliar bureaucracy, yet it has thus far been almost entirely neglected in scholarship.

Significant documentary records of church councils were already produced over the course of the fourth century (and sporadically even before that). ${ }^{7}$ These, however, survive only in part and indirectly; they are usually embedded in a secondary textual context, for example in polemical treatises and historical narratives, rather than being preserved in their original shape and context. ${ }^{8}$ The use of such texts in polemical and historical treatises proves their availability to the interested (near-)contemporary reader and writer. Yet how those original council records were stored for safekeeping and future use is uncertain. Writing in 375/6, Jerome, for example, speaks of 'church-papers' (ecclesiarum chartae) stored in 'public archives' (scrinia publica) ${ }^{9}$ in which he found the records of a particular controversial instance, and he invites the readers of his treatise to be assured of his account's veracity by ascertaining the original acts from the archive. ${ }^{10}$ He does not mention which archive stored the relevant record, but since at the time of writing he sojourned in the East, moving between Antioch and Constantinople, there is a strong likelihood that the file in question could be found in one of these

\section{Millar 2006.}

7 For a very helpful listing of conciliar documents in the Latin-speaking west of the empire, see now Weckwerth 2013; for the Greek east, see Geerard 1980.

8 A significant number of pertaining documents is being edited in the collection Dokumente zur Geschichte des Arianischen Streites (=Athanasius Werke, Bd. 3, Lfg. 1-2: Urkunden zur Geschichte des Arianischen Streites 318-328, ed. Opitz 1934 (repr. 2012); Lfg. 3: Bis zur Ekthesis Makrostichos, ed. Brennecke/Heil/von Stockhausen/Wintjes 2012; Lfg. 4: Bis zur Synode von Alexandrien 362, ed. Brennecke/von Stockhausen/Müller/Heil/Wintjes 2014; additional volumes are in preparation.

9 Hieronymus, Altercatio Luciferiani et Orthodoxi 18 (154,37-41, Canellis 2003): Quod si quis a nobis fictum putauit, scrinia publica scrutetur. Plenae sunt certe ecclesiarum chartae; recens adhuc rei memoria est. Supersunt homines qui illi synodo interfuerunt et, quod ueritatem firmet, ipsi Ariani haec ita ut diximus gesta non denegent. (156,51-53, Canellis 2003): Quae si quis plenius discere cupit, in Ariminensis synodi actis reperiet, unde et nos ista libauimus.

10 For an interpretation of Jerome's evidence with respect of the modes of synodical procedure seen from the vantage points both of theological and cultural expectations, see Graumann 2017b. 
great centres. ${ }^{11}$ Another example where archival storage of ecclesiastical documents can be traced is provided by a colloquium or conference (called collatio in the sources) between bishops of two conflicting churches-conventionally called Donatists and Catholics respectively-in North Africa, held in Carthage in 411 CE. ${ }^{12}$ The colloquium was convened on imperial orders and chaired and overseen by an imperial official; its minutes were deposited on his orders in the public archives, perhaps those of the provincial governor (but this is uncertain). ${ }^{13}$ Since we are dealing here with a case of imperial adjudication, albeit on a matter of competing religious claims, the acts find their place in a public archive quite naturally, rather than in an ecclesiastical one. Just as church matters had become a concern for imperial governance generally, and ecclesiastical decision-making processes were both shaped by and, in turn, resulted in, imperial law making, the records, specifically, of administrative and ecclesiastical bodies were not always strictly separate. We may ask whether this was also the case in relation to the storage of such records and the keeping of archives.

The convention of archival storage as such is, at any rate, in evidence from the acts emanating from church councils, but we know very little about the internal workings or organisation of church archives-or libraries-over the course of the fourth century. By contrast, at least a glimpse into archival practices and concerns is afforded by the records of church councils from the reign of Theodosius II in the first half of the fifth century. They reveal a situation that is very likely specific to the capital Constantinople, where much of the dispute to which these records relate played out, but they may have wider implications for our question and can be supplemented by sporadic observations from other localities. Importantly the records of

11 Jerome for a time assisted Pope Damasus in a secretarial function (see Hieronymus, Epistula 123,9 [82,14f., Hilberg 1918]: cum in chartis ecclesiasticis iuuarem damasum, romanae urbis episcopum, et orientis atque occidentis synodicis consultationibus responderem [...]). This gave him insight, Jerome claims, into the workings of the papal 'court' (he may have overstated his familiarity with the Pope and his proximity to the centre of power), but unfortunately he uses no technical terminology for the institution or space-whether library, archive or office-, in which he served.

12 For the conference and its context in the Donatist Schism, see the brief introductions in Lancel/Alexander 1996-2002, 606-638; Schindler 1977, 648-700, esp. 654-668. Of the abundant scholarship on the issue, see for example, Lancel 2002 (French original: 1999), 275-305, for the events leading up to and including the conference esp. 287-300; Frend 1952, on the conference 275-289; and generally Kriegbaum 1986; as well as Grasmück 1964. For the Donatist 'standpoint' in the meeting, see also Graumann 2011.

13 The deposition of the original acts in publica monumenta is stated CTh XVI 5,55 (constitution by Emperor Honorius of 30 August 414). Both Tengström (1962, 27-30) and Lancel (1972-1991, at vol. I.351f.) consider the use of the proconsular archive for this purpose more likely than that of any municipal archive. 
these meetings survive not just in extracted form like so much of the fourth-century material but in their entirety-or at least in their original shape.

It is not necessary for our purposes to present in detail the theological and hierarchical disputes from which these records arise. ${ }^{14}$ Suffice to briefly sketch the circumstances under which records were produced and used on these occasions. After disputes about the understanding of the incarnation of Christ had raged since $428 \mathrm{CE}$ and an imperial council in Ephesus in $431 \mathrm{CE}$ (the later so-called Third Ecumenical Council) had initially failed to solve the conflict, subsequent negotiations achieved an uneasy truce, which was ratified in $433 \mathrm{CE}$. Relative calm was restored on the surface for some fifteen years, even though propagandistic writing continued. In 447/8 CE, after the death of many of the original protagonists of the dispute, the crisis broke out afresh, and with renewed vehemence. Against this background, in $448 \mathrm{CE}$ a monastic leader (archimandrite) by the name of Eutyches was accused of heterodoxy before the bishop of Constantinople, Flavian. ${ }^{15}$ His case was heard before what is called the 'resident' or 'standing synod' of the church in the capital (synodos endemousa). This synod was composed of bishops present in the capital on other business and spontaneously convened whenever a matter for deliberation and adjudication arose. ${ }^{16}$ The synod found Eutyches guilty of heterodox teaching, and deposed and excommunicated him. This hearing produced a record pertaining to eight meetings or sessions, where the interventions of participants were minuted and a number of pleas and documents were read out and entered into the files. However, soon after this verdict Eutyches and his supporters accused the synod of procedural improprieties and of a blatant falsification of its records. An imperial commission revisited the records of the synod. The commission conducted three meetings in Constantinople in the spring of $449 \mathrm{CE}$; from two of these meetings minutes survive. ${ }^{17}$ Some discrepancies in the records were discovered and some circumstances of the synod's activities remained questionable but no clear verdict as to any manipulation of the records could be reached. After the imperial investigation about the correctness of procedure and minuting had finished, the matter was

14 A helpful narrative overview of the events and conflicts is provided by Fraisse-Coue 1995, 499-550 and 1998, 9-77; as well as Perrone 1993, 11-118. Still useful are the classical accounts by Kidd 1922, III.192-339; Hefele/Leclerq 1908. There are numerous specialist examinations of the theological questions concerned.

15 For the events, see Schwartz 1929; May 1989.

16 See, in brief, Papadakis 1991, I.696-697; see further Stephanides 1936; Hajjar 1962.

17 The records of the imperial inquires are contained in the minutes of the first session of the Council of Chalcedon, where they were read out; see CChalc. sess. I.555-828 (records of 13 April 449), ACO II.1.1, 148-176; and I.829-849 (of 27 April 449), ACO II.1.1, 177-179. 
later passed on for adjudication of the substance of the case-the question of orthodox faith (not strictly a matter for imperial adjudication)-to an ecumenical (that is empire-wide) council. It assembled on Theodosius II's orders in the August of the same year $449 \mathrm{CE}$ in Ephesus, the metropolis of Asia. In a plenary session this synod once more studied and head read out aloud to them all the documents and records mentioned and, as was expected, produced a protocol of its own proceedings. With this council's verdict the matter seemed closed. But there was widespread criticism, particularly in the west. After the death of Theodosius II a change in imperial religious policy occurred. His successor Marcian called another council to meet in Chalcedon in $451 \mathrm{CE}$, which reversed almost all the decisions taken in Ephesus two years previously. To do this, the existing records were read out once more and discussed at great length. This process was-again-minuted. What results is a complex layering of protocols from a sequence of meetings over the course of three years-all of which claim to be the verbatim record and authentic minute of events and were read and quoted as such-beginning with the Constantinopolitan 'resident synod', which had taken place in November of $448 \mathrm{CE}$, and culminating in their re-reading-in some cases for a second or third time-in the Council of Chalcedon in October of $451 \mathrm{CE}$. We owe it to the special circumstances of the case, that this treasure of interrelated documents and acts has been preserved. Together they form the first part (i.e.: the minutes of the first session) of the Acts of the Council of Chalcedon, from where they need to be carefully disentangled. They need to be studied by reversing the process of their creation: by pealing away layer after layer of re-reading and discussion to identify the original shape of the protocol from each event in its turn. ${ }^{18}$ It has already become apparent in this brief sketch that the reliability and authority of the various minutes were very much the focus of repeated critical examination at a number of these events. It is for this reason, I want to argue, that we find in the minutes occasional but detailed attention to the physicality of the documents and acts concerned. Physical features were displayed and 'read' by those involved in the meetings as evidence for the provenance of such documents and taken as indicative of their authenticity. Even if that argument is never explicitly made in the records themselves, a comparison to many other similar occasions, where there is hardly ever any mention of the physical shape and form of

18 The text is edited Acta Conciliorum Oecumenicorum, iussu atque mandato Societatis Scientiarum Argentoratensis ed. Schwartz 1932-1938; for the texts of the transactions especially II.1.13 (Greek texts) and II.3.1-3 (Latin translation); all future references are to this edition [ACO]. See English translation: Price/Gaddis 2005. Price provides a helpful table of the layering of documents from the different occasions at vol. I.113f. 
documents and acts, proves that such ostensive attention to texts as material objects is worthy of note. Precisely because council acts do not routinely refer to themselves or to the processes by which they come into existence, the very frequent attention given to this question in the acts of the meetings we want to examine must be considered significant. For the purpose of our investigation into manuscripts and archives in particular, both the attention to physical textual objects and the ways in which they were being passed on and kept between different meetings, of both ecclesiastical and imperial bodies, deserves our attention.

I want to focus on one telling example, the reading of documents and acts belonging to the Council of Ephesus (449 CE) that is conducted at the later Council of Chalcedon (451 CE), and will occasionally point out parallel instances from those other occasions mentioned. The Council of Chalcedon was tasked to revoke the decisions taken in Ephesus that were no longer deemed acceptable to the new imperial regime. The bishops scrutinised the entire case file, now with particular attention to the handling of the question in the Council of Ephesus in 449. Pope Leo famously had denounced the Ephesine Council a 'Robbers' Den'; and questions of potential violation of procedural propriety and outright manipulation were at the heart of the investigation. So the acts of Ephesus were being read, which contained all the other pieces already mentioned. The reading of the Ephesine proceedings is, in this way, at the same time a reading of the entire file and the older documents.

\section{The imperial letters}

After the session had been formally opened and initial squabbling over some participants' role on the occasion and differences about the desired sequence of agenda items had been resolved, the Chaldedonian council's investigation started by the reading, first, of several letters written by the Emperor Theodosius II to summon and instruct the council of 449 CE. These letters outlined that council's main task and agenda, instructed various members about who should preside over the council's business; who was allowed, or even ordered, to participate in it; which bishops, by contrast, were to be excluded; and what the roles of certain imperial official were to be on the occasion.

The acts note that the secretary Constantine from the imperial offices (the 'di-

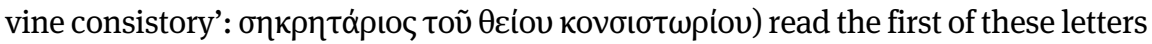

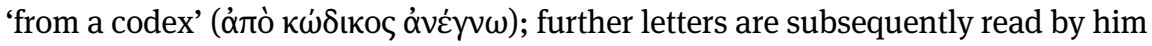




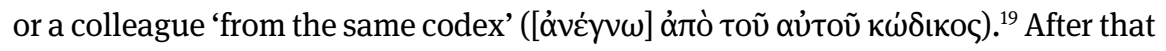
and at a crucial junction a significant change in the reading material is stated: A new document is introduced, and the acts inform us of its origin: Aetius, the Archdeacon of the Church of Constantinople hands this object over for reading to the same imperial secretary. ${ }^{20}$

This new document is called a schedarion ( $\sigma \chi \varepsilon \delta \alpha \dot{\rho} \rho \circ)$ ). ${ }^{21}$ It is introduced for the first time at the very beginning of readings from the Acts of Ephesus II themselves, and since the text read out aloud starts with the conventional opening elements of a conciliar minute-date and place of the meeting, imperial orders, attendance list ${ }^{22}$-we can be sure that the schedarion contains the Ephesine protocol from its very beginning. Whenever the reading of this (Ephesine) text was subsequently interrupted by discussion at Chalcedon, and later resumed, the acts note that the officers read, once more, 'from the same schedarion'. ${ }^{23}$

We thus have to consciously register the fact that the imperial letters and the Ephesine Acta were being read from two different textual objects, two different manuscripts. The imperial letters read at the beginning of the session were found in a 'codex' separate from the Ephesine acts. Yet the same letters were also contained in the acts of the council and were in fact read again later, at the places where they occurred in the sequence of these acts. ${ }^{24}$ The reading from a codex, hence, does not provide information which was not otherwise obtainable and must serve a different purpose.

19 CChalc. sess. I.23 (ACO II.1.1, 67.37); after that consistently repeated: CChalc. sess. 46 (ACO II.1.1, 70.38); 47 (71.18); 48 (72.1f.); 49 (731f.); 50 (73.19f.).

20 The significance of this observation, one can hypothesise, is in the suggestion that this new document is of ecclesiastical provenance, perhaps taken from the archives of the bishop of the capital.

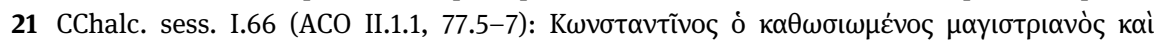

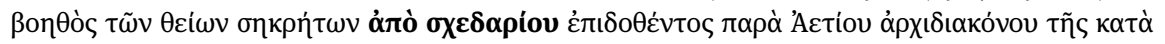

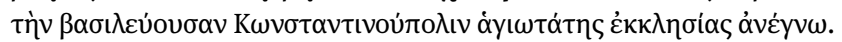

22 This is the required formal document head (protokollon) in late roman and byzantine documents generally, see Wenger 1953, 747, with reference to the relevant prescriptions in Justinian, Novella 47 (of 537 CE) postdating the council; and Dölger/Karayannopulos 1968, 49f., 51f. In later byzantine custom dating is usually transferred to the eschatokollon at the end of the document.

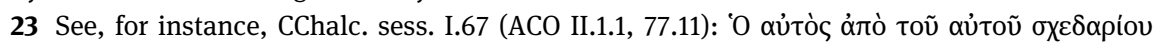

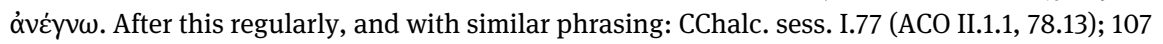
(85.6); 140 (88.32f.); 163 (92.4); 184 (94.23); 196 (97.15f.); 237 (103.3f.).

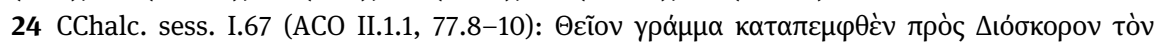

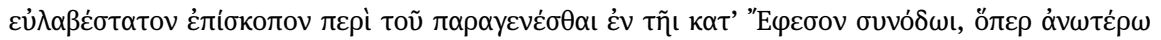

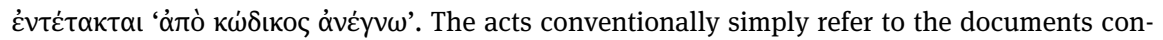
cerned in this abbreviated manner. They refer back to its previous reading and insertion in the minutes, rather than transcribing the text in full again. Whether this was an original feature of the acts or at what point in the text's transmission this happened is difficult to discern. The other 
A number of observations allow exploring the character and provenance of the codex further. Important indications come from the way in which the codex versions of the letters are represented. After a version of the letter of invitation addressed personally to Dioscorus of Alexandria, the designated chairman of the Ephesine council, had been read, the secretary was able to point out that other bishops had received letters of the same tenor. ${ }^{25}$ This information, we may surmise, was most probably provided from an annotation on the copy from which he read. Similarly, the reading of the emperor's instructions to the senior imperial representative Helpidius concludes with a note that a mandate of the same tenor was also issued to Eulogius, a junior colleague in his task. ${ }^{26}$ This time the note is undoubtedly part of the text read, not an explanatory remark by the secretary. ${ }^{27}$ And again, a note affirming that a letter of the same tenor was also sent to Juvenal of Jerusalem follows each of two further instructions addressed to Dioscorus of Alexandria, which specifically order the attendance of the monk Barsaumas-unusual in a council-and prohibit that of Bishop Theodoret of Cyrus. ${ }^{28}$ The letter to Helpidius lacks the salutation and the closing lines and the two letters mentioned last are also missing the closing lines. ${ }^{29}$ From these observations there remains little doubt that the codex resembled a kind of register of imperial letters and mandates. Summary remarks about additional addressees and documents in kind here substituted for the keeping of multiple, in all other elements identical, copies. ${ }^{30}$ It is the kind of summary that imperial secretaries would routinely keep

instances of repeated reading out aloud of the imperial letters are noted CChalc. sess. I.81 (ACO II.1.1, 82); 108 (85); 112 (86); 115 (86).

25 CChalc. sess. I.25 (ACO II.1.1, 69.9-11).

26 CChalc. sess. I.49 (ACO II.1.1, 72.31).

27 This may be inferred from the absence of any remark in the minutes indicating that the reading officer provided this information, as had been the case at I.25 (see above note 25).

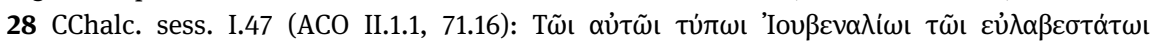

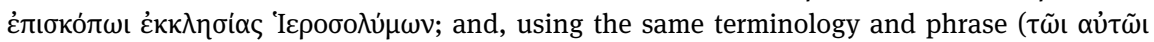
$\tau \cup \dot{\pi} \omega \mathrm{l}$ ) again I.52 (ACO II.1.1, 74.29f.).

29 Imperial letters cited at CChalc. sess. I.49; I.52 and I.47 (see previous notes). The classifications and descriptions of later byzantine documents frequently observe the missing of protocols and eschatocols as a typical feature of registry copies preserved in the sender's archive; see Dölger/Karayannopulos 1968, 133 f.

30 Two letters are retained (at CChalc. sess. I.49 and 50 of the minutes), which give a fascinating insight into the drafting of such letters and the use of stock phrases. The mandate to Helpidius, outlining his responsibilities, and the letter to Proclus the proconsul of Asia, informing him of Helpidius' task and decreeing provision of any assistance necessary to him, share in common a first paragraph, in which the general purpose and reason for the calling of the council are briefly stated: it is word for word identical. Only when the distinct tasks are mandated, does the drafting go separate ways. 
for future reference. ${ }^{31}$ Such a registry copy would most probably have been produced in the imperial consistory where the originals had been issued, and kept there. This hypothesis seems to be further supported by the observation that a clerk of the imperial consistory handled the copy from which reading pursued..$^{32}$ The codex from which reading was conducted, therefore, was an archival copybook of imperial letters.

Our reconstruction thus appears to establish the existence of an imperial archive in which to produce and keep a register of imperial letters. Yet, the difficulties encountered in compiling the Theodosian Code only some two decades before (the assemblage of the Code was ordered in 429 and its publication happened in 438), the fact that the compilers had to travel the provinces and explore obscure libraries and private collections, it is argued by some scholars, militates against the notion of a central archive. ${ }^{33}$ The circumstances for the compilation of the Code, however, differ greatly from those here in view. Whereas the compilers sought out legislation spanning a century and from a time when the court was still mainly itinerant, the secretaries here only needed recourse to texts produced two years ago, and relating to events intimately connected to the current case. No

31 Writing in the reign of Justinian, John Lydus reports of what he describes as ancient practice in cases of law, by which secretaries would keep a synopsis of the main import of a decision to prevent later addition or subtraction; De magistratibus rei publicae Romanae 3.11.2 (Dubu-

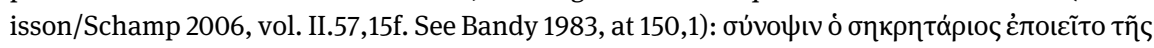

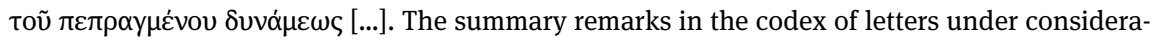
tion betray a similar mode of operation in the imperial offices. By adding information about additional addressees of equivalent messages and excising what must be standard opening and closing formulae, the officers generate a kind of 'register' of imperial letters.

32 CChalc. sess. I.23 (ACO II.1.1, 67.34-36). The 'secretary of the divine consistory' informs the council's chairman that he has these documents 'to hand' and is ready to read them out. Since in other cases it is pointed out in the minutes when documents had been received from a different person or source, we may surmise that these letters were in fact available to him in his office or the respective branch of the imperial administration and were very likely sourced there in preparation of the meeting and on the orders of the meeting's imperial chairmen. The case may therefore be analogous to the provision of documents from the imperial scrinia on another occasion the year before (see below 289), even though no repository is explicitly mentioned.

33 For the vexed questions of the origin of texts included in the Theodosian Code, see the discussion in Honoré 1998, 136-142; Matthews 2000. Sirks 2007, esp. 109-127, considers a central source in the capital Constantinople the most plausible origin of (most) texts (141). This seems to be the case, by and large, for pronouncements emanating from the eastern court and starting approximately in the year 398 (Honoré 1998, 139f.), whereas earlier laws, it seems, might well have been retrieved from provincial archives and even private libraries. On the limitations and partial absence of a sophisticated systems of document retrieval in general, see also Kelly 2004, esp. 117-120. 
big central archive is necessary for our hypothesis. A much smaller collection or depository with only a narrow thematic focus-we could exempli gratia call them ecclesiastical affairs-and chronological span would suffice to assure the existence of a register of imperial pronouncements and constitutions pertinent to this context. There is no strong case against some archival depository that kept a register of the letters written by Theodosius II for the organisation of the council. It is even conceivable that the difficulties encountered earlier in his reign by the compilers of the Law Code motivated an improvement in imperial record keeping.

In the event, all letters concerned made another appearance in the Ephesine Acts and were during the same session at Chalcedon subsequently read again from the schedarion that also contained them. The procedural logic and purpose of the initial reading in Chalcedon 'from a codex' is by now already apparent. The procedure assured, and demonstrated to all concerned, that for its cognizance of the original invitations and instructions issued to the council and to various individuals by the Emperor Theodosius II, the Council of Chalcedon did not simply rely on the Ephesine Acts, which contained them. It employed, rather, a text independent of these acts-a text whose character and provenance, moreover, were identifiable by its appearance in the codex-form as a government copy; its authority was thus underlined. Theodosius' instructions, in other words, were read from the source of origin-that is: Theodosius' government offices-rather than from a version attested by the recipient-in theory, and depending on the individual letters: specific council members, or individual bishops, or the government officials addressed by Theodosius in each case, but in reality by the acts of Ephesus II which assembled all of them. They were read before the acts of the council (where the same letters and mandates appear again), so that the adherence to the original instructions could be tested.

The procedure, in this part of the proceedings, thus rests on the record-keeping of the imperial offices, not an ecclesiastical repository. Because the documents were originally produced just a couple of years earlier, we may question whether they should be considered archival in the strict sense. For the Emperor Theodosius II, the case was closed with the judgement passed by the Ephesine Council of $449 \mathrm{CE}$, and so it is not unreasonable to presume that the pertaining instructions for that event were no longer handled as a 'live' case file, but archived. When after his death the new Emperor Marcian called a new council, the matter again turned into a present concern, and the documents were retrieved for the occasion. On this evidence, the imperial archival practices functioned smoothly on the occasion. 


\section{The conciliar files}

The understanding of the second object from which reading progresses, the schedarion of the ephesine acts, presents a greater difficulty. First of all, the contrast between this manuscript and the codex used before implies that the schedarion is not a codex. Had it been a codex as well, the acts would have needed to mark the contrast by a note amounting to something like 'he read from a different codex'. The note that the reading took place from a codex would not otherwise sufficiently distinguish the two objects.

What kind of a document are we faced with, and what can we ascertain about its storage? At least three further texts handled in the wider context of the Eutychian affair and the councils of Ephesus and Chalcedon are also identified in each case as a schedarion. One is the transcript of the first inquiry into Eutyches' trial held on 8 April 449. This schedarion, we are able to place in an archive: it was fetched for reading, just five days later on 13 April from the 'divine office of

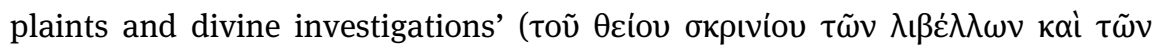

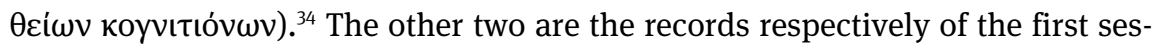
sion (8 October) of the Chalcedonian Council that was read in the fourth session of the same council on 17 October, 9 days later; ${ }^{35}$ and a separate one of the second session held on 10 October and read out on the same occasion, seven days later. Schedaria, thus are records of proceedings, the precise status and format of which needs yet to be determined. In each case the intervals between meetings and the drawing up and re-reading of records are very short; we should not speak of 'archival' retrieval of records in these cases. ${ }^{36}$ Another example, however, employed in a later session, shows that such a schedarion could be kept for a longer duration. In the fourteenth session (31 October) that deals with contested episcopal claims to the bishopric in Perrha (in the Province Syria Euphratensis), ${ }^{37}$ a sche-

34 CChalc. sess. I.557 (ACO II.1.1, 149.29f.); for the date see I.556 (149.21f.).

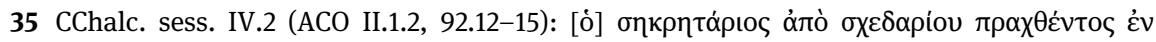

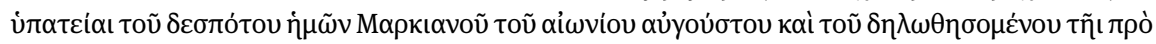

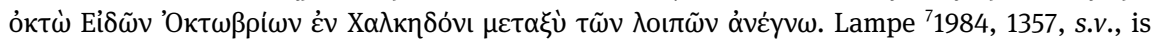
surely missing the point when he subsumes this passage to the meaning of '(any) short document' (see below).

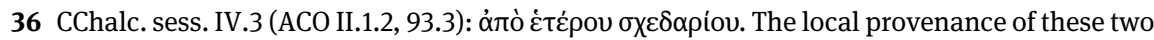
schedaria is not specified, but we may infer that a conciliar 'bureau' was preparing and handling these records of meetings conducted only a few days previously.

37 See Schieffer 1984, 248f. s.v. Perrha. 
darion is brought of a synod hearing the case in Antioch in 445 CE. This document, too, provides a transcript of the meeting, but is significantly curtailed in that it misses all relevant documents. ${ }^{38}$ Importantly a physical defect of the object at the beginning is observed and noted in the Chalcedonian acts. ${ }^{39}$ Over the course of six years since the original hearing, the file had suffered unspecified damage or decay, perhaps of the kind that may be associated with archival storage in unsuited conditions such as damp or that is caused by insect larvae.

The meaning of the word schedarion given in conventional late antique-byzantine (and modern) lexica is either that of a draft, or (because of the diminutive) that of any short document. ${ }^{40}$ The length of the ephesine acts precludes the latter understanding. It seems equally problematic to understand the schedarion read aloud during the session as a draft ${ }^{41}$-at least without further qualification. After all, the intense scrutiny afforded to the acts would seem to make an unfinished and preliminary textual instantiation unsuited for the purpose.

Of the very few occurrences of the term in Greek literature-apart from very late byzantine sources-a highly technical, and somewhat obscure passage in John

38 The effects of the file's state for the conduct and outcome of the case require separate examination (forthcoming).

39 CChalc. sess. XIV.14 (in the Greek enumeration of sessions retained by Schwartz, this is the

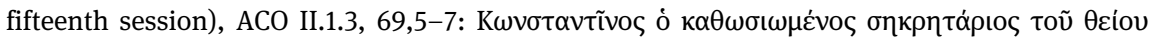

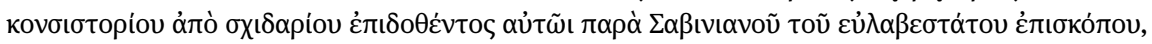

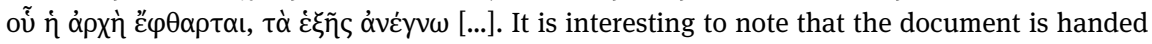
over by the present bishop of Perrhe, Sabinianus. Does this suggest that the document was kept in his episcopal library or archive, rather than that of Antioch, where the hearing had been conducted?

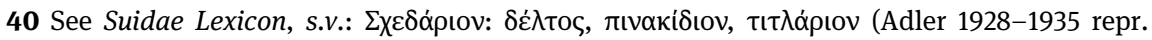

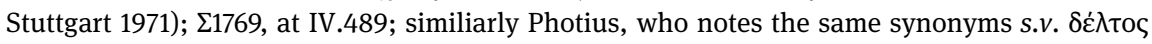
(Theodoridis vol. $1(A-\Delta)$ 1982) $\Delta$ 170, p. 387. See Liddell/Scott/Jones 1996, 1743 s.v.; Passow 1970, vol. II.2, col. 1789 s.v.; Lampe ${ }^{7} 1984,1357$ s.v. See however Stephanus ${ }^{3} 1831-1865$ (repr. 1954), VIII, 1645 where the approximate equivalence with the Latin scheda is already appropriately noted.

41 The acts differ markedly from other examples of ancient usage, where the draft-character of the documents is apparent. A papyrus from Oxyrhynchos, P.Princ. 296, dated to either 551-2 or 556-7

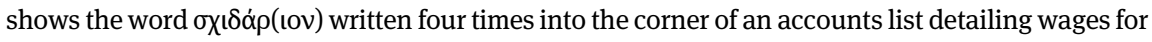
various people; this is clearly a 'draft' in the full sense of the word; see Harrauer/Sijpesteijn 1986, 115-116; and the database http://papyri.info/ddbdp/p.princ;2;96 (last accessed: 01/03/2017). The papyrus P.Oxy 24. 2416, dated to before 566, (see http://papyri.info/ddbdp/p.oxy;24;2416) that concerns an inheritance, and whose regulations may indeed be of a preliminary character, is the only other instance of the word on papyrus contained in the database. In private law suits a draft resolution could be presented to the judge by the parties, which might then be accepted or modified for his decision. 
Lydus $^{42}$ (De magistratibus rei publicae Romanae) that describes the issuing of court documents in pre-Justinian times may shed light on the usage of the term in the acts. The schedarion finds its proper place in the elaborate bureaucratic choreography that ensured the proper handling and safeguarding of the documentary records of law cases and the formal steps and requirements for their authorisation; it is what is in Latin called the recensum, that version of text, which is authorised for the subsequent production of an issuable copy to the relevant parties. ${ }^{43}$ The passage distinguishes a recensum (a 'collacted copy') from earlier textual stages; this is then handed to the magistrate for signing and thus turns into a katharon (a genuine, fine, copy)-it is important to note that this still is the same physical object-, which is read carefully once more by the secretaries before it is subsequently issued to the 'litigator' and allowed to leave the offices. We may take from John Lydus' description the emphasis on the need for administrative authentication of documents and the character of the schedarion as both original and provisional: original in presenting the record in the form that becomes, through the officer's signature, the right and proper record (katharon); provisional in that further steps are still required for its issue and release outside the office. ${ }^{44}$ The schedarion thus retains the connotation of 'not-the-last' step in the sequence of textual practices set in motion by the recording of discussion. It is still awaiting publication. That the missing formal publication-which only happened if there was cause for it $^{45}$ - did not invalidate the original and authentic status of the document may be inferred from the appellation

42 For a very brief introduction see Maas 1992; the best interpretation of the work in a historical perspective, and for our understanding of the bureaucratic procedures, is Kelly 2004, see especially $18-63$.

43 Johannes Lydus, Mag. 3.11-12 (II.56-59 Dubuisson/Schamp 2006; see 148-152 Bandy 1983);

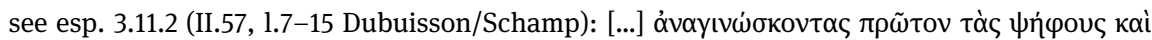

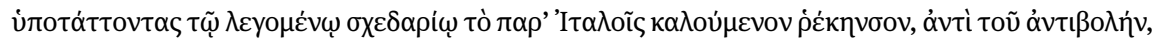

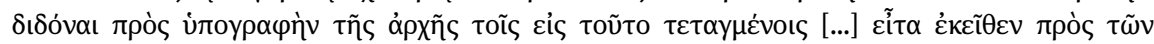

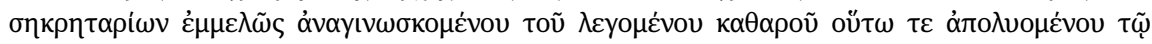
$\lambda ı$

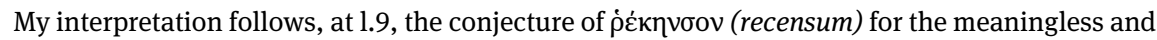
corrupted $\rho \varepsilon \kappa ı v o v$ in the manuscripts (for which see Bandy 1983, 149.21 with app. ad locum and commentary ibid. 307), also accepted by the most recent editors Dubuisson/Schamp 2006, see app. ad locum and, with discussion, 'notes complémentaires' $157 f$.

44 In an analysis of the Carthaginian protocols, Tengström 1962, had concluded-largely based on internal evidence - that the scheda mentioned there must denote the original record of the minutes (p. 40: [das] 'nicht reingeschriebene Originalprotokoll' or 'Grundoriginal'). See Wenger $1953,746,750$.

45 See Wenger 1953, 313, 751ff., and index s.v. For the slow and very limited circulation of information and documents from the councils of Ephesus and Chalcedon in the West, see Wyrwa 1997, 147-189, esp. 148-158. 
given to the trial record in the case of Eutyches. In a short narrative description of the process of comparative reading employed there, the document produced by Aetius is emphatically called the authenticon schedarion, ${ }^{46}$ emphasising in this way the originality of the document over its provisionality. The Council of Chalcedon, then, and the imperial commission before it, both, and on separate occasions, took cognizance specifically and purposefully of an original document. The safekeeping of such documents was therefore of primary importance and archival habits must have been operative in both imperial and ecclesiastical offices to underpin this way of proceeding. ${ }^{47}$

What, if anything, may be inferred for the keeping of the original document of transactions from the Council of Ephesus? If the schedarion read at Chalcedon consisted of the original record of the Ephesine Council, where had it been kept in the intervening two years? Is the fact that the Constantinopolitan Archdeacon Aetius hands it over for reading in any way relevant to this question? The same archdeacon had already been tasked to produce the original trial record against Eutyches at the inquiry of 13 April 449. ${ }^{48}$ That trial record appears to have been in the archdeacon's possession, because of his very close personal connection to it. He had directly overseen both the minuting and the editorial assemblage of the record. It would not be a surprise, then, if his duties also extended to the safekeeping of the documents in whose making he had been instrumental. Yet in a later statement before the imperial commission, Aetius claimed that all his notes and texts had been

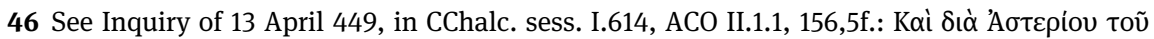

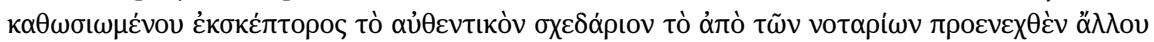

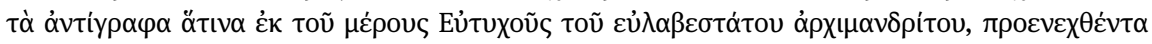
бчүкріvovтоৎ $\alpha v \varepsilon \gamma v \omega \dot{\sigma} \sigma \theta \eta \sigma \alpha v$. It is essential to this process, that the record read by Asterius should be the original and authentic one.

47 This use of original documents is significant. In the case of Eutyches, officially issued copies were available. After all his attorneys brought their complaint on the basis of such a copy issued to him. In the case of Ephesus II, the availability of an authorized version is at least likely. Pope Leo, it seems, had the opportunity to have a Latin translation prepared before the Council of Chalcedon, contained in the Collectio Novarensis de re Eutychis, ed. Schwartz 1932. And even Nestorius, in exile in the Egyptian oasis, relates events from the meetings that seem to presuppose knowledge of the acts; see Nau et al. 1910), in particular at Hercl. II 2 (473ff. Bedjan; see 302ff. Nau). The conflation of seemingly precise references to events mentioned in the acts and other narrative features of his writing about the council that bear no resemblance with these acts requires further examination.

48 Inquiry into the minutes of the Resident Synod, held on 13 April 449, cited CChalc. sess. I.580-596, ACO II.1.1, $153 \mathrm{f}$. 
taken away two or three month prior to the inquiry. ${ }^{49}$ So the record moved from being held by an ecclesiastical officer-whether in a personal capacity and 'private' storage facility or in an official archive attached to and hosted by the episcopal offices is impossible to say-to become part of a case-file of the government inquiry. When the investigation took place, other records were brought from the imperial scrinium. ${ }^{50}$ Where the actual schedarion of the trial against Eutyches was obtained is not specified in the minutes of the inquiry. That Aetius was requested to make it 'public', then, need not be an indication of the distinct place of archival safekeeping, be it in the episcopal archive for which he worked or be it in his private storage-after all he had claimed that papers had been taken away from him. Rather it more probably served as a symbolic act to demonstrate the ecclesiastical character and provenance of the document concerned as well as asserting his personal responsibility in drawing it up. In the particular instance, all documents 'travelled' only between different people and places within the city of Constantinople. In the case of the acts from the Council of Ephesus the matter is more complex. Here, too, Aetius hands over the schedarion for reading in the Chalcedonian Council. If we wanted to read the Constantinopolitan archdeacon's ability to hand over the text as an indication of its physical location prior to being brought to Chalcedon-just across the straights of the Bosporus-we needed to explain how it could have got to Constantinople and the episcopal offices in the first place. The Carthaginian Conference had its protocol stored in the provincial archive. On that model, the Ephesine acts ought to have been stored in Ephesus. But at Chalcedon Bishop Stephen of Ephesus insisted that he had not received a copy of the minutes. ${ }^{51}$ Taken strictly this statement relates only to the period between the close of the session and the signing of the decision, and does not rule out the later storage in a public provincial archive there. To understand his firm denial we have to take into account, additionally, his intention to exculpate himself from any involvement in Dioscorus' alleged

49 I.827, ACO II.1.1, 176. The person who took Aetius' papers was one Asterius, called in this context a fellow presbyter and notary. Interestingly the person reading at the inquiry is also called Asterius, holding the office of exceptor, evidently in the imperial administration and most probably associated with the head of the inquiry, the patrician Florentius. The same name could be pure coincidence, or might Asterius have served, on different occasions or moving from one position to another over time, both the ecclesiastical and the imperial administration?

50 Inquiry of 13 April 449 (see n. 48 above), in CChalc. sess. I.557, ACO II.1.1, 149.29: [...]

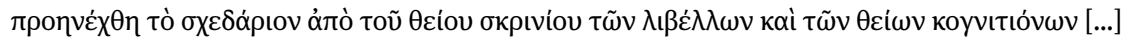

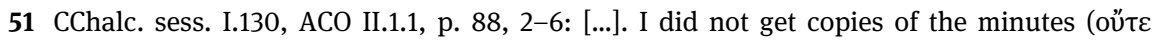

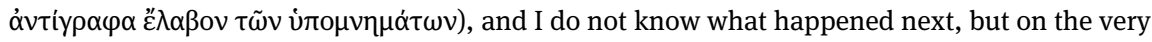

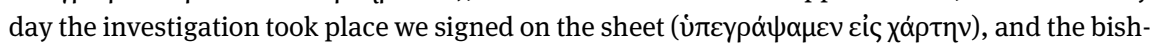
ops who had not signed it did so under my guarantee on the following day. 
machinations at Ephesus. Even so his protestations make the hypothesis of Ephesus as the location of the storage of original acts less likely. Alternatively, and because all the record-keeping in Ephesus had been carried out by Alexandrian clergy from the staff of the council's chairman, Bishop Dioscorus of Alexandria, we might assume that responsibility for the raw-original remained with them, and the document travelled to Alexandria with them to be stored there. Yet it is decisively not by an Alexandrian clergyman but by one from Constantinople that the document is being produced at Chalcedon. Any hypothesis that immediately after the Ephesine Council the acts might have gone directly to the episcopal offices in Constantinople has little plausibility because of the deposition of its bishop on the occasion; the relationship was hostile. However, if the indirect evidence of a Latin translation and the knowledge of events gleaned from Nestorius' narrative point to an official, imperially endorsed and arranged 'publication', the raw-original would likely have been used to this end in a branch of the imperial administration and subsequently kept in an archive associated with it. This seems, to me, to be the most plausible explanation for a Constantinopolitan provenance of the documents put before the Chalcedonian council. Yet even if (in what is perhaps a less probable hypothesis) original acts were initially kept in an ecclesiastical and not an imperial archivewhether in Ephesus or, more likely, in Alexandria-, in order to be available in Chalcedon in 451 they needed to be seized by imperial officials prior to and in preparation for the council. In either hypothetical scenario the original schedarion ends up in imperial safekeeping, and therefore most probably in an imperial archive, from which it was subsequently taken to Chalcedon for transaction.

In this respect, the handover performed by a Constantinopolitan cleric-once again-does not so much provide evidence of the document's specific archival provenance; it is rather full of symbolic resonance. The Alexandrian bishop Dioscorus had been responsible for the deposition of the then bishop of Constantinople-Flavian, the predecessor of the current incumbent-in Ephesus; now he was under a cloud of accusations himself, and so the prominent role of a Constantinopolitan clergyman in presenting and handing-over the decisive document, on which he was going to be judged, neatly illustrated the reversal of fortunes.

All potential scenarios for the keeping of the document have to remain hypothetical; our limited evidence does not support a firm conclusion. What should have become apparent, nevertheless, is that by the middle of the fifth century, a complex bureaucratic operation was underway in regulating church affairs and huge amounts of paperwork were being produced in the process. There was an acute sense of the need to work with authoritative documents, and their status was inferred not least from physical features of the manuscripts in question. The need 
for handling original documents in subsequent efforts of adjudication also required arrangements for storage and safekeeping.

Bishops at important major sees such as Constantinople, Antioch and Alexandria lead, and were supported by, substantial administrative operations; these included infrastructure and practices of storing and retrieving important documents in a way that must have been similar to imperial administrative habits. The files of the case of Eutyches originally heard in Constantinople, those of the Second Ephesine Council-and also the one, only briefly mentioned, ${ }^{52}$ produced by a synod in Antioch in 445 and brought to Chalcedon in an already damaged state-are examples for archival habits presumably more widespread in the church. Incidentally, the damaged Antiochene file also illustrates the ever-present difficulties in protecting stored documents from damage and loss that any archive faces.

We note, first of all, that in the sequence of events documents and entire sets of acts were passed on between different bodies: on the one hand meetings chiefly of churchmen (synods or councils) and on the other hearings held under the auspices of high government officials or administrators authorised to conduct inquiries by the emperor. In each case the file of a previous meeting (or set of meetings) was produced for reading and in this way entered the new proceedings. The revisiting of texts also resulted in the movement of the physical objects between the relevant branches: so the ecclesiastical acts of a Constantinopolitan Resident Synod came to form part of an imperial case-file when a commission undertook to inquire into their propriety. This file was brought forth for reading on a subsequent occasion from the scrinia of the law branch of the central imperial administration..$^{53}$ Later it re-entered the ecclesiastical sphere when the records were read once more in a meeting of bishops, this time the imperial synod convened at Ephesus. Probability suggests that the file was physically passed on into the safekeeping of the church as would have been the norm in civil law cases, but theoretically a copy could also have been made and included in the acts of the synod, while the previous-original-file was returned to its hypothetical place of storage in the imperial offices. What is important to note is the crossover between imperial and church bodies handling the same physical objects, and with it, we may surmise, the crossover between the employ of storage facilities belonging to either organisation. What the specific archival arrangements, internal to the ecclesiastical or imperial bureaucracies and their physical, even spatial configurations looked like in each case, our sources do not reveal. In particular whether administrative habits and the underly-

52 See above 285 with n. 39.

53 See above n. 50. 
ing infrastructure showed any distinction between libraries and archives is impossible to garner from the cases in view in this paper. At least this must be said where the church is concerned; the imperial administrative archives-in contrast-must surely be considered discrete, physically and in inspiration, from any literary ambition and artistic context, whatever their architectural reality. ${ }^{54}$

The cases here in view do show, however, that no strict separation of church and state archives and archival habits can always be expected in practice, while at the same time the handling of documents provided ways to express symbolically the primary 'affiliation' of a document. The involvement of churchmen and imperial officers respectively in acts of handling and reading allowed showcasing 'where' the document ultimately belonged and 'whence' it originated and derived its principal authority: from the church or the imperial administration. The distinction was important but so was the close collaboration and indeed intersection between the two spheres and their administrative operations. At least in the contexts of imperial Church councils, not the distinction of separate spheres of authority but the collaboration between them translated readily into bureaucratic and archival practices. Textual production, handling, and storage mirrored closely the ideological and organisational intertwining of the late antique Roman Church and Empire. And so church acts will have been found frequently in 'public' archives associated with the imperial administration at various levels-be it one of the central government branches or be it a provincial or local office-and the fate of church acta also illustrates imperial archival practices.

\section{References}

Acta Conciliorum Oecumenicorum (=ACO), iussu atque mandato Societatis Scientiarum Argentoratensis ed. Eduardus Schwartz [Ser. 1], Tomus Alter: Concilium universale Chalcedonense: Berlin 1932-1938.

Adler, Ada (1928-1935), Suidae lexicon, 4 vols [Lexicographi Graeci 1.1-1.4.], Leipzig: Teubner, repr. Stuttgart 1971.

Bandy, Anastasius C. (ed.) (1983), loannes Lydus On Powers, or The Magistracies of the Roman State, introduction, critical text, translation, commentary, and indices (Memoirs of the American Philosophical Society, 149), Philadelphia: American Philosophical Society.

Brennecke, Hanns Christof, Uta Heil, Annette von Stockhausen and Angelika Wintjes (eds) (2012), Athanasius Werke III/1: Dokumente zur Geschichte des Arianischen Streites herausgegeben

54 For the situation of Constantinopolitan archives in the sub-structure of the Hippodrome, see Kelly 1996, 161-176. 
im Auftrag der Berlin-Brandenburgischen Akademie der Wissenschaften. Lfg. 3: Bis zur Ekthesis Makrostichos, Berlin, New York: De Gruyter.

Brennecke, Hanns Christof, Annette von Stockhausen, Uta Heil and Angelika Wintjes (eds) (2014), Athanasius Werke III/1: Dokumente zur Geschichte des Arianischen Streites herausgegeben im Auftrag der Berlin-Brandenburgischen Akademie der Wissenschaften. Lfg. 4: Bis zur Synode von Alexandrien 362, Berlin, Boston: De Gruyter.

Canellis, Aline (ed.) (2003), Jérôme, Débat entre un luciférien et un orthodoxe = Altercatio Luciferiani et Orthodoxi, introduction, texte critique, traduction, notes et index (Sources Chrétiennes 473), Paris: Les Éditions du Cerf.

Collectio Novarensis de re Eutychis, ed. Eduard Schwartz, ACO (= Acta Conciliorum Oecumenicorum) II.2.1, Berlin, Leipzig 1932.

Dölger, Franz, and Johannes Karayannopulos (1968), Byzantinische Urkundenlehre. Erster Abschnitt. Die Kaiserurkunden (Byzantinisches Handbuch III.1.1 = Handbuch der Altertumswissenschaften, 12. Abt., 3. Teil, 1. Bd., 1. Abschnitt), Munich: C.H. Becksche Verlagsbuchhandlung.

Dubuisson, Michel, and Jacques Schamp (eds) (2006), Jean le Lydien, Des magistratures de l'état romain, texte établi, traduit et commenté, 2 vols (Collection des universités de France, série grecque 450. 452), Paris: Belles lettres.

Fraisse-Coué, Christiane (1995), 'Le débat théologique au temps de Théodose Il.: Nestorius', in Charles( $(t)$ and Luce Pietri (eds), Histoire du Christianisme: des origines à nos jours, vol. II: Naissance d'une chrétienté (250-430), Paris: Desclée, 499-550.

Fraisse-Coué, Christiane (1998), 'D'Éphèse à Chalcédoine: “la paix trompeuse” (433-451)', in Luce Pietri (ed.), Histoire du Christianisme: des origines à nos jours vol. III: Les Églises d'Orient et d'Occident (432-610), Paris, Desclée, 9-77.

Frend, William H.C. (1952), The Donatist Church: A Movement of Protest in Roman North Africa, Oxford: Clarendon Press.

Geerard, Maurice (1980), Clavis Patrum Graecorum, Vol. IV: Concilia. Catenae, Turnhout: Brepols. Gelzer, Heinrich (1907), 'Die Konzilien als Reichsparlamente', in Ausgewählte Kleine Schriften, Leipzig: Teubner, 142-155 (first printed in: Deutsche Stimmen (1900) no. 14).

Girardet, Klaus Martin (1975), Kaisergericht und Bischofsgericht. Studien zu den Anfängen des Donatistenstreites (313-315) und zum Prozeß des Athanasius von Alexandrien (328-346), Bonn: Habelt.

Grasmück, Ernst Ludwig (1964), Coercitio. Staat und Kirche im Donatistenstreit (Bonner Historische Forschungen, 22), Bonn: L. Röhrscheid.

Graumann, Thomas (2011), 'Upstanding Donatists: Symbolic communication at the Conference of Carthage (411)', in Zeitschrift für antikes Christentum, 15, 329-355.

Graumann, Thomas (2017a), 'Synodale Praxis und administratives Handeln in der spätantiken Kirche: Einige Schlaglichter', in Peter Gemeinhardt (ed.), Was ist Kirche in der Spätantike? Publikation der Tagung der Patristischen Arbeitsgemeinschaft in Duderstadt und Göttingen (02.05.01.2015) (Patristic Studies, 14), Leuven: Peeters, 117-143.

Graumann, Thomas (2017b), 'Theologische Diskussion und Entscheidung auf Synoden: Verfahrensformen und -erwartungen', in Uta Heil and Annette von Stockhausen (eds), Die Synoden im trinitarischen Streit / The Synods in the Trinitarian Dispute (Texte und Untersuchungen zur Geschichte der altchristlichen Literatur, 177), Berlin: De Gruyter, 51-81.

Hajjar, Joseph (1962), Le synode permanent dans l'Église byzantine des origines au Xle siècle (Orientalia Christiana Analecta 164), Rome: Pont. Institutum Orientalium Studiorum.

Harrauer, Hermann, and Pieter J. Sijpesteijn (1986), 'P.Princeton II 96 und Schreibübungen', in Zeitschrift für Papyrologie und Epigraphik, 64, 115-116. 
Hefele, Carl Joseph, and Henri Leclerq (1908), Histoire des Conciles d'après les documents originaux, vol. Il.1, Paris: Letouzey et Ané.

Hilberg, Isidorus (ed.) (1918), Sancti Eusebii Hieronymi Epistulae. Pars III: Epistulae CXXI-CLIV (Corpus Scriptorum Ecclesiasticorum Latinorum, 56), Vienna: F. Tempsky/Leipzig: G. Freytag.

Honoré, Tony (1998), Law in the Crisis of Empire 379-455 AD: The Theodosian Dynasty and its Quaestors, Oxford: Oxford University Press.

Humfress, Caroline (2013), 'Court (ecclesiastical)', in The Encyclopedia of Ancient History, Oxford: Blackwell, 1817-1818.

Kelly, Christopher (1996), 'Later Roman bureaucracy: Going through the files', in Alan K. Bowman and Greg Woolf (eds), Literacy and Power in the Ancient World, Cambridge: Cambridge University Press, 161-176.

Kelly, Christopher (2004), Ruling the Later Roman Empire, (Revealing antiquity 15), Cambridge/ Mass.: Belknap Press of Harvard University Press.

Kidd, Beresford James (1922), A History of the Church to AD 461, 3 vols, Oxford: Clarendon Press.

Kriegbaum, Bernhard (1986), Kirche der Traditoren oder Kirche der Märtyrer. Die Vorgeschichte des Donatismus, Innsbruck: Tyrolia-Verlag.

Lampe, Geoffrey William Hugo ('1984), A Patristic Greek Lexicon, Oxford: Clarendon Press.

Lancel, Serge (1972-1991), Actes de la conférence de Carthage en 411, 4 vols (Sources Chrétiennes, 194, 195, 224, 373), Paris: Les Éditions du Cerf.

Lancel, Serge (2002), St. Augustine, transl. by A. Nevill, London: SCM Press (French original: Paris: Librairie Arthème Fayard 1999).

Lancel, Serge, and James S. Alexander (1996-2002), 'Donatistae', in Augustinus-Lexikon, vol. 2, Basel: Schwabe.

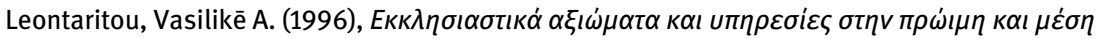

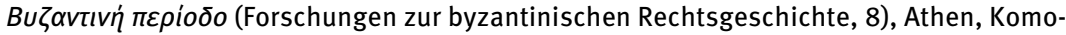
tene: Sakkulas.

Liddell, Henry George, Robert Scott, and Henry Stuart Jones (eds) (1996), A Greek-English Lexicon. Ninth Edition with Revised Supplement, Oxford: Clarendon Press.

Maas, Michael (1992), John Lydus and the Roman Past. Antiquarianism and Politics in the Age of Justinian, London, New York: Routledge.

Matthews, John F. (2000), Laying Down the Law: A Study of the Theodosian Code, New Haven: Yale University Press.

May, Gerhard (1989), 'Das Lehrverfahren gegen Eutyches im November des Jahres 448. Zur Vorgeschichte des Konzils von Chalkedon', in Annuarium historiae conciliorum, 21, 1-61.

Millar, Fergus (2006), A Greek Roman Empire: Power and Belief under Theodosius II (408-450), Berkeley CA, London: University of California Press.

Nau, François avec le concours de R.P. Bedjan et de M. Brière (transl.) (1910), Le livre d'Héraclide de Damas, Paris: Letouzey et Ané.

Opitz, Hans-Georg (ed.) (1934), Athanasius Werke III/1: Dokumente zur Geschichte des Arianischen Streites herausgegeben im Auftrag der Berlin-Brandenburgischen Akademie der Wissenschaften. Lfg. 1-2: Urkunden zur Geschichte des Arianischen Streites 318-328, Berlin (repr. Berlin: De Gruyter 2012).

Papadakis, Aristeides (1991), 'Endemousa Synodos', in Alexander P. Kazhdan et al. (eds), The Oxford Dictionary of Byzantium, 3 vols, Oxford: Oxford University Press.

Passow, Franz (1970), Handwörterbuch der griechischen Sprache (repr. of the 5th edition Leipzig 1857), Darmstadt: Wissenschaftliche Buchgesellschaft. 
Perrone, Lorenzo (1993), 'Da Nicea (325) a Calcedonia (451)', in Giuseppe Alberigo (ed.), Storia dei concili ecumenici, 2a ed. aggiornata, Brescia: Queriniana, 11-118.

Price, Richard, and Michael Gaddis (2005), The Acts of the Council of Chalcedon (Translated Texts for Historians 45), 3 vols, Liverpool: Liverpool University Press.

Schieffer, Rudolf (1984), Index generalis tomorum I-IIII, pars tertia: Index topographicus, (=Acta Conciliorum Oecumenicorum, ed. Eduard Schwartz et al., vol. IV.3.3), Berlin: De Gruyter.

Schindler, Alfred (1977), 'Afrika I', in Theologische Realenzyklopädie, 1, 648-700.

Schwartz, Eduard (1929), 'Der Prozeß des Eutyches' (Sitzungsberichte der Bayerischen Akademie der Wissenschaften. Philosophisch-Historische Klasse, 5), Munich: Verlag der Bayerischen Akademie der Wissenschaften.

Selb, Walter (1967), 'Episcopalis audientia von der Zeit Konstantins bis zur Novelle XXXV Valentinians III', in Zeitschrift der Savigny-Stiftung für Rechtsgeschichte: Romanistische Abteilung, 84, 162-217.

Sirks, A.J. Boudewijn (2007), The Theodosian Code: A Study (Studia Amstelodamensia. Studies in Ancient Law and Societies, 39), Friedrichsdorf: Editions Tortuga.

Sirks, A.J. Boudewijn (2013), 'The episcopalis audientia in Late Antiquity', in Droit et cultures, 65, 79-88.

Steinwenter, Artur (1934), 'Der antike kirchliche Rechtsgang und seine Quellen', in Zeitschrift der Savigny-Stiftung für Rechtsgeschichte: Kanonistische Abteilung, 23, 1-116.

Steinwenter, Artur (1950), 'Audientia episcopalis', in Reallexikon für Antike und Christentum, 1, 915-917.

Stephanides, Basileios (1936), 'Die geschichtliche Entwicklung der Synoden des Patriarchats von Konstantinopel', in Zeitschrift für Kirchengeschichte, 55, 127-157.

Stephanus, Henricus ( $\left.{ }^{3} 1831-1865\right)$, Thesaurus Graecae Linguae, 9 vols, Paris, repr. Graz: Akademische Druck- und Verlagsanstalt 1954.

Tengström, Emin (1962), Die Protokollierung der Collatio Carthaginensis. Beiträge zur Kenntnis der römischen Kurzschrift nebst einem Exkurs über das Wort scheda (schedula) (Studia Graeca et Latina Gothoburgensia, 14), Göteborg: Acta Universitatis Gothoburgensis.

Theodoridis, Christos (ed.) (1982-2013), Photii patriarchae lexicon, 3 vols, Berlin, New York: De Gruyter. Weckwerth, Andreas (2013), Clavis Conciliorum Occidentalium septem prioribus saeculis celebratorum (Corpus Christianorum Claves - Subsidia, 3), Turnhout: Brepols.

Wenger, Leopold (1953), Die Quellen des römischen Rechts (Österreichische Akademie die Wissenschaften. Denkschriften der Gesamtakademie, 2), Vienna: Adolf Holzhausen.

Wyrwa, Dietmar (1997), 'Drei Etappen der Rezeptionsgeschichte des Konzils von Chalkedon im Westen', in Johannes van Oort and Johannes Roldanus (eds), Chalkedon: Geschichte und Aktualität. Studien zur Rezeption der christologischen Formel von Chalkedon (Studien der Patristischen Arbeitsgemeinschaft, 4), Leuven: Peeters, 147-189. 
The Middle Ages 



\begin{abstract}
To many scholars, Japan's twelfth century represents of decline of imperial authority and disorder, representing a transition into the medieval age of warrior rule and an increasing reliance on resolving disputes with arms. And yet, this era also appears to represent an increased reliance on literary manuscripts and historical documents rather than a move away from them. Such a conclusion is borne out by an analysis of Taira no Kiyomori (1118-1181), the first warrior-aristocrat to control the imperial court, and of Japan's first warrior government, the Kamakura shogunate (1185-1333). Both were newcomers to the national political scene, but they also made extensive use of existing manuscript traditions, resulting in an increase of written. Indeed, it would be no exaggeration to state that the more competitive and tumultuous the socio-political context, the more important was the possession of prescriptive and culturally valuable manuscripts.
\end{abstract}

\title{
1 Introduction
}

To many scholars, Japan's twelfth century reflects a decline of central authority and increasing disorder, culminating with the Genpei War of 1180-1185 and the establishment of the Kamakura shogunate (1185-1333). As such, it has come to represent a transition into the age of warrior rule and an increasing reliance on resolving disputes with arms. And yet, while violence was indeed common, this era also appears to represent an increased reliance on documents and books rather than a move away from them, as one might expect. Indeed, sales deeds and transfer documents became more important in demonstrating rights to land, Buddhist scriptures were commissioned by warrior aristocrats to accrue merit in this life as well as in the next, Chinese books were highly valued and Japan's first warrior government (shogunate or bakufu), founded in 1185, even issued its own set of laws in 1232. Unsurprisingly, these objects had to be stored somewhere so we find at this time also a proliferation of archives. And while archives in the modern sense of the word did not exist, we find the beginnings of documents and literary manuscripts being collected. The question then becomes why that is. Would not raw strength be what 
dictated control of land and governance in an age where warriors rose to national prominence? Not necessarily, as we shall see, and for good reasons.

In this essay, I will examine the role played by written artefacts during what we might call 'early medieval Japan' (roughly 1100-1400), by paying special attention to the written customs of two newcomers: Taira no Kiyomori (1118-1181) and the Kamakura shogunate (1185-1333). ${ }^{1}$ Whereas these are two different entities, they were both upstarts in a court-centered society and they both left legacies that would affect Japanese society for centuries. Kiyomori was a warrior-aristocrat who rose through the ranks during the tumultuous times of the mid-twelfth century when the headship of the imperial family was at stake and armed men were for the first time brought to the capital to solve tensions between disputing factions. Eventually, he would eclipse his own master, Retired Emperor Go-Shirakawa (1127-1192; r. 1155-1158, retired emperor, 1158-1192), to become the de facto leader of the imperial court in the late 1170s. Kiyomori's rule was, however, short-lived as the outbreak of the Genpei War in 1180 soon spelled the end of the Ise Taira and its leader. ${ }^{2}$ It was following the Taira defeat in 1185 that we find a new warrior leader in charge, Minamoto no Yoritomo (1147-1199), the founder of Japan's first shogunate. Contrary to what used to be the view, however, Yoritomo did not set out to undermine or replace the authority of the imperial court, but rather to complement it. Thus, he focused on containing the ambitions of local warriors and their aristocratic commanders, and on maintaining peace. ${ }^{3}$ What is noteworthy is that both Kiyomori and later the Kamakura shogunate pursued their agendas by enforcing and mimicking laws and precedents of the imperial court, not by subverting them. In this process, legal documents and literary manuscripts were integral not just to these actors, but in fact to medieval Japanese society in general, severe political changes at the top notwithstanding.

1 Thomas Keirstead cautions against the use of 'medieval' (as well as 'feudal') in the Japanese context. While I agree in principle that there are issues with such a transference, for the sake of convenience, I have retained it in this essay. See Keirstead 1998, 47-71.

2 The Taira were imperial offshoots who had been eliminated from imperial succession, but while they had a common ancestry, the many families stemming from this tree were too diverse to be thought of as a coherent clan. Kiyomori's family were commonly known as the Ise Taira after the province where they developed their stronghold. Following Kiyomori's rise to power, contemporary sources sometimes use the Chinese reading with the added suffix of 'house' to refer to his family as the Heike, which has been adopted in most literary sources as well, such as the Heike monogatari. For a discussion of this naming practice, see Masaaki 2009, 12-13. Note also that I follow Japanese naming practices, whereby surname comes first followed by the given name. For large, high ranking families, a genitive 'no' is inserted between the two, rendering the meaning 'of'. Thus, Taira no Kyiomori might be translated as Kiyomori of the Taira. This practice is no longer used.

3 This was the argument of Jeffrey P. Mass (1940-2001), who spent his academic career exploring the Kamakura bakufu and its founder. See for example Mass 1999. 


\section{Precedents and document traditions}

Following the implementation of the statutory laws (known as the ritsuryō, or 'penal and administrative' codes) in the seventh and eight centuries, the early Heian period (794-1185) saw gradual adjustments to the envisioned imperial bureaucratic state based on the model of the Chinese Tang dynasty (618-907). Beginning with the emergence of non-imperial regents from the Northern Fujiwara family in the late ninth century (earlier regents had all been members of the imperial family), ${ }^{4}$ we find a trend of privatization of political power, economic resources, state administration and even religious ceremonies, where family assets were used to conduct court affairs. These developments took centuries and are accordingly too complex and extensive to deal with comprehensively here. ${ }^{5}$ Yet, they are essential for understanding an increasing reliance on documents, precedents and other written records that developed concomitantly with this process of privatization. For example, as land was given to temples and nobles for their services, and later made tax exempt and perpetually private, deeds and proofs of rights to land naturally became essential. Importantly, such records were not held by the central government, but rather each beneficiary of a donation, sale or bequest was expected to maintain proof of their rights to the property in question. Consequently, the storing and the occasional presentation of such documents were an important part of ownership, so it is not difficult to understand the salient place of archives for each noble, temple and even for provincial elites.

This reliance on documents has led to an astonishing number of sources available to researchers of Japan's premodern age. One major group is commonly referred to as komonjo, which literally means 'old documents'. They include both legal and private documents, such as letters, decrees, charters, codicils, all produced for an intended recipient or audience. ${ }^{6}$ In Japan, komonjo are generally his-

\footnotetext{
4 Like the Taira, the Fujiwara consisted of a set of branches and sub-branches. Stemming from the founder, Fujiwara no Kamatari (614-669), four branches emerged in the seventh century as the most prominent at the imperial court. Among those, the Northern Fujiwara came to exert more influence than any other family throughout Japan's history.

5 For a concise argument about the Heian privatization process, see Adolphson/Kamens/Matsumoto 2008, 9-10.

6 The Nihon rekishi daijiten (Tokyo: Kawade shobô shinsha, 1985) notes 139 different categories of komonjo, ranging from imperial edicts, appeals, verdicts, various land and temple records to private land transfers and letters. For the most comprehensive treatment of komonjo, see Satō Shin'ichi 2003, especially chapter 1, 'Komonjo to komonjo gaku'.
} 
torical documents of legal character, dealing with matters related to property, especially land, often appearing as orders and edicts as well as judicial verdicts. And yet, not all were issued by the state. As property and other assets were privatized, noble, religious and military elites began issuing edicts concerning their own properties. Moreover, appeals and complaints filed by officials and farmers also belong to this category, as well as deeds, wills and various transfer documents. As a result, the total number of komonjo for the Heian and Kamakura periods alone are counted in the tens of thousands, likely rivaling any area in Western Europe for the same period (794-1333). ${ }^{7}$

The need for written texts goes well beyond the confinements of komonjo, as we also see an increase in the production of religious and literary manuscripts during this age. For example, as new rituals were added to sanctify individuals as well as the state itself, documentation on how to perform them was created and saved for future generations in chronicles, new ritual collections (such as the Engi shiki, Procedures of the Engi Era, of 918) and ritual manuals. Even the writing of noble diaries, which became more proliferate from the mid-Heian period, was a reflection of a need to keep records of customs and procedures in a society where new forms were often invented and where competition for power engaged numerous strong players. Finally, legends were produced and written down to lend historical and spiritual legitimacy to institutions and individuals throughout the Heian and Kamakura ages.

Looking at this vast collection of written artefacts, one can broadly divide them into categories based on content, function and form: legal and administrative documentary texts, diaries, literary works (poetry collections and various stories, including the well-known monogatari, or 'tales'), chronicles and Buddhist scriptures. Other categorizations are plausible and not everything may fit neatly in one of the groups, but they are useful for the purposes of this essay. Among these categories, documents related to land easily represent the largest in terms of remaining numbers. During the time that private estates (shōen) were present (roughly from the eighth through the early sixteenth centuries), more than 40,000 documents remain covering some 600 known estates throughout Japan. ${ }^{8}$ Of course, many more were likely produced but the sheer number of those that survive attests to their importance. In fact, their value prompted proprietors to make copies, and when considered salient in legal proceedings, documents were frequently quoted

7 The highest number of documents in Europe can likely be found in Italian trading cities for the twelfth and thirteenth centuries, where tens of thousands of documents were produced for a variety of transactions. See Esch 1985, 532-534.

8 Mass 1976, 9-10 briefly discusses the documents of the Kamakura age. 
in verdicts and lawsuits. It is no wonder that all students of medieval Japanese history are exposed to these documents in Japanese universities, where komonjo classes are frequently taught focusing almost exclusively on shōen documents.

Since these private estates were exempt from taxation and judicially immune, they were beyond the statutes of the penal and administrative codes (the Ritsuryō Codes) that had been put in place in the preceding centuries. For that reason, documents were needed for the creation of each private estate, not just to establish its existence as an immune and exempt unit, but also to create necessary ties between the different levels of administration from land managers to proprietors and patrons in the capital area. In fact, much of the ingenuity of the shōen lay in this arrangement, where a land manager might negotiate shares depending on local customs and the patron might receive various degrees of rent, reflecting the estate system's flexibility and inclusiveness. In other words, it allowed for revenues to be shared by different stakeholders with the rate of revenues for each levels tailored to individual demands and the specific powers of the people involved. The very nature of these documents therefore reflects a condition where few universal laws were in place, and each area could have a variety of rules, as they relied heavily on precedent. Such a lack of consistency naturally led to conflicts over harvests and borders, which in turn necessitated more documents to prove rights to properties and establish legacies. Numerous examples exist throughout the Heian and Kamakura eras, but allow me to just quote one here:

Agreement cosigned by the farmers of Yokawakami Estate

Regarding the foregoing, the intent is that no one shall be faithless to Hōkōji. In the event of unforeseen difficulties, whether involving mountains, plains, or lamp oil paddy and uplands, estate officers and monks, acting as one, will direct their lament to the court. The agreement is thus.

Third year of Kennin [1203], eighth month, fifth day.

Signed for the temple: Monk Ryōzen (monogram), monk Sōzen (monogram)

Signed for the estate: Takamukō Yukitoshi (monogram), Hayashi Morishige (monogram) ${ }^{9}$

This is the first known document pertaining to the Yokawakami Estate in Harima Province (corresponding to the western part of modern Hyōgo Prefecture), so we cannot know what exactly prompted this agreement. However, the context is that

9 Translation of 'Yokawakami no shō hyakushōra keijō' (Kamakura ibun 3, doc. \#1373) in Mass 1976, 77. I have made minor adjustments based on more current readings, and shortened the document slightly. 
the farmers, who were likely quite influential based on their status as estate officials and their ability to sign the document, vowed to deliver taxes as promised to the temple-proprietor. The monks, for their part, agreed to join the farmers in potential complaints against any intrusions. What is not readily visible here is that there was a third party that caused the agreement to be signed in the first place. Following the war of 1180-85, many warrior-administrators took liberties in their appointed areas, obstructing tax payments to the proprietors while at the same time making life difficult for farmers. The document thus expresses an adhoc agreement between farmer-officials and representatives of the proprietor to maintain status quo, and to have a potential dispute with local warriors settled by the court, should such an occasion arise. ${ }^{10}$ It reflects not just the problems of the time, but also the need to find solutions where written laws and codes were insufficient.

The importance of documents notwithstanding, other forms of communication were additionally part of the establishing of precedents, judicial boundaries and contracts. The boundaries of some estates were recorded not only in documents but also with maps, which have been invaluable for scholars in tracing the composition of villages in landed properties. Some scholars also argue that there was a strong aspect of orality in documents pertaining to estates and edicts, whereby the reading out loud of the texts served to spread knowledge to those who had limited reading abilities or were entirely illiterate. ${ }^{11}$ Naturally, such claims can only be confirmed in a few cases and it is difficult to assess how general such practices were, or when they were prominent for that matter since practices in the twelfth century were quite different from those in the sixteenth. Nevertheless, it needs to be recognized that orality was an important part of judicial proceedings but also that primacy was given to written documents and that oral testimonies and readings enhanced judgments and texts rather than competed with them. ${ }^{12}$

While widely considered highly private and personal, diaries in the early medieval age served much the same function as shoen documents albeit solely at the court level. Noble diarists certainly recorded their own perspectives and added commentary on events, so on the surface such diaries therefore resemble those in the West, but they served additional purposes in Japan. In short, they were meant to be used by descendants of the diarist as manuals for proper procedures

\footnotetext{
10 Mass 1976, 77.

11 See for example Fröhlich 2007.

12 Thomas Conlan's book review (2008, 161-163) of Fröhlich's work raises some of the problems in assuming typicality of practices based on a case study of one estate.
} 
and rules, not mainly as they had been recorded in the statutory codes, but rather as they had developed during the changes that occurred in the Heian and Kamakura periods. Indeed, all major courtiers, and some of middle rank as well, kept diaries that stayed within the families. The earliest remaining diaries date to the tenth century, where perhaps the Teishin kō ki (The Diary of Lord Tadahira) by Fujiwara no Tadahira (880-949) stands out as one of the most informative. ${ }^{13}$ About a century later, the greatest courtier of the Heian age, Fujiwara no Michinaga (966-1029), wrote in his diary, the Mido kanpaku ki, about procedures, codes and customs. ${ }^{14}$ No other courtiers could rival Michinaga in terms of power and influence in the entire Heian age, as indicated by a famous statement attributed to Michinaga from a different contemporary diary: 'When I reflect, this world is indeed mine'. ${ }^{15}$

But it is in the twelfth century that we find the largest number of diaries remaining and likely for good reasons. This was a century of dramatic changes, of upheavals, of battles in the capital and of intense factionalism that started when the imperial family returned to the stage of competition for power. It was the beginning of what the Japanese historian Kuroda Toshio described as an age of shared rulership, where elites from three different blocs (the aristocracy, religious institutions and the warrior elites) enjoyed both the privileges and responsibilities of ruling the state. In general, the different blocs did indeed collaborate, but within each bloc, the competition for control was fierce. Thus, temples competed with one another for rights to land and appointments, courtiers vied for favors and positions, and warrior-aristocrats competed with one another for governorships and land appointments. ${ }^{16}$ The challenge was that none of these elites was strong enough to dominate on its own accord, and so alliances were essential. It is this context, of course, that commanders and their military retainers were brought into the capital, and it was, perhaps somewhat ironically, those leading figures that continued the promotion of written records.

13 Teishin kō ki, Dai Nihon kokiroku 8 (Tokyo: Iwanami shoten, 1956). Parts of the diary have been translated into English by Piggott/Sanae 2010.

14 Midō kanpaku ki, Dai Nihon kokiroku 1 (Tokyo: Iwanami shoten, 1952).

15 The quote comes from a poem written by Michinaga in celebration of his daughter being elevated to the position of imperial consort. See Shōyuki, 11 vols. Dai Nihon kokiroku (Tokyo: Iwanami shoten, 1959-86), Kannin 2 (1018) 10/16.

16 This is the gist of Kuroda's kenmon theory, which I have dealt with extensively elsewhere. See Adolphson 2000, 10-19. 


\section{Kiyomori's cultural capital}

Though of imperial descent, Taira no Kiyomori was the first of many secularized descendants who had turned to land management and warrior leadership to reach the pinnacle of the court hierarchy. Like his father and grandfather, he made his career as a commander serving the retired emperor's household, receiving appointments to land and provincial governorships in return. As violence increased and numerous contenders used military might to challenge for family headships in the capital, the role of warriors and their commanders naturally increased. It was such a conflict over the imperial throne in the so-called Hōgen Incident of 1155-56 that opened up new doors for Kiyomori. Go-Shirakawa, whose right to the throne had been challenged by a relative, benefitted the most from Kiyomori's victory and he promptly expressed his gratitude by bestowing governorships and court titles to the Ise Taira. While Kiyomori's father and grandfather had also dealt with local uprisings and ensuring a flow of income to the capital in return for lucrative appointments, it was only with Kiyomori that a member of the Taira reached the upper echelons at court, owing to his continued protection of Go-Shirakawa's interests in the 1160s and 1170s.

But Kiyomori was more ambitious than perhaps even his master realized. After having risen to the top of the court hierarchy in 1167 when he became Grand Minister of State (daijō daijin), he also managed to have his daughter become imperial consort. By the late 1170s, Kiyomori's aspirations had put him on collision course with his own master. At that time, the tables had turned in Kiyomori's favor, and so he took the unprecedented step of putting a retired emperor (Go-Shirakawa) under house arrest shortly before having his own grandson ascend the throne early in 1180. While emulating the great Fujiwara of the past in his control of the imperial family, Kiyomori was in fact attempting to establish a new imperial line through his grandson. This was accompanied by numerous initiatives, including appropriating religious rituals and spaces, as well as the creation of a new capital close to his own estate in Fukuhara in present day Kobe. The move of the capital was without any doubt the biggest enterprise, and though generally neglected in Western scholarship, was a shocking development to many courtiers. ${ }^{17}$ One of the leading courtiers lamented as a procession of nobles left Kyoto for Fukuhara:

17 Two very recent essays that came out within months of one another have finally brought the Heike capital to light. See Adolphson 2015, 17-38; Wakabayashi 2015, 1-39. 
Sixth month, second day [of 1180]. The emperor travelled to Kiyomori's villa in Fukuhara at the hour of the rat (5-7AM). The senior retired emperor [Go-Shirakawa] and the retired emperor [Takakura] also departed. It is difficult to find examples in the distant past when the emperor temporarily resided outside Kyoto. Indeed, ever since the Enryaku age [782-806], there has never been an example like this. How can we not call these events strange? There are surely no people who know of any precedent for this. ${ }^{18}$

That the diarist, Fujiwara no Kanezane (1149-1207), was opposed to the move is beyond doubt, but what is important here is his argument, which hinges on precedent. And while the precedent itself would have been well known to his contemporaries, it seems abundantly clear that Kanezane also means to leave a written record of the events for later generations. In fact, when the move eventually failed and Kiyomori was forced to return to Kyoto just five months later, Kanezane was quick to point out what he considered the main reasons, most of which note Kiyomori's failure to act appropriately within the context of the state. When he does so, he is not simply recording things for himself but also reminding later readers of the importance of not violating precedent and of not upsetting the gods. ${ }^{19}$

Kiyomori's efforts to legitimize his new regime included a number of strategies, one of which was a heavy emphasis on books. The best known manuscript is undoubtedly the Heike nōkyō (Sutras Dedicated by the Heike), produced by Kiyomori and many of his male relatives. A custom that dates to the eighth century in Japan, but goes back to the Indian origins of Buddhism, sutra-copying was believed to accrue merit to the copyist, but it also became a point of pride and competition for status. ${ }^{20}$ Fujiwara no Michinaga used this practice extensively, and Kiyomori quite purposefully imitated someone who was already by then known as the courtier par excellence in order to legitimize his ambitious claims.

The Heike nōkyō consists of thirty-three scrolls mainly copied from the Lotus Sutra, but also four additional sutras in addition to a dedication vow by Kiyomori himself. And Kiyomori spared no expenses in its production, which is especially notable seeing how early in his career it was commissioned just after his rise in the court hierarchy. The manuscript is an exquisite work of art lavishly decorated with gold, silver and indigo, and with hand-painted polychrome images and Japanese poetry in the background design. It is the oldest extant manuscript of the Lotus sutra showing both text and images, and one of the best preserved sutras

18 Gyokuyō, 3 vols (Tokyo: Meicho Kankōkai, 1993), Jishō 4 (1180) 6/2.

19 Gyokuyō, Jishō 4 (1180) 11/29; Takahashi Masaaki, Fukuhara no yume (Tokyo: Kōdansha, 2007), 260.

20 For a brief introduction of the Heike nōkyō, see Kornicki 1998, 88-90. See also Meech-Pekarik 1976. 
from the Heian age, so it is hardly surprising that it has been designated a National Treasure. ${ }^{21}$ The sutra set was meant not just to create a firm bond between the copier, the deities and the shrine, but also to unite relatives over whom Kiyomori claimed leadership, since each member had been put in charge of one scroll each. As such it served as a symbolic expression of the unity of the Ise Taira under Kiyomori's leadership, while establishing the sutra set as a 'signature artefact,' which was used to display the power and cultural erudition of its creators. As such, it was a form of cultural capital that served Kiyomori well as he competed with other houses for social status. ${ }^{22}$ Upon completion in 1164, it was donated to Itsukushima Jinja, the shrine that Kiyomori patronized on the island of Miyajima close to present-day Hiroshima as the main religious centre of his regime. For a warrior-aristocrat, the Heike nōkyō was an unprecedented production designed to augment the chieftain's status above the foremost nobles of the time, on the level of the most paramount of all nobles, such as Michinaga. Kiyomori obviously wanted no doubt as to his status and to the legitimacy of his grandson's and those of his descendant to the imperial throne.

In sharp contrast to the Heike nōkyō, Kiyomori used a different set of sutras (the Issai kyō; the complete Buddhist canon), as a material and spiritual foundation for a new quay in the harbor just next to Fukuhara. This new structure was meant to provide additional space for ships to dock at Kiyomori’s port, Ōwada no tomari, where traders arrived from numerous provinces as well as from China via the main port in Kyushu, Hakata. It is also possible that the quays themselves were meant to stabilize the area from waves and other obstacles, so the sutras were likely meant to give spiritual protection to the new construction. Needless to say, while some text was carved into the rocks that were sunk, no manuscripts remain from this pier, which was named Sutra Island (Kyōgashima). ${ }^{23}$ From the perspective of the imperial court, however, it was probably the import from Song China of the Taiping yulan (Imperial Readings of the Taiping Era), completed in 983, that stood out the most among Kiyomori's textual enterprises. He obtained this printed multi-volume set-a rarity in Japan at this point-known as the Taihei gyoran in Japanese, in the second month of 1179, presenting it to Emperor Takakura (his son-in-law), while also having an exquisite copy made for his young grandson, the future Emperor Antoku (1178-1185, r. 1180-1185). ${ }^{24}$

21 Dix 2015, 99-100.

22 Heather Blair uses the term 'signature text', but for the purpose of manuscript studies, 'signature artefact' is more appropriate. See Blair 2015, 61-63.

23 Adolphson 2015, 17-20, 32-33.

24 Adolphson 2015, 33. 
The significance of this textual artefact should not be underestimated. The Taiping yulan was the most magnificent and massive encyclopaedia in China, consisting of 1,000 volumes but also, it was said, a text that the Song rulers were highly reluctant to send abroad. For example, the Korean court had repeatedly asked for copies but it had been rejected until 1100. Kiyomori, on the other hand, seemed to have had no problem in securing a copy of this set. ${ }^{25}$ Seeing the challenges with acquiring such a treasure, one has to conclude that Kiyomori specifically ordered it through the many Chinese traders who frequented Japan's main import town of Hakata, and that he somehow played his cards right or offered enough in exchange to convince sellers in China to go through with the transaction. Again, this was not a new practice but rather established among ranking courtiers. Michinaga had acquired books from China and a contemporary of Kiyomori, Fujiwara no Yorinaga (1120-1156), was also known to be an avid collector of such prized items. Accordingly, it seems apparent that Kiyomori intended for this object to be another example of a signature artefact, or a hallmark, for the new imperial line. ${ }^{26}$ While scholars today may find Kiyomori's commitment to such objects surprising because of his background as a commander, it was entirely in line with the spirit of the time, and with his status as both a warrior and a noble.

Finally, I would be remiss if I did not mention aristocratic poets, who were equally committed to, if not obsessed with, literary traditions. Kiyomori's father, Tadamori (1096-1153), made strong efforts to master court poetry, though he was not as acknowledged for his production as he might have wished. Instead, it was above all Kiyomori's brothers, Tsunemori (1124-1185) and Tadanori (1144-1184), and his nephew Tsunemasa (Tsunemori's son, c.1147-1184), who became the pillars in what Anne Commons has labelled an Ise Taira 'poetry circle', patronized by the well-known poet Fujiwara no Shunzei (1114-1204). ${ }^{27}$ Tadanori's commitment has become legendary as he is described in the war tale Heike monogatari in an episode bearing his name: 'Tadanori's Flight from the Capital'. In it, Tadanori returns to the capital in the midst of his kinsmen's flight during the tumultuous retreat in 1183 in order to leave with his patron Shunzei some poems in the hope that they would be included in an imperial anthology. Tadanori's wish was

25 Sankaiki, Zoku Shiryō Taisei, vols 26-28 (Kyoto: Rinsen shoten, 1965), Jishō 3 (1179) 2/13, 12/16; Ōyama, 'Heishi seiken to Ōwada no tomari,' in Hyōgo ken shi 2 (hyōgo: Hyōgo ken shi henshū senmon iinkai, 1975), 24, 28; Takahashi, Fukuhara no yume, 197-198; Takahashi, 'Fukuhara sento o meguru seiji shi: Jishō ninen kara dō yonen hachigatsu made,' in Rekishigaku kenkyū 816 (2006), 3; Kornicki 1998, 287.

26 Adolphson 2015, 33; Blair 2015, 63; Kornicki 1998, 287.

27 Commons 2015, 78-79. 
only partially fulfilled as several poems were indeed included, but without noticing his name. ${ }^{28}$ This narrative has been interpreted in various ways, most commonly as evidence of the aristocratization of the Heike, but the belief in poetry compilations and literary legacies must not be overlooked. By the twelfth century, they had become essential to sustain or create exalted positions for any ambitious aristocrat or aristocrat within the context of the imperial court in Kyoto.

\section{Documentary foundations for warrior rule}

Born out of war and representing a class of military men, the shogunate was nevertheless committed to written records, though more for their judicial than their cultural value. For example, in adjudicating land conflicts, it was written evidence that carried the most evidence. As Jeffrey Mass has shown, beginning with its founder, Minamoto no Yoritomo, the shogunate took as its main task not to promote the interests of warriors, but rather to contain their ambitions. ${ }^{29}$ This was necessitated by self-preservation as much as a commitment to the old order since Yoritomo's own position as leader of the warrior class would be undermined if he were unable to restrict illegal activities by his retainers. Warriors, who had challenged the authority of central landholders as part of their campaigns during the Genpei War, felt entitled to violate contracts and precedents when it came to paying dues from private estates, where they served as land managers. Proprietors and patrons soon realized that the only way to preserve or even retain some rights to land was to appeal to the bakufu. As a result, the shogunate was inundated by complaints from nobles, shrines and temples throughout the 1190s and beyond. As is clear from these appeals, the culprits were mainly warrior-managers who intruded into estates, refused to pay agreed upon rent or harassed local farmers, thereby challenging proprietors' right to revenues from the estates. The document quoted above from 1203 represents an attempt to solve such a situation through collaboration between the proprietor and farmers without engaging the shogunate.

Remarkably, the shogunate quickly established advanced methods for adjudicating disputes, putting most weight on written evidence, which of course further reinforced the emphasis on documents. But since even ranking members of the warrior class had little training in reading, much less in legal matters, mid-

28 Commons 2015, 89.

29 Mass 1999, 7-8. 
ranking courtiers were brought to Kamakura to help with the establishment of a judicial system, which developed over the first few decades after 1185. Ōe no Hiromoto (1148-1225), a ranking aristocrat and legal specialist, was perhaps one of the most outstanding of those choosing to make the move. ${ }^{30}$ The system that developed was in either case quite sophisticated for its time, shunning any form of witch trials. In case of an appeal from a civil proprietor, the bakufu would ask the accused party to respond in writing, requesting documents that might support why intrusions or the lack of payments due to the central elite had occurred. Failing at that, the bakufu would normally judge in favor of the aggrieving party, but more frequently, the conflict continued until a trial confrontation occurred, where oral testimonies might also be taken into account. Since land managers often lacked documentary support for their activities, they would on occasion 'induce' a local farmer of some standing to support him via an affidavit, or by simply referring to precedents.

Considering the ambitions of the warrior-manager class, it is hardly surprising that the shogunate was preoccupied with lawsuits over land for most of the thirteenth century. Like the imperial court, it did not retain records of its own judgments, which meant that the onus was upon the winners of a trial to retain evidence for their future rights. Needless to say, this was a major inducement for central elites to produce and preserve records. To offer two examples from a verdict already in English translation, we might consider the actions of the land manager (jitō) in Shimōsa Province (modern Chiba and Ibaraki Prefectures in the Kantō) in 1209:

Ordered: To the jitō and officers of [Katori] Shrine, Shimōsa Province
[...]
Item: The enlistment of shrine officials for Kyoto and Kamakura labor services shall cease
At the trial confrontation, the statement presented by the shrine administrator and various
other shrine officials was not without justice. Forthwith, in accordance with precedent, la-
bor services by shrine officials are to cease. ${ }^{31}$
[...]
Item: The willful seizure of paddy, upland and homestead areas from among vacated hold-
ings of shrine officials who have fled shall cease.
At the trial confrontation, the statement of shrine administrator Hirofusa was just. Likewise,
the edict from the Fujiwara chancellery is clear in urging that seizures by the jitō shall cease

30 Mass 1979, 66; Hall 1906, 5; Varley 1982, 147-148.

31 The jito had, in other words, forced officials at the shrine to work for him, calling it labor service for Kyoto and Kamakura. As an exempt shrine, there should be no such service. 
in regard to the vacated lands of deceased or departed shrine officials. ${ }^{32}$ Henceforth, the jitō seizures are to stop.

[...]

By command of the Lord of Kamakura, the foregoing matters are thus decreed. Wherefore, it is so commanded.

Third year of Jōgen [1209], third month, seventeenth day. ${ }^{33}$

While it is beyond this essay to judge typicality, disputes such as the one in the document above were far from rare as most adjudications by the shogunate indicate. Indeed, what the military land steward had done reflects common strategies among local warrior-managers to extend their influence well beyond agreements they had often signed off on themselves. And as is clear from the two articles (out of nine in the original document) above, the shogunate had little to go on except previous contracts and precedents, all of which it was up to the proprietor to prove since the shogunate rarely had any knowledge of local conditions. Absent such knowledge, it made effective use of trial confrontations by carefully weighing testimonials. In this way, the bakufu's verdicts became a piecemeal way of handing down judgments and establishing a legal foundation for what eventually became the first set of principles for adjudication in land disputes involving the warrior class. Known as the Jōei shikimoku (the Jōei Formulary after the era, alternatively Goseibai shikimoku, or The Formulary of Adjudication), it was compiled by the shogunal regent Hōjō Yasutoki (1183-1242) and proclaimed in 1232. Necessitated by a dramatic increase of disputes following the failed attempt to overturn the shogunate in 1221 by Emperor Go-Toba (1180-1239, r. 1183-1198, retired emperor, 1198-1221), it was also meant to establish principles based on three decades of adjudication. Despite sparse attention from non-Japanese scholars, the code is a valuable source containing clauses that offer unique insights to conditions well beyond the shogunate's judicial dealings. ${ }^{34}$

The Jōei Formulary consists of 51 articles designed, just like the shogunate itself following the Genpei War of 1180-85, not to promote the ambitions of warriors and land managers under its rule, but to maintain status quo by supporting

32 Farmers who were subject to extreme demands from a local warrior-manager had few options except to leave the land they cultivated. The jito may have made excessive demands exactly to drive them away. The Fujiwara chancellery's involvement indicates that the family served as patron (honke) of the estate, while the shrine was the local proprietor (ryōke), representing the two highest levels in the shōen order.

33 Mass 1976, 118-120. The original document can be found in Chiba ken shiryō, chūsei hen: Katori monjo (Chiba: Chiba ken shi hensan shingikan, 1962), 68-69.

34 An early translation and introduction by John C. Hall has garnered little attention in current scholarship and studies of the law code are all but non-existent since then. See Hall 1906, 1-46. 
the property rights of the traditional capital elites among nobles and religious institutions. Thus, we find articles explicitly prohibiting local managers from taking control of land and from withholding rents due the proprietors, as we saw in the verdict quote above. But there is in addition a range of articles that reveal other concerns and challenges of a growing warrior class, where patterns of inheritance were of particular concern. Nine clauses deal specifically with the transfer of property, which was the foundation for the livelihood of warrior families. That loyalty even within the family was also a concern is abundantly clear from the text, as it proclaims the rights of parents to revoke land already given to sons and daughters should they misbehave. ${ }^{35}$ Another theme is the rights of daughters and wives within the warrior class. Article 16 is fascinating enough to deserve a translation:

\footnotetext{
Item. Regarding the matter of whether or not parents may revoke property transferred to a daughter because of discordant behavior.

Although names for women and men differ, their filial obligations are the same. This has been stated by legal experts. However, if a daughter were able to rely on an irrevocable letter [of transfer], then there would be no reason for her to fear unfilial deeds. ${ }^{36}$ Thus, if mothers and fathers have reason to think that it may lead to adversarial disputes, they should surely not transfer property to their daughters. It would mean the beginning of the severing of the parent-child relationship. It is also the foundation for violations of the proper code of conduct. If a daughter wavers in her behavior, parents should be prudent in their course of action. If these principles are understood, daughters will surely perform their duties of filiality in order to obtain a transfer deed, while parents will, for the sake of giving their loving care, evenly give affection and love [to their children]. ${ }^{37}$
}

As should be obvious, this article addresses conditions facing the warrior class, but above all informs us of the need for documentation at this time. Precedents were not enough to steer clear of chaos and disruption, but neither were individual verdicts or notions of familial loyalty, causing the shogunate to promulgate a code of behavior for the warrior class. As if there were any remaining doubts, the very writing itself also makes it clear of the audience. The Jōei Formulary was written in a simpler style than the regular Sino-Japanese used in court documents, using a heavy dosage of kana, the Japanese syllable script. The difference between the two styles was substantial; while Sino-Japanese only employs Chinese characters that need to be rearranged to be read out in Japanese, the insertion of simplified kana syllables representing phonemes enabled a straight reading of

35 Mass 1989, 69-71.

36 In other words, she would have no reason to be filial.

37 Shin'ichi and Yoshisuke 2002, 13. The translation is mine. For an older version, see Hall 1906, 28. 
the characters. ${ }^{38}$ In fact, Yasutoki himself remarked to his younger brother, Hōjō Shigetoki (1198-1261), that 'This will be often used among those who only know kana. Therefore, it will be generally understandable to as well as appeal to warriors'.39

At the same time, it is worth noting that in contrast to leading figures at court, the shogunate did not seem interested in producing signature artefacts to set it apart from other institutions. While Kamakura patronized and supported temples from the time of Yoritomo, there are few signs of sutra-copying, poetry compilations or the acquisition of expensive Chinese books. Legitimacy was, on the other hand, a much bigger concern for the shogunate. This had come to the fore in the Jōkyū War of 1221, when Retired Emperor Go-Toba challenged the Hōjō family's control of the bakufu. As is well known, the Hōjō were Yoritomo's in-laws, who took control of the bakufu following the deaths of Yoritomo's youngest son in 1219. It was under the Hōjō that the shogunate developed its judicial procedures, but only later that it created a chronicle to justify their position. Known as the Azuma kagami (Mirror of the East), the chronicle covers the history of the shogunate, starting in 1180 with Yoritomo joining the uprising against Kiyomori. The last entry is dated 1266, and it is therefore believed that the chronicle was written at that time or shortly thereafter..$^{40}$ The purpose of the chronicle is abundantly clear as it favors the Hōjō extensively, while criticizing the Minamoto, from whom they took control of the bakufu. Thus, it has limited value as a narrative of the late twelfth and early thirteenth centuries, even when it comes to dealings among elite warriors, but it does reflect the importance placed on a written record even 80 years after the shogunate's founding.

38 While Chinese has straight word order like English (S-V-O), Japanese has reversed order (S-O-V). 39 Letter dated Jōei 1 (1232)11/9, cited in Ishii Susumu, ed., Chūsei seiji shakai shisō vol. 1 (Tokyo: Iwanami shoten, 1972), 41. I have borrowed the translation from Howell 2002, 55. Howell in turn cites Yoshihiko 1990, 341. The letter itself has been printed in Nihon shisō taikei (Tokyo: Iwanami shoten, 1990-), vol. 21, 40-41. See also Fröhlich 2007, 22.

40 The Azuma kagami remains untranslated into English, but was used extensively and partially translated by Shimoda 1960. It was the standard account of the Kamakura bakufu in English until Jeffrey Mass's work were published in the mid-1970s. Mass pointed out the obvious biases and inventions in the account in many of his works, but for an example, see Mass 1999, 7. 


\section{Archives in the Japanese medieval context}

Needless to say, the survival of such a large quality of documents and literary manuscripts from Japan's medieval age hails not just from their importance in the political and cultural contexts, but also from good storage practices. Ultimately, the need for storing documents and manuscripts generally stemmed from one of two purposes: either to keep evidence of proprietorship of land or to safeguard manuscripts that were seen as cultural assets. Foremost among institutions storing records were especially temple and shrine complexes, such as Tōdaiji, Kōfukuji, Tōji, Enryakuji and Itsukushima Shrine. These institutions were naturally prone to preserve Buddhist scriptures both for usage in rituals but often more for their importance as cultural products, a custom that began as soon as temples were built from the seventh century. The above-mentioned Heike nōkyō is an obvious example, as Taira no Kiyomori understood and used the value of such an object, but gave it to his main shrine complex at Itsukushima Jinja. Most temples and shrines maintained separate storages for documents, likely because of the high risk of fire in the main halls, where incense and candles were used. The structures themselves were of course wooden, but in addition, important storages were commonly raised off the ground to prevent damage from flooding, though insects remained a problem in Japan's damp climate. By and large these practices were successful, but while the collections at temples such as Tōdaiji, Kōyasan and Daigoji yielded some of the most extensive collections of premodern documents, others were less fortunate. The imperial temple Tōdaiji and the influential Kōfukuji, both located in Nara, were destroyed on numerous occasions, but the latter also lost its document collections. Nevertheless, the most poignant case of document destruction is that of Enryakuji, which vehemently and violently opposed the efforts of the great warlord Oda Nobunaga (1536-1582) to submit to his rule. With little fear of the Buddhas as well as of the temple's protective native deities, Nobunaga launched an all-out attack with some 30,000 warriors, killing residents on the mountain indiscriminately and burning the vast monastery to the ground in 1571, along with it all the Buddhist treasures and written artefacts.

Needless to say, the need for scriptures in Buddhist monasteries has been instrumental since the very introduction of Buddhism in Japan, so it can hardly be surprising that there was an emphasis on production and storage of manuscripts for most of their history. What is perhaps of more interest are the documentary practices of noble houses. Those who held titles as patrons and proprietors of estates not only needed to keep records to support any claims to land, but in fact also needed administrative headquarters where scribes kept records and issued edicts from the head of the house. In most cases, we do not know where 
these headquarters were located, but when it comes to the influential Northern Fujiwara, we do know that the Kangakuin, which was originally established in as a university for members of the Fujiwara in Kyoto, was from the mid-Heian period used as the official secretariat.

As noted above, diaries in Heian and Kamakura Japan were not wholly private. Rather, they were intended to be used as guidelines for following generations but also as a repository of precedent. Thus, we frequently see references to various diaries by later writers when there were controversial discussions at court. It is not surprising then that various noble lineages kept diaries closely guarded, occasionally making copies for safekeeping. In fact, such families were described with a specific term that means 'houses of diaries' (nikki no ie). In other words, though there was nothing restricting specific families or individuals from keeping diaries, it was the ranking families with higher titles that were expected to keep records that could serve future generations. Hence, the term 'houses of diaries' emerges. Importantly, the term itself is mainly restricted to the very period under examination here, that is from 1100 to around 1400, providing further evidence that in those specific times of change, the keeping of written records was perhaps even more important than in the periods preceding it. ${ }^{41}$

To note one example of how such diaries were used, one of the leading members of the Northern Fujiwara, Yorinaga, sent out a call in 1148 to his noble colleagues to inquire about proper procedures for the pending installation of his daughter as imperial consort. Yorinaga noted not just who had diaries in their possession, but also whose diaries they had in a neat list, reflecting the importance of such texts. Moreover, we learn as well that while these assets were kept by individual houses, they were shared for the purpose of discussing and establishing precedent. ${ }^{42}$ Another example of more poignant proportions can be found at the time of the Great Angen Fire (Angen no taika) of 1177, when large parts of the Inner Imperial Palace, including the Enthronement Hall, the imperial university, the Fujiwara family's administrative headquarters as well as dozens of noble residences were damaged or entirely destroyed. One of the leading courtiers at the time, Fujiwara no Kanezane, sent messengers to the most prominent 'diary houses', not just to enquire which records had survived but also to ask what had been recorded about the fire itself so that he could get a better sense of the extent of the damage, which turned out to the most serious since the construction of Kyoto in the late eighth century. The importance of these manuscripts

41 Matsuzono Hitoshi, Nikki no ie: Chūsei kokka no kiroku soshiki (Tokyo: Yoshikawa kōbunkan, 1997), 9-10.

42 Matsuzono, Nikki no ie, 27-29; Taiki, Kyūan 4 (1148) 7/11. 
to the various noble houses is obvious in Kanezane's diary, as he equates the loss of a diary to the decline of the house itself. ${ }^{43}$ In fact, for these houses, ancestral diaries were similar to the signature artefacts noted above, and thus essential for the continued prominence of the diary houses.

Regardless of where we look for medieval archives-among temples, shrines or noble houses-it cannot be denied that their importance increased at the very time when the imperial court's overall and direct control of religious and political spheres was relaxed in favor of a more decentralized top, where individual elites maintained their own cultural and political assets. Indeed, the very survival of so many diaries undoubtedly owe much to this particular setting. Because of the risk of fires and need to be able to consult diaries, copying became a crucial enterprise. And, of course, those records that were considered especially important were likely subject to more copying than less useful diaries, so the survival of specific manuscripts is less a coincidence than one might assume. In fact, it is notable that there is a correspondence between surviving diaries and the number of times they have been referred to or quoted in later manuscripts. ${ }^{44}$ In a sense, such noble diaries were used in a similar way to land documents, substituting for laws and customs that were not written and proving, through records and precedence, what was appropriate and accepted within different cultural and political settings, be they at the level of the imperial court or in public land or private estates in the provinces.

\section{Conclusions}

Many scholars have argued that the move away from the statutory codes reflected a decline of imperial authority and centered rule. Others have viewed the adjustments as a necessary process of privatization to both ensure the survival of the imperial throne and the centrality of the court. In fact, through privatization, the elites, though increased in number compared to the early Heian age, actually improved their control of estates and revenues, done by including rather excluding other groups of power, such as local landholders. It is hardly surprising that in this context of change and competition between elites, new procedures and precedents were established, which in turn needed to be recorded. But not all texts held equal value to all elites. For the capital elites, the copying of sutras went

43 Matsuzono, Nikki no ie, 33-35; Gyokuyō, Angen 3 (1177) 4/29; Hyakurenshō, Angen 3/4/28.

44 Matsuzono 1997, 41, 47. 
hand in hand with patronage of monks from various temples. For instance, Kiyomori's sutra production was accompanied by the promotion of Itsukushima and numerous attempts to create a close relationship with Enryakuji through the head abbot Myoun (1115-1183). ${ }^{45}$ By the same token, other books, such as the Taping yulan, held enough cultural and political capital to be used by Kiyomori as a signature artefact in support of his efforts to establish a Heike imperial line. In contrast, while the Kamakura shogunate also supported monks, we do not find the same commitment to books as cultural treasures and social capital. Its main goal was above all to ensure that the established temples could continue their activities of sanctifying the imperial court, and the idea of signature texts does not seem to have been a high priority. Precedence and legitimacy did on the other hand play a major role, as indicated by the Joei Code and the Azuma kagami.

Both Kiyomori and his adversary, Yoritomo, were military aristocrats and as such well acquainted with the customs and procedures of court life. What separates them was that while the former made his career in the capital region, the latter spent most of his adult life in the Kantō area, which undoubtedly influenced his decision to establish the shogunate away from and in parallel to Kyoto. Thus, while they both can be described as warrior leaders, their ultimate goals were different. Kiyomori dreamed of using his command of warriors to establish a new imperial line within existing structures, whereas Yoritomo seemed to be satisfied with being at the top of a growing class of warriors. His need for traditional courtly written texts was thus less than that of Kiyomori, whose family produced not just books containing sutras and iconic texts but also poetry. Kiyomori did not, on the other hand, produce a diary, and if the ones that remain today are any indication, very few members of his family did. A couple of Taira diaries by other branches exist, but Kiyomori, who was highly effective in using rituals and cultural objects to gain status, needed to create new precedents to replace the Fujiwara as the most powerful family behind the imperial throne. A Heike diary depicting how he and his descendants had circumvented traditions may not have been high on his list of priorities.

In contrast, to maintain order of provincial warriors, the shogunate required a legal foundation for warrior behavior, which began with edicts and verdicts and culminated with a unique warrior law code. Missing from this context are the 'feudal bonds' that modern scholars long sought in Japan. Loyalty and ties of fealty were conspicuous only insofar as they were utterly missing from warrior behavior, despite ideals to the contrary portrayed in later war tales. Indeed, it was the very absence of common understandings of behavior and propriety that prompted the

45 See Adolphson 2000, 157-160. 
production of both new and old types of written artefacts. The emergence of military commanders on the national scene did not result in a decline of written needs but it signaled instead the beginning of a shift in the character of records and literary manuscripts needed to rule effectively. This rule was neither courtly nor military, but a little bit of both.

\section{References}

Adolphson, Mikael S. (2000), The Gates of Power: Monks, Courtiers, and Warriors in Premodern Japan, Honolulu: University of Hawaii Press.

Adolphson, Mikael S. (2015), 'Fukuhara: Kiyomori's Lost Capital', in Mikael Adolphson and Anne Commons (eds), Lovable Losers: The Heike in Action and Memory. Honolulu: University of Hawaii Press, 17-38.

Adolphson, Mikael S., Edward Kamens, Edward, and Stacie Matsumoto (eds) (2008), Heian Japan, Centers and Peripheries, Honolulu: University of Hawaii Press.

Blair, Heather (2015), 'Kiyomori, Itsukushima, and Fukuhara', in Adolphson and Commons 2015, 58-77.

Chiba ken shiryō, chūsei hen: Katori monjo, Chiba: Chiba ken shi hensan shingikan, 1962.

Commons, Anne (2015), 'The Heike Poets', in Adolphson and Commons 2015, 78-79.

Conlan, Thomas (2008), Book review of Judith Fröhlich, Rulers, Peasants and the Use of the Written Word in Medieval Japan: Ategawa no shō 1004-1304, Bern: Peter Lang 2007 in Monumenta Nipponica, 63/1, 161-163.

Dix, Monika (2015), 'Heike Nōkyō as Repertoire: Contextualizing Kiyomori’s Devotional Practice of Copying Sutras', in Adolphson and Commons 2015, 99-124.

Esch, Arnold (1985), 'Überlieferungs-Chance und Überlieferungs-Zufall als Methodisches Problem des Historikers', in Historische Zeitschrift, 240/3, 532-534.

Fröhlich, Judith (2007), Rulers, Peasants and the Use of the Written Word in Medieval Japan: Ategawa no shō 1004-1304, Bern: Peter Lang.

Gyokuyō, 3 vols. Tokyo: Meicho Kankōkai, 1993.

Hall, John Carey (1906), 'Japanese Feudal Laws: The Hojo Code of Judicature', in Transactions of the Asiatic Society of Japan, 34, 1-44.

Hitoshi, Matsuzono (ed.) (1997), Nikki no ie: Chūsei kokka no kiroku soshiki. Tokyo: Yoshikawa kōbunkan.

Howell, Thomas R. (2002), Setsuwa: Knowledge and the Culture of Reading and Writing in Medieval Japan. Ph.D. dissertation, University of Pennsylvania.

Keirstead, Thomas (1998), 'Inventing Medieval Japan: The History and Politics of National Identity', in Medieval History Journal, 1/1, 47-71.

Kornicki, Peter (1998), The Book in Japan: A Cultural History from the Beginnings to the Nineteenth Century, Leiden: Brill.

Masaaki, Takahashi (2007), Fukuhara no yume, Tokyo: Kōdansha.

Masaaki, Takahashi (2009), Heike no gunzō: Monogatari kara shinjitsu e, Tokyo: Iwanami shoten. Mass, Jeffrey P. (1976), The Kamakura Bakufu: A Study in Documents, Stanford: Stanford University Press 
Mass, Jeffrey P. (1979), The Development of Kamakura Rule 1180-1250: A History with Documents, Stanford: Stanford University Press.

Mass, Jeffrey P. (1989), Lordship and Inheritance in Early Medieval Japan: A Study of the Kamakura Sōryō System, Stanford: Stanford University Press, 69-71.

Mass, Jeffrey P. (1999), Yoritomo and the Founding of the First Bakufu: The Origins of Dual Government in Japan, Stanford: Stanford University Press.

Meech-Pekarik, Julia (1976), 'Taira Kiyomori and the Heike Nōgyō’, Ph.D. dissertation, 2 vols, Harvard University.

Midō kanpaku ki, Dai Nihon kokiroku 1. Tokyo: Iwanami shoten, 1952.

Nihon rekishi daijiten. 22 vols. Tokyo: Kawade shobô shinsha, 1985.

Piggott, Joan, and Yoshida Sanae (trans.) (eds) (2010), Teishinkōki: What Did a Regent Do? The Year 939 in the Journal of Fujiwara no Tadahira, Ithaca, NY: Cornell University East Asia Program.

Shimoda, Minoru (1960), The Founding of the Kamakura Shogunate, 1180-1185. New York: Columbia University Press.

Shin'ichi, Satō, and Ikeuchi Yoshisuke (eds) (2002), Chūsei hōsei shiryō shū: Dai ikkan, Kamakura bakufu hō, Tokyo: Iwanami shoten.

Shōyuki, 11 vols. Dai Nihon kokiroku. Tokyo: Iwanami shoten, 1959-86.

Susumu, Ishii (ed.) (1972), Chūsei seiji shakai shisō vol. 1. Tokyo: Iwanami shoten.

Taiki. 3 vols, Zōho shiryō taisei. Kyoto: Rinsen shoten, 1965.

Varley, H. Paul (1982), 'The Hōjō Family and Succession to Power', in Jeffrey P. Mass (ed.), Court and Bakufu in Japan: Essays in Kamakura History, Stanford: Stanford University Press, 143-167.

Wakabayashi, Haruko (2015), 'Disaster in the Making: Taira no Kiyomori’s Move of the Capital to Fukuhara', in Monumenta Nipponica, 70/1, 1-39.

Yoshihiko, Amino (1990), 'Nihon no moji shakai no tokushitsu', in Nihon ron no shiza, Tokyo: Nihon shōgakkan. 


\title{
Securing and Preserving Written Documents in Byzantium
}

\begin{abstract}
The administrative organisation (civil, military, ecclesiastical) of the Byzantine Empire belonged to the most sophisticated in the medieval world. The power of the written word was omnipresent. However, almost no material evidence concerning archives can be found, but written sources provide some information on storage of data. The reconstruction of libraries is a more promising endeavour, since manuscripts sometimes disclose their original storing place. Lists of books allow the reconstruction of libraries echoing also the importance of their social capital. Collections of manuscripts in monasteries give an idea of their medieval predecessors.
\end{abstract}

\section{Introduction}

'Libraries are the self-conscious accumulation of written texts, both literary and documentary, which preserve information for other readers and other writers'. This quotation can be found in a volume of collected essays published in 2002, explicitly devoted to literacy and manuscript transmission in Byzantium. ${ }^{1}$ According to the author of the essay quoted, the safekeeping of information seems to have been more important than the transmission of (mainly ancient) knowledge in Byzantium. This idea forms the main argument here and may differ slightly from the views of classical philologists and ancient historians who tend to emphasise aspects of preservation and survival of classical Greek literature. It also contradicts notions of a static Byzantine culture-a culture said to lack innovation and transformation. The investigation of Byzantine libraries and archives was mostly related to questions concerning the transmission and preservation of ancient texts. ${ }^{2}$ Much of the research conducted in recent decades has focused on detecting traces of lost authors or unearthing unknown ancient texts such as the famous Archimedes palimpsest, a tenth-century manuscript that was written over by monks in the thirteenth century. It was discovered in 1906, but deciphered in the last decade. ${ }^{3}$

\footnotetext{
1 Waring 2002, 167.

2 For example, Harlfinger 1980.

3 Netz/Noel/Tchernetska/Wilson 2011.
}

https://doi.org/10.1515/9783110541397-011, (c) BY-NC-ND (c) 2018 M. Grünbart, published by De Gruyter. This work is licensed under the Creative Commons Attribution-NonCommercial-NoDerivs 3.0 License. 
The reconstruction of libraries and the original storage places of Byzantine manuscripts belongs to the realm of palaeographical and codicological research, but apart from the localisation of a book, ${ }^{4}$ its production and its attachment to a scriptorium, almost nothing else can be said about its storage, presentation and usage; the physical appearance of a library or an archive, how it was organised and what size it was are still practically unknown.

Byzantine libraries have already been discussed from multiple perspectives in other publications. ${ }^{5}$ Carl Wendel devoted a series of articles to the history of book collections. ${ }^{6}$ In his thesis, Otto Volk accumulated information on monastic libraries in the Middle Byzantine period, ${ }^{7}$ while Nigel Wilson focused on ancient authors, their afterlives in Byzantium and the value of books. Wilson understands the term 'library' to mean a collection of books gathered by learned men who used them in their classes and valued them as sources of rhetorical refinement; florilegia, i.e. selections of excerpts by different authors, played an important role here-appropriate sections of various kinds of literature were easily at hand. The culture of encyclopaedism and florilegia is a growing field of interest in Byzantine studies. ${ }^{8}$ On the one hand, a florilegium reflects the process of concentration on specific topics, while on the other hand, it stands for a library as well. ${ }^{9}$

Book-hunting and the search for classical Greek texts intensified in the last few centuries of Byzantium. Western scholars became interested in both classical Greek texts and works dealing with Byzantium enemies. The historical works of Laonikos Chalkokondyles (a famous Byzantine Greek historian in the second half of the fifteenth century) described the Ottoman Turks and were held in particularly high regard; these were printed and translated into Latin relatively early. Many Byzantine/Greek books found their way into Western libraries and became precious imperial artefacts. ${ }^{10}$

\footnotetext{
4 A new form of 'book' emerged in Late Antiquity and codices became the main information carriers instead of scrolls. However, imperial and patriarchal charters, legal documents and liturgical texts continued to be made in a scroll format (until the end of the Byzantine Empire). This may have caused problems regarding storage, an issue that libraries and archivists still face today; see Hunger 1989, 25-26 (including references to the process of transformation).

5 Wilson 1968 (see also Wilson 2008); Hunger 1989; see also Waring 1998. A good starting point for information on Byzantine libraries is Harlfinger 1980 (which includes a detailed index).

6 Wendel 1954 and 1974.

7 Volk 1955.

8 Van Deun/Macé 2011.

9 See the classic study by Treadgold 1980 on the library of Photius; translation in Wilson 2002.

10 See the study by Wilson 1992.
} 
The function of written documents in Byzantine society ${ }^{11}$ and the status of book collections and their owners have seldom been the objects of systematic reflection, however, and a cultural history dealing with Byzantine archives and libraries is still lacking. It should definitely include official documents and tax registers-besides their design, layout and contents.

\section{Sources}

The investigation of libraries and archives in Byzantium is a rather frustrating undertaking compared to studies focused on Antiquity since there are almost no archaeological or physical traces of them from the Greek Middle Ages. ${ }^{12}$ The site of the Hellenistic library at Pergamon, for instance, is still visible and the remains of the building allow a reconstruction of its sophisticated design and structure. Libraries also belonged to the urban topography of the Roman world: traces of them have been found in the capital of the Empire and in many provincial towns. In one telling example, a building for books was commissioned by Senator Tiberius Julius Celsus Polemaeanus in Ephesos. The foundations of the library were laid in $117 \mathrm{CE}$ and the building took three years to complete. The library was built to store 12,000 scrolls, but also served as a monumental tomb for Celsus, who was entombed in a sarcophagus beneath the building. Since it was generally unusual to be buried within a library or within city walls, the monument underlines the extent to which the Ephesians appreciated and honoured their benefactor. The library was open to the public and reflects the importance of literacy, literature and books even in the provinces. Nothing remained of the library's interior after it was destroyed by fire in $262 \mathrm{CE}$. The surviving parts were transformed around $400 \mathrm{CE}$ into a nymphaeum-a monument or fountain dedicated to the nymphs. The façade was destroyed in the Byzantine period, but reconstructed by Austrian archaeologists in the 1970s. ${ }^{13}$

The situation took a turn for the worse in later centuries. Plans for storing the imperial book collections and patriarchal archives have not been found anywhere, even in the capital of the East Roman Empire. Byzantine monastic libraries partly save the day, since they reflect the medieval habit of storing and collecting books (at the monasteries of Mount Athos or St John on the island of Patmos, for example). Hidden manuscripts can also be detected-at the Monastery of St Catherine at Mount Sinai, for instance. ${ }^{14}$

11 Hunger 1984, a study on the regulation of daily life by the Byzantine administration.

12 See the overview on ancient libraries by Hoepfner 2002.

13 Hoepfner 2002, 123-126; Wiplinger/Wlach 1996, 31-36, 124-127.

14 The New Finds of Sinai 1999. 


\section{Archives}

Ever since classical Greek historiography began, the term archeion (ảpxciov) has designated a wide range of things: (a) a town hall, residence, or office of chief magistrates, (b) public records, archives, (c) a college or board of magistrates, magistracy, and (d) a headquarters in a military camp..$^{15}$ However, in many instances, 'library' and 'archive' cannot be clearly differentiated.

Although the Byzantine administrative system was one of the most elaborate of the Middle Ages, continuing in the same vein as the Roman tradition, tax lists, land registries, military lists or maps are almost non-existent. A unique example of a copied cadastre is preserved in the manuscript Vaticanus graecus 215 (representing eleventh- and twelfth-century tax lists from the Greek town of Thebes). ${ }^{16}$ Fragments of account books from the late Byzantine period have been preserved. ${ }^{17}$ The situation is all the more tragic, given that Constantine I decided to transform Constantinople into his primary residence within the Empire. It goes without saying that Constantinople became the administrative centre as well. It needed archives that kept track of any information dealing with the emperor's subjects. But where were they housed? Several years ago, Christopher Kelly discussed a unique example of a possible imperial archive in a study devoted to Late Roman bureaucracy. ${ }^{18}$ He focused on structures under the Hippodrome of Constantinople that were attached to the imperial palace: the British expedition of 1927 recorded that five rooms roughly rectangular in shape (approx. 3.5 to $8 \mathrm{~m}$ ) were found in the substructures of the Hippodrome's south-eastern side. They opened out onto a corridor lit by high arched windows. A total of 25 to 30 such rooms could have been situated between the imperial box in the hippodrome and the so-called Sling (sphendone, $\sigma \varphi \varepsilon v \delta o ́ v \eta)$. These rooms offered an impressive amount of storage space and provided a steady temperature and optimum fire protection, since they were embedded into the foundations of the enormous building complex. Kelly's line of argument seems convincing as the rooms were integrated into the system of the imperial palace. This archaeological record can be combined with a passage from John the Lydian, who lived in the sixth century and wrote an instructive work on the administration of the Empire. John reports:

\footnotetext{
15 Liddell/Scott/Jones 1996, s.v. ápxeĩov.

16 Svoronos 1959.

17 Edited and commented by Schreiner 1991.

18 Kelly 1994.
} 


\begin{abstract}
Also closely attached to the scrinium of the commenta was the so-called instrumentarius, namely, 'document-guardian of the archives of the court of justice,' for signing and filling in the decision-records. And an area has been set aside for him from olden times in the Hippodrome to the South below the Emperor's balcony down to the so-called 'Sling'; and all the matters that have been transacted since the reign of Valens in the greatest courts of justice at that time are preserved there and are available to those who ask for them in such a way as if they had been transacted yesterday by chance. ${ }^{19}$
\end{abstract}

Since hardly any physical evidence of archives can be traced, it is necessary to consider other strategies for reconstructing or defining space for storing docu-

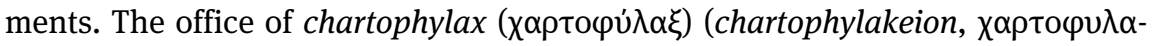
кعĩov) was an influential post in the patriarchal administration and illustrates the importance of preserving documents, including books, that had to be available for providing documentary evidence and substantiation. ${ }^{20}$ The position is first mentioned in the acts of the Synod of Constantinople in 530. The chartophylax was responsible for managing the patriarchal archive, but there was no sharp distinction made between storing charters and storing books. According to Anastasius, a learned ecclesiastic of the ninth century, the chartophylax was the guardian of records and performed the same duties within the Church of Constantinople as the bibliothecarius in Rome. The chartophylax rose to become one of the most powerful officials in the patriarchal administration. He was responsible both for correspondence and for introducing clerics to the patriarch. He wrote down the decisions of the patriarch, who then signed and sealed them. The relationship between the chartophylax and the patriarch has been compared to that of Aaron and Moses, emphasising the high esteem in which the position was held. ${ }^{21}$ The chartophylax took precedence over the bishops in elective assemblies, general meetings outside the patriarchal palace and in public ceremonies. From the twelfth to the fifteenth century, the chartophylax continued to be the right hand of the patriarch.

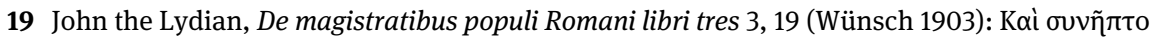

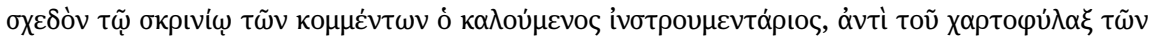

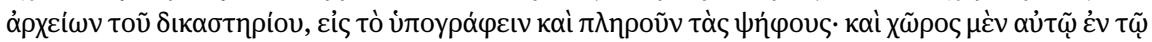

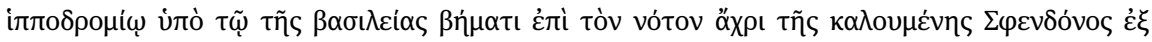

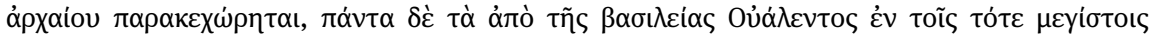

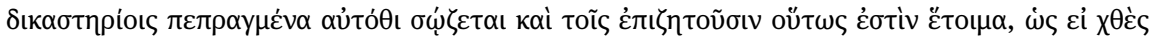

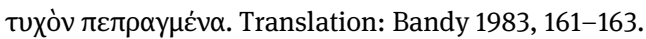

20 Leontaritou 1996, 628-660.

21 The chartophylax Nikephoros; see Krausmüller 2014, 120. 
There is a document preserved in the collection of Patriarch Nicholas Mystikos (901-907 and 912-925), who started his career in the civil service as a mys-

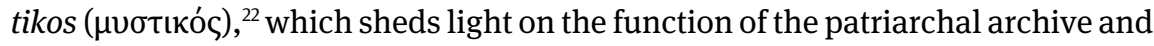
its sophisticated organisation. The heading of the text reads as follows: 'The patriarch Nicholas the Ancient: that the patriarchal letters should be made available free on request, according to the text preserved in the archives'. ${ }^{23}$ After some remarks about the old custom of using archives, the document focuses on the office of chartophylax:

Its keeper (of the chartophylakeion), who bears the title of ostiarius, used to demand fees from those who requested patriarchal letters, in payment for the copy, a thing he should not have done; the practice was utterly outrageous and preposterous, one that besides rousing God's wrath was also an insult to this venerable place and compromised the very dignity of the priesthood. In order to preclude any pretext on the part of the ostiarius, however, we have fixed an annual salary for him and have consigned this evil practice to utter oblivion and everlasting banishment. Decreeing in the name of the Holy Spirit that henceforth it shall in no way be tolerated, we enjoin upon those who shall successively hold the office of chartophylax and upon the scribes at their disposal to maintain the present regulation and to see to it at all times that no indifference or negligence (an eventuality which it is sinful even to envisage, let alone to bring about) shall lead to the smallest infringement. ${ }^{24}$

This passage reflects the need to keep information available and accessiblereading and copying documents seem to have been normal procedures.

There were other forms of documentation besides the patriarchal and imperial archives. It seems that civil servants regularly officiated at their homes in Late Antiquity, coinciding with the decline of public buildings. ${ }^{25}$ Houses and palaces served as administrative buildings in Byzantine times as well. Michael Hagiotheodorites, who lived in twelfth-century Constantinople and held the office of

22 Magdalino 1984; the mystikos is a confidant of the emperor.

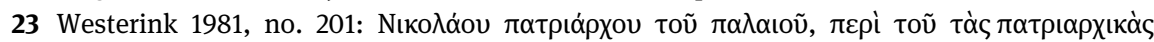

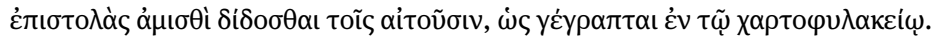

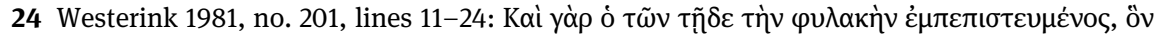

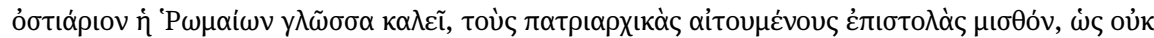

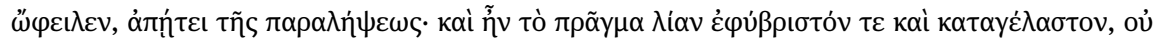

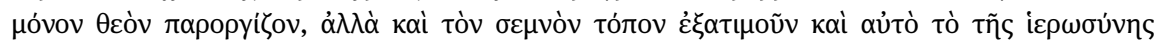

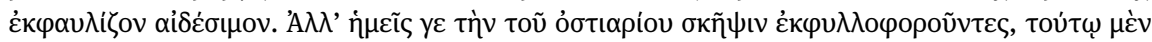

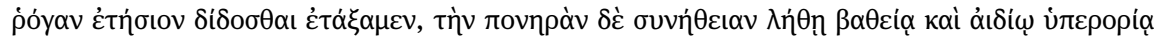

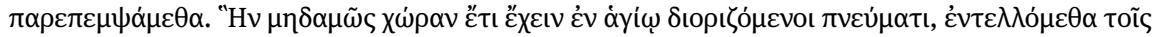

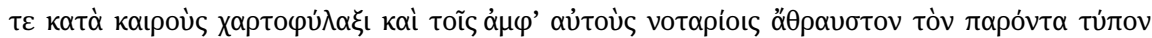

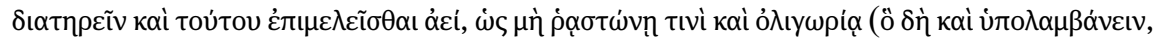

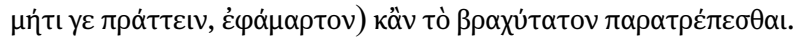

25 Saradi 1993, 22-23. 


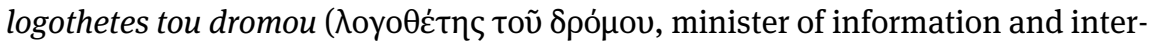
nal affairs), owned a palace that was besieged by petitioners. It transpires that the high official also stored at least some of his files at home. ${ }^{26}$ During the riots prior to the usurpation of Andronikos (I) Komnenos in 1183, many palaces and rich people's homes were attacked and destroyed. ${ }^{27}$ Even the oikos belonging to Theodoros Pantechnes, Eparch of Constantinople (the governor of the city), was plundered by the mob. Theodoros was able to escape, but the contents of his palace were ravaged. As Nicetas Choniates, the principal historian of the last decades of the twelfth century, reports: ${ }^{28}$

They did not confine these activities only to the vicinity of the Milion but also gathered at the turning post of the magnificent Hippodrome while they faced the palace. When this was repeated over many days, the populace was incited to open rebellion. In a rage, many wilfully pulled down the most splendid dwellings and plundered their furnishings while the protosebastos ( Among these was the beautiful residence of Theodore Pantechnes, the eparch of the City, who presided over the probate court, distinguished himself on the judge's bench, and saved his own life by taking flight. The mob carried off everything within, even the public law codes containing those measures which pertained to the common good of all or to the majority of citizens; these were powerless before the craving for private gain and could not wet the winebibber's pharynx. ${ }^{29}$

This habit did not change until the end of the Byzantine Empire, as is echoed in the satire of Mazaris. It was written in the fifteenth century, but reflects practices

26 See the oration of Constantine Manasses addressed to Hagiotheodorites, Horna 1906, 182,

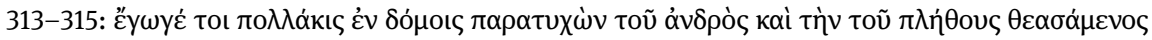

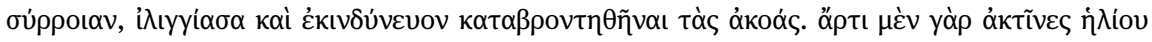

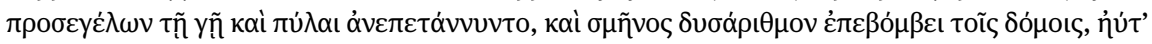

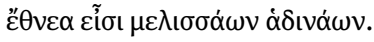

27 Nicetae Choniatae historia 235, 12-14 (van Dieten 1975).

28 Ibid., 14-17 (van Dieten 1975).

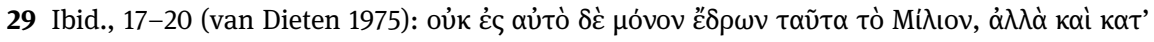

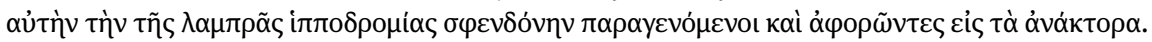

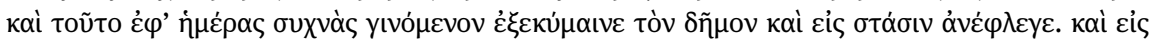

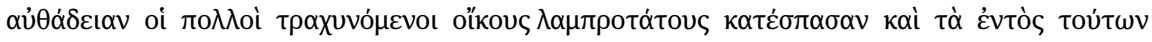

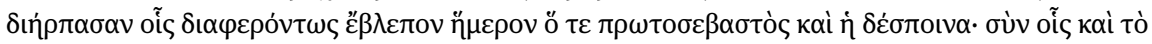

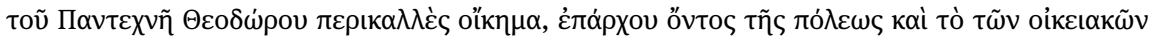

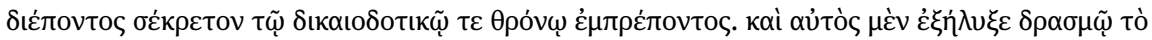

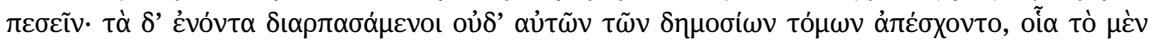

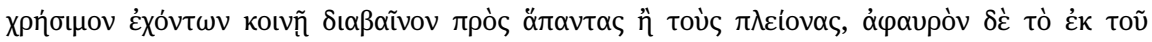

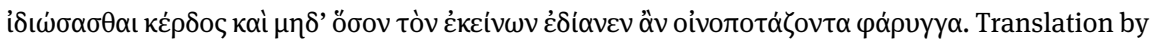
Magoulias 1984, 132-133; see Grünbart 2015, 128. 
common in the middle Byzantine period. Officials still kept their archives and files at home (including charters and golden bullae). When the health of the protagonist Mazaris began to deteriorate rapidly, the emperor ordered all documents to be stolen from his household and brought to safety; if the emperor had not acted in this fashion, Mazaris would have burnt all of the documents. The passage in the satire reads as follows:

Fourth and last: when the invincible Emperor heard from vampires in the medical profession that there was no hope for me, he began to worry that my nephew Alexios the Varmint might also steal the Golden Bulls and Divine Decrees I had in my possession, some already signed in red ink, some still without [a] signature, as well as the box in which I kept written records of everything, just as he had stolen my personal effects the way I told you. ${ }^{30}$

There are a few cases where archives can be reconstructed from collections of documents or bundles of papers: the compilations of two high officials are preserved from thirteenth-century Byzantium, namely Demetrios Chomatenos and John Apokaukos. Both were leading figures within the ecclesiastical hierarchy in the regions of Epirus and central Greece. The miscellaneous manuscripts include both letters and juridical documents which reflect and preserve the character of private archives in the provinces. ${ }^{31}$

\section{Libraries}

In Byzantine sources, the terms bibliotheke and more commonly chartophylakeion were used to describe collections of documents. No clear distinction can generally be made between the terms, although chartophylakeion refers more to charters and documents that were not necessarily books.

The emperor Constantine also founded a library that became the central repository for storing knowledge, since municipal libraries increasingly disappeared in the last few centuries of the Roman Empire (especially in the West). ${ }^{32}$ The imperial library left only a few traces in written sources, however; it was damaged by fire

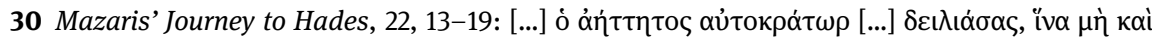

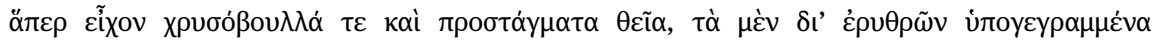

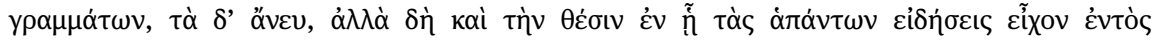

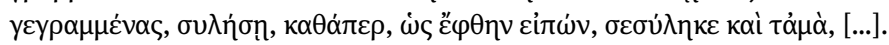

31 Prinzing 2002; Magdalino 1987.

32 Wendel 1942. 
several times, and information on its dimensions remains rather vague. It was frequently used nonetheless: books were borrowed to be consulted during court meetings. The newly founded library, which was possibly open to the public and attached to a scriptorium, was recorded under Emperor Constantius II and Julian (who possibly expanded it); Valens and Theodosius II supported the library, but it was burnt down in 475 (when 120,000 volumes were reportedly destroyed). An 'im-

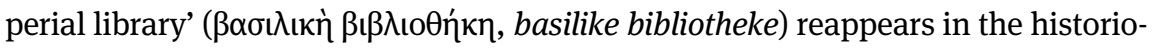
graphical writings from the court of Constantine VII Porphyrogenitus. The eleventh and twelfth centuries saw the emergence of an increasingly learned stratum in society centred in the capital that went hand in hand with an accumulation of manuscripts and documents. ${ }^{33}$ Book collections were also attached to 'schools' and mon-

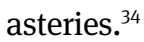

The so-called Fourth Crusade marked the end of a prospering period: the city of Constantinople suffered three fires before the crusaders captured the city in 1204 . It is possible that some losses were incurred, but there is no indication of the existence of a formal imperial library at the time and no source that mentions lost manuscripts kept in the palace. ${ }^{35}$ If there was a library in the palace, it most certainly ceased to exist in 1204 at the latest. In the remaining parts of the Empire, attempts were undertaken to build up collections of books. John III Doukas Vatatzes (r. 12221254), ruler of the 'exiled' Empire of Nicaea, is the only Byzantine emperor on record to have founded several collections of books which were open to the public. After the re-installation of the Empire in 1261, the administrative centre returned to Constantinople and intellectual life resumed. ${ }^{36}$ Books from a reinstated imperial library' were housed in the Chora monastery in the late thirteenth century; in 1437, the traveller Pero Tafur described a small library in the Blachernai Palace.

It goes without saying that the emperor and the patriarch possessed the richest collections of books. A patriarchal library is first attested under Patriarch Sergios I in the seventh century. George of Pisidia wrote a poem celebrating the patriarch's collection:

You gaze upon a collection of God-written books, the Patriarch Sergios's property; through these the spiritual meadow grows and fills the earth with incense for the soul

33 For general information on the learned circles in the capital, see the volume by Steckel/ Gaul/Grünbart 2014; on the so-called university at Constantinople see Speck 1974.

34 Fuchs 1926.

35 Madden 1992.

36 See Constantinides 1982. 
and grafts new shoots of fruitless hearts.

You who behold the grace of paradise

And who see here the harvests of the teachers,

Be not troubled lest you observe, among the roses,

Thorns; for no bramble can grow up beside them

In a garden mystically worked by hoes. ${ }^{37}$

Libraries were an important resource for synods and theological discussions, as various examples will show. The patriarchal library is mentioned a couple of times in the context of the Ecumenical Council at Nicaea supporting the iconophile movement in 787. The majority of books displayed and used during the ecclesiastical meeting came from the patriarchal library; seventy books are recorded, fifty of which were stored there. It is possible to imagine the process of retrieving and reshelving books from various passages in the records:

We have come bearing the holy books which we have brought from those deposited in the library of the Holy Patriarch of Constantinople, namely the canons of the Holy Apostles and of the holy Synods, and the books of our holy Father Basil and of the other holy Fathers. ${ }^{38}$

Further detailed information is provided:

Patriarch Tarasios (in office from 784-806) said: Yesterday the abbot of Maximinus gave us the leimonarion ( $\lambda \varepsilon \varepsilon \mu \omega v \alpha$ ópıov, i.e. a collection of sayings of the Church Fathers) and it was read; and we, too, have found in the library a copy of the same leimonarion, which had the folia dealing with icons cut out. ${ }^{39}$

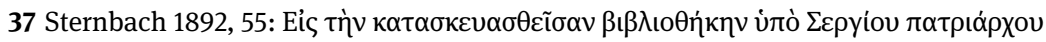

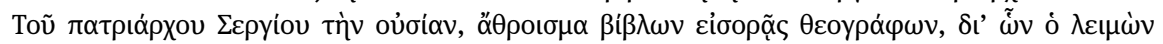

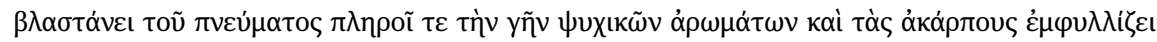

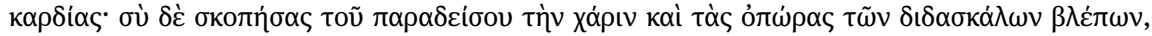

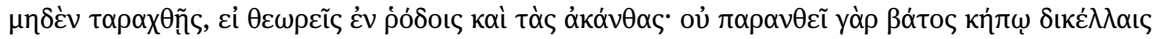

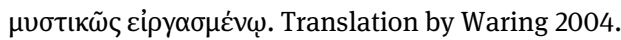

38 Sacrorum conciliorum nova et amplissima collectio, XII 1019D (Mansi 1960): Katà tìv

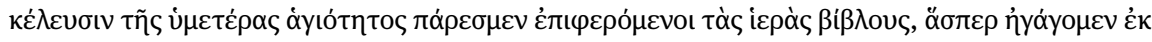

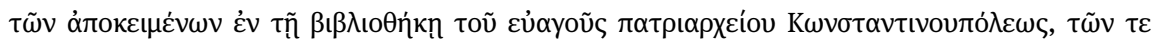

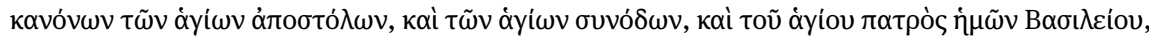

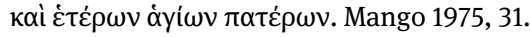

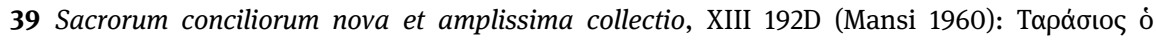

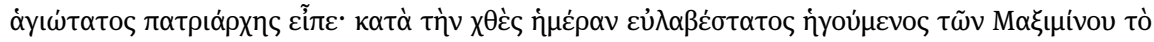

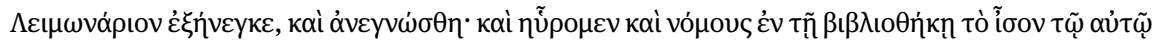

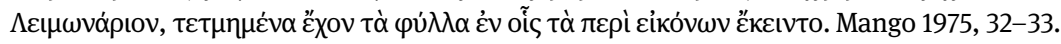


In preparation for the synod of 815, books were collected from churches and monasteries all over Constantinople, however, as the holdings of both the patriarchal and imperial libraries proved insufficient. ${ }^{40}$

As mentioned previously, the reconstruction of libraries relies heavily on written sources. In addition to protocols of theological debates and historiographical texts, information on the organisation of libraries is also provided by the works of scholars who had access to books or were able to find manuscripts

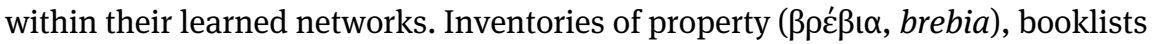
and wills ( $\delta\llcorner\alpha \theta \tilde{\eta} \kappa \alpha \mathrm{l}$, diathekai) reflect the private use of manuscripts; monastic

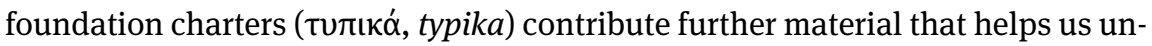
derstand the economic and social capital generated by books. ${ }^{41}$ Library lending lists represent promising sources that shed further light on the contents of monastic book collections. ${ }^{42}$

The private collections of learned men such as Photios, Arethas, Michael Psellos, John Tzetzes and Michael Choniates allow us to reconstruct which books they possessed and what reading habits they had. An example which is often quoted is the so-called Myriobiblon ('Thousand Books') or Bibliotheke ('Library'). It was written by Photios, patriarch of Constantinople, in the middle of the ninth century and is a central document for tracking down texts in Byzantine book collections of that period. ${ }^{43}$ It comprises around 280 texts or codices in the form of notes, commentaries and excerpts from classical authors. Photios preserves unique passages written by classical writers such as Ktesias, Memnon of Heraclea, Konon, Diodoros Sikulos or Arrian. The florilegium does not contain any ancient poetry or philosophical texts, however. Photios provides commentaries on the authors excerpted in his work. His notes vary in length, but they nevertheless provide insights into both the appreciation and interpretation of classical authors in Byzantium and the availability of texts in the capital (there was a great deal of discussion about Photios' access to the texts he analysed).

40 Mango 1975.

41 The publication of Typika includes a useful index containing many references to books, inventories and libraries; see Thomas et al. 2000.

42 Waring 2002 (focusing on the monastery of St John at Patmos); Oikonomides 1988 investigated documents from the Athonite libraries concerning levels of literacy.

43 Treadgold 1980, the text of Photios partly translated by Wilson 1992. 
Scholars sometimes left traces of their thinking in manuscripts in the form of annotations or short commentaries; John Tzetzes, for example, wrote in the margins of the codex now known as Heidelbergensis $252 .{ }^{44}$ Eustathios of Thessaloniki bequeathed autograph manuscripts reflecting his work on the epics of Homer. ${ }^{45}$

However, writing notes in books or adding passages to documents could cause serious problems. John Tzetzes tells a story to this effect in one of his letters. Byzantine letter collections intrinsically reflect the idea of storing archival material or arranging a copybook. Many of them were copied and survived because they provided templates for people to write their own compositions. They also preserved an image of the personality of the writer. ${ }^{46}$ Information on normal daily procedures can sometimes be detected, such as Tzetzes writing to the official John Smeniotes, who went to Greece in order to collect taxes. ${ }^{47}$ The passage in question reads as follows:

I beg you, writing this letter, if you meet the governor of the thema ( $\theta \varepsilon \dot{\mu} \mu \alpha$, province), please try to persuade him not to punish the boy who wrote verses at the bottom of a legal document. The boy did the same thing in a document of yours some time ago, writing his iambs at the end of the document. ${ }^{48}$

While unauthorised additions to a document-or 'paratexts' according to the definition by Jean Genette-could compromise the validity of the document; however, such short texts enrich the reconstruction of contemporary literary taste and the Byzantine poetry tradition. ${ }^{49}$

Wills offer detailed insights into private book collections and libraries. Several documents are preserved and many of them have already been translated. Collections belonging to high officials such as Eustathios Boilas or Michael Attaleiates have been studied (both eleventh century). These libraries were often

44 Luzzatto 1999.

45 See Cullhed 2012, who recently dealt with manuscripts written by Eustathios.

46 Grünbart 2015b.

47 Grünbart 1996, 120.

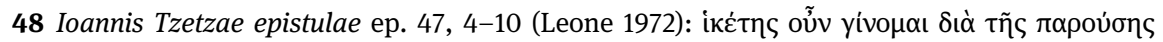

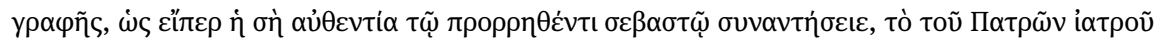

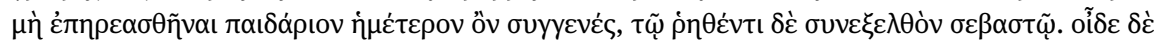

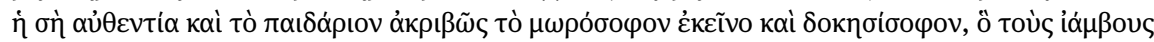

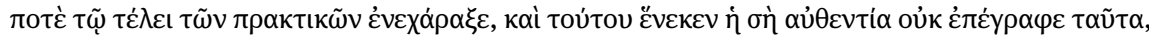

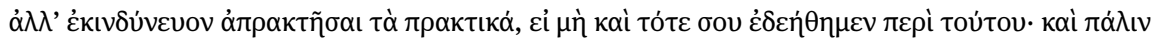

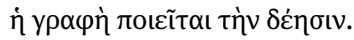

49 Genette 2001. There is a project at Ghent University devoted to this kind of text; see 'Book Epigrams from Medieval Greek Manuscripts. Compilation of an Unexplored Corpus and Creation of a Searchable Database'; http://www.dbbe.ugent.be/about. 
donated to monasteries which were founded or supported financially by local benefactors. Books and other precious objects are mentioned in the monastic foundation charters, such as a famous and much-discussed will written by Eustathios Boilas, an eminent provincial magnate in the first half of the eleventh century. In 1059, he wrote his will somewhere at the eastern frontier of the Empire and it was copied into a manuscript. Eustathios possibly lived in Edessa in Syria after fleeing eastwards from Cappadocia. He accumulated a large fortune and owned an estate which included a chapel dedicated to the Mother of God; this was where he wanted to be buried. ${ }^{50}$ He listed around 90 books starting with a precious gospel (written in gold letters and featuring images of the evangelists). ${ }^{51}$ His collection included theological works, but also the Alexander romance Leucippe, a dream book, and collected letters of Isidore of Pelusium. There is a similar example of a private library belonging to Michael Attaleiates, who studied law and worked in the judicial system. He composed a work known as the Diataxis ( $\delta\llcorner\alpha \dot{\tau} \alpha \xi \iota)$, an Ordinance for the Poor House and Monastery, which he founded in Constantinople in the mid-1070s. It provides invaluable information regarding Attaleiates' microcosm and includes a catalogue of around fifty books, plus an additional thirty from other sources available in the monastery's library. ${ }^{52}$ Although theological and liturgical books again predominate, a book on earthquakes and thunder also found its way into the collection. Comparing these two documents, the description of items focuses on their appearance and script-the most precious pieces are bibles, possibly for home use. It is important to list all books, and Attaleiates mentions a 'catalogue' in his Diataxis. Counting the books in documents of this kind, the number of items does not normally exceed 100. While charters and archival material are not usually mentioned in listings such as these, it may be taken for granted that they contained other items of information as well concerning the donor person. Monasteries were a safe harbour for books and manuscripts, since they were constructed for eternity and relatively safe from imperial and fiscal afflictions.

Why were documents stored? Byzantines were aware of the importance of the written word, as the poet Theodore Prodromos remarks in a speech addressed to John Agapetos, Patriarch of Constantinople from 1111 to 1134:

50 Vryonis 1957; Lemerle 1977, 15-63 (Le testament d'Eustathius Boilas).

51 The design and materiality of the books in Eustathios' collection is discussed by Parani/Pitarakis/Spieser 2003.

52 Edition Lemerle 1977, 67-112 (La diataxis de Michel Attaliate (mars 1077)) and Gautier 1981, English translation Talbot 2000, 358-359, 367-369. 
Books are among life's major necessities, because they have the function of memory and they are most effective against time .... But while the things themselves have grown old with time, their memory flourishes in books. ${ }^{53}$

It has become apparent that archives and libraries housed information and stored records such as registers of land, lending contracts and property-possession certificates. ${ }^{54}$ Information on ethnography, explanations of natural phenomena and handbooks were also kept. Archives and libraries turned into resources for decision-making as they housed documents that served as guides for composing charters or writing letters, for example.

Another aspect is the notion of social capital-or prestige-and self-image. Education was a social marker in Byzantium, just as it was in many other societies. But sponsoring poets and displaying knowledge became a sign of distinction and exclusivity, ${ }^{55}$ as can be demonstrated conclusively by means of an example. Foundation documents composed by an important figure in twelfth-century Byzantium have been preserved. Isaac Komnenos (who held the title of sebastokrator) donated his fortune to the monastery of Kosmosoteira at Pherrai in Thrace, which he chose as his burial place. Besides organising the processes in the mon-

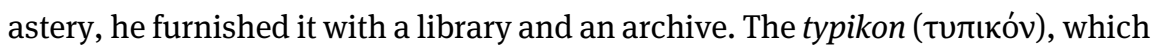
can be dated to 1152, offers some detailed insights. Firstly, the patron wanted to be sure that all documents were kept in a safe place:

Since the original documents for the immovable [properties] assigned to the monastery and to the old-age infirmary have been given to the superior, and copies of the originals have been authorized with an indication from the bishop, the superior must not exhibit the originals when they are requested, but their copies. For the originals must be stored in a secure storehouse for all time, along with the original inventory and this typikon. Copies of these should always pass through the hands of the superior and the rest of the monks, for reference. For these are my commands, this is the way I want what must be done to be done.

All the things proposed with the idea of bringing to completion the construction work going on at the monastery, if they are not made ready during my sorely troubled life, if something

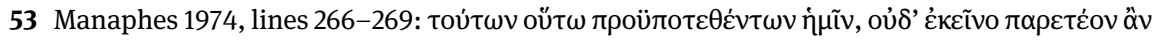

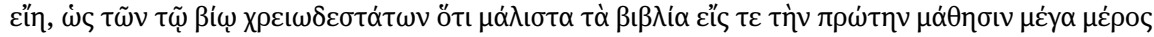

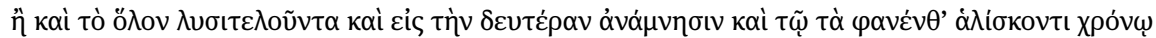

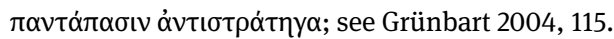

54 Oikonomides 1997.

55 See Grünbart 2015, 171-188. 
is still left incomplete for the repose of the monks and of their servants, let it too be completed without hesitation and without fail by the superior, lest the entire project be unfinished. ${ }^{56}$

Secondly, John Komnenos wished to create a place where the monks should commemorate their benefactor:

I have bequeathed some books to the monastery (how many there are is indicated by [the list of] their titles in the inventory of the monastery). I bequeathed another book in addition to these, one that I composed with great effort. It [contains] heroic, iambic and political verse, as well as various letters and ekphraseis. I do not want this [book] to lie in an obscure place, but to be displayed often as [something to] read (and in memory of me) to those especially industrious men (and they [are the ones who] want to come upon books and pictures). I do not wish these books to be alienated by the monastery, but to survive here forever. $^{57}$

This passage clearly demonstrates the wish of an eminent person to stay alive in the memory of later generations. Besides keeping his portrait, a copy of which was also stored in the monastery, literary works and letters were thought to be the best way to remember and honour a donor. Again, the notion of securing information and authoritative self-representation is shimmering through these lines.

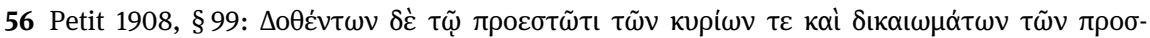

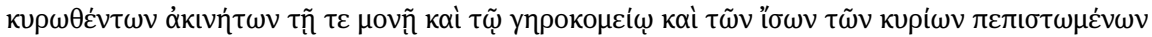

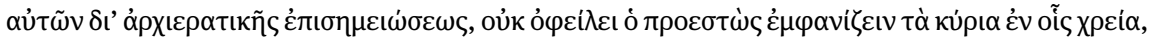

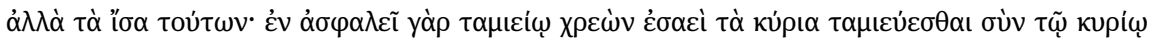

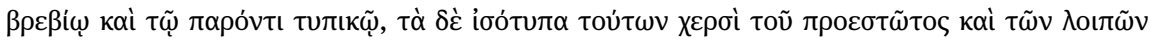

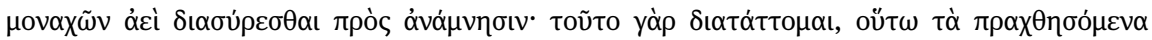

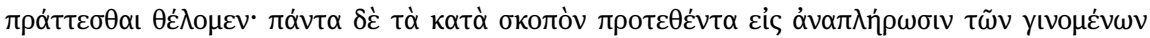

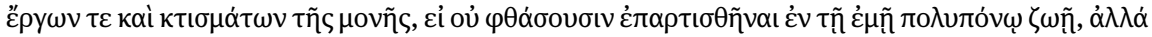

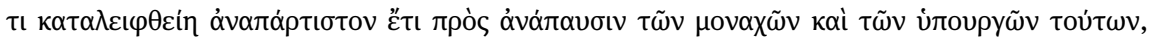

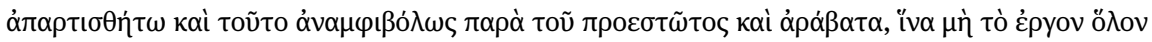

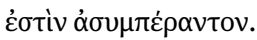

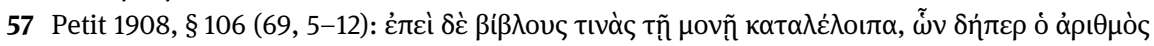

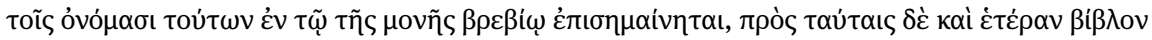

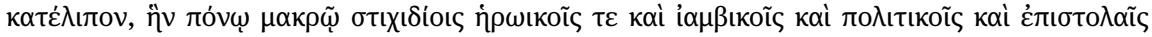
$\delta ı \alpha \varphi \rho_{\rho}$

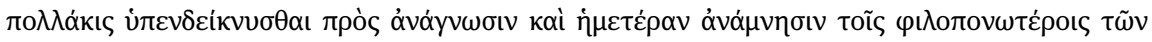

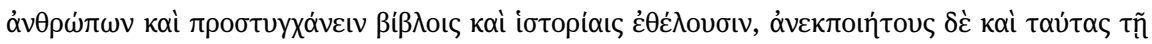
$\mu$ 


\section{Concluding remarks}

Byzantium was a society based on written communication and administration. It goes without saying that literacy and written documents played an important role at all levels of society in Byzantium. Even on the market-place a basic knowledge of letters (on weights, sun-dials, coins etc.) can be assumed.$^{58}$ However, traces of the administrative aspects of daily life and information concerning the storage of documents are sparse. Our current reconstruction of the structure of archives and libraries is primarily based on written sources since archaeological research has not unearthed many remains of these containers of knowledge and memory so far. The administration was centred in the capital, Constantinople, but it was rather loosely organised as some high officials had their offices and archives in their own palaces. 'Semi-private' archives like these were vulnerable and provided easy targets during times of turmoil.

'Central' libraries existed in the capital of the Byzantine Empire. The function of the imperial and patriarchal libraries is clear: to keep records and collect knowledge. 'Back-up copies' are even mentioned in Byzantine sources, since duplicating documents supported their durability. Availability of information was essential for the imperial government in terms of controlling the distribution of goods, making decisions and preparing for diplomatic action. In the event of ecclesiastical controversies, the archives became important resources for reference and verification. They were containers of knowledge which supported the authority of both the secular and the ecclesiastical ruler. Collections of documents were also a strong weapon against oblivion. Byzantine donors and patrons were aware of the function that could be assumed by a manuscript, a collection of books or even a library. The best way to be remembered in future was to donate a collection to monasteries as they were built to last eternally. Preserving the name of a donor or patron fits perfectly with the competitive habits of aristocratic families in Constantinople: sponsoring literature and accumulating manuscripts became a social marker and a sign of distinction.

58 Hunger 1984; see Grünbart forthcoming. 


\section{References}

Bandy, Anastasius C. (ed.) (1983), Ioannes Lydus On Powers, or The Magistracies of the Roman State, introduction, critical text, translation, commentary, and indices (Memoirs of the American Philosophical Society, 149), Philadelphia: American Philosophical Society.

Constantinides, Costas (1982), Higher Education in Byzantium in the Thirteenth and Early Fourteenth Centuries (1204- ca. 1310) (Texts and Studies of the History of Cyprus, 11), Nicosia: Cyprus Research Centre.

Cullhed, Eric (2012), 'The Autograph Manuscripts Containing Eustathius' Commentary on the Odyssey', in Mnemosyne, 65, 445-461.

Fuchs, Friedrich (1926), Die höheren Schulen von Konstantinopel im Mittelalter, Leipzig, Berlin: Teubner.

Gautier, Paul (1981), 'La Diataxis de Michel Attaliate', in Revue des Études Byzantines, 39, 5-143.

Genette, Gérard (2001), Paratexts: Thresholds of Interpretation, Cambridge: Cambridge University Press.

Grünbart, Michael (1996), 'Prosopographische Beiträge zum Briefcorpus des loannes Tzetzes', in Jahrbuch der österreichischen Byzantinistik, 46, 175-226.

Grünbart, Michael (2004), 'Byzantium - a Bibliophile Society?’, in Basilissa, 1, 113-121.

Grünbart, Michael (2015a), Inszenierung und Repräsentation der byzantinischen Aristokratie vom 10. bis 13. Jahrhundert, Paderborn: Wilhelm Fink.

Grünbart, Michael (2015b), 'From Letter to Literature - a Byzantine Story of Transformation', in Christian Høgel and Elisabetta Bartoli (eds), Medieval Letters: Between Fiction and Document (Utrecht Studies in Medieval Literacy), Utrecht: Brepols, 291-306.

Grünbart, Michael (forthcoming), Die Macht der Buchstaben im byzantinischen Alltag, Berlin: LIT.

Haldon, John F. (ed.) (1990), Constantine Porphyrogenitus, Three Treatises on Imperial Military Expeditions. Introduction, Edition, Translation and Commentary (Corpus Fontium Historiae Byzantinae, 23), Vienna: Verlag der österreichischen Akademie der Wissenschaften.

Harlfinger, Dieter (ed.) (1980), Griechische Kodikologie und Textüberlieferung, Darmstadt: Wissenschaftliche Buchgesellschaft.

Hoepfner, Wolfram (2002), Antike Bibliotheken, Mainz: von Zabern.

Holmes, Catherine, and Judith Waring (eds) (2002), Literacy, Education and Manuscript Transmission in Byzantium and beyond (The Medieval Mediterranean, 42), Leiden: Brill.

Horna, Konstantin (1906), 'Eine unedierte Rede des Konstantin Manasses', in Wiener Studien, 28, 171-204.

Hunger, Herbert (1984), 'Die Herrschaft des “Buchstabens”. Das Verhältnis der Byzantiner zu Schrift- und Kanzleiwesen', in Deltion of the Christian Archaeological Society, IV 12, $17-$ 38.

Hunger, Herbert (1989), Schreiben und Lesen in Byzanz. Die byzantinische Buchkultur, Munich: C.H. Beck, ('Buch und Gesellschaft. Bibliotheken'), 130-136.

Jagoda Luzzatto, Maria (1999), Tzetzes lettore di Tucidide. Note autografe sul codice Heidelberg Palatino greco 252 (Paradosis, 1), Bari: Dedalo.

Kelly, Christopher (1994), 'Later Roman Bureaucracy: Going through the Files', in Alan Bowman and Greg Woolf (eds), Literacy and Power in the Ancient World, Cambridge: Cambridge University Press, 161-176. 
Krausmüller, Dirk (2014), 'Establishing Authority in the Constantinopolitan Religious Discourse of the Eleventh Century: Inspiration and Learning in the Writings of the Monk Niketas Stethatos', in Sita Steckel, Niels Gaul and Michael Grünbart (eds), Networks of Learning. Perspectives on Scholars in Byzantine East and Latin West, c. 1000-1200 (Byzantinistische Studien und Texte, 6), Berlin: LIT, 107-124.

Lemerle, Paul (1977), Cinq études sur le Xle siècle byzantin, Paris: Éd. du Centre Nationale de la recherche scientifique.

Leone, Petrus A. (ed.) (1972), loannis Tzetzae epistulae, Leipzig: Teubner.

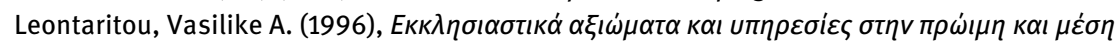

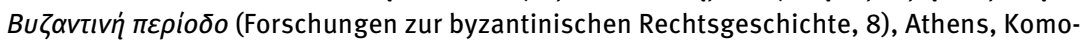
tene: Sakkulas.

Liddell, Henry George, Robert Scott, Henry Stuart Jones and Roderick McKenzie (1996), GreekEnglish Lexicon, Oxford: Oxford University Press.

Madden, Thomas F. (1992), 'The Fires of the Fourth Crusade in Constantinople, 1203-1204: A Damage Assessment', in Byzantinische Zeitschrift, 84/85, 72-93.

Magdalino, Paul (1984), 'The Not-so-secret Functions of the Mystikos', in Revue des Études Byzantines, 42, 229-240.

Magdalino, Paul (1987), 'The Literary Perception of Everyday Life in Byzantium: Some General Considerations and the Case of John Apokaukos', in Byzantinoslavica, 48, 28-38.

Magoulias, Harry J. (1984), O city of Byzantium. Annals of Niketas Choniates, Detroit: Wayne State University Press.

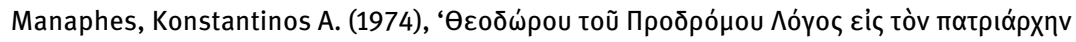

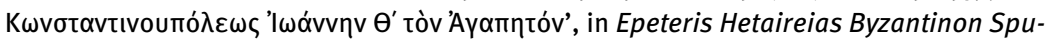
don, 41, 223-242.

Mango, Cyril (1975), 'The Availability of Books in the Byzantine Empire, A.D. 750-850', in Byzantine Books and Bookmen, Dumbarton Oaks: Center for Byzantine Studies, 29-45.

Mansi, Giovanni Domenico (1960), Sacrorum conciliorum nova et amplissima collectio, 1-31, Graz: Akademische Druck- und Verlagsanstalt.

Mazaris' journey to Hades or interviews with dead men about certain officials of the imperial court. Greek text with translation, notes, introd. by Seminar Classics 609, State University of New York at Buffalo, Buffalo: Arethusa 1975.

Netz, Reviel, William Noel, Natalie Tchernetska and Nigel Wilson (eds) (2011), The Archimedes Palimpsest. 1. Catalogue and Commentary, 2. Images and Transcriptions, Cambridge: Cambridge University Press.

Oikonomides, Nicolas (1988), 'Mount Athos: Levels of Literacy', in Dumbarton Oaks Papers, 42, 167-178.

Oikonomides, Nicolas (1997), 'Byzantine Archives of the Palaiologan Period, 1258-1453', in Richard Britnell (ed), Pragmatic Literacy, East and West, 1200-1330, Woodbridge: Boydell Press, 168-197.

Parani Maria, Brigitte Pitarakis and Jean-Michael Spieser (2003), 'Un exemple d'inventaire d'objets liturgiques. Le Testament d'Eustathios Boilas (Avril 1059)', in Revue des Études Byzantines, 61, 143-165.

Petit, Louis (1908), 'Typikon du monastère de la Kosmosotira près d'Aenos (1152)', in Izvestija Russkago Archeologičeskago Instituta v Konstantinopol'e, 13, 17-75.

Prinzing, Günter (ed.) (2002), Demetrii Chomateni Ponemata diaphora (Corpus Fontium Historiae Byzantinae, 38), Berlin, New York: De Gruyter. 
Saradi, Helen (1993), 'Privatization and Subdivision of Urban Properties in the Early Byzantine Centuries: Social and Cultural Implications', in The Bulletin of the American Society of Papyrologists, 30, 17-43.

Schreiner, Peter (1991), Texte zur spätbyzantinischen Finanz- und Wirtschaftsgeschichte in Handschriften der Biblioteca Vaticana (Studi e testi, 344), Rome: Biblioteca Apostolica Vaticana.

Ševčenko, Nancy Patterson (2000), 'Kosmosoteira: Typikon of the Sebastokrator Isaac Komnenos for the monastery of the Mother of God Kosmosoteira, near Bera', in John P. Thomas and Angela Constantinides Hero (eds), Byzantine Monastic Foundation Documents, Washington, DC: Dumbarton Oaks Research Library and Collection 2, 782-857.

Speck, Paul (1974), Die Kaiserliche Universität von Konstantinopel (Byzantinisches Archiv, 14), Munich: Beck.

Steckel, Sita, Niels Gaul, and Michael Grünbart (eds), Networks of Learning. Perspectives on Scholars in Byzantine East and Latin West, c. 1000-1200 (Byzantinistische Studien und Texte, 6), Berlin: LIT.

Sternbach, Leo (1892), 'Georgii Pisidae carmina inedita', in Wiener Studien, 14, 51-68.

Svoronos, Nicolas (1959), 'Recherches sur le cadastre byzantin et la fiscalité aux Xle et XIle siècles: Le cadastre de Thèbes', in Bulletin de Correspondance Hellénique, 83, 1-145.

Talbot, Alice-Mary (2000), 'Attaleiates: Rule of Michael Attaleiates for his Almshouse in Rhaidestos and for the Monastery of Christ Panoiktirmon in Constantinople', in John P. Thomas and Angela Constantinides Hero (eds), Byzantine Monastic Foundation Documents, Washington, DC: Dumbarton Oaks Research Library and Collection 1, 326-376.

The New Finds of Sinai, Holy Monastery and Archdiocese of Sinai, Athens: Ministry of Culture, Mount Sinai Foundation 1999.

Thomas, John, Angela Constantinides Hero, Giles Constable, and Robert Allison (eds) (2000), Byzantine Monastic Foundation Documents. A Complete Translation of the Surviving Founders' Typika and Testaments 1-5, Washington, D.C.: Dumbarton Oaks Research Library and Collection.

Treadgold, Warren T. (1980), The Nature of the Bibliotheca of Photius (Dumbarton Oaks Studies, 18), Washington, D.C.: Dumbarton Oaks Research Library and Collection.

Van Deun, Peter, and Caroline Macé (eds) (2011), Encyclopedic Trends in Byzantium? Proceedings of the international conference held in Leuven, 6-8 May 2009 (Orientalia Lovaniensia Analecta, 212), Leuven: Uitgeverij Peeters en Departement Oosterse Studies.

van Dieten, Jan Louis (ed.) (1975), Nicetae Choniatae historia (Corpus Fontium Historiae Byzantinae, 11), Berlin, New York: De Gruyter.

Volk, Otto (1955), Die byzantinischen Klosterbibliotheken von Konstantinopel, Thessalonike und Kleinasien, PhD. Diss. Munich.

Vryonis, Speros, Jr. (1957), 'The Will of a Provincial Magnate, Eustathius Boilas (1059)', in Dumbarton Oaks Papers, 11, 263-277.

Waring, Judith (1998), Byzantine Monastic Libraries in the eleventh and twelfth centuries, PhD. Diss. Belfast.

Waring, Judith (2002), 'Literacies of Lists: Reading Byzantine Monastic Inventories', in Holmes and Waring (eds) 2002, 165-186.

Waring, Judith (2004), “'On the Furnishing of the Library by Sergius the Patriarch” by George of Pisidia', in Basilissa, 1, 66.

Waring, Judith (2010), 'Byzantine Book Culture', in Liz James (ed), A Companion to Byzantium, Chichester: Wiley-Blackwell, 275-288. 
Wehmeyer, Jeffrey M. (1997), 'The Chartophylax: Archivist and Librarian to the Patriarch in Constantinople', in Libraries \& Culture, 32, 107-112.

Wendel, Carl (1942), 'Die erste kaiserliche Bibliothek in Konstantinopel', in Zentralblatt für Bibliothekswesen, 5, 193-209.

Wendel, Carl (1954), 'Bibliothek', in Reallexikon für Antike und Christentum, 2, 231-274.

Wendel, Carl (1974), Kleine Schriften zum antiken Buch- und Bibliothekswesen, edited by Werner Krieg, Cologne: Greven.

Westerink, Leendert Gerrit (ed.) (1981), Nicholas I Patriarch of Constantinople, Miscellaneous Writings, Greek Text and English Translation, (Corpus Fontium Historiae Byzantinae, 20), Washington, D.C.: Center for Byzantine Studies.

Wilson, Nigel (1967), 'The Libraries of the Byzantine World', in Greek, Roman and Byzantine Studies, 8, 53-80.

Wilson, Nigel (1975), ‘Books and Readers in Byzantium', in Byzantine Books and Bookmen. Dumbarton Oaks Colloquium 1971, Washington, D.C.: Dumbarton Oaks Center for Byzantine Studies.

Wilson, Nigel (1992), From Byzantium to Italy. Greek Studies in the Italian Renaissance, London: Duckworth.

Wilson, Nigel (2002), Photius. A Selection Translated with Notes, London: Duckworth.

Wilson, Nigel (2008), 'Language, education, and literacy. Libraries', in Elisabeth Jeffreys, John Haldon and Robin Cormack (eds), The Oxford Handbook of Byzantine Studies, Oxford: Oxford University Press, 820-826.

Wiplinger, Gilbert, and Gudrun Wlach (eds) (1996), Ephesos. 100 Jahre österreichische Forschungen, Vienna, Cologne, Weimar: Böhlau.

Wünsch, Richard (ed.) (1903), loannis Lydi De magistratibvs populi Romani libri tres, Stuttgart, Leipzig: Teubner 1903 (ed. stereotypa 1967). 


\title{
Archival Practices in the Muslim World prior to $\mathbf{1 5 0 0}$
}

\begin{abstract}
This paper is basically a critical evaluation of the current debate on the question of why so little remains of a large body of documents from both government and cadis' offices from the pre-Ottoman Muslim world. It also tries to enlarge the regional basis of the debate by including the state of affairs in Persianspeaking lands. The focus is put on archival practices here: who stored which documents, where, and why? Archival practices included discarding and documents that were no longer required. This is closely linked to the reuse of writing materials as draft paper. A central question here is who actually kept archives and in particular whether this was an institutional task or a private matter. One new perspective is research on the physical forms of document storage (containers and buildings). The legal and social context of writing down documents and storing them is also mentioned briefly, as this also needs to be addressed by future studies. Ultimately, research on archival practices may offer better prospects of enlarging the pool of sources for the social history of the Near and Middle East than continuing to search for The Great Central State Archive.
\end{abstract}

\section{Introduction}

Historians concerned with the Middle East agree that pre-modern governments in the Muslim world beginning early on in the history of Islam, namely in the seventh century, developed impressive bureaucratic apparatuses both in the capitals and in the provinces. On another level, the output of paper at cadis' courts was no less important; it is evident that record-keeping was essential. However, not much of this wealth of paper has survived the ravages of time, even though millions if not billions of sheets of paper must have been involved over the years (papyrus was used in Egypt until the tenth century and parchment and other materials were employed in other regions until roughly the ninth century). Only a handful of pieces are extant today in their original form out of the entire Abbasid 
production in Baghdad and Samarra, the Abbasid capital roughly during the second half of the ninth century. ${ }^{1}$ The situation is rather different in the provinces (see below), but it is striking that even there, nothing has survived that was written in the central Abbasid chanceries. The transmission of documents becomes denser after $c .1500$, above all upon the introduction of more centralised and systematic archival practices in the Ottoman Empire.

Exactly why this is so is one of the great unanswered questions in the history of this region of the world, in particular since the situation is quite different for manuscript books: it is not uncommon for researchers to work with manuscripts from pre-Ottoman and even pre-Mongol times. As an example, 24 autograph volumes by the Egyptian polymath Maqrīzì (d. 1442) are known to us, and autograph copies of the works of the Iranian poet Ğāmī (d. 1492) exist in many libraries in Iran and Central Asia. A look at any of the major catalogues of manuscript collections will show that manuscripts from before 1500 have survived in impressively large numbers.

This paper is basically a critical evaluation of the current debate on the question of why so little remains of a large body of documents from both government and cadis' offices. At the end, I shall present some research questions.

\section{Perishable matter}

Paper and other organic substances used for writing have a limited life. The climate in the environment where they are used-in particular moisture and consequently mould-can affect their lifespan. There are also animals that feed on paper, such as worms, beetles, ants and mice. This holds true for all countries, of course, both East and West: Venice is much moister than, say, Damascus, and yet it has managed to keep thousands upon thousands of archival documents, whereas the record for Damascus is very different. ${ }^{2}$ Another point, which is perhaps the most important one in this case, is that paper is flammable. One need only think of the Mongol invasions of Central Asia, Iran, Iraq, Anatolia and partly

1 In the context of this paper, an 'original' is the version of a document in the form in which it was first issued by its source (cf. van Berkel 2014; see also van Berkel 2013, which has an extensive bibliography, but no debate of the question at hand, viz. why no mediaeval archives have survived to this day).

2 Robinson 2003 seriously adduces climatic factors as the specific difference for the non-preservation of records. Bauden is quite justified in making fun of him (Bauden 2013, 32). Bauden's article has a very useful summary of earlier attempts at explaining the lack of archival material. 
Syria (from the 1220s to the end of the thirteenth century, with the burning and sacking of Baghdad, including the Abbasid palaces, in 1258) and the no less devastating campaigns of Timur (d. 1405) in roughly the same area, and invoke the numerous destructive wars fought all over the region to immediately understand that these were unfavourable conditions for the preservation of documents. Not all regions were affected by the Mongol and Timurid invasions, however: Egypt was not, and neither were North Africa or the Arab Peninsula. Manuscript books also burn, of course, but they have been preserved to a larger degree than loose documents, even though we know that many libraries lay in ashes when the Mongols left. So the first reason why Ottoman documents survived where pre-Ottoman ones did not is probably that the Ottoman conquest of the Middle East in the fifteenth and sixteenth centuries was the last time the regions changed hands before the coming of the Europeans (beginning with Napoleon's campaign in Egypt, 1798-1802). Political instability and the short lifespan of Middle Eastern dynasties certainly did not favour the preservation of documents, but again, one should not imagine Latin Europe as being a model of political stability either. Political stability is also one of the elements which Astrid Meier adduces in her brief notes on 'Archives and Chanceries: Arab World': she thinks that 'what was lacking were long-lasting repositories and a bureaucracy with a vested interest in preserving their collections'. ${ }^{3}$ This is indeed part of the received explanation.

But there must be more, and this is what has puzzled historians for many generations. No conclusive answer has been found yet. The debate has now moved on to more concrete and more researchable questions, however.

One of the main factors that triggered the current debate was the publication of Michael Chamberlain's study on the scholars and notables of medieval Damascus. ${ }^{4}$ His basic question regarding the lack of archives is this: 'Is accidental loss the reason that historians have so few original document collections from the high medieval Middle East?'5 This is a rhetorical question. He presumes that other historians think that this loss of archival materials is indeed accidental, but his own answer is 'no', the reason being that documents did not matter as much in mediaeval Damascus, they were not as important for transmitting status, wealth and positions, and so they were not kept. In short, there are no traces of archives today because there were none back then. Quite a number of authors have responded to this, and all of them argue that Chamberlain is wrong. They do so along different lines, however. What emerges as a consensus is discomfort with

3 Meier 2012. This article is a useful survey of archives in the modern Arab world.

4 Chamberlain 1994. For a summary of some reviews of it, see Hirschler 2016a.

5 Chamberlain 1994, 13. 
the lamentation that we do not have any archives, an increasing focus on differences in place and time, and a turn to investigate archival practices instead of looking for the missing archives themselves, including archives as dedicated areas for storing documents which are no longer of immediate legal or administrative value. If I had to summarise the debate in one question, it would be about who kept which records where (and in what form). I would also ask what they were kept for and how these records were preserved and transmitted-or rather, neither preserved nor transmitted, but discarded or simply thrown away.

\subsection{What do we have, then?}

At this point, a very brief survey of which fragments of archives have been found is in order. Only documents from the pre-Ottoman period are taken into account here, that is, we are looking at the entire period from the beginnings of Islam to c.1500. This survey does not aim to produce a complete list, of course.

First of all, there are the Egyptian papyri, which have been found in great numbers. Quite a lot of them represent the remains of archives. The Arab Papyri Database housed at Munich University now contains 11,620 files. ${ }^{6}$ Not all of them stem from cadis' courts or government officials, but many of them do. Those fragments of archives which have survived typically come from family archives. The papyri of the Bifām family, for instance, were found where they had been stored, in a sealed ceramic jar. ${ }^{7}$ Vorderstrasse has argued that these groups of documents are not really family archives at all, but that the documents follow people's property, as it were: 'The fundamental organizing principle of archives was the properties and not the owners'. ${ }^{8}$ She assumes that the documents were legal proof that a certain kind of action had been taken and that they were passed on together with the owner's property.

The famous Cairo Genizah, part of the synagogue of Old Cairo, has yielded enormous amounts of correspondence written on papyrus and paper. Most of it is commercial in character, but some legal and administrative matters are mentioned in it as well. This is the contrary of an archive, however: it was a 'memory hole' where Jews threw the papers they did not need any longer for fear of the Name of God being defiled (some form of the Name is practically on every single

6 www.apd.gwi.uni-muenchen.de:8080/apd/project.jsp (last accessed on 06/09/2016).

7 A list of archives or fragments of archives found in situ is provided in Hirschler 2016a, 5.

8 Vorderstrasse 2013, 284. 
sheet). ${ }^{9}$ In Egypt, it is a well-known fact that most of the archives that have survived were kept in non-Muslim institutions: Jewish ones such as schools and synagogues, ${ }^{10}$ and Christian ones such as St Catherine's Monastery on Mount Sinai, the Georgian Monastery of the Holy Cross in Jerusalem and so forth. ${ }^{11}$ These archives sometimes span several centuries and several Egyptian dynasties, and include many government decrees, but also legal opinions by Muslim jurists which the monks elicited. ${ }^{12}$

Research on genizah documents is currently going on in a number of places. The Friedberg Genizah Project aims at assembling the whole Cairo Genizah again, but on a virtual platform, since the holdings have gradually been spread over a host of libraries in different countries. ${ }^{13}$ The Geniza Lab, based at Princeton, is one of the most active research groups in this field. ${ }^{14}$

To give an example of what is happening in this sector nowadays, let us turn to Marina Rustow, who recently reported about her attempts to 'reunite' a taxfarmer's archive. ${ }^{15}$ The documents she refers to here are more than 30 tax receipts concerning a tax farmer-probably a Jew-and his Christian cashier in 1012-15. Twenty of these receipts were published by Geoffrey Khan in $1993 .{ }^{16}$ All in all, Rustow estimates that there are several hundred chancery documents in the genizah collections, and that is probably a conservative estimate, as she acknowledges herself-we may well be looking at thousands of Arabic genizah documents in reality. ${ }^{17}$ It should be noted from the start that the reconstructed archive was a personal archive: the tax farmer put it together, kept it, and at the end of its useful life, he or his heirs discarded it by throwing it into the genizah.

9 This treasure trove makes the Jewish community of Old Cairo one of the best-researched groups of people in the mediaeval Mediterranean. See Goitein 1967-1993. The given explanation of what a genizah was and why it was established also needs to be discussed.

10 Rustow 2010.

11 See Hirschler 2016a, 6.

12 El-Leithy 2011. The author also provides a list of the non-Muslim communities whose archives have survived.

13 www.genizah.org (last accessed on 27/09/2016).

14 www.princeton.edu/ geniza (last accessed on 28/09/2016).

15 www.lib.cam.ac.uk/collections/departments/taylor-schechter-genizah-research-unit/fragment-month/fragment-month-april-0 (April 2016; last accessed on 27/09/2016).

16 Khan 1993.

17 Rustow 2010, 3. Marina Rustow is 'currently writing a book on Fatimid documents of state preserved in the Geniza'. www.princeton.edu/nes/people/display_person.xml?netid=mrustow (last accessed on 27/09/2016). 
Six more groups of documents must be mentioned here, too, partly because they are sometimes overlooked in the present debate (presumably since they do not come from Egypt):

First comes a find from eastern Iran-a family archive belonging to a notable rural family from what is now central Afghanistan, from the second century AH/eighth century CE, comprising 32 Arabic documents plus another group of some 150 pieces written in Bactrian, the local Iranian language. Most of the Arabic documents are tax receipts. ${ }^{18}$

The second group comes from roughly the same region, from Bāmiyān in central Afghanistan; the 'Bactrian documents' relate to a highland valley just north of Bāmiyān. Vladimir Minorsky published a small group of six documents as early as $1943^{19}$ and Gianroberto Scarcia published another one in $1963-1966 .{ }^{20}$ But in the early twenty-first century, larger groups of documents from Bāmiyān have come to light together with manuscript books. The first group, consisting of 29 items, was exaggeratedly called the 'Afghan Genizah' because much of this material related to a Jewish community there. Later, in September 2016, the National Library of Israel announced the acquisition of hundreds of items, apparently from the same (undisclosed) source. This number includes documents from the eleventh to thirteenth centuries which are only partly concerned with Jewish communities. ${ }^{21}$

The third group of documents comes from fifteenth-century Granada: it covers several hundred items, among which there is a small family archive again, this one hidden behind a wall that the owner of the house and archive, Muhammad al-Qirbilyānī of Baza in the province of Granada, evidently built when it became clear that Granada would be taken by the Spaniards in $1492 .{ }^{22} \mathrm{~A}$ substantial number of the Andalusian documents are purchase deeds relating to transactions from the late fifteenth century, used as legal proof when the articles

18 Khan 2007 and French version 2013; the illustrations are better in the French publication. The Bactrian documents have been edited and studied by Nicholas Sims-Williams in a number of publications. It should be kept in mind that the exact place where these documents were found is unknown; they simply 'popped up' on the local market one day. But the general localisation and the archival character is quite clear, as is the fact that both linguistic groups belong together. 19 Minorsky 1943. The first part, published in the same journal in 1942, concerns a single document from Khotan (Xinjiang, China).

20 Scarcia 1963 and 1966.

21 See www.nli/org.il/sites/NLI/English/library/news/Pages/Afghan-Geniza.aspx, the official website of the National Library of Israel (last accessed on 13/11/2016).

22 Zomeño 2007 and 2011. 
were sold to Christians after the conquest, and they have been kept in Spanish archives ever since then.

The fourth group is a spectacular find-the remains of the archive of the early Safavid Sufi order at Ardabil, Iranian Azerbaijan, in 1970, roughly 300 items of which relate to the period prior to $1500 .{ }^{23}$ These documents were stored on the premises of the Safavid shrine and were eventually forgotten by the shrine's administration. Some of the documents were kept in boxes; it is not known whether these were the original boxes, however, or who put them there.

The fifth group is the find at the Haram al-Šarif (the Temple Mount) in Jerusalem, which was made in the 1970s by Amal Abu 1-Hajj, who was then working at the museum there. Again, the collection had been forgotten at some point. It comprises around 800 documents, most of which are from the fourteenth century. The majority of them relate to a single cadi (judge) who worked in Jerusalem for some time in the late fourteenth century. Christian Müller has shown that the group of documents is not part of this judge's archive, as was thought at first. In fact, the collection was made by another cadi using a selection of documents from a much larger corpus which the first cadi had left behind; the true compiler of the collection was directing an investigation into his colleague's involvement in embezzlement and other such criminal activities. ${ }^{24}$

The sixth group is the collection of documents stemming from the Qubbat alHazna, a structure in the courtyard of the Umayyad Mosque in Damascus known since the late nineteenth century. The documents and manuscripts are mostly kept at the Museum of Turkish and Islamic Arts (Türk ve İslam Eserleri Müzesi) in Istanbul today. ${ }^{25}$ Although it is not known how many documents or what kind of documents this group includes, the publications available seem to indicate that many documents stem from cadis' courts and were preserved by their addressees. ${ }^{26}$ Researchers qualify the Qubbat al-Hazna as a 'genizah-like' institution, and

23 Herrmann 1971, and Fragner 1975. Herrmann has published the royal decrees from that collection (Herrmann 2004). Monika Gronke has published the pre-Mongol private documents, which are mostly purchase deeds (Gronke 1982), and she has written an extensive study of social history based to a large degree on this collection (Gronke 1993).

24 Müller 2015; a shorter presentation of the matter is in Müller 2011.

25 Regarding the history of the collection and its transfer to the Ottoman capital, and for an idea of what could be found in it, see D'Ottone 2013.

26 Publications: Mouton/Sourdel/Sourdel-Thomine 2013a. A full list of earlier publications is to be found on pp. 13-15. One work not on that list, however, is Mouton/Sourdel-Thomine/Sourdel 2013b, which was published in the same year. 
more examples of such storerooms are quoted, like one at the Great Mosque of Kairouan (Tunisia) and a comparable room in the Great Mosque of San ${ }^{\mathrm{c}} \bar{a}^{\mathrm{J}} .^{27}$

And finally, there is one group of documents that is a major exception in terms of absent documentary evidence, regardless of individual finds in individual places: we are fortunate enough to have a large number of endowment deeds, some of them original documents, others copies made later. I mention these here even though they may not be part of an archive; if they once belonged to an archive concerning an endowment, then they are often the sole survivors. There are, however, also cases where endowments' trustees actually did store their archival materials.

As an example, I would like to mention the endowment deed written by Rašìd al-Dīn, a vizier for the Mongols in Iran in the first few years of the fourteenth century. ${ }^{28}$ Quite a number of endowment deeds are extant from Timurid Herat and other places in eastern Iran. ${ }^{29}$ In Muslim Central Asia, endowment deeds have also survived in large numbers, the oldest known original dating back to the end of the thirteenth century. ${ }^{30}$ Another famous piece is the endowment made by Ğağa (Caca), a Mongol emir in Anatolia, in 1272. ${ }^{31}$ The Egyptian State Archives in Cairo currently keep around 900 endowment deeds from all periods of the country's long history. I am sure that we have still many such documents in countries where the institution of the Muslim endowment (waqf) was once established. It is possibly not by pure chance that in Iran, most if not all of the document collections known are situated on the premises of shrines or other 'holy' sites; this, of course, includes the endowments made in favour of these shrines. ${ }^{32}$ Shrine or endowment archives are probably the closest thing to institutional archives from the Muslim world (Christian monasteries, as we have seen, kept their documents in an archive on a much more regular basis).

To sum up what has been said so far, it is not entirely true that we do not have any archives or archival documents in general from the pre-Ottoman period. All

27 D’Ottone 2013, 65.

28 Hoffmann 2000.

29 Subtelny 2007; McChesney 1991 is a brilliant example of what can be made of endowment deeds plus chronicles plus other types of sources.

30 Arends/Khalidov/Chekhovich 1979. Another example, with documents partly from the late fifteenth century, is the collection relating to the Naqshbandi Sufi sheikh 'Ubaydallāh Aḥrār: Chekhovich 1974.

31 Temir 1959.

32 Sheikh al-Hokamaee 2013. This author makes the sweeping statement that there is nothing left of these archives, only to quote the Ardabil collection straight afterwards. 
in all, the corpus of documents we do have is not a negligible one, and it is actually growing constantly, and growing fast. Two groups of documents are emerging clearly: administrative writings, in particular tax receipts, but also privileges and decrees on the one hand, and all kinds of legal matters on the other-documents stemming from the cadi's court, many of them from notarial practice. The fact that endowment deeds - which are also cadis' documents from notarial practice, by the way-have survived in large numbers must be taken into account if we are looking for a reason why other types of documents have not come to light. The small number of archives found in situ, without the link between the human agents behind the archive and the archive itself being broken, must also be explained. As Hirschler has observed quite correctly, most of what we have today is due to 'counter-archival practices': documents have survived in spite of their having been discarded (or, in the case of the Cairo Genizah, exactly because they were discarded).

Another point which proves the existence of archives (and also hints at the mostly private character of the relevant collections) is the large number of documents which have survived in literary works. We have a fair amount of state correspondence and administrative documents in chronicles, often quoted more or less verbatim; in administrative handbooks and collections meant to direct the apprentice clerk to the finer forms of bureaucratic Persian or Arabic or Ottoman (inš $\bar{a}^{\jmath}$ ), we have decrees, appointment deeds, oaths of fealty and much more. ${ }^{33}$ Legal documents have been transmitted in several types of legal literature: collections of legal expert opinions (fatāwā), works on legal procedure (šurūṭ) and the position and work of the judge ( $a d a b$ al-qā $\bar{i}$ ). The authors of these various types of literary sources had access to collections of documents, and even if the transmitted texts cannot be treated as documents technically (simply because they do not possess the necessary diplomatic features), there is little doubt that many of them represent administrative practice at the time they were written.

Sometimes, we may presume that family archives were transcribed into books (and probably the originals were 'forgotten' afterwards). Such is the case with the correspondence of the shaykhly family from Ğām, in eastern Iran; their letters to regional rulers (in the fourteenth and fifteenth centuries) were copied by a member of the family who had access to the originals. ${ }^{34}$ Another family archive which has survived because the documents were copied into a book mostly transmits pieces from the sixteenth century, but is listed here nevertheless: the

33 Paul 1998, with a bibliography of published collections from (Greater) Iran in both Arabic and Persian. Many more collections are in manuscript form.

34 Ğalāl al-Dīn Yūsuf-i Ahl n.d. The collection has 318 texts in all. 
Ğūybārī ḩwājas from Bukhara had hundreds of purchase deeds and other materials put together in a book. ${ }^{35}$ It thus seems that the chances of preservation were higher if the documents were copied and bound in a book, for whatever reason the copy was made. The manuscript books which originated in this way were multiple-text manuscripts, and more particularly of the type we could call the 'corpus organiser': ${ }^{36}$ the corpus they organised was-or had been-an archive. On the other hand, the practice of writing many documents on a single scroll-sometimes documents concerning one property-also makes this scroll a 'corpus organiser': an archival scroll.

The fact that records were kept in large numbers and that administration involved a high amount of paperwork is thus beyond doubt, pace Chamberlain. ${ }^{37}$ But who kept what kinds of records and why? It is essential to make some distinctions here which were not always made in the general lament about the absence -or silence-of archives. First of all, we need to regard administrative (i.e. government) and cadis' documents separately. Second, we have to look at the producers of documents on the one hand and the addressees or beneficiaries on the other. In the case of cadis' documents, it is important to know whether a given item is the cadi's copy or the version handed out to one of the parties concerned (or yet another person).

I will first address the subject of administrative documents here and then turn to cadis' documents.

\section{Administrative documents}

As I have shown above, tax receipts are among the earliest documents we have been able to find so far, from Egypt as well as eastern Iran. The fact that charging and receiving taxes involved a huge amount of paperwork is very clear from literary sources. What we have today is therefore only a microscopically small portion of what was actually written, and it has come down from the receipt side, that is, from family archives kept by the taxpayers or other local figures, not from the 'state' side of the record. Maaike van Berkel has found that in the Abbasid administration, there must have been registers which were kept long enough to

35 Iz arkhiva sheikhov Juybari 1938. For a history of this collection, see Paul 1997. At least one item in this collection has also survived as an original document.

36 Bausi 2010.

37 This point has been made by many authors: Sijpesteijn 2007, Rustow 2010, el-Leithy 2011, Bauden 2013 and Hirschler 2016a, for example. 
serve as the basis for processing complaints, but she also says that such records tended to be seen as private property belonging to the secretaries..$^{38}$ In Egypt, the rules of writing tax receipts were so well known that secretaries enquired about the possibility of making exceptions; this is proof indeed that writing documents of this kind was the norm in the taxation field. ${ }^{39}$ The Egyptian secretaries sometimes made no distinction between state archives and private records either. When the secretaries in the administration in Old Cairo learned that the hostile Ihšĩdid forces were advancing and threatened to take the city, they took the tax registers away with them-this (inevitably) led to the destruction of the documents. ${ }^{40}$ Registers may have been destroyed even more frequently, in fact: Rustow provides a list of riots and revolts in Cairo during the Fatimid period; Bauden and Rustow observe that there was large-scale destruction when Fatimid rule came to an end in $1171 .^{41}$ During a fire in the Cairene citadel in 1292, the Mamluk soldiers broke into the chancery and took many of the documents away with them to sell them as paper on the market. ${ }^{42}$ This was not a unique occurrence either: in 1389-90, rioting soldiers broke into the chancery ( $q \bar{a}^{c} a t$ al-inš $\left.\bar{a}^{\supset}\right)$ once again and carried off a great many documents, and again they were sold as paper on the market. ${ }^{43}$ Hirschler was the first to ask what was the precise nature of the office from which the rioters took the documents; he states that it is quite clear from the text of the source that this was not an archive in the proper sense, but a chancery, and that the documents to be found there were unlikely to have ended their administrative life when they were taken away. ${ }^{44}$

The fact that the tax administration could be reconstructed even if the central registers were gone is shown in the case of the Ottoman takeover in 1517: the Ottomans did not use the old registers at first, but proceeded to establish new ones in the provinces. ${ }^{45}$ This was not untypical of Ottoman practice, but it is equally clear that the Ottomans did not actively destroy the older records ${ }^{46}$ Hirschler also warns against concentrating too much on the archive, that is, the Great Central

\footnotetext{
38 van Berkel 2014.

39 Sijpesteijn 2007.

40 Sijpesteijn 2007, 164.

41 Rustow 2010, 18-20; Bauden 2013, 35-36.

42 El-Leithy 2011, 429-430.

43 Bauden 2013, 36-38; el-Leithy 2011, 426; Hirschler 2016a, 9; Rustow 2010, 18.

44 Hirschler 2016a, 9-10.

45 Michel 2013.
}

46 Burak 2016. It was Claude Cahen who adduced that the Ottoman campaigns to re-register taxation were one of the reasons why so few written records have survived; Bauden 2013, 30. 
State Archive, but advises researchers to look at diverse archival practices instead, which may have allowed decentralisation on a much greater scale as well as a much more personal way of keeping records. ${ }^{47}$

The first question to emerge here, then, is to what extent records-including tax registers-were kept privately by the secretaries. There is no conclusive answer to this as yet, but it may be assumed that private record-keeping was widespread. This not only holds true for tax registers, but for general accounts as well. Historians frequently had jobs working in administrative fields, and they used the records they had access to in writing their chronicles. ${ }^{48}$

Another question that arises is that if paper containing administrative texts was occasionally sold as scrap paper at the market, how often did that actually happen? Was this always done by rioting soldiers or marauders, or was it a practice among the secretaries? Bauden has analysed this question in great detail and came to the conclusion that official documents were reduced to mere paper again once their administrative life had ended, after which this paper was often sold. His evidence is based on his search for reused paper of this kind: he found no less than 509 sheets of reused paper in the 24 autograph volumes known from Maqrīzī, all of which are drafts. In Bauden's opinion, this practice must have been quite common. In Maqrīzì, it is the verso sides-which do not have any writing on them-that were reused. In other cases, Bauden thinks, it is the large spaces left blank between lines in official correspondence and some types of sultanic decrees which led to these documents being cut up and sold as paper. ${ }^{49}$ The documents therefore must have left the administrative circuit after a while. This procedure would account for many of the losses, Bauden concludes, so if we are looking for documents, we should not look for an archive as such, but sift through individual draft manuscripts instead. Certain types of administrative documents lost their legal value as soon as the recipient died or left service; there was no need to keep them any longer after that. ${ }^{50}$

Konrad Hirschler has followed this line of research and gone beyond Bauden on a number of points. In a study of numerous manuscripts kept at the National Library of Syria, he detected and reconstructed around a hundred documents from the Ayyubid and Mamluk periods, most of them stemming from notarial

47 Hirschler 2016a, 26-27.

48 One example is 'Imād al-Dīn al-Ișfahānī, who used such records in his biography of Saladin (1169-1193). Another example is Bū l-Faḍl Bayhaqī, who also worked from (his memory of) his personal archives in his history of the reigns of Mahmūd and Mas ${ }^{\mathrm{c}} \overline{\mathrm{u} d}$ the Ghaznavids (eastern Iran, 998-1040).

49 Bauden 2013, 38-40.

50 Hirschler 2016a, 27-28. 
practice (marriage contracts, deeds of sale, etc.). This is currently the largest body of legal documents from Damascus we know of from this period (as long as the Qubbat al-Hazna materials have not been fully published, at least). However, Hirschler argues that in a significant number of cases, the reuse did not just involve the paper, but the text(s) written on it as well. ${ }^{51}$

Marina Rustow also remarks that many of the legal and administrative Arabic documents (on papyrus as well as paper) in the genizah (many of which do not concern Jews at all) have been preserved because Hebrew texts were written on the verso sides. Searching through genizah documents in the Bodleian holdings, she found around fifty petitions and decrees on top of the 173 documents which had been known before. 'All are fragments cut and reused for Hebrew texts', she adds. ${ }^{52}$ To explain the fact that Jews preserved Arabic documents (concerning Muslims), she points to their need to have recourse to models for writing petitions to the central government.

Reusing administrative documents was an old practice, at least in Egypt. Petra Sijpesteijn has published a papyrus fragment from the second/eighth to third/ninth century which was reused in this way: somebody wrote some prophetic tradition on the verso side of an administrative text. Never mind that only three or four letters have survived from that text - the fragment is proof that even in this early period, papyrus documents were reused in very much the same way as later documents on paper were. It stands to reason that many more cases of such early reuse will come to light once researchers start looking for them. ${ }^{53}$

It thus appears that the reuse of discarded documents was widespread and that this practice does, indeed, go at least some way in explaining why the preserved documents were not preserved in situ, but by counter-archival practices. The ways of discarding such texts and the reasons for this practice still remain largely unexplained, though. To what extent was the text of the document itself important for its preservation, as Hirschler and Rustow ask? To what extent are we merely looking at the economic reuse of material rather than specific texts? The reuse of paper (or parchment or papyrus), its various forms and the strategies and purposes behind it are questions that are clearly emerging now in a new line of research.

The fact that documents were discarded-by selling them as paper or just by throwing them away-is attested from other countries as well as Egypt. Another

51 Hirschler 2016b. My thanks to Konrad Hirschler for agreeing to be quoted in this paper and also for a number of valuable remarks on a draft of the article.

52 Rustow 2010, 4, n. 11.

53 Sijpesteijn 2015. 
procedure for destroying documents is known from Iran, for example, where the texts on them were simply washed off in the 'bowl of justice', as it was known. ${ }^{54}$ This practice probably concerned privileges that were revoked when the beneficiaries fell out of favour, as can be shown from various narrative sources. ${ }^{55}$ Washing the writing off a document is discussed in legal literature as one of the ways to invalidate it (besides burning it, throwing it away or burying it). ${ }^{56}$

Recent research, thus, stresses diverse agencies in archival practices. The State is not the monolith we thought it was, but is, in fact, made up of many different players-it is more like a field where diverging interests are vying against one another. ${ }^{57}$ Many of these different players also had their own routines for record-keeping and for discarding documents which were no longer useful to them.

\subsection{Cadis' documents}

The second large group of documents comes from cadis' courts. Bauden names two earlier explanations of the loss of the respective archives, provided by Sauvaget and Cahen, which he thinks are relevant. First, Islamic law does not accept documentary evidence as proof of a past action and insists on witnesses of the act being questioned. Second, Islamic law does not recognise legal persons and insists on natural persons as legal agents. ${ }^{58}$ In both cases, legal documents would not need to be kept over long periods of time. Both positions need to be qualified, however. First, regarding documentary evidence, Johansen has shown that leading Hanafī theorists from among the Central Asian classics (eleventh and twelfth centuries) thought that 'documents and records that do not have witnesses but are produced by the commercial and political elites should be accepted as reliable evidence' ${ }^{59}$ This position became increasingly important in Ottoman times, but must have been at least an option even earlier, even in regions where other schools of law than the Hanafi one, which was the most important one in the Ottoman Empire, dominated. ${ }^{60}$ In his discussion of the cadi's court and

54 Sheikh al-Hokamaee 2013, 139.

55 Paul 2016, 356.

56 Bauden 2013, 30.

57 See the introduction to Paul 2016, 60-72.

58 Bauden 2013, 28-30.

59 Burak 2016, 241; see Johansen 1997. For Müller’s position, see Müller 2010.

60 Zomeño 2011 explains that documentary evidence was not universally accepted as independent proof in Muslim Spain (where the Mālikī school of law was predominant), but it still had some value below that level. 
the registers it kept, Hallaq also comes to the conclusion that documentary evidence could be accepted, at least in some cases. ${ }^{61}$ What did that effectively mean for the preservation of cadis' documents, though?

As I have shown above, again, those cadis' documents that have come down to us from the period prior to 1500 apart from the Cairo Genizah, genizah-like institutions, literary transmission or reused paper (counter-archival practices) were preserved in family or institutional archives (at shrines or on behalf of the endowment administrators). Some of the extant documents evidently have the properties proposed by Vorderstrasse; this may also be the case for endowment deeds. ${ }^{62}$

To the best of my knowledge, no archive of a pre-Ottoman cadi has come to light yet. Nevertheless, there can be little doubt that cadis' archives did, indeed, exist and that keeping them was considered an essential part of a judge's work.

Hallaq (1998) has provided the most detailed description of what a cadi's archive was in pre-Ottoman Syria and Egypt. This probably also applied to other regions as well. A cadi's dīwān included copies of the judge's decisions, cases he was involved in, but also a list of prisoners with the dates of their possible release, lists of property belonging to orphans for whom the cadi acted as a trustee, lists of endowments along with the names of the people managing them, lists of professional witnesses and so forth. It is thus not only the cases heard and transactions attested which made up the cadi's archive (dīwān al-qā these documents were kept in a kind of 'bookcase' (Hallaq's term) called a qimațr from a comparatively early period..$^{63}$ Cases and other documents were put aside and stored regularly, perhaps on a monthly basis, sometimes kept in leather bags which were sealed. All this documentation was linked to the cadi as a person; Hallaq explains this as being due to the absence of a specific area for the dispensation of justice-there was no 'courthouse' as such; rather, a cadi could sit in any publicly accessible place and conduct his work. Whenever a cadi left office or died and another man took over, the documents were transferred in a complicated and strictly regulated way which involved copying the material twice, once for the new judge and once for the witnesses who attested the procedure. After the material had been transferred, the old 'originals' remained in the outgoing judge's possession-and lost their legal validity the moment he lost his office. ${ }^{64}$

61 Hallaq 1998.

62 Vorderstrasse 2013.

63 Lane's dictionary adds that a qimațr in this sense was made of reed.

64 Hallaq 1998. Sheikh al-Hokamaee confirms this: Sheikh al-Hokamaee 2013, 139; he explains that these papers then went to 'the druggist's store'-probably to be sold there as scrap paper. 
In the documents from Granada (see section 2.1 above), there is at least one example of an 'updated' document: a purchase deed from 1432 that was updated in 1488; the update concerns the signatures of the professional witnesses who had attested to the authenticity of the original document. ${ }^{65}$

In the ideal case, all previous documents were obliterated once they had been copied into a new cadi's papers. It is therefore hardly surprising that such documents have only survived in family and institutional archives and that cadis' archives have not been preserved. This pattern changed with the Ottomans, who took a different approach to documentary evidence; they loosened the link between the cadi as a person and his archives. ${ }^{66}$

Endowment deeds are a major exception to this general rule. They were cadis' documents, but they were carefully preserved by the individuals behind the endowment. Even if the endowments were not legal persons from a technical point of view-a concept which Islamic law, strictly speaking, does not knowthey acted as such for all intents and purposes: they 'owned' property, they 'bought' and 'sold' items, and so forth. ${ }^{67}$ It is this specificity of the endowment as a quasi-legal person that is behind the large number of endowment deeds which have been preserved, unlike other types of cadis' documents. In this respect, endowments can be likened to non-Muslim institutions (such as monasteries) that also kept their documents and to Iranian shrines, which, as Sheikh al-Hokamaee asserts, also have numerous documents among their holdings. ${ }^{68}$

Hallaq concludes his article with a discussion of why these materials have not survived. He gives two very interesting reasons for this happening: first, he thinks that loose leaves survive much less frequently than bound books, being discarded much more easily by negligence and even used by households as fuel for the fire. Second, he assumes that there was no reason to keep them, and that they were discarded or trashed because they did not contain anything of literary value: no poetry, no prophetic tradition and so forth, and that their content was therefore no longer of interest to anyone.

\footnotetext{
65 Zomeño 2011, 469.

66 Burak 2016.

67 Behrens-Abouseif 2009.

68 Sheikh al-Hokamaee 2013.
} 


\subsection{The last step}

Historians who are concerned with the 'archival question' have seen the divide at around $1500 \mathrm{CE}$, with the introduction of new archival practices in the Ottoman Empire and the Empire's new acquisitions on the Balkans and in the Arab world. Non-Ottoman regions have been rather neglected in the process, but it is clear that in Iran and Muslim Central Asia, to name just two regions, we can also see an increase in the number of surviving documents after $c .1500 .{ }^{69}$ The question of how the archives passed through the colonial period into the age of the nation state is also largely unexplored. ${ }^{70}$ As we approach early modern and modern states, we need to reconsider the very concept of an 'archive' and take its possible Benthamian and Foucaultian connotations into account. ${ }^{71}$

Another observation which has not yet been made in this context is that a huge number of countries experienced a cultural break in the nineteenth or twentieth century. This concerns all the regions which came under colonial rule at some point, meaning that Islamic law was no longer practised there or at least not practised alone (British India, French North and West Africa, Russian Central Asia, Dutch Indonesia and so forth). In many countries, colonial or not, the Arabic script was abolished or abandoned in the twentieth century: modern Turkey, the Balkans even where Islam continued (Bosnia and Albania), parts of the Soviet Union, large parts of sub-Saharan Africa all saw this happen. During the colonial period or after the foundation of modern nation states, documents of historical interest were often transferred to national archives or museums-a very late step in many cases (the Iranian National Archive was only founded after the Second World War, for instance). The colonial states applied their own (very idiosyncratic) organising principles to the papers they often took to the metropolitan areas (St Petersburg, London, places in the Netherlands), with the result that the original archival practices are now difficult to reconstruct because the order in which the materials had been arranged was disturbed, if not destroyed. In transferring the collections to the new archives or museums, they were inevitably transformed from being a 'living' collection of documents into a 'dead' museum

69 Fragner 1980 shows this increase for Iran.

70 This observation was the rationale behind the international conference Persianate Cultures of Documentation: An International Symposium, convened by James Pickett and Paolo Sartori, Vienna, June 2016. The contributions mainly concerned South Asia.

71 Sartori 2016. Thanks to Paolo Sartori for sharing his research with me before publication. I would also like to thank him for a number of thought-provoking discussions we had together. 
collection, an archive only of interest to historians. This is equally true of the Ottoman archives, which now are part of the national archives of the Turkish Republic.

Cultural disruption could even lead to situations which directly threatened the survival of written materials. Thus, during Stalin's reign of terror in the 1930s, it was dangerous to have books or even anything written in Arabic script in one's house. People therefore either hid or buried their books and documents, many of which were eventually lost at some point.

In general, I believe, the colonial situation and the founding of nation states may have led to two separate developments: on the one hand, many materials found their way into the newly founded colonial or national archives where they now await their readers-no longer cadis, administrators or parties to legal disputes, but $\mathrm{PhD}$ students and researchers in general. On the other hand, it is highly probable that many documents are still kept in private collections together with manuscript books, out of filial piety or pride in owning such things (the age of which is often greatly exaggerated) or out of mistrust of the official collections. This is most probably the case in countries such as Iran where cultural disruption was not as pronounced in the colonial period.

\section{Conclusion}

A number of research questions have emerged at the end of this brief survey. The question of the archive remains unresolved, but I think it has become clear that the search for a central institutionalised archive which the state used for recordkeeping needs to be modified now. Archival practices have been central in the debate on this question over the last few years, and the results are encouraging. Moreover, besides discussing diverse techniques and strategies of record-keeping, of preserving and passing on records and knowledge related to records, we must also talk about the practice of discarding records, of discontinuing their use and of their reverting back to paper again-a commodity which had a certain value on Middle Eastern markets due to demand. Discarding documents therefore frequently meant reusing paper.

Another research question is linked to record-keeping practices and their material and the space used for them. From the ceramic jar of the family archive to the 'bookcase' (qimatr) of an Egyptian judge and the building of caches for documents, how did the material and the space used in the process of record-keeping influence the social practice? In the same vein, it is quite evident that there is a difference between a bound book and a collection of loose leaves. Whereas bound 
books were routinely preserved, collections of loose leaves evidently were not. Did a collection of documents require a codex as a protective 'envelope' in order to enhance its chances of survival? And why do we have so many copies of records in books, but not the originals?

The most important research question in my mind is about the agency of recordkeeping. Who exactly kept records? And what became of these records once the individual creator of the collection had died? How were records passed on? After all, we are looking at periods which are more than five hundred years in the past now and thus quite remote. Perhaps the transmission of records is therefore even more important than the question of their constitution. It is here that the great cultural breaks must be taken into account-the Mongol invasions are one example of interruptions in the pre-Ottoman period, just like the Ottoman takeover itself, the colonial period and eventually the emergence of the nation state. How did the new masters treat the records of those whom they had vanquished? Is the case of the Ottoman conquest of Egypt typical? They bypassed the older records, but incorporated some of them later, only to thoroughly forget the earlier books and documents. Is it of any significance that those documents that we do possess now stem to a significant extent from depositories which had been created by shrines, or more precisely, shrine families acting as endowment administrators?

Last but not least, the question of record-keeping, of archival practices that included the act of discarding documents and throwing them away, cannot be discussed without knowing their specific legal and socio-political context. We cannot hope to understand the fate of archives in societies where some form of Islamic law was predominant without understanding the status of written proof in them-of witnesses and documents and so forth on the one hand and the question of the legal person on the other. As for administrative documents, we are still far from understanding the significance of private individuals in the state administration. And we are far from understanding the workings of the administration itself, the interplay of central and local actors, and the relative importance of formal and informal practices. 


\section{References}

Arends, K.A., A.B. Khalidov, and O.D. Chekhovich (eds) (1979), Bukharskii vakfXIIlogo veka, Moscow: Nauka.

Bauden, Frédéric (2013), 'Du destin des archives en Islam. Analyse des données et éléments de réponse', in Denise Aigle and Stéphane Péquignot (eds), La correspondance entre souverains, princes et cités-États. Approches croisées entre l'Orient musulman, l'Occident latin et Byzance (XIle-début XVle siècles), Turnhout: Brepols, 27-49.

Bausi, Alessandro (2010), 'A Case for Multiple Text Manuscripts being “Corpus-Organizers”', in Manuscript Cultures, 3, 34-36.

Behrens-Abouseif, Doris (2009), ‘The Waqf: A Legal Personality?’, in Astrid Meier, Johannes Pahlitzsch and Lucian Reinfandt (eds), Islamische Stiftungen zwischen juristischer Norm und sozialer Praxis, Berlin: Akademie Verlag, 55-60.

van Berkel, Maaike (2013), 'Archives and Chanceries: pre-1500, in Arabic', in Encyclopedia of Islam-Three, 2013.4, 24-32.

van Berkel, Maaike (2014), 'Reconstructing Archival Practices in Abbasid Baghdad', in Journal of Abbasid Studies, 1, 7-22.

Burak, Guy (2016), 'Evidentiary truth claims, imperial registers, and the Ottoman archive: contending legal views of archival and record-keeping practices in Ottoman Greater Syria (seventeenth-nineteenth centuries)', in Bulletin of the School of Oriental and African Studies, 79/2, 233-254.

Chamberlain, Michael (1994), Knowledge and social practice in medieval Damascus, 11901350, Cambridge: Cambridge University Press.

Chekhovich, O.D. (ed.) (1974), Samarkandskie dokumenty, Moscow: Nauka.

Fragner, Bert (1975), 'Das Ardabiler Heiligtum in den Urkunden', in Wiener Zeitschrift für die Kunde des Morgenlandes, 67, 169-215.

Fragner, Bert (1980), Repertorium persischer Herrscherurkunden, Freiburg: Klaus Schwarz.

Ǧalāl al-Dīn Yūsuf-i Ahl, Farā’ị̣-i gìyāțī (n.d.), 2 vols, ed. Ḥeshmat Moªyyad, Tehran: Intishārāt-i farhang-i İrān.

Goitein, Shlomo (1967-1993), A Mediterranean Society, 6 vols, Berkeley: University of California Press.

Gronke, Monika (1982), Arabische und persische Privaturkunden des 12. und 13. Jahrhunderts aus Ardabil (Aserbaidschan), Berlin: Klaus Schwarz.

Gronke, Monika (1993), Derwische im Vorhof der Macht. Sozial- und Wirtschaftsgeschichte Nordwestirans im 13. und 14. Jahrhundert, Stuttgart: Steiner.

Hallaq, Wael (1998), 'The 'qāḍī's dīwān' (sijill) before the Ottomans', in Bulletin of the School of Oriental and African Studies, 61/3, 415-436.

Herrmann, Gottfried (1971), 'Urkunden-Funde in Āḍarbāyǧān', in Archäologische Mitteilungen aus Iran, NF 4, 250-262.

Herrmann, Gottfried (2004), Persische Urkunden der Mongolenzeit, Wiesbaden: Harrassowitz. Hoffmann, Birgitt (2000), Waqf im mongolischen Iran: Rašiduddīns Sorge um Nachruhm und Seelenheil, Stuttgart: Steiner.

Hirschler, Konrad (2016a), 'From Archive to Archival Practice: Rethinking the Preservation of Mamluk Administrative Documents', in Journal of the American Oriental Society, 136/1, 128. 
Hirschler, Konrad (2016b), 'Text Reuse in Medieval Syrian Manuscripts', paper presented at the Comparative Oriental Manuscript Studies workshop 'Looking back - looking ahead', held at Hamburg, September 26, 2016.

Iz arkhiva sheikhov Juybari (1938), no editor given (probably F.B. Rostopchin), Moscow-Leningrad: Izdatel'stvo Akademii Nauk.

Johansen, Baber (1997), 'Formes de langage et fonctions publiques: Stéréotypes, témoins et offices dans la preuve par l'écrit en droit musulman", in Arabica, 44/3, 333-376.

Khan, Geoffrey (1993), Arabic legal and administrative documents in the Cambridge Genizah collections, Cambridge: Cambridge University Press.

Khan, Geoffrey (2007), 'Newly discovered Arabic documents from early Abbasid Khurasan', in Petra M. Sijpesteijn, Lennart Sundelin, Sofia Torallas Tovar and Amalia Zomeño (eds), From al-Andalus to Khurasan. Documents from the Medieval Muslim World, Leiden : Brill, 201-215 ; French as: 'Documents arabes du début de l'Islam, récemment découverts dans le Khorassan', in Anne Regourd (ed.), Documents et histoire. Islam, VIle-XVIe siècle, Genève (Droz) 2013, 175-197.

el-Leithy, Tamer (2011), 'Living Documents, Dying Archives: Towards a Historical Anthropology of Medieval Arabic Archives', in al-Qanțara, 32/2, 389-434.

McChesney, Robert (1991), Waqf in Central Asia. Four Hundred Years in the History of a Muslim Shrine, 1480-1889, Princeton: Princeton University Press.

Meier, Astrid (2012), 'Archives and chanceries: Arab world', in Encyclopedia of Islam-Three, 2012/4, 17-22.

Michel, Nicolas (2013), “'Les Circassiens avaient brûlé les registres”, in Benjamin Lellouch and Nicolas Michel (eds), Conquête ottomane de l'Egypte (1517): Arrière-plan, impact, échos, Leiden: Brill, 225-268.

Minorsky, Vladimir (1943), 'Some early documents in Persian II', in Journal of the Royal Asiatic Society, 75/1-2, 86-99.

Mouton, Jean-Michel, Dominique Sourdel and Janine Sourdel-Thomine (2013a), Mariage et séparation à Damas au Moyen Âge: un corpus de 62 documents juridiques inédits entre 337/948 et 698/1299, Paris: Académie des Inscriptions et Belles-Lettres.

Mouton, Jean-Michel, Janine Sourdel-Thomine and Dominique Sourdel (2013b), 'Deux documents touchant au rachat de captifs détenus par les Francs', in Archiv für Papyrusforschung, 59/2, 406-420.

Müller, Christian (2010), 'Ecrire pour établir la preuve orale en Islam. La pratique d'un tribunal à Jérusalem au XIVe siècle', in Akira Saito and Yusuke Nakamura (eds), Les outils de la pensée. Etude historique et comparative des 'textes', Paris: Editions de la Maison des sciences de l'homme, 63-97.

Müller, Christian (2011), 'The Ḥaram al-Šarîf Collection of Arabic Legal Documents in Jerusalem: a Mamlūk Court Archive?', in: al-Qanțara, 32/2, 435-459.

Müller, Christian (2015), Der Kadi und seine Zeugen: Studie der mamlukischen Haram-Dokumente aus Jerusalem, Wiesbaden: Harrassowitz.

D’Ottone, Arianna (2013), 'Manuscripts as Mirrors of a Multilingual and Multicultural Society: the Case of the Damascus Find', in Barbara Crostini and Sergio La Porta (eds), Convivencia in Byzantium? Cultural Exchanges in a Multi-Ethnic and Multi-Lingual Society, Trier: Wissenschaftlicher Verlag Trier, 63-88.

Paul, Jürgen (1997), 'La propriété foncière des cheikhs Juybari', in L'Héritage timouride. IranAsie centrale-Inde, XVe-XVIIIe siècles. Cahiers d'Asie centrale, 3-4, 183-202.

Paul, Jürgen (1998), ‘Enšā’’, in Encyclopedia Iranica vol. 8, 455-457. 
Paul, Jürgen (2016), Lokale und imperiale Herrschaft im Iran des 12. Jahrhunderts: Herrschaftspraxis und Konzepte, Wiesbaden: Reichert.

Robinson, Chase (2003), Islamic Historiography, Cambridge: Cambridge University Press.

Rustow, Marina (2010), 'A petition to a woman at the Fatimid court (413-414 A.H./1022-23

C.E.)', in Bulletin of the School of Oriental and African Studies, 73/1, 1-27.

Sartori, Paolo (2016), 'Seeing Like a Khanate: On Archives, Cultures of Documentation, and Nineteenth-Century Khvārazm', in Journal of Persianate Studies, 9, 228-257.

Scarcia, Gianroberto (1963), 'A preliminary report on a Persian legal document of 470-1078 found at Bāmiyān', in East and West, 14, 73-85.

Scarcia, Gianroberto (1966), 'An edition of the Persian legal document from Bāmiyān', in East and West, 16, 290-295.

Sheikh al-Hokamaee, 'Emad al-Din (2013), 'La vision religieuse des Safavides, la conservation des archives pré-safavides et l'altération des documents', in Anne Regourd (ed.), Documents et histoire. Islam, VIle-XVle siècle, Genève: Droz, 137-154.

Sijpesteijn, Petra (2007), 'The Archival Mind in Early Islamic Egypt: Two Arabic Papyri', in Petra Sijpesteijn, Lennart Sundelin, Sofia Torallas Tovar and Amalia Zomeño (eds), From al-Andalus to Khurasan. Documents from the Medieval Muslim World, Leiden: Brill, 163-186.

Sijpesteijn, Petra (2015), 'A Hadīth Fragment on Papyrus', in Der Islam, 92/2, 321-331.

Subtelny, Maria Eva (2007), Timurids in Transition. Turko-Persian Politics and Acculturation in Medieval Iran, Leiden: Brill.

Temir, Ahmet (ed.) (1959), Kırşehir Emiri Caca Oğlu Nur el-Din'in Arapça-Moğolca Vakfiyesi, Ankara: Türk Tarih Kurumu Basımevi.

Vorderstrasse, Tasha (2013), 'Reconstructing Houses and Archives in Islamic Egypt', in Anne Regourd (ed.), Documents et histoire. Islam, VIle-XVIe siècle, Genève: Droz, 281-311 (284).

Zomeño, Amalia (2007), 'Notaries and their formulas: The legacies from the University Library of Granada', in Petra M. Sijpesteijn, Lennart Sundelin, Sofia Torallas Tovar and Amalia Zomeño (eds), From al-Andalus to Khurasan. Documents from the Medieval Muslim World, Leiden: Brill, 59-77.

Zomeño, Amalia (2011), 'From Private Collections to Archives: How Christians Kept Arabic Legal Documents in Granada', in al-Qanțara, 32/2, 461-479. 


\title{
Christian Müller
}

\section{The Power of the Pen: Cadis and their Archives}

\section{From Writings to Registering Proof of a previous Action taken}

\begin{abstract}
This study is about cadis' archives and their institutional importance from a long-term perspective. It combines information on the cadi's archive as reported in documentary sources from the middle of the eighth century onwards with an analysis of surviving legal documents and with juridical discussion on the legal status of writing as proof of a past action in fiqh literature in a strictly chronological approach. Putting these rather disparate elements together reveals a fundamental change in the use of writing an attestation and the cadi's archive during the period of time considered here. The refusal by ninth-century jurists to see a judge being bound to conduct a lawsuit by writings from their predecessor's archive was eventually replaced by accepting cadis' certificates as a means of proof. This legal change involved the tenth-century sophistication of attesting as a witness in two stages, where a written attestation implied that the witnesses had a legal obligation to provide an oral account of the matter at hand to the cadi. Hence, documents from a cadi's archive acquired the function of a 'living' archive that could safeguard subjective rights for long periods of time.
\end{abstract}

This study explores the importance of cadis' archives for the evolution of judicial institutions in the pre-modern Islamic world. Earlier studies have considered the existence of cadis' archives (dīwān al-qā only changed when Ottoman court registers were introduced. This was mainly because historians of the Middle East had a host of Ottoman court registers (Arabic: siǧill, Ottoman: sicill) at their disposal from the sixteenth century onwards, ${ }^{2}$ whereas systematic cadis' records were unknown before that period. The availability of source material-or rather the lack of it-contributed to the widespread belief about a growing gap between the theory and practice of Islamic law since its beginnings as a jurists' law in the eighth century. Historians of Islamic law considered Ottoman records to reflect legal practice as opposed to legal theory,

1 For a short description, see Tyan ${ }^{2} 1960$, 191f, also see Masud/Peters/Powers 2006, here 21f. and Schacht 1964.

2 For a brief survey, see Faruqi 1997, 9: 539a-544b, and Akgündüz 2009.

https://doi.org/10.1515/9783110541397-013, (c)BB-NC-ND (c) 2018 Ch. Müller, published by De Gruyter. This work is licensed under the Creative Commons Attribution-NonCommercial-NoDerivs 3.0 License. 
which insisted on oral proof such as acknowledgements, testimonies or judicial oaths. ${ }^{3}$ This had two consequences for the study of judicial archives. First of all, the mention of testimonies in judicial proof documents, i.e. the šuhūd al-ḥāl in Ottoman court registers, was considered to be a legal fiction that did not reflect any practice of performing orally an attestation, nor as being of any performative consequence. ${ }^{4}$ Secondly, as written proof was not part of legal theory in the eighth century, the non-existence of archives seemed coherent in a world where the theory and practice of Islamic law (still) went hand in hand with each other. According to this view, later archives only illustrate the gap between legal theory that accepted only oral proof and judicial practice based on written archives as proof-instruments. In the following, I challenge these assumptions by describing the changing notions of the 'cadi's archive', the documents it contained and its legal function, using three types of sources in the process: (1) literary references on cadis' archives, (2) preserved documents and (3) legal doctrines on the law of evidence.

An important objection to the idea of non-existing judicial archives in Islamic society before the Ottoman period came from Wael Hallaq, a scholar of Islamic law. In his article from $1998,{ }^{5}$ he asserted the existence of cadis' court archives as a 'formal institution that was kept systematically [and] was taken for granted by all members of the legal profession'. ${ }^{6}$ Schematically, his study of literary sources centres around three terms: first, the dīwān al-qā dī, meaning the 'totality of records kept by the cadi (Arabic: qāḍ̄, pl. quḍāh)'; second, the qimațr, a box where the cadi kept documents under seal; and third, the siğill, the document as a physical object, which Hallaq understood as a 'register'. As we will see, literary sources support Hallaq's general statement on the existence of $q \bar{a}$ dị̂s' archives. ${ }^{7}$ They do not reveal much about an archive's function, however-either as a depository for current or discarded documents or as a 'living' archive that provided legal arguments from former judgements on current affairs, for example. To be able to answer such questions, we need to trace the evolution of 'judicial archives' on the basis of surviving documentary evidence and compare these with a functional approach to what is, or might be, an 'archive'. Did the archival material cover ongoing affairs that were passed on to the cadi's successor? Or even

3 For a discussion of this point, see Johansen 1997, 333-376, particularly 333-335.

4 Tyan ${ }^{2} 1959$. According to Tyan, Ottoman authors accepted writing as proof. Also see Johansen 1997.

5 Hallaq 1998, 415-436.

6 Hallaq 1998, 429.

7 See Tillier 2009 for the Abbasid period up to the middle of the tenth century. 
more importantly for the institution, did the archive also contain older documents, providing long-term security for their legal validity?

Since Hallaq's article was published, our knowledge of pre-sixteenth-century legal documents has increased considerably. The data used in this article comes from the CALD database (Comparing Arabic Legal Documents), which allows us to make detailed textual comparisons. ${ }^{8}$ This advanced dataset provides a new perspective on judicial practice in general and on $q \bar{a} d \bar{c}$ s's' procedures in particular, the latter involving oral testimonies and written attestation complementarily to establish the rights and duties of litigants. Arabic legal documents involving testimonies by witnesses are scattered throughout time and space. What they all have in common is that they are authentic specimens of legal texts reflecting the legal practices for which they were initially issued. They originate from different regions of the Islamic world spanning from Central Asia and the Middle East to Muslim Spain. In quantitative terms, the number of preserved legal documents rose over time from just a few specimens in the early centuries to several hundred from the twelfth and thirteenth century onwards. Far from belonging to one archive, their provenance and the reasons for keeping them vary considerably. Early papyri were mostly deposits found on Egyptian soil. Later documents were kept by religious institutions like the Șafawīd shrine in Ardabil, Christian monasteries and church institutions, while others belonged to depositories of unused or discarded papers such as the Cairo Genizah. With some possible exceptions, most of these documents were used privately before being disposed of or put away in an archive for safekeeping. At the moment, we are not aware of any particularly large sets of judicial archives from the pre-Ottoman period. ${ }^{9}$ Nevertheless, the authentic specimens that are known to us provide us with valuable information on the form and uses of legal documents at the time they were made and through the ages, which can inform us about the utility of judicial archives. By combining such information with literary evidence and legal doctrine in a strictly chronological perspective, we are able to discern various steps in the evolution of judicial archives in Islamic society.

8 I gratefully acknowledge support by the ERC FP7 project 'Islamic Law Materialised' (ILM). CALD contains roughly 2,400 Arabic documents from the eighth to the sixteenth century. A detailed description of the corpus is in preparation.

9 See the article by Jürgen Paul in this volume. 


\section{Archives, documents and early legal doctrine}

The fact that cadis kept important documents in a special box (qimațr) is attested by sources from the Umayyad and early Abbasid period. ${ }^{10}$ We also know of early juridical dissent on the status of documents in the cadi's dīwān in the mid-eighth century. ${ }^{11}$ Literary sources mention the term 'cadi's archive' (diwān al-qā $\left.\bar{d} \bar{l}\right)$ when referring to documents handed down from judge to judge in the Abbasid Empire from the ninth century onwards. ${ }^{12}$ Several tenth- to thirteenth-century letters of appointment from Abbasid caliphs refer to the cadi's archive and his task of guaranteeing former judgements as an important aspect of a cadi's work. In their ways of defining the cadi's office, these letters clearly belong to the same Abbasid tradition, with the caliph nominating chief judges whose judicial role was anchored in Islam as a religion. ${ }^{13}$ One may argue that the Mamluk author al-Qalqašandī (d. 821/1418) cited these letters to tie in with this bygone Abbasid tradition. Over these three centuries, however, changing terminology highlights a shift in judicial practice as juridical thinking and legal practices advanced. The cadi's task of 'not changing any former judgements' from the tenth-century letter of appointment reappears in twelfth- to thirteenth-century letters in new terms: 'ratifying formerly ratified judgements'. ${ }^{14}$

The documents kept in the cadi's archive according to a description by alHyașạaf (d. 261/874) and the Abbasid nomination letters were known as 'siğillāt' and were issued after the cadi had passed his judgement. ${ }^{15}$ In Umayyad al-Andalus, the practice of registering cadis' sentences went at least back to the judge Muhammad b. Bašīr (d. 198/813-4). ${ }^{16}$ In early times, the administrative term siğill-from Latin

10 Tillier 2009, 400f.

11 Tillier 2009, 370f., n. 25, with reference to doctrinal differences between Abū Ḥanïfa and Ibn Abī Laylā.

12 Ibid., 50, 329-330, 402ff., Hallaq 1998, 427-429.

13 See Qalqašandī 1913-19, 10: 276-291, for letters issued by the caliphs al-Ṭā'î‘‘ (r. 974-999 CE), al-Mustaršid (r. 1118-1135 CE) and al-Nāṣir lil-Dīn Allāh (r. 1180-1225 CE). All three mention the task of carefully keeping the archive (Qalqašandī 1913-19, 274, 284, 291) and the necessity of safeguarding prior judgements (ibid., 273, 285, 290). See Hallaq 1998, 426.

14 Qalqašandī 1913-19, 273, 290 (letters under al-Mustaršid and al-Nāṣir lil-Dīn Allāh); for the early letter, see Qalqašandī 1913-19, 284 (letter under al-Ṭā'î').

15 See Tillier 2009, 403f.

16 See Hुušanī 1982, 75, Nubāhī 1948, 48 and Müller 1999, 151. 
sigillum - was not just limited to cadis' written judgements alone, ${ }^{17}$ but it is difficult to assess its exact use within future court litigations today. As Muslim jurists did not consider 'a writing' as legal evidence in general, the papers in the cadi's archive will simply have helped him to recall the details of ongoing cases. After the cadi's death (or loss of office, as the case may be) neither his word nor his papers were legally valid proof of his judgements unless their validity was attested by witnesses. ${ }^{18}$ The long-established habit of cadis calling upon individuals to act as occasional legal witnesses of decisions turned into permanent assistance during audiences with the cadi in the early ninth century, ${ }^{19}$ the same period when the cadi's call for attestation (išha d) in order to have written proof of his own court decisions is first mentioned in the context of maintaining a siǧill or registration (tasǧil).$^{20}$

At that time, however, a siğill, or court register, was not in itself regarded by a cadi's successor as written proof of an action. The newly appointed cadi could not use any documents he had found from his predecessor to pass a hukm (judgement) in ongoing cases without having to hear the witnesses again. ${ }^{21}$ In his widely accepted work al-Mudawwana, the ninth-century author Sahnūn (d. 240/854) cites Mālik's doctrine (d. 179/795):

\begin{abstract}
The cadi could not use the testimony effected under his predecessor and noted in his papers for a concordant decision without any testimonial proof of its current validity (bayyina). His predecessor, if still alive, could not confirm the fact since he had acted as a judge and would not have been accepted as a witness. The person concerned then had the possibility of swearing that the testimony from the cadi's papers was not the one used against him. If he refused to make this oath, the testimonies were 'validated against him' (umdiyat 'alayhi tilka alšahādāt) and the assignee swore to confirm his claim. The testimonies were then certified and the new cadi was able to adjudicate in accordance with his predecessor's decision. ${ }^{22}$
\end{abstract}

The non-binding character of written attestations from the former cadi's documents played a decisive role in a famous ninth-century trial concerning the well-known scholar Baqī b. Mahlad (d. 276/889), which was held in Muslim Spain. Confronted

17 Some ninth-century siğills concern tax leases; see Frantz-Murphy 2001 with nos 12, 16, 17, 23, $25,27,28,31$ and 34 stating that they are a siğill. If tax-lease siğills were issued by tax administrators, then siǧill was either a generic term used by the early Arab administration for any official 'notification', including cadis' documents as well, or the cadi issued these tax-lease documents in addition to other court notifications and the term was then limited to judicial use.

18 See Johansen 1997, 346, 352.

19 Tyan ${ }^{2} 1960,246$.

20 For Umayyad Spain, see above regarding the cadi Muhammad b. Bašǐr (d. 198/813-4); for the Abbasid Empire, see Johansen 1997, 346, n. 75.

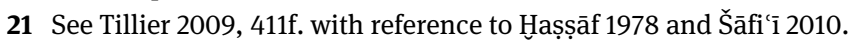

22 Saḥnūn n.d. 5: 145-146 (cited in kitāb al-qaḍā'). 
with a large number of negative testimonies about Baqi's blasphemy made by hostile jurists, which would inevitably have led to the scholar's condemnation, the ruler was advised to dismiss the acting judge. This he did, and the succeeding judge never renewed the attestations, which saved the accused scholar from the death penalty. ${ }^{23}$ This case corroborates the doctrine that a written notice of a testimony could only be used by the judge who had heard the witnesses, not by his successor. The same attitude about writing not counting as proof of a testimony is reflected in the well-known doctrine of 'one judge writing to another judge' (kitāb qā din ilā $q \bar{a}$ din) to inform him about an ongoing case, which was only accepted as legally valid if accompanied by witnesses' statements. ${ }^{24}$

At that stage of procedural law, any mention of attestation in authentic documents referred to the cadi having heard witnesses and accepted their testimony as proof. Several eighth- to ninth-century documents mention a witness's attestation ( ̌̌ahāda) as part of its text written by a single hand. The eighth-century parchments from Hurāsān (now Iran) name witnesses before the final date ${ }^{25}$ in a similar way to Egyptian papyri of the same period. ${ }^{26}$ A new style appeared several decades later, when the formula 'this was attested' (šuhida 'alā dālika) closes the text following the date, albeit without any witnesses' names being mentioned. Some documents ended there, ${ }^{27}$ but in other ninth-century specimens of the same type, the witnesses added their names in their own handwriting. ${ }^{28}$ This document type asserts that its content had been confirmed by a witness-proof and the additional witness signatures might refer to later repeated attestations. None of these documents refer to a cadi's judgement ( $q a d \bar{a}^{\prime}$ ' or $h u k m$ ), so they are not siğill documents. They may correspond to other types of documents kept in the cadi's archive, however, since judges issued documents along with a copy for the litigants and kept one specimen in their own archive (dīwān al-qāạī). ${ }^{29}$ What needs more research at the moment is

23 See Müller 2000, 169, with further indications.

24 Johansen 1997, 354f., Tillier 2009, 366-399.

25 Khan 2007; document nos 5, 7, 11, 12, 14 (mukätaba, 160/777), 20 and 21, all between the years 138-160/755-777. No. 29 begins with šahida 'alayhi followed by names, but without any date.

26 See Cahen/David-Weill 1978, document no. 24, dated 123/741, edition, p. 152, and DavidWeill 1971, document no. 16, edition pp. 12-13, dated 156/773.

27 Khoury 1993, document no. 40, edition pp. 77-78 (Berlin 11975, dated 232 AH/847 CE). Also: Ber_7902 (202AH), CaiN_173 (297AH), Chi_17657r (275AH), PhiPe_16320 (242AH) and VieAp_10489 (276AH).

28 For some examples of documents signed by witnesses, see Ber_7515 (276AH), CaiM_15649 (268AH), CaiM_17493 (272AH), CaiM_17494 (293AH), CamMb_134 (280AH) or PhiPe_16413/7 (268AH).

29 See Hallaq 1998, 420, n. 27 for some literary sources. 
whether or not unattested documents found their way into the cadi's archive as well as attested ones. The earliest known deeds that were personally signed by witnesses go back to the year 180/796. ${ }^{30}$ Not all sale contracts were signed at that time, however. The phenomenon of witnesses signing documents after attestation coincides with attributing the status of 'honorable witness' (šâhid 'adl) to a small group of people accredited by the cadi, which excluded large parts of the Muslim population. ${ }^{31}$ At present, it is hard to say exactly when witnesses had to sign their names after making an attestation and what types of documents this step was required for.

Although writing was not regarded as legal proof of an action and needed confirmation by a witness's testimony, the documents the cadi kept in his archive served to safeguard individual rights since confirmation by witnesses might have been problematic in another city. In the year 221/836, the cadi of Basra refused an order to transfer deeds (șikāk) from his archive to the cadi of Bagdad for confirmation (tatabbut) since the documents ante-dating his period in office were confirmed by testifying in his presence as valid proof (bayyina) and a transfer might have annulled some of the rights concerned, which would have conflicted with his duty as a judge. ${ }^{32}$

From our sources, it is very clear that no written attests from the ' $\operatorname{i} \bar{w} \bar{a} n$ al-qā $d \vec{\imath}$ had the status of legal proof required for a hukm during the third/ninth century; it only had indicatory value. ${ }^{33}$ This certainly limited the use of the cadi's archive. How, then, could judicial archives become important as an institution that preserved the validity of former judgements? The answer lies in a development of legal doctrine concerning witnesses' testimonies that took place after the ninth century.

We have more detailed information on cadis' documents for the tenth century. In the context of Islamic law and following a description in Tahāwīi (d. 321/935), we may translate the term siğill as 'notification (of a judgement)'. His examples of cadis' siğillāt mention conjointly material and procedural facts on which the final decision was based. The winning party was entitled to a siğill as an 'argument' (ḥuğğa) of the decision (qad $\left.\bar{a}^{\prime}\right),{ }^{34}$ terminology repeated in later texts. The second copy stayed with the cadi in case he needed it. ${ }^{35}$

30 See Khoury 1993, no. 64 (VieAp_1151) and CamMb_59, both of which were lease contracts.

31 Tyan ${ }^{2} 1960,239 f$. In Egypt this was introduced in 174/790.

32 See Tillier 2009, 646-647.

33 See also Tillier 2009, 411f., referring to Hुașșāf 1978; and al-Šāfi'ī, K. al-Umm, for the second process under the successor.

34 Ṭahāwī 1974, 1084. For some examples of cadis' notifications, see ibid., 1084-1121.

35 Ibid. See also Müller 1999 and Hallaq 1998 for a similar practice in Muslim Spain. 
In tenth-century Muslim Spain, various judicial magistrates (hukkām, sing. hākim: 'those that adjudicate') could issue a registration (tasğil). ${ }^{36}$ These tasğil documents in mālikī legal tradition shared most elements as described by Ṭahāwī without being limited to a cadi's decision. According to Ibn al-'Aț̣ār (d. 399/1008), all tasğill documents begin with an official call for a testimony, 'ašhada ...', include procedural and material facts followed by a decision (nazar) and finally the attestation of it. ${ }^{37}$ The document itself is termed 'siǧill'. ${ }^{38}$ Here, again, the winning party may demand a siǧill over his right ${ }^{39}$ as an 'argument' that supported the decision. ${ }^{40}$

\section{Enhancing the value of documents as proof of an action}

As has been said above, Islamic law did not accept writing as proof of an action in the period with which we are concerned here, and early documents merely served as personal aide-memoires regarding what had happened in the past, including witnesses attesting an action, which the cadi at the time had accepted as proof. How could a written attestation refer to the past on the one hand, but also lead to an oral testimony that a cadi could accept as proof in the future? In other words, how was it possible to turn the act of writing an attestation into an instrument with which to create long-lasting proof?

This enhancement of the utility of written documents occurred when the notion of 'testimony' ( $\check{a} a \bar{a} d a$ ) was formally divided into two distinct steps, namely 'taking a testimony upon oneself' (tahammul al-šahāda) and 'performing a testimony' (adā' al-šahāda), an evolution of legal doctrine that most probably took

36 See Ibn al-'Aț̣āa 1983. Even military or administrative officials were able to notarise a siğill in cases that did not require a hukm; ibid., 607. See also Ibn Sahl 1997, 90, who mentions the eleventh-century case of a magistrate who became a cadi.

37 See Ibn al-'Aț̣ār 1983, 130, 515, 519, 524, 528, 531, 545, 584, 588, 599, 611, 615, 618, 620, 626, 635 and 638 on the beginning of tasğil documents as opposed to 'deeds' (wață’iq) without any procedural elements; ibid., passim. tasğil formularies include procedural facts like raising the claim, its acceptance by a judge, final considerations or hukm and its attestation by witnesses. They copied material facts from relevant documents.

38 Ibid., 591, 622, 631.

39 Ibid., 514, etc.

40 Ibid., 599, 609: to obtain a 'ḥuğğa'. Ibn al-'Aț̣ār sometimes states the exact number of tasğil copies, one being for the dīwān: three copies (ibid., 131, 527) and two (ibid., 549). 
place in the tenth century..$^{41}$ In the first step, the witness took upon himself an individually binding obligation to attest to certain facts personally. He mentioned this by writing 'I attested', or less personally 'he attested', followed by his name. In the second step of 'performing a testimony', the witness made an oral testimony in the cadi's presence, which the cadi could then accept as proof of an action. A witness only needed to be 'honourable' when performing a testimony, not when accepting the call to make a testimony.

As a result of this evolution in legal doctrine, the words 'I attested' no longer referred to the proof the witness in question had furnished at the cadi's court, but only signified the first step in the procedure: the witness's legal obligation to testify. Since witnesses effectively acted as notaries, claimants could present any notarial document in court and be sure that the 'notary' would show up to testify orally if required to do so by the judge. Thus, attestations on documents constituted potential oral proof, not-as in the past-notification of proof of an action provided by a witness. Documents show us that this shift in legal practice occurred in the tenth century, when judges began to write the words 'I attended to this' on top of documents signed by witnesses or they affirmed that they had 'confirmed the validity' of the documents. ${ }^{42}$ The only possible explanation of this change in protocol is that witnesses' signatures no longer included the aspects of judicial verification and acceptance as proof. Since earlier documents never bear such annotations by cadis, we may assume that the words 'he attested' then implied the cadi's acceptance of the witnesses' statements as proof.

What consequences were there for cadis' written decisions, and how were they rendered performative for future litigation? As has been said before, tenth-century siğill formula documents reflect a solution to the above-mentioned legal problem, namely that a cadi could not confirm his own actions after having closed the court session. Since no authentic annotated specimens have been preserved from this period, however, it is uncertain whether such tenth-century court registers were simple notifications of past events or already served as instruments for obtaining proof of past action in later litigations.

Most formulae cited by al-Ṭahāwī in the early tenth century refer to the attestation of cadis' documents ( $m \bar{a}$ šahida 'alayhi), ${ }^{43}$ whereas the later tasğil formula by

41 Müller 2010, 65f.; Müller 1999, 180; the distinction is absent from juridical manuals of the ninth century.

42 For an early example, see LonNo_4684_8 from the year 384/994.

43 'hād 1104:1l. 4-5, 1118: 1. 5, 1120: 11. 3-4; hādā mā šahida 'alayhi al-šuhūd al-musammūn fì hādā lkitāb šahidū ğamī'an anna al-qāẹī fulān ašhadahum bi-madīna ... annahu țabata 'indahu 1084: 
Ibn al-'Aț̣ār always began with the standard išhād phrase, referring to the cadi's call for witnesses. In the middle of the tenth century, a cadi verified the content of a siğill written by his secretary until the term 'he attested' (šahida) then wrote the call for attestation himself (išhād) and had the document (!) attested..$^{44}$ If meant to formulate a testimony for future performance, the document's text necessarily interlinks actions, rights or obligations directly with the person concerned, either in his favour (lahu) or at his charge ('alayhi). Authentic documents mention the step of calling upon a witness at charge of a private person since the beginning of the tenth century ${ }^{45}$ and at the charge of a judge since the eleventh century. ${ }^{46}$

Later, when cadi-išhād documents were used as instruments to furnish proof of an action, the testimony of court procedure not only mentioned the cadi's appeal for attestation (ašhada), but that he 'appealed to attest at his charge' (ašhada 'alayhi), ${ }^{47}$ or even more explicitly, 'at the charge of his soul' (ašhada 'alā nafsihi [alkarima]). ${ }^{48}$ This kind of testimony confirms the cadi's responsibility for the legality of court procedures, and the witnesses could attest to this in the future. Since neither the tenth-century išhād formula used by al-Ṭaḥāwī and Ibn al-'Aț̣ār, nor other sources ${ }^{49}$ consistently refer to the cadi's obligation, siǧills may not have served as instruments for providing proof at that time. The earliest known authentic siğill document, which dates back to 494/1101, uses the phrase 'the judge had called for it [the document] to be attested' without including any signatures from witnesses. ${ }^{50}$

11. 11-14, 1095: 11. 9-10, 1100: 11. 5-6, 1104: 11. 4-5, 1118: 1. 5, 1120: 11. 3-4, and for a non-tasğil document, see 1122. Only once: hād $\underline{a}$ kitāb ašhada 'alayhi al-qāộ̄ fulān al-šuhūd al-musammīn fihi, 1095: 11. 6-7.

44 See Ibn al-'Aț̣āar 1983, 642, for the Cordoban judge Muhammad b. Abī 'Īsā (d. 339/950-1). This does not necessarily imply a notarisation by a witness over the išhād.

45 See Ber_13002 (304AH).

46 See the Fatimid cadis' išhād document from 429AH, originally preserved by the Karaite community in Cairo, published by Gottheil 1907, 467-539 with edition, 472-478.

47 Early ones are from Yarkand and Ardabil, see LonSy_6 (503AH) in the form of a qadi's disposition (yaqūl al-hāakim); see Gronke 1986, 489, for witnesses no. 2-5; also witnesses: ašhadanī al$q \bar{a}$ ḍī, see Ardabil ArdS_5 (599AH) and ArdS_8 (604AH), Gronke 1982, 158 and 218; for a reference in the text al-ḥākim al-mušhid 'alā ḥukimihi wa-qaḍā'ihi ašhadahum 'alā dōalika, ArdS_5, ibid., 156 , line 23

48 See below for thirteenth-century documents.

49 al-Hušanī (d. 361/971) only cites the išhād 'țumma sağğala finā wa-ašhada' for the cadi Muhammad b. Bašĩr (d. 198/813-4), Hušanī 1982, 75, whereas the fourteenth-century author alBunnāhī added to the same report the obligation 'fa-sağğala fihā wa-ašhada 'alā nafsihi'; see Nubāhī 1948, 48. On Bunnāhī/Nubāhī, see Lirola Delagado/Puerta Vílchez 2012, 282-286.

50 See Gronke 1986, no. 1, pp. 479-480, line 2. 
Interestingly enough, another document of the same origin bears witnesses' signatures indicating the cadi's išhād. ${ }^{51}$

As the rare authentic documents do not cover all aspects of complex legal evolution, we can only note a few milestones here: the absence of marginal notes in eighth- to ninth-century documents indicates their use as simple notifications. Annotations by cadis since the tenth century illustrate the practice of the two-step testimony. Moreover, the above-mentioned early eleventh-century cadi-išhād document supported the use of specimens as documents providing proof long after the išhād formula had appeared in notarial manuals (šurūṭ). Here, again, we cannot exclude the loss of earlier documents of this kind.

\section{Cadis' archives}

We must assume that these changes in notarial and judicial practices heavily influenced the function and organisation of cadis' archives. As historical settings differed in time and space, and the smooth functioning of the cadi's court depended on political authorities and stability, the following observations, based on glimpses from sources, can only indicate the general importance of the cadi's archive in specific cases.

Keeping an archive was a task that distinguished a cadi from other officials with judicial functions. As mentioned above, receiving the previous cadi's archive was important for incoming Abbasid judges, whose role was to preserve people's rights. ${ }^{52}$ In Umayyad al-Andalus, various magistrates (hukkām) acted as judges, but only the cadi kept an archive (dīwān al-quḍat) and certain fields of law were reserved for the $q \bar{a}$ ḍìs jurisdiction; ${ }^{53}$ the noting (tadwīn) of orphans' property could only be done in this dīwān al-quḍatt, for example..$^{54}$ Compared to early Mālikī tradition as described by Sahnūn, the tenth-century cadi's archive represented a major shift in legal practice: debts that had been recorded (mudawwan) in the dīwān al-quḍāt by a predecessor without notification of an acquittal could only be cleared from this record by judicial procedure. ${ }^{55}$ This illustrates the

51 See Gronke 1986, document no. 6.

52 See above.

53 Müller 2000, 168, along with Ibn Sahl (d. 486/1093), who drew on older sources; Ibn Sahl $1997,331$.

54 Ibn Sahl 1997, 91f., citing Ibn Ziyād (d. 312/924).

55 See Müller 2000, 168, along with Ibn Sahl 1997, 1001; the muftis lived at the beginning of the tenth century. 
legal value of such entries in the dīwān, which served as an institutional archive beyond the mandate of the cadi who had originally established the facts.

Early sources report that Abbasid documents were stored in closed boxes (sing. qimațr) that were only accessible to the cadi or his fiduciaries. When a new cadi took office, he checked his predecessor's archive, looking at a register from each box that listed the names of beneficiaries and the overall document number in the box, written by two individuals who checked the archive. ${ }^{56}$ Later authors confirm the existence of a registry facilitating access to information. According to the Transoxanian jurist al-Samarqandī, who probably lived during the eleventh century, an annual inventory (ğarīda) summarised all the archived documents and listed them according to specific types. If they were still relevant, documents were to be re-registered in the inventory the following year. ${ }^{57}$

Our sources mention a variety of documents kept in a cadi's archive, not only certificates on the cadi's judgements (siǧillāt), documents of 'presence' (maḥạdir) and deeds (waț $\left.\bar{a}^{\prime} i q\right) .{ }^{58}$ Authentic specimens of some of these types of document have survived to this day, but it is difficult to correlate these with the descriptions of the cadi's archive since practices changed and the external form of the documents changed as a result. These documents were only able to serve as the basis of legal evidence in future litigations once writing authenticated by witnesses had become an 'instrument of proof'. However, not every case was solved by a formal judgement (hukm), which might have left room for wider use of written documents by succeeding cadis. Thanks to the preservation of authentic judicial išhād documents, the internal functioning of the cadi's archive becomes clearer to us from the thirteenth century onwards.

\section{The 'judgement archive' and its 'documents of proof' (thirteenth-fifteenth century)}

With the enhanced use of documents as instruments to provide proof of past action, the cadi's archive with its different types of documents arranged and filed in weekly or monthly intervals ${ }^{59}$ must have considerably grown in size over the

56 Tillier 2009, $403 f$.

57 See Hallaq 1998, $427 f$.

58 See Tillier 2009, 403f., Hallaq 1998, 426-429, along with Qalqašandī 1913-19,10: 274, 284 and 290.

59 See Hallaq 1998, 429. 
years. Systematic recopying of the archive only makes sense if the legal value of its documents is preserved, which would mean reproducing authentication by judges and witnesses as well. If this seems impossible for all the cadi's papers, we have good reason to assume that legal validity was specifically assured for a section of the corpus of official documents called the 'archive of adjudication' (dīwān al-ḥukm) in thirteenth-century sources, with cadis' documents on ongoing and finalised cases. The term appears in the twelfth century ${ }^{60}$ and is cited as a specific branch in the appointment letter during the reign of Caliph al-Nāșir lilDīn Allāh (r. 1180-1225 CE) and in the cadi's manual of the Ayyubid author Ibn Abī l-Dam (d. 642/1244). ${ }^{61}$ Its maḥạdir and siğillāt documents were collected every week and stored in the cadi's box (qimațr), a repository for books and documents for the cadi's exclusive use, after having being filed and stamped. ${ }^{62}$ According to the manual, the incoming cadi had to systematically go through the siǧillät and other documents from the dīwān al-ḥukm that were handed down from his predecessor. If he found that only one or two of the four original witnesses to a procedure were still alive, he had to renew the certification (iš̆a $\bar{a} l) .{ }^{63}$ This procedure of assuring authentication of rendered judgements might correspond to the cadi's task of 'ratifying what the judges before him had ratified', which appointment letters mention. ${ }^{64}$ Although no original isğâlāt from the Ayyubid period are known at present, the practice of periodically renewing isğâl is confirmed by entries found in Ottoman registers. ${ }^{65}$ In conformity with earlier examples, Ibn Abī lDam's isğâl model cites the establishing of facts as legally valid and confirmed by judgement, but also clearly expresses the cadi's responsibility in the call for witnesses, ${ }^{66}$ as was required for attestation. His description of documents and the

60 See dīwān al-qaḍa $\bar{a}^{\prime}$ wal-ḥukm, Qalqašandī 1913-19, 10: 290, in a letter of appointment issued between 1118 and $1135 \mathrm{CE}$.

61 See Qalqašandī 1913-19, 10: 283, specifically ‘dīwān ḥukmihi’; on his archive and its various documents in general: 'dīwānuhu', ibid., 284, which earlier letters of the tenth and early twelfth century call dīwān al-qaḍā'; ibid., 274, and dīwān al-qaḍā' wal-hukm, ibid., 290; on dīwān alḩukm, see Ibn Abī l-Dam ${ }^{2} 1982,122$.

62 Ibn Abī l-Dam 21982, 123. For a definition of these document types, see ibid., 553. See Hallaq 1998, 435.

63 Ibn Abī l-Dam ${ }^{2} 1982,123$.

64 Qalqašandī 1913-19, 10: 273 and 290.

65 On Saladin's endowment deed for the Șalāhiiyya convent in Jerusalem and its repeated certifications, see 'Asalī 1983 and 1985, 1: 83-100, based on the Jerusalem siğill no. 95 from $2^{\text {nd }}$ Dū lHị̆ğa 1022/13.1.1614.

66 Hādā māa ašhada 'alā nafsihi bihi sayyidunā al-qādī, Ibn Abī l-Dam ²1982, 555. 
judges' authentication of isğāl corresponds to later Mamluk documents.$^{67}$ It does not, however, refer to the validation of earlier procedures in a cadi's certificate (siğill), known at present only from Mamluk documents.

The Mamluk cadi's certificate (siğill) certified the cadi's ruling $(h \mathrm{ukm})$ over the legal validity (sihḥa) of all its content, which might be highly complex, including court documents from various judges, past and present, and consecutive certifications (isğāalāt). ${ }^{68} \mathrm{~A}$ siğill's complexity was due to differences in notarising proceedings concerning (case a) the cadi's own court session, the procedure of establishing facts from witnessed documents or based on ratified cadis' documents, or (case b) the confirmation of former judgements. Witnessed documents notarised the first step in providing proof by means of a witness's testimony (tahammul al-šahäda). To use these in litigation, the judge questioned the witnesses and accepted their testimony ( $a d \bar{a}^{\prime} a l-s ̌ a h \bar{a} d a$ ) as a way of 'establishing facts' (tubūt). He then ratified the document with his well-known motto ('alāma) and called witnesses for attestation of the procedures leading to facts being established and eventually to a judgement on the matter in question. Cadis from different cities used a ratified cadi's document of this kind-at least in ongoing cases-as a means of establishing facts without having to call on witnesses to testify about facts or legal procedures. The cadi ratified the document with his own motto a second time and called his own instrumental witnesses to vouch for the legal procedure. He did not mark the earlier signatures with a note confirming that a testimony had been made, however. ${ }^{69}$ Such procedures did not necessarily lead to a formal judgement by the cadi, ${ }^{70}$ but whenever the judge passed a judgement, it became effective (tanfid al-ḥukm) after attestation (išhād). In some complex cases, the cadi referred to various certified documents as arguments that led him to his judgement, along with other established facts. ${ }^{71}$ When it became necessary to corroborate a former judgement by a different judge through isğăl (case b), the cadi took an existing document on such a previous judgement as the basis for rendering it effective (tanfid al-hukm). This procedure probably asserted the authenticity of the former document and its signatures, which was possibly done

67 'After verification, the cadi wrote the date and hamdala in the space that the secretary had left in the text'; Ibn Abî l-Dam 21982; 567 (this court record ended with a hukm, but the author did not call it isğāl or siğill).

68 See Asyūṭī 1996, 2: 327. Pace Hallaq 1998, 420.

69 See Müller 2013, 329-383, for details of ongoing cases.

70 See Müller 2006.

71 See the example of the Haram document no. 355 summarising documents that the cadi had used for the case; in Little 1998, 93-193. 
by a procedure called 'testifying a testimony' that did not require the cadi questioning instrumental witnesses again, who might be dead or absent. No cadi was supposed to annul any of his predecessor's judgements unless new evidence had appeared in the meantime that made this step necessary. The difference between hearing witnesses to establish facts and render a judgement, notarised as judicial išhād, and certifying a predecessor's judgement in the form of iš̆āl becomes obvious in the introductory formula and the forms of authentication that were used. ${ }^{72}$ Authentic documents from the Haram Corpus in Jerusalem, ${ }^{73}$ the Aleppan Scroll and from Cairo's archives confirm these descriptions. Wherever documents include isğâl certifications that were renewed periodically, the primary cadiišhād refers to rendering the qā one or more isğâl procedures.

A Mamluk cadi's certificate (siǧill) could combine all these elements-various cadis' certificates and judgements-to create a single document and rule for its legal validity. It could either contain all the certifications needed for a complex court case or certify several documents collated together with their originals. ${ }^{74}$ When preparing such a siǧill, the cadi scrutinised all these documents (kutub) not only from a legal perspective, but in terms of their establishment as facts and consecutive ratifications leading up to his own approval (ittișāl). ${ }^{75}$ Contrary to what has been said on Ayyubid practice, the Mamluk description avoids mentioning the need for personal testimonies from surviving instrumental witnesses for this last step. When the cadi decided to validate the siğill prepared by his secretary, the judge had to ensure that cited documents had been meticulously transcribed and collated (muqābala) by the secretary and a second witness using the originals to form the siğill. He then had to 'pronounce the establishment [of its content] as fact' (nāțiqan bi-țubūtihā) to make it a ḥuğğa for all it contained at that moment and for the future as well. It was the cadi's task to combine older attestations into a unified 'argument' that became an instrument capable of providing legal proof of past actions. The issuing judge, named in detail after a long

72 '[T] his is what he 'takes as grounds for' (bihi) what he has attested' (hād $\bar{d} \bar{a}$ mã ašhada bihi 'alā nafsihi al-karima). In the išhād, the formula runs: 'this is what he has attested' (hā 'alā nafsihi al-karima). Things were not as clear in the Ayyubid period: Ibn Abī l-Dam (21982, 555) cited the above-mentioned isğāl formula in a model document, but gave the išhād formula as the isğāl standard (553).

73 The Ḥaram document no. 333 copied the successive isğăl-notices belonging to a waqf-document; see Müller 2013, 76, with certifying judges mentioned; ibid., 242-245.

74 On the details of a Mamluk cadi’s certificate (siğill), see Asyūṭi 1996, 2: 323-325, with the two types.

75 Asyūṭī 1996, 2: 324. For a different understanding of ittișāl, see Johansen 1997. 
hamdala (not the basmala) and introductory formula, ratified the siğill with his 'alāma at the top of the document, then wrote the date and hasbala with a particular broad pen in the spaces left for them by his secretary, and called for witnesses to certify the procedure. These certification marks distinguished the Mamluk siğill from contemporary išhād documents, which were limited to procedures taking place in the cadi's court up to a first judgement.

Authentic examples of Mamluk siğills confirm this description in the cadi's manual. A twenty-metre-long scroll from the archives of an Aleppan family was one such siğill. ${ }^{76}$ Issued in the fifteenth century, some of its certified documents go back over a hundred years, with various descriptions of authentications in former procedures and uninterrupted series of isǧâl notices (ma the past cadi's certificate to the latest document. The isğâlāt notifications on the verso side (non-edited) have no connection with the document on the recto side. Written on originals kept in the cadi's archive, each isğâl of the predecessor's judgements consisted of an independent document using formulae, titles and eulogies for the issuing judge, which witnesses attested and signed. If necessary, the scribe glued new sheets to the existing scroll. ${ }^{77}$ When a cadi referred to earlier isğâl procedures in a certificate (siǧill), he used the shortened isğāl notice (maḍūn isğâl) with the judge's name, place of office and isğāl date, but without any eulogies or witnesses' names. ${ }^{78}$ Other original registration documents (iš̌ālāt) were part of larger transactions, like the properties transferred to the foundation of the last Mamluk sultan, al-Ġawrī. ${ }^{79}$ Any siǧill might become the object of later isğāl procedures. ${ }^{80}$

\section{The cadi’s 'living archive'}

For the Mamluk period, we have a large variety of witnesses' documents at our disposal that notarise all kinds of legal steps, ranging from simple witnessed inspections and attestations to records and judgements. These concerned a broader section of the population, as illustrate inventories of personal estates for inheritance

76 Edited by Saghbini 2005. Today, the scroll is $20 \mathrm{~m}$ long and $30 \mathrm{~cm}$ wide.

77 The joint for a new sheet was called wașl; on certification of such joints, see Gronke 1982, 123, 182, 199, 221f., 248, 301, 351f., 430f.

78 See the Aleppo scroll. Different independent isğāls on the verso, not edited.

79 'Abd al-Lațîf 1957, 293-420.

80 See 'bi-gamī' mā nusiba ilayhi fi isğālihi ... al-musațtar bi-zāhir șadr al-siğill al-musaț̣ar bāṭinahu', in: BerHo_6948 (Aleppan scroll), forth notification verso, ed. by Saghbini 2014, 40 (Arabic text). 
cases. An incoming cadi could use all the witnessed documents from his predecessor's term of office after calling on the original witnesses to attest to their validity in his own court of law. These sources of information allow us to reconstruct judicial procedures in detail, ${ }^{81}$ but it is still unclear whether such witnessed documents actually became part of the cadi's own archive-and in which section they were put if this really did happen-as hard evidence is lacking. ${ }^{82}$ In a more general manner, manuals describe ways to notarise isğâlāt based on documents of acknowledgement confirmed by making an oath, or on attestations by witnesses with the inclusion of a cadi's formal judgement $(h u k m) .{ }^{83}$ The function of the lost judicial archives $^{84}$ for 'rendering justice' becomes clearer if such a bottom-up perspective is taken.

Long-lasting instruments for providing proof like siğillāt or other certified documents continued to be kept in the cadi's archive for years. Mamluk practice probably followed the earlier Ayyubid institution to a large extent, but it is difficult to retrace the gradual changes and ruptures that occurred in detail. It seems beyond doubt, however, that Mamluk judges also renewed older cadis' judgements by isğâl to render them effective from time to time. The systematic verification of whether or not instrumental witnesses were still alive, as described for incoming cadis in the Ayyubid period, seems less certain, however. There are several reasons for this. First, a procedure of this kind is not mentioned in any of the detailed descriptions that have come to light so far. Second, Mamluk cadis always issued isğâl documents 'on demand', according to the sources. This may seem like a stock phrase, but court procedures cost money-who would want to pay for them without a specific call for one by a party to a dispute? Third, certain formulae suggest that proof-providing documents served as 'witness' for the legal facts they contained (al-šāhid bihāa). ${ }^{85}$ This rendered oral testimonies unnecessary for documents whose authenticity was beyond doubt. It is unclear exactly when such procedures began to be adopted, but we may assume that certified documents from the cadi's archive would fulfil such a condition. Repeated Mamluk certifications (isğālāt) would not systematically ensure authentication by living witnesses, but confirmed the validity of a past judgement, either by judges of the other four accepted law schools or during litigation, and rendered such a judgement effective.

81 For this, see the study of the Haram documents, Müller 2013.

82 Regarding the argument that the Ḥaram documents were not a systematic court archive, see Müller 2011, 435-459.

83 Ğarāwānī 2010, 332-333.

84 See Jürgen Paul in this volume.

85 This formula appears in documents from the late fifteenth century. For an example, see Reinfandt 2003, 157 (the Arabic text is on line 35f.). 
Thus, Mamluk siğills were cadis' certificates in the form of scrolls containing several 'certifications' (isğālāt), but no 'registers' or register entries showing systematic archiving. They were either kept in the archive or handed to the parties concerned. Manuals describe in detail how the original ( $a s l)$ of a court procedure kept in a box (qimatr) by the cadi was used to issue further documents for the parties. This could be done in two different ways: either as a copy (nusha) that reproduced all the marks of authentication left by the ruling judge and his witnesses or as a 'cadi's certificate' (siǧill). ${ }^{86} \mathrm{~A}$ 'copy' of it could only be issued at the same time as or shortly after the original was notarised, as otherwise neither the cadi nor his witnesses would be available. ${ }^{87}$ This restriction did not apply to cadis' certificates, though. The cadi therefore had a 'living archive' at his disposal from which he could issue legally valid documents. Authenticated siǧills served as an 'argument' (huğğa) in future claims or litigations, which led to continuous reciprocation between archived originals and handed-out copies for arguing legal cases, which might lead to new original documents being produced concerning cadis' decisions.

Mamluk cadis' documents only survived in the hands of private families, Christian ecclesiastical institutions or the central waqf administration. The cadi's archive-the source of his power to safeguard long-term subjective rights by rendering former judgements effective and issuing siğill cerificates-did not outlast the changes that occurred as a result of introducing Ottoman court records and their different definition of the judicial siğill, however.

\section{Ottoman court records (fifteenth-sixteenth centuries)}

When the Ottomans took over Egypt in 1517, a number of important changes took place in terms of judicial organisation and record-keeping that stirred up the population when initially introduced. ${ }^{88}$ An Ottoman court register (siǧill) generally recorded different types of legal documents such as attestations, acknowledgements and litigation records upon validation by the judge in a chronologically arranged

86 See Asyūṭī 1996, 2: 326f. and Ǧarāwānī 2010, 333, editing ms Berlin Or. 2011, entitled Kitāb alkawkab al-mušriq fi l-warāqa, ibid., 16.

87 Seen from that perspective, the is $\check{g} \bar{a} l$ documents from the Monastery of St Catherine on Mount Sinai are 'copies' with authentication marks concerning procedural steps.

88 See for this Ibn Iyās 1974. 
register called a defter. ${ }^{89}$ Each entry was followed by the names of instrumental witnesses (known as šuhūd al-ḥâl) who assured its validity, not necessarily the legality of the court procedure. Independently notarised proof-related documents (huğğa, Ottoman: hüccet) that were destined for the parties concerned were very similar to those from the Mamluk era in terms of their juridical formulations and requirements such as witnesses' signatures. ${ }^{90}$ They differed by beginning with the place of adjudication (mahkkama šar'iyya) of a city and its acting judge. The latter ratified documents of this kind using a notation called 'unwān at the top left above the basmala, ${ }^{91}$ a practice already used in earlier Seldjuk documents from Anatolia and the Ardabil documents. Each Ottoman document serving as proof of a past action was registered and could be traced back to a dated entry in the court register, even if the judge had changed or several deputy judges were acting at the same court of law. Thus, the court register allowed the validity of each document presented for a claim to be verified.

The mentioning of a place of adjudication in the Ottoman documents acting as proof of a former cadi's actions illustrates the change from a personalised 'cadi's certificate' to a 'court certificate' where the legal institution itself (mahkama) was emphasised. When legal certificates were issued by a court of law that kept a record of them, and not by the cadi himself, then any periodical replacement of the officeholder had far less impact on legal life than in the past. Ottoman court registers with their chronologically arranged entries allowed cases to continue under newly appointed judges without earlier attestations of authenticity or truth having to be repeated. None of the register entries on legal titles needed a long and specific reference to the certifying cadi and his place of adjudication as this was determined by the archiving; the whole court register functioned as a siğill (certificate) verifying the judge's actions during a court session. Therefore, any entry in an Ottoman court register could be the basis of an authentic, proof-related document handed out to the parties in a dispute, and inversely, documents acting as proof of past action

89 Okawara 2015, 21, highlights the changes in early Ottoman court registers of the Arabic provinces. The Ḥamā court register no. 3 of 942/1535 begins with '[t]his is a register to record siğills (hād $\bar{a}$ daftar al-siğillāt)', ibid., with the bound volume being referred to as daftar and its content as the cadi's certificates (siǧillāt). This hesitation to use the term siğill for the register did not last long. After the year 977/1569 with an example from Aleppo '[t]his is a register to be preserved (hād $\underline{a}$ siğill maḥūz)', almost all court registers of Bilād al-Šām that conserved their first page were called siğill, ibid.

90 See Müller 2012 for a comparison; on hüccets in Ottoman court registers see Akgündüz 2009, 212-216.

91 Veselý 1972, 312-343; 332 here. 
could be incorporated into a court register..$^{92}$ No chronological registers of ongoing affairs that were of value as proof prior to the Ottoman court register are known at present. Obviously, Ottoman register entries were not periodically re-authenticated after the witnesses' death, as Ibn Abī l-Dam had postulated for the Ayyubid dīwān $a l-h u k m$. Judgements needed to be rendered effective from time to time, however, possibly to defend them against other claims. This new way of handling court records was introduced in every Arab province in the Ottoman Empire during the sixteenth century, and Mamluk siğills concerning long-term property titles or foundations found their way into the new Ottoman court registers. ${ }^{93}$ This type of court register kept a record of all legally significant actions undertaken at the cadi's court, including those that recorded stages preceding a final judgement. This is what made the older Mamluk siğill scrolls obsolete, not the use of documents as instruments to provide proof as such, which continued to function much the same way as before. As a result, Mamluk court archives with their scrolls stored in boxes were replaced by Ottoman Sharia court records in the form of register books.

\section{The cadi's court of law as an institution}

These glimpses of archival practices and the history of cadis' certificates from premodern Egypt and other parts of the Islamic world provide new elements that help us to understand the cadis' long-ranging historical role. The importance of a cadi did not depend primarily on his individual personality, but on an institution that was based on the jurists' law and its interpretation of Islam's normativity, bypassing and crossing political boundaries. The cadis' 'power of the pen' allowed them to notarise the subjective rights of the population and its rulers during ongoing litigations and long-term cases. The cadi's archive proved essential to fulfil this role in a Muslim society. With the development of procedural law, especially the two phases of testimony and the cadi's call for attestation by witnesses since the tenth century, cadis' documents became instruments for obtaining proof of past actions-and not only for the acting judge as in early time, but for his successors as well. The different uses made of the cadi's siğill over the

92 On the legal value of the Ottoman siğill, see Michel 2005, 225-252; 229-230 here. On the subject of noting on a proof-related document that its hukm was considered by the cadi's court, see Müller 2012, 451.

93 See above for the certification of the waqfiyya of Șalāḥ al-Dīn for the Hanqāh al-Ṣalāhiiyya in Jerusalem, as reproduced in siğill no. 95 on $2^{\text {nd }}$ Dū l-Hịğğa 1022/13.1.1614; ed. 'Asalī 1983 and 1985, 1: 83-100, also including Ottoman certifications. 
years highlight this development. Early on, a siğill was a notification of a court decision that required the original witnesses to be questioned again by the new judge, possibly in a lighter procedure, but without difference to other documents from the archive. From the tenth century onwards, cadis' certificates (siğillāt) combined the use of notarial documents with the attestation of court procedure. At the latest when the cadi's call for the procedure to be attested engaged his own responsibility, such an attestation about the legality of the previous procedure allowed any of his acting cadi-colleagues to confirm the former judgement without repeating the earlier procedures. When done systematically for all siğillāt from the archive and by drawing on the earlier cadi's responsibility for arranging a legally valid procedure, as described for the Ayyubid period, the cadi's archive turned into an instrument for obtaining institutionalised judicial proof.

In this period, any earlier gap between legal theory and practice was reduced or closed altogether as the fiqh rules of oral testimonies by witnesses determined the way in which rights and judgements should be notarised and how they should be validated by succeeding cadis. The legal conformity of certified judgements was a strong argument against them being turned over by another cadi, as the law insisted in principle on respecting prior judgements if they were still legally valid. Endowment deeds illustrate that only the repeated certification of their conformity to sacred law guaranteed it had remained effective throughout the centuries and could continue to be so. Making copies of certified originals of siğills kept in the cadi's archive was therefore a widespread practice and was not just limited to the Mamluk state. ${ }^{94}$

The cadi's archive contained current certificates and those issued by the judge's predecessors. His power over such a 'living archive', which could prolong the validity of earlier legal proof to the present day, distinguished a cadi from other magistrates and state officials. To achieve this, the cadi did not act alone, but-and not only in the Mamluk era-was assisted by a group of witnesses-often professional notaries-whose role it was to guarantee the legality of notarisations and court procedures. Although the way in which the cadi's archive functioned changed with the introduction of Ottoman court registers, which were housed by the Sharia courts (maḥkama šar 'iyya), the role of a cadi still persisted. Documentary analysis reveals no antagonism between procedural law on oral proof and proof-related documents recorded in Ottoman court registers. From a systemical point of view beyond historical diversity, the institution of the cadi's court consisted of three pillars: (1) the judge as a person, (2) accredited witnesses

94 A thirteenth-century waqfiyya copy from the Central Asian town of Bukhara mentions its collation with the siğill. See Arends/Khalidov/Chekhovich 1979, edition of this part 47-60. 
acting as notaries, and (3) the cadi's archive. We may therefore consider the cadi's capacity of safeguarding legal rights as his power over an 'institutionalised memory ${ }^{95}$ based on law.

The overall importance of cadis throughout Muslim history, also illustrated by thousands of biographical notes on cadis in biographical dictionaries (țabaqāt), was based on their role as the head of an institution that applied the sacred law to earthly situations, among other normative references. As the jurists' law (fiqh) limited the cadi's investigative power and did not define any executive functions, the cadi's role in settling conflicts often depended on a collaboration with other officials in ways that were determined by political and administrative rules that differed from one historical setting to another. ${ }^{96}$ As for the longevity of the cadi's court of law as a pivotal institution throughout the ages and in several Islamic empires, any lack of executive competences seemed less relevant than the preponderant prerogative of validating and preserving subjective rights thanks to the cadi's power of adjudication based on testimonies by accredited witnesses and access to his archive of documents.

\title{
8 List of documents cited with a sigle*
}

\author{
ArdS_5 (599AH): edited in Gronke 1982, 152-160, no. 5 \\ ArdS_8 (604AH): edited in Gronke 1982, 213-222, no. 8 \\ Ber_7515 (276AH): Berlin, Papyrussammlung, ed. Khoury 1993, 104, no. 56 \\ Ber_7902 (202AH): Berlin, Papyrussammlung, ed. Frantz-Murphy 2001, 26 \\ Ber_11975 (232/847): Berlin, Papyrussammlung, ed. Khoury 1993, 77f., no. 40 \\ Ber_13002 (304AH): Berlin, Papyrussammlung, ed. Khoury 1993, 49-50, no. 22 \\ BerHo_6948: Berlin, Staatsbibliothek, Ms. or. 6948 recto, ed. Saghbini 2005, verso partially \\ ed. Saghbini 2014 \\ CaiM_15649 (268AH): Cairo, Museum of Islamic Art, ed. Fahmī 1973, 29-31, no. 4 \\ CaiM_17493 (272AH): Cairo, Museum of Islamic Art, ed. Fahmī 1973, 32-35, no. 5 \\ CaiM_17494 (293AH): Cairo, Museum of Islamic Art, ed. Fahmī 1973, 36-38, no. 6 \\ CaiN_173 (297AH): Cairo, Dār al-kutub, ed. Khoury 1993, 35-36, no. 13 \\ CamMb_59: Cambridge, University Library, Michaelides; no. 59, ed. Khan Geoffrey 2003, 228
}

95 See Johansen 1997, 349: 'mémoire institutionnelle du tribunal'.

96 For an example of such a collaboration between the cadi court of law and police forces, see Müller 2017.

* The sigles adopted in CALD (see n. 8) refer to where a document is conserved, not to editions: the first three letters for the city, any fourth capital letter to its institution, any fifth to a subcollection or distinctive inventoring marks, followed by its inventory number. 
CamMb_134 (280AH): Cambridge, University Library, Michaelides; no. 134, ed. Ragheb 2002, 9-11 Chi_17657r (275AH): Chicago, Oriental Institute Museum, ed. Frantz-Murphy 2001, 122f. no. 4 LonNo_4684_8 (384AH): London, British Library: P.Lond. or. 4684 (8), ed. Ragheb 2002, 3033, no. 11

LonSy_6 (503AH): London, SOAS, ed. Gronke 1986, 487-489, no. 2

PhiPe_16320 (242AH): Philadelphia University Museum, Ellen W. Harrison Collection, ed. Levi Della Vida 1981, 87, no. 36

PhiPe_16413/7 (268AH): Philadelphia University Museum, Ellen W. Harrison Collection, ed. Levi Della Vida 1981, 69-70, no. 31

VieAp_1151: Vienna, National Library, Inv. Ar. Pap. 1151, ed. Khoury 1993, 118-119, no. 64 VieAp_10489 (276AH): Vienna, National Library, Inv. Ar. Pap. 10489, ed. Khoury 1995, 35f., no. 7

\section{References}

'Abd al-Lațīf, Ibrāhīm (1957), 'al-Tawtīqāt al-šar'iyya wa-l-išhād fĩ ẓahr wațīqat al-Ġawrī’, in Mağallat Kulliyyat al-Ādāb, Ğāmi'at al-Qāhira, 19, 293-420 with 15 Tables.

Akgündüz, Ahmed (2009), Shari'ah Courts and Shari'ah Records: The Application of Islamic Law in the Ottoman State, in Islamic Law and Society, 16, 202-230.

Amīn, Muḥammad M. (1981), Catalogue des documents d'archives du Caire de 239/853 à 922/1516 (depuis le Ille siècle jusqu'à la fin de l'époque mamlouke) suivi de l'édition critique de neuf documents, (Textes arabes et études islamiques, vol. 16), Cairo.

Arends, K.A., A.B. Khalidov, and O.D. Chekhovich (eds) (1979), Buxarskii vakfXIIlogo veka, Moscow: Nauka.

al-'Asalī, Kāmil Ğamīl (1983 and 1985)Wațāiiq maqdisiyya ta'rīhiyya, 2 vols, Amman.

al-Asyūțī (1996), Ğawāhir al-'uqūd wa-mu'īn al-quḍāh wa-Jmuwaqqi'̄in wal-shuhūd. ed. Mus'ad 'Abd al-Ḥamīd al-Sa'danī, Beirut.

Cahen, Claude, and Jean David-Weill (1978), 'Papyrus Arabes du Louvre III', in Journal of the Economic and Social History of the Orient, 21, 146-164.

David-Weill, Jean (1971), 'Papyrus arabes du Louvre II', in Journal of the Economic and Social History of the Orient, 14, 1-24.

Faruqi, Soraya (1997), 'sidjill.3', The Encyclopaedia of Islam, vol. 9:539a-544b.

Frantz-Murphy, Gladys (2001), Arabic Agricultural Leases and Tax Receipts from Egypt, 148-427 A. H./765-1035 A. D., Corpus Papyrorum Raineri XXI, Wien: Verlag Brüder Hollinek.

al-Ǧarawānī, Muḥammad b. 'Abd al-Mun 'im al-Ḥasanī al-Šāfi 'ī: Al-Kawkab al-mušriq fìmā yaḥtāğu ilayhi al-muwattiq li-'ālim aš-šurūț. Hg. und kommentiert von Souad Saghbini, Bonn 2010.

Fahmī, Muḥammad Abd al-Raḥmān (1973), 'Wațā'iq al-ta'āqud min fağr al-islām fĩ Miṣr’, in Mağallat al-Mağma' al-Ilmī al-Mișrī, 54, 1-58.

Gottheil, Richard (1907), 'An Eleventh-century Document Concerning a Cairo Synagoge', in Jewish Quarterly Review, 467-539.

Grohmann, Adolf (1934-36), Arabic Papyri in the Egyptian Library (in 6 vols). Vol.1: Protocols and Legal Texts. Cairo 1934 and vol. 2: Legal Texts. Cairo.

Gronke, Monika (1982), Arabische und persische Privaturkunden des 12. und 13. Jahrhunderts aus Ardabil (Aserbeidschan), Berlin: Klaus Schwarz. 
Gronke, Monika (1986), 'The Arabic Yārkand documents', in BSOAS, 49, 454-507.

Hallaq, Wael (1998), 'The qāọī’s dīwān (sijill) before the Ottomans', in BSOAS, 61, 415-436.

al-Hașșāf (1978), Kitāb adab al-qāḍī - with the commentary of al-Ğașșāṣ (d. 370/980), ed.

Farhạăt Ziyāda, Cairo.

al-Hูušanī (1982), Kitāb al-qựāh bi-Qurțuba, ed. Ibrāhīm al-Abyārī, Cairo-Beirut.

Ibn Abī l-Dam Šihāb al-Dīn Abī Isḥāq Ibrāhīm (21982), Kitāb adab al-qaḍā' wa-huwa al-durar almanẓūmāt fĩ l-aqḍiya wal-ḥukūmāt. ed. M. al-Zuḥaylī. Damascus.

Ibn al-'Aț̣ār (1983), Kitāb al-wațā'iq wal-siğillāt, ed. P. Chalmeta and F. Corriente, Madrid: Instituto Hipano-Árabe de Cultura.

Ibn Iyās (1974), Badā'i' al-zuhūr fí waqā'i' al-duhūr. vol. I/2, ed. Muḥammad Mușṭafā, Wiesbaden.

Ibn Sahl (1997), Abū l-Așbaġ, Diwān al-ahkām al-kubrā, 2 vols, ed. Rašīd al-Nu'āymī, Riyad: Šarikat al-șafahāt al-ḍahabiyya.

Johansen, Baber (1997), 'Formes de language et fonction publiques: stéréotypes, témoins et offices dans la preuve par l'écrit en droit musulman', in Arabica, 44, 333-376.

Khan, Geoffrey (1993), Arabic Legal and Administrative Documents in the Cambridge Genizah Collection, Cambridge: Archaeopress Archaeology.

Khan, Geoffrey (2003), 'An Early Arabic Legal Papyrus', in Lawrence H. Schiffman (ed.), Semitic Papyrology in Context, Leiden, Boston: Brill, 227-237.

Khan, Geoffrey (2007), Arabic Documents from early Islamic Khurasan (Studies in the Khalili Collection, volume V), London: David Brown Book Co.

Khoury, Raif G. (1993), Chrestomathie de Papyrologie Arabe, Leiden-New York: Brill.

Khoury Raif G. (1995), Papyrologische Studien zum privaten und gesellschaftlichen Leben in den ersten islamischen Jahrhunderten, Wiesbaden: Harrassowitz.

Levi Della Vida, Giorgio (1981), Arabic Papyri in the University Museum in Philadelphia (Pennsylvania) (Classe di Scienze morali, storiche e filologiche), Rome: Accademia nazionale dei Lincei.

Lirola Delagado, Jorge, and José Miguel Puerta Vílchez (eds) (2012), Bibliotheca de al-Andalus, vol. 1, Almeria.

Little, Donald (1984), A Catalogue of the Islamic Documents from al-Haram aš-Šarîf in Jerusalem, Beirut, Wiesbaden: Franz Steiner.

Little, Donald (1998), 'Documents Related to the Estates of a Merchant and His Wife in Late Fourteenth Century Jerusalem', in Mamluk Studies Review, 2, 93-193.

Masud, Mahmud Khalid, Ruud Peters, and David Powers (2006), 'Qāọīs and their Courts: an historical Survey', in M. K. Masud, R. Peters and D. S. Powers (eds), Dispensing Justice in Islam: Qadis and their Judgments, Leiden: Brill, 1-44.

Michel, Nicolas (2005), 'Registres de cadis d’Égypte (1743-1744) et notariat de Provence: pertinence d'une méthodologie comparative', in Gabriel Audisio (ed.), L'historien et l'activité notariale. Provence, Vénétie, Égypte XVe-XVIIIe siècles. Toulouse: Presses universitaires du Mirail, 225-252.

Müller, Christian (1999), Gerichtspraxis im Stadtstaat Córdoba. Zum Recht der Gesellschaft in einer mālikitisch-islamischen Rechtstradition des 5./11. Jahrhunderts, Leiden: Brill.

Müller, Christian (2000), 'Judging with God's Law on Earth: Judicial Powers of the Qāḍi aljamā'a of Cordoba in the 5th/11th Century’, in Islamic Law and Society, 7,159-186.

Müller, Christian (2006), 'Settling litigations without judgment: The importance of a hukm in qadi-cases of Mamlūk Jerusalem', in M. K. Masud, R. Peters, D. S. Powers 2006, 47-69. 
Müller, Christian (2010), ‘Écrire pour établir la preuve orale en Islam: la pratique d’un tribunal à Jérusalem au XIVe siècle', in Akira Saito and Yusuke Nakamura (eds), Les outils de la pensée. Étude historique et comparative des «textes », Paris: Éditions de la Maison des sciences de l'homme, 63-97.

Müller, Christian (2011), 'The Ḥaram al-Šarīf collection of Arabic legal documents in Jerusalem: a Mamlūk court archive?', in al-Qanțara, 32, 435-459.

Müller, Christian (2012), 'Osmanische Gerichtsurkunden des 16. Jahrhunderts aus der ägyptischen Provinz: Zu Kauf und Bezahlung einer Handelsladung ḥālūm-Käse', in Verena M. Lepper (ed.), Forschung in der Papyrussammlung - Festschrift für das Neue Museum, Berlin: Akademie Verlag, 435-453.

Müller, Christian (2013), Der Kadi und seine Zeugen. Studie der mamlukischen Haram-Dokumente aus Jerusalem, Wiesbaden: Harrassowitz.

Müller, Christian (2017), 'Crimes without criminals? 14th-century injury- and homicide-cases from the Ḥaram al-Šarîf-collection in Jerusalem', in Maaike van Berkel, Léon Buskens and Petra Sijpesteijn (eds), Legal Documents as Sources for the History of Muslim Societies: Studies in Honour of Rudolph Peters, Leiden: Brill, 129-179.

al-Nubāhī (1948), Histoire des Juges d'Andalousie/ al-Marqaba al-'ulyā fĩ man yastahiqqu alqaḍ̄à' wal-futyā, ed. Lévi-Provencal, Cairo.

Okawara, Tomoki (2015), 'Reconsidering Ottoman Qāọī Court Records: What Are They? Who Produced, Issued and Recorded them?' in Vanessa Gueno and Stefan Knost (eds), Lire et écrire l'histoire ottomane, Beirut: Presses de l'ifpo - Orient-Institut Beirut, 15-37.

al-Qalqašandī, Aḥmad (1913-19), Șuḅ̣ al-a'šā fí șināat al-inšā'. 14 vols, Cairo.

Ragheb, Yūsuf (2002 and 2006), Actes de vente d'esclaves et d'animaux d'Égypte médiévale. 2 vols, Cairo: Institut français d'archéologie orientale.

Reinfandt, Lucien (2003), Mamlukische Sultansstiftungen des 9./15. Jahrhunderts, nach den Urkunden der Stifter al-Ašraf İnāl und al-Mu'ayyad Ahmad Ibn İnäl. Berlin: Schwarz.

Saḥnūn (1323/1905-6), al-Mudawwana al-kubrā lil-imām Mālik, 16 vols in 7, Cairo: Maṭba'at alSa'āda.

Saḥnūn (n. d.), al-Mudawwana al-kubrā lil-imām Mālik, 16 vols in 6, reprint Beirut: Dār al-Șādir.

Saghbini, Souad (2005), Mamlukische Urkunden aus Aleppo: Die Urkundensammlung (ğāmi almustanadāt) der mamlukisch-aleppinischen Familie Ugulbak, Hildesheim: Olms.

Saghbini, Souad (2014), Ǧāmi' al-mustanadāt, Eine Edition der fünf Kaufverträge und der WaqfUrkunde des Emir Faḩr al-Dīn Abū 'Amr 'Uțmān b. Uğulbak al-Ḥalabi, Göttingen: V\&R unipress $\mathrm{GmbH}$.

Schacht, Joseph (1964), An introduction to Islamic Law, Oxford: Clarendon Press.

al-Ṭaḥāwī, Abū Ǧa'far Aḥmad (1974), al-Šurūṭ al-șagīir mudadaylan bi-mā 'uṭira 'alayhi min alšurūṭ al-kabīr, ed. Rūhī Ūzağān, 2 vols, Bagdad: Ri'āsat Dīwān al-Awqāf.

Thung, Michael (2006), Arabische juristische Urkunden aus der Papyrussammlung der oesterreichischen Nationalbibliothek, Corpus Papyrorum Raineri XXVI, Leipzig, Generaldirektion der Österreichischen Nationalbibliothek.

Tillier, Mathieu (2009), Les cadis d'Iraq et l'État Abbaside (132/750-334/945), Damascus: Presses de l'Ifpo.

Tyan, Émile (21959), Le notariat et le régime de la preuve par écrit dans la pratique du droit musulman, Beirut: Faculté de droit de Beyrouth.

Tyan, Émile (21960), Histoire de l'organisation judiciaire en pays d'Islam, Leiden: Brill.

Veselý, Rudolf (1972), 'Die Hauptprobleme der Diplomatik arabischer Privaturkunden aus dem spätmittelalterlichen Ägypten’, in Archiv Orientální, 40, 312-343. 



\title{
Emmanuel Francis \\ Indian Copper-Plate Grants: Inscriptions or Documents?
}

\author{
Under king Bhoja double is the lack: \\ Iron, because of the fetters enchaining his enemies, \\ Copper, because of the plates bearing his orders.
}

Ballāla’s Bhojaprabandha, verse 156

\begin{abstract}
Indian copper-plate grants, initially issued by ruling kings from the third century CE onwards and increasingly by private individuals as time passed, are very specific documents, as they are kept by the grant beneficiaries as title-deeds. They are usually treated as inscriptions due to them being made of such hard material. However if the main character of an inscription is its being publicly displayed, copperplate grants are not inscriptions, as they were often found buried for safety's sake. Based on South Indian materials, it is argued here that Indian copper-plate grants are neither inscriptions (i.e. publicly displayed writings on temple walls, steles, rocks, etc.) nor documents or archival records (i.e. private or state records on palm leaf), but are situated at the 'hinge' between these two categories, as revealed by their format, content and purpose.
\end{abstract}

Among the many issues raised by the nature of archival records, I will address here only a selection. How, by whom and for which purposes are administrative, legal, archival records produced? Is there any observable difference between archives, inscriptions and literary manuscripts concerning materials, formats, and producers? Where are archives stored? Are there other objects stored together with the records? Which practices are involved inside the archive, how and by whom are they used?

I will deal with these issues by focussing on Indian copper-plate grants, in particular South Indian examples of the first millennium CE and the beginning of the second, which show that the copper-plate grants' content and format are similar to that of palm-leaf account books. Still, Indian copper-plate grants are traditionally treated as inscriptions because of the durability of the material. But are they? And if not, what are they? Documents? My argument is that copper-plate grants, i.e. charters of donation inscribed on copper so as to serve as permanent title-deeds, are a peculiar type of documents to be situated at the intersection between inscriptions and archives for several reasons, which, I hope, will be clear at the end of this essay. 


\section{Copper-plate grants}

In his Bhojaprabandha, Ballāla (sixteenth century) narrates the imaginary meeting of the famous king Bhoja (first half of the eleventh century) with a brahmin. Bhoja wonders why this brahmin carries water in a leather gourd (kamandalu), since the skin of a dead animal is particularly impure. The reason, says the brahmin, is scarcity of iron and copper, the usual material in which water-pots are made. When Bhoja asks him the reason for this scarcity, he replies:

asya śrībhojarājasya dvayam eva sudurlabham |

śatrūṇāṃ śṛnkhalair lohaṃ tāmraṃ śāsanapatrakaị̣ \|

(Under the rule) of this king Bhoja two things are very rare: iron because of the fetters (enchaining) his enemies, copper because of the plates (bearing) his orders. ${ }^{1}$

In a copper-plate inscription of the king Karna (mid-eleventh century), we find another telling verse, pointed out to me by Dominic Goodall:

kị̣ tasya karṇanrpater bata varṇayāmo yasya dvijātijanaśāsanatāmrapațtaiḥ | utkīryamāṇanibị̣ākṣaracakravālavācālitair badhirabhāvam iyāya viśvam ||

What can we describe of that king Karṇa by whose copper-plates, (given) to Brāhmaṇas,which made a loud noise as multitudes of closely packed letters were being incised on them,- the (whole) universe is deafened. ${ }^{2}$

Both these verses praise a king for what he is expected to be: a great donor. King Bhoja is so liberal that copper (tämra) cannot be found anymore in his realm, because it is required to engrave the many plates bearing his grant orders (śāsanapatraka). So is king Karna-by the way a fitting name for a donor since the epic character Karna is a paragon of the liberal donor (Vielle 2011, 370, n. 13)-as the world resonates with the noise made when beating and engraving the copper plates recording his grant orders (śāsana-tāmra-patța). ${ }^{3}$ Both these verses also illustrate a

1 Ballāla's Bhojaprabandha, verse 156, 107-8. This is quoted, as verse 162, by Chhabra 1951, 2, who uses another edition. Unless otherwise indicated, translations are mine.

2 Original text normalised from two versions available, i.e. verse 30 of the Goharwa plates (CII 4, p. 258, with variant -vacālitair) appearing also as verse 32 of the Rewa stone inscription (CII 4, p. 271). Translation by Mirashi (CII 4, p. 262).

3 This means that Karna issues many grants and/or that each grant contains long lists of gifts and recipients. 


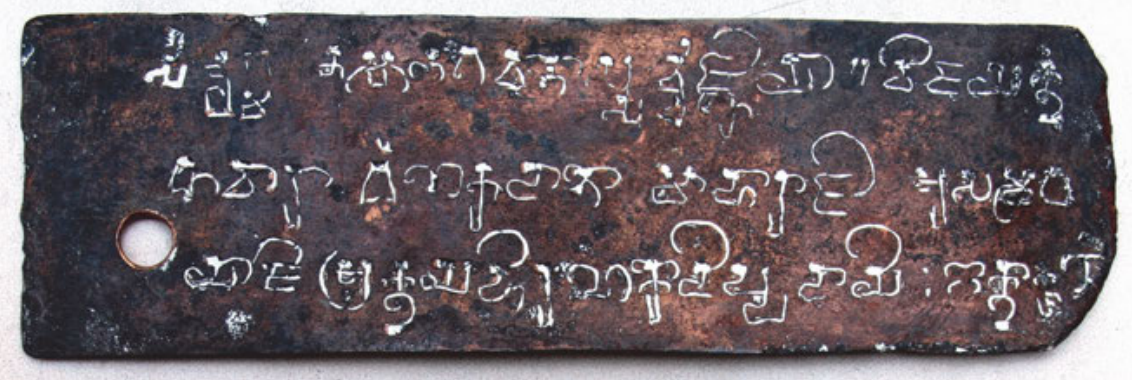

Fig. 1: Pātagaṇ ḍigūḍem plates, verso of plate 1, undivided Andhra Pradesh, South India, third century. Telangana State Museum, Hyderabad. Approximately $22,5 \times 7 \mathrm{~cm}$. Photo: Arlo Griffiths.

very common practice in ancient India: the engraving of royal grant orders on copper plates, which are given to the recipients as title-deeds. Such copper-plate grants have been produced in India by the hundreds, as evinced by the extant specimens, and probably by the thousands, from the third century CE onwards. ${ }^{4}$ The two volumes of Dynastic List of Copper Plate Inscriptions Noticed in Annual Reports on Indian Epigraphy published by the Archaeological Survey of India comprise respectively 1637 and 413 items, i.e. a little more than 2,000, a total which however includes records, other than grants, also inscribed on copper plates. ${ }^{5}$

As Fleet $(1907,27)$ already put it, the 'usual copper record (...) was a donative charter, in fact a title-deed, and passed, as soon as it was issued, into private personal custody'. Almost one century later, Salomon $(1998,114)$ states that the 'earliest specimens of copper plate charters come from southern India, issued by the early Pallava and Śālañkāyana dynasties and datable, according to Sircar (SIE 107) [i.e. Sircar 1965, 107], to about the middle of the fourth century A.D'. Recently, a late thrid-century example surfaced, the Pātagaṇdigūdem copper-plate grant (Fig. 1) of the Ikṣvāku king Ehavala Cāntamūla (see Falk 2000), which helps us to push back in time the practice in South India to an earlier dynasty. Salomon $(1998,114)$ adds that probably 'the oldest extant copper plate grant from northern India is the Kalāchalā grant of Î́svararāta, in Sanskrit, dated on palaeographic grounds by Sircar (EI 33, 303-6) to the later part of the fourth century A.D'. Probably older than the Kalāchalā grant are plates of the Bagh hoard (Ramesh/Tewari 1990), if they are

4 For general introductions on Indian copper-plate grants, see Fleet 1907, 27-34; Chhabra 1951; Sircar 1965, 74-77 and 103-160; Gaur 1975; Salomon 1998, 113-118.

5 See Gai 1986, and Padmanabha Sastry 2008. For regional corpora of copper plates edited, see the list in Sohoni 2016, 87 n. 1, to which many might be added. 
indeed internally dated, as usually thought, to the Gupta era, which means that many among these would date to the second half of the fourth century. Salomon (ibid.) adds that there 'is clear evidence, however, that the origins of the copper plate charters or their prototypes go back farther than the fourth century, for some of the donative cave inscriptions of the Western Kṣatrapa and Sātavāhana kings from Nāsik, datable to the first or second century, are evidently copies on stone of original documents written on portable materials, possibly copper (SIE 108) [i.e. Sircar 1965, 108]'. He further mentions $(1998,114)$ that the 'tradition of recording land grants on copper plates continued throughout the medieval era and even into the European period'. ${ }^{6}$

The plates were prepared by braziers using hammers, while according to Gaur (1975, ix), some 'scholars believe that the letters may have been scratched into the surface of the plate with a sharp instrument (as a stylus is used on the palmyra leaf) while the plates were covered with a layer of mud'. We know of writings on stone and copper where, as a preliminary step, the text was written down with ink or paint. Salomon $(1998,65)$ provides examples 'wherein the ink or paint is still visible in the inscription ... or where the final step of carving the inscription was never carried out' ${ }^{7}$ It seems possible that other plates have been cast through the lost-wax technique or engraved when heated. According to Natarajan and Kasinathan (1992, 70), in the earlier period, the technique seemingly was 'cutting with chisel,' whereas in the later period, the writing was made on the plate 'in molten condition'.

\subsection{Other Indian metal inscriptions}

In fact, what Sircar $(1965,107)$ calls 'copper-plate charters of the usual type', which are the focus of the present contribution, are not the earliest Indian examples of writings on metal. However, these earlier examples of such writings are not grants or title-deeds. ${ }^{8}$

In the first centuries CE dedications were engraved on tablets in copper, such as the Kalawān plate (EI 21, no. 39), which Salomon (1998, 269-270) dates to 77 CE,

6 See the examples in Salomon's note. For copper-plates issued by colonial authorities, see DLCPI, vol. 2, no. 413, about the erection of Dupleix's statue in Pondicherry in 1870 under Napoléon III, or 'British 1' in Ayyangar 2000 [1918], 1 about a settlement on water distribution from a river's channels.

7 Salomon/Chhabra 1951, 5 mention, for instance, the Kasia copper plate (ASIAR 1910-11, 73-77).

8 I found most of the examples of early Indian inscriptions on metal mentioned here in Sircar 1965, 74ff. and Salomon 1998, $129 \mathrm{ff}$. 
or the Sui Vihār plate (CII 2.1, no. 74, pp. 138-141) dated to the year eleven of Kanișka, i.e. 138 CE according to the most recent dating of the accession of the Kuṣāna king. The Sohgaurā bronze plaque, believed to be of the Maurya (third century BCE) or post-Maurya period, records regulations about storehouses. ${ }^{9}$ Dedicatory or votive records are found also on gold leaves or scrolls, such as the Taxila gold plate (CII 2.1, no. 31, pp. 83-86) or the Senavarma gold plaque inscription. The latter, dated to the first century CE and found rolled in a buried casket, records the restoration of a stūpa damaged by lightning at the order of king Senavarma of Odi (Salomon 1986). Also found are silver scrolls-for instance at Taxila (CII 2.1, no. 27, pp. 70-77)-and copper scrolls or plates-such as the dedicatory copper scroll in the Schøyen collection (Melzer 2006). ${ }^{10}$ An exceptional example of metal inscription is the famous Meharauli iron pillar inscribed with a praise of king Candra, who has been identified as Candragupta II (late fourth to early fifth centuty CE; CII 31, 139-142, CII 32, 257-259). Such are examples of writings on supports especially designed and formatted to receive it, although this is debatable concerning the Meharaulī pillar, since it is principally a flag-staff for the god Viṣnu. Other objects in silver, copper, bronze or brass-relic casket, ladle, seal, bell, image, mask, vase, cup, vessel plate, sieve, disk-also receive inscriptions, but are not created in the first place as writing supports.

Many inscribed artefacts just mentioned above belong to Buddhist culture and were in fact buried, that is they were no more meant to be read after burying. This fact points towards a ritual or performative function of these writings: by collocating the name of the donor with his foundation they make him present there in person (Schopen 1996). We find the same function with other writings-on metal, gold or silver foils for instance, but also on stone and clay and even paper-, often buried, which are citation inscriptions, i.e. inscriptions consisting entirely or mostly in citation of scriptures. ${ }^{11}$ Such written artefacts can, as dharma-relics, represent the Buddha and his doctrine (dharma). When buried, they make a place a caitya (i.e. a sacred $\operatorname{spot}^{12}$ ), function as protective formulae (dhāraṇis, laid in foundation deposits or carried as amulets ${ }^{13}$ ), and/or generate merit for the one who writes them or has them written. ${ }^{14}$ Another type of metal

9 See Fleet 1907; SI, pp. 82-83; Ghosh 2007; Sohoni 2016, 88, n. 3.

10 See also early examples (fragments) from Gandhāra mentioned by Rahman/Falk 2011, 23-24.

11 For examples from Indonesia, see Griffiths 2014.

12 See Paranavitana 1933, 204-205, on scriptures as dhamma-dhātu substituted for bodily relics (śārīika-dhātu) in accordance with the Prajñāpāramitā; Schopen 1976; 1989; Bentor 1995.

13 On dhāraṇis, see Hidas 2015. For examples of printed dhāraṇīs found in tomb, see Formigatti 2016, 79, and in stūpas, see Scherrer-Schaub 1994.

14 See Skilling 2005. 


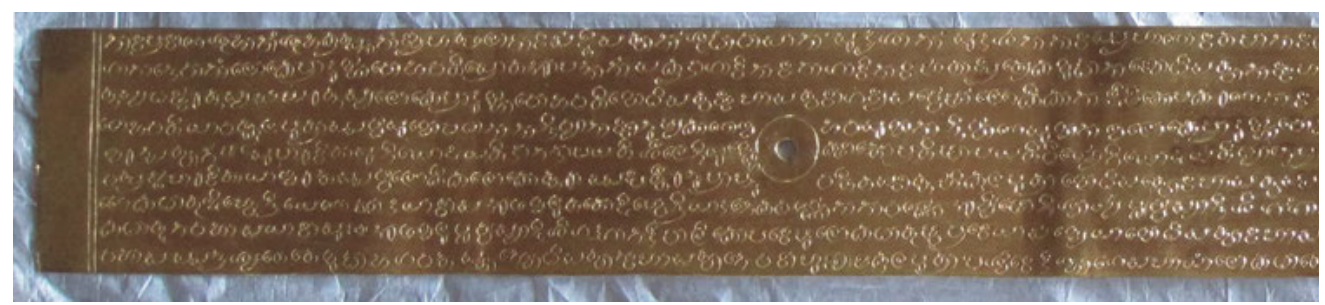

Fig. 2: Leaf of gold manuscript of the Pañcaviṃśatisāhasrikā Prajñāpāramitāsūtra, from Anurādhapura, Sri Lanka, ninth century. Colombo National Museum. Approximately $63 \times 6 \mathrm{~cm}$. Photo: Arlo Griffiths.

writings, although later than copper plates, are the lavish manuscripts of scriptures, like, for instance, tin manuscripts from Burma, or, possibly, the ninth-century gold manuscript of the Pañcaviṇśatisāhasrikā Prajñāpāramitāsūtra from Anurādhapura in Sri Lanka (Fig. 2).$^{15}$ As the central visible elements of a cult of the book, such manuscripts, like their lavish palm-leaf counterparts, can be exhibited, displayed and honoured, but are not meant to be read either. ${ }^{16}$ We will see that copper-plate grants are sometimes buried too and that they are not meant in the first place to be read except when received by their owners or in case of legal disputes.

\subsection{Copper-plate grants as legal documents}

The copper-plate grants thus have in common with other earlier metal inscriptions the durability of their support, but differ in content and purpose. They are notably known as rāja-śāsanas, 'royal orders,' and (tāmra-)śāsanas, 'orders (on copper),' two terms which denote the textual content as well as the material container. ${ }^{17}$ These are official documents often recording royal orders, typically grants, i.e. allocation of land revenue and tax exemptions mainly to religious institutions or figures. They are frequently issued by royal chancelleries but also by provincial authorities as, for instance, plates from Bengal and Bihar dated to the fifth and sixth century (Yamazaki 1982).

15 For such manuscripts, in tin, see Salomon 1998, 130 and Goswamy et al. 2006, 84-85 (a nineteenth-century example). On the Anurādhapura gold manuscript, see von Hinüber 1984.

16 On the cult of the book, see De Simini 2016.

17 See Chhabra 1951, 3-4, Sircar 1965, 103ff., Lubin 2015, 244. 


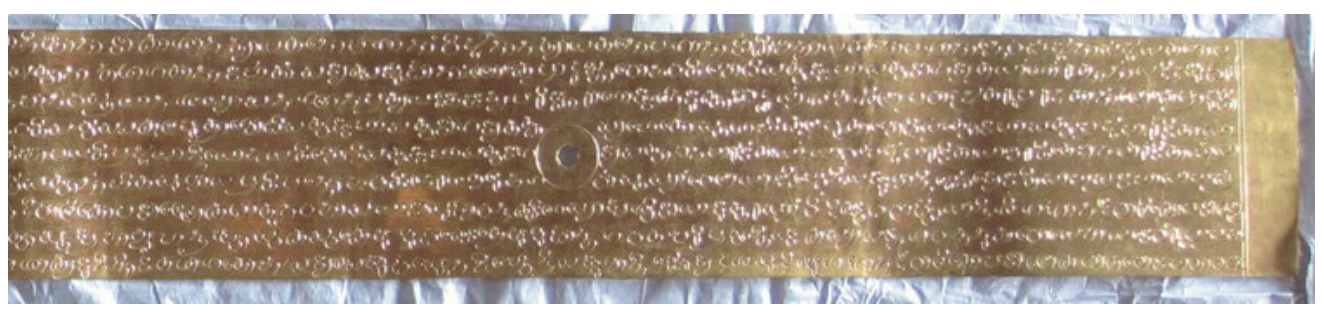

As pointed out by several scholars, the so-called law books (dharmaśāstras) of classical India mention that the donor-king should send a document to the recipients of grants. ${ }^{18}$ The Viṣnusmṛti lays down (3.82): ${ }^{19}$

yeșām ca pratipādayet teșām svavaṃśyān bhuvah parimāṇaṃ dānacchedopavarnanamạ ca pațe vā tāmrapațte vā likhitam svamudrānikaṃ cāgāminrpativijñānārtham dadyāt \||

To whomever he [the king] donates land, he should also give a deed written on a piece of cloth [pața] or on a copper plate [tāmra-patța] and marked with his seal intended to inform future kings, a deed that contains the names of his predecessors, the extent of the land, and an imprecation against anyone who would annul the gift.

Several copper-plate inscriptions are internally stated to have been given to the recipient. For instance in early Pallava records (fourth to fifth century) we often find the mention that the plates (pațtikā) or copper plates (tāmra-pațtikā) were given (dattā), i.e., implicitly, to the grantees. ${ }^{20}$ In the late eleventh-century smaller Leiden plates (EI 22, no. 35), the king is requested to make a copper order for a grant and agrees to the request, addressing an order to his officers so that they make it and give it to the grantees. ${ }^{21}$ In a fifteenth-century Sri Lankan example, the Oruvala Sannasa (EZ 3, no. 3), an individual requests a copper plate from the king so that a land already granted to him for his service as purohita (royal chaplain) be permanently secured for his lineage, as an hereditary grant (see especially pp. 54 and 68).

18 See, with further references to original sources, notably the Yãjñavalkyasmṛti and its commentary, the Mitākșarā, Kane 1941, 860, Sircar 1965, 104ff. As for guidelines for the redaction of such documents, see the Arthaśāstra 2.10 (topic 28: topic of decrees) or the Lekhapaddhati. About the diplomatic of copper-plate grants, see Chhabra 1951, Sircar 1965, 126ff.; 1974, $52 \mathrm{ff}$.

19 Text and translation by Olivelle; my additions between square brackets.

20 See IR 2, plate 8r1 = line 27; IR 5, plate 4r1 = line 19; IR 7, plate 5r5 = line 34; IR 8, plate 5v4 = line 36; IR 10, plate 5r4 = line 32; IR 11, plate 3r4 = line 19.

21 See plate 1v10-13: tāmraśāsañam paṇnit tara vēṇțum eñru ... tāmraśāsanam paṇnik kuṭukkav enru ... tirumukam. 
Copper-plate grants are thus legal documents, granting permanent rights, as long as the sun and the moon, as encapsulated in a recurrent formula. 'Donative decrees and settlements doubled as deed or title to property rights and privileges and there are a number of instances in which the record refers to its own capacity to forestall or resolve future disputes over such rights' (Lubin 2015, 227). 'In certain cases such documents have been adjudged to be still legally valid in modern times' (Salomon 1998, 115, with reference to Kane 1941, 865). Besides grants, there were other types of śāsanas, not engraved on copper but on stone, or not recording grants, as for instance sale-deeds (kraya-śāsanas), i.e. record of private transactions, or records of revenue-paying grant (kara-śāsanas), as described by Kane (1946, 309ff.) and Sircar (1965, 109ff.; 1974, 66ff.). The Bengal and Bihar plates of the fifth and sixth century studied by Yamazaki (1982) are, for instance, saledeeds of land converted into grants.

As legal documents, copper-plate grants are distinct from other early metal inscriptions, which are dedicatory, votive or performative. Copper-plate grants may however have a performative function at an initial stage, when they are remitted to the grant's recipients and in a certain way act to implement the grant. In the course of time other types of copper plates appeared, not issued by the royal chancellery and not granting land. But it is a fact that many of the earlier copper-plate grants are royal, such as those of the Pallava dynasty (fourth to ninth century; see Francis 2013, 69), and that this medium has been in use for long to convey royal orders of donation, to which will be added, at a further stage, eulogies of the donor-king and his lineage. The text and the artefact as official documents are authenticated by the royal seal that comes with them. ${ }^{22}$

The legal value of copper plates, as title-deeds, sale-deeds or assessment of revenue has several practical implications and consequences. Firstly, as the gift is theoretically perpetual, a durable document is expected, whence the choice of copper, as opposed to other supports such as palm leaf, fast-decaying under the Indian climate. ${ }^{23}$ 'The durability of the written document is paramount. Records often close with a formula invoking their validity in perpetuity, "as long as the moon and sun endure," and warning future rulers not to violate their terms' (Lubin 2015, 227). Secondly, such documents are subject to tampering and forgeries surely were made, a subject dealt with in detail by Salomon (1998, 118, 165ff.; 2009). Thirdly, it happened often that copper-plates were buried for safekeeping. The Tiruvālaṅkāṭu (SII 3, no. 205) and the Ecālam Cōla-period plates (first half of the eleventh century), recording devadāna (gift to a god), 'were found within ...

22 On seals, see Fleet 1907, 29ff., Chhabra 1962, Sircar 1965, $150 \mathrm{ff}$.

23 See Salomon 1998, 4, n. 8, Willis 2009, $125 \mathrm{ff}$. 
temples and along with bronze images' and obviously 'both were buried in troubled times to safeguard the bronzes and charters' (Nagaswamy 1987, 9). ${ }^{24}$ I must simply repeat here Salomon's statement (1998, 115):

Since the use of copper instead of ordinary perishable writing materials reflects a desire to establish the document as a permanent record, in effect a deed to the granted lands, it is not surprising that copper plates are most often found underground where they had been buried for safekeeping by the grantees or their descendants according to the traditional Indian practice. Such finds are usually made accidentally by villagers in the course of plowing their fields or digging a foundation for a house..$^{25}$

Sohoni $(2016,92)$ also remarks that copper-plates 'were often buried in small earthen or metal sealed vessels, a mode of physical protection and social convention that paper documents could not enjoy'. In actual fact, one wonders if burying was the usual way of storing or safekeeping plates or just the practice in troubled political times (as seems the case when copper-plates and bronze images were stored together). It also happens that a religious institution, such as a temple or a 'monastery' (mața), accumulates grants. In such a case, the collection of plates could be kept in a store-room. Gopinatha Rao (1986 [1917], 1), who edited the collection of copper plates of the Śrīsañkarācārya mațha at Kāñcīpuram, states that he accessed the plates 'preserved in the treasury of the maṭha.'

\section{Manuscripts, inscriptions, and documents}

To have a better idea of the place of copper-plate grants among Indian writings, we must now briefly categorize modes and supports of textuality in ancient India. There are mainly three types of ancient Indian written texts.

Manuscripts - Manuscripts are usually written on perishable material such as palm leaf, birch-bark and, later, paper. They bear for the most texts that in the west would be considered as scriptures, literature and treatises. These can be long texts and only perishable support makes the writing down, transportation and diffusion convenient. Some manuscripts are however not meant to circulate when belonging to libraries. Manuscripts are also commodities as there was

24 According to Nagaswamy 1987, 2, 'two main periods of invasion seem to have caused these waves of fear and consequent burial[:] (1) [t]he Muslim invasion [i.e. the establishment of the Maturai sultanate in Tamil Nadu] in the $14^{\text {th }}$ century [and] (2) [t]he Portuguese invasion [in the $16^{\text {th }}$ century].'

25 See also Sircar 1965, 97ff. and plates XXIV-V. 
script-mercantilism in precolonial India as argued by Pollock (2007, 87ff.), but maybe not as developed as he contends (see Formigatti 2016, 111ff.). Manuscripts are thus the books of a pre-print culture. They were in use in India from at least the beginning of the Common Era.

Inscriptions - Writings upon a durable support (stone, metal) are commonly treated as inscriptions in Indian scholarship. These, especially stone writings, usually do not travel but are meant to be inscribed on a specific spot and remain there: decrees, dedications, donations on temple-walls, commemoration of deceased warriors. This means that a text can be found inscribed in different places, all equally concerned by its content. Epigraphy in India is known from at least the third century BCE with the first coherent corpus of inscriptions (the royal proclamations or edicts of Aśoka). According to the late Silvio Panciera $(2012,9)$ the specificity of an inscription 'consists in the decision to effect a communication that is not directed at a single person or a group but to an entire community and that therefore necessitates the abandonment of the tools or media (or both) that a given culture employs for writing that is literary or documentary or in every day use and substitutes for them others more suitable to its purpose'. As such, an inscription is meant to be (more or less) public, as for instance, on a temple-wall, a stele, and a planted stone. ${ }^{26}$ It is exposed to some eyes, which however might not be able to read and understand the text.

Archives - As for archives, if these are 'collections of administrative, legal, commercial and other records or the space where they are located', ${ }^{27}$ we have equivalents in ancient India in the royal offices of the records where registers of grants (implying a tax remittance) were kept. From Bengal, we have knowledge of boards of record-keepers (EI 20, p. 64), while the Cōla state apparatus included a land revenue department (Heitzman 1997, 156ff.). The Arthaśāstra 2.7, as noted by Cox (2010, 10 and n. 13), mentions the akșa-pațala ('office of the records'). There are various terms in Tamil, attested epigraphically or not, that reveal the existence of registers and revenue offices, such as vari-p-pottakam ('tax register; an ancient office'), oluku ('land record containing particulars of the ownership, etc., of lands; register of a temple giving an account of its properties, and its history'), vāra-t-titțam ('a register kept by the village accountant of the respective shares of the produce assignable to the cultivators and proprietors'). ${ }^{28}$

26 See also Petrucci's concept of 'scritture esposte' (1985).

27 See outline of the November 2014 CSMC conference, here p. IX.

28 These are the translations from the Madras Tamil Lexicon. See also Subbarayalu 2003, 130 and 539. 
Documents and archival records are originally kept apart, for the use of their owners: for instance, administrative registers or personal 'correspondence', which are valued and will be or might be useful in the future, for oneself or for others. As for ancient Indian documents, we can say, as far as South India is concerned, that they were written down on palm leaf, from the sixth to the nineteenth century in present-day Tamil Nadu. Even if paper was known, it is believed that, in South India, it was too expensive to be an alternative to the abundant and cheaper palm leaf.

Grants - Copper-plate grants, as legal documents, have evidentiary value, are normally transportable and not meant to be exposed in public. Furthermore they are continuous with paper or palm-leaf records, their administrative equivalents, of which they are permanent surrogates meant for the grantees.

In the course of time, copper plates were replaced by paper documents. In the Deccan, from 'the thirteenth century onwards, copper-plate grants were increasingly replaced by farmāns (royal edicts) on paper, signed and stamped by court officials' (Sohoni 2016, 89). But copper plates could surface again. Sohoni $(2016,91-$ 92) further notices that at the local level, some of the paper documents were copied on copper, because such 'extra-official copperplate grants had a greater social value than paper farmāns for at least two reasons. First, the aura of the format, which suggested an antiquarian (and therefore old and well-established) basis for any claim of land tenure or revenue rights; and second, the pragmatism of using metal documents in a region where nature conspires with humans towards the loss of paper was well appreciated'. Moreover, as pointed out by Lubin $(2015,228)$, quoting Subbarayalu (1991, xiii), 'even palm-leaf legal documents produced in the midnineteenth century "are written in a documentary language which has been in vogue since medieval times"; indeed, "they resemble very closely medieval inscriptions in style, format and contents and so they indirectly help in a better understanding of the inscriptions"". ${ }^{29}$ The Islamic-Persian practices and the relatively high cost of copper plates certainly made paper and palm leaf cheaper alternatives. We also know instances where an original grant written on palm leaf (tāla-patraśāsana) was burnt in a house fire and was replaced by a newly issued copper-plate grant. ${ }^{30}$

29 See Lubin's note (2015, 228, n. 11) about Subbarayalu's publication, not available to me, which concerns 'a collection from one family in the Tiruchirapalli District,' the records of which consist 'of inscribed palm leaves bearing the legal fee stamps typical of the colonial legal system' which 'do indeed often mimic the structure and idioms of the inscriptions'. Two seventeenthcentury examples are discussed by Nagaswamy 1978, 90ff. and 106ff.

30 See Salomon (1998, 166; 2009, 111), about the Kurud plates (c.500; EI 31, nos 35-36). 
The following table summarises the main characteristics of the different types of ancient Indian written texts, including grants.

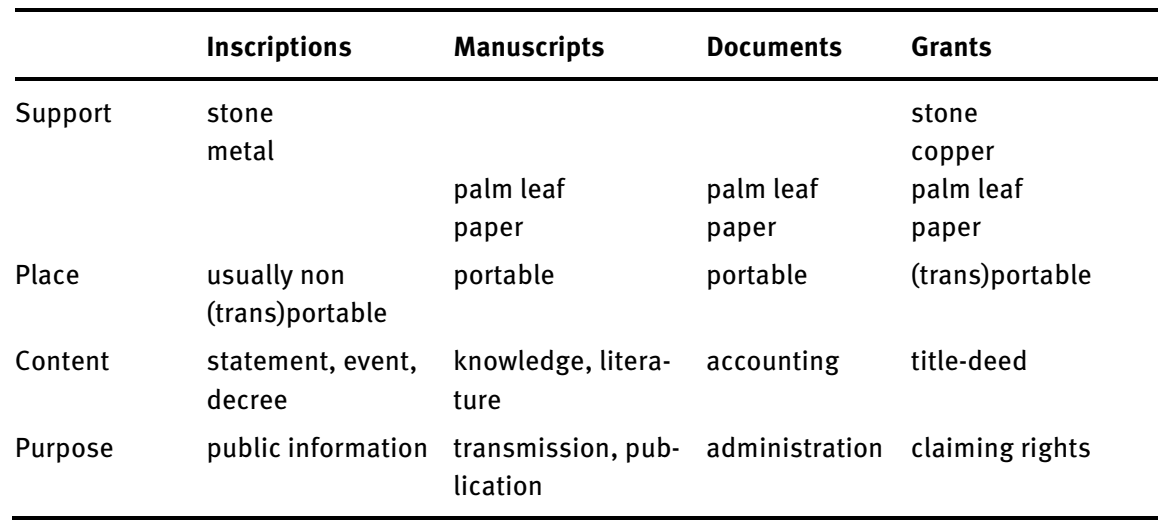

I hasten to add that there are exceptions to such a neat compartmentalisation-for instance: sections of inscriptions or copper-plate grants are pieces of poetry and as such literature; inscribed images and utensils are (trans)portable-but one sees that the only type of document that could be written down on the four different supports is the grant.

\subsection{Format of copper plates}

The format of the copper plates varies with time and place. Two main types might be distinguished in the Indian subcontinent. In South India, copper plates were long designed in the landscape format and since, most of the time, the record spread on several plates, these were joined by a ring passing through a hole made in each of the plates and soldered with a seal (Figs 3-4; fourth and fifth century; IR 3 and 16). In North India we often meet copper-plate inscriptions consisting in only one plate, also in landscape format, with a seal attached for authentication, like the plate issued by Pradyumnabandhu (Fig. 5; c.550-650; see Griffiths 2015, 27ff.). The portrait format is however known, like for the Nālandā plate of Devapāladeva (Fig. 6; ninth century; EI 17, no. 17). We also find, with the Paramāra dynasty for instance (eleventh to thirteenth century; CII 7), the landscape format, but with a height almost as long as its breadth, and two holes for the ring in case of multiple-plate sets. The portrait format is found in South India for later copper plates consisting in one plate and probably emulating the paper farmān format, from the period of Vijayanagara onwards, as, for instance, with the copper-plate 
grants of Tirumalai Nāyaka (seventeenth century; Kācinātan et al. 1994) or of the Toṇțaimān kings of Pudukkottai (Fig. 7; early nineteenth century; see Rājāmukamatu/Kōvintarāj 2009, 118ff.). As Salomon aptly summarises (1998, 114):

The writing usually goes along the longer direction of the plates, though inscriptions written across the shorter dimension are not uncommon, especially in Eastern India and in the plates of the Vijayanagara kings in southern India. Charters on multiple plates are joined together with a ring (occasionally two rings, one at each end) of copper or bronze which is inserted through holes in the plates. The ends of the ring are soldered together onto a seal, usually of bronze, which is intended to certify the authenticity of the document and to prevent tampering by the addition or removal of plates. The number of plates varies widely; in general, later specimens are larger and longer, and examples with several dozen plates and weighing as much as two hundred pounds total are known.

In South India, we find that the early Pallava copper plates (300-550 CE) are more oblong than the later Pallava (550-900), early Pāṇdya (late eighth to early tenth century) and Cōla ones (tenth to eleventh century). It seems thus that the original format was closer to the format of a palm leaf (Fig. 8). Plates from Sri Lanka, even contemporary with Cōla plates, are closer to the palm-leaf format, even having two holes as is often seen in the usual manuscripts. ${ }^{31}$ I will here be dealing in particular with early examples of the oblong format from South India, since they can be considered, due to their format, as durable metal palm leaves. But let us first consider the content correlation between copper-plate and palm-leaf documents.

31 See for instance the eleventh-century Panakaduwa plates, illustrated in A Guide to the National Museum Colombo (2012, 33). 


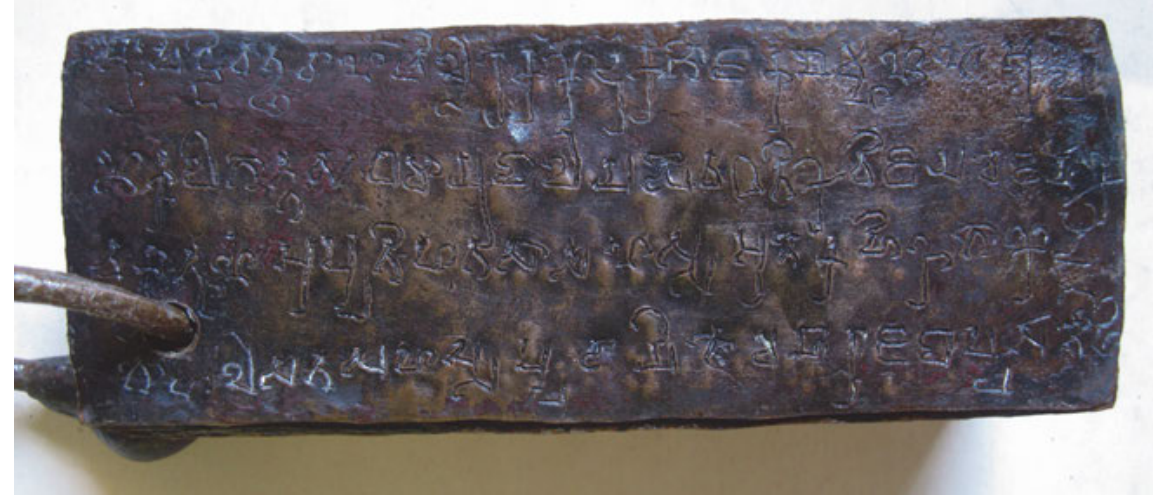

Fig. 3: Hīrahaḍaga!̣li plates (IR 3), verso of plate 2, found in Karnataka, South India, middle of fourth century. Chennai Government Museum. Approximately 20,5 $\times 9,5 \mathrm{~cm}$. Photo: Emmanuel Francis.

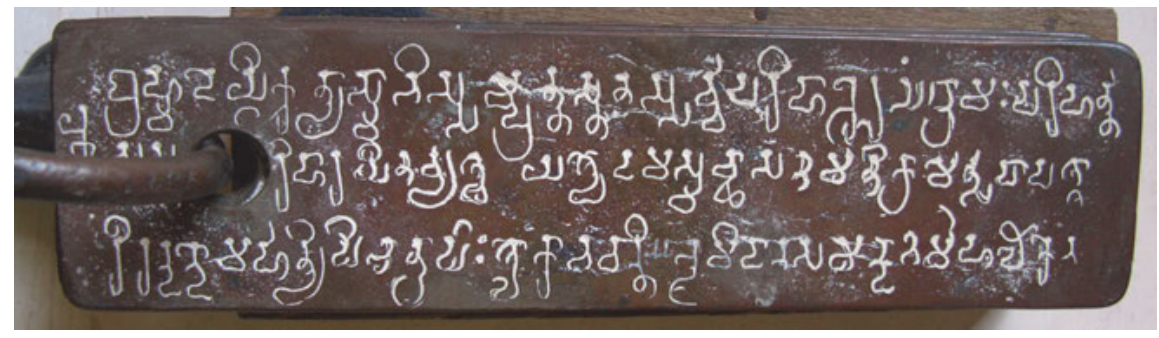

Fig. 4: Pīkira grant (IR 16), verso of plate 4, undivided Andhra Pradesh, South India, middle of fifth century. Chennai Government Museum. Approximately $18 \times 4,5 \mathrm{~cm}$. Photo: Emmanuel Francis. 


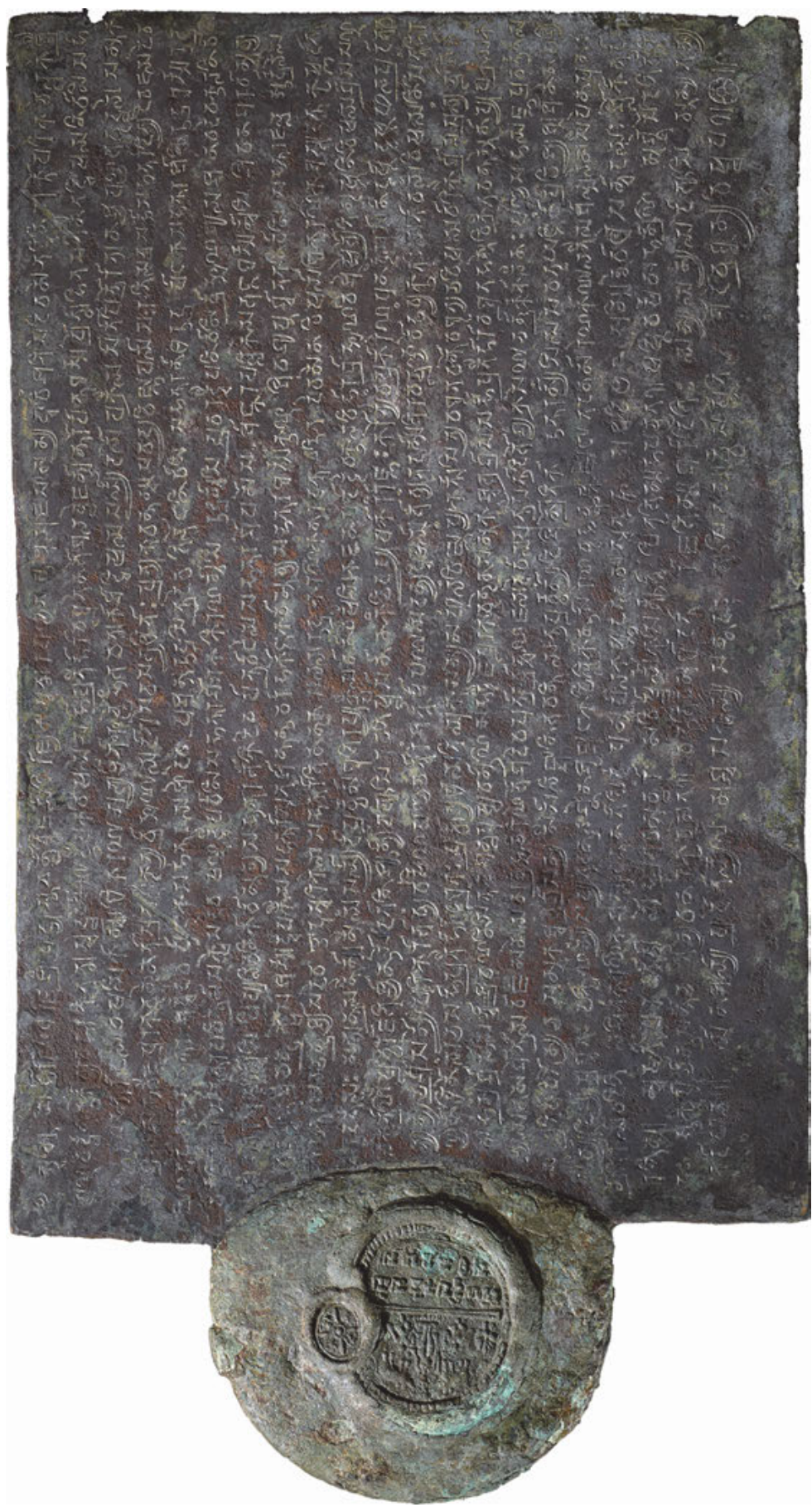

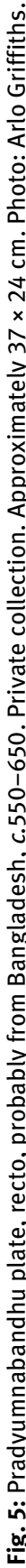




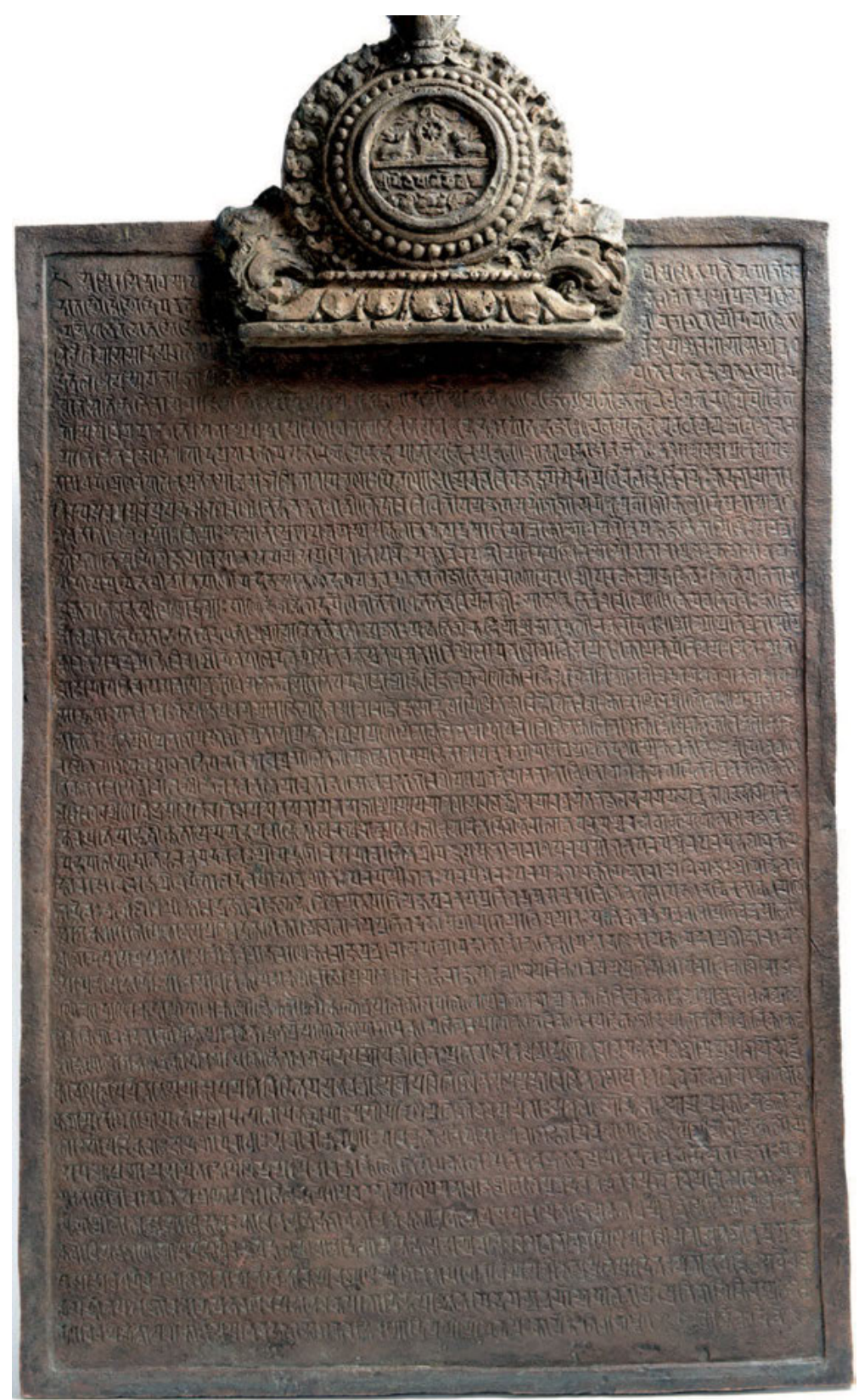

Fig. 6: Nālandā plate of Devapāladeva, recto, Bihar, North India, ninth century. National Museum, New Delhi. Approximately $38 \times 42,5 \mathrm{~cm}$ for the inscribed surface. Photo: National Museum, New Delhi. 


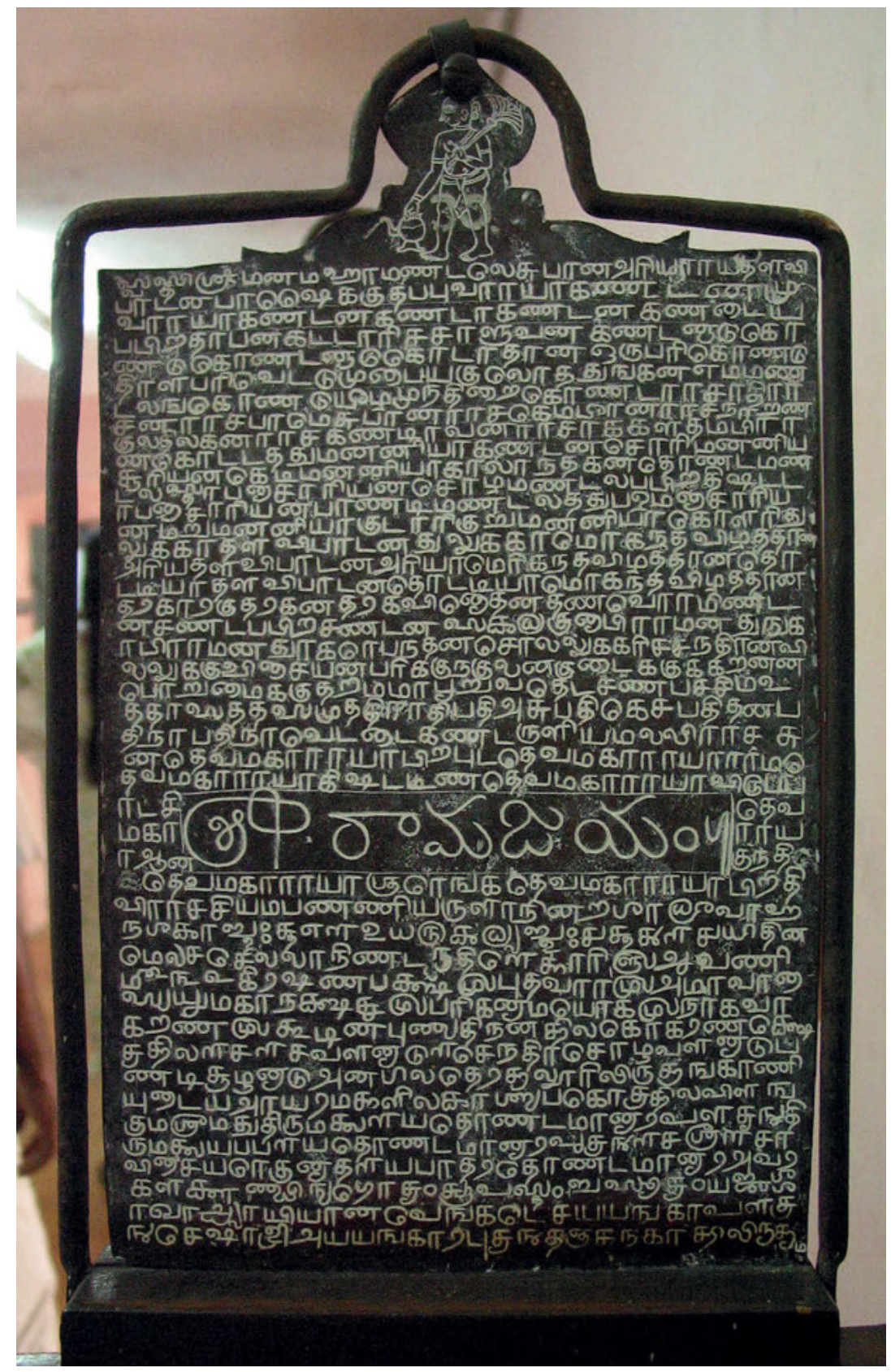

Fig. 7: Toṇṭaimāñ Raghunātha's grant, recto plate, Tamil Nadu, South India, 1803 CE. Pudukkottai Museum (copper plate no. 30). Approximately $27 \times 19 \mathrm{~cm}$. Photo: Emmanuel Francis. 


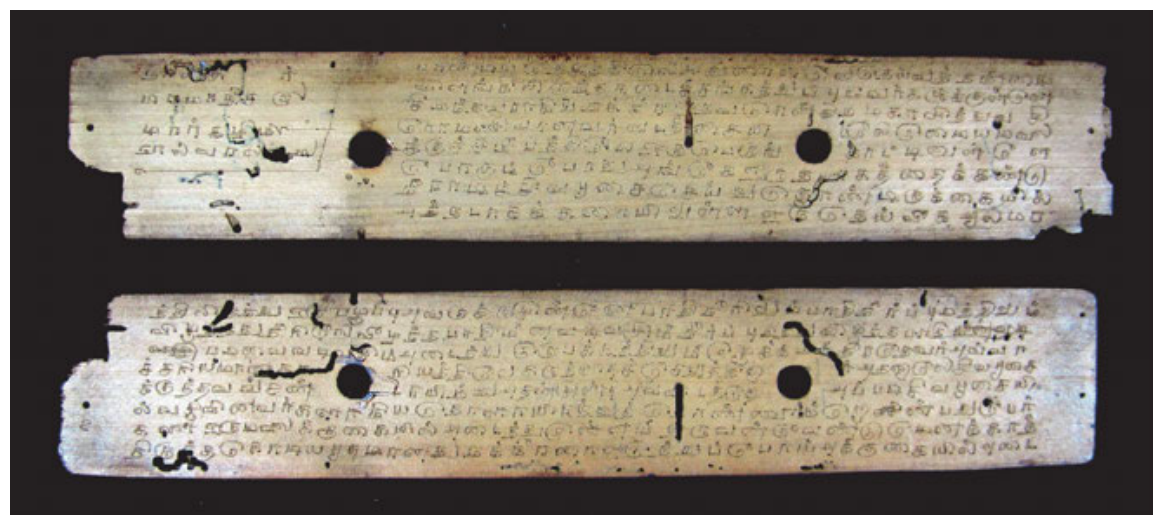

Fig. 8: Folios $1 \mathrm{v}$ and $2 \mathrm{r}$ of a manuscript copy of a mid-nineteenth-century printed edition of the Tirumurukārruppațai, Tamil Nadu, nineteenth or twentieth century. Annamalai University Library (cat. no. 97; Acc. no. 340049 [old] and 860 [new]). Approximately $19 \times 3,5$ cm. Photo: Emmanuel Francis.

\subsection{Copper plates and palm leaves}

One of the earliest copper-plate grants from Tamil Nadu-the Pallan Kōyil plates (mid-sixth century or possibly a later copy of a mid-sixth century original; Subramaniam 1959)-provides interesting details about the procedure for the execution of royal grants. It tells us (lines 27-36):

kōvicaiyasiṃhavarmmaṛku yāṇț’ ārāovatu veṇkuñrakkōtțatup perunakaranātțu nātțāā kāṇka tann nātțu amaṇcērkkai paruttikkuñril vajranandikkuravarkkup paḷiccantamākak koțuttōn tān்kaḷm pațākai națantu kallun kaḷilyun nāțti araiyōlai ceytu koțuttu vițutakav eñru nātțāarkut tirumukam vița nāțțārun tirumukan் kaṇțu tolutu talaikku vaittu pațākai națantu kalluñ kalliyu nātți nāțțār vițunta araiyōlaip pațikk’ ellai ...

In the sixth year of the victorious king Simhhavarman, let the nātțārs (district officials) of Perunakaram in Veṇkunrakkōțtam know (literally: see) (the following order). We have given as palliccantam (a specific name for a Jaina establishment) to the Guru Vajranandin in Paruttikkuñru (the village of) Amaṇcērkkai in their nāțu (district, as a subdivision of the kingdom). After the glorious order was sent to the nātțārs, specifying that they, themselves, walking the pațākai (the plot of land granted), planting stones and bushes, making a palmleaf document, should send it, all the nātțārs, having seen the glorious order, having worshipped it, having put it on their heads, having walked the pațākai, having planted stones and bushes, the boundaries according to the palm-leaf document sent by the nāttāars (are as follows:) ... 
Then are precisely described and situated the four boundaries of the land, object of the grant. This is followed by details of the conditions of the grant, by the description of the four boundaries of another land, also object of the grant, and finally the notification of grant and the mention of the officer responsible for the execution of the order. Note the very official language of the text. It describes the procedure of execution of the royal order in the locality in the presence of district officials and of a royal official. ${ }^{32}$ Note also the term ōlai ('palm leaf'), which occurs twice. It denotes a written document, containing the detailed boundaries of the granted land, that the nātțārs (district officials) are enjoined to make and send. As for the royal order (tirumukam ${ }^{33}$ ), to which due honour is given as if it was the king in person, it is not explicit in which form it reached the locality.

Later inscriptions seem to confirm that the royal order is first sent as a palmleaf document for execution. The copper-plate grant is created only after the particulars of the land, recorded on a palm-leaf document, reached the revenue department. Several copper-plate grants issued under the Cōlas in the eleventh century similarly show a long process from the initial order of the king to the reception of the copper-plate grant. For instance, in the Sanskrit/Tamil bilingual Tiruvālańkāṭu plates (1018 CE; ${ }^{34}$ SII 3, no. 205), three dates in the reign of the issuing king Rājendracōla I are mentioned in the Tamil section (SII 3, p. 392):

\footnotetext{
$6^{\text {th }}$ regnal year, $88^{\text {th }}$ day (line 6 ). - The king orally issued in his palace an order that the village of Palaiyanūur changes status. It will no more be a brahmadeya (a land enjoyed by brahmins), but from now becomes, as explicated further in the plates, a devadāna (a land enjoyed by a god). Several officials, concerned with the recording of the order into the account books, are then mentioned by name. In the Sanskrit portion (stanza 125), the regnal year $6^{\text {th }}$ is mentioned as the date when the king ordered the said village to be granted to the god Śiva (SII 3, p. 425).

$6^{\text {th }}$ regnal year, $90^{\text {th }}$ day, i.e. two days later (line 62). - The order was redacted and entered into account books. Again a long list of officials concerned, some already mentioned, are listed.
}

32 The same procedure is described, in sometimes exactly the same words, in other later Pallava plates.

33 Literally 'the glorious face' or 'mouth,' as a reference to the order being originally uttered by the king's mouth.

34 This date of 1018 CE corresponds to the sixth regnal year of the king, when he issued his order. This is not however the date of issue of the plates. The Sanskrit eulogy of the grant was written at least ten years later (according to SII 3, p. 384) since it records events in the career of the king that took place later in his reign. 
$7^{\text {th }}$ regnal year, $155^{\text {th }}$ day, i.e. one year and 65 days later (line 517). - The order, after having reached the nățtārs and having been executed in the locality (lines 118-484, with the description of it being honoured and executed in terms similar to that found in the earlier Pallava plates), is entered into the registers. According to SII 3, p. 392, the registers concerned are those of the village, not of the central royal administration, because the officials mentioned here in a long list are different from the above-mentioned.

It is not crystal clear what amount of detail was entered into the account books in the $90^{\text {th }}$ day of the $6^{\text {th }}$ regnal year, nor whether the account books concerned by the operation of the $155^{\text {th }}$ day of the $7^{\text {th }}$ regnal year were the same royal (and central) account books or village account books. In both cases, the Tamil phrase for entering the grant into the (palm-leaf) account books is vari-y-il itu-tal, literally 'having put in the tax' ${ }^{35}$ It is possible that such account books were kept both at the central revenue office and at a district office, as the nātțārs could have in fact been responsible for the distribution of land income and allocation of granted land revenue in their nătus (Stein 1980, 131). Note also that the plates mention official titles and phrases that include the term ōlai, 'palm leaf,' such as ōlaināyakan or ōlai elutum. ${ }^{36}$ The Ecālam and other Cōla plates show, with the same vocabulary and formulae, the same interaction between the royal and the local.

Commenting on these Tiruvālańkāțu plates, Daud Ali (2000, 173-174) appropriately recapitulates:

It should be clear that the inscription ... records its own complicated story, from its inception as a request to the king, through its performance and instantiation, and finally to its transcription onto copper. These texts encode an entire political procedure. A donation of land, even if we begin just with the king's word, was a complex procedure that involved a variety of sociopolitical agents. As the king dictated, the order was transcribed onto palm leaf, scrutinized, and checked for form by a series of officials whose title involved the word 'palm leaf' (ōlai). It then took on the status of 'edited' or 'refined' (tițțu), a status that enabled the grant to be entered into the permanent record books and/or sent in the form of a communication called an 'order' (tirumukam) to the relevant local authorities. The royal order, called in Tamil the 'auspicious face' or 'auspicious mouth' (tirumukam) of the king, was received at the locality as if it were the king himself. The 'men of the district' honored it by placing the order on their heads and then, mounting it on a female elephant, circumambulated the village to be donated. The plates could only be inscribed after these acts were performed.

35 See Madras Tamil Lexicon s.v. vari ('impost, tax, toll, duty; contribution') and Subbarayalu 2003, 539, s.v. variyil ițtu.

36 See also Nagaswamy 1987, 17, 24-25. 
The Tiruvālan̉kāṭu plates contain also an additional Tamil section, which comes right after the Sanskrit section on plate 10r-10v. It concerns a further gift made in the $120^{\text {th }}$ day of the $6^{\text {th }}$ regnal year of Rājendracōla I, but the script reveals that it has been engraved possibly one century later (SII 3, p. 384). The lines 16-21 read thus:

ippațikku variyilum ițtuc cempilum iț̣u śīlālekaiyum paṇnik koḷlac connōm colla nam ōlai elutum uyyakkonțārvalanāțțu tiruvaluntūrnātțu tulāruțaiyān karraliyāña uttamacōlattamilataraiya $<\underline{n}>$ eluttu $\|-$

We (further) ordered that it may thus be entered in the registers, engraved on copper and written on stone. For this statement (of Ours), (this is) the writing (i.e., the signature) of Our Secretary (ōlai elutum) Karrạ̣i alias Uttamaśōla Tamiladaraiyan of Tulâar, (a village) in Tiruvalundûr-nâdụ, (a subdivision) of Uyyakkoṇ̣âr-valanâḍu. ${ }^{37}$

We find here mention of three types of documents in which the order (theoretically) should be recorded:

(1) Palm leaf (ōlai). - The phrase vari-y-il-um ițtu literally means, as just mentioned, 'having put in the tax (register)' and is generally understood as meaning 'having entered into the account books' as vari, 'tax' is used here, by metonymy, to designate such registers.

(2) Copper (cempu). - The phrase cempil-um ițtu, in which we find again ițutal, literally means 'having put in the copper (document)' and designates the durable document handed to the beneficiary.

(3) Stone (śîlā). - The phrase śillā-lekai-y-um paṇni literally means 'having done the stone-written document' and refers to the copy exposed to (some) public eyes on the wall of the village temple, for instance.

The above examples, spanning a period of several centuries, show that, in South India, copper, stone and palm leaf were used to record grants. The royal order is first redacted and entered by officials into the palm-leaf account books. ${ }^{38}$ It seems most probable that first information (or intimation) of a royal order routinely reached the locality also as a palm-leaf document. ${ }^{39}$ Then the order is executed in the presence of district and royal officials. Local specifications are then

37 Text and translation by Krishna Sastri, SII 3, pp. 402 and 426.

38 See Lubin 2015, 227: 'An enormous number of inscriptions on stone and copper plates have survived, and these presuppose and sometimes explicitly attest to the use of palm leaves and other perishable materials for the purpose of framing and transmitting such documents.'

39 For an early tenth-century Cōla instance of a royal order (dealing with the administration of a brahmin settlement) sent in ōlai form at the local level, then executed and recorded on stone, see Lubin 2015, 246ff. For a mid-thirteenth-century example, see Lubin 2013, 439ff. 
transmitted to the revenue department. In the Pallava period, these local details were dispatched on palm-leaf documents, as is explicitly stated in the text of the copper plates. Epigraphical sources thus evince that the production of a copper plate-which serve as title-deed for the grantee(s)-occurs only as the final step (possibly not even always taken) of a complex process, which can take several years.

Comparing the format of the early South Indian plates (Figs 1, 3-4) with that of South Indian manuscripts on palm leaf (Fig. 8) we observe that they are quite similar. ${ }^{40}$ That Indian copper-plate grants copy the format and dimensions of documents written on perishable material is not a discovery. Sircar (1965, 121-122) associates the South Indian format to palm leaf, the North Indian format to bark sheets (see also Chhabra 1951, 3). Salomon $(1998,113)$ agrees that such 'inscriptions are engraved on one or more plates of copper which vary widely in size but generally reproduce the shape of traditional nonepigraphic writing materials such as palm leaves and bark strips, or sometimes stone stelae'. Ali $(2000,171)$ goes on step further when stating:

The plates, we should note right away, present themselves to us as a text. In medieval India, texts were usually inscribed on palmyra leaves which were then bound with a string that fit through a hole bored through all the sheaves. The copper plates were bound similarly, indicating, as we shall see, that they themselves were the durable 'hard copies' of less permanent documents kept at the palace of the king.

Indian copper-plate grants are thus continuous-in content (grant), format (oblong) and material characteristics (one or two holes to bind the document)-with other records written down on perishable material. Indeed they appear as their enduring versions, although with another purpose: as durable copies of royal orders, they were meant for the recipients as long-lasting proof of ownership. But does the hardness of copper-plate grants make them inscriptions?

\subsection{Copper plates and inscriptions}

Burton Stein (1980, 131-132) has reflected on the 'practical and semiotic differences' between stone and copper-plate inscriptions. According to him, during the Cōla period (tenth to thirteenth century), copper plates 'record gifts to individual

\footnotetext{
40 No South Indian palm-leaf manuscript as old as these early South Indian plates are extant, but representations on sculpture show that the format has not changed much in the course of time.
} 
priests or teachers-Hindu, Buddhist, or Jaina-or to groups of such persons as recipients; attention is focused upon the receiver or receivers and that which is received, and both are very elaborately described'. By contrast, most 'stone inscriptions differ in that they record the beneficence of a donor or donors to the god of priests of the temple, and the major focus is upon the giver'. Stein had to admit nevertheless that the eulogistic portion in Sanskrit praising the donor and found in copper-plate inscriptions 'would belie this distinction,' as it focuses on the donor whom it praises. For this, Stein offers no real explanation, except that the Sanskrit plates were executed separately. Indeed we have instances, like the Tiruvālañkātu plates, where it is possible that the Sanskrit plates were added later, but they do not make it a rule and it remains possible that the whole set of copper plates (Sanskrit eulogy and Tamil operative section) were executed together, but much later than the recorded date of the initial royal order. Furthermore, there are copper plates recording gifts to temples (devadāna) and examples of stone inscriptions which mention the instruction for the engraving of the royal orders on stone and copper. Let us give just a few examples: ${ }^{41}$

ippațikku innnāẹ mutal cantirātittavaraiyum cella kallilum cempilum vețtik koḷlavum (SII 1, no. 87, lines 57ff.; 1364 CE), 'This (order) shall be engraved on stone and copper, in order that it may last from this day forward, as long as the moon and the sun. ${ }^{42}$ Note here that the explicit reason for engraving on stone and copper is that the grant is perpetual.

inta ōlaiyē cātanamākak koṇțu kallilum cempilum vetțik koṇțu (PI 488, line 7; $1323 \mathrm{CE}$ ), '(those to whom the order had been transmitted) having taken this palm leaf itself as the royal order (cātañam, i.e. Sanskrit śāsana) and having engraved it on stone and copper'.

Such mentions again illustrate the fact that the same text can be written on different material supports, and in the present case, pace Stein, the continuity between stone and copper writings. These mentions come from stone inscriptions which record the royal instruction of double engraving given in the royal order that arrived in a palm-leaf document. Whether the double engraving was done or not is another question. It cannot be ruled out that the copper records were lost, due to the reuse of the raw material. Note also that the duty of issuing the copper plate records is seemingly put on the shoulders of local people, in contradistinction with the dharmaśāstra's statements that the king should issue and give the copper record to the recipient.

41 See, for several other examples from early medieval Tamil Nadu, PI, vol. 2, p. 353, s.v. 'kallil veț̣ivittu'.

42 Text and translation by Hultzsch, SII 1, p. 123. 


\section{Document or inscription?}

In Indological scholarship copper-plate grants have been traditionally treated as inscriptions and published in epigraphical series such as Corpus Inscriptionum Indicarum, Epigraphia Indica, South Indian Inscriptions, etc., as the dominant opposition has been between manuscripts and inscriptions, stressing the material factor, that is perishable vs. durable. But if, following Panciera (2012), one considers that communication to a general audience is the determining factor that sets apart inscriptions from other types of written texts, copper-plate grants, as title-deeds, are not inscriptions. They are not meant to be displayed, but rather kept in a safe place. They might have been received in a public ceremony and read aloud, but afterwhile they are not publicly exhibited but rather safe-kept in a secret or secure place. If the mostly non-public nature of copper-plate grants disqualifies them as inscriptions, are they archival records? They are at least not 'state' archives, as they are in the hands of 'private' persons and in fact are durable copies (or partial copies) of records, on perishable supports, kept in 'state' archives for revenue administration purpose. It might well be that the text is not exactly the same on the copper plates and in the archives, but the gist would be similar: peculiars of the gift, including the description of the boundaries of granted land and the list of grantees. We have unfortunately no official account books of Pallava or Cōla period to check their contents against that of extant copper plates. Only the durable copper made its way up to present day.

\subsection{Other uses of copper plates}

It is not enough to state that copper-plate grants are durable copies of royal orders meant as title-deeds for the grantees, for two reasons. Firstly, copper-plate grants can be more than just grants. Secondly, there are copper plates which are not grants.

Other functions of copper-plate grants - Once a type of medium is invented and used for a specific reason, it also can serve other purposes. From an early date, copper-plate grants begin, as preamble, with a eulogy, increasingly long as time passes, of the donor and his family.

Besides their legal value as title-deeds, copper-plate grants thus fulfilled other functions. Hermann Kulke (1997) elaborated on their political functions, beyond their apprehension as acts of 'religious devotion' or as legal documents. According to Kulke, copper plates are rare, valuable and exceptional objects, 
which 'enhanced the social status and political position of both donees and donors' (p. 238). They contributed to spread 'the standardized message of the great kingship to various parts of the kingdom,' (p. 239) as they were read at the donation ceremony and also in case of legal dispute. From this perspective, one can apprehend the durability of copper-plate grants not only because they are titledeeds, but also because they are vehicles of royal glory, which is made durable, as in stone panegyrics. For Kulke, copper plates are an 'effective medium of instruction (and political propaganda)' (p. 239) in three aspects: they 'establish and confirm royal claims of legitimacy and the conformity of their own and their forefather's rule with rājadharma [i.e. royal duty];' they 'corroborate or ... change the administrative hierarchy' and strengthen 'the king's position on top of this hierarchy;' they 'set up new or confirm old measures of standardized tax collection and administration through a network of privileged Brahmin villages' (p. 243).

Other types of copper-plates - Given the legal and official status associated with copper-plate grants, which makes them authentic documents summoned to settle disputes, and given their durability, agencies other than royal chancelleries issued, in the course of centuries, copper plates in order to record permanently rights and duties.

An early example is the Cōla-period Tirukkalar copper-plate set, ${ }^{43}$ issued by a temple authority and concerning transactions that do not involve the king, who appears only through his regnal year used for the internal date of the record (Orr 2009 , 98). The absence (or at least mention, in the reports) of authenticating seal confirms that these plates were not issued by the royal chancellery. Copper-plate grants were also increasingly issued at the initiative of private individuals or communities in order to secure their rights in various contexts. Lubin $(2015,248-50)$ provides several examples of published statutes of this type. For instance, in a 1604 CE copper-plate inscription, a shepherd secures hereditary rights on his lands for his sons after asking for a copper-plate document (cempu-p-pattaiyam). Lubin $(2015,249)$ remarks that what 'is remarkable about this case is that we see a relatively humble individual taking recourse to a permanent written record in order to secure his legal land rights for his heirs. Although it is unusual for such documents to be preserved in metal (as opposed to perishable palm leaf), its existence suggests that by this time documentation of this sort was produced not only for elites or groups.' Another example, also discussed by Lubin (ibid.), is the settlement of a land-dispute between two mutaliyārs (officials and dignitaries)

43 The Tirukkalar set in fact consists in five different plates of different dates concerning properties of the Tirukkalar temple (SII 3.207-211). 
recorded in a 1535 CE copper-plate inscription after a local potentate (rāyar) examined an earlier copper-plate grant (ceppētu) and four other mutaliyārs had been consulted. In both these cases, there is still an issuing authority and the records concern land.

More illustrative of the shift of content and issuing agency are late copper plates, a good sample of which, from South India, are available online through the Endangered Archives Program of the British Library. ${ }^{44}$ In this collection, among other types of archives, are copper plates recording caste customs, rights over tank water (EAP689/10/8/7), precedence rights (mutal mariyātai, 'first rights') in temple rituals (EAP689/10/8/9), in which sometimes no issuing authority is referred to other than the local individuals concerned (EAP689/6/1/145). Other examples of various transactions recorded on copper plates are to be found among the 'Miscellaneous' and 'Anonymous' in the two volumes of DLCPI and in Srītar (2005). Furthermore, some of these copper plates which have the appearance of documents issued by a royal authority might in fact be ancient forgeries, in the sense that they were issued by the groups concerned and framed as official documents of an earlier time, of which no perishable copies in records office ever existed. Such forgeries are debunked, for instance, through inconsistencies between the internal date and the date of the purported issuing king or palaeographical features.

A final example of a very specific use of copper plates-although we have approximate precedents with the lavish manuscripts which are cult objects-concerns Telugu devotional hymns. The compositions of the Tāllapāka family were engraved in the sixteenth century on a set of 2691 plates-including 2289 plates for approximately 1300 poems by the famous Annamayya-and are today kept at the Tirupati temple in Andhra Pradesh. This is described as 'possibly the most expensive publishing venture in the history of premodern South Asia' (Narayana Rao/Shulman 2005, 105).46 The Tāllapāka plates might not be a lavish manuscript, although they were worshipped, but an authoritative edition, made intangible and durable through the hardness of copper. ${ }^{47}$

44 See EAP 314, EAP458, and EAP689 of the project 'Digital Archive of Tamil Agrarian History (1650-1950)' of the team 'Caste, Land and Custom.'

45 See edition and translation in Headley 2012, 260-264.

46 It took 29 printed volumes to edit these plates. Similar copper plates are found in other temples and additional copies were in circulation in sets of five plates. See Narayana Rao/Shulman 2005, 104-106.

47 See also Sircar 1965, 77 about other purported copper-plate books. 


\section{Conclusions}

Indian copper-plate grants in general and many other examples of texts engraved on metal do not comply to what is a restrictive definition of inscriptions as exposed or publicly displayed texts, as they were usually kept privately and sometimes buried. There is further the fact that texts (or parts of texts) found engraved on copper are also recorded on other supports such as the palm leaf or paper of account books, which fall in the category of archival records since they are administrative documents, or the stone of temple-walls and steles, which fall in the category of inscriptions since they are public records. The same text could thus be materially instantiated for different reasons: account keeping (archives), public information, proclamation and personal display (inscriptions), securing future rights (copper plates).

But one question remains: why take so much effort in placing at the beginning of copper-plate grants lengthy eulogies of kings, if these documents were not meant in the first place to be read? The answer might be that there were occasions when the plates had a 'public life,' when read, possibly at the time they were delivered to the grantees with a kind of ritual reception or at the time they were produced in case of legal dispute. Anyhow, if we are to keep the general label copper-plate inscriptions, we should hasten to add that, due to their value as title-deeds, these, especially grants, are not usual inscriptions in spite of their enduring support, nor usual state archives, but rather belong to an intermediate category, for which the best label would simply be copper-plate grants.

\section{Acknowledgements:}

Many thanks to Arlo Griffiths for providing me excellent pictures of North Indian copper-plate grants and of the Pātagaṇdigūọem plates, for polishing my English and for offering many suggestions. I am also indebted to R. Balasubrahmanyam for the permission to photograph copper plates in the collections of the Chennai Government Museum and to R.K. Tewari and Ryosuke Furui for the picture of the Nālandā plate. 


\section{References}

\section{Primary Sources}

Arthaśāstra (2013), King, Governance, and Law in Ancient India: Kauțilya's Arthaśāstra. A New Annotated Translation. By Patrick Olivelle. New York: Oxford University Press.

Bhojaprabandha (1926), bhoja-prabandhah śrīballāla viracitah = The Bhoj-Prabandha of Sree Ballal. (With English Translation). By Saradoprasad Vidyabhusan. $3^{\text {rd }}$ edition. Calcutta: S.C. Auddy \& Co.

Lekhapaddhati (2002), Die Lekhapaddhati-Lekhapañcāśikā: Briefe und Urkunden im mittelalterlichen Gujarat. Text, Übersetzung, Kommentar. Glossar (Sanskrit-DeutschEnglisch). By Ingo Strauch. Berlin: D. Reimer.

Vișnusmṛti (2009), The Law Code of Vișnu: A Critical Edition and Annotated Translation of the Vaișnava-Dharmaśāstra. By Patrick Olivelle. Cambridge: Department of Sanskrit and Indian Studies, Harvard University.

\section{Inscriptions}

Quotations of epigraphical texts are corrected and normalized.

ASIAR = Archaeological Survey of India Annual Report. Archaeological Survey of India.

$\mathrm{CII}=$ Corpus Inscriptionum Indicarum. 7 volumes (1887-1991), Archaeological Survey of India.

DLCPI = Dynastic List of Copper Plate Inscriptions Noticed in Annual Reports on Indian

Epigraphy. 2 volumes. See Gai (1986) and Padmanabha Sastry (2008).

Ecālam plates - See Nagaswamy (1987).

$\mathrm{EI}=$ Epigraphia Indica 42 volumes (1892-1992), Archaeological Survey of India.

$\mathrm{EZ}=$ Epigraphia Zeylanica. 4 volumes (1904-1934), Government of Ceylon.

$\mathrm{IR}=$ Pallava royal inscriptions, as per the list found in Francis (2013).

Kācinātañ, Nataña, Cu. Irācakōpāl \& Ve, Vētācalam (eds) (1994), Tirumalaināyakkar

ceppēțkal. Cennnai: Tamilnāțu aracu tolporu! āyvutturai.

Paḷnan Kōyil plates - See Subramaniam (1959).

$\mathrm{PI}=$ Pondicherry Inscriptions. 2 volumes (2006 and 2010). Compiled by Bahour S. Kuppusamy. Edited and translated by G. Vijayavenugopal. Pondicherry: IFP \& EFEO.

Ramesh, K.V. and Tewari S.P. (1990), A Copper-Plate Hoard of the Gupta Period from Bagh, Madhya Pradesh. New Delhi: Archaeological Survey of India.

Rājāmukamatu, Je. \& Ce. Kōvintarāj (2009), Putukkōțtai Toṇțaimāñ ceppētțukal. Cennnai: Aracu arunkāṭciyakam.

Senavarma gold plaque - See Salomon (1986).

SI = Sircar, D.C. (1965), Select Inscriptions Bearing on Indian History and Civilization. Volume 1. From the Sixth Century B.C. to the Sixth Century A.D. Second edition. Calcutta: University of Calcutta.

SII = South Indian Inscriptions. 27 volumes (1890-2001). Archaeological Survey of India.

Srītar, Ti. Śrī (2005), Tamillakac ceppēțkal. Tokuti 1. Egmore: Tamil Nadu State Department of Archaeology. 


\section{Secondary Sources}

Ali, Daud (2000), 'Royal Eulogy as World History: Rethinking Copper-Plate Inscriptions in Cōla India', in Ronald Inden, Jonathan Walters and Daud Ali, Querying the Medieval: Texts and the History of Practice in South India, New York: Oxford University Press, 165-229.

Ayyangar, R. Srinivasa (2000), Catalogue of Copper Plate Grants. Government Museum Madras. Reprint of 1918 edition, Chennai: Commissioner of Museums, Government Museum.

Bentor, Yael (1995), 'On the Indian Origins of the Tibetan Practice of Depositing Relics and Dhâraṇîs in Stûpas and Images', in Journal of the American Oriental Society, 115, 248261.

Chhabra, B.C. (1951), 'Diplomatic of Sanskrit Copper-Plate Grants', in The Indian Archives, 5/1, $1-20$.

Chhabra, B.C. (1962), 'Seals of Ancient India', in The Indian Archives, 14, 1-14.

Cox, Whitney (2012), 'Scribe and Script in the Cālukya West Deccan', in Indian Economic and Social History Review, 47/1, 1-28.

De Simini, Florinda (2016), Of Gods and Books: Ritual and Knowledge Transmission in the Manuscript Cultures of Premodern India (Studies in Manuscript Cultures, 8), Berlin: De Gruyter.

Falk, Harry (2000), 'The Pātagaṇḍigūọem Copper-Plate Grant of the Ikṣvāku king Ehavala Cāntamūla', in Silk Road Art and Archaeology, 6, 275-283.

Fleet, J.F. (1907), 'The Inscription on the Sohgaura Plate', in Journal of the Royal Asiatic Society of Great Britain and Ireland, 509-532.

Formigatti, Camillo A. (2016), 'A Forgotten Chapter in South Asian Book History? A Bird's Eye View of Sanskrit Print Culture', in Hildegard Diemberger, Karl Ehrhard and Peter F. Kornicki (eds), Tibetan Printing: Comparison, Continuities, and Change, Brill: Leiden, 72134.

Francis, Emmanuel (2013), Le discours royal dans l'Inde du Sud ancienne. Monuments et inscriptions pallava (IVème-IXème siècles). Tome 1 : Introduction et sources, Louvain-laNeuve: Université catholique de Louvain.

Gai, G.S. (1986), Dynastic List of Copper Plate Inscriptions Noticed in Annual Reports on Indian Epigraphy from 1887 to 1969, Mysore: Director (Epigraphy), Archaeological Survey of India.

Gaur, Albertine (1975), Indian Charters on Copper Plates in the Department of Oriental Manuscripts and printed Books, London: The British Library.

Ghosh, Ranjusri (2007), 'Re-reading of the Sohgaura Plaque by D.C. Sircar: A Note', in Journal of the Asiatic Society (Calcutta), 49/4, 110-113.

Gopinatha Rao, T.A. (1986), Copper-plate Inscriptions Belonging to the Sri Sankaracharya of the Kamakoti-Pitha. Reprint of 1917 edition, Delhi: Gian Publishing House.

Griffiths, Arlo (2014), 'Written Traces of the Buddhist Past: Mantras and Dhāraṇis in Indonesian Inscriptions', in Bulletin of SOAS, 77/1, 137-194.

Griffiths, Arlo (2015), 'New Documents for the Early History of Punḍravardhana: Copperplate Inscriptions from the Late Gupta and Early Post-Gupta Periods', in Pratna Samiksha: A Journal of Archaeology, NS 6, 15-38.

Headley, Zoé E. (2012), 'Of Dangerous Guardians and Contested Hierarchies: An Ethnographic Reading of a South Indian Copper plate', in A. Murugaiyan (ed.), New Dimensions in Tamil Epigraphy, Chennai: Cre-A, 253-281. 
Heitzman, James (1997), Gifts of Power: Lordship in an Early Indian State, Delhi: Oxford University Press.

Hidas, Gergely (2015), Dhāraṇi Sūtras, in Jonathan Silk (editor-in-chief), Brill's Encyclopedia of Buddhism. Vol. I. Literature and Languages, Leiden: Brill, 129-137.

Hinüber, Oskar von (1984), 'Sieben Goldblätter einer Pañcaviṃśatisāhasrikā Prajñāpāramitā aus Anurādhapura', in Nachrichten der Akademie der Wissenschaften in Göttingen, Philologisch-historische Klasse, 1983/7: 187-207.

Kane, P.V. (1941), History of Dharmaśāstra (Ancient and Mediaeval Religious and Civil Law). Vol. II.2, Poona: Bhandarkar Oriental Research Institute.

Kane, P.V. (1946), History of Dharmaśāstra (Ancient and Mediaeval Religious and Civil Law). Vol. III, Poona: Bhandarkar Oriental Research Institute.

Kulke, Hermann (1997), 'Some Observations on the Political Functions of Copper-Plate Grants in Early Medieval India', in Bernhard Kölver and Elisabeth Müller-Luckner (eds), Recht, Staat und Verwaltung im klassischen Indien, Munich: R. Oldenbourg Verlag, 238-243.

Lubin, Timothy (2013), 'Legal Diglossia: Modeling Discursive Practices in Premodern Indic Law', in Whitney Cox and Vincenzo Vergiani (eds), Bilingual Discourse and Cross-Cultural Fertilisation: Sanskrit and Tamil in Medieval India, Pondicherry: IFP \& EFEO, 411-455.

Lubin, Timothy (2015), 'Writing and the Recognition of Customary Law in Premodern India and Java', in Journal of the American Oriental Society, 135, 225-259.

Melzer, Gudrun, in collaboration with Lore Sander (2006), 'A Copper Scroll Inscription from the Time of the Alchon Huns', in Jens Braarvig (ed.), Manuscripts in the Schøyen Collection: Buddhist Manuscripts. Vol. III, Oslo: Hermes Publications, 251-314.

Nagaswamy, Ramachandran (1978), Studies in Ancient Tamil Law and Society, Madras: State Department of Archaeology, Government of Tamil Nadu.

Nagaswamy, Ramachandran (1987), 'Archaeological Finds in South India. Esālam Bronzes and Copper-Plates', in Bulletin de l'École française d'Extrême-Orient, 76, 1-68.

Narayana Rao, Velcheru, and David Shulman (2005), God on the Hill: Temple Poems from Tirupati, New York: Oxford University Press.

Natarajan, Avvai, and Natana Kasinathan (1992), 'Metal Used as Medium of Writing', in Art Panorama of Tamils, Madras: State Department of Archaeology, 70-72.

Orr, Leslie C. (2009), 'Tamil and Sanskrit in the Medieval Epigraphical Context', in M. Kannan and Jennifer Clare (eds), Passages: Relationships Between Tamil and Sanskrit, Pondicherry: Institut Français de Pondichéry \& Berkeley: Tamil Chair, Department of South and Southeast Asian Studies, University of California at Berkeley, 97-114.

Padmanabha Sastry, C.A. (2008), Dynastic List of Copper Plate Inscriptions Noticed in Annual Reports on Indian Epigraphy from 1969-70 to 1996-97, New Delhi: Archaeological Survey of India.

Panciera, Silvio (2012), 'What Is an Inscription? Problems of Definition and Identity of an Historical Source', in Zeitschrift für Papyrologie und Epigraphik, 183, 1-10.

Paranavitana, S. (1933), 'Indikatusaya Copper Plaques', in EZ 3, no. 20, 199-212.

Petrucci, Armando (1985), 'Potere, spazi urbani, scritture esposte: proposte ed esempi', in Culture et idéologie dans la genèse de l'État moderne. Actes de la table ronde de Rome (15-17 octobre 1984), Rome: École Française de Rome, 85-97.

Pollock, Sheldon (2007), 'Literary Culture and Manuscript Culture in Precolonial India', in Simon Eliot, Andrew Nash and Ian Willison (eds), Literary Cultures and the Material Book, London: The British Library, 77-94. 
Rahman, Aman Ur, and Harry Falk (2011), Seals, Sealings and Tokens from Gandhāra, Wiesbaden: Reichert Verlag.

Salomon, Richard (1986), 'The Inscription of Senavarma, King of Oḍi', in Indo-Iranian Journal, 29, 261-293.

Salomon, Richard (1998), Indian Epigraphy: A Guide to the Study of Inscriptions in Sanskrit, Prakrit, and the other Indo-Aryan Languages, New York: Oxford University Press.

Salomon, Richard (2009), 'The Fine Art of Forgery in India', in Gérard Colas and Gerdi Gerschheimer (eds), Écrire et transmettre en Inde classique, Paris: École française d'Extrême-Orient, 107-134.

Scherrer-Schaub, Cristina A. (1994), 'Some Dhāraṇī Written on Paper functioning as Dharmakāya Relics. A Tentative Approach to PT 350', in Per Kvaerne (ed.), Tibetan Studies: Proceedings of the 6th Seminar of the International Association for Tibetan Studies, Fagernes 1992. Vol. II, Oslo: Institute for Comparative Research in Human Culture, 711727.

Schopen, Gregory (1976), 'The Phrase "sa prthivīpradeśaś caityabhūto bhavet” in the Vajracchedikā: Notes on the Cult of the Book in Mahāyāna', in Indo-Iranian Journal, 17, 147-181.

Schopen, Gregory (1989), 'A Verse from the Bhadracaripraṇidhāna in a Tenth-Century Inscription Found at Nālandā', in Journal of the International Association of Buddhist Studies, 12/1, 149-157.

Schopen, Gregory (1996), 'What's in a Name: The Religious Function of the Early Donative Inscriptions', in Vidya Dehejia (ed.), Unseen Presence. The Buddha and Sanchi, Mumbai: Marg Publications, 58-73.

Sircar, D.C. (1965), Indian Epigraphy, Delhi: Motilal Banarsidass.

Sircar, D.C. (1974), Studies in the Political and Administrative Systems in Ancient and Medieval India, Delhi: Motilal Banarsidass.

Skilling, Peter (2005), 'Buddhist Sealings: Reflections on Terminology, Motivation, Donors' Status, School-Affiliation, and Print-Technology', in Catherine Jarrige and Vincent Lefèvre (eds), South Asian Archaeology 2001. Vol. II. Historical Archaeology and Art History, Paris: Recherches sur les Civilisations, 677-685.

Sohoni, Pushkar (2016), 'Paper Documents and Copper-Plates: Localization of Hegemonic Practices', in Bulletin of SOAS, 79/1, 87-101.

Stein, Burton (1980), Peasant State and Society in Medieval India, Delhi: Oxford University Press.

Subbarayalu, Y. (1991), Tiruccirāppa!̣ı māvatța ōlai āvananina! = Palm-Leaf Records of the Tiruchirapalli District, Thanjavur: Tamiḷp palkalaikkalakam.

Subbarayalu, Y. (2003), Glossary of Tamil Inscriptions = Tamillk kalvețtuc collakarāti. 2 vols, Chennai: Santi Sadhana.

Subramaniam, T.N. (1959), 'Pa!̣nankōvil Jaina Copper-plate Grant of Early Pallava Period', in Transactions of the Archaeological Society of South India, 41-83.

Vielle, Christophe (2011), 'Ravivarman Kulaśekhara the Yādava and Sagara the Son of Yãdavī: Real and Ideal Kings in Matrilineal Kerala', in Religions of South Asia, 5/1-2, 365-387.

Willis, Michael (2009), Archaeology of Hindu Ritual: Temples and the Establishment of the Gods, Cambridge: Cambridge University Press.

Yamazaki, Toshio (1982), 'Some Aspects of Land-Sale Inscriptions in Fifth and Sixth Century Bengal', in Acta Asiatica: Bulletin of the Institute of Eastern Culture (Tokyo), 43, 17-36. 



\section{Epilogue: Why and how to compare}





\title{
Epilogue: Archives and Archiving across Cultures-Towards a Matrix of Analysis
}

\begin{abstract}
The essays in this volume explore how writings have been stored and kept available for future use across time and space. They can be regarded as some of the first steps towards a cross-cultural and even global study of archives and archival practices. Taken as a whole, the papers indicate many of the topics (and difficulties) that would need to be addressed in a future global investigation of archives and archival practices.
\end{abstract}

\section{Archives from a cross-cultural perspective}

Any attempt at a global investigation of archives will quickly encounter a basic terminological difficulty: there is no denying that 'the archive' is a thoroughly European concept. Following a line of thought harking back to Max Weber's concept of 'bureaucratic rationality', archives are frequently seen as integral components and indicators of well-organised administration, and as such, they count as key elements of the modern nation-state as it evolved in nineteenth-century Europe. ${ }^{1}$ National states created national archives, and national archives supported the ideological construction of national histories. ${ }^{2}$ In as far as the developing European monarchies and states projected their power overseas, archives can be said to have played a significant role as 'agents' or 'infrastructures' of colonial oppression. ${ }^{3}$ To the degree that the politics of archives has become

\footnotetext{
Preliminary note: After attending the conference on which this volume is based, the editors asked me if I was willing to provide a few concluding remarks to this book. I have read all the papers and have added a few other pieces of information culled from various readings. I would like to point out that the following remarks are the remarks of a Europeanist by training who cannot claim any expertise in archival developments outside Western Europe. Any details without any further references come from the papers in this volume. Alessandro Bausi, Michael Friedrich and Jürgen Paul read the text and helped me to avoid at least some of the errors I might otherwise have made.
}

1 For a nuanced and global perspective on 'bureaucratic rationality' in the nineteenth century, see Osterhammel 2010, 866-882. On the national dimension, see Verschaffel 2012, 29-46.

2 Berger/Conrad 2014.

3 See, for example, Mignolo 2003; Richards 1993; Stoler 2002, 87-109.

https://doi.org/10.1515/9783110541397-015, (c) BY-NC-ND @ 2018 Markus Friedrich, published by De Gruyter. This work is licensed under the Creative Commons Attribution-NonCommercial-NoDerivs 3.0 License. 
identified with the politics of identity-building and collective self-fashioning, the history of the archive is often considered to be quasi-identical with the history of nationalism and the (nation-)state, especially in its European variant. ${ }^{4}$

Classic definitions of 'archives' mirror this state-centred understanding. A widely known Dutch definition first articulated in 1898 states in an authoritative way: 'An archival collection (archief) is the whole of the written documents, drawings and printed matter, officially received or produced by an administrative body or one of its officials, insofar as these documents were intended to remain in the custody of that body or that official'. ${ }^{5}$ In many ways, this conceptual connection between the state/bureaucracy/administration and archives still remains powerful, albeit in a softened language. Many recent definitions of 'archive' continue to rely on the traditional idea that archival documentation is produced 'organically' as a result of routine protocols of business in public or private 'organisms'-which is, of course, still very close to the Dutch version's 'administration' ${ }^{6}$

Given this deep connection with the rise of European (nation-) states and their modes of political and cultural operation, it is little wonder that national archives are frequently considered European institutions. The search for archives elsewhere, then, might well seem to be a Eurocentric procedure, and the reservations against simply using the fully developed Western concept of 'the archive' across cultural borders in unreflected ways is understandable. And yet a comparative approach to archives and archiving across cultures is certainly possible and can actually be helpful for several reasons. ${ }^{7}$

Firstly, the classic understanding of archives as modern institutions has lost some of its persuasiveness. Rethinking periodisation and methodology has contributed to two broader shifts: a growing body of recent scholarship on pre-modern European collections of documents has revealed the long past of the modern archive (thus also questioning any exclusive correlation to ideologies of nationalism), while other studies have started to seriously question the modernity of archives of the nineteenth and early twentieth century. ${ }^{8}$ Moreover, in terms of methodology, scholarly attention has begun to shift away from the history of archives as

4 Fritzsche 2005, 15-44; Berger 2012.

5 Muller 2003, 13.

6 See Galland 2016, p. 3, for example. Also see Dietmar Schenk's paper in this volume.

7 I have found a useful parallel to my approach in the equally pragmatic globalisation of the term 'philology' in Pollock/Elman/Chang 2015 (p. 1f. in this case). What is quite different from allowing a global use of 'philology' is the question of what one should think of the broader project of a 'future philology'. On a European level, see the recent paper by Head 2017, 433-455.

8 Friedrich et al. 2017, 3-13. 
institutions to the history of archiving as a social practice. ${ }^{9}$ This development has created the opportunity for a much more flexible use of the terms 'archive' and 'archiving' and also seems to allow their usage in non-European contexts more easily. Thus, specialists working on and in non-European archives now find it possible to call for a 'de-centring' of archival history, by which they mean a shift away from an almost exclusively European history of archives towards a growing incorporation of non-European, 'peripheral' archives. ${ }^{10}$

Secondly, the connection between state-building, bureaucratisation and archival development has been re-evaluated from at least two sides. On the one hand, bureaucratic rationality and archival development are being regarded less and less as genuinely European phenomena. A growing body of research stresses that the connection between administrative organisation and archiving was by no means an exclusively Western achievement. Imperial bureaucracies have traditionally been acknowledged for several important polities, including the ancient civilizations of Assur, Egypt and China, but also early modern examples such as the Indian state of Cholon and the Mughals, the Islamic empires of the Safavids or the Ottomans, and Ming and Qing China. ${ }^{11}$ More tellingly, similar developments and at least embryonic archival developments are diagnosed elsewhere, too. Even the Ancient Greek cities, traditionally considered to be governed by public debate in a face-to-face mode, are now considered to have been 'more "bureaucratic" than is usually thought', including complex archival arrangements. ${ }^{12}$ Pre-modern Ethiopia is another case in point; recent research has started to document a vast increase in land-related record-making and record-keeping after 1700 which seems to have been independent of external influences. ${ }^{13}$ Building on such results, a cross-cultural comparative study of the relevance of

9 For a recent survey of the methodological state of the art (mostly regarding European cases), see Walsham 2016, 9-47. I have proposed such an approach myself in Friedrich 2018 ( $1^{\text {st }}$ German ed. 2013). 10 See the discussion in Jungen/Raymond 2012, online since 14 May 2012, viewed on 10/11/2017 (URL: http://ateliers.revues.org/9080; DOI: 10.4000/ateliers.9080). The following quotes come from ibid., no. 9. Jungen and Raymond, however, also state the difference between Near Eastern and European 'archives'; ibid., nos 29f.

11 See Crooks/Parsons 2016, for example. Little is said there about the role of archives, however. On other archival developments in the context of complex administrative services, see Zhang 2004, 17-38 in addition to the papers in this volume. There seems to be very little information available about Mughal archives; cf. Ghose 1963, 15-21.

12 Faraguna (forthcoming), pre-print available at http://www.oxfordhandbooks.com/view/ 10.1093/oxfordhb/9780199599257.001.0001/oxfordhb-9780199599257-e-14), p. 3. Cf. p. 8f. on legal procedure.

13 Habtamu Mengistie 2015, 433-461, who approvingly quotes Guidi 1906, 651-698. 
archives for the exercising of bureaucratic power almost seems the next logical step now.

On the other hand, the rationalising effects of bureaucratisation and archival developments have become much more doubtful in recent research than a simple Weberian approach would suggest. It is becoming clear that the role of archives in the process of government and as tools of state power is much more complex than we have often assumed. It is well documented by now that archives were frequently not used in the process of political decision-making and that they often were not facilitators of governance as much as sources of insecurity and ambiguity. Archives are, thus, no longer seen as natural by-products or simple infrastructures of state power; rather, their role in actual government has now been questioned and their efficiency is seen in highly critical terms. ${ }^{14}$ In addition, more and more cases have come to light in which archival innovation was not necessarily the result of centralised state power at all, but originated elsewhere. Mikael Adolphson's explorations of medieval Japan are a case in point: archiving occurred in decentralised, regional institutions (monasteries) despite (or, rather, because of) the lack of an overarching political system. ${ }^{15}$ In sum, without totally severing the classic connections between archives and the bureaucratised modern nation-state, a much more nuanced assessment of this connection is actually required. With such a re-evaluation firmly on its way, a cross-cultural approach to the study of archives may well be possible.

Finally, the intention to compare archival phenomena across space (and time) need not necessarily be seen as Eurocentric or modernist per se. Quite to the contrary: there is a long tradition of cross-cultural archival comparison which is by no means limited to European examples. Consider the case of the Indian empire of Vijayanagar, where, as far as we can tell, a considerable and highly functional collection of state papers existed in the late Middle Ages. Two men from very different cultural backgrounds went to see the collection in 1442 and 1637: the Persian scholar and traveller Abd-al-Razzāq Samarqandī (1413-1482) and the Englishman Peter Mundy (c.1600-1667). Both left descriptions of these collections, and their notes clearly show how impressed both visitors were. The Persian al-Razzāq, obviously comparing the bureaucracy of Vijayanagar with his own Persian experiences, simply declared the Indian empire's documents to be a

14 See Brendecke 2016, for example.

15 For archival practices, see his contribution to this volume. For a more institutional perspective, see Adolphson/Ramseyer 2009, 660-668. 
defter-khaneh, that is, a governmental 'archive'. ${ }^{16}$ Mundy went even further in identifying the Indian and the European situation:

The country people write on Palme leaves with an Iron bodkin as before mentioned. They say they will endure 100 yeares. Att my beeing at Eecary [sc. Ikkeri] I was att the Kings Secretaries, where in his house I saw many hundreds (I may say thousands) of those written palme leaves, beeing very long and Narrow, handsomely rouled up, those againe tied into bundles, hung upp in order about his roome or office, soe that he May (not improperly) bee stiled Master of the Roules. ${ }^{17}$

Similarly, early Spanish observers of pre-contact traditions in the Americas had no trouble calling the vast collections of quipus that were the basis of Inca administration and the purely oral memories of the Andean highlands arquivios (archives).$^{18}$ Obviously, people often simply knew when they were looking at an archive and had little difficulty in assimilating parallel phenomena under one category. ${ }^{19}$

\section{Manuscript cultures between archival and counter-archival practices}

What all the contributions to this volume show is, first of all, a very basic, yet utterly fundamental point: archiving occurred almost everywhere where writing was used. Scholars become more and more aware of the fact that the history of archiving should be seen as a crucial dimension of the history of writing. It is becoming clearer and clearer now that handwritten documents of all kinds were and are carefully and lovingly kept by many different kinds of people and institutions. This is why the case for a new 'social history of archives' is currently being made, which would refocus attention on the activities of non-elite players and generally stress the diffusion of archival practices throughout societies. ${ }^{20} \mathrm{Ar}$ chiving was and is not restricted to the elites or a few prominent flagship

16 Narrative of the Voyage of Abd-Er-Razzak 1857, 25.

17 Mundy 1919, 98.

18 De Murúa 2008, fol. 246r (chapter 10, part II). Friedrich 2018, 78f. Burns 2010, 4-11. Also see Hosne 2014, 177-191; and 2012, 30-40.

19 For a similar argument regarding a cross-culturally shared understanding of 'empire' in the early modern world, see Marcocci 2016, 511-525, esp. 516-521.

20 See Friedrich 2016, 49-70. The volume generally attempts to map the social breadth of European archival practices. 
institutions; rather, in most societies there was and is a much wider tendency to collect, store and preserve documents and manuscripts. Recent work on Ethiopia, for instance, has started to uncover hitherto unknown local administrative writing facilities and archival deposits. ${ }^{21}$ And in the Chinese case, James Robson has forcefully emphasised the fact that substantial bodies of manuscripts existed across China even in highly remote villages. ${ }^{22}$ Scholarship on Tibet also forcefully demonstrates the social and geographical reach of archival practices. ${ }^{23}$ The papers collected here add significant weight to the impression that practices of archiving were and are deeply integrated into the social fabric of many societies and cultures. It is important to stress that manuscript preservation remains a prominent practice even if new media such as the printing press or the computer screen start providing alternatives to the use of manuscripts. Scholars now realise that such media changes do not eliminate handwriting and do not render assorted technologies (including archiving) superfluous. ${ }^{24}$

This newly established cultural and social prominence notwithstanding, it needs to be stressed that 'archiving' could actually mean some very different things. The typically modern Western notion, for instance, that archives (at least ideally) keep all records permanently ready for almost instantaneous access was by no means shared everywhere at all times and was hardly reality in Europe for most of its history. In fact, the essays in this volume demonstrate over and over again that assumptions about what documents should be available for whom and for how long have differed widely across time and space. There is no uniform balance between the twin goals of preserving documents and using them-some cultures highlight preservation, while elsewhere usability is considered particularly important.

Preservation could lead to forgetting, as the Indian land-grants or deeds on copper show. These documents were forgotten after being buried and only turn up by accident now when peasants plough their fields. It is often only a very fine line that separates archiving from oblivion. In fact, the archival strategy of burying documents seems to border on the 'counter-archival'. ${ }^{25}$ This term designates ways of handling documents that (seem to) contradict the archival goals of 'preserving documents' and 'keeping documents available for use'. A wide range of

21 Bosc-Tiessé/Derat 2011, 85-110.

22 Robson 2012, 317-343.

23 See the paper by Charles Ramble in this volume. In addition, see the many publications by Dieter Schuh, e.g. 2016 and 2014, 311-338.

24 Robson 2012.

25 The term 'counter-archival practices' has been borrowed from Hirschler 2016, 1-28. 
activities fall under the category of 'counter-archival behaviour'. Some of them end the existence of documents physically, e.g. by burning them or by washing off the ink. Such intentionally destructive practices may follow very different kinds of cultural logic. Purging records for political purposes, e.g. after a regime change, is one reason for intentional memory loss. ${ }^{26}$ Occasionally, acts of ritual destruction are a key part of legal culture, for instance when contracts were rinsed in a 'bowl of justice' in order to be destroyed, as occurred in pre-Mongol and Safavid Persia. ${ }^{27}$ In Late Antiquity, documents relating to slaves were occasionally cancelled by crossing them out with lines-hence, the content was preserved, but the document mutilated..$^{28}$ Often, it is purely pragmatic considerations that lead to intentional destruction. In fact, routine weeding out of unnecessary documents seems to have occurred almost everywhere, although in very different ways. Some Ancient Egyptian collections show evidence of a 'periodic process of disposal of tablets' (Hagen). In China, as Max Fölster reports, the regional administration emptied out archives roughly once every 13 years during the Han period. And if, in modern Western societies, more than 75 per cent of all public records are methodically singled out for destruction, ${ }^{29}$ then archival preservation has become more the exception than the rule, at least quantitatively speaking. In many cultural settings, it seems, people have thought as extensively about how to destroy or mutilate writings as they thought about how to keep them. ${ }^{30}$

Not all counter-archival activities lead to physical destruction or to a loss of information in absolute terms, however. It may seem paradoxical, but in quite a few cases documents survived in spite of-or even because of-counter-archival forms of using them. The best example here is the Jewish Genizot. ${ }^{31}$ In this case, a great number of documents were intentionally taken out of circulation, but they were nevertheless preserved physically; in fact, modern scholars have been using them to reconstruct old archives. Similarly, in pre-Ottoman Muslim territories, the recycling of used papers or the re-using of parchment for bindings was fairly common, at least partially accounting for the disappearance of larger archives. ${ }^{32}$ Again, this can be reversed and the original archives can be reconstructed, as

26 This is frequently considered to be a major reason for the loss of most pre-Ottoman Islamic archives; see, for example, Bauden 2013, 27-29, 35-38.

27 Al-Hokamaee 2013, 137-154, 138.

28 Feissel/Gascou 1989, 535-561, 544, 558. Also see El-Leithy 2011, 422-425.

29 This figure is taken from Hollmann 2016, 199-206; 203 here.

30 Sadan 2007, 193-218.

31 For some summaries, see Beit-Arié 1996, 407-414; Horowitz et al. 2007, vol. 7, 460-483; Habermann 2007, 460.

32 Bauden 2013, 39-41. 
Konrad Hirschler has demonstrated in his recent essay on pre-Ottoman Muslim archives. ${ }^{33}$ Furthermore, used material that had some blank space left on it (mostly on the verso sides) was often employed again for a new round of writing-several ancient Egyptian papyri that have survived the course of time illustrate how scrap material could be re-used, for example. ${ }^{34}$ Once again, the original archives might well have been destroyed by such practices, but enough traces of them have remained for experts to be able to reconstruct them partially today.

Taking such counter-archival tendencies seriously can serve as a crucial caveat against triumphant narratives of archival history. Generally speaking, archival continuity should not be overestimated. Put a little differently, there are very few old archives that still exist today and are living testimonies of their own efficiency, as it were; most of the materials from the European Early Middle Ages, for instance, have not survived in their original archival contexts. Archives and individual collections were scattered and fragmented, and only stray pieces have found their way through time and space-at least partially a counter-archival form of transmission. Often, only literary sources are left to inform us that substantial archives once existed..$^{35}$ Archival and counter-archival practices are thus crucial aspects of all cultures of writing. Taken together, and only taken together, they provide insights into the social and cultural functions associated with writing by different peoples at different times.

The question is therefore not as much whether any counter-archival practices existed, but how they were controlled and by whom. A cross-cultural study of archives and archival practices must be particularly concerned with understanding the specific balance between keeping and destroying documents and making them available for use or withdrawing them. The difference between preservation and disappearance was (and still is) often one of originators, i.e. who first produced them-the chance of documents surviving depended on factors like gender, for instance. Documents from male originators are often said to be more likely to survive, while those written by females are considered particularly vulnerable to counter-archival practices. This is at least partly due to the fact that gender roles in many contexts intersected with a distinction between private (or personal) and public (or political/administrative/legal) writing. Private documents written by women, it is generally assumed, were least likely to become part of routines of long-term preservation, while public writings by men had the best

33 Hirschler 2016.

34 Luiselli 2008, here 686f. with a list of examples.

35 For more on the Carolingian period, see the collection of evidence in Mersiowsky 2015, 904-933. 
chance. ${ }^{36}$ These factors affecting document survival may intersect with issues of class and social standing, although it was not necessarily the elites who used the most advanced archival routines-in Europe, for instance, the nobility was not necessarily the avant-garde of record-keeping. Archival practices were layered in multiple ways, it seems.

In all this, it is important to understand the terms 'archival' and 'counterarchival' not as 'either/or' categories, but rather as two extremes that allow for a wide variety of possibilities. Documents can easily move back and forth from fairly archival to more counter-archival states of existence, and vice versa. What is a throw-away object of writing in one cultural context may be (or become) a treasured possession in another environment. Keeping seemingly worthless stubs of entrance tickets or local bus tickets obtained on trips to places is a widespread practice among tourists today, for instance. Many documents 'live' complicated lives, moving in and out of cultural contexts, hence their status can easily shift back and forth between attention and neglect, high value and low regard, and archival and counter-archival status.

\section{A matrix for describing and comparing archival practices}

The papers in this collection suggest several ways of relating archival practices from across time and space to each other in a meaningful way. At least five topics or analytical perspectives may be identified according to which comparison is used. If, as Jürgen Kocka has argued, 'one cannot compare totalities', then it would not make sense to simply juxtapose two or more 'archives' from different cultures. ${ }^{37}$ 'Rather, one compares in certain respects', Kocka continues. This should also hold true when comparing archival practices. Here it might help to recall that the word 'archive' and its offshoots usually mean different things, albeit related ones: a body of documents, a building, an institution, a profession, a group of experts, and so on. ${ }^{38}$ While all of these dimensions may be present in the classic case of Western state or national archives, in other historical situations

36 To my knowledge, the gendered aspects of archival practices have only been discussed very recently, mostly in connection with the Western world; see Daybell 2017, 25-45, and 2016, 210236, for example. On South-East Asia, see Lambert-Hurley 2013, 61-84, and Burton 2003.

37 Kocka 2003, 39-44; here: 41f.

38 See Galland 2016, 3f, for instance. 
only a few or maybe even only one of these dimensions can be addressed meaningfully. In most cases, it is simply impossible to compare archives in their ideal totality of implications, even though it is perfectly possible to detect at least family resemblances between archival practices and to compare segments and individual elements of what constitutes an archive. Moreover, Kocka's plea to only compare limited phenomena fits in well with current methodological claims that archival history should generally apply a 'micro-historical lens' and be highly alert to the 'historical specificity' of individual archives and their contexts, as Tamer El-Leithy has written regarding pre-Ottoman Arabic archives. ${ }^{39}$ Since historians have recently become wary of broader narratives of archival progress and professionalisation, they realise that what archives do and what they don't do for a given context can only be assessed by detailed investigation of individual cases. The papers in this collection, with their empirical basis and general reluctance to making broad generalisations, fit this bill perfectly.

The five aspects that follow allow for a meaningful comparison of archival developments across time and space:

1. Material and spatial dimensions

2. Tools and routines for organising and navigating multitudes of documents

3. Intended purposes of archiving

4. Environment of institutions and practices

5. Any concepts of time, history or memory that are implied.

1. The papers in this volume highlight the importance of the material and spatial dimensions of archives. Collecting and storing handwritten documents requires buildings or spaces, boxes, containers and additional materials to be used (like string, pins, wrappings, etc.). These aspects deserve close scrutiny, as they indicate and influence the ways in which archives are embedded in society. Assyrian merchants, for instance, set up archive-rooms in their private homes so as to keep the complex clay objects that contained contracts and letters readily accessible. Presumably, the records played a significant role in everyday life. But the idea that archival rooms should be specifically designed to serve the purposes of reading, searching and working with documents should not simply be regarded as self-evident: Fredrik Hagen refers to one Egyptian archive that was narrow and without any windows, which would have made its actual usage 'extremely difficult'.

39 El-Leithy 2011, 389-434; 393 here. 
Seen from a global perspective, the basic set of spatial techniques involved in archiving was ultimately fairly limited. Many of them, such as stringing together documents and hanging them up in the air to protect them from vermin, have been found helpful at different times by different people, as the cases of Tibet, Pharaonic Egypt and pre-modern Europe show. Special ways of folding documents were well known in many places, too. ${ }^{40}$ Regarding archival furniture (if any specialised furniture was used at all), it seems there were mainly two alternatives: large, box-like chests without any internal dividers or shelves of one kind or another. Also regarding containers, wooden boxes such as the one from Pharaonic Egypt described by Fredrik Hagen (Figs 2a-c) could also be found in use centuries later and hundreds of kilometres away. Nevertheless, some physical storage facilities used for archiving documents were highly specific and regional. ${ }^{41}$

The essays in this volume also show that archival practices may have strongly influenced people's preferences for certain writing forms and writing materials. Sometimes, archiving went hand in hand with the selection of especially durable writing materials. This point has been illustrated well by Emmanuel Francis, who demonstrates that in India, writing on palm leaves was copied onto copper, which was much more durable, in order to increase the chances of an archive's survival. There is no clear direction here, though. ${ }^{42}$ Daniel Soliman, for example, highlights the opposite media change in his contribution: he shows how fairly durable ostraca were copied onto easily perishable papyri for the sake of archiving. According to his interpretation, such copying might have occurred because it enabled the aggregation and synthetisation of information into higher-order documents-in this particular case a yearly account-book (in the form of a 'daybook').

Soliman's evidence hints at a point that is even more significant: archiving usually implies aggregating individual documents into larger objects. Files of some sort were and are created in many cultural contexts, and the operation of filing has rightly been called a fundamental archival practice, as the logic of filing strongly determines how archival documentation can be accessed and used. ${ }^{43}$ The practical creation of files, in turn, must necessarily take the material aspects of writings into account. Roman administrators, for instance, who were required

40 For an Arabic example, see Regourd 2008, 13-16.

41 Although it is not motivated by 'archival' considerations in a proper sense, but by motives of religious veneration, the Buddhist tradition of placing religious texts in statues (in India, Korea, Japan and China) still deserves mentioning here; see Robson 2012.

42 Faraguna (forthcoming) highlights the fact that in ancient Athens the same writing materials could be used both for public display and archival storing (p. 1f. of the pre-print).

43 For general statements and European case studies, see especially Vismann 2008. See Gitelman 2014 as well. 
to store their official letters and documents, created 'files' out of their papyrus letters by glueing numerous documents together to form lengthy sheets that could be rolled up and stored in official archives. Private administrations of great latifundia followed this public example as well. ${ }^{44}$ All writing materials have advantages and disadvantages when it comes to filing and archiving, and it will be the task of a future global history of archives to illustrate in detail just how the usage and usability of archives was purposefully managed by adjusting the materiality of manuscripts.

Hence, the examples and cases presented in this volume allow us to develop a thought further that was expressed by Harold A. Innis back in 1972. In his classic book Empire and Communication, Innis suggestively linked cultural preferences for certain writing materials (stone-based vs. paper/parchment-based societies) to cultures of communication and cultures of power. ${ }^{45}$ Nowadays, what with the advances in our knowledge about the global history of archives, it is possible to add a further dimension: cultural preferences concerning writing materials might, in addition to Innis's points, also rest upon assumptions about the purposes, requirements and necessities of archiving, which, in turn, are closely connected to the management of power.

2. Once larger bodies of documents have been accumulated, keeping track of what is available and where can be a daunting task. In principle, actors involved in handling these archives could rely on their memory and mnemonics, and in actual fact, there are several examples available to show that this was the case. Very often, however, specific forms of writing were employed to organise and structure the collected documents. 'Writings about writings', one might say, are a key element of most attempts to manage documents. Again, some solutions to the common problem of handling large quantities of documents appear to be fairly universal. Dorsal notes and the use of paratexts both helped archivists in Amarna in Pharaonic Egypt as well as medieval monks in Western Europe, for instance. In some cases, in fact, the paratext is the archive; in Ethiopia, to give just one example, record-keeping actually meant writing records in other manuscripts such as religious texts, which were highly venerated and thus had the greatest chance of survival. ${ }^{46}$

44 Significantly, personal letters were rarely treated in such ways; see Luiselli 2008, 712f. Also see Clarysse 2003, 344-359. Some examples are available at www.trismegistos.org/arch/archives/pdf/548.pdf

45 Innis 1972.

46 In cases such as this, newly applying the terminology of 'archiving' helps to re-evaluate scriptural phenomena otherwise classified as 'annotation' or 'marginalia'. In fact, strictly 
Aids to finding documents that have been stored somewhere-inventories, indexes, catalogues, etc.-can be found in many different archival cultures, and their shared features and dissimilarities can both be studied as a result. Their investigation could be particularly important from a comparative perspective, as catalogues can reveal a great deal about a given manuscript culture's perception of itself. Arrangements of archival organisation and the production of aids of this kind were strongly linked to concepts of power, territory and governance, for instance, as Peter Rück and Randolph Head have both demonstrated for central European cases. ${ }^{47}$ While a considerable amount of effort has already gone into analysing the ordered knowledge underpinning European library catalogues and archival inventories, much less of an effort has been made to evaluate non-Western parallels so far. ${ }^{48}$ Max Fölster's paper on China in this volume demonstrates what can be learned from applying such methods to other contexts.

Inventorying what information is available frequently involves assessing what is missing as well. Historically speaking, surveys of extant library holdings, for instance, have frequently been triggered by an overwhelming 'sense of loss', as was the case for most of the many Chinese state-sponsored bibliographies compiled since $6 \mathrm{BCE}^{49} \mathrm{~A}$ similar sense of melancholy also spurred the hunt for lost books during the European Renaissance. What is obvious in the case of books and libraries and their catalogues also seems to hold true for archives. The Chinese emperors, for instance, were not only able and willing to replenish their central libraries by staging vast campaigns involving regional searches for unknown books, but they frequently sent out requests to local or regional office-holders asking for copies of local documents as well. ${ }^{50}$ It seems that such campaigns were driven by a sense of incompleteness and a fear of losing (or not possessing) important knowledge that was still available, and yet other examples seem to show that the 'presence [...] and completeness [... of records] were not in [...] themselves meaningful to medieval actors'. ${ }^{51}$ Ideals of and approaches to completeness obviously varied.

3. A third line of investigation could seek to establish what purposes and functions were associated with the preservation of documents in different cultures, and what 'hopes and horrors' there were to boot, both by looking at explicit

speaking, the added texts should not be called 'paratexts' any longer. This point is made well in Wion/Bertrand 2011, vii-xvi (p. x here).

47 See Head 2017 for a summary of this work.

48 On Europe, see Derolez 1979 and Becker 2012, for instance.

49 Dudbridge 2000, 6-8. Also see Max Fölster's contribution to this volume.

50 Wagner 2004, 9-90, 30f. (for the Tang period).

51 El-Leithy 2011, 395 regarding medieval Muslim legal documents. 
commentary (where available) and by extrapolating from implicit evidence. 'Archival ideologies' - to adapt a term coined by Matthew S. Hull ${ }^{52}$-are a highly important part of archival history. Some of the hopes that underpinned the creation of archives were widely shared across cultures. One key trope associated with writing and record-keeping was the alleged power of these exercises to safeguard social peace and justice. Documents can supposedly 'prove' what was agreed on in the past and, hence, are thought to be capable of distinguishing correct from incorrect claims to property. This idea can be detected in early Muslim societies, for instance, even though the status of written documents in legal proceedings was highly contested in Muslim law. ${ }^{53}$ Nonetheless, several important legal experts such as the ninthcentury Egyptian lawyer Al-Ṭahāwī expressed clear their hope that archival recordkeeping would have a pacifying function. ${ }^{54}$ In Europe, this hope was a central component of legal practice..$^{55}$

The experience that this was frequently nothing more than utopian thinking must have been equally universal, however. Fraud and the forging of documents will no doubt have been a concern from very early on..$^{56}$ Quite evidently, legal papers such as contracts, wills or financial documents did not simply end social conflict, but triggered or fuelled it in some cases. Islamic jurists of the early modern period were engaged in long battles over the evidentiary status of specific archival documents, for instance. ${ }^{57}$ Complex thoughts about how to guarantee the authenticity of individual documents-whether by examining archival context or analysing material features such as the script, writing material, wording or seals used-were required and put forward, and yet conflict about what documents could and did actually prove remained an everyday reality. Rather than simply safeguarding the law, archives often spurred debate and strife. In the future, one might ask how such discrepancies between the hopes that were

52 Hull 2012, 14: 'Graphic ideologies are sets of conceptions about graphic artifacts held by their users, including about what material qualities of an artifact are to count as signs, what sorts of agents are (or should be) involved in them, and what the roles of human intentions and material causation are'. Significantly, Hull hardly talks about archives (or other forms of preserving documents) as such.

53 See Christian Müller's paper in this volume on the complex status of written evidence in Muslim law. Also cf. Bauden 2013, 28f. (summarising Jean Sauvaget) and Lydon 2009, 647-659, esp. 654f.

54 See El-Leithy 2011, 393f. (with quotes).

55 Lepsius/Wetzstein 2008.

56 See Calhoun 1914, 134-144, for example.

57 Burak 2016, 233-254, esp. 242, 244 and 250. Burak focuses on debates about the imperial defter, but cites in passing early-modern discussions about many other types of documents as well. 
focused on writing and archives and the realities of their social and cultural functions were perceived and understood.

4. Archives are frequently described (metaphorically) as 'storage-houses' or 'armouries', receiving documents from outside and housing them until they are claimed again by (new) outside users. While this passive image of the archive as a mere receptacle is far too simplistic, it does hint at the fact that archives and the practices related to them are never isolated, but exist in more or less complex environments of other institutions and/or practices. This is why their relation to and distinction from these different but related neighbouring institutions and/or practices should also be taken into account.

Many possibilities could be explored in terms of overlapping practices, from scholarly to religious and political activities. One example that comes to mind is 'decision-making', a social practice that is currently receiving some scholarly attention again. ${ }^{58}$ What role can archives play in the process of deciding on matters? Modern political decision-making, for instance, often claims to be well informed, hence a range of activities have been created (over centuries, in fact) to improve and develop the information base that political actors draw upon. 'Seeing like a state', as the metaphor goes, is now considered a crucial part of modern political decision-making. Archiving has an important role to play in this process, at least in theory. ${ }^{59}$ The questions only start at this point, however. How were archives actually used on a day-to-day basis while deliberating and deciding on political options? How did an archive-based information mode of deciding relate to other modes of deciding? The case of pre-Ottoman Muslim government (studied by Jürgen Paul), for instance, which relied strongly on pragmatic literacy, but invested relatively little in coherent archiving, forces us to describe in more precise terms how and in what ways archives were (or were not) crucial cogs in the engine of a well-oiled imperial machine. It seems to me there are enormous possibilities for future research here.

In a parallel line of research, the connection between archival and economic practices should also be scrutinised. Roberta Mazza and Chris Wickham, among others, have suggested, for instance, that the well-developed Greco-Roman economic archives of Late Antiquity must be connected to complex practices relating to accounting and estate management. These archive-based economic and managerial activities, they argue, can best be understood if they, in turn, are

58 See, for example, Stollberg-Rilinger 2016.

59 The title of James Scott's book Seeing like a State. How Certain Schemes to Improve the Human Condition Have Failed (New Haven, 1998) has been turned quite fruitfully into a shorthand expression in archival history. See Sartori 2016, 228-257 and Head 2003, 745-782, for instance. 
connected to the specific tax-oriented extractive forms of political organisation in the late Roman Empire. ${ }^{60}$ The papers by Charles Ramble on Tibetan and Cécile Michel on Assyrian economic archives raise my hopes that similarly wide-ranging interpretations of the links between archiving and economic practices will eventually be possible in a comparative light.

Archives could and should also be related to a wide range of neighbouring or even overlapping institutions, including obvious ones such as imperial courts, government agencies, monasteries and law courts. There is a particularly pressing need to relate archives to their closest neighbours, i.e. to institutions that are also involved in producing, managing and storing writings. Hence, the culturally diverse relationships of and conceptual boundaries between archives, libraries, museums or scriptoria need to be traced (if they ever existed at all). How these institutions are separated from each other in specific cultural settings is a question that should be answered empirically, not by applying preconceived terminology. Ultimately, a broader integration of archives into networks of institutions could lead to new questions. In the case of the Assyrian archive of Kültepe studied by Cécile Michel, we might ask, for instance, how the creation and meaning of such an archive presupposed the existence of long-distance postal networks. Furthermore, the Kültepe archives also seem to presuppose far-reaching legal institutions, since they appear to have been premised on the assumption that documents held in Anatolia could be meaningfully deployed to safeguard economic transactions in far-away Mesopotamia.

5. If it is a truism to say that archiving is a practice meant to support and create memory, this still leaves room for many more questions. In fact, the simple equation of archives (together with libraries and museums) and memory rather begs the more specific question of what archives precisely do for what kind of memory. In some cases, the relationship between memory and archiving might have been conceptualised in simple and unambiguous ways. Some documents were, indeed, designed and handled with pretension to eternity: 'as long as the moon and the sun exist', to paraphrase the frequent formula found on Indian copper plates cited by Emanuel Francis. And at least some Muslim authors called the practice of archiving 'eternalising' ${ }^{61}$ But in many other cases, the mnemonic intention of archiving is much less totalising and hence much more complicated. If archives were meant to keep documents ready 'for future use', when exactly was this future and how long were the documents meant to lie there waiting? What kind of social approaches to the future were presupposed by or mirrored in the archive? What kind of expectation

60 Mazza 2001; Wickham 2006, esp. 245-272.

61 Bauden 2013, 34. 
for the future was connected to what kind of archive? What kind of strategies for future action were associated with archives? ${ }^{62}$ How did the memorising of the past that was done through archiving actually work? Was the past that had been memorised in the archive really meant to be read? Or was it supposed to be beheld in awe, as the well-kept silver and gold inscriptions found in Southern India seem to imply? If archival documents were actually read and studied in order to create meaningful images of the past, in what ways was this done and using which criteria? Evidently, different answers were given to these questions in different cultural settings, even if most people would have agreed on the importance of archiving for the cultivation of memory.

On a more specific level, the relationship between archiving and history-writing (understood in a very broad sense) also deserves our attention. If the role that archives served as crucial infrastructures for historiography has become more and more prominent in Europe since the nineteenth century, the historical dimension that archives have should by no means be considered self-evident, as Max Fölster's essay about Han China reminds us. ${ }^{63}$ This entire topic could be approached from different vantage points. One aspect concerns social history. In the European case, it would appear that the roles of archivist and historian were only differentiated properly in the eighteenth century. ${ }^{64}$ One could ask if similar developments can be observed elsewhere, too. The question could also be approached by looking at the relationship between documents ('sources') and historiography ('history'). Archive-based historiography occurred in many cultures, yet with potentially different implications. ${ }^{65}$ While it seems that in the European context the production of historical narratives did not diminish the value and status of the archival evidence (which had to remain available for future historiographical enterprises that were potentially different), in many East Asian contexts the production of official historical narratives frequently led to the destruction of the original sources. ${ }^{66}$ If remembering the past through archiving was a shared

62 The concept of 'archival strategies'-an adaptation of Bourdieu's terminology-is used by ElLeithy 2011, 406. Regarding the seemingly parallel concepts of 'Nutzungserwartung' and 'Überlieferungsabsicht', see Kluge 2014a, passim, and 2014b, 86f. Also see Groys 1992 on archives, the future and the concept of 'innovation'.

63 'It would be wrong to assume that the main purpose of the archives was to preserve documents for writing history', Fölster states on p. 218.

64 See de Vivo/Guidi/Silvestri 2015, for example.

65 Wagner 2004, 9-90, speaks about an 'industrial' ('fabrikmäßig', i.e. 'factory-like') work routine transforming archival documentation into historiography in Qing China.

66 Youn 2012; Wagner 2004, 11f., 14. 
concern for many cultures, this goal translated into a variety of different outcomes that sometimes seem to be contradictory.

These five dimensions should not be seen in isolation, but rather in a web of mutual relationships. Cultural decisions and assumptions regarding each of the five points are related to decisions and assumptions in each of the other areas -material features relate to and influence organisational strategies, which, in turn, reflect and embody notions of social or political order which are closely related to a society's institutional landscape and its ideas about time and memory. Eventually, then, a comparison should also consider these connections and relationships by asking questions such as these: how did similar social hopes translate into different archival arrangements? How did parallel attitudes to history and historiography go together with different archival arrangements, as was the case with the Ming and Manchu rulers of China ${ }^{67}$ Did certain preferences for writing materials originate from perceptions of society, and how was the intended purpose of archiving related to concepts of the future? Did similar approaches to the past or to empire-building followed by different cultures necessitate similar ideals of the archive, and how were these, in turn, influenced by the writing materials available? Did similarly 'feudal' concepts of society in Tibet and medieval Europe entail similar archival practices? And given the fact that significant changes in the practices of writing and archiving occurred precisely because of changes in land-holding in Ethiopia and Sudan, is a broader trend observable across cultural boundaries connecting archival developments to changes in the economic and legal management of land-holding $?^{68}$ Could such private cultures of keeping legal documents lead to employing these written artefacts in acts of resistance against overbearing lords?

This plea for a (cautious) comparison of archival practices on a global level must also include some remarks about the limits of such an approach, of course. By no means all archival phenomena can meaningfully be compared. In particular, we should be extremely reluctant to compare phenomena on different scales. How can we find an adequate parallel phenomenon to private record-keeping in the remote valleys of the Himalayas so vividly described by Dieter Schuh ${ }^{69} \mathrm{Com}-$ paring that to the state archives of modern Nepal, India or China is perhaps less

67 Fitzgerald 2015, 75-80.

68 On Ethiopia, see Habtamu Mengistie 2015, esp. p. 443. On Sudan, see Crummey 2011, 1-42 (pp. 29-36 here). On Europe and the medieval connection between land and archives, see the remarks made in Esch 1985, 529-570. See Clanchy 1993 on the relationship between the Doomsday Book and archival improvements.

69 Schuh 2014, 1-4. 
appropriate than making a long-distance comparison with the archival situation of modern-day Alpine France, as analysed by Valérie Feschet a few years ago. ${ }^{70}$ Obviously, a comparison should not be foiled by the use of superficial parallels. Consider two cases of political forgetting here: in Guatemala City, tens of thousands of pages of torture files produced by the secret police during the civil war were 'accidentally' found in 2005, after being 'forgotten' for more than ten years. ${ }^{71}$ Equally recently, several finds looted from Indonesia in 1949 were discovered in the Dutch Rijskarchief, again after decades of convenient oblivion. ${ }^{72}$ It might be tempting to assume parallel motives behind such acts of politically convenient forgetting, but the differences should not be overlooked: the time spans are very different, the institutions involved function very differently, and the societies concerned are generally in very different shape. Rather than simply trying to compare apples with pears, researchers should presumably start by asking sceptically in the first place if-and to what degree and on what level-a comparison between such archival events is possible at all.

\section{Archival entanglements}

Comparative perspectives alone will not suffice to integrate cross-cultural research on archival practices. Rather, archival history is full of episodes of entanglement, especially if seen on a global scale. Cases of archival entanglements are by no means restricted to the era of European expansion either, ${ }^{73}$ but they deepened considerably as a consequence of colonialism. Extended contact with and suppression by highly bureaucratised European colonial organisations frequently created significant archival dynamics in extra-European cultures. This started as early as the conquest itself, as Kathryn Burns, for instance, has shown for the creation of Spanish-style archives in Peru during the Early Modern Period. ${ }^{74}$ Another case in point is the widespread creation of 'national archives' in the

70 Feschet 1998.

71 Weld 2014.

72 See Karabinos 2013, 279-294, and 2015.

73 Chinese archival practices were exported to and adopted in Korea ever since the eleventh century. The local Korean tradition, in turn, which had grown significantly more sophisticated since the late fifteenth century, was ultimately changed-dramatically-in 1910, not by direct contact with the West, but because of the military occupation by Japan, which, had started to adopt German archival practices. See Youn 2012.

74 Burns 2010. 
former colonial states in the twentieth century, which could in many ways be seen as the result of a cultural export, no matter how incomplete or hybrid the final results may have been. ${ }^{75}$ Furthermore, the practice of using archival research as a basis for narrating history has been adopted in many places, but only after contact with European practices, as the cases of the East Indies and Jordan illustrate-in both places, only the twentieth century saw the establishment of indigenous academic historiography and concomitant archival practices. ${ }^{76}$

Frequently, such archival entanglements occur in highly asymmetric power situations which lead to a one-sided appropriation and/or re-valuation of one archival culture by another. Many cases of (forced) European overpowering of indigenous manuscript collections-whether physically or epistemically-are known to us today. The re-conceptualisation of local documents as 'archives' and their ensuing exploitation by colonialists often had a strong imperial function. The transformation of Javanese temple manuscripts into historical archives by Thomas Stamford Raffles and Colin Mackenzie at the beginning of the nineteenth century was one such instance. ${ }^{77}$ Other more violent forms of re-purposing indigenous archives occur where documents of all kinds are simply looted or stolen -again, an abundance of examples can be cited from most colonial episodes in world history, right up to the very recent past. ${ }^{78}$ And yet this was and is not a one-way street-archival entanglements have been and are still working in multiple directions. It would be entirely misleading to understand post-colonial archival history simply as an imposition of European models. ${ }^{79}$ Books like Christopher Bayly's on nineteenth-century India or Matthew Hull's on modern Pakistan's administrative apparatus alert us to the complex mixture of pre-colonial, colonial and post-colonial technologies that constitute contemporary forms of governance. ${ }^{80}$

Ultimately, a global archival history shares many of the difficulties every global history runs into: difficulties regarding terminology, difficulties of scale, difficulties in defining phenomena. And yet there can be no doubt that storing,

75 See Punzalan 2007, 381-392, Wright 1965, 511-520, and Schneider 2003, 447-454, for instance. The relative lack of coherence in these activities in much of the Arab world has already been pointed out by Astrid Meier: s.v. 'Archives and Chanceries: Arab World', in EI³, 2013-2, 17-22.

76 I rely on Jeurgens 2013, 84-106, and Jungen 2009, online since 18 March 2009, viewed on 10/11/2017. URL: http://ateliers.revues.org/8195; DOI: 10.4000/ateliers.8195

77 Jeurgens 2013, $92 \mathrm{f}$.

78 See Caswell 2011, 211-240 regarding an ongoing and much-debated case.

79 Calls for a 'post-colonial archive' have become louder; see Kurtz 2006, 63-90, for example (in a highly metaphorical use of 'archive'). With a stronger connection to 'traditional' archives, see Bastian 2003. Also see Caswell 2011, passim.

80 Hull 2012. Also see Bayly 1996. 
handling and using manuscripts were crucial elements of all cultures where writing was (and is) used. While not being exhaustive by any means, the papers presented in this volume amply demonstrate the enormous extent to which archiving was part of writing. It is to be hoped that future research will follow the direction in which these essays point and lead to a host of new insights.

\section{References}

Adolphson, Mikael, and J. Mark Ramseyer (2009), 'The competitive enforcement of property rights in medieval Japan. The role of temples and monasteries', in Journal of Economic Behavior \& Organization, 71, 660-668.

Bastian, Jeannette Allis (2003), Owning History. How a Caribbean Community lost its Archives and found its Future, Westport/London: Libraries Unlimited.

Bauden, Frédéric (2013), 'Du destin des archives en Islam. Analyse des données et éléments de réponse', in Denise Aigle and Stéphane Péquignot (eds), La correspondance entre souverains, princes et cités-États. Approches croisées entre l'Orient musulman, l'Occident latin et Byzance (XIIle-début XVIe siècle), Turnhout: Brepols, 27-49.

Bayly, C.A. (1996), Empire and Information. Intelligence gathering and social communication in India, 1780-1870, New York: Cambridge University Press.

Becker, Regina (2012), Enzyklopädische Gedächtniswelten. Bibliotheksmodelle in der Architekturtheorie des Barock, Cologne: Böhlau.

Beit-Arié, Malachi (1996), 'Genizot. Depositories of Consumed Books as Disposing Procedure in Jewish Society', in Scriptorium, 50, 407-414.

Berger, Stefan (2012), 'The role of national archives in constructing national master narratives in Europe', in Archival Science, 12, 1-22.

Berger, Stefan, and Christoph Conrad (2014), The Past as History. National Identity and Historical Consciousness in Modern Europe, Basingstoke: Palgrave Macmillan.

Bosc-Tiessé, Claire and Marie-Laure Derat (2011), 'Acts of Writing and Authority in BəgwənaLasta between the Fifteenth Century and the Eighteenth Century. A Regional Administration Comes to Light', in Northeast African Studies, 11, 85-110.

Brendecke, Arndt (2016), The Empirical Empire, Berlin, Boston: De Gruyter Oldenbourg.

Burak, Guy (2016), 'Evidentiary truth claims, imperial registers, and the Ottoman archive. Contending legal vies of archival and record-keeping practices in Ottoman Greater Syria (seventeenth-nineteenth centuries)', in Bulletin of SOAS, 79, 233-254.

Burns, Kathryn (2010), Into the Archive: Writing and Power in Colonial Peru, Durham: Duke University Press.

Burton, Antoinette M. (2003), Dwelling in the Archive. Women Writing House, Home, and History in Late Colonial India, Oxford: Oxford University Press.

Calhoun, George Miller (1914), 'Documentary Frauds in Litigation at Athens', in Classical Philology, 9, 134-144.

Caswell, Michelle (2011), “'Thank you very much, now give them back”. Cultural Property and the Fight over the Iraqi Baath Party Records', in American Archivist, 74, 211-240. 
Clanchy, Michael T. (1993), From Memory to Written Record. England 1066-1307. 2nd edn., Oxford: Blackwell.

Clarysse, Willy (2003), 'Tomoi Synkollesimoi', in Maria Brosius (ed.), Ancient Archives and Archival Traditions. Concepts of Record-Keeping in the Ancient World, Oxford: Oxford University Press, 344-359.

Crooks, Peter, and Timothy H. Parsons (eds) (2016), Empires and Bureaucracy in World History. From Late Antiquity to the Twentieth Century, Cambridge: Cambridge University Press.

Crummey, Donald (2011), 'Gondär Land Documents. Multiple Copies, Multiple Recensions', in Northeast African Studies, 11, 1-42.

Daybell, James (2016), 'Gendered Archival Practices and the Future Lives of Letters', in James Daybell and Andrew Gordon (eds), Cultures of Correspondence in Early Modern Britain, Philadelphia: University of Pennsylvania Press, 210-236.

Daybell, James (2017), 'Gender, Politics and Archives in Early Modern England', in James Daybell and Svante Norrhem (eds), Gender and Political Culture in Early Modern Europe, 14001800, London: Routledge, 25-45.

de Murúa, Martín (2008), Historia general del Piru. Facsimile of J. Paul Getty Museum Ms. Ludwig XIII 6, Los Angeles: The Getty Research Institute.

de Vivo, Filippo, Andrea Guidi, and Alessandro Silvestri (eds) (2015), Archivi e archivisti in Italia tra Medioevo ed età moderna. Prima edizione, Rome: Viella.

Derolez, Albert (1979), Les catalogues de bibliothèques, Turnhout: Brepols.

Fitzgerald, Devin (2015), 'Research Note: Between Paper and Wood, or the Manchu Invention of the Dang'an', in Saksaha. A Journal of Manchu Studies, 13, 75-80.

Dudbridge, Glen (2000), Lost Books of Medieval China (The Panizzi lectures, 1999), London: The British Library.

El-Leithy, Tamer (2011), 'Living Documents, Dying Archives: Towards a Historical Anthropology of Medieval Arabic Archives', in Al-Qanțara, 32, 389-434.

'Emad al-Din Sheikh al-Hokamaee (2013), 'La vision religieuse des Safavides, la conservation des archives pré-safavides et l'altération des documents', in Anne Regourd (ed.), Documents et histoire. Islam, VII -XVIe siècle, Geneva: Droz, 137-154.

Esch, Arnold (1985), 'Überlieferungs-Chance und Überlieferungs-Zufall als methodisches Problem des Historikers', in Historische Zeitschrift, 240, 529-570.

Faraguna, Michele (forthcoming), 'Archives, Documents, and Legal Practices in the Greek Polis', in Edward M. Harris and Mirko Canevaro (eds), The Oxford Handbook of Ancient Greek Law, Oxford. Published online: DOI: 10.1093/oxfordhb/9780199599257.001.0001

Feissel, Denis, and Jean Gascou, (1989), 'Documents d'archives romains inédits du Moyen Euphrate (IIle s. ap. J.-C.)', in Comptes rendus de l'Académie des Inscriptions et BellesLettres, 535-561.

Feschet, Valérie (1998), Les papiers de famille. Une éthnologie de l'écriture, de la mémoire et des sentiments en Provence alpine, Aix-en-Provence: Presses de l'Université de Provence.

Friedrich, Markus (2016), 'The Rise of Archival Consciousness in Provincial France. French Feudal Records and Eighteenth-Century Seigneurial Society', in Past and Present Supplements, 11, 49-70.

Friedrich, Markus (2018), The Birth of the Archive. A History of Knowledge, Ann Arbor: University of Michigan Press. 1st German ed. 2013.

Friedrich, Markus, Philipp Müller, and Michael Riordan (2017), 'Practices of Historical Research in Archives and Libraries from the Eighteenth to the Nineteenth Century', in History of Humanities, 2, 3-13. 
Fritzsche, Peter (2005), 'The Archive', in History and Memory, 17, 15-44.

Galland, Bruno (2016), Les archives, Paris: Presses universitaires de France.

Ghose, Sailen (1963), Archives of India, Kalkutta: K.L. Mukhopadhyay.

Gitelman, Lisa (2014), Paper Knowledge. Toward a Media History of Documents, Durham: Duke University Press.

Groys, Boris (1992), Über das Neue. Versuch einer Kulturökonomie, Munich: Hanser.

Guidi, Ignazio (1906), 'Gli archivi in Abissinia', in Atti del Congresso internazionale di scienze storiche (Roma, 1-9 aprile 1903), III, Rome 1906, 651-698.

Habermann, Abraham Meir (2007), 'Genizah', in Michael Berenbaum and Fred Skolnik (eds), Encyclopaedia Judaica. 2nd Edition. Vol. 7, 460.

Habtamu Mengistie, Tegegne (2015), 'Recordmaking, Recordkeeping and Landholding - Chanceries and Archives in Ethiopia (1700-1974)', in History in Africa, 42, 433-461.

Head, Randolph (2003), 'Knowing like a State. The Transformation of Political Knowledge in Swiss Archives, 1450-1770', in Journal of Modern History, 75, 745-782.

Head, Randolph (2017), 'Historical case studies of pre-modern European archives. A comparative approach', in Anne J. Gilliland, Susan Marilyn MacKemmish and Andrew J. Lau (eds), Research in the archival multiverse, Clayton: Monash University Publishing, 433-455.

Hirschler, Konrad, 'From Archive to Archival Practices: Rethinking the Preservation of Mamluk Administrative Documents', in Journal of the American Oriental Society, 136, 1-28.

Hollmann, Michael (2016), 'Bestandspolitik', in Ulrich Raulff and Marcel Lepper (eds), Handbuch Archiv. Geschichte, Aufgaben, Perspektiven, Stuttgart: Metzler, 199-206.

Horowitz, Yehoshua et al. (2007), 'Genizah, Cairo', in Michael Berenbaum and Fred Skolnik (eds), Encyclopaedia Judaica. 2nd Edition. Vol. 7, 460-483.

Hosne, Ana Carolina (2012), 'The "Art of Memory" in the Jesuit missions in Peru and China in the late $16^{\text {th }}$ century', in Material Culture Review, 76, 30-40.

Hosne, Ana Carolina (2014), 'Assessing indigenous forms of writing. José de Acosta's view of Andean Quipus in Contrast with Chinese "Letters"', in Journal of Jesuit Studies, 1, 177-191.

Hull, Matthew S. (2012), Government of Paper. The Materiality of Bureaucracy in Urban Pakistan, Berkeley: University of California Press.

Innis, Harold A. (1972), Empire and Communications. Revised by Mary Q. Innis. Foreword by Marshall McLuhan, Toronto: University of Toronto Press.

Jeurgens, Charles (2013), 'The untamed archive. History-writing in the Netherlands East Indies and the use of archives', in History of Human Sciences, 26, 84-106.

Jungen, Christine (2009), 'De source sûre. Expérimentations croisées sur l'archive', in Ateliers d'anthropologie, 33 (URL: http://ateliers.revues.org/8195; DOI: 10.4000/ateliers.8195)

Jungen, Christine, and Candice Raymond (2012), 'Introduction', in Ateliers d'anthropologie, 36 (URL: http://ateliers.revues.org/9080; DOI: 10.4000/ateliers.9080)

Karabinos, Michael Joseph (2013), 'Displaced Archives, Displaced History. Recovering the Seized Archives of Indonesia', in Bijdragen tot de Taal-, Land- en Volkenkunde, 169, 279294.

Karabinos, Michael Joseph (2015), The Shadow Continuum. Testing the records continuum model through the Djogdja Documents and the Migrated Archives. PhD Dissertation, Leiden.

Kluge, Mathias (2014a), Die Macht des Gedächtnisses. Entstehung und Wandel kommunaler Schriftkultur im spätmittelalterlichen Augsburg (Studies in Medieval and Reformation Traditions, 181), Leiden: Brill.

Kluge, Mathias (2014b), Handschriften des Mittelalters. Einführung in die Paläographie, Ostfildern: Jan Thorbecke Verlag. 
Kocka, Jürgen (2003), 'Comparison and beyond', in History and Theory, 42, 39-44.

Kurtz, Matthew (2006), 'A Postcolonial Archive? On the Paradox of Practice in a Northwest Alaska project', in Archivaria, 61, 63-90.

Lambert-Hurley, Siobhan (2013), 'Life/History/Archive. Identifying Autobiographical Writing by Muslim Women in South Asia', in Journal of Women's History, 25, 61-84.

Lepsius, Susanne, and Thomas Wetzstein (eds) (2008), Als die Welt in die Akten kam. Prozeßschriftgut im europäischen Mittelalter (= Rechtsprechung. Materialien und Studien; Vol. 27), Frankfurt: Vittorio Klostermann.

Luiselli, Raffaele (2008), 'Greek Letters on Papyrus. First to Eighth Century, a survey', in Asiatische Studien, 62, 677-738.

Lydon, Ghislaine (2009), 'A paper economy of faith without faith in paper. A reflection on Islamic institutional history', in Journal of Economic Behavior \& Organization, 71, 647-659.

Marcocci, Giuseppe (2016), 'Too Much to Rule. States and Empires across the Early Modern World', in Journal of Early Modern History, 20, 511-525.

Mazza, Roberta (2001), L'archivio degli Apioni. Terra, lavoro e proprietà senatoria nell'Egitto tardoantico, Bari: Edipuglia.

Meier, Astrid (2013), 'Archives and Chanceries: Arab World', in El', 2013-2, 17-22.

Mersiowsky, Mark (2015), Die Urkunde in der Karolingerzeit. Originale, Urkundenpraxis und politische Kommunikation. 2 vols, (Schriften der Monumenta Germaniae Historica, 60), Wiesbaden: Harrassowitz.

Mignolo, Walter (2003), The Darker Side of the Renaissance. Literacy, Territoriality, and Colonization, 2nd edn., Ann Arbor: University of Michigan Press.

Muller, Samuel et al. (2003), Manual for the Arrangement and Description of Archives. Translation of the second edition by Arthur H. Leavitt, Chicago: Society of American Archivists.

Mundy, Peter (1919), The Travels of Peter Mundy. Volume III, Part 1, London: The Hakluyt Society.

Osterhammel, Jürgen (2010), Die Verwandlung der Welt. Eine Geschichte des 19. Jahrhunderts, Munich: Beck.

Pollock, Sheldon, Benjamin Elman, and Ku-ming Kevin Chan, (eds) (2015), World Philology, Cambridge: Harvard University Press.

Punzalan, Ricardo L. (2007), 'Archives of the new possession. Spanish colonial records and the American creation of a "national" archives for the Philippines', in Archival Science, 6, 381-392.

Regourd, Anne (2008), 'Folding of a Document for Quseir al-Qadim. A method of archiving?’, in al-' 'Ușūr al-wusțā, 20, 13-16.

Richards, Thomas (1993), The Imperial Archive. Knowledge and the Fantasy of Empire, London: Verso Books.

Robson, James (2012), “Brushes with Some "Dirty Truths”. Handwritten Manuscripts and Religion in China', in History of Religions, 51, 317-343.

Sadan, Joseph (2007), 'New materials regarding purity and impurity of books in Islam in comparison with Judaism. Al-Burzuli and other Muslim scholars on defiled parchment, papyrus and paper', in Jerusalem Studies in Arabic and Islam, 33, 193-218.

Sartori, Paolo (2016), 'Seeing Like a Khanate: On Archives, Cultures of Documentation, and Nineteenth-Century Khvārazm', in Journal of Persianate Studies, 9, 228-257.

Schneider, Leander (2003), 'The Tanzania National Archives', in History in Africa, 30, 447-454.

Schuh, Dieter (2014), 'Vier Rechtsdokumente des "Munshi Aziz Bhat Museum of Central Asian and Kargil Trade Artefacts” in Kargil (Purig)', in Zentralasiatische Studien, 43, 311-338. 
Schuh, Dieter (2016), Herrschaft, örtliche Verwaltung und Demographie des äußersten Westens des tibetischen Hochlandes: Rechtsdokumente aus Purig und Spiti. Teil 1: Purig, Andiast

Scott, James (1998), Seeing like a State. How Certain Schemes to Improve the Human Condition Have Failed, New Haven: Yale University Press.

Stoler, Ann Laura (2002), 'Colonial Archives and the Art of Government', in Archival Science, 2, 87-109.

Stollberg-Rilinger, Barbara (2016), Cultures of Decision-Making (= German Historical Institute, The Annual Lecture 2015), London: German Historical Institute.

Verschaffel, Tom (2012), “'Something More than a Storage Warehouse”. The Creation of National Archives', in Ilaria Porciani and Jo Tollebeek (eds), Setting the Standards. Institutions, Networks and Communities of National Historiography, Basingstoke: Palgrave Macmillan, 29-46.

Vismann, Cornelia (2008), Files. Law and Media Technology, Stanford: Stanford University Press.

Wagner, Vivian (2004), 'Archive am chinesischen Kaiserhof. Geheime Arsenale im Dienste dynastischer Erinnerungspolitik', in Archivalische Zeitschrift, 86, 9-90.

Walsham, Alexandra (2016), 'Introduction: The Social History of the Archive. Record-Keeping in Early Modern Europe', in Past and Present Supplements, 11, 9-47.

Weld, Kirsten (2014), Paper Cadavers. The Archives of Dictatorship in Guatemala, Durham: Duke University Press.

Wickham, Chris (2006), Framing the Early Middle Ages. Europe and the Mediterranean, 400800, Oxford: Oxford University Press.

Wion, Anaïs, and Paul Bertrand (2011), 'Production, preservation and use of Ethiopian archives $\left(14^{\text {th }}-18^{\text {th }}\right.$ centuries)', in Northeast African Studies, $11 / 2$, vii-xvi.

Wright, Marcia (1965), 'The Tanganyika Archives', in The American Archivist, 28, 511-520.

Youn, Eunha (2012), 'Archival traditions in Korean History. From Medieval Practice to the Contemporary Public Records Management Act', in Archival Science, 12, 23-44.

Zhang, Wenxian (2004), 'Dang An. A Brief History of the Chinese Imperial Archives and Its Administration', in Journal of Archival Organization, 2, 17-38. 


\title{
List of Contributors
}

Mikael S. Adolphson is the Keidanren Professor of Japanese Studies at the University of Cambridge. His interests range from religious, social, economic and intellectual history to historical narratives. He has published two monographs: The Gates of Power: Monks, Courtiers, and Warriors in Premodern Japan (2000) and The Teeth and Claws of the Buddha: Sōhei and Monastic Warriors in Japanese History (2007). He is also the co-editor of Heian Japan, Centers and Peripheries (2007) and of Lovable Losers: The Heike in Action and Memory (2015).

\begin{abstract}
Alberto Camplani is Professor of History of Christianity and the Churches at Sapienza University of Rome and holds courses on New Testament, Syriac language and Coptic language in Milano Università Cattolica and Institutum Patristicum Augustinianum. He has been 'congress secretary' of the Tenth International Congress of Coptic Studies (Rome, 2010) Former director of the journal Studi e materiali di storia delle religioni, from 2013 is editor of Adamantius. Annuario di Letteratura Cristiana Antica e di Studi Giudeoellenistici. His main scientific interests are Egyptian christianity, Syriac Christianity, orthodoxy and heresy, institutional church and canonical literature.
\end{abstract}

Max Jakob Fölster is coordinator and researcher at the Max Weber Foundation / China Branch Office in Beijing. He is affiliated to the Centre for the Study of Manuscript Cultures at University of Hamburg where he has obtained his PhD in 2017 on The Imperial Collection of the Former Han and the Origins of Philology in China. A Study of the Bielu, Qilüe and Hanshu Yiwenzhi.

Jean-Luc Fournet is a papyrologist. In March 2015, he was appointed professor at the Collège de France (Paris), which created for him its first chair of papyrology named 'Written Culture in Late Antiquity and Byzantine Papyrology'. Prior to his current position, he was a scientific member of the Institut Français d'Archéologie Orientale in Cairo (1992-1996), researcher (chargé de recherche) at the CNRS in Strasbourg (1996-2004), and professor at the École Pratique des Hautes Études (Department of Historical and Philological Sciences) in Paris (2004-2015). He was elected again in 2017 as 'directeur d'études cumulant' at the École Pratique des Hautes Études. He devotes much of his scholarly activity to editing new texts, including papyri and Greek inscriptions on late antique amphorae, the system of which he was the first to understand, and has a special interest in the culture of Late Antiquity-particularly poetry, multilingualism, and modalities of written culture.

Emmanuel Francis is research fellow at the CNRS and is affiliated to the CEIAS (Centre d'Études de l'Inde et de l'Asie du Sud-Center for South Asian Studies) in Paris. He is an historian of Tamil Nadu using inscriptions and manuscripts for his research on the social and cultural history of Tamil language. He has published a two-volume study on the Pallavas of South India entitled Le discours royal dans l'Inde du Sud ancienne: Monuments et inscriptions pallava (IVème-IXème siècles) (Publications de l'Institut Orientaliste de Louvain nos 64-65). 
Markus Friedrich is Professor for the History of the Early Modern Period at Hamburg University. He is interested in the history of knowledge and archives, the history of early modern religion, the history of administration und bureaucracy. He has published Die Geburt des Archivs. Eine Wissensgeschichte. Oldenbourg, München 2013 which is now translated into English (The Birth of the Archive. A History of Knowledge, Ann Arbor: University of Michigan Press 2018).

Thomas Graumann is Reader in Ancient Christian History and Patristic Studies at the University of Cambridge. He researches the intellectual and cultural history of Christianity in its late antique context(s), including the formation of theological norms and discursive strategies. His most recent research focuses in particular on the emergence and evolution of church councils and synods as a fulcrum of these developments. A forthcoming monograph will analyse the characteristics and purposes of conciliar acta, exploring the interrelationship between distinct textual practices, material object reality, and auctorial designs.

Michael Grünbart is Professor of Byzantine Studies at the Westfälische Wilhelms-Universität Münster. His main areas of research are Byzantine epistolography, material culture, cultural history, religion and politics, and rituals. Besides publishing several articles on these topics, he has authored several entries in the Lexikon des Mittelalters and in the Oxford Dictionary of the Middle Ages.

Fredrik Hagen is Professor of Egyptology at the University of Copenhagen. As a social historian he works with ancient Egyptian papyri and ostraca, primarily of the New Kingdom, with a focus on literature, administration, and the material culture of writings.

Cécile Michel is a historian and Assyriologist, Director of Research at the National Centre of Scientific Research (CNRS) in the team Histoire et Archéologie de l'Orient Cunéiforme (Archéologies et Sciences de l'Antiquité) at Nanterre, coordinator of the International Research Network (GDRI) Ancient Textiles from the Orient to the Mediterranean (ATOM), Professor at Hamburg University, and PI of the Centre for the Study of Manuscript Cultures. Working on the decipherment and study of cuneiform texts from the first half of the second millennium BCE, her main research interests are archival studies, the materiality of texts and palaeography, literacy and education, writing and computing, history of sciences (mathematics), economy and society in Mesopotamia and Anatolia, families, women and gender studies, daily life and material culture (food, stones, metals, fauna, textiles, etc.), calendars and chronology, and historical geography.

Christian Müller is Directeur de recherche at the CNRS/IRHT, section arabe. His research interests are premodern Islamic law in theory and practice, with special focus on 1) judicial institutions (cadis and other magistrates), 2) the study of legal documents and the link of notarial practices to the evolution of legal doctrine, and 3) the sacralisation of legal thinking (sharia law).

Jürgen Paul is working on the pre-Mongol history of Iran and Muslim Central Asia. He is interested in the relationships between rulers and their immediate retainers, local rule, and rule by nomads. Recent publications include: Lokale und imperiale Herrschaft im Iran des 12. Jahrhunderts. Herrschaftspraxis und Konzepte. Wiesbaden: Reichert 2016. 
Charles Ramble is Directeur d'études (Professor of Tibetan History and Philology) at the Ecole Pratique des Hautes Etudes, Paris, a position he has held since 2009, and a member of East Asian Civilisations Research Centre (CRCAO, UMR 8155, Paris, France, http://www.crcao.fr/). From 2000 to 2010 he was the Lecturer in Tibetan and Himalayan Studies at the University of Oxford, where he continues to hold a position as University Research Lecturer. His publications include The $\mathrm{Na}$ vel of the Demoness: Tibetan Buddhism and Civil Religion in Highland Nepal (2008), and several volumes in a series entitled Tibetan Sources for a Social History of Mustang $(2008,2016,2017)$. His research interests include Tibetan social history, Bon, biographical writing, and Tibetan ritual literature and performance.

After studying history, mathematics, and philosophy, Dietmar Schenk received his Ph.D. from Westfälische Wilhelms University of Münster. He completed the Archives School Marburg and, in 1991, became head of the Archives of the Berlin University of the Arts that he has built up in its present form. He has directed various research and archival projects, most recently 'Vorbilder Nachbilder. Das Fotoarchiv des Künstlers im 19. Jahrhundert' (2017-2020). He is also the author of numerous articles and several books focusing on the cultural history of Berlin, particularly music history, and on archival theory and history. His book publications include Kleine Theorie des Archivs (2008, 2. edn 2014), “'Aufheben, was nicht vergessen werden darf'. Archive vom alten Europa bis zur digitalen Welt” (2013).

Daniel Soliman is a Post-doctoral research fellow at the University of Copenhagen, where his research concerns the social and organizational aspects of tomb construction in ancient Egypt. His work at Leiden University focused primarily on scribal practices and administration in the community of Deir el-Medina. 


\section{List of Documents}

\section{Papyri}

\section{Arabic Papyri}

\section{Ardabil}

No. 5 (paper) ed. Gronke 1982, 152-160, no. 5370 n. 47, 382

No. 8 (paper) ed. Gronke 1982, 213-222, no. 8370 n. 47,382

\section{Berlin}

Ägyptisches Museum und Papyrussammlung, Staatliche Museen zu Berlin

P.Berlin 7515366 n. 28, 382

P.Berlin 7902366 n. 27, 382

P.Berlin 11975366 n. 27, 382

P.Berlin 13002370 n. 45, 382

\section{Cairo}

Museum of Islamic Art

inv. 15649 ed. Fahmī 1973, 29-31,

no. 4366 n. 28,382

inv. 17493 ed. Fahmī 1973, 32-35,

no. 5366 n. 28,382

inv. 17494 ed. Fahmī 1973, 36-38,

no. 6366 n. 28,382

\section{National Library}

Dār al-kutub 173355 n. 27, 382

\section{Cambridge}

University Library

Michaelides 59367 n.30, 382

Michaelides 134366 n. 28, 383

\section{Chicago}

Oriental Institute Museum

Or. 17657366 n. 27, 383

\section{London}

British Library

P.Lond. or. 4684 (8) (paper) ed. Ragheb 2002, 30-33, no. 11369 n. 42, 383

School of Oriental and African Studies Library

Arabic No. 6 (Yarkand collection, paper) ed. Gronke 1986, 487-489, no. 2 370 n. 47, 383

\section{Philadelphia}

University Museum, Ellen W. Harrison Collection

Inv. 16320366 n. 27, 383

Inv. $16413 / 7 \quad 366$ n. 28,383

\section{Vienna}

Österreichische Nationalbibliothek Inv. Ar. Pap. 1151367 n. 30, 383 Inv. Ar. Pap. 10489366 n. 27, 383

\section{Ancient Egyptian Papyri}

\section{Amiens}

Musée de Picardie

Papyrus Amiens 129-131

\section{Berlin}

Ägyptisches Museum und Papyrussammlung, Staatliche Museen zu Berlin

P.Berlin 10001A 95 n. 78

P.Berlin 10055 92-94 Fig. 5 (translation)

P.Berlin 10023B 97 Fig. 8

P.Berlin 10038A 98 n. 88

P.Berlin $10038 \mathrm{C} 98 \mathrm{n} .89$

P.Berlin 10056A 96 n. 81

P.Berlin 1006696 
P.Berlin 1007498 n. 91

P.Berlin 10496 147 Fig. 16, 148

P.Eleph. 178

\section{Boston}

Museum of Fine Arts

Papyrus Reisner I 123, 127

Papyrus Reisner II 122, 127

Papyrus Reisner III 124, 127

Papyrus Reisner IV 124, 127

\section{Cairo}

Egyptian Museum

Papyrus Boulaq 18 102, 115

\section{Deir el-Medina}

P.DeM 28145

\section{Dublin}

Chester Beatty Library

P.Chester Beatty I 145

\section{Leiden}

Museum of Antiquities

P.Leiden I 350 127-128

\section{London}

British Museum

P.Baldwin (BM EA 10061) 129-131

P.BM EA 73666113

P.BM EA $10221=$ P.Abbott VI 145

P.BM EA $10752=$ P.Ramesseum C

116 n. 166

P.BM EA $10771=$ P. Ramesseum 18

117 n. 170

P.BM EA $10246=$ P.Anastasi III 121

P.BM EA 10326 151-152

P.BM EA 10401133

P.BM EA 10683145 n. 252

Semna Dispatches 116-121
Petrie Museum of Egyptian Archaeology

P. Harageh 3 = UC32775 131-132

Fig. 13

Paris

Bibliothèque Nationale

P.BnF 203 110, 113

P.BnF 204 110, 111 Fig 10

P.BnF 205114

P.BnF 206114

P.BnF 209-213 110 n. 145

Louvre

P.Louvre E. 3226 132-133

P.Louvre N 3169145 n. 253

\section{St Petersburg}

Russian National Library

1116A 125-126

1116B 126

Turin

Museo Egizio

P.Turin 2008 128-130

P.Turin 2016 128-130

P.Turin Cat. 1932 141-142

P.Turin Cat. 1939 141-142

P.Turin Cat. $1946+1949149$

Turin Indictment Papyrus 1887154

Vienna

Kunsthistorisches Museum

Papyrus Ambras 155

\section{Greek Papyri}

\section{Ann Arbor}

The University of Michigan Library

P.Mich. VIII 490-491 (P.Mich.inv. $4527+4528) 181$ n. 34 
The archives of Dioscorus of Aphrodite Edited in Fournet 1999

P.Aphrod.Lit. I 194

P.Aphrod. Lit. II 192-193

P.Aphrod. Lit. III 1 = P.Cair.Masp. II 67275194

P.Aphrod. Lit. IV 194

\section{Cairo}

Egyptian Museum

P.Cairo inv. JE 43227194

P.Cair.Masp. II 67166175 n.13

P.Cair.Masp. II 67167175

Papyrus grecs de l'Institut Français d'Archéologie Orientale

IFAO ONL $318+325 \quad 149$

\section{Dublin and Cologne}

Chester Beatty Library

Biblical papyri I-XII 191

P.Panop.Beatty 180

\section{Florence}

Biblioteca Medicea Laurenziana

P.Flor. II 259193

Milan

Università Statale

P.Mil.Vogl. I 11 (= Corpus die Papiri

filosofici I.1*6) 188

\section{New Haven}

Yale University, Beinecke Library

P.Dura 28238 (Syriac/Greek)

\section{London}

British Library

P.Lond.Lit 6 (inv. 1873) 193 n. 72

P.Lond.Lit. 11185 n. 47
P.Lond.Lit. 97 (inv. 1984) 185 n. 47, 189-190

\section{Oxford}

Bodleian Library

Ms. gr.class. f. 72 (P) 184-185, 184

n. 43,185 Fig. 3

\section{Manuscripts}

\section{Berlin}

State and University Library

Ms. or. 6948376 n. 80

\section{Colombo, Sri Lanka}

Colombo National Museum

Leaf of gold manuscript of the

Pañcavimśatisāhasrikā

Prajñāpāramitāsūtra, from Anurādhapura, Sri Lanka 392-393, Fig. 2

\section{Heidelberg}

Universitätsbibliothek

Pal. gr. 252329

Paris

Bibliothèque Nationale

Par.syr. 62258

\section{Tamil Nadu}

Annamalai University Library

cat. no. 97; Acc. no. 340049 [old] and 860 [new]) 404 Fig. 8

\section{Vatican}

Biblioteca Apostolica Vaticana

Vat. Borg. Syr. 148258 n. 98

Vat. gr. 215322

\section{Verona}

Biblioteca Capitolare

Codex veronensis LX $\quad 249,252-257$ 


\section{Ostraca}

\section{Berlin}

O.Berlin 12626143

\section{Deir el-Medina}

O.DeM 40143
O.DeM 41143

O.DeM39 + 174149 Fig. 17

\section{Elkab}

O.Elkab 173

\author{
Kom Aushim \\ Karanis Museum \\ O.Narm.Dem. II, l-li 177 n. 21
}

\section{Strasbourg}

O.Strasbourg H. 42143

\section{Indic Inscriptions}

Inscriptions are cited by their generally accepted designations, normally referring to their original findspot, if known. References are given to Corpus Inscriptionum Indicarum (CII), South Indian Inscriptions (SII), and Pallava royal inscriptions (IR) (Francis 2013) or to standard epigraphic journals, especially Epigraphia Indica (El) or Archaeological Survey of India Annual Report (ASIAR).

Goharwa plates (CII 4, p. 258) 388 n. 2

Hīrahaḍaga!̣̣i plates (IR 3) 400, Fig. 3

Kalawān plate (El 21, no. 39) 390

Kasia copper plate (ASIAR 1910-11, 73-77) 390 n. 7

Kurud plates (El 31, nos 35-36). $397 \mathrm{n}$. 30

'Smaller' Leiden plates (El 22, no. 35) 393

Meharaulī iron pillar of Candra (CII $3^{1}$, 139-142, CII 32 , 257-259) 391

Nālandā plate of Devapāladeva (El 17, no. 17) 398, 402 Fig. 6

Oruvala Sannasa (EZ 3, no. 3) 393

Pātagaṇ̣̣igūḍem copper-plate grant (EI 33, 303-6) 389-390, Fig. 1

Panakaduwa plates $\left(11^{\text {th }} \mathrm{C}\right.$. illustrated in $A$ Guide to the National Museum Colombo 2012, 33
Pīkira grant (IR 16) 400, Fig. 4

Pradyumnabandhu plate, probably from

Bangladesh, c.550-650. 401, Fig. 5

Rewa stone inscription (CII 4, p. 271) 388 n. 2

Senavarma gold plaque inscription (findspot unknown) (Salomon 1986) 391

Sui Vihār plate (CII 2.1, no. 74, pp. 138141) 391

Taxila gold plate (CII 2.1, no. 31, pp. 8386) 391

Taxila silver scrolls (CII 2.1, no. 27, pp. 70-77)....391

The Tiruvālańkāțu plates (SII 3, no. 205) 394, 405, 407, 409

Toṇțaimān Raghunātha's grant, plate, Tamil Nadu, South India, 1803 CE. Pudukkottai Museum (copper plate no. 30). 403 Fig. 7 


\section{Index of Persons}

'Abd al-Razzāq Samarqandī 424

Abgar V, King of Edessa 236-239, $240 \mathrm{n}$. 31

Abraham, bishop of Hermonthis 243244

Abū Ḥanīfa 364 n. 13

Aetius, Archdeacon of Constantinople $280,287-288,288$ n. 49

Agapetos, John 331

Akhenaten, King 134-136

Alexander of Alexandria 251

Alexander the Great 240

Ali-ahum 51, 57-60-61, 63

Amenemhat I 122 n. 185

Amenemhat II 96

Amenemhat III 94

Amenemope 147 Fig. $16 \mathrm{n}$.

Amenhotep III 99, 118

Amenmesse 146

Amennakht 151-153

Ammianus Marellinis 249

Amun 127-129

Amun-Re 128

Amurru-bāni 56

Anastasius of Sinai $\quad 248-249,256,323$

Angmo, Phurba 35-36

Ankhaef, Prince, son of Snefru 76

Ankhu, Egyptian vizier 104

Annamayya 412

Annunītum 47

Antoku, Emperor 306

Anubis, King 92

Apiarius, Priest 253

Apokaukos, John 326

Appianus 193

Arethas of Caesarea 329

Aristophanes 184-185

Arius, presbyter 249

Arrian 329

Arsinoite 190

Aśoka, Emperor 396

Aššur-bāni 55,61

Aššurbanipal 45

Aššur-damiq 64
Aššur-idī 64 n. 18

Aššur-mūtappil 57,61

Aššur-țāb 55, 57, 61

Aššur-taklāku 51, 58-61, 64

Athanasius of Alexandria 253

Attaleiates, Michael 330-331

Babatha 178,181

Ballāla 387-388

Ban Gu 班固 201, 209 n. 35, 218

Baqī b. Mah̆lad 365-366

Baron, Hans 9 n. 19

Bayhaqī, Abū 'l-Faḍl 350 n. 48

Besas Alopex Antoninus 180

Bing Ji 214

Bhoja, King 387-388

Blumenberg, Hans 5

Boniface, Pope 255

Borchardt, Ludwig 89-91

Buddha 391

Bumpa, Tshewang 36

al-Bunnāhī 370 n. 49

Butehamun, scribe 151-152

Butri, Ngachok 34

Candra, King 391

Candragupta II, Emperor 391

Cappon, Lester J. 12, 12 n. 26, 13-14

Celsus, Tiberius Julius Polemaeanus 321

Chalkokondyles, Laonikos 320

Chao Cuo 昆錯 212

Cheng, Emperor 214

Chomatenos, Demetrios 326

Choniates, Michael 329

Choniates, Nicetas 324

Constantine, Emperor $322,325,326$

Constantine VII Porphyrogenitus 327

Cyril of Alexandria 248 n. 67

Damasus I, Pope 246, 251, 255, 276 n. 11

Dalai Lama 26, 29

Derrida, Jacques 6, 6 n. 10

Devapāladeva, King 398

Diodoros Sikulos 329 
Dionysus Exiguus 256

Dioscorus of Alexandria 281, 288-289

Dioscorus of Aphrodite $\quad 172,173$ n.9, 193-195

Djedkare, King 88

Djehutymose, official scribe $130,151-$ 152

Dong Zhongshu 212

Dorje, Ösal 35-38

Dupleix, Joseph François 390 n. 6

Ehavala Cāntamūla, King 389

Elamma 59, 61, 63

Ennam-Aššur 56

Enna-Suen 61

Eusebius, bishop of Caesarea 236-237, 240 n. 31, 241

Eustathios Boilas 330-331

Eustathios of Thessaloniki 330

Eutyches, presbyter 277, 284, 287, 287 n. $47,288,290$

Feith, Adriaan Johan 9

Fiaccadori, Gianfranco X, X n. 2, 235

Flavian, bishop of Constantinople 277, 289

Foucault, Michel 6, 6 n. 10, 355

Franz, Eckhardt G. 14, 175, 176 n. 16

Frederick William III, King 9

Fruin, Robert 9

Fujiwara no Kamatari 299 n. 4

Fujiwara no Kanezane 305, 314

Fujiwara no Shunzei 307

Fujiwara no Tadahira 303

Fujiwara no Yorinaga 307,314

Ǧağa (Caca), Mongol emir 346

Ğàmī 340

George of Pisidia 327

Gilbert, Felix 9 n. 19

Go-Toba, Emperor 310

Go-Shirakawa, Emperor 298, 304-305

Guru Vajranandin 404

Gyalpo, Tsering 29-30

Gyaltsen, Tenpa 35-36
Hagiotheodorites, Michael 324

Hammurabi, King of Babylon 46

Harshire, scribe 152

al-Ḩașșāf, Abū Bakr Aḥmad 364 n. 13

Hašta'ili 61

Hekanakhte, Priest 74

Helpidius 281, 281 n. 30

Hōjō Shigetoki 312

Hōjō Yasutoki 310

Homer 193-195, 330

Honorius 276 n. 13

Horemheb, King 140

Horemsaf, scribe 97 Fig. 8

al-Hูušanī, Abū 'Abd Allāh Muḥammad 370 n. 49

Ibn Abī Laylā 364 n. 13

Ibn Abī l-Dam Shihāb al-Dīn Abu Ishāq Ibrāhīm 373

Ibn al-'Aț̣ār 370

Iddin-abum 57-58

Iddin-Suen 60,62

Ignatius of Antioch 236

Ikūnum, King 54

Ilabrat-bāni 54

'Imād al-Dīn al-Iṣfahānī 350 n. 48

Irma-Aššur 62

Isidore of Pelusium 331

Issu-arik 62

Ištar-lamassī 55

İ́svararāta 389

Jenkinson, Hilary 12

Jerome, Saint 245 n. 54, 275, 275 n. 10, 276 n. 11

Jesus 232, 234-235-237, 239

Jia Yi 賈誼 212

John III Doukas Vatatzes 327

Joshua the Stylite 239

Julius II, Pope 246, 247, 256, 259

Kanișka, King 391

Karṇa, King of Anga $\quad 388,388$ n. 3

Keller, Hagen 7

Khaemwaset, son of Ramesses II 127128

Khan, Gushri 26 
Khnumnakht 155

Khentkawes (Khentkaus) I, Queen 83-84, 85 Fig. $4 a$

Komnenos, Andronikos (I) Emperor 325

Komnenos, Isaac 332-333

Konon 329

Ktesias 329

Leo I, Pope 279, 287 n. 47

Liang Qichao 梁啟超 202 n. 7

Liu Bang, Emperor Gaozu 216-217, 216 n. 76

Liu De 劉德 see Xian of Hejian

Liu Xiang 劉向 201, 202 n. 4, 205, 205 n. 18,207 n. 23, 209, 216, 216 n. 71, 217, 218 n. 81, 225

Liu Xie 劉劦思 208, 211

Liu Xin 劉歆 201, 205, 209, 216

Lü, Empress 217

Lucius Calpurnius Piso 186

Lušitiya 59

Lydus, John 282 n. 31, 286, 322

Manasses, Constantine $\quad 324,342$ n. 26

Maqrīzī 340, 350

Marcian, Emperor $\quad 255,275,278,283$

Mazaris 325

Meinecke, Friedrich $9-10,10$ n. 21

Melitius of Lycopolis 253

Memnon of Heraclea 329

Menander 194-195

Merenptah, King 107, 121 Fig. 12

Michinaga 303,303 n. 15, 305-307

Minamoto no Yoritomo 298, 308, 312, 316

Mongus, Peter 248

Montu 104

Mose 153-154, 158

Moses of Khorene 239 n. 27

Muhammad al-Qirbilyānī of Baza 344

Muḥammad b. Abī 'Īsā 370 n. 44

Muḥammad b. Bašǐr 364, 365 n. 20, 370

n. 49

Muller, Samuel 9

Mundy, Peter 424-425

al-Mustaršid 364 n. 13 and n. 14

Mystikos, Nicholas 323-324
Napoléon III 341, 390 n. 6

al-Nāșir lil-Dīn Allāh 364 n. 13 and n. 14, 373

Neferhotep, scribe 102, 156

Neferirkare Kakai, King 85 Fig. 4b, 87 Fig. $5,88-89$

Nestorius, archbishop 287 n. 47, 289

Nikephoros, the chartophylax 323 n. 21

Oda Nobunaga 313

Ōe no Hiromoto 309

Paul of Samosata 240 n. 31

Paul of Tarsus 234

Pepi, King I 88

Philogonios of Antioch 251

Photios (Photius), patriarch of Constantinople 285 n. 40, 320 n.9, 329

Pisenthius, bishop of Keft 243-244

Posner, Ernst 15, 44 n. 1

Pradyumnabandhu, King 398

Prodromos, Theodore 331

Psellos, Michael 329

Puzur-Ana, son of Elālī 57

Puzur-Ištar 57, 61

al-Qalqašandī 364,364 n. 13, 373 n. 61

Qenhirkhopshef, scribe 146,150

Rājendracōla I, King 405, 407

Ramesses II, King 99, 107, 127-128, 146, 154

Ramesses III, King $140,142,146,148$, 151

Ramesses IV, King 115, 140, 142, 151-152

Ramesses V, King 154

Ramesses VIII, King 129

Ramesses IX, King 86, 116

Ramesses X, King 141

Ramessesnakhte, Priest 129

Raneferef, King 82, 83 Fig. 3, 84, 86, 8889

Rangdrol, Lama 36

Rangdrol, Rigden 36

Ranke, Leopold von 7

Rašĩd al-Dīn 346 
Saḥnūn (Abū ibn Sacīd 'A Abd al-Salām b.

Ḥabib al Tanūh̄ī) 365, 371

Saladin 350 n. 48, 373 n. 65

Šalim-Aššur 54, 62, 64 n. 18

Šalimma 55

al-Samarqandī (Transoxanian jurist, $11^{\text {th }}$ century) 372

Šamaš-hazir 46

Šamaš-rē'i 61

Sanasiya 54

Sarki, Kāmi 33

Šayḥ al-Hukamā'ī (Sheikh al-Hokamaee) 354

Sefkhy 124

Šeltunnaya 47

Senavarma of Oḍi, King 391

Senwosret I, King 122 n. 185

Senwosret II, King 88-89, 93-94, 99

Septimus Severus 238

Seti I, King 109-110, 127, 140, 146

Severus of Antioch $\quad 251-252,251$ n. 80

Sima Qian 司馬遷 218

Siṃhavarman, King 404

Siptah, King 146

Śiva 405

Smeniotes, John 330

Snefru (Snofru), King 77

Sobekaa, scribe 77

Sobekhotep II, KIng 102

Solon, bishop of Seleucia in Isauria 251

Sotas of Oxyrhynchus 241, 243, 243 n. 44 and n. 45

Spiegelberg, Wilhelm 109, 114 n. 155

Śrīśankkarācārya 395

Šū-Ištar 61

Šumī-abiya 57, 61

Ṭāb-șilli-Aššur 55

Tadamori 307

Tadanori 307

Tafur, Pero 327

Taira no Kiyomori 297, 304-316

Tariša 58-59

al-Ṭạ̣āwī 367-370, 434

al-Ṭầ'î‘ li-Amr Allāh 364 n. 13 and n. 14

Takakura, Emperor 305

Tertullian 236, 241
Theodoret of Cyrrhus $\quad 250-251,256-258$, 281

Theodoros Pantechnes, Eparch of Constantinople 325

Theodosius II, Emperor 275-276, 278279, 283

Theophilus, Patriarch of Alexandria 250

Thutmose I King 139

Thutmose II King 89

Thutmose III, King 89, 99, 100 Fig. 9, 101 n. $96,115-116,124,132$

Timur (Temür ibn Taraghai Barlas), Emperor 341, 346

Tirumalai Nāyaka, King 399

Tiye, (Tiy) Queen 99

Tjanuni, scribe 115

Trashi, Sister Pen 37

Tsunemasa 307

Tsunemori 307

Tulpunnaya, daughter of Šeltunnaya 47

Tzetzes, John 329-330

Ur-Utu 47

Vișṇu 391

Wang Yinglin 王應麟 207

Weber, Max 423

Wei Xiang 魏相 212-214

Wu, Emperor 213, 225

Xian of Hejian 河間獻王, King 225 see Liu De

Xiaowu, Emperor 210

Xuan, Emperor 217

Xue Xuan 薛宣, Imperial Counsellor 214

Yan Shigu 顏師古 205 n. 18, 208, 208 n. 29

Zenon of Kaunos $178,181,183$

Zosimus, Pope 254-255

Zukua 64 n. 18 


\section{Index of Places}

Abusir (temple archives) 82, 85 Fig. 4a, $86,88-92,101,110,113,157$

Afghanistan 344

Aleppo 379 n. 89

Alexandria (Egypt) 182, 189, 231, 235, $245,248,253-255,258,274,289-$ 290

Amarna 122, 134-136

Anatolia 436

Andhra Pradesh 412

Antioch 231, 235, 250-251, 254, 258, 274-275, 289-290

Anurādhapura (Sri Lanka) 392 Fig. 2, 392 n. 15

Ardabil 345,346 n. 32, 363, 370 n. 47

Aššur 44, 48, 59, 63-64

Assiut 129

Athos (monasteries of Mount Athos) 312, 324

Babylonia 44

Baghdad 340-341, 367

Bangladesh 401 Fig. 5

Balat 84,158

Bāmiyān (Afghanistan) 344

Bāmiyān 344

Basra 367

Bengal 392, 394, 396

Bihar 392, 394, 402 Fig. 6

Bilād al-Šām 379 n. 89

Blachernai Palace (Istanbul) 327

Buhen 117, 119

Bukhara 347, 381 n. 94

Burma 392

Burušhattum 60

Cairo 346, 370 n. 46,

Cappadocia 331

Carthage 241, 247, 253-255, 276

Chalcedon 278, 280, 283, 288-289

Chang'an 长安 205, 218

China 201-229, 423, 426, 433

Chora monastery (Istanbul) 327
Constantinople 247 n. 63, 249, 254, 275-276, 282 n. 33, 288-290, 322, $325,327,328,331$

Daigoji 313-314

Dakhla oasis 79

Damascus 340-341, 345, 351

Darmstadt 14

Dendera Temple complex 92

Deir el-Bahari (Dayr al-Bahari) 99-100, 101 n. 96, 245

Deir el-Medina 73, 107, 137, 139-153, 157

Dishna 187

Djoser 81

Durhumit 58

Edessa 235, 237-239, 239 n. 27, 240, 245, 249 n. 71, 331

Egypt $71-165,181,241,344,348,351$, $357,363,367$ n. $31,378,423$

Elephantine 155

Elkab (Upper Egypt) 173

Enryakuji (Mount Hiei in Ōtsu) 314

Ephesus 277-279, 281

Ethiopia 242, 243 n. 44, 249 n. 71, 256 n. $89,257,423,426,432,438$ n. 68

Fayyum 183

Ǧām (eastern Iran) 347

Gangtok 30

Gebelein $77-78$

Germany $4-5,12$ n. 25

Gîza 76

Gnostic Library of Nag Hammadi 187,191 n. 70

Goharwa 388 n. 2

Granada 354

Great Mosque of Kairouan (Tunisia) 346

Great Pyramid of Khufu (Giza) 76

Great Temple of the Aten (Amarna) 134

Gurob 103, 105, 107-108 
Ḥaram al-Šarîf (the Temple Mount) Jerusa-

lem 345

Hathor temple (Dendera) 92

Heliopolis 128

Heracleopolis 190

Herculaneum 186

Hermopolis (Ashmunen) 184

Hyderabad 389 Fig. 1

India 389-413

Iran 340, 344, 350 n. 48, 352, 355

Iraq, Anatolia 340

Jerusalem 373 n. 65, 375, 380 n. 93

Jumla (Nepal) 37

Juyan 居延 222

\section{Kalhu 47}

Kāñcīpuram 395

Kalhu (Nimrud) 47

Kalawān (Taxila) 390

Kaneš 44, 48, 52, 57, 60, 64

Karanis 173,177

Karnak temple of $86,99,116,131$

Karnataka 400 Fig. 4

Kasia 390 n. 7

Kathmandu 31

Kayseri 48

Khotan (Xinjiang, China) 344 n. 19

Kōfukuji 314

Kom Medinet Gurob 105, 107

Kom Ombo see Temple of Sobek

Korea 439 n. 73

Kōyasan 313-314

Kültepe 43, 48, 52, 57-61, 65, 436

Künzang Chöling 37

Kundeling (monastery of) 28

Kurud 397 n. 30

Kyoto 304-305, 307-308, 314, 316

Labla 178

Ladakh 29

Lahun 82, 88-92, 94 Fig. 7, 96, 99, 105$106,108,110,113,137,157$

Lhasa $25,28-29$

Liye 里耶 (Hunan) 220, 224

Luoyang 216
Lycopolis 184,191

Malqata $81 \mathrm{n} .29,136$

Medinet Habu 140, 152, 156

Meharaulī 391

Memphis (Egypt) 76, 80-81, 103, 107, 109-115, 124, 127-128, 193

Mesopotamia 4, 48-49, 61, 436

Monastery of Apa Jeremias (Saqqara) 191

Monastery of the Holy Cross (Jerusalem) 343

Monastery of Kosmosoteira (Pherrai in Thrace) 332

Monastery of Phoibammon 245

Monastery of Saint Arsene (Tura) 191

Sinai (St Catherine's Monastery) 321, 343, 378 n. 87

Monastery of Saint Epiphanius (Luxor Governorate) 186

Mustang (Nepal) 22 Fig. 2, 23 Fig. 3, 25

Figs 5 and 6, 31-35

Naga ed-Deir 75 Fig. 1, 122

Nahal Hever (Judean Desert) 177

Nālandā (Bihar) 398, 402 Fig. 6

Narmouthis temple 176

Nāsik 390

Nepal 19, 22-23, 32, 438

Nicaea 254, 256

Nile valley $79,118,120,127,155$

Nimrud see Kalhu

Ninive 45, 232 n. 1

Nisibis 239 n. 27

Nubia 118, 120, 151

Numida 247 n. 63

Nuzi (Transtigris) 47

Oruvala Sannasa 393

Oxyrhynchus $186,190,242-243$

Pakistan 29, 440

Palace of Nuzi (Transtigris) 47

Panopolis 180, 187, 188 n.55, 190

Paruttikkunru 404

Patmos (Monastery St John) 321, 329 n. 42

Pergamon (Hellenistic library) 321 
Perrha 284

Peru 439

Perunefer 124-126

Pherrai 332

Philadelphia (Egypt) 183

Piramesse 127-128

Pochengzi 破城子 (Gansu) 223

Pondicheryy 390 n. 6

Porong (Pong rong) 29

Pudukkottai 399

Purig 29

Qubbat al-Hazna $\quad 345,351$

Rewa 388 n. 2

Rome 4, 231, 235, 253-254

Șafawīd shrine (Ardabil) 363

Șalāḥ al-Dīn 380 n. 93

Samarra 340

Saqqara $76,81,109,154,156$ n. 289, 191

Semna 116-117

Serapeion (Memphis) 193

Serapeum 173 n. 9, 190

Serdica 254

Shuihudi 睡虎地 (Hubei) 220

Sinai (St Catherine's Monastery) 321, 343,378 n. 87

Sikkim (India) 30

Sippar 45

Sobek $96-97$

Spiti 29

Sri Lanka 392, 399

Sudan 438 n. 68

Sui Vihār 391

Sun-temple Setibre $87-88$

Syria 46, 120, 237-239, 259, 261, 331, $341,350,353$

Talit 180

Tamil Nadu 395 n. 24, 397, 403, Fig. 7, 404, Fig. 8, 404, 409 n. 41

Taxila (Pakistan) 391

Te 36-37

Tebtynis temple $176,180,191$

Tell el-Amarna 134

Temple of Amun-Re (Thebes) 129
Temple of Anubis (Lahun) 92

Temple of Gaozu 217

Temple of Hatshepsut (Dayr al-Bahari) 245

Temple of Medinet Habu 155

Temple of Montu (Medamud, Karnak) 103-104

Temple of Khnum (Elephantine) 155

Temple of Senwosret II (Lahun) 93-94

Fig. 7, 97, 99, 105, 107, 110, 157

Temple of Ramesses II (Thebes) 98

Temple of Ramesses III (Medinet Habu) 140

Temple of Seth (Perunefer) 126

Temple of Sobek (Kom Ombo) 96-97

Temple of Thutmose III (Deir el-Bahari) 99-100, 101 n. 96

Temple Upper Tshognam 37

Thebes 79, 82, 99, 100 Fig. 9, 102, 116117, 122, 129, 136, 138 Fig. 15, 144, 151,191

This 75,122

Thmouis 181

Tibet $19-39,426,438$

Timurid Herat 346

Tirukka!̣ar temple 411 n. 43

Tirumalai Nāyaka 399

Tirupati temple 412

Tjaru (Tell el-Hebua I) 120, 121 Fig. 12

Tōdaiji temple 313-314

Tshug, Te 36

Tura 76,191

Umayyad al-Andalus 364,365 n. 20, 371

Umayyad Mosque (Damascus) 345

Upper Tshognam 36-37

Uronarti 118 Fig. 11

Vijayanagara 398-399, 424

Wadi el-Jarf 76

Wadi Natrun monasteries 188

Wuwei 武威 (Gansu) 221

Yarkand 370 n. 47

Yinwan 尹灣 (Jiangsu) 220, 223

Zhangjiashan 張家山 (Hubei) 220, 223 


\section{General Index}

accounts $35,55,58,76-81,86-89,91-$ 94, 97-102, 106, 108, 110-113, 123$133,137,142,145-153,156$ n. 288 , 157-159, 219-220, 285 n. 41, 350,

adā'al-šahāda (performing attestation), taḥammul al-šahāda (taking upon oneself to attest)

Archival History 4

Archival Science 3-5, 11

archives

- burned archives 177, 394-395, 397

- Counter-archival practices XIV, 347, 351, 353, 426-429

'dead' archives 45, 65, 79, 180, 355-356

- destruction of documents 27 , 177, 314, 343, 427-428

- discarded archives 27, 79-80, 146, 178-180, 187, 193-194, 223-225, 343, 351-352, 356357

- 'living' archive (archives vivantes) $45-46,60,79,361$ 362, 376, 378, 381

- Metaphor of Archive IX, 6, 236, 435

- $\quad$ private archive $31,43,46-50$, $65,74,156,175,183,231,265$, 326, 334

- $\quad$ purpose of burial 223, 413, 426

- reconstruction of 172-173, 181, 252, 257-258

- recycled archives 180-181, 427

attestation (oral and other, cf. šahāda)

362-363, 365-370, 373-381

Ayyubids 350, 373, 375, 377, 380-381

Azuma kagami 312, 316

Bishop 232-233, 232 n. 4, 235, 240, 242, 246, 248-249, 258, 274, 277, 279,280 n. $20,283,288$ n. 51, 290
Bodmer Library 187, 191

book-hunting 320

booklist 329

cadi $339-340,342,345,347-348,352-$ 354, 356, 361-382

dīwān al-qāọī /dīwān al-qựāt (cadi archive) 353, 361-362, 366-367

Cadi certificate (cadi's certificate) (siǧill) 374-379

Cairo Genizah 342-343, 347, 353, 363

Canonical collections 258 n. 95, 260

catalogue 201, 206-207, 225 of manuscript collection

chartophylax 323-324

Church Council see synod

clay tablets $15,43-65,71,79-80,121$, 136, 204

Cōla (dynasty) 396, 399, 405, 410

collection 5-6, 13, 171-174, 176, 204, 206, 209, 218, 224-225, 428

composite manuscript 253, 255

contracts $31,34,46-47,54-60,64,244$, $302,308,310,332,351,367,427$, 430, 434

copper plates $387-413$

copybook 282, 330

Council of Chalcedon 273,277 n. 17, 278-280, 284, 286 n. 45, 287, 287 n. 47

Council of Ephesus 246 n. 57, 283-286 n. 45, 287-289

Council of Nicaea 249, 251, 253-256

Council of Serdica 253-254, 257-258

Court of law 59, 377, 379-380, 382, 382 n. 96

Court records, court registers (siğill) 363-381

Cultural Revolution (Tibet) 27, 29, 38 cuneiform 43-46, 48, 65, 122, 134, 136

daybook 76, 91-108,114, 116-121, 126, $131,144,149,153,156$ n. 289, 157159,431 
decision-making 332, 365, 367, 435

decree 30, 85-86, 137, 212 n.53, 218 n. $83,220,240,254,256-257,262-$ 264, 299, 326, 343, 345 n.23, 347, 350-351, 394, 396, 398

Deeds (wațā'iq)

dhāraṇī 391

dharma-relics 391

dīwān al-ḥukm (archive of adjudication) 373,380

Donatists 276,276 n. 12

Donatist Schism 276 n. 12

dossier 79, 156, 181

duplication 148-149

endowment deed 346-347, 353-354, 373 n. 65,381

envelope $21,46,53-59,63,65,357$

epigraphic source 207, 213, 233 n. 7, $396,408,410$

florilegium 320, 329

Former Han dynasty $\quad 201,205,207,219$, 224

Ganden Phodrang 26-28

ğarïda (annual inventory) (p.12)

Genpei War 297-298, 308, 310

grant 387-413, 426

Gupta (dynasty) 390

Gupta script 20

Heike nōkyō (Sutras Dedicated by the Heike) 305-306, 313

Hippodrome 291 n. 54, 322-323, 325

Historia episcopatus Alexandriae

History of the Alexandrian Episcopate 257-258

History of the Han (Hanshu 漢書) 201, 207, 211, 214-215, 219, 222

History of the Later Han (Hou Hanshu 後漢 書) 214

History of writing 425

ḥuğğa (hüccet) (argument) 367, $368 \mathrm{n}$. 40, 375, 378-379

hukm (judgement) 365-368, 372-377, 380 imperial archive 322

Imperial collection 201, 202 n. 4, 205, 206 n. 19, 216, 224

imperial letters 280,281 n. 24 and n. 29, 282

impressions, filing archives $46,53,55-$ 56,221

inscriptions $387-399,405,407$ n. 38, 408-414, 437

inventory $80,85-86,101,155,173,189$, $210,225,332,372,433$

isğāal (certification) 373-378

isğālät (documents on an isğāl)

išhād (call for attestation)

Islamic law, see fiqh

Itsukushima 306, 313, 316

Jōei Shikimoku (Goseibai Shikimoku) 310 Juyan 居延 manuscripts 222, 222 n. 106 and n. 107

Kamakura shogunate (1185-1333) 297298, 316

komonjo 299-301

labour, organisation of (construction)

Late Brahmi (script) 20

legal document $26,106,154-155,175$, 298, 320 n.4, 330, 347, 351-352, $361,363,378,392,394,397,410$, 433 n. 51, 438

legal validity (șiḥha) 374

letter $31,75,79-81,86,88,96-98,118-$ $121,127,145,193,233$ n. $8,240,244$, 52-325

- Hekanakhte letters 156 n.288

library

‘Archive-libary' 171, 194-195

distinction archive $72 \mathrm{n} .1,171$, 176, 184, 192, 202-205, $202 \mathrm{n}$.

4, 25 n. 16, 224-225, 235, 235

n. $13,241,322$

- reconstruction of 172,185 , $187,194,316,326-334$

Library of Alexandria 185

Liye 里耶 manuscripts 220, 224, $224 \mathrm{n}$.

117 
magic $35,100,116,128,159,190,192$, maḥādir (documents of 'presence') 372373

mahkkama šariyya (Sharia courts) 379, 381

Mamluks 364, 374-381

media change 148-149, 426, 431

merchants $43,47-48,50,52,57-61,64$, 430

monastery $20-21,24,28,194,313,333$, 395

Museum archaeology 187

name-list $75,77,93,95,104,108,114$, 122-123, 136, 141

nuns $36-38$

official archives $46,48,181,189,222 \mathrm{n}$. 106, 432,

Oral testimony $154,368-369$

Ottoman Empire 340, 352, 355, 380

Ottomans $349,354,378,423$

palimpsest 124, 140, 256, 319

Pallava (dynasty) 389, 393-394, 399, 405 n 32, 406, 408, 410

palm leaf 387, 392, 394-395, 397-399, 404-408

proof-providing documents 377

proof-related documents 379,381

qimațr (box where cadis held documents) $353,356,362,364$, 372.373, 378

register $154,159,173,215-223,240$, 280-283, 321, 332, 348-350, 353, 378-380, 396, 406-407

registry $7,10,13$

reshelving books 328

reuse (of paper) 339, 350-353, 409, 427-428

safekeeping 287, 289-290, 319, 394395,410 šahāda (attestation) 365-366, 368, 374

śāsana 388, 392, 394, 397, 409

schedarion 280, 284, 284 n. 36, 288

scrinium 245, 247, 282 n. 32, 288

scroll 320 n.4, 321

seal $46,53-57,61,63-65,80-81.84,86$, 104,128, 131, 206 n.19, 221-222, 223, 342, 353, 362, 393, 394-395, 398-399, 411, 434

Semna Dispatches 116-121

Seldjuk 379

Seven Epitomes (Qilüe 七略) 201, 216

shōen 300-303, 310 n. 32

shrine $85,217,306,308-310,310$ n. 32 , 313, 315, 345-346, 353-354, 357

social capital $316,329,332$

storage of documents IX, 19-20, 55, 61, $65,76,79,81-84,117,130,134,136$, 142, 145-153, 155, 158, 202 n. 5, 203-205, 218 n. 88, 219, 246, 276, 284-285, 288-291, 313, 319-320, $322,334,339,441,425$

Synod of Carthage 247 n. 63, 255

Synod of Constantinople 323

Synod 233, 247 n. 63, 273-276, 274 n. 4, 291

Taiping Yulan (Imperial Readings of the Taiping Era) 306-307

tanfíd al-hukm (render a judgement effective)

tasğ̄ill (registration) $\quad 365,368-370$

temple archive $74,82,88-90,94-96$, $99,101,105-107,110,116,155,156 \mathrm{n}$. 290, 157-158

Treatise on Classics and other Texts (Yiwenzhi 藝文志) 201, 205-210, 208 n. 28, 217, 224

țubūt (establishing facts) 374 typikon 332

waqf 346,375 n. 73,378

waqfiyya 380 n. 93,381 n. 94

White Monastery Library 186,191 